
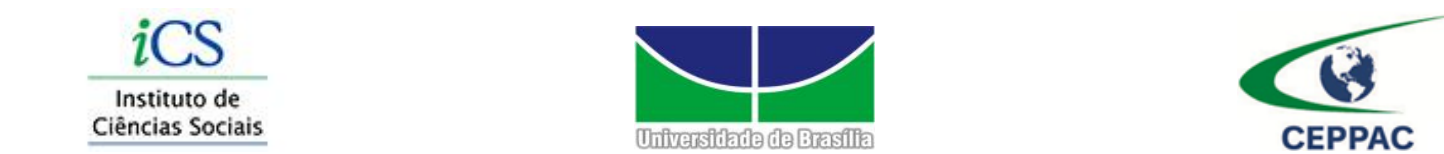

UNIVERSIDADE DE BRASÍLIA - UnB

INSTITUTO DE CIÊNCIAS SOCIAIS - ICS

CENTRO DE PESQUISA E PÓS-GRADUAÇÃO SOBRE AS AMÉRICAS - CEPPAC PROGRAMA DE PÓS-GRADUAÇÃO EM ESTUDOS COMPARADOS

MAURÍCIO EBLING

\title{
ESTRATÉGIAS DE DESENVOLVIMENTO E POLÍTICA INDUSTRIAL DE PETRÓLEO E GÁS: uma comparação entre Brasil, México e Noruega
}




\section{ESTRATÉGIAS DE DESENVOLVIMENTO E POLÍTICA INDUSTRIAL DE PETRÓLEO E GÁS: uma comparação entre Brasil, México e Noruega}

Tese apresentada ao Programa de PósGraduação em Estudos Comparados, do Centro de Pesquisa e Pós-Graduação sobre as Américas - CEPPAC, do Instituto de Ciências Sociais - ICS, da Universidade de Brasília - UnB, como requisito parcial para a obtenção de título de Doutor.

Linha de Pesquisa: Desenvolvimento, Globalização e Regionalização

Orientador: Prof. Dr. Luiz Guilherme de Oliveira 


\begin{abstract}
UNIVERSIDADE DE BRASÍLIA - UnB
INSTITUTO DE CIÊNCIAS SOCIAIS - ICS

CENTRO DE PESQUISA E PÓS-GRADUAÇÃO SOBRE AS AMÉRICAS - CEPPAC PROGRAMA DE PÓS-GRADUAÇÃO EM ESTUDOS COMPARADOS
\end{abstract}

TESE DE DOUTORADO

\title{
ESTRATÉGIAS DE DESENVOLVIMENTO E POLÍTICA INDUSTRIAL DE PETRÓLEO E GÁS: uma comparação entre Brasil, México e Noruega
}

Autor: Maurício Ebling

Banca Examinadora:

Titulares:

Prof. Dr. Luiz Guilherme de Oliveira (CEPPAC/UnB) - Orientador

Prof. Dr. Benício Viero Schmidt (CEPPAC/UnB)

Prof. Dr. Paulo Du Pin Calmon (IPOL/UnB)

Prof. Dr. Mário Lúcio de Ávila (PPGP/UnB)

Prof. Dr. Luciano Cunha de Sousa (STI/MDIC)

Suplente:

Prof. Dr. Martin-Léon-Jacques Ibañez de Novion (CEPPAC/UnB) 
Dedico este trabalho a três mulheres que não estão mais aqui para poderem ver brotar os frutos de minha caminhada, mas que muito me ajudaram a plantar as sementes que me trouxeram até aqui.

Para minha vó materna, Walli Arendt Dienstmann, de quem eu não pude estar por perto na hora de sua partida, porque esta pesquisa me exigiu ir para longe. Foi o preço mais alto que paguei por este trabalho.

Para minha vó paterna, Paula Elisabeth Ruth Ebling, que mesmo já tendo me deixado há mais tempo, parece que conhecia o meu caminho antes mesmo de mim. Queria muito que ela pudesse ver onde já cheguei.

E a minha terceira vó, Mathilde Camilo Issa Musse, que mesmo já tendo partido, representa aqui toda uma família que me adotou e que fez eu me sentir parte dela. Jamais teria chegado até aqui sem eles.

Dedico este trabalho também a uma mulher que esteve do meu lado nos melhores e nos piores momentos desta pesquisa, e com quem espero dividir todos os momentos que ainda virão em nossas vidas.

Para minha noiva, Anita Cunha Monteiro, que me inspira diariamente para que eu seja sempre a melhor versão de mim mesmo. Da maneira mais simples e verdadeira, ela é a mulher que eu amo e que me faz feliz. 


\section{AGRADECIMENTOS}

Este trabalho não seria possível sem a ajuda de muitas pessoas que contribuíram de diferentes maneiras para torná-lo realidade. Seria impossível elencar aqui todos aqueles que fizeram parte deste processo, pois muitos contribuíram para minha formação, muitos foram meus amigos durante o caminho e muitos foram atenciosos e dedicados mesmo com os menores detalhes, que também são parte importante de um longo trabalho como este. Por isso, agradeço a todos que fizeram parte desta história, mas me sinto obrigado a destacar algumas pessoas que tiveram uma participação mais direta durante o trabalho de pesquisa.

Ninguém merece mais agradecimentos do que minha noiva, Anita Cunha Monteiro, que me apoiou mesmo nos momentos mais desafiadores e que me deu todo suporte que eu precisava. Ela ouviu todas minhas ideias e planos, me indicou caminhos quando eu estava perdido, me ensinou muita coisa que eu não sabia, enfrentou tudo que foi necessário para que esse projeto fosse possível, nos sustentou sozinha para que eu pudesse me dedicar somente a esta pesquisa, suportou minhas crises, cuidou das minhas dores, aguentou minha ausência, me cobrou quando eu precisava ser cobrado e me deu carinho quando eu precisava de carinho. Este trabalho é meu e dela.

Agradeço a minha sogra, Maria do Socorro Cunha Pereira, que me acolheu na sua casa sempre que precisei e que viveu comigo os últimos meses deste trabalho, onde todas dificuldades afloraram. Tanto apoio e compreensão, só mesmo uma mãe pode dar.

Agradeço a minha mãe, Suzete Dienstmann, que durante toda a minha vida sempre esteve do meu lado, me apoiando mesmo quando ela acreditava que eu estava errado. Esse trabalho é uma obra minha, mas eu sou uma obra dela. Tudo que sou, devo a ela.

Agradeço a meu pai, Fredo Ebling Júnior, que tanto me apoiou nesta caminhada, seja debatendo sobre a tese, seja me apoiando para que eu pudesse fazer muito mais do que poderia fazer sozinho. Esta tese não seria a mesma sem ele.

Agradeço a meu segundo pai, Carlos Alberto Issa Musse, que nunca se limitou ao papel de padrasto e sempre fez tudo que pôde por mim. Ninguém me ensinou tanto sobre a importância de me dedicar aos meus estudos. Espero estar começando a retribuir.

Agradeço a meu vô, Fredo Arno Ebling, que sempre demonstrou interesse sobre tudo que fiz na vida, e esse interesse dele sempre foi uma das minhas maiores motivações para tentar fazer tudo da melhor maneira possível. Ele é minha referência.

Agradeço a meu amigo, Michel Fernandes da Rosa, com quem compartilhei as dúvidas e angústias de todo processo que envolve o doutorado. É muito bom ter alguém que nos entenda e em quem a gente acredite para enfrentar esses desafios.

Agradeço a meu orientador, professor Luiz Guilherme de Oliveira, por todo apoio e compreensão ao longo deste caminho cheio de obstáculos. 
Agradeço a meu supervisor durante o doutorado sanduíche na Universidade de Oxford, professor Diego Sánchez-Ancochea, que abriu novos horizontes para esta pesquisa, e a quem tenho como um exemplo de profissional sério e dedicado a ser seguido.

Agradeço à professora Rosemary Thorp, para quem tive a honra de trabalhar, e que me ensinou que é possível conciliar sucesso profissional com humildade, sem diminuir em nada a vontade por seguir trabalhando, aprendendo e contribuindo.

Agradeço à Elvira Ryan, que me deu todo suporte necessário durante o doutorado sanduíche, e me ensinou que não há nada que a força de vontade não ajude a superar.

Agradeço ao professor Yuri Kasahara, que me recebeu na cidade de Oslo e contribuiu para o debate levantado por esta tese, para questões metodológicas importantes para a realização desta comparação e para o entendimento sobre a realidade norueguesa.

Agradeço ao professor Helge Ryggvik, que teve a atenção e dedicação de compartilhar seu conhecimento e experiência sobre o setor de petróleo norueguês.

Agradeço à professora Pamela Starr, por dividir seus conhecimentos sobre o caso mexicano e pela ajuda com o trabalho de campo realizado no México.

Agradeço a Eduardo Fernando Santos, da Petrobras, por toda atenção e dedicação, que foram fundamentais para a realização do trabalho de campo no Brasil.

Agradeço ao Conselho Nacional de Desenvolvimento Científico e Tecnológico CNPq, pela bolsa de doutorado pleno no Brasil, que permitiu a realização desta pesquisa.

Agradeço à Coordenação de Aperfeiçoamento de Pessoal de Nível Superior CAPES, pela bolsa do programa de doutorado sanduíche no exterior, que permitiu a realização do estágio de doutorado sanduíche na Universidade de Oxford.

Agradeço a Daniella Bittencourt, do Instituto Brasileiro de Petróleo, Gás e Biocombustíveis, que mesmo sem me conhecer, nem ganhar nada em troca, me deu de presente (e enviou do Rio de Janeiro para Brasília) o livro do professor Ryggvik, que foi fundamental para a realização deste trabalho. São atitudes como essa que fazem toda dificuldade valer a pena. 


\section{RESUMO}

Esta pesquisa procura responder à pergunta sobre o que serve de base para a definição da política industrial de petróleo e gás no Brasil, no México e na Noruega. A hipótese a ser testada é a de que a política industrial de petróleo e gás desses três países seja definida com base na estratégia de desenvolvimento adotada por cada governo. Conforme o referencial teórico utilizado, existe uma polarização entre dois paradigmas político econômicos, que destacam a importância do papel do Estado ou do mercado para o desenvolvimento de um país. A literatura sobre política industrial parece seguir a mesma divisão, destacando a necessidade de intervenção estatal ou de liberalização de mercado para o desenvolvimento. Dessa forma, governos com estratégias de desenvolvimento baseadas no Estado estariam relacionados com a adoção de políticas industriais intervencionistas, utilizando instrumentos como fechamento do mercado, empresas estatais, adoção do modelo de partilha da produção e políticas de nacionalização da cadeia produtiva, como políticas de conteúdo local. Já governos com estratégias de desenvolvimento baseadas no mercado estariam relacionados com a adoção de políticas industriais liberalizantes, utilizando instrumentos como abertura do mercado, privatização de empresas estatais, adoção do modelo de concessão, e políticas de internacionalização, com uma cadeia produtiva globalizada. A teoria também oferece modelos que procuram se distinguir dessa polarização entre o foco no papel do Estado ou no papel do mercado como agentes de desenvolvimento. Enquanto o novo desenvolvimentismo procura combinar a importância destes dois papéis, o estruturalismo da CEPAL destaca a relação entre estrutura e ambiente e a literatura sobre política industrial tenta alinhar a utilização de instrumentos protecionistas com instrumentos liberalizantes. Outros autores utilizam uma perspectiva econômica evolucionista para analisar as diferenças entre ciclos econômicos, entre setores da indústria e entre países desenvolvidos e em desenvolvimento. Todas estas variações parecem contradizer à polarização excludente entre Estado e mercado, apontando para a necessidade de mecanismos que permitam uma definição mais ágil e flexível de cada política industrial. Utiliza-se também a literatura sobre análise sistêmica e mecanismos de monitoramento e avaliação de políticas como uma alternativa à essa visão polarizada. Para testar a hipótese levantada são realizadas análises sobre a história da indústria de cada país, procurando encontrar correlações entre as estratégias de desenvolvimento adotadas por cada governo e os instrumentos de política industrial adotados por eles, que possam indicar a ocorrência de algum padrão ao longo do tempo. Entrevistas em profundidade foram realizadas com representantes do governo e das associações empresariais, para tentar aprofundar a compreensão sobre a forma como é feita a definição da política industrial de cada país. Para a análise dos dados, primeiramente se apresenta uma sistematização dos dados dentro de cada grupo de atores. Em seguida, essas informações são cruzadas, para que se compare as respostas apresentadas pelo governo e pelas associações de cada país. Por último, é feita a comparação entre os três estudos de caso, indicando como que a experiência de cada país pode contribuir para a realidade dos demais países analisados.

\section{Palavras Chave: Desenvolvimento - Política Industrial - Petróleo e Gás}




\section{ABSTRACT}

This research aims to answer the question of what serve as a basis for the definition of the industrial policy for the oil and gas sector in Brazil, Mexico and Norway. It will test the hypothesis that the industrial policy for oil and gas in these three countries is defined based on the development strategy adopted by each government. According to the theoretical framework analysed, there is a polarization between two political economic paradigms, which highlight the role of the state, or the role of the market for a country's development. Literature on industrial policy seems to follow the same division, highlighting the need for state intervention, or the need for market liberalization for the development of a country's industry. Thus, governments with development strategies based on the state's role would be related to the adoption of interventionist industrial policies, using tools such as market closing, state-owned companies, adoption of a sharing model for production, and nationalization policies for the supply chain, such as local content requirements. Governments with market-based development strategies would be related to the adoption of liberalizing industrial policies, using tools such as market opening, privatization of state-owned companies, adoption of a concession model, and internationalization policies, adopting a global production chain. Theory also offers some models that seek for distinguish from this polarization. While new developmentalism seeks to combine the importance of these two roles, ECLAC's structuralism highlights the relationship between structure and environment and the literature on industrial policy tries to align the use of protectionist and liberalizing instruments. Other authors use an evolutionary economic perspective to analyse the differences between economic cycles, between industry sectors and between developed and developing countries. All these variations appear to contradict the exclusionary polarization between state and market, pointing to the need for mechanisms that allow a more agile and flexible definition of each industrial policy. It is also used a literature on systemic analysis and on policy monitoring and evaluation mechanisms as an alternative to this polarized view between only two possible types of industrial policy. To test the hypothesis and try to answer the research question, analyses are performed on the history of each country's industry, trying to find correlations between the development strategies adopted by the Brazilian, Mexican and Norwegian governments and the industrial policy instruments adopted by them, that could indicate the occurrence of a pattern over time. In-depth interviews were conducted with representatives from the government and the business associations from the oil and gas industry of the three countries, to try to deepen the understanding of how it is made the definition of the industrial policy of each country. For the data analysis, first it presents a data systematization within each group of actors. Then, this information is crossed, in order to compare the answers given by the government and the associations in each country. Finally, the comparison between the three case studies is made, indicating how the experience of each country can contribute to the reality of other countries analysed.

\section{Key-Words: Development - Industrial Policy - Oil and Gas}




\section{SUMÁRIO}

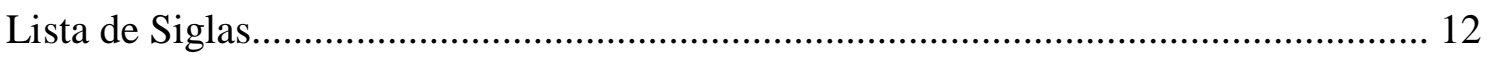

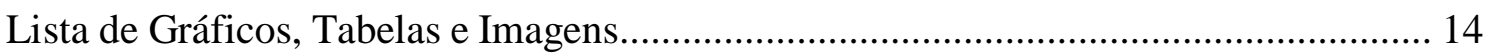

INTRODUÇÃ

Capítulo 1 - Análise do Referencial Teórico................................................................... 25

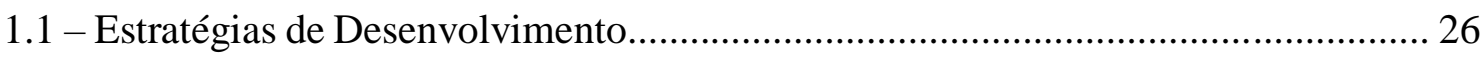

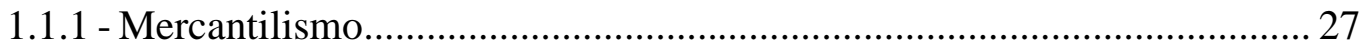

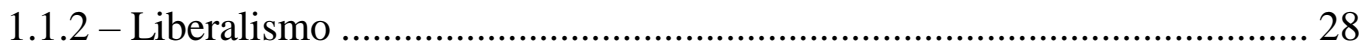

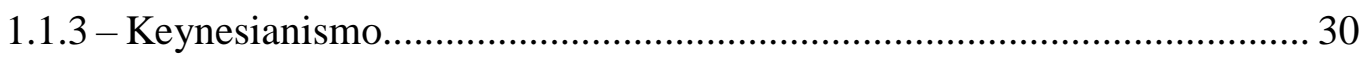

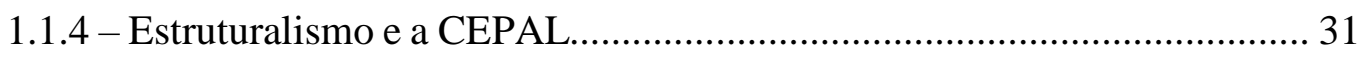

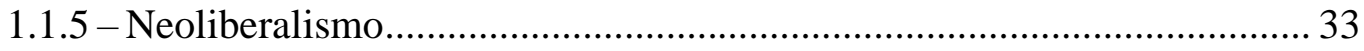

1.1.6 - Novo Desenvolvimentismo............................................................... 34

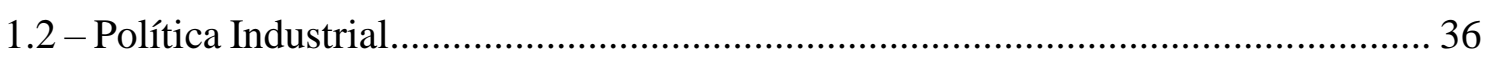

1.2.1 - Intervenção ou Liberalização.................................................................. 37

1.2.2 - Evolucionismo Econômico....................................................................... 40

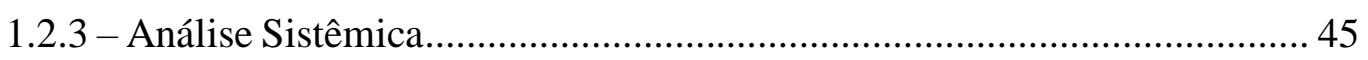

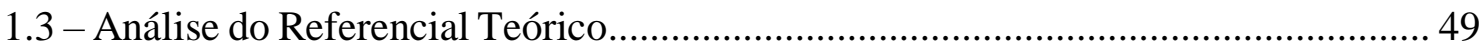

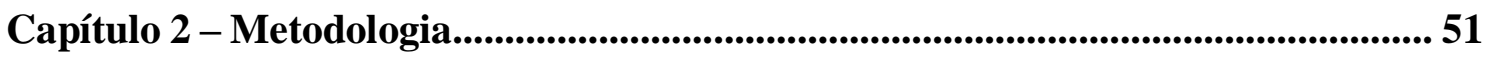

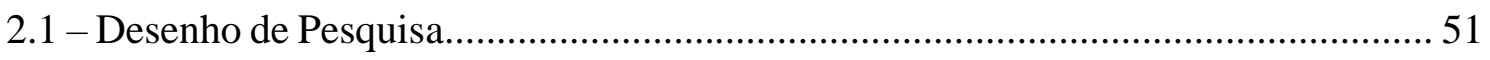

2.2 - Estrutura da Contextualização Histórica................................................................ 52

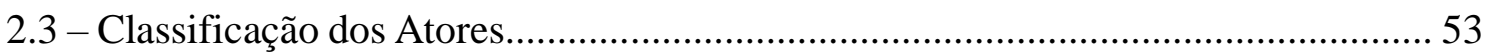

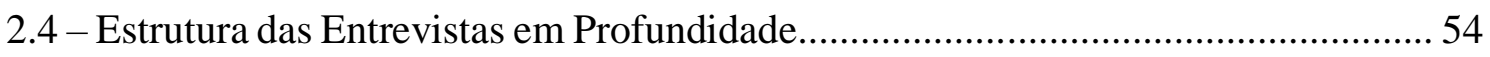

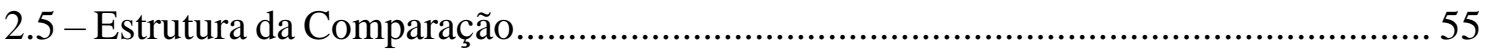

Capítulo 3 - Estudo de Caso: Brasil............................................................................ 61

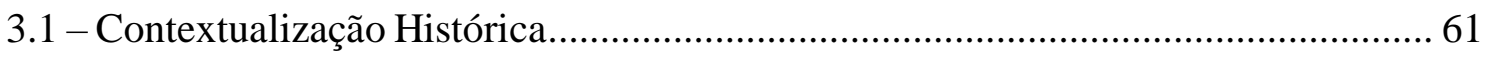

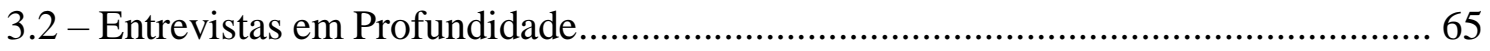

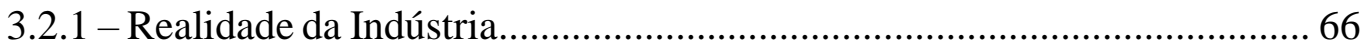

3.2.2 - Valores da Política.......................................................................... 74 


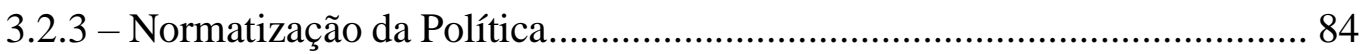

3.2.4 - Implementação da Política................................................................... 89

3.2.5 - Resultados da Política............................................................................. 95

3.2.6 - Avaliação da Política....................................................................... 100

3.2.7 - Reação aos Resultados da Política......................................................... 103

3.28 - Resultado das Avaliações.................................................................... 106

3.2.9 - Relação Entre Atores......................................................................... 110

Capítulo 4 - Estudo de Caso: México...........................................................................117

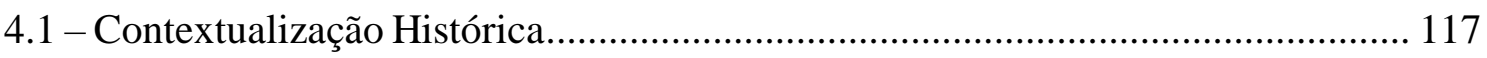

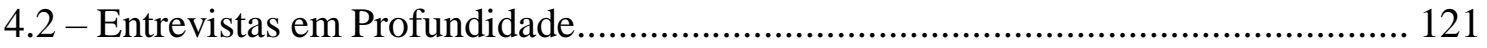

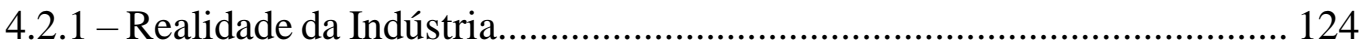

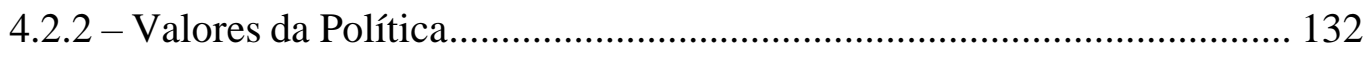

4.2.3 - Normatização da Política................................................................... 140

4.2.4 - Implementação da Política.................................................................. 146

4.2.5 - Resultados da Política......................................................................... 154

4.2.6 - Avaliação da Política......................................................................... 160

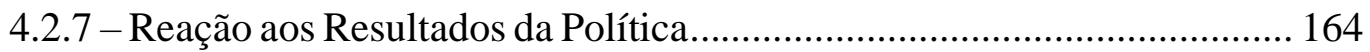

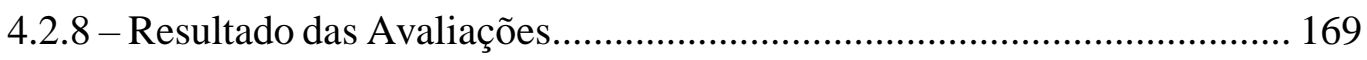

4.2.9 - Relação Entre Atores.................................................................... 174

Capítulo 5 - Estudo de caso: Noruega..................................................................... 184

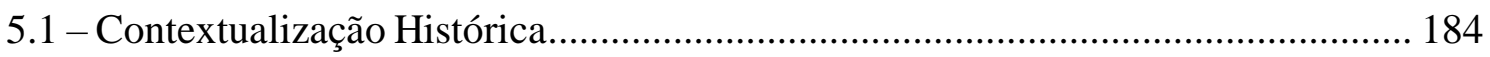

5.2 - Entrevistas em Profundidade.......................................................................... 191

5.2.1 - Realidade da Indústria.................................................................... 193

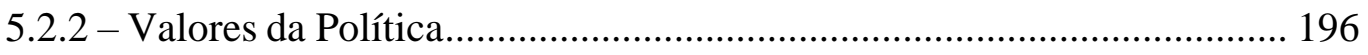

5.2.3 - Normatização da Política...................................................................... 203

5.2.4 - Implementação da Política............................................................... 207

5.2.5 - Resultados da Política........................................................................... 211

5.2.6 - Avaliação da Política....................................................................... 215

5.2.7 - Reação aos Resultados da Política........................................................ 219

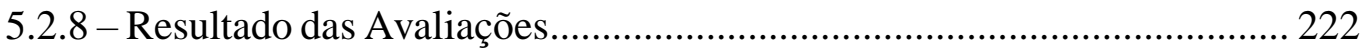

5.2.9 - Relação Entre Atores...................................................................... 226 
6.1.1 - Total das Avaliações Objetivas........................................................... 233

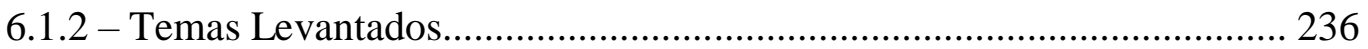

6.1.3 - Variação das Avaliações Objetivas..................................................... 241

6.1 .4 - Relação Entre Atores...................................................................... 248

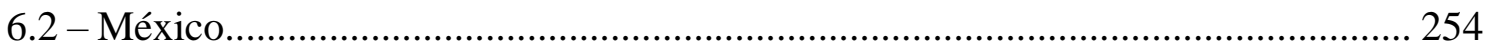

6.2.1 - Total das Avaliações Objetivas............................................................ 254

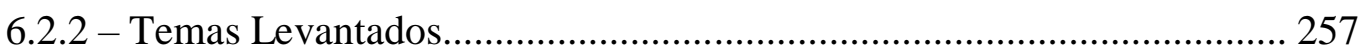

6.2.3 - Variação das Avaliações Objetivas........................................................ 264

6.2.4 - Relação Entre Atores......................................................................... 271

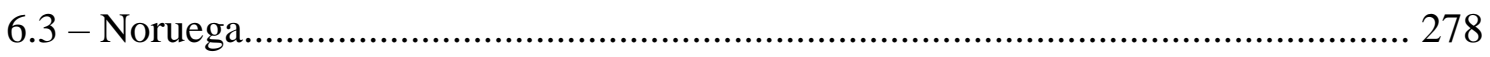

6.3.1 - Total das Avaliações Objetivas......................................................... 278

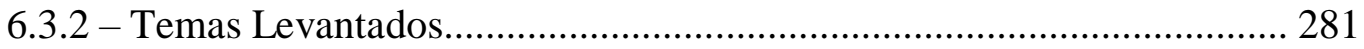

6.3.3 - Variação das Avaliações Objetivas..................................................... 288

6.3.4 - Relação Entre Atores......................................................................... 294

Capítulo 7 - Comparação entre Brasil, México e Noruega....................................... 301

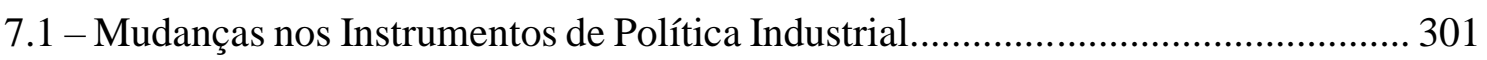

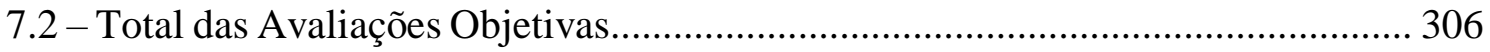

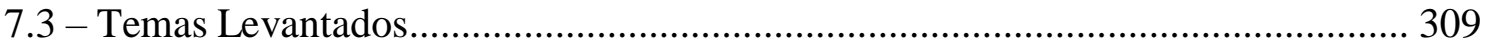

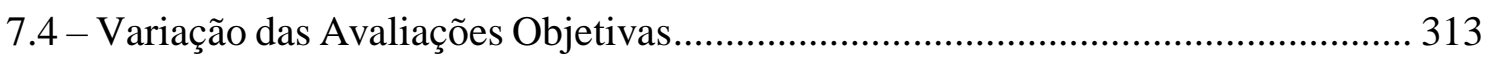

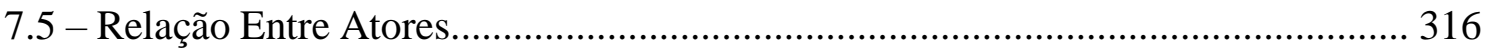

CONSIDERAÇÕES FINAIS....................................................................................... 323

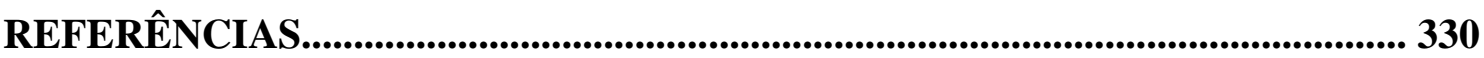

ANEXO I - LISTA DE ENTREVISTADOS........................................................ 342

ANEXO II - ROTEIROS DAS ENTREVISTAS............................................. 350 


\section{LISTA DE SIGLAS}

ABESPetro

ANP

BNDES

BP

CEPAL

CFE

CIDAC

CIDE

CNH

CNPE

Cofemer

ECLAC

EITI

Embraer

EPC

FMC

FPSO

Gás LP

IBP

IMCO

INTSOK

MDIC

MME
Associação Brasileira das Empresas de Serviços de Petróleo

Agência Nacional do Petróleo, Gás Natural e Biocombustíveis

Banco Nacional do Desenvolvimento

British Petroleum

Comissão Econômica para a América Latina e o Caribe

Comisión Federal de Electricidad

Centro de Investigación para el Desarollo

Centro de Investigación y Docencia Económicas

Comisión Nacional de Hidrocarburos

Conselho Nacional de Política Energética

Comisión Federal de Mejora Regulatoria

Economic Commission for Latin America and the Caribbean

Extractive Industry Transparent Initiative

Embraer S.A.

Engineering, Procurement, Construction

FMC Technologies

Floating, Production, Storage and Offloading

Gás Liquefeito de Petróleo

Instituto Brasileiro de Petróleo, Gás e Biocombustíveis

Instituto Mexicano de la Competitividad

Norwegian Oil \& Gas Partners

Ministério do Desenvolvimento, Indústria e Comércio Exterior

Ministério de Minas e Energia 
NAFTA

NORAD

NORSOK

OMC

ONIP

OPEP

P\&D

PAN

PBM

PDVSA

Pemex

Petrobras

PRI

Prominp

QCA

TEC

TPP

UE

UFRJ
Tratado Norte-Americano de Livre Comércio

Norwegian Agency for Development Cooperation

Norwegian Shelf's Competitive Position

Organização Mundial do Comércio

Organização Nacional da Indústria do Petróleo

Organização dos Países Exportadores de Petróleo

Pesquisa e Desenvolvimento

Partido Acción Nacional

Plano Brasil Maior

Petróleos de Venezuela

Petróleos Mexicanos

Petróleo Brasileiro S.A

Partido Revolucionário Institucional

Programa de Mobilização da Indústria Nacional de Petróleo e Gás Natural

Qualitative Comparative Analysis

Instituto Tecnológico de Estudios Superiores de Monterrey

Trans-Pacific Partnership

União Europeia

Universidade Federal do Rio de Janeiro 


\section{LISTA DE GRÁFICOS, TABELAS E IMAGENS}

Imagem 1 - Desenho de pesquisa

Tabela 1 - Lista de atores entrevistados pela pesquisa e seus respectivos

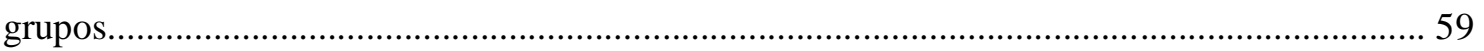

Tabela 2 - Variáveis utilizadas para a construção dos instrumentos de

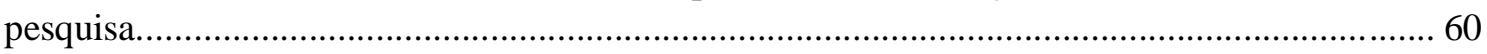

Gráfico 1 - Avaliações dos entrevistados do governo do Brasil sobre a realidade da indústria que serviu de base para a política industrial do país.

Gráfico 2 - Avaliações dos entrevistados das associações empresariais do Brasil sobre a realidade da indústria que serviu de base para a política industrial do país

Gráfico 3 - Avaliações dos entrevistados do governo do Brasil sobre os valores da política industrial de petróleo e gás no país. .75

Gráfico 4 - Avaliações dos entrevistados das associações empresariais do Brasil sobre os valores da política industrial de petróleo e gás no país.

Gráfico 5 - Avaliações dos entrevistados do governo do Brasil sobre a normatização da política industrial de petróleo e gás no país 84

Gráfico 6 - Avaliações dos entrevistados das associações empresariais do Brasil sobre a normatização da política industrial de petróleo e gás no país.

Gráfico 7 - Avaliações dos entrevistados do governo do Brasil sobre a implementação da política industrial de petróleo e gás no país

Gráfico 8 - Avaliações dos entrevistados das associações do Brasil sobre a implementação da política industrial de petróleo e gás no país.

Gráfico 9 - Avaliações dos entrevistados do governo do Brasil sobre os resultados da política industrial de petróleo e gás no país

Gráfico 10 - Avaliações dos entrevistados das associações empresariais do Brasil sobre os resultados da política industrial de petróleo e gás no país.

Gráfico 11 - Avaliações dos entrevistados do governo do Brasil sobre a avaliação da política industrial de petróleo e gás no país 100

Gráfico 12 - Avaliações dos entrevistados das associações empresariais do Brasil sobre a avaliação da política industrial de petróleo e gás no país.

Gráfico 13 - Avaliações dos entrevistados do governo do Brasil sobre a reação aos resultados da avaliação da política industrial de petróleo e gás no país. 104

Gráfico 14 - Avaliações dos entrevistados das associações empresariais do Brasil sobre a reação aos resultados da avaliação da política industrial de petróleo e gás no país...... 105

Gráfico 15 - Avaliação sobre as diferentes etapas da política industrial de petróleo e gás no país, pela entrevista 1 do governo do Brasil. 
Gráfico 16 - Avaliação sobre as diferentes etapas da política industrial de petróleo e gás no país,

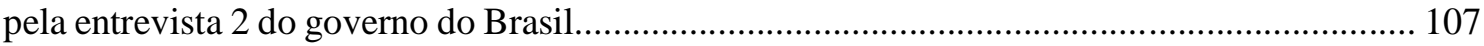

Gráfico 17 - Avaliação sobre as diferentes etapas da política industrial de petróleo e gás no país, pela entrevista 3 do governo do Brasil. 108

Gráfico 18 - Avaliação sobre as diferentes etapas da política industrial de petróleo e gás no país, pela entrevista 1 das associações empresariais do Brasil. 108

Gráfico 19 - Avaliação sobre as diferentes etapas da política industrial de petróleo e gás no país, pela entrevista 2 das associações empresariais do Brasil. 109

Gráfico 20 - Avaliação sobre as diferentes etapas da política industrial de petróleo e gás no país, pela entrevista 3 das associações empresariais do Brasil.

Gráfico 21 - Avaliação sobre as diferentes etapas da política industrial de petróleo e gás no país, pela entrevista 4 das associações empresariais do Brasil.

Gráfico 22 - Percentual de menções positivas e negativas nas respostas do governo sobre a relação entre os atores na orientação da política industrial brasileira.

Gráfico 23 - Percentual de menções positivas e negativas nas respostas das associações empresariais sobre a relação entre os atores na orientação da política industrial brasileira. 114

Gráfico 24 - Avaliações dos entrevistados do governo do México sobre a realidade da indústria que serviu de base para a política industrial do país. 124

Gráfico 25 - Avaliações dos entrevistados das associações empresariais do México sobre a realidade da indústria que serviu de base para a política industrial do país.

Gráfico 26 - Avaliações dos entrevistados do governo do México sobre os valores da política industrial de petróleo e gás no país.

Gráfico 27 - Avaliações dos entrevistados das associações empresariais do México sobre os valores da política industrial de petróleo e gás no país..... 136

Gráfico 28 - Avaliações dos entrevistados do governo do México sobre a normatização da política industrial de petróleo e gás no país

Gráfico 29 - Avaliações dos entrevistados das associações empresariais do México sobre a normatização da política industrial de petróleo e gás no país 144

Gráfico 30 - Avaliações dos entrevistados do governo do México sobre a implementação da política industrial de petróleo e gás no país.

Gráfico 31 - Avaliações dos entrevistados das associações empresariais do México sobre a implementação da política industrial de petróleo e gás no país.

Gráfico 32 - Avaliações dos entrevistados do governo do México sobre os resultados da política industrial de petróleo e gás no país

Gráfico 33 - Avaliações dos entrevistados das associações empresariais do México sobre os resultados da política industrial de petróleo e gás no país.

Gráfico 34 - Avaliações dos entrevistados do governo do México sobre a avaliação da política industrial de petróleo e gás no país. 
Gráfico 35 - Avaliações dos entrevistados das associações empresariais do México sobre a avaliação da política industrial de petróleo e gás no país.

Gráfico 36 - Avaliações dos entrevistados do governo do México sobre a reação aos resultados da avaliação da política industrial de petróleo e gás no país.

Gráfico 37 - Avaliações dos entrevistados das associações empresariais do México sobre a reação aos resultados da avaliação da política industrial de petróleo e gás no país.

Gráfico 38 - Avaliação sobre as diferentes etapas da política industrial de petróleo e gás no país, pela entrevista 1 do governo do México.

Gráfico 39 - Avaliação sobre as diferentes etapas da política industrial de petróleo e gás no país, pela entrevista 2 do governo do México.

Gráfico 40 - Avaliação sobre as diferentes etapas da política industrial de petróleo e gás no país, pela entrevista 3 do governo do México.

Gráfico 41 - Avaliação sobre as diferentes etapas da política industrial de petróleo e gás no país, pela entrevista 4 do governo do México.

Gráfico 42 - Avaliação sobre as diferentes etapas da política industrial de petróleo e gás no país, pela entrevista 1 das associações empresariais do México...

Gráfico 43 - Avaliação sobre as diferentes etapas da política industrial de petróleo e gás no país, pela entrevista 2 das associações empresariais do México. 172

Gráfico 44 - Avaliação sobre as diferentes etapas da política industrial de petróleo e gás no país, pela entrevista 3 das associações empresariais do México.

Gráfico 45 - Avaliação sobre as diferentes etapas da política industrial de petróleo e gás no país, pela entrevista 4 das associações empresariais do México.

Gráfico 46 - Percentual de menções positivas e negativas nas respostas do governo sobre a relação entre os atores na orientação da política industrial mexicana 174

Gráfico 47 - Percentual de menções positivas e negativas nas respostas das associações empresariais sobre a relação entre os atores na orientação da política industrial mexicana.

Gráfico 48 - Avaliações dos entrevistados do governo da Noruega sobre a realidade da indústria que serviu de base para a política industrial do país. 193

Gráfico 49 - Avaliações dos entrevistados das associações empresariais da Noruega sobre a realidade da indústria que serviu de base para a política industrial do país.

Gráfico 50 - Avaliações dos entrevistados do governo da Noruega sobre os valores da política industrial de petróleo e gás no país.

Gráfico 51 - Avaliações dos entrevistados das associações empresariais da Noruega sobre os valores da política industrial de petróleo e gás no país.

Gráfico 52 - Avaliações dos entrevistados do governo da Noruega sobre a normatização da política industrial de petróleo e gás no país.

Gráfico 53 - Avaliações dos entrevistados das associações empresariais da Noruega sobre a normatização da política industrial de petróleo e gás no país. 
Gráfico 54 - Avaliações dos entrevistados do governo da Noruega sobre a implementação da política industrial de petróleo e gás no país.

Gráfico 55 - Avaliações dos entrevistados das associações empresariais da Noruega sobre a implementação da política industrial de petróleo e gás no país.

Gráfico 56 - Avaliações dos entrevistados do governo da Noruega sobre os resultados da política industrial de petróleo e gás no país.

Gráfico 57 - Avaliações dos entrevistados das associações empresariais da Noruega sobre os resultados da política industrial de petróleo e gás no país.

Gráfico 58 - Avaliações dos entrevistados do governo da Noruega sobre a avaliação da política industrial de petróleo e gás no país.

Gráfico 59 - Avaliações dos entrevistados das associações empresariais da Noruega sobre a avaliação da política industrial de petróleo e gás no país.

Gráfico 60 - Avaliações dos entrevistados do governo da Noruega sobre a reação aos resultados da avaliação da política industrial de petróleo e gás no país.

Gráfico 61 - Avaliações dos entrevistados das associações empresariais da Noruega sobre a reação aos resultados da avaliação da política industrial de petróleo e gás no país.

Gráfico 62 - Avaliação sobre as diferentes etapas da política industrial de petróleo e gás no país, pela entrevista 1 do governo da Noruega.

Gráfico 63 - Avaliação sobre as diferentes etapas da política industrial de petróleo e gás no país, pela entrevista 2 do governo da Noruega......

Gráfico 64 - Avaliação sobre as diferentes etapas da política industrial de petróleo e gás no país, pela entrevista 1 das associações empresariais da Noruega.

Gráfico 65 - Avaliação sobre as diferentes etapas da política industrial de petróleo e gás no país, pela entrevista 2 das associações empresariais da Noruega... 224

Gráfico 66 - Avaliação sobre as diferentes etapas da política industrial de petróleo e gás no país, pela entrevista 3 das associações empresariais da Noruega......

Gráfico 67 - Avaliação sobre as diferentes etapas da política industrial de petróleo e gás no país, pela entrevista 4 das associações empresariais da Noruega...

Gráfico 68 - Percentual de menções positivas e negativas nas respostas do governo sobre a relação entre os atores na orientação da política industrial norueguesa...... 226

Gráfico 69 - Percentual de menções positivas e negativas nas respostas das associações empresariais sobre a relação entre atores na orientação da política industrial norueguesa..

Gráfico 70 - Total das avaliações sobre as diferentes etapas da política industrial de petróleo e gás nas entrevistas do governo do Brasil.

Gráfico 71 - Total das avaliações sobre as diferentes etapas da política industrial de petróleo e gás nas entrevistas das associações empresariais do Brasil.

Gráfico 72 - Comparação entre as medianas do total das avaliações sobre as diferentes etapas da política industrial de petróleo e gás no Brasil. 235 
Gráfico 73 - Variação das avaliações sobre as diferentes etapas da política industrial de petróleo e gás nas entrevistas do governo do Brasil.

Gráfico 74 - Desvio entre a avaliação de cada entrevistado e a média das avaliações do governo, para cada etapa da política industrial de petróleo e gás no Brasil.

Gráfico 75 - Variação das avaliações sobre as diferentes etapas da política industrial de petróleo e gás nas entrevistas das associações empresariais do Brasil.

Gráfico 76 - Desvio entre a avaliação de cada entrevistado e a média das avaliações das associações empresariais, para cada etapa da política industrial de petróleo e gás no Brasil. 244

Gráfico 77 - Comparação dos desvios dentro de cada grupo, nas respostas sobre as avaliações de cada etapa da política industrial de petróleo e gás no Brasil.

Gráfico 78 - Percentual de variação na avaliação de cada grupo sobre todas as etapas da política industrial de petróleo e gás no Brasil. 246

Gráfico 79 - Soma dos desvios entre a avaliação de cada entrevistado e a média das avaliações dos dois grupos, para cada etapa da política industrial de petróleo e gás no Brasil. 247

Gráfico 80 - Percentual de menções positivas e negativas nas respostas dos dois grupos brasileiros sobre a percepção que um grupo tem do outro. 248

Gráfico 81 - Percentual de menções positivas e negativas nas respostas dos dois grupos sobre a participação do seu próprio grupo na política industrial do Brasil.

Gráfico 82 - Percentual de menções positivas e negativas nas respostas dos dois grupos brasileiros sobre o recebimento da sua participação pelo outro grupo.

Gráfico 83 - Percentual de menções positivas e negativas nas respostas dos dois grupos sobre a interação dos atores na política industrial brasileira

Gráfico 84 - Total das avaliações sobre as diferentes etapas da política industrial de petróleo e gás nas entrevistas do governo do México.

Gráfico 85 - Total das avaliações sobre as diferentes etapas da política industrial de petróleo e gás nas entrevistas das associações empresariais do México

Gráfico 86 - Comparação entre as medianas do total das avaliações sobre as diferentes etapas da política industrial de petróleo e gás no México. 256

Gráfico 87 - Variação das avaliações sobre as diferentes etapas da política industrial de petróleo e gás nas entrevistas do governo do México.

Gráfico 88 - Desvio entre a avaliação de cada entrevistado e a média das avaliações do governo, para cada etapa da política industrial de petróleo e gás no México. 266

Gráfico 89 - Variação das avaliações sobre as diferentes etapas da política industrial de petróleo e gás nas entrevistas das associações empresariais do México. 267

Gráfico 90 - Desvio entre a avaliação de cada entrevistado e a média das avaliações das associações empresariais, para cada etapa da política industrial de petróleo e gás no México. 268 
Gráfico 91 - Comparação dos desvios dentro de cada grupo, nas respostas sobre as avaliações de cada etapa da política industrial de petróleo e gás no México.

Gráfico 92 - Percentual de variação na avaliação de cada grupo sobre todas as etapas da política industrial de petróleo e gás no México.

Gráfico 93 - Soma dos desvios entre a avaliação de cada entrevistado e a média das avaliações dos dois grupos, para cada etapa da política industrial de petróleo e gás no México. 271

Gráfico 94 - Percentual de menções positivas e negativas nas respostas dos dois grupos mexicanos sobre a percepção que um grupo tem do outro.

Gráfico 95 - Percentual de menções positivas e negativas nas respostas dos dois grupos sobre a participação do seu próprio grupo na política industrial do México.

Gráfico 96 - Percentual de menções positivas e negativas nas respostas dos dois grupos mexicanos sobre o recebimento da sua participação pelo outro grupo..... 276

Gráfico 97 - Percentual de menções positivas e negativas nas respostas dos dois grupos sobre a interação dos atores na política industrial mexicana.

Gráfico 98 - Total das avaliações sobre as diferentes etapas da política industrial de petróleo e gás nas entrevistas do governo da Noruega......

Gráfico 99 - Total das avaliações sobre as diferentes etapas da política industrial de petróleo e gás nas entrevistas das associações empresariais da Noruega.

Gráfico 100 - Comparação entre as medianas do total das avaliações sobre as diferentes etapas da política industrial de petróleo e gás na Noruega.

Gráfico 101 - Variação das avaliações sobre as diferentes etapas da política industrial de petróleo e gás nas entrevistas do governo da Noruega. 288

Gráfico 102 - Desvio entre a avaliação de cada entrevistado e a média das avaliações do governo, para cada etapa da política industrial de petróleo e gás na Noruega... 289

Gráfico 103 - Variação das avaliações sobre as diferentes etapas da política industrial de petróleo e gás nas entrevistas das associações empresariais da Noruega.

Gráfico 104 - Desvio entre a avaliação de cada entrevistado e a média das avaliações das associações empresariais, para cada etapa da política industrial de petróleo e gás na Noruega.

Gráfico 105 - Comparação dos desvios dentro de cada grupo, nas respostas sobre as avaliações de cada etapa da política industrial de petróleo e gás na Noruega.

Gráfico 106 - Percentual de variação na avaliação de cada grupo sobre todas as etapas da política industrial de petróleo e gás na Noruega

Gráfico 107 - Soma dos desvios entre a avaliação de cada entrevistado e a média das avaliações dos dois grupos, para cada etapa da política industrial de petróleo e gás na Noruega.......

Gráfico 108 - Percentual de menções positivas e negativas nas respostas dos dois grupos noruegueses sobre a percepção que um grupo tem do outro. 
Gráfico 109 - Percentual de menções positivas e negativas nas respostas dos dois grupos sobre a participação do seu próprio grupo na política industrial da Noruega.

Gráfico 110 - Percentual de menções positivas e negativas nas respostas dos dois grupos noruegueses sobre o recebimento da sua participação pelo outro grupo.

Gráfico 111 - Percentual de menções positivas e negativas nas respostas dos dois grupos sobre a interação dos atores na política industrial norueguesa.

Tabela 3 - Relação entre os instrumentos de política industrial utilizados e as estratégias de desenvolvimento de cada governo, ao longo da história brasileira. 303

Tabela 4 - Relação entre os instrumentos de política industrial utilizados e as estratégias de desenvolvimento de cada governo, ao longo da história mexicana. 304

Tabela 5 - Relação entre os instrumentos de política industrial utilizados e as estratégias de desenvolvimento de cada governo, ao longo da história norueguesa 305

Gráfico 112 - Comparação entre a média do total das avaliações de ambos os grupos, sobre as diferentes etapas da política industrial de petróleo e gás, nos três países. 306

Gráfico 113 - Percentual de aprovação na avaliação de cada grupo, sobre todas as etapas da política industrial de petróleo e gás, em cada um dos três países. 308

Gráfico 114 - Comparação dos desvios entre a avaliação de cada entrevistado e a média das avaliações dos dois grupos em cada país, para cada etapa da política industrial de petróleo e gás, nos três países.

Gráfico 115 - Percentual de variação na avaliação de cada grupo, sobre todas as etapas da política industrial de petróleo e gás, em cada um dos três países..

Gráfico 116 - Percentual de menções positivas e negativas nas respostas dos três países sobre a percepção que um grupo tem do outro.

Gráfico 117 - Percentual de menções positivas e negativas nas respostas dos três países sobre a participação do seu próprio grupo na política industrial.

Gráfico 118 - Percentual de menções positivas e negativas nas respostas dos três países sobre o recebimento de sua participação pelo outro grupo.

Gráfico 119 - Percentual de menções positivas e negativas nas respostas dos três países sobre a interação dos atores na definição da política industrial. 321 


\section{INTRODUÇÃO}

O estudo sobre desenvolvimento é um tema bastante recorrente na literatura das ciências sociais. Há séculos que se procura descobrir a razão pela qual alguns países seriam mais ricos do que outros, assim como as razões do fracasso de muitos países nessa tentativa de se desenvolver. Por mais rica que seja essa literatura, e por mais variadas que sejam as receitas que decorrem dessas análises, poucos são os exemplos de países que efetivamente conseguiram se desenvolver através delas.

Um desses poucos exemplos é a Noruega, que era um país relativamente pobre até o final da década de 1960, mas conseguiu desenvolver uma economia forte e uma excelente qualidade de vida, em menos de cinquenta anos. Nessa história norueguesa, não há como ignorar o papel da indústria de petróleo e gás, que foi o grande motor de todo esse processo. Mesmo que os primeiros anos tenham sido cercados de dúvidas, atualmente é muito difícil encontrar contestações ao sucesso do caso norueguês.

Com base na experiência norueguesa, quando o governo brasileiro descobriu enormes reservas de petróleo e gás na camada pré-sal do litoral do país, tentou desenvolver uma política para estimular o crescimento da indústria nacional. Para atingir esse objetivo, adotou a exigência de índices mínimos de conteúdo local no setor de petróleo, porque essa teria sido a fórmula utilizada pelos noruegueses para desenvolverem a indústria na Noruega.

Mais recentemente, o governo do México iniciou um processo de reforma no setor energético do país. Os mexicanos adotaram uma política de abertura para a participação de empresas privadas estrangeiras, levando ao fim do monopólio estatal da Pemex. Para embasar essa política, utilizaram a experiência de alguns outros países nesse setor, com uma especial atenção ao exemplo de sucesso norueguês.

Brasil e México são as duas maiores economias da América Latina. O setor de petróleo é o que mais contribui para essas duas economias. As empresas estatais de petróleo, Petrobras e Pemex, estão entre as maiores empresas de seus países. Estas duas empresas estão fortemente relacionadas a ideais nacionalistas e têm um longo histórico de relação com a política. E as condições para exploração no litoral brasileiro e no Golfo do México são relativamente parecidas. Com essas semelhanças, chama a atenção o fato 
desses dois países terem adotados políticas tão diferentes com relação a este setor. Especialmente porque ambos utilizaram a Noruega como referência de sucesso para o desenvolvimento de suas políticas de petróleo e gás.

Ainda mais curioso é o fato de que as políticas adotadas por Brasil e México para seus setores de petróleo, na verdade, representam formas opostas de se tratar a questão sobre o desenvolvimento industrial. Enquanto a política brasileira apresenta uma característica intervencionista, a política mexicana segue uma lógica de livre mercado. Essa diferença entre uma política e outra, levanta dúvidas sobre se estes dois países estariam efetivamente utilizando o modelo norueguês como referência.

Para esclarecer esta questão, cabe uma análise sobre a história da política norueguesa para o seu setor de petróleo e gás. No início dessa indústria no país, os noruegueses adotaram uma política de abertura para o mercado internacional, procurando atrair investimentos, tecnologia e conhecimento para o território norueguês. Logo que adquiriram uma certa experiência e capacidade nas atividades do setor, mudaram completamente a orientação de sua política, adotando um caráter muito mais intervencionista, com o claro objetivo de proteger as empresas norueguesas da concorrência que existe no mercado internacional. Através de diferentes barreiras protecionistas, muitas empresas norueguesas conseguiram se desenvolver a ponto de adquirirem competitividade internacional. Então, novamente, houve uma redefinição da política industrial de petróleo e gás na Noruega, iniciando um novo período de abertura para o mercado global, e adotando o claro objetivo de internacionalizar empresas norueguesas que fornecem produtos e serviços para o setor de petróleo e gás.

Com esta análise, fica mais fácil compreender as diferenças entre as políticas adotadas por brasileiros e mexicanos, e como pode estas duas políticas opostas estarem baseadas no mesmo exemplo. Após mais de setenta anos de monopólio da Pemex e buscando quebrar uma sequência de resultados negativos, a política industrial mexicana pretende atender às demandas do mercado internacional para atrair investimentos estrangeiros. Já a Petrobras vinha batendo recordes mundiais de extração de petróleo em águas profundas e ultraprofundas, fazendo com que o governo fundamentasse a política brasileira na demanda que seria gerada pela Petrobras na exploração da camada pré-sal do litoral brasileiro para incentivar o desenvolvimento da indústria nacional. 
Ou seja, o governo mexicano estaria seguindo o exemplo norueguês no que se refere àquele primeiro período de abertura para a atração de investimentos e tecnologia. Já o governo brasileiro estaria seguindo o exemplo norueguês no que se refere à fase protecionista, com foco no aumento da participação da indústria nacional. Mas esta conclusão levanta outra dúvida, sobre como um país sabe qual o tipo de política que deve ser adotado em cada momento, e como seria capaz de perceber uma eventual necessidade de mudança na definição dessa política.

Os noruegueses souberam sair de uma política liberalizante para uma política intervencionista e voltar para uma política liberalizante. Todas essas mudanças no direcionamento da política parecem ter sido feitas no momento correto, onde a política anterior já tinha atingido seus objetivos e a nova política abriu novas possibilidades. A reforma energética mexicana também representou uma mudança de estratégia com relação à política que era adotada até então no país. Saiu-se de uma política extremamente protecionista, para uma de abertura. A política de conteúdo local brasileira, da mesma forma, mas no sentido oposto, representou uma mudança na orientação da política industrial nacional. Saiu-se de uma política que procurava uma maior abertura, para uma retomada de políticas protecionistas.

Uma melhor compreensão sobre estes momentos de mudança na orientação das políticas industriais desses países, é a razão desta pesquisa. Aparentemente, os governos do Brasil e do México estariam utilizando suas estratégias de desenvolvimento como base para a definição de suas políticas industriais de petróleo e gás, mas a Noruega não está muito claro se a Noruega utilizaria esta mesma base para a definição de sua política. Entender como que o governo de cada um desses países faz para decidir pela mudança ou manutenção de suas políticas é o objetivo do trabalho. Por isso, será desenvolvida uma análise que busque responder à pergunta sobre o que serve de base para a definição da política industrial de petróleo e gás no Brasil, no México e na Noruega.

Com base na literatura que será analisada em seguida, foi levantada a hipótese de que seja a estratégia de desenvolvimento adotada por cada governo, que sirva de base para esta definição. Nesse sentido, estratégias de desenvolvimento baseadas no Estado estariam relacionadas com políticas industriais intervencionistas, que adotam instrumentos como o fechamento do mercado, a criação de empresas estatais, a adoção do modelo de partilha da produção e políticas de nacionalização da cadeia produtiva, como as políticas de conteúdo local. Já estratégias de desenvolvimento baseadas no 
mercado estariam relacionadas com políticas industriais liberalizantes, que adotam instrumentos como a abertura do mercado, a privatização de empresas estatais, a adoção do modelo de concessão, e políticas de internacionalização, com uma cadeia produtiva globalizada.

Para testar esta hipótese e tentar responder à pergunta de pesquisa, serão realizadas análises sobre a história da indústria de cada país e entrevistas com representantes do setor de petróleo do Brasil, do México e da Noruega. Estas informações serão posteriormente agrupadas e organizadas para que seja possível uma análise comparada entre os estudos de caso realizados em cada país.

No primeiro capítulo desta tese, será apresentada uma análise sobre o referencial teórico que envolve a questão, abordando questões como as estratégias de desenvolvimento e os modelos de política industrial utilizados ao longo da história. Em seguida, o capítulo sobre a metodologia deste trabalho irá explicar detalhadamente a forma como a pesquisa foi estruturada. No terceiro capítulo, será apresentado a sistematização dos dados sobre o estudo de caso sobre o Brasil, incluindo a análise histórica sobre a política industrial de petróleo brasileira e os dados obtidos com entrevistas de profundidade realizadas com representantes do governo e das associações empresariais brasileiras. O quarto capítulo fará o mesmo com relação ao estudo de caso sobre o México, e o quinto capítulo com relação ao estudo de caso na Noruega. No capítulo seis será realizada a sistematização comparativa entre as respostas dos dois grupos de entrevistados, em cada um dos três países. Já o sétimo capítulo irá apresentar a análise comparativa entre os três estudos de caso, e as respectivas comparações entre seus grupos, para procurar testar a hipótese levantada nesta tese e responder à pergunta que orienta esta pesquisa. 


\section{Capítulo 1 - Análise do Referencial Teórico}

Neste capítulo será analisado o referencial teórico utilizado como base para esta pesquisa. Este referencial pode ser dividido com base em três diferentes perspectivas. Uma delas, que serviu de base para a divisão das seções deste capítulo, está relacionada aos diferentes níveis de política econômica. Aqui se analisa a relação entre as duas principais variáveis que compõem a pergunta desta pesquisa. Enquanto a literatura sobre estratégias de desenvolvimento irá trabalhar com questões de política macroeconômica, a literatura sobre política industrial analisa questões de política microeconômica. Será exatamente na relação entre estas duas variáveis que se tentará confirmar ou negar a hipótese levantada.

Uma outra perspectiva importante que permeia toda a literatura analisada é a relação entre os principais atores que fazem parte do objeto de análise desta pesquisa. Ao longo de toda a literatura sobre estratégias de desenvolvimento e na primeira parte da literatura sobre políticas industriais, o principal foco é o papel que o Estado deve desempenhar na política econômica de um país, assumindo uma postura mais intervencionista ou liberalizante. Na segunda parte da literatura sobre políticas industriais, o foco se transfere para análises mais específicas sobre o papel de setores industriais e de empresas, que procuram identificar qual seria o melhor caminho para o acúmulo de capacidades tecnológicas e o desenvolvimento de inovações. Já a terceira parte da literatura sobre políticas industriais concentrará sua análise na relação entre estes atores para a definição de políticas, utilizando uma matriz sistêmica que ajuda a destacar o papel da comunicação nesta relação.

Além destas perspectivas, o referencial teórico também pode ser dividido com base em correntes filosóficas mais amplas. As primeiras estratégias de desenvolvimento analisadas apresentam um forte viés positivista, procurando encontrar leis universais que se apliquem a qualquer situação analisada. Conforme a teoria sobre estratégias de desenvolvimento vai evoluindo, este positivismo parece ir se relativizando e abrindo margens para uma variedade maior de possibilidades e combinações. No referencial sobre políticas industriais essa relativização ganha ainda mais corpo, levando a pesquisa a incluir uma abordagem evolucionista, que ofereça elementos mais adequados para a análise da realidade que se pretende realizar. Este evolucionismo aumenta ainda mais a 
variedade de possibilidades e combinações a serem incluídas na análise, fazendo com que o objeto adquira um grau de complexidade que passa a ser problemático para a pesquisa. Para tentar contornar os obstáculos trazidos pela complexidade do objeto analisado, utiliza-se a literatura sobre análise sistêmica, que tem como um de seus objetivos viabilizar a análise sobre temas complexos.

Ao final deste capítulo, apresenta-se um resumo das questões levantadas ao longo da análise do referencial teórico. Estas considerações servirão de base para a construção metodológica do desenho de pesquisa desta tese e para toda a análise que será realizada no capítulo sobre a comparação dos estudos de caso realizados.

\section{1 - Estratégias de Desenvolvimento}

Na primeira parte deste capítulo será analisada a literatura sobre estratégias de desenvolvimento. Estas estratégias correspondem a diferentes orientações que servem de base para a definição sobre a política macroeconômica, com o objetivo de desenvolver os níveis gerais da economia de um país. Para isso, os governos geralmente utilizam instrumentos de política fiscal, monetária e cambial.

A maior parte das análises sobre estratégias de desenvolvimento, ou mesmo sobre correntes de pensamento econômico, iniciam a partir de Adam Smith e sua defesa da liberdade de mercado. Apesar disso, optou-se por iniciar a análise do referencial teórico desta pesquisa com uma rápida apresentação sobre o estágio anterior, o período mercantilista, por se acreditar que o efeito que uma corrente de pensamento exerce na corrente de pensamento seguinte seja um elemento importante a ser analisado.

Neste mesmo sentido, procura-se analisar toda corrente de pensamento econômico que teve início com Keynes. Seja defendendo a intervenção estatal para combater os efeitos negativos dos ciclos econômicos, ou da relação de dependência entre os países de centro e os de periferia, o foco no papel do Estado como principal agente de desenvolvimento parece ser uma clara reação à corrente de pensamento anterior, que tinha seu foco no papel do mercado.

Para completar as diferentes correntes de pensamento teórico sobre estratégias de desenvolvimento, utiliza-se uma literatura que procura combinar a atuação do Estado e do mercado para a promoção do desenvolvimento de um país. Apesar de apresentarem 
importantes diferenças nas suas estruturas de análise, tanto estudos estrangeiros que trabalham com a perspectiva do new developmentalism, quanto estudos nacionais que utilizam a abordagem do novo desenvolvimentismo, defendem o reconhecimento sobre a importância do papel do mercado para o desenvolvimento, mas parecem manter uma primazia do papel do Estado nesse processo.

Um dos principais objetivos da primeira parte deste capítulo é demonstrar como ocorre, ao longo da história, uma relativização, ou desconstrução, de um paradigma positivista, que fazia com que as primeiras abordagens defendessem a existência de uma estratégia de desenvolvimento universal. Mercantilistas, liberais, keynesianos e neoliberais abrem pouco espaço para dúvidas sobre seu viés positivista. Mesmo os desenvolvimentistas da CEPAL, que adotam uma abordagem estruturalista, abrem a possibilidade da coexistência de duas realidades distintas, mas seguem um modelo rígido, que não deixa de ter uma grande base positivista. Já os novo desenvolvimentistas (nacionais e estrangeiros) trabalham com uma realidade teórica muito mais dinâmica e variada, que permite diferentes formas de combinação, mas suas conclusões práticas parecem não ser tão variadas quanto a teoria permite.

\subsection{1 - Mercantilismo}

Entre os séculos XV e XVIII, em muitos países europeus, o Estado passa a ter um papel de maior destaque na economia. Esta tendência estava alinhada à teoria e prática econômica conhecida como mercantilismo, que é anterior à própria consolidação da economia enquanto campo de estudo. Os autores deste período, na verdade, não compartilhavam um mesmo referencial teórico e seus trabalhos tinham uma orientação para questões práticas cotidianas, fundamentadas em intuições e observações. Dessa forma, esses trabalhos apresentavam uma grande variedade de conteúdos e posicionamentos, mas de uma maneira geral, verifica-se um forte estímulo a práticas protecionistas, ideais nacionalistas e o fortalecimento do comércio. Mesmo já existindo alguma crítica a essa estratégia, a intervenção do Estado na economia era vista como um fator determinante para o sucesso de uma nação (EKELUND; HÉBERT, 1997).

Foi neste período que o austríaco Von Hornick sintetizou em nove regras os fundamentos do mercantilismo, destacando a importância do estímulo à produção e ao trabalho. Escritos no final do século XVII, os principais pontos defendidos por ele 
tratavam basicamente da importância da exportação dos excedentes de produção (com exceção da exportação de outro e prata, que deveria ser evitada) e na redução, ao mínimo possível, das importações de produtos estrangeiros, para gerar uma balança comercial positiva (EKELUND; HÉBERT, 1997).

O barão francês Montesquieu, no início do século XVIII, escreveu o seu trabalho mais conhecido (MONTESQUIEU, 2000), onde classificou diferentes tipos de governos (república, monarquia e despotismo) para procurar identificar a razão de alguns países apresentaram uma forma de governo enquanto outros apresentam formas diferentes. Ele não se insere entre os teóricos mercantilistas, mas pode ser considerado um dos primeiros a transferir um paradigma das ciências exatas (mais especificamente as leis de Newton) para a análise de fenômenos políticos, econômicos e sociais. Os ideais renascentistas e iluministas, que serviram de pano de fundo para as teorias desenvolvidas durante todos estes séculos, foram consolidados numa corrente filosófica, política e sociológica que ficou conhecida como positivismo. Procurando se colocar como um contraponto à teologia e à metafísica que dominaram os séculos anteriores, o principal fundamento positivista seria o conhecimento científico como a única forma de conhecimento verdadeiro. O método científico proposto pelo francês Auguste Comete, no início do século XIX, buscava o conhecimento objetivo e preciso da verdade, procurando excluir todas as formas de superstição e de subjetividade (TRINDADE, 2007).

\subsection{2 - Liberalismo}

Apesar do forte apoio recebido pelos ideais mercantilistas à sua época, a primeira pessoa a utilizar o termo "mercantilismo", foi justamente um dos seus críticos mais conhecidos. O escocês Adam Smith é considerado um dos fundadores do campo de estudo sobre política econômica. A inspiração inicial de seu trabalho teria sido a obra de Bernard Mandeville conhecida como "Fábula das Abelhas", onde ele defende a ideia de que “vícios privados” podem gerar "benefícios púbicos” (MANDEVILLE, 1997). A principal ideia presente na obra é o questionamento à hipocrisia das chamadas "virtudes cristãs" e à intervenção do Estado na vida privada.

Inspirado na fábula de Mandeville, no final do século XVIII, Adam Smith desenvolve as ideias que levariam ao seu trabalho mais conhecido, onde ele argumenta que o que move os mercados não seria a benevolência das pessoas, mas sim a busca de 
seus próprios interesses privados. A mão invisível do mercado seria a forma mais eficiente para a alocação de recursos nas áreas onde eles rendem os maiores retornos. Assim como na obra de Mandeville, Smith também faz uma forte crítica à participação do Estado na economia. Para ele, a riqueza e o desenvolvimento de um país seriam muito mais facilmente alcançados através do estímulo a instrumentos que ofereçam a maior liberdade possível às atividades de mercado e reduzam a intervenção estatal ao mínimo. Ao contrário do que orientava o pensamento da época, ele sugeria que a riqueza de uma nação não deveria ser medida pela quantidade de ouro que ela possuía, mas sim pela quantidade de riquezas (SMITH, 1983).

Como justificativa para o equilíbrio econômico alcançado através da mão invisível do mercado, foi identifico um modelo chamado de "lei da preservação do poder de compra", ou "lei de Say". O francês Jean-Batiste Say procurou explicar o funcionamento dos mercados apresentado por Adam Smith, com base em um princípio que defendia que a demanda por um produto era definida pela oferta de outros produtos. Ou seja, numa análise mais ampla, haveria um equilíbrio entre a oferta agregada e a demanda agregada, fazendo com que a oferta acabe criando a sua própria demanda (SAY, 2001).

Outro autor liberal que serve de referência é o britânico David Ricardo, que teve como um de seus principais focos de estudo a forma como a sociedade distribui o produto gerado pelo trabalho. O objetivo seria encontrar leis universais que definam a forma de distribuição do produto gerado pelo trabalho entre os proprietários de terras, os trabalhadores e os arrendatários capitalistas (RICARDO, 1982). A definição sobre o conceito de "renda", especialmente o conceito de "renda da terra", que estava relacionada à parcela respectiva aos proprietários de terra, é especialmente importante para que se entenda a relação entre Estado e iniciativa privada na política industrial de petróleo e gás. O que David Ricardo chama de "renda da terra" equivale ao que se chama de "renda do petróleo", nos estudos sobre este setor. Essa renda trata de uma renda adicional (muito acima dos níveis normais de lucro) que se pode obter com a exploração de campos de petróleo. Ou seja, a exploração de petróleo e gás oferece a possibilidade de uma renda muito acima daquela necessária para garantir os lucros mínimos para que uma atividade seja comercialmente atrativa. Essa renda extra, renda da terra, ou ainda renda do petróleo, é o que será objeto de disputa entre Estado e empresas privadas e o equilíbrio dessa disputa será um elemento fundamental para a análise sobre a definição de uma política industrial de petróleo e gás. 
De qualquer maneira, é importante destacar que a lógica positivista segue fundamentando o pensamento econômico e político até aqui. A crença em uma verdade absoluta a ser desvendada pela ciência permaneceu intacta, enquanto a estratégia de desenvolvimento baseada no papel do Estado, que prevaleceu durante o período mercantilista, foi sendo substituída por uma estratégia que destacava o papel do mercado na organização econômica. Seguindo a característica dos paradigmas das ciências exatas, teóricos políticos, econômicos e sociais descartavam o paradigma anterior, pois o novo paradigma se baseava numa lógica de exclusão, que não abria espaço para a coexistência de dois paradigmas diferentes. Dessa forma, o fundamento de uma estratégia de desenvolvimento estava fortemente vinculado à negação da estratégia de desenvolvimento anterior.

\subsection{3 - Keynesianismo}

Bem mais adiante na história, surge um movimento de contestação à eficiência do mercado proposta por Adam Smith e outros teóricos liberais. O economista inglês John Maynard Keynes, já no início do século XX, defende que, quando a demanda seja insuficiente, medidas de combate ao desemprego devem ser tomadas, impulsionando os gastos públicos. Ele procurou explicar os mecanismos cíclicos que estão presentes nos momentos de recessão e como seria fundamental a intervenção do Estado para corrigir estes defeitos apresentados pelo mercado (KEYNES, 1936).

Ao contrário da crença numa auto-regulação dos ciclos econômicos, para ele a economia seria baseada no "espírito animal" dos empresários e, por isso, não seria capaz de oferecer emprego para todos aqueles que querem trabalhar. Isso seria a constatação de uma deficiência dos mecanismos de mercado, que deveria ser corrigida através da intervenção do Estado na economia. Mesmo o investimento estatal em atividades absolutamente improdutivas seria interessante em momentos de recessão, pois ajudaria a quebrar com a tendência de estagnação que seria característica deste ciclo (KEYNES, 1936). Nos Estados Unidos, o "New Deal" do presidente Franklin Roosevelt foi uma das estratégias de governo pioneiras em utilizar a intervenção do Estado como ferramenta para combater os efeitos indesejados do modelo liberal, que teria levado à crise de 1929. As ideias de Keynes foram colocadas em prática por diversos países que procuraram desenvolver suas economias através da intervenção estatal. Em muitos países europeus, 
a responsabilização estatal pela garantia de benefícios sociais que permitissem níveis mínimos de qualidade de vida para a população, proposta por Keynes, serviu de base para a defesa de uma nova forma de organização político-econômica conhecida como "Estado de bem-estar social" (VISSER, 2000). Mas a influência do pensamento keynesiano foi além destes países europeus e dos Estados Unidos, chegando até os países latinoamericanos, onde serviram de base para uma nova corrente teórica que pode ser considerada como o início de uma nova perspectiva sobre as teorias envolvendo estratégias de desenvolvimento.

\subsection{4 - Estruturalismo e a CEPAL}

As ideias de Keynes serviram de base para uma série de autores que integraram a Comissão Econômica para a América Latina e o Caribe - CEPAL, utilizando uma perspectiva estruturalista para explicar o desenvolvimento e se concentrando na análise das relações entre a estrutura e o seu ambiente. O economista argentino Raúl Prebish é um dos nomes mais conhecidos entre os estruturalistas cepalinos, defendendo que o processo de desenvolvimento de um país envolveria a realocação da sua força produtiva, de setores com baixa produtividade para setores de alta produtividade. Foi dele a obra que serviu de base para a teoria da industrialização através da substituição de importações, que propunha a imposição de tarifas de importação para proteger a indústria doméstica (PREBISCH, 1982).

Instrumentos protecionistas semelhantes aos utilizados durante o mercantilismo foram retomados para proteger as indústrias nacionais de empresas estrangeiras. Esta estratégia de desenvolvimento ficou conhecida como desenvolvimentismo, muito utilizadas por governos brasileiros e mexicanos ao longo do século XX. Uma das bases da teoria estruturalista desenvolvimentista se encontra na dicotomia entre centro e periferia. Países industrializados, com economias maduras e especializados na produção de manufaturas, são considerados de centro, enquanto países em desenvolvimento, especializados na produção de produtos primários, são considerados de periferia. Essa diferença fundamental nas estruturas de suas economias faria com que a maior parte dos ganhos econômicos seja direcionada para os países de centro, mantendo os países periféricos numa situação de permanente dependência dos países de centro. Com base nessa perspectiva, que ficou conhecida como teoria da dependência, a competição no 
comércio internacional não seria suficiente para que os países periféricos saiam dessa situação. A industrialização seria o elemento fundamental para a transformação dessa estrutura, mas ela não seria alcançada de forma espontânea pois, além de existir uma série de barreiras internas para os países periféricos, os países de centro também tentariam impor a divisão internacional do trabalho, que serviria como obstáculo para essa transformação (PALMA, 1989).

A visão de mundo dos estruturalistas pode ser considerada uma inovação, comparada a um contexto onde as demais teorias econômicas trabalhavam com a ideia de uma única lógica de desenvolvimento para todos os países. O foco nas diferenças estruturais entre países industrializados e não-industrializados e nos desafios específicos que os países latino-americanos para se desenvolver, indicou um caminho onde as estratégias de desenvolvimento poderiam ser diferentes, dependendo do país analisado. Mesmo assim, a perspectiva estruturalista entendia essa relação entre os países de forma muito rígida, seguindo uma objetividade positivista. Haveria uma série de restrições, obstáculos e gargalos que serviriam para impedir qualquer tentativa de mudança (LITTLE, 1982). Foram exatamente essa rigidez e essa dificuldade de mudança que serviram de base para os autores estruturalistas justificarem a defesa da adoção de uma política intervencionista por parte do Estado.

Isso demonstra que os estruturalistas abriram a possibilidade de um caminho diferente para os países periféricos, mas mantiveram a polarização com viés positivista, entre alternativas que focam no papel do Estado ou no papel do mercado para alcançar o desenvolvimento. De acordo com eles, no caso dos países latino americanos, a participação do Estado na economia seria inevitável e o liberalismo seria uma estratégia adequada para a realidade de países de centro. Portanto, entre os autores estruturalistas, estratégias de desenvolvimento baseadas no Estado poderiam coexistir com estratégias de desenvolvimento baseadas no mercado, mas as primeiras estariam relacionadas a países periféricos e as últimas a países de centro. Com isso, ocorre uma mudança de patamar na polarização existente entre estas duas estratégias. Deixando de ser uma polarização excludente para ser uma polarização que representa diversidade. Essa mudança pode ser entendida como uma relativização de uma perspectiva comum a todas estratégias de desenvolvimento anteriores, que costumavam ser entendidas como uma verdade objetiva e absoluta. 


\subsection{5 - Neoliberalismo}

Após um início de muita aceitação, as ideias de Keynes começaram a ser cada vez mais contestadas, especialmente por teóricos do movimento conhecido como neoliberalismo. As enormes dívidas estatais, os altos impostos e a desaceleração da economia na década de 1970 serviram de base para argumentos contrários à intervenção estatal na economia. O economista americano Milton Friedman é considerado um dos principais nomes desta retomada dos valores liberais, juntamente com outros economistas da chamada "escola de Chicago", que procurava aplicar a lógica econômica a outras áreas da ciência, como história, direito, sociologia e ciência política. Para esta escola, ou mais especificamente para a sua facção conhecida como "monetarista", da qual Friedman também é um dos principais expoentes, não seria mais o nível de demanda, mas a quantidade de moeda disponível, que determinaria as flutuações verificadas na atividade econômica. Entre os autores destas escolas, havia uma forte resistência ao conceito de falhas de mercado e à teoria econômica keynesiana. O foco agora estava no combate à inflação, que deveria ser mantida sempre sob controle, através da restrição na oferta de moeda (FRIEDMAN, 1970).

Muitos governos adotaram as ideias de Friedman e outros teóricos neoliberais. $\mathrm{O}$ Reino Unido, de Margareth Thatcher, e os Estados Unidos, de Ronald Reagan, são os exemplos mais conhecidos. Esta estratégia de desenvolvimento ficou conhecida como o Consenso de Washington, recomendando políticas de austeridade e liberalização econômica, tanto para países desenvolvidos, como para países em desenvolvimento. Aqui também é retomada uma visão bastante crítica com a corrente teórica anterior, apontando com ênfase para as ineficiências da gestão estatal em comparação com os modelos de gestão da iniciativa privada, baseados no livre mercado.

Outra escola de pensamento neoliberal que merece destaque é a chamada "escola austríaca", que surgiu no final do século XIX e teve entre seus principais autores Friedrich von Hayek, Ludwin von Mises e Joseph Schumpeter (que será analisado mais adiante). Um de seus principais fundamentos era o chamado "individualismo metodológico", analisando princípios básicos da ação humana individual (e não em questões coletivas ou sociais), como os fundamentos para uma teoria econômica, através de um método chamado de praxeologia (MISES, 1990). Um dos maiores opositores à teoria keynesiana foi o economista austríaco von Hayek, com sua teoria sobre investimentos e capital e sobre como os preços influenciam tomadas de decisão individuais (HAYEK, 1941). Sua 
obra acabou não tendo uma maior repercussão na literatura econômica devido às críticas dirigidas a ele e outros autores da escola austríaca, pela falta de rigor científico na metodologia adotada (CAPLAN, 2003).

Apesar da escola austríaca procurar trabalhar com uma análise do indivíduo, que abre margem para um nível de subjetividade muito maior do que o trabalhado por outras teorias econômicas até aqui, o viés positivista permanece muito forte como um fundamento filosófico mais amplo. Assim como na escola de Chicago, trabalha-se com uma visão muito rígida sobre a participação do Estado na atividade econômica. De uma maneira geral, as diferentes escolas de pensamento neoliberal consideram a ineficiência estatal na promoção do desenvolvimento como uma verdade objetiva e absoluta, independentemente do caso analisado.

\subsection{6 - Novo Desenvolvimentismo}

Enquanto o mercantilismo, o keynesianismo e o desenvolvimentismo enfatizam a função do Estado na promoção do desenvolvimento de um país, o liberalismo e o neoliberalismo enfatizam a função do mercado na promoção desse desenvolvimento. Como todas abordagens compartilham a ideia de que um ator é mais importante do que o outro, a abordagem sobre um "novo desenvolvimentismo" aparece como uma alternativa, procurando combinar a importância do papel do Estado e do papel do mercado, para a promoção do desenvolvimento de um país.

Existe uma variedade muito grande de autores que trabalham com essa abordagem, mas destaca-se aqui as contribuições de alguns autores tidos como chave para o tema, como a australiana Linda Weiss. Com sua tese sobre uma "interdependência governada", onde ela argumenta que Estado e empresas devem trabalhar de forma cooperativa para que um aprimore as capacidades do outro e, assim, possam promover o desenvolvimento de um país. Ela destaca a importância de um Estado forte e de um setor privado forte, mas sem que o papel de um se sobressaia ao papel do outro. Trabalhando lado a lado, o Estado e a iniciativa privada de um determinado país poderiam intensificar mutuamente suas capacidades (WEISS, 2003).

A abordagem utilizada pelo norte-americano David Trubek também é uma referência entre os novo desenvolvimentistas, por tentar se distanciar da ideia de uma 
única estratégia que atenda de maneira satisfatória a todos os casos possíveis. Seu trabalho coloca ênfase nos processos de conhecimento e aprendizagem, desenvolvidos através de estruturas colaborativas entre Estado e mercado. Com base no que ele chama de uma "nova política econômica do desenvolvimento", ele defende que as variações entre essas estruturas colaborativas, que incluem Estado e mercado, permitiriam que cada nação molde, de forma customizada, suas características institucionais de acordo com suas necessidades específicas (SANTOS; TRUBEK, 2008).

Talvez o mais conhecido entre os autores do novo desenvolvimentismo seja o norte-americano Peter Evans. Em seu trabalho ele defende um Estado desenvolvimentista que se diferencie tanto do desenvolvimentismo quanto do neoliberalismo. Para isso, ele apresenta seu conceito de "autonomia inserida", onde o Estado, o capital local e o capital estrangeiro podem ter ganhos mútuos se trabalharem em conjunto. Seu principal argumento é que a coerência e a capacidade da organização burocrática das agências e instituições do Estado (que ele chama de "estruturas internas do Estado" ou "autonomia") e a conectividade social entre Estado e capital industrial (que ele chama de "estruturas industriais externas" ou "inserção") não estão em oposição uma com a outra mas que, pelo contrário, podem se reforçar mutuamente. Dessa forma, ele constrói o conceito de autonomia inserida, onde o Estado deve ser dotado de "autonomia" para definir sua própria organização, mas deve fazer isso de forma alinhada com a sua "inserção" nesse projeto conjunto com os demais grupos de atores (EVANS, 1995).

Apesar dessa intenção de conciliar a participação do Estado e do mercado na promoção da atividade econômica, pode-se entender a abordagem adotada por estes autores como, na verdade, uma retomada do desenvolvimentismo. Em um de seus trabalhos, o próprio Peter Evans alega que a história e a teoria sobre desenvolvimento servem de prova sobre a impossibilidade de um processo de desenvolvimento sem a presença de um Estado desenvolvimentista (EVANS, 2010). Entre os autores brasileiros, a análise de Luiz Carlos Bresser-Pereira serve de referência, defendendo o estabelecimento de um pacto nacional entre os diferentes atores e a adoção de taxas de juro e de câmbio competitivas, também dando prioridade à análise do papel do Estado sobre os mecanismos de mercado (BRESSER-PEREIRA, 2010). Utilizando diferentes perspectivas, os autores do novo desenvolvimentismo, sejam eles nacionais ou estrangeiros, compartilham uma mesma visão teórica sobre a complementaridade entre os papéis do Estado e do mercado, mas também compartilham conclusões práticas que 
ressaltam o papel do Estado, sem a devida compensação com relação ao papel do mercado, para que aquele equilíbrio teórico se reflita em seus reflexos práticos.

Com isso, se percebe a predominância de estratégias de desenvolvimento baseadas numa lógica positivista, que trabalha com a possibilidade de um único modelo ideal, excluindo qualquer outra alternativa que se apresente. Os teóricos estruturalistas da CEPAL foram os primeiros a abrir a possibilidade da coexistência de duas realidades distintas, uma de centro e outra de periferia, mas mantêm a rigidez positivista na limitação a estas duas variações do mesmo tema. Já os autores que trabalham com o novo desenvolvimentismo procuram conciliar os dois extremos da relação polarizada que se estabeleceu ao longo da história, com relação ao papel do Estado e do mercado na promoção do desenvolvimento. Mas apesar dos seus esforços teóricos, suas conclusões práticas não se distinguem de forma contundente das teorias anteriores que eles criticam e procuram superar.

\section{2 - Política Industrial}

Após analisar a literatura sobre estratégias de desenvolvimento, será feita a análise da literatura sobre política industrial, seguindo uma divisão do estudo sobre política econômica em diferentes níveis. De acordo com essa divisão, políticas macroeconômicas seriam responsáveis por influenciar o nível geral da economia de um país, utilizando instrumentos de política fiscal, monetária e de taxa de câmbio. Já políticas microeconômicas seriam responsáveis por influenciar a alocação de recursos entre os diferentes setores da economia de um país, utilizando instrumentos de política industrial, comercial e trabalhistas. Enquanto políticas sociais seriam responsáveis pela distribuição de recursos entre grupos e indivíduos, utilizando instrumentos de políticas de saúde, educação e distribuição de renda. Apesar de cada nível de política econômica ter uma responsabilidade principal, todos os níveis acabam influenciando, de uma maneira ou de outra, todos os demais níveis. Dessa forma, a política macroeconômica pode afetar a política industrial, que pode ter efeito sobre a distribuição de renda, que pode influenciar a política comercial, tendo impacto, novamente, na política macroeconômica (GREENAWAY; MILNER, 1993). Apesar dessa inter-relação permear os três níveis de política econômica, este trabalho não irá analisar diretamente questões envolvendo políticas sociais, pois o foco aqui será nas questões relativas à relação entre a política 
macroeconômica (considerada como uma estratégia de desenvolvimento para o país) e a política microeconômica (especificamente o que se refere à política industrial).

\subsection{1 - Intervenção ou Liberalização}

Assim como na análise sobre as estratégias de desenvolvimento, a literatura sobre política industrial também pode ser dividida entre duas abordagens: uma enfatizando o papel do Estado na promoção da indústria, geralmente através de medidas intervencionistas; e outra enfatizando o papel do mercado, onde a promoção da indústria se dá através da não-intervenção estatal, com a liberalização da economia. $\mathrm{O}$ foco na política, que até então era o desenvolvimento econômico do país como um todo, passa a ser mais específico, concentrado no desenvolvimento das capacidades produtivas do país. Apesar de seguir esta mesma divisão, ao passar da análise macroeconômica sobre estratégias de desenvolvimento para a análise microeconômica sobre políticas industriais, a fronteira que separa estas duas perspectivas parece ficar menos objetiva, rígida e excludente.

Ainda no século XIX, o alemão Friedrich List procurava entender como que a Alemanha e os Estados Unidos, que até então eram economias relativamente atrasadas, poderiam atingir o mesmo nível de desenvolvimento da Inglaterra, que era a grande referência de desenvolvimento econômico da época. Criticando as ideias de livre comércio defendidas por Adam Smith, que List chamava de "sistema britânico", ele defendeu a adoção do que ele chamava de "sistema americano". De acordo com esse sistema, o Estado teria um papel fundamental na promoção do desenvolvimento de um país. Cada país teria uma dinâmica específica para alcançar o seu desenvolvimento e até mesmo cada estágio de desenvolvimento seguiria lógicas distintas, o que demandaria diferentes políticas e instrumentos de proteção. Em estágios iniciais de desenvolvimento, ou em estágios de desenvolvimento avançado, políticas liberalizantes de livre mercado poderiam ser positivas. Mas políticas protecionistas seriam as mais indicadas para serem adotadas durante o processo de desenvolvimento e, por isso, ele defendia a adoção de tarifas de importação para bens manufaturados, visando a proteção da indústria nascente nacional. Segundo ele, ao contrário da liberdade econômica defendida por Smith, seria o desenvolvimento das forças produtivas de um país através da intervenção estatal, a verdadeira causa para a riqueza de algumas nações (LIST, 1986). 
O britânico Stuart Mill seguiu muitas das ideias liberais de Adam Smith, mas também apresentou algumas críticas a esta visão. Segundo ele, o papel do Estado poderia ser tanto positivo quanto negativo. $\mathrm{O}$ que definiria esta questão seria a influência da atuação estatal na liberdade individual, pois quando diminuísse essa liberdade, a atuação do Estado seria vista como negativa, mas a participação estatal seria positiva sempre que servisse para aumentar a liberdade individual. Nesse sentido, assim como List, ele também defendeu a intervenção do Estado na economia, mas ressaltando a necessidade de limites a esta proteção, restringindo-a somente para aquelas industrias que poderiam competir internacionalmente (MILL, 1996).

Procurando evitar a ortodoxia do Consenso de Washington, que era contrário à adoção de qualquer tipo de política industrial que interferisse nos mecanismos de mercado em favor de algum setor específico, alguns autores identificaram o que eles chamaram de uma "política industrial de livre mercado" (open economy industrial policy) (KUZNETSOV; SABEL, 2011). Essas políticas teriam sido adotadas por alguns países latino americanos a partir da década de 1980, com o objetivo de aumentar as exportações e a integração desses países nas cadeias produtivas globais. Ao contrário das tarifas de importação utilizadas pelo modelo de industrialização através da substituição de importações, esta política industrial teria como base a utilização de incentivos e não de punições (SCHRANK; KURTZ, 2005, KING; SZNAJDER, 2006).

Políticas industriais de livre mercado teriam sido adotadas por governos neoliberais de países latino americanos, como forma de compensar o setor privado industrial de seus países pelas perdas oriundas das reformas neoliberais adotadas por estes governos (KURTZ; BROOKS, 2008). O Brasil, por exemplo, durante a década de 1990, substituiu o modelo de substituição de importações por instrumentos de uma política industrial de livre mercado. Nesse sentido, mesmo abandonando uma política industrial mais ampla, o governo brasileiro ofereceu linhas de crédito subsidiadas e incentivos fiscais para exportações (ALMEIDA, 2009).

Por outro lado, instrumentos protecionistas e a propriedade estatal de empresas têm sido utilizados por países latino americanos que procuram se desenvolver através de um modelo baseado em exportações (PERES, 2011). Apesar de alguns autores criticarem a adoção de políticas industriais protecionistas, Ha-Joon Chang (2002) demonstra que elas foram utilizadas por diversos países ao longo da história. Reproduzindo uma expressão inicialmente utilizada por List, ele aponta que estes países estariam “chutando 
a escada" que eles utilizaram para se desenvolver, com o objetivo de impedir que os países em desenvolvimento utilizem o mesmo caminho.

Nesse sentido, a recomendação do Consenso de Washington a respeito de políticas industriais teria sido sempre muito clara com relação a ser contra qualquer tipo de intervenção estatal. Mesmo assim, diversos autores apontam que políticas industriais estariam sendo adotadas, tanto por países desenvolvidos, quanto por países em desenvolvimento (BERGER, 1989; WADE, 2010; STIGLITZ; LIN, 2013). O atual cenário, de uma economia globalizada, oferece menos espaço para a adoção de certos instrumentos de política industrial, que eram adotados no século passado. Para estes autores, a política industrial moderna seria a crença em que o Estado tem um importante papel a desempenhar na definição econômica, pois, na verdade, não haveria outra opção (LIN; CHANG, 2009). Mas também é feito o alerta de que, para cada caso de política industrial de sucesso, existiria uma centena de casos de fracasso (WADE, 2013).

Algumas análises destacaram as diferenças que existem entre instrumentos de política industrial voltados para a substituição de importações ou para a promoção de exportações. Estes instrumentos devem procurar atingir os objetivos propostos pela política e, portanto, não devem ser permanentes, mas haveria muita dificuldade em se estabelecer o momento exato em que as barreiras protecionistas utilizadas para estimular a indústria nascente devem ser retiradas. Uma política poderia seguir diferentes orientações, com base numa divisão básica entre o dirigismo, com participação ativa do Estado de forma intervencionista (que pode assumir um viés voltado para questões internas, como geração de empregos, ou para questões externas, como o estímulo às exportações), e o laissez-faire, com um Estado passivo baseado na mão invisível do mercado e numa política de não-intervenção. Apesar de não haver indicadores mais precisos que sejam amplamente aceitos, para essa classificação sobre a orientação de políticas, esta divisão é considerada conceitualmente precisa o suficiente para esta análise. Mesmo assim, há que se destacar a dificuldade para a aplicação desta classificação na prática, pois os governos costumam combinar elementos de intervenção e liberalização, além de alternar ao longo do tempo, entre estas duas orientações para suas políticas (GREENAWAY; MILNER, 1993).

Todos estes trabalhos, mesmo se baseando em orientações diferentes (e até opostas) para a definição de políticas, apontam para uma complexidade maior na relação entre os papéis do Estado e do mercado na promoção do desenvolvimento, do que o que 
foi identificado na análise macroeconômica presente na literatura sobre estratégias de desenvolvimento. Nem o Estado e nem o mercado atuam perfeitamente na coordenação de mecanismos de desenvolvimento, cada um apresentando seus prós e seus contras, fazendo com que sejam mais adequadas para determinadas situações e menos adequadas para outras (CHANG, 1994). Mesmo assim, ao mesmo tempo que estes estudos trabalham com a ideia de necessidade de diferentes combinações entre intervenção estatal e liberalização econômica, parece permanecer uma certa polarização no que se refere às suas conclusões, ou às suas propostas de aplicação prática. Assim como na literatura sobre estratégias de desenvolvimento, mesmo quando a teoria fala sobre combinação entre Estado e mercado, se acaba focando no papel de um ou de outro, de forma individualizada, e não na análise sobre formas e alternativas para que a combinação mencionada na teoria possa ser colocada em prática.

De forma ainda incipiente, se verifica o surgimento de análises que procuram considerar de forma mais rigorosa essa necessidade de equilíbrio entre as diferentes orientações que uma política pode apresentar. Para combinar o papel do Estado com o do mercado na promoção do desenvolvimento, se destaca a importância da transparência na formulação e implementação da política industrial como sendo tão importante quanto os resultados alcançados pela política. Esse debate sobre posições contrárias ou a favor da adoção de políticas industriais muitas vezes se demonstra improdutivo. A partir disso, sugere-se a aceitação de que a intervenção estatal através de políticas industriais continuará sendo uma ferramenta importante de desenvolvimento e o foco em análises mais precisas sobre experiências de sucesso, que ajudem a se entender melhor como e porque estes casos chegaram a resultados positivos (KASAHARA; BOTELHO, 2016).

\subsection{2 - Evolucionismo Econômico}

Uma outra perspectiva de análise macroeconômica serviu de base para uma abordagem teórica diferente. Sendo considerada uma das primeiras a questionar a abordagem estática de padrões econômicos - segundo a qual a atividade econômica se repetiria de forma contínua e idêntica ao longo do tempo - a teoria dos ciclos econômicos de Joseph Schumpeter analisou os processos de desenvolvimento através de uma perspectiva baseada em sistemas dinâmicos não lineares. Segundo ele, o desenvolvimento seria atingido através da industrialização e teria o empresário inovador como o seu 
principal agente. O surgimento de inovações faria com que uma economia saísse de um estado de estagnação e entrasse num processo de crescimento. $\mathrm{O}$ autor destaca as diferenças que existem entre estes dois ciclos econômicos, uma vez que períodos de prosperidade e de recessão, mesmo sendo elementos naturais ao processo de desenvolvimento econômico, apresentariam lógicas de comportamento distintas entre si (SCHUMPETER, 1934; 1939).

Schumpeter se opôs a muitas das ideias defendidas por Keynes, servindo como contraponto à teoria keynesiana ao retirar o foco da análise do papel exercido pelo Estado. Nesse sentido, seu trabalho não se diferencia de outras análises macroeconômicas que, como apresentado anteriormente, polarizam a relação entre o papel do Estado e do mercado. Mas ao estabelecer a distinção entre os períodos de prosperidade e de recessão, ele acabou contribuindo para a adoção de uma perspectiva econômica não estática. A partir de Schumpeter, foram desenvolvidos muitos trabalhos que analisaram o desenvolvimento econômico a partir de uma perspectiva evolutiva, que contrariava a ideia de uma única estratégia de desenvolvimento defendida por desenvolvimentistas e liberais, onde não eram consideradas as diferenças geradas pelas variações relativas aos diferentes ciclos econômicos.

Entre estes trabalhos que seguiram a perspectiva evolucionista de Schumpeter, um dos mais influentes foi o de Richard Nelson e Sydney Winter, que permitiu a aplicação empírica de modelos econômicos teóricos. Eles foram alguns dos primeiros a utilizar a abordagem evolucionista schumpeteriana para analisar esta evolução no nível microeconômico, estudando o desenvolvimento de inovações a partir de mudanças no comportamento, nos processos e nas rotinas das empresas. Como eles identificaram diferenças entre as rotinas cognitivas e organizacionais de diferentes empresas, haveria também diferença entre as estratégias a serem utilizadas e os resultados que podem ser alcançados por cada empresa (NELSON; WINTER, 1982).

Outro estudo de destaque que segue na mesma direção foi o realizado por Keith Pavitt, analisando os padrões encontrados nas trajetórias setoriais. Ele procurou encontrar padrões específicos a cada setor industrial, com relação ao desenvolvimento de produtos e processos, considerando os processos de aprendizagem tecnológica de cada um. A partir dos resultados encontrados por ele, os setores industriais foram divididos em três categorias: setores dominados por fornecedores; setores intensivos em produção; e setores de base científica. Esta última categoria ainda se dividiria entre setores intensivos em 
escala e setores com fornecedores especializados. Cada uma destas categorias apresentaria diferentes padrões de tecnologia e de inovação. Com isso, empresas de um determinado setor apresentariam características que afetariam o ritmo de desenvolvimento e de difusão de inovações, gerando e reforçando assimetrias tecnológicas, que acabariam resultando em diferenças estruturais entre diferentes setores (PAVITT, 1984; BELL; PAVITT, 1993). Seguindo esta perspectiva de análise, quando uma empresa introduz um melhoramento, através de um esforço inovador, ela acumularia competência tecnológica. Esta acumulação de competência tecnológica, por sua vez, estaria relacionada a uma série de mecanismos de aprendizagem subjacentes (BELL, 1984).

No início da década de 1970, os trabalhos acadêmicos sobre tecnologia nos países em desenvolvimento passaram a dar maior importância às mudanças que a tecnologia apresentava ao longo dos anos, adotando uma perspectiva dinâmica. O foco destas pesquisas era identificar como as empresas haviam promovido estas mudanças tecnológicas (STEWART; JAMES, 1982). Esses trabalhos incluíram abrangentes revisões sobre esta literatura (BELL, 1982), trabalhos sobre empresas da América Latina (KATZ, 1987; HERBERT-COPLEY, 1990), pesquisas sobre empresas da África (HERBERT-COPLEY, 1992) e sobre empresas da Ásia (WORLD DEVELOPMENT, 1984).

Com o final da política de substituição de importações e a abertura de seus mercados, as empresas de países emergentes teriam começado a sofrer uma forte concorrência externa e se viram obrigadas a se reestruturar para alcançar um nível de competitividade internacional. De acordo com alguns estudos, até então estas empresas eram incentivadas a serem relativamente ineficientes (FLEURY, 1985), uma vez que operavam em um mercado em expansão, mas fortemente protegido e subsidiado. Além disso, o modo como determinadas empresas organizavam a sua produção foi considerado como sendo uma barreira para que seus funcionários procurassem se qualificar profissionalmente (FLEURY, 1977; HUMPHREY, 1982).

Estes trabalhos apresentaram uma série de conclusões que trouxeram uma diversidade muito grande para a análise sobre o acúmulo de competência tecnológica dentro das empresas. Entre toda a variedade encontrada, aparecem questões relativas ao controle acionário, à orientação mercadológica, ao porte e ao tempo de existência de uma empresa, que seriam fundamentais para a definição da estratégia tecnológica a ser adotada 
(MUKDAPITAK, 1994). A existência de uma complexa sequência que começa em níveis de aquisição de competência tecnológica mais básicos e passa para níveis mais elevados, e a influência que a política governamental tem neste processo também foram levantadas (LALL, 1987) Também se trabalhou com a ideia de que as transições tecnológicas e de mercado das empresas evoluem das atividades simples para as complexas, assim como mecanismos organizacionais interempresariais (como subcontratações, joint ventures e licenciamento) permitem a aquisição de conhecimentos e a adaptação de tecnologia estrangeira na empresa (HOBDAY, 1995) A não-linearidade nas trajetórias de acumulação de competência tecnológica de empresas de países emergentes, (HWANG, 1998) e a identificação de diferenças nas trajetórias com relação aos tipos de vinculação adotados entre a subsidiária e a matriz (ARIFFIN; BELL, 1996) foram mais alguns desses elementos trazidos por pesquisas relacionadas.

Alguns autores seguiram esta mesma perspectiva, mas focaram nos processos de aprendizagem subjacentes à acumulação de competência tecnológica. Estas pesquisas apontam que a liderança e o e a efetiva busca pela aquisição de conhecimento influenciam a acumulação de competência tecnológica (GIRVAN; MARCELLE, 1990) Essa aquisição de conhecimento pode se dar através de diferentes programas de treinamento, através de processos cooperativos, do foco na aquisição de conhecimentos externos à empresa e da transferência de saberes entre funcionários estrangeiros e funcionários locais (SCOTT-KEMMIS, 1988) O papel positivo da liderança e os processos de conversão da aprendizagem individual em aprendizagem organizacional foram apontados como tendo grande importância nas trajetórias bem-sucedidas de empresas de países emergentes como as sul-coreanas Hyundai (KIM, 1995) e Samsung (KIM, 1997a), mas estes processos de aprendizagem teriam menos importância do que as condições externas, como a existência de um sistema nacional de inovação que efetivamente funcione (KIM, 1997b).

Ao adotar a perspectiva evolutiva sobre as atividades tecnológicas das empresas, no início da década de 1980, alguns autores se basearam em estudos sobre a rotina no comportamento organizacional (MARCH; SIMON, 1958), e sobre a chamada "racionalidade limitada" (SIMON, 1959; 1961). Trabalhava-se com a ideia de que cada empresa teria suas competências específicas, que seriam o elemento mais importante para a definição sobre o seu desempenho (PENROSE, 1959). Seguindo esta linha, definiramse os conceitos de que as empresas seriam "organizações dinâmicas" que acumulam 
conhecimento sobre como realizar tarefas e de que, especificamente, cada empresa seria uma forma de "repositório de saber produtivo", fazendo com que ela e seu processo de desenvolvimento se diferencie até mesmo de empresas que atuem da mesma área (WINTER, 1988). Reunindo-se estes conceitos, entende-se melhor a diversidade de realidades que cada empresa apresenta, mesmo quando elas fazem parte do mesmo setor de um mesmo país, quando se analisa o processo de desenvolvimento das atividades tecnológicas dentro das empresas (FIGUEIREDO, 2003; NELSON, 1991).

Esta perspectiva dinâmica traz embutida uma noção referente assimetrias permanentes com relação às capacidades tecnológicas de diferentes empresas. Ou seja, em geral as empresas poderiam ser classificadas como "melhores" ou "piores" de acordo com o seu grau de desenvolvimento tecnológico (DOSI, 1985) e esta diferença poderia ser interpretada como o resultado de um processo de acumulação de capacidades tecnológicas (DOSI, 1985; 1988). Estas diferenças estariam diretamente relacionadas com as a forma como se realiza processos de inovação em cada empresa, que seria variável (NELSON, 1991) e dependeria da trajetória adotada por cada processo de aprendizagem (DOSI, 1988; PAVITT, 1988; TEECE, 1988).

Voltando às especificidades com relação às empresas de países emergentes, adotase o conceito de que elas iniciariam de uma etapa onde não apresentam competitividade internacional (indústria nascente) e o principal desafio que teriam que enfrentar para atingir um nível de maturidade industrial seria a acumulação de competência tecnológica (BELL; ROSS-LARSON; WESTPHAL, 1984). Para que se alcance esta acumulação, seriam necessários esforços internos que sigam uma sequência evolutiva (KATZ, 1985). As trajetórias de acumulação tecnológica também sofreriam a influência das políticas governamentais macroeconômicas, tendências relativas a cada setor e características da indústria de cada local (FIGUEIREDO, 2003; LALL, 1987).

Alinhado com a abordagem setorial da taxonomia de Pavitt (1984), que propôs uma classificação dos setores industriais de acordo com a estrutura e a tecnologia que cada setor utiliza para alcançar inovações, o conceito de sistema setorial de inovação desenvolvido por Malerba $(2002 ; 2004)$ indica que os fatores que influenciam a inovação em um determinado setor seriam os conhecimentos, os processos de aprendizagem e tecnologias, os atores e as redes que eles formam as respectivas instituições de cada país. 
O conceito de sistema de inovação foi desenvolvido pelos teóricos da escola de pensamento neo-Schumpeteriana (FREEMAN, 2002; LUNDVALL, 2007), para tentar explicar a aproximação tecnológica entre diferentes países e para servir como foco de análise para futuras pesquisas. A definição de setor diz respeito a um conjunto específico de conhecimentos, tecnologias e outras aquisições necessárias para o desenvolvimento de um produto (MALERBA, 2002). Os principais atores de um setor são as empresas, acompanhadas por universidades, agências de governo e outros agentes, que assumem diferentes papéis, de acordo com cada setor (MALERBA, 2002; 2004).

Toda essa variedade entre as dinâmicas de cada empresa, de cada setor, de cada estágio de desenvolvimento, de países desenvolvidos ou em desenvolvimento, leva à desconstrução da ideia de que exista uma única estratégia de desenvolvimento que possa ser a mais indicada para todos estes casos. As análises microeconômicas indicam uma que, diferentemente da teoria sobre desenvolvimento, quando aplicado à realidade prática de um setor ou de uma empresa, os papéis do Estado e do mercado no desenvolvimento de capacidades produtivas se misturam, se combinam e se confundem.

\subsection{3 - Análise Sistêmica}

Embora o papel de nenhum destes atores seja a solução definitiva para todos os casos, eles são algumas das ferramentas que se tem à disposição e que podem e devem ser utilizadas. Portanto, mesmo que se desconstrua a ideia de "uma verdade absoluta", isso não impede que se procure por mecanismos que ajudem a identificar de forma mais precisa as "diversas e complexas verdades", que parecem representar de forma mais fidedigna a realidade da qual tratam as políticas industriais.

Destaca-se aqui duas vertentes teóricas que procuraram analisar os mecanismos e os processos de definição de políticas. A “abordagem das arenas políticas” diferencia as políticas públicas (que incluem as políticas industriais) conforme a interação que se verifica entre os atores envolvidos nessa política. Dessa forma, políticas públicas podem ser implementadas através de alianças, da competição, do conflito ou do confronto. Os atores envolvidos numa determinada política reagiriam a ela com base em avaliações sobre suas expectativas a respeito da forma como essa política pode vir a afetar seus próprios interesses (LOWI, 1972; 1985). 
De acordo com essa abordagem, as políticas públicas (policies) seriam a causa (variável independente) e a atividade política no seu sentido mais amplo (politics) seria o efeito (variável dependente). Assim, as políticas públicas seriam o primeiro momento, determinando a forma de interação entre os atores e de toda a sociedade, definindo a forma como irá ocorrer o jogo político no seu sentido mais abrangente. Essa "abordagem das arenas políticas" foi, na verdade, uma reação a uma outra abordagem, chamada de "abordagem sistêmica", que defendia uma relação de causalidade inversa na definição de políticas públicas. Nessa perspectiva, a atividade política no seu sentido mais amplo (politics) seria a causa (variável independente) e as políticas públicas (policies) seriam o efeito (variável dependente). Dessa forma, a principal função da atividade política desempenhada pelos governos seria atender às demandas que lhe são feitas (tanto por atores privados quanto por atores públicos). Portanto, para a "abordagem das arenas políticas" as políticas públicas formam as arenas, mas para a "abordagem sistêmica" são as arenas que formam as políticas públicas (RUA, 2013).

O principal autor da "abordagem sistêmica" foi David Easton que, analisando os processos de elaboração de políticas, apontou que as ações governamentais são "alocações autoritativas" de valores para a sociedade. O conjunto de atividades relacionadas a essas alocações autoritativas formaria o que ele chamou de "sistema político". Como qualquer sistema, o sistema político estaria sujeito a influências do ambiente no qual se encontra, assim como este ambiente seria afetado pela atividade do sistema político. Sistema político e ambiente estariam ligados um ao outro por uma relação de "input-output". Desta forma, ao analisar as ações governamentais, a sociedade deveria considerar as ideologias subjacentes, assim como contextos, estruturas e processos, o que ajudaria o entendimento sobre a coerência destas ações governamentais e permitiria que a sociedade tenha controle sobre o governo na sua tarefa de desenvolver valores públicos (EASTON, 1953; 1957).

De forma simplificada, o sistema político de Easton é visto como um delimitado e fluido sistema de fases de tomada de decisão, onde ocorrem basicamente cinco etapas. Na primeira, mudanças no ambiente social geram demandas e apoios que servem como “inputs" para o sistema. Na segunda, esses grupos de demandas e apoios estimulam a competição no sistema político gerando decisões, ou "outputs". Já na terceira etapa, esta decisão interage com o ambiente externo ao sistema e produz mudanças neste ambiente, ou "outcomes". Na quarta etapa, esses "outcomes" podem gerar novas demandas ou 
apoios de grupos contrários ou favoráveis à política. Até que na quinta etapa a retroalimentação, ou "feedback", leva o sistema de volta à primeira etapa, formando um ciclo sem fim. Ou seja, o sistema político de Easton entende que a interação entre os atores na atividade política (politics) processando de demandas (inputs) tem como produto (output) políticas públicas (policies). Esse sistema se caracteriza por ser baseado em metas, por transformar a si mesmo, por se adaptar de forma criativa e por regular seu comportamento através do monitoramento de informações para sua retroalimentação. Quando um sistema político é visto dessa forma, ele adquire as características de um processo contínuo, como um círculo inquebrável, no qual cada fase influencia todas as fases seguintes (EASTON, 1965).

Quando se utiliza a análise sistêmica para o estudo de políticas, entende-se uma política como um sistema que pode ser dividido em subsistemas menores, que representam as diferentes etapas percorridas por essa política. Desde os valores utilizados para fundamentar a escolha da política adotada, passando pela normatização desses valores e pela implementação dessa política, diversos estudos apontam para a importância daquela que é considerada uma das "últimas" etapas de uma política. Diferentes políticas exigiriam, respectivamente, a utilização de diferentes mecanismos de avaliação (PAPACONSTANTINOU; POLT, 1999). A avaliação de políticas públicas é um ramo que destaca a seleção de indicadores de resultado, seja para apresentar uma maior prestação de contas ou transparência, seja para aumentar a efetividade da política, ou ainda para atender a exigências feitas em troca de auxílio econômico de organismos internacionais, os governos vem sendo expostos a uma exigência crescente de demonstrar o atingimento de seus objetivos através de resultados concretos, para os demais atores envolvidos em suas políticas (KUSEK; RIST, 2004).

A avaliação de políticas públicas teria sido historicamente marcada por quatro diferentes ondas, que apresentaram características distintas. A primeira, entre as décadas de 1950 e 1960, foi marcada por uma orientação científica. Conhecida como "modelo de engenharia" tinha como base o objetivo de retirar a subjetividade da análise de políticas públicas e se basear em critérios racionais e objetivos, conforme a lógica positivista que lhe servia de pano de fundo (VEDUNG, 2010). Entre as décadas de 1960e 1970, este modelo vai perdendo força e dá espaço para um novo modelo que tem como base o conceito de diálogo. Durante esta onda de avaliação, privilegiou-se questões relativas aos diferentes atores envolvidos na política avaliada e a importância de que suas opiniões 
fossem levadas em consideração para a definição da política (PICCIOTTO, 2015). Verifica-se aqui a transição de uma lógica positivista para uma lógica construtivista, que abria a possibilidade de uma variedade muito maior de realidades a serem analisadas (VEDUNG, 2010). Já entre as décadas de 1970 e de 1980, o terceiro modelo de avaliação de políticas passa a ter seu foco na obtenção de resultados alinhados ao conceito de livre mercado, uma vez que tinha como base a teoria neoliberal que predominou nesse período (PICCIOTTO, 2015). A última e atual fase, se inicia na década de 1990 e tem a característica de ser um modelo baseado na evidência, pois tem como fundamento a comprovação sobre o sucesso das atividades governamentais (VEDUNG, 2010).

A análise sobre estas ondas de avaliação ao longo da história destaca a importância da definição de indicadores de desempenho para as políticas a serem avaliadas, especialmente com relação a políticas de inovação. Para que se criem os mecanismos que sirvam de referência para a análise de um setor industrial, seria necessário que se estabeleçam os respectivos indicadores de desempenho. Sendo considerados um dos mais importantes indicadores para essa avaliação, os indicadores utilizados para medir a inovação seguiram diferentes paradigmas, iniciando por um modelo linear de inovação até um modelo sistêmico. Ainda hoje, haveria um certo descolamento entre estes dois modelos, pois já se teria admitido a necessidade da adoção do modelo sistêmico de inovação, mas a falta de indicadores adequados para uma análise sistêmica faria com que ainda não se possa classificar as avaliações de políticas de inovação como efetivamente sistêmicas (MORAES SILVA; FURTADO, 2015).

Para desenvolver sua análise, Easton se baseia na teoria dos sistemas, desenvolvida por Niklas Luhmann (2012). No sistema social desenvolvido por Luhmann, um dos aspectos chave é a comunicação (LUHMANN, 2002). De acordo com ele, um sistema se comunica com o seu ambiente selecionando (através de estruturas especializadas) quais informações serão processadas por ele, e quais não serão. Essa é a base da "teoria dos sistemas que observam", ou "sistemas autorreferentes", onde o foco não está na observação dos sistemas em si, mas na observação sobre como os sistemas observam a si mesmos e aos demais sistemas que fazem parte do seu entorno (LUHMANN, 1985; 1995). Para explicar este processo de retroalimentação como autorreferência de um sistema, Luhmann utilizou um termo das ciências biológicas: autopoiese (LUHMANN, 2013). Essa tentativa de utilizar analogias com as ciências biológicas fez que com a teoria de Luhmann sofresse muitas críticas. Mas entende-se que 
a principal ideia por trás desse argumento é fundamental para o trabalho de pesquisa que aqui se desenvolve. Procurar entender o que um sistema utiliza para se reorientar é justamente a questão que se procura entender através da pergunta sobre o que serve de base para a definição da política industrial de petróleo e gás.

\section{3 - Análise do Referencial Teórico}

A partir dessa revisão realizada, percebe-se que o referencial selecionado oferece as bases teóricas para que se responda à pergunta sobre o que serve de base para definição de políticas industriais de petróleo e gás. Essa análise também permite que se verifique a hipótese levantada sobre se são as estratégias de desenvolvimento adotadas por cada governo que servem de base para a definição dessas políticas.

A literatura sobre estratégias de desenvolvimento não deixa dúvidas sobre a existência de uma polarização entre as possíveis alternativas a serem utilizadas. A contraposição do papel do Estado ao papel do mercado na promoção do desenvolvimento de um país se verifica ao longo de todas as diferentes correntes de pensamento macroeconômico que se propõem a analisar o tema sobre desenvolvimento. Quando se passa à análise sobre políticas industriais, percebe-se que esta polarização permanece, assim como o caráter positivista, objetivo e excludente, de um polo com relação ao outro. Até aqui, parece que a literatura indica a existência de alguma relação entre estas duas variáveis, uma vez que é marcante a presença da divisão entre a primazia do papel do Estado ou do mercado em ambas literaturas.

Quando se passa à análise sobre os economistas evolucionistas que trabalham questões de política microeconômica, relacionadas à orientação de políticas industriais, o foco se transfere da atividade estatal para os processos específicos a determinados setores industriais ou empresas. Enquanto aquela polarização citada acima se verifica ao longo de toda literatura que tem o Estado (e sua relação com o mercado) enquanto principal foco de análise, ao longo da literatura que toma como foco as empresas e seus setores industriais não parece seguir a mesma divisão. Mesmo tratando de diferenças entre países em desenvolvimento e países desenvolvidos, ou entre diferentes estágios de desenvolvimento apresentados pelas empresas, a participação do Estado ou de mecanismos de mercado aparece de forma muito menos excludente e sem nem mesmo uma precisa definição entre estas fronteiras. Já a literatura sobre análise sistêmica 
apresenta a importância da análise sobre a relação que existe entre estes atores na definição sobre uma política. Seja adotando a abordagem das arenas políticas ou a abordagem sistêmica, percebe-se uma relação cíclica de retroalimentação entre as arenas políticas formadas pelos diferentes atores e as políticas públicas que formam essas arenas, ao mesmo tempo que também são formadas por elas. Depreende-se daí a importância da comunicação e da interação entre os atores nesse processo de definição da política e se apresentou alguns trabalhos que destacam a importância da definição de métricas e indicadores de desempenho que sirvam de referência para essa relação.

Essa variedade de realidades apresentadas pelas distintas empresas e setores industriais aparece como resultado da adoção de uma lógica evolucionista pelos economistas que seguiram o modelo dos ciclos econômicos schumpeterianos, baseados na inovação. Essa diversificação serviu como contraponto para a lógica positivista que predominava até então, e seguiu predominando em análises que seguem outras abordagens. A ideia de uma verdade absoluta dá lugar a diferentes verdades capazes de coexistir, não só entre diferentes países, assim como dentro de um mesmo país, ou mesmo dentro de um mesmo setor industrial. Essa diversidade atinge uma variedade tão grande que faz com que o objeto de pesquisa assuma uma complexidade capaz de inviabilizar qualquer tentativa de análise. Para contornar este problema, utiliza-se a literatura sobre análise sistêmica, que permite a redução da complexidade encontrada em um determinado sistema através da divisão desse sistema em subsistemas menores, que apresentem um nível de complexidade mais baixo e viabilizem a análise sobre estes temas. 


\section{Capítulo 2 - Metodologia}

\section{1 - Desenho de Pesquisa}

Com base na análise dessa literatura, foi desenvolvido o desenho de pesquisa para este trabalho, que é apresentado de forma esquemática na imagem 1, ao final deste capítulo. A pergunta que se pretende responder aqui é sobre o que serve de base para a política industrial de petróleo e gás no Brasil, no México e na Noruega. A hipótese que será testada é a de que seja a estratégia de desenvolvimento adotada por cada governo, que sirva de base para a definição destas políticas.

De acordo com o referencial teórico analisado e com as informações obtidas ao longo da pesquisa de campo, estratégias de desenvolvimento baseadas no Estado estariam relacionadas com políticas industriais intervencionistas, que adotam instrumentos de intervenção como o fechamento do mercado, a criação de empresas estatais, a adoção do modelo de partilha da produção e políticas de nacionalização da cadeia produtiva, como as políticas de conteúdo local. Já estratégias de desenvolvimento baseadas no mercado estariam relacionadas com políticas industriais liberalizantes, que adotam instrumentos de liberação como a abertura do mercado, a privatização de empresas estatais, a adoção do modelo de concessão, e políticas de internacionalização, com uma cadeia produtiva globalizada.

Dessa forma, adota-se como variável independente a estratégia de desenvolvimento adotada por cada governo e como variável dependente os instrumentos de política industrial utilizados para o setor de petróleo e gás. A relação entre estas variáveis, as estratégias de desenvolvimento adotadas pelos governos e os instrumentos de política industrial utilizados, é que devem levar à resposta da pergunta e à verificação da hipótese levantada. Quando estas duas variáveis estiverem relacionadas (estratégias de desenvolvimento baseadas no papel do Estado com instrumentos de política industrial intervencionistas, ou estratégias de desenvolvimento baseadas no papel do mercado com instrumentos de política industrial liberalizantes) entende-se que a hipótese não possa ser negada, e que se tem um indício de que a estratégia de desenvolvimento possa estar sendo utilizada como base para a definição da política industrial de petróleo e gás. Já quando não houver correlação entre as duas variáveis (estratégias de desenvolvimento baseadas no papel do Estado com instrumentos de política industrial liberalizantes, ou estratégias 
de desenvolvimento baseadas no papel do mercado com instrumentos de política industrial intervencionistas) entende-se que a hipótese levantada possa ser negada, e que algum outro elemento que não a estratégia de desenvolvimento adotada é que esteja servindo de base para a definição da política industrial de petróleo e gás.

Para testar esta hipótese e tentar responder à pergunta de pesquisa, foram utilizadas diferentes estratégias de pesquisa, procurando combinar análises qualitativas e quantitativas. Além das estratégias de estudos de casos e a análise comparativa, foram utilizadas revisões bibliográficas para análises históricas. Todas estas estratégias foram colocadas em prática utilizando a álgebra booleana para a classificação e combinação entre variáveis. Tanto através de uma divisão dicotômica, que permite que se trabalhe apenas com valores binários, através da utilização de uma variedade maior de valores, que permite que se trabalhe com os intervalos que existem entre essas divisões binárias, captando também variações de intensidade nos dados obtidos pelas pesquisas de campo e bibliográfica (RAGIN, 1987). Dessa forma, as avaliações objetivas que os entrevistados realizam ao longo das entrevistas em profundidade são convertidas em diferentes variações de intensidades com relação a uma escala binária, entre opções de avaliação positivas e negativas (que serão detalhadas mais adiante neste capítulo). Já as estratégias de governo e os instrumentos de política industrial foram classificados entre dois valores binários que correspondem à predominância da intervenção estatal ou da liberalização de mercado, nestas duas variáveis.

\section{2 - Estrutura da Contextualização Histórica}

Seguindo esta classificação, nas análises sobre a história da indústria de petróleo de cada país, as estratégias de desenvolvimento adotadas pelos governos serão cruzadas com os instrumentos de política industrial adotados por eles. Com isso, pretende-se verificar a existência de uma relação entre estratégias de desenvolvimento baseadas no Estado e políticas industriais intervencionistas, assim como entre estratégias de governo baseadas no mercado e políticas industriais liberalizantes. Caso se encontre alguma relação entre as estratégias de desenvolvimento e as políticas adotadas, é possível que a primeira sirva de base para a definição da segunda, confirmando a hipótese desta tese. Mas caso essa correlação não se confirme em algum dos casos analisados, é possível que as estratégias de desenvolvimento não estejam sendo utilizadas como base para a 
definição da política industrial, fazendo com que a hipótese seja negada e seja necessária a análise de outros elementos, para que se procure encontrar uma resposta para a pergunta de pesquisa.

\section{3 - Classificação dos Atores}

Com base na análise da literatura sobre a abordagem das arenas políticas e sobre a abordagem sistêmica, depreende-se que a relação entre os atores envolvidos numa política é importante por duas razões. Primeiro, ela serve como indicativo sobre a qualidade da política industrial que já existe, uma vez que, de acordo com a abordagem das arenas políticas, são as políticas que definem as arenas políticas. Mas por outro lado, seguindo a abordagem sistêmica, a relação entre estes atores também serve como um indicativo sobre a qualidade da política que será resultado dessa relação e, portanto, ainda está por vir (LOWI, 1972; 1985; EASTON, 1953; 1957).

A partir dessa análise, foram realizadas entrevistas em profundidade com atores do setor de petróleo brasileiro, mexicano e norueguês. De acordo com a teoria analisada, dividiu-se os atores de cada país em dois grupos, onde um reúne atores ligados ao governo de cada país, e o outro grupo reúne atores ligados ao mercado. Com base no critério de reputação, no grupo de entrevistados do governo, foram selecionadas as instituições governamentais mais representativas para o setor, incluindo ministérios e agências reguladoras. Também com base no critério de reputação, o grupo de entrevistados do mercado reuniu diferentes associações empresariais ligadas à indústria de petróleo e gás de cada país. Também foram realizadas entrevistas com representantes das empresas de petróleo estatais de cada país, Petrobras, Pemex e Statoil. Como a posição destas empresas operadoras não se enquadra no grupo de atores do Estado, nem no grupo de atores do mercado, estas entrevistas não foram utilizadas para fins de comparação das respostas obtidas. Apesar disso, as informações coletadas por estas entrevistas foram utilizadas para orientar o desenho geral da tese e para ajudar numa melhor compreensão de cada um dos estudos de caso analisados.

As entrevistas foram realizadas de forma presencial (com exceção da entrevista com a CNI, no Brasil, onde a entrevista foi realizada através de resposta por escrito; e da entrevista com o CCE, do México, onde a entrevista foi realizada por telefone), seguindo os roteiros das entrevistas em profundidade, que se encontram no Anexo II. A tabela 1, 
ao final deste capítulo, apresenta a lista completa das instituições que tiveram representantes entrevistados nesta pesquisa. No Anexo I, encontra-se a lista completa das pessoas que foram entrevistadas em cada uma das instituições, assim como seu respectivo cargo e tempo de trabalho na instituição. Estes entrevistados responderam aos questionários em seus nomes e não em nome de suas respectivas instituições. Algumas adaptações foram necessárias ao longo da pesquisa, e serão devidamente indicadas junto com a descrição de cada estudo de caso. Para deixar os entrevistados à vontade para tratarem de questões polêmicas que envolvam o tema analisado, houve o comprometimento desta pesquisa em não apresentar citações diretas a trechos das respostas dos entrevistados e em não realizar nenhuma análise de forma individual. Exatamente por esta razão, as análises serão apresentadas sempre de forma agrupada, reunindo todas as respostas dos entrevistados de cada grupo de cada país, para que não seja possível a vinculação entre respostas e respondentes.

\section{4 - Estrutura das Entrevistas em Profundidade}

Mais uma vez, seguindo o que foi encontrado na revisão teórica, utilizou-se a literatura sobre as diferentes etapas de uma política, para definir as etapas da política industrial que são analisadas nesta pesquisa. De acordo com essa literatura, a análise de um sistema pode ter sua complexidade diminuída, dividindo este sistema em diferentes subsistemas (EASTON, 1965; LUHMANN, 2012). Toda política surge de um fato, sobre o qual se aplica um determinado valor, para que seja criada uma norma. Essa norma serve de base para a implementação da política, que gera seus respectivos resultados. Também há que se considerar as relações da política com o meio no qual ela está inserida. Analisando a política industrial como um sistema, seus resultados passam a ser informações que o sistema despeja no ambiente (outputs). Essas informações podem ser captadas através do monitoramento e da avaliação dos resultados da política e retornar ao sistema como nova informação (input), configurando sua retroalimentação (feedback). Assim, uma política pode ser analisada como um sistema autorreferente, capaz de decidir quais informações vai ou não vai processar para manter, adaptar ou alterar a si mesmo.

Cada uma destas etapas foi transformada em um bloco do roteiro de entrevistas em profundidade que foi aplicado nos três países. Em cada um desses blocos, foi feita uma pergunta objetiva sobre a avaliação do entrevistado sobre esta etapa da política no 
seu país. Para cada um desses blocos também foram feitas perguntas abertas, explicando a avaliação da etapa, perguntando sobre o que se sabe da forma como os atores do grupo contrário avaliam esta etapa, sobre se a instituição do entrevistado participou da definição desta etapa da política no seu país e se essa participação, caso tenha ocorrido, foi bem recebida pelos demais atores.

Na tabela 2, no final deste capítulo, estão apresentadas todas as etapas da política industrial, que serviram de base para a criação de cada bloco das entrevistas, assim como as perguntas, fechadas e abertas, de cada um desses blocos e os valores utilizados para a tabulação das perguntas objetivas.

\section{5 - Estrutura da Comparação}

Para realizar as análises comparativas, primeiramente se realizou a sistematização dos dados apresentados ao longo de todas as entrevistas realizadas. Num primeiro momento, foi feita uma síntese das respostas em forma de tópicos. Dentro de cada grupo e com relação a cada bloco da pesquisa (que equivale a cada etapa da política industrial), estes tópicos foram agrupados com base nos temas dos quais tratavam. A consolidação destes grupos de tópicos temáticos foi apresentada de forma que, para cada grupo de atores que se apresenta, estas informações apareçam na ordem das que mais se repetiram em mais de uma entrevista, até aquelas que foram mencionadas por apenas um dos entrevistados. Esta sistematização foi realizada ao longo dos capítulos 3, 4 e 5, pois assim como a apresentação sobre o contexto histórico de cada país, esta primeira parte dos estudos de caso não inclui a realização de nenhuma análise. Cogitou-se apresentar estas informações de forma separada do corpo principal da tese, no lugar de um anexo, mas devido à importância destacada sobre alguns temas por diversos dos entrevistados, optouse por garantir que todos os assuntos relevantes que foram levantados durante as entrevistas fossem apresentadas dentro da estrutura principal do trabalho.

Para a realização das entrevistas, foi combinado com todos os entrevistados que não seriam realizadas analises individualizadas, mas apenas de forma agrupada dentro de cada grupo de atores. No mesmo sentido, foi combinado que não seria feita a referência direta a trechos das falas apresentadas pelos entrevistados, para evitar a exposição destes e uma possível vinculação de seus nomes às respostas apresentadas. Esta foi uma estratégia adotada para permitir que uma maior quantidade de temas polêmicos fosse 
tratada durante as entrevistas, sem que houvesse o receio com relação à utilização das informações apresentadas. Para compensar essa ausência de referências diretas às falas dos entrevistados, a descrição das respostas ao longo dos três capítulos que iniciam os estudos de caso (capítulos 3, 4 e 5) foi feita com uma linguagem menos acadêmica, procurando passar para o leitor a essência e o formato das respostas da maneira mais semelhante possível com a fala original de cada um. Alguns termos que utilizam linguagem informal foram reproduzidos ou traduzidos para que seu conteúdo conotativo não fosse perdido, mas aparecem sempre estre aspas. A forma de apresentação das repostas nestes capítulos, assim como no capítulo seguinte, obedeceu a ordem em que as respostas foram apresentadas durantes as entrevistas. Dessa forma, pode-se perceber que as informações apresentadas pelos entrevistados brasileiros e mexicanos aparecem muitas vezes desencontradas dos seus respectivos blocos em que deveriam aparecer. Já entre os entrevistados noruegueses, as informações apresentadas pelos entrevistados seguiram de forma mais precisa os diferentes blocos da entrevista e suas respectivas etapas da política industrial. Devido a isso, a leitura dos capítulos 3 e 4, assim como das seções do capítulo 6 referentes aos estudos de caso do Brasil e do México, apresentam uma leitura um pouco mais confusa e menos precisa do que aquela que se verifica no capítulo 5, sobre o estudo de caso norueguês. Para entender esta diferença, dois elementos verificados durante as entrevistas parecem ser importantes: os entrevistados noruegueses, na sua maioria, demonstraram claramente que haviam lido com antecedência os roteiros das entrevistas e já conheciam a sua estrutura de antemão; além disso, de uma maneira geral, os noruegueses também demonstraram uma maior familiaridade com a análise sistêmica dividindo a política industrial em diferentes etapas, o que parece não ter ficado muito claro para alguns dos entrevistados brasileiros e mexicanos.

No sexto capítulo é apresentada a sistematização da análise dos dados através da comparação entre as respostas de um grupo com as respostas do outro grupo. Esse cruzamento das respostas dos entrevistados do governo de cada país com as respostas dos entrevistados das respectivas associações empresariais, assim como nos três capítulos anteriores, é apresentada sem a realização de análises sobre estes dados, e sem a relação com a teoria utilizada como base para este trabalho. Nesse sentido, foram comparados os temas mais levantados por cada grupo e apresentados de forma que os temas de um grupo se confrontassem com os mesmos temas levantados pelo outro grupo. Com isso, o objetivo era a identificação de semelhanças e diferenças nos temas levantados e nas 
opiniões apresentadas sobre eles. Aqui também se deu destaque às respostas que estivessem relacionadas com os instrumentos de política industrial adotados e com formas de definição sobre a política industrial.

Ainda no sexto capítulo, se começa a construção dos gráficos para a comparação das respostas apresentadas nas avaliações objetivas. Dessa forma, ainda no que se refere à relação entre os dois grupos de atores analisados, foram comparados os totais das respostas objetivas apresentadas em cada grupo. Também foram comparadas as variações nas respostas objetivas de cada grupo e entre os dois grupos de cada país. Ao final, foram analisadas e comparadas as respostas sobre a percepção que os atores de um grupo têm sobre os atores do outro grupo, sobre como cada ator percebe a sua própria participação na definição da política industrial de seu país e sobre como que cada ator sente que esta sua participação é recebida pelos demais atores. Todas estas análises foram realizadas para cada um dos estudos de caso aqui trabalhados.

Após esta comparação entre os dois grupos de atores de cada país, as informações prestadas por estes dois grupos foram reunidas para que fosse possível a comparação entre países. Assim como na comparação anterior, aqui também foram comparados os totais das respostas objetivas apresentadas em cada país. Com relação às respostas abertas, foram comparadas as semelhanças e diferenças entre os temas levantados nas entrevistas de cada país. Também se deu destaque às respostas relacionadas com os instrumentos de política industrial adotados e com formas de definição sobre a política industrial. Também foram comparadas as variações nas respostas objetivas de cada grupo e entre os dois grupos de cada país. E ao final, foram analisadas e comparadas as respostas sobre a percepção que os atores de um grupo têm sobre os atores do outro grupo, sobre como cada ator percebe a sua própria participação na definição da política industrial de seu país e sobre como que cada ator sente que esta sua participação é recebida pelos demais atores. Diferentemente dos capítulos anteriores, esta comparação final entre os estudos de caso fundamenta sua análise nos principais elementos trazidos pelo referencial teórico utilizado como base para esta pesquisa. 


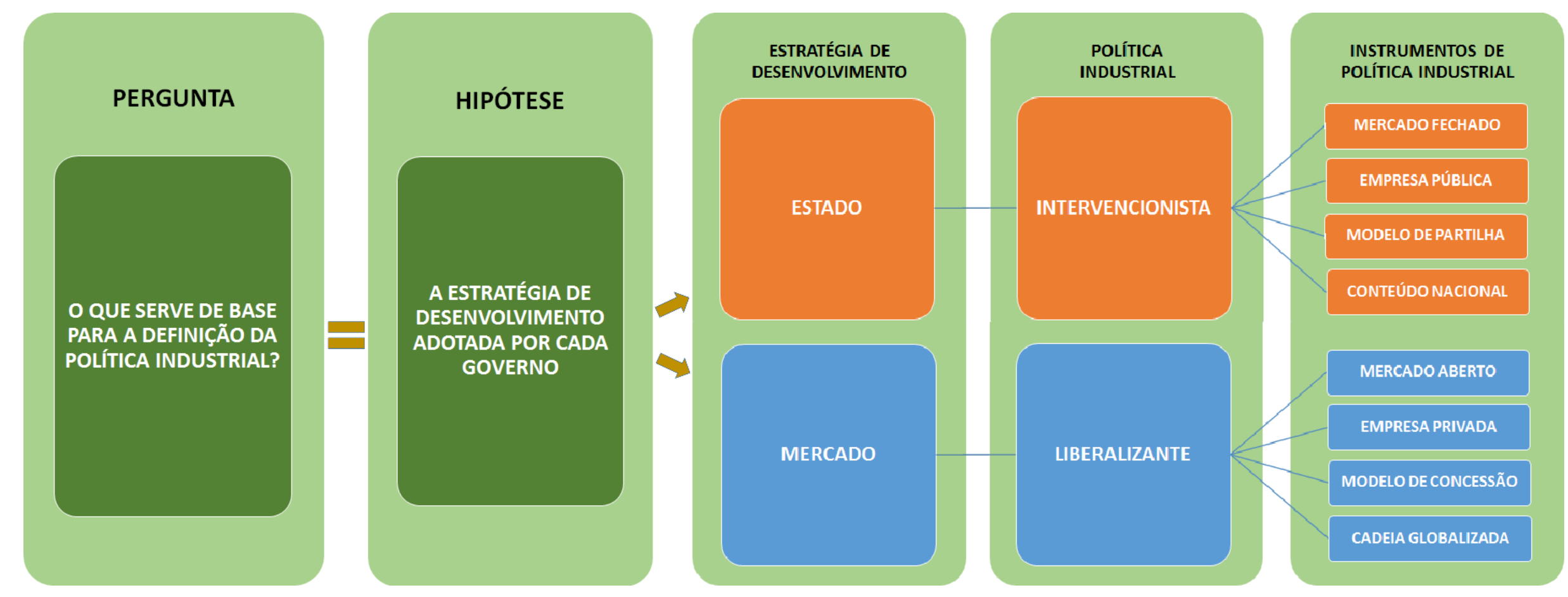

Imagem 1 - Desenho de pesquisa. 


\begin{tabular}{|c|c|c|c|c|}
\hline & & BRASIL & MÉXICO & NORUEGA \\
\hline \multirow{5}{*}{$\begin{array}{l}\mathrm{E} \\
\mathrm{S} \\
\mathrm{T} \\
\mathrm{A} \\
\mathrm{D} \\
\mathrm{O}\end{array}$} & \multirow{3}{*}{$\begin{array}{l}\text { G } \\
\text { O } \\
V \\
E \\
R \\
\text { N } \\
O\end{array}$} & MME - Ministério de Minas e Energia & SENER - Secretaría de Energía & Norwegian Ministry of Petroleum and Energy \\
\hline & & $\begin{array}{l}\text { MDIC - Ministério do Desenvolvimento, da Indústria e } \\
\text { do Comércio Exterior }\end{array}$ & SE - Secretaría de Economía & Norwegian Ministry of Foreign Affairs \\
\hline & & ABDI - Agência Brasileira de Desenvolvimento Industrial & CNH - Comisión Nacional de Hidrocarburos & PSA - Petroleum Safety Authority Norway \\
\hline & $\begin{array}{c}\text { ÓRGÃO } \\
\text { REGULADOR }\end{array}$ & ANP - Agência Nacional de Petróleo & CRE - Comisión Reguladora de Energia & NPD - Norwegian Petroleum Directorate \\
\hline & OPERADORA & Petrobras & Pemex & Statoil \\
\hline \multirow{5}{*}{$\begin{array}{c}\text { M } \\
\text { E } \\
R \\
C \\
A \\
D \\
0\end{array}$} & \multirow{5}{*}{$\begin{array}{l}\text { A } \\
\text { S } \\
\text { S } \\
\text { O } \\
\text { C } \\
\text { I } \\
\text { A } \\
\text { Ç } \\
\text { o } \\
\text { E } \\
\text { S }\end{array}$} & CNI - Confederação Nacional da Indústria & $\begin{array}{l}\text { CONCAMIN - Confederación de Cámaras Industriales de } \\
\text { los Estados Unidos Mexicanos }\end{array}$ & Norwegian Oil and Gas Association \\
\hline & & $\begin{array}{c}\text { IBP - Instituto Brasileiro de Petróleo, Gás e } \\
\text { Biocombustíveis }\end{array}$ & CCE - Consejo Coordinador Empresarial & $\begin{array}{l}\text { Norwegian Agency for Development Cooperation: } \\
\text { Norad - Oil for Development Programme }\end{array}$ \\
\hline & & ONIP - Organização Nacional da Indústria de Petróleo & COMEXI - Consejo Mexicano de Asuntos Internacionales & INTSOK - Norwegian Oil and Gas Partners \\
\hline & & $\begin{array}{l}\text { ABENAV - Associação Brasileira das Empresas de } \\
\text { Construção Naval e Offshore }\end{array}$ & $\begin{array}{c}\text { AMESPAC - Asociación Mexicana de Empresas de } \\
\text { Servicios Petroleros }\end{array}$ & Norwegian Shipowners' Association \\
\hline & & $\begin{array}{c}\text { ABIMAQ - Associação Brasileira da Indústria de } \\
\text { Máquinas e Equipamentos }\end{array}$ & & \\
\hline
\end{tabular}

Tabela 1 - Lista de atores entrevistados pela pesquisa e seus respetivos grupos. 


\begin{tabular}{|c|c|c|c|c|c|c|c|c|}
\hline \multirow{2}{*}{ ETAPA } & \multirow{2}{*}{ DESCRIÇÃO } & \multirow{2}{*}{\multicolumn{2}{|c|}{$\begin{array}{c}\text { QUESTIONÁRIO FECHADO } \\
\text { AVALIACCÃOO }\end{array}$}} & \multicolumn{5}{|c|}{ QUESTIONÁRIO ABERTO } \\
\hline & & & & SER & DEVER-SER & O OUTRO & AÇÕES & RECEPÇÃO \\
\hline \multirow{5}{*}{ Realidade } & \multirow{5}{*}{$\begin{array}{c}\text { Contexto no qual a política } \\
\text { está baseada }\end{array}$} & Muito Bom & +3 & \multirow{5}{*}{$\begin{array}{l}\text { Qual o potencial do país para } \\
\text { desenvolvimento de uma } \\
\text { indústria nacional? }\end{array}$} & \multirow{5}{*}{$\begin{array}{l}\text { Quais as desvantagens em } \\
\text { relação a outros países } \\
\text { produtores de petróleo? }\end{array}$} & \multirow{5}{*}{$\begin{array}{l}\text { O que os outros atores } \\
\text { pensam sobre isto? }\end{array}$} & \multirow[t]{5}{*}{ - } & \multirow[t]{5}{*}{ 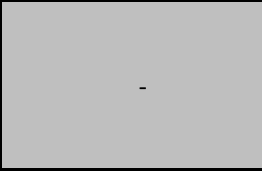 } \\
\hline & & Bom & +2 & & & & & \\
\hline & & Pouco Bom & +1 & & & & & \\
\hline & & $\begin{array}{c}\text { Pouco Ruim } \\
\text { Ruim }\end{array}$ & $\begin{array}{l}-1 \\
-2\end{array}$ & & & & & \\
\hline & & Muito Ruim & -3 & & & & & \\
\hline \multirow{4}{*}{ Valores } & \multirow{4}{*}{$\begin{array}{l}\text { Valores que orientam a } \\
\text { política }\end{array}$} & Muito Adequados & +3 & \multirow{4}{*}{$\begin{array}{c}\text { Foram utilizados valores } \\
\text { adequados? }\end{array}$} & \multirow{4}{*}{$\begin{array}{c}\text { Que valores deveria ter sido } \\
\text { priorizados? }\end{array}$} & \multirow{4}{*}{$\begin{array}{c}\text { O que os outros atores } \\
\text { pensam sobre isto? }\end{array}$} & \multirow{4}{*}{$\begin{array}{c}\text { A instituição do } \\
\text { entrevistado tomou } \\
\text { alguma ação sobre esta } \\
\text { etapa? }\end{array}$} & \multirow{4}{*}{$\begin{array}{l}\text { Como esta ação foi } \\
\text { recebida pelos demais } \\
\text { atores? }\end{array}$} \\
\hline & & $\begin{array}{c}\text { Adequados } \\
\text { Pouco Adequados }\end{array}$ & +2 & & & & & \\
\hline & & $\begin{array}{l}\text { Pouco Adequados } \\
\text { Pouco Inadequados }\end{array}$ & $\frac{1}{-1}$ & & & & & \\
\hline & & $\begin{array}{c}\text { Inadequados } \\
\text { Muito Inadequados } \\
\end{array}$ & $\begin{array}{l}-2 \\
-3 \\
\end{array}$ & & & & & \\
\hline \multirow{5}{*}{ Normatização } & \multirow{5}{*}{$\begin{array}{c}\text { Normas que regem a } \\
\text { política }\end{array}$} & Muito Adequadas & +3 & \multirow{5}{*}{$\begin{array}{l}\text { Como são as regras que } \\
\text { regem a política? }\end{array}$} & \multirow{5}{*}{$\begin{array}{c}\text { Como deveriam ser as regras } \\
\text { que regem a política? }\end{array}$} & \multirow{5}{*}{$\begin{array}{l}\text { O que os outros atores } \\
\text { pensam sobre isto? }\end{array}$} & \multirow{5}{*}{$\begin{array}{l}\text { A instituição do } \\
\text { entrevistado tomou } \\
\text { alguma ação sobre esta } \\
\text { etapa? }\end{array}$} & \multirow{5}{*}{$\begin{array}{l}\text { Como esta ação foi } \\
\text { recebida pelos demais } \\
\text { atores? }\end{array}$} \\
\hline & & Adequadas & +2 & & & & & \\
\hline & & Pouco Adequadas & +1 & & & & & \\
\hline & & $\begin{array}{l}\text { Pouco Inadequadas } \\
\text { Inadequadas }\end{array}$ & $\begin{array}{l}-1 \\
-2\end{array}$ & & & & & \\
\hline & & Muito Inadequadas & -3 & & & & & \\
\hline \multirow{5}{*}{ Implementação } & \multirow{5}{*}{$\begin{array}{l}\text { Forma como a política é } \\
\text { implementada }\end{array}$} & Muito Adequada & +3 & \multirow{5}{*}{$\begin{array}{l}\text { Como a política é } \\
\text { implementada? }\end{array}$} & & & & \\
\hline & & Adequada & +2 & & & & A Instituiç̧ao do & Como esta ação foi \\
\hline & & Pouco Adequada & +1 & & Como a politica deveria ser & que os outros atores & entrevistado tomou & recebida pelos demais \\
\hline & & $\begin{array}{l}\text { Pouco Inadequada } \\
\text { Inadequada }\end{array}$ & $\begin{array}{l}-1 \\
-2\end{array}$ & & & pensam sobre isto? & alguma ação sobre esta & atores? \\
\hline & & Muito Inadequada & -3 & & & & & \\
\hline & & Muito Adequados & +3 & & & & & \\
\hline & Resultados obtidos pela & $\begin{array}{c}\text { Adequados } \\
\text { Pouco Adequados }\end{array}$ & +2 & Quais os resultados obtidos & Que resultados deveriam ser & O que os outros atores & entrevistado tomou & \\
\hline Resultados & política & Pouco Inadequados & -1 & pela política? & obtidos pela política? & pensam sobre isto? & alguma ação sobre esta & recebida pelos demais \\
\hline & & $\begin{array}{c}\text { Inadequados } \\
\text { Muito Inadequados }\end{array}$ & $\frac{-2}{-3}$ & & & & etapa? & \\
\hline & & Muito Adequados & +3 & & & & & \\
\hline & Mecanismos de & Adequados & +2 & Como são os mecanismos de & como devarmos & O gue os outros a & Antrevictaça do & Como esta ação foi \\
\hline Avaliação & monitoramento e avaliação & $\begin{array}{l}\text { Pouco Adequados } \\
\text { Pouco Inadequados }\end{array}$ & $\begin{array}{c}+1 \\
-1\end{array}$ & monitoramento e avaliação & monitoramento e avaliacão & pensam sobre isto? & alguma acão sobre esta & recebida pelos demais \\
\hline & da política & $\begin{array}{c}\text { Inadequados } \\
\text { Muito Inadequados }\end{array}$ & $\begin{array}{l}-2 \\
-3\end{array}$ & da política? & da política? & & etapa? & atores? \\
\hline & & Muito Adequado & +3 & & & & & \\
\hline & Processo de definição sobre & Adequado & +2 & definicão sobre a & de definicão sobre a & O que os outros atores & entrevistado tomou & Como esta ação foi \\
\hline Reação & manutenção, correção ou & $\begin{array}{l}\text { Pouco Adequado } \\
\text { Pouco Inadequado }\end{array}$ & $\frac{+1}{-1}$ & manutencão, correcão ou & manutencão, correcão ou & pensam sobre isto? & alguma acão sobre esta & recebida pelos demais \\
\hline & mudança da política & Inadequado & -2 & mudança da política? & mudança da política? & & etapa? & atores? \\
\hline
\end{tabular}

Tabela 2 - Variáveis utilizadas para a construção dos instrumentos de pesquisa. 


\section{Capítulo 3 - Estudo de Caso: Brasil}

Neste capítulo serão apresentados os resultados do estudo de caso sobre a política industrial de petróleo e gás brasileira. Num primeiro momento, utiliza-se uma breve contextualização histórica, procurando relacionar os instrumentos de política industrial de petróleo e gás adotados por cada governo com a estratégia de desenvolvimento nacional que serviu de base para cada um desses governos. Em seguida, serão apresentadas as informações obtidas durante as entrevistas em profundidade com representantes do governo e das associações empresariais.

\section{1 - Contextualização Histórica}

Durante a década de 1920, iniciou-se no Brasil um debate sobre os papéis do Estado, do setor empresarial nacional e do capital estrangeiro nas atividades petrolíferas do país. De um lado estavam os nacionalistas, defendendo a participação direta do Estado e do setor privado nacional, de outro, grupos contrários à participação estatal e favoráveis à presença de empresas estrangeiras. No dia 21 de setembro de 1953 os defensores do controle estatal sobre o petróleo conseguiram aprovar a Lei 2.004/53, que autorizava a criação da empresa estatal e monopolista Petróleo Brasileiro S.A. (Petrobras). O presidente brasileiro da época, Getúlio Vargas, do Partido Trabalhista Brasileiro, assinou a lei de criação da empresa no dia 3 de outubro do mesmo ano, encerrando com um longo ciclo de disputas políticas e ideológicas sobre o tema. As principais missões dadas à empresa foram a diminuição das importações de combustíveis para complementar as necessidades de abastecimento interno e a indução do desenvolvimento industrial através de uma rede de fornecedores de serviços para o setor de petróleo (MORAIS, 2013).

A partir da década de 1950, com a criação de empresas estatais e um aumento da participação do Estado na economia, ocorre uma aceleração da industrialização brasileira (BAER, 2008). A distribuição da propriedade das maiores empresas brasileiras, até a década de 1960, ainda era de mais empresas privadas do que estatais. Já partir da década de 1970, essa relação se inverte, fazendo com que quase todas as grandes empresas nacionais passassem a ser estatais (TREBAT, 1983). 
Em 1955 houve a criação do CENAP (Centro de Aperfeiçoamento e Pesquisas de Petróleo), voltado à capacitação profissional e à pesquisa tecnológica, que foi substituído, em 1966, pelo CENPES (Centro de Pesquisa e Desenvolvimento da Petrobras), voltado para a pesquisa na área de petróleo. Logo após, entre 1968 e 1973, ocorrem as primeiras descobertas de campos em águas costeiras, no litoral do nordeste brasileiro, culminando com a descoberta das reservas na Bacia de Campos, em 1974. Nesse sentido, em 1986, a Petrobras formula o PROCAP (Programa de Capacitação Tecnológica em Águas Profundas (para viabilizar a produção de novos campos em águas com até 1.000 metros de profundidade). Este programa foi relançado em 1992, com o nome de PROCAP 2000 (para campos em profundidades de até 2.000 metros) e em 2002, como PROCAP 3000 (para profundidades de até 3.000 metros) (MORAIS, 2013).

No início da década de 1990, o presidente Fernando Collor implanta o Programa Nacional de Desestatização (PND), que realizou privatizações nas áreas de petroquímica e fertilizantes (LEITE, 2007). O inciso primeiro do artigo primeiro da lei do PND (Lei 8.031/90) não deixa dúvidas sobre a mudança de estratégia adotada pelo novo governo, expressando que um dos objetivos fundamentais desse programa era o de "reordenar a posição estratégica do Estado na economia, transferindo à iniciativa privada atividades indevidamente exploradas pelo setor público".

No governo seguinte, o Plano Real alcançou o esperado controle da inflação através da adoção de medidas de austeridade, que visavam à estabilidade econômica nacional (CARDOSO; GRAEFF, 2012). Durante o governo do presidente Fernando Henrique Cardoso, em 1995, o PND passa a fazer parte do Programa Diretor da Reforma do Aparelho do Estado, que também tinha o objetivo de reduzir o papel do Estado na economia, e serviu de base para a intensificação das privatizações no país (ANDRÉS et al., 2008). Em novembro desse ano, a Emenda Constitucional $\mathrm{n}^{\circ} .09$ permitindo a participação de empresas privadas nas atividades do setor de petróleo que, até então, eram realizadas somente pela Petrobras. Apesar dessa abertura do mercado, não havia espaço político para uma proposta de privatização da empresa (FILIPE, 2010).

A Lei do Petróleo, de agosto de 1997, criou a Agência Nacional do Petróleo (ANP), o Conselho Nacional de Política Energética (CNPE) e redefiniu o papel da Petrobras, que passou a ser uma empresa de capital aberto, mas mantendo o controle acionário da empresa com a União (BAIN \& COMPANY; TOZZINIFREIRE 
ADVOGADOS, 2009). O artigo vinte e três dessa lei definiu a adoção do modelo de concessões para a oferta de blocos exploratórios (TOLMASQUIM; PINTO JR., 2011). Essa mesma lei, no seu artigo segundo, ainda instituiu a necessidade de comprometimento com o incremento dos índices mínimos de conteúdo local.

A eleição do presidente Lula significou a adoção de duas posturas diferentes com relação às políticas adotadas pelo governo anterior. Enquanto na política macroeconômica o novo governo adotou uma postura prudente, sem grandes mudanças, com relação às políticas para o setor de petróleo houve uma inversão da tendência de privatização do governo anterior, e a busca do fortalecimento da Petrobras. Essa mudança de papéis na Petrobras acabou fazendo com que ela tivesse uma atuação dupla, ora como uma empresa concorrendo no mercado internacional, ora como um instrumento do governo na condução da política energética do país (LEITE, 2007). Logo no primeiro ano de governo, foi criado o Programa de Mobilização da Indústria Nacional de Petróleo e Gás Natural (PROMINP), com o objetivo de incrementar o índice de conteúdo nacional na indústria de petróleo e gás (ALMEIDA; OLIVEIRA; SCHNEIDER, 2014).

Desde a primeira rodada de licitações (1999), a oferta de conteúdo local era um elemento considerado para a definição do vencedor da licitação. Na quinta (2003) e na sexta rodada (2004) havia a exigência de um índice mínimo de conteúdo local, mas a comprovação do atingimento desse índice era feita pelas empresas através da declaração de origem de suas compras, o que acabou demonstrando não atender aos objetivos da política. Justamente por isso, a partir da sétima rodada (2005) houve um aumento dos índices exigidos, a adoção da cartilha de conteúdo local e a medição dos índices por empresas certificadoras, com a previsão da aplicação de multas em caso de descumprimento (FEDERAÇÃO DAS INDÚSTRIAS DO ESTADO DA BAHIA., 2015).

A chamada Política Industrial, Tecnológica e de Comércio Exterior (PITCE) foi adotada entre 2004 e 2007, com o objetivo de colocar a política industrial novamente na agenda como uma prioridade (FERRAZ; KUPFER; MARQUES, 2014). Entre 2006 e 2007 foram descobertos reservatórios gigantes e supergigantes na camada pré-sal da Bacia de Santos e da Bacia de Campos (MORAIS, 2013). Após essas descobertas, o Conselho Nacional de Política Energética (CNPE), por meio da resolução nº.6, de 08 de novembro de 2007, determinou a retirada dos blocos que estavam em áreas do pré-sal da 
nona rodada de licitações que seria realizada em seguida. Em 2008, foi implementado um programa de política industrial chamado Política de Desenvolvimento Produtivo, que tinha o objetivo de promover alguns campeões nacionais em cadeias globais de produção (COUTINHO et al., 2012).

No último ano do segundo mandato do presidente Lula, foram aprovados importantes projetos para o setor de petróleo no país. A Lei $\mathrm{n}^{\circ}$. 12.276/10 autorizou a cessão onerosa de áreas da camada pré-sal para a Petrobras, com o objetivo de ajudar a empresa a se capitalizar para que pudesse enfrentar os desafios tecnológicos que seriam impostos pela exploração nessa área. Em seguida foi aprovada a Lei $\mathrm{n}^{\mathrm{o}}$. 12.304/10, autorizando a criação de uma empresa estatal (Petrosal), para a gestão dos contratos de partilha e de comercialização. Já a Lei 12.351/10 estabeleceu o regime de partilha da produção para a exploração e produção em áreas da camada pré-sal, determinou que a Petrobras seria a única operadora nessas áreas, com a necessidade de participação mínima de $30 \%$ no caso de formação de consórcio e criou o Fundo Social (OXFORD ANALYTICA, 2010).

A presidente Dilma manteve o claro objetivo iniciado nos governos Lula de aumentar a participação da Petrobras na política industrial promovida pelo governo. Por outro lado, também se verificou o uso da empresa para o atendimento a uma agenda paralela, envolvendo interesses externos à política industrial, como o cumprimento da meta fiscal em 2010. Já em 2012, a presidente defendeu a política de conteúdo local como uma forma de maximizar os empregos no Brasil, e não em outros países, pois essa seria uma das bases para o desenvolvimento nacional (ALMEIDA; OLIVEIRA; SCHNEIDER, 2014). As primeiras declarações de comercialidade de campos na camada pré-sal são declaradas entre 2010 e 2012. Em 2011 é lançado um novo programa de política industrial, chamado Plano Brasil Maior (PBM), com o objetivo de aumentar a competitividade da indústria nacional (FERRAZ; KUPFER; MARQUES, 2014).

O Projeto de Lei $n^{\circ}$. 4.567/16, de autoria do senador José Serra, foi aprovado pelo Senado Federal em 2016, e propõe a retirada da obrigatoriedade da atuação da Petrobras como operadora única dos campos da camada pré-sal. O início do governo de Michel Temer e a adoção de um discurso menos nacionalista do que o do governo anterior, indicam o fortalecimento desse projeto, que depende da aprovação na Câmara de Deputados, para ser encaminhado para sanção presidencial. 


\section{2 - Entrevistas em Profundidade}

Dos dez atores brasileiros que foram contatados, nove atenderam à pesquisa $\mathrm{e}$ responderam às entrevistas em profundidade. A única exceção foi a ABESPetro, cujo representante inicialmente prontificou-se a participar, mas posteriormente demonstrou-se indisponível, mesmo após reiteradas tentativas de contato (dez tentativas ao longo de nove meses). Esta falta não chegou a prejudicar a capacidade comparativa da pesquisa, uma vez que outras cinco associações empresariais do setor participaram da pesquisa e a quantidade ideal de entrevistas necessárias eram quatro entrevistas por grupo.

Um dos entrevistados das associações empresariais optou por não responder as perguntas objetivas dos três últimos blocos (sobre os resultados da política, avaliação da política e reação aos resultados da avaliação), alegando que os resultados eram muito controversos, que não havia avaliação da política, nem reação a esta avaliação, e que, portanto, não poderia avaliar estas etapas. Devido a isto, as respostas objetivas desta entrevista foram desconsideradas, permitindo que se mantivesse a quantidade mais adequada de quatro respondentes por grupo. Todavia, as informações apresentadas por este entrevistado durante as perguntas abertas foram consideradas e serão utilizadas para complementar as informações das demais entrevistas.

Outra dificuldade encontrada foi junto à ANP. Apesar da pesquisa ter mantido contato com a ANP desde a fase de entrevistas exploratórias em 2014, o nome que foi indicado como mais apropriado para responder sobre a política industrial nacional, acabou não participando da pesquisa. A entrevista chegou a ser marcada, mas foi cancelada no momento em que deveria ser realizada. Este mesmo nome se comprometeu a enviar as respostas por escrito posteriormente, mas as respostas nunca foram encaminhadas, nem se conseguiu uma nova oportunidade de entrevista presencial, mesmo após reiteradas tentativas de contato (dez tentativas ao longo de seis meses). Apesar da atenção e prestatividade de outras pessoas da ANP em atender à pesquisa (fornecendo valiosas informações durante a fase exploratória e até mesmo fazendo um esforço para tentar responder às perguntas da entrevista em profundidade), como o tema abordado não era a especialidade dessas pessoas, que tentaram colaborar, optou-se por deixar estas respostas de fora da análise, para não prejudicar a precisão dos dados apresentados. A não participação da ANP nas respostas ao questionário é uma falta importante para o trabalho 
de pesquisa, devido à importância desta agência para a política industrial brasileira. De qualquer forma, este fato entra como dado para a pesquisa, servindo como indicativo de uma certa dificuldade de acesso a parte dos funcionários deste órgão do governo brasileiro.

Assim sendo, serão analisadas três entrevistas de representantes do governo brasileiro e quatro entrevistas de representantes de associações empresariais brasileiras do setor de petróleo e gás (complementadas com dados de uma quinta entrevista). As entrevistas foram realizadas entre os dias 13 e 24 de julho de 2015 e as respostas devem ser compreendidas levando em consideração o contexto presente neste período.

Antes mesmo de iniciar as perguntas relativas ao roteiro das entrevistas em profundidade, como uma forma de comentário prévio, um dos entrevistados do governo ressaltou que, muitas vezes, a política industrial brasileira não é definida com base em critérios técnicos, medições ou avaliações, pois existem questões políticas e até ideológicas que podem impedir que se realizem aprimoramentos, ou que se faça o que é considerado o mais certo numa determinada situação. Já os entrevistados das associações empresariais brasileiras não fizeram nenhum comentário prévio à aplicação dos questionários.

\subsection{1 - Realidade da Indústria}

\section{a) Governo}

O gráfico 1, abaixo, apresenta as respostas dos entrevistados do governo brasileiro, sobre a avaliação da realidade que serviu de base para a formulação da política industrial de petróleo e gás no país. 


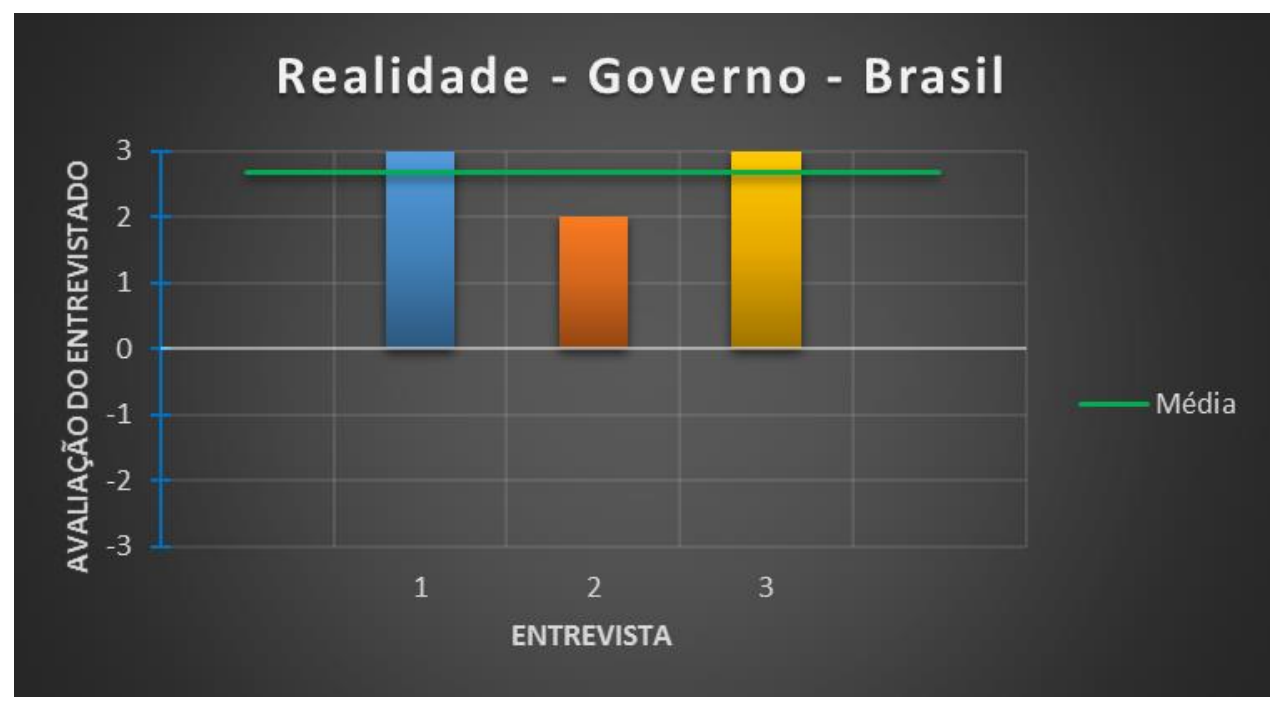

Gráfico 1 - Avaliações dos entrevistados do governo do Brasil sobre a realidade da indústria que serviu de base para a política industrial do país.

Em todas as três entrevistas, a descoberta de petróleo na camada pré-sal foi citada como um elemento que aumentou muito o potencial brasileiro para o desenvolvimento de sua cadeia de produção. Por um lado, foi mencionada a alta produtividade encontrada nos campos do pré-sal, que teria feito do campo de Lula a maior fonte de petróleo do país e com que Lula, Mexilhão e Jubarte (que ainda fazem parte do regime de concessão) tenham ultrapassado as produções da bacia de Campos. Por outro lado, o pré-sal se apresenta como um desafio tecnológico para a indústria nacional, pois algumas inovações serão necessárias para permitir a exploração de petróleo nas condições oferecidas por um ambiente tão diferenciado, que foi comparado a ida à Lua.

Em contrapartida, a queda do preço do barril de petróleo também foi mencionada em todas as três entrevistas. Este seria o principal fator para a queda de investimentos no setor de petróleo nacional e internacional. Esta queda é vista como algo conjuntural, envolvendo a exploração não convencional nos Estados Unidos e a disputa com a Arábia Saudita. Porém, considera-se que o preço não deva ficar muito distante de sessenta a oitenta dólares o barril, o que já viabilizaria a exploração da camada pré-sal brasileira.

Além da unanimidade em mencionarem a descoberta de petróleo na camada présal, a menção em termos mais gerais aos níveis das reservas brasileiras como um todo, também esteve presente nas três entrevistas. A valorização destas reservas serviu de base para um outro tema que também foi levantado em todas as três entrevistas: a importância 
da política de conteúdo local. Esta política foi considerada como a responsável por fazer com que fique no Brasil uma maior parte dos valores previstos para investimento neste setor. Foi lembrado que a política de conteúdo local era mais flexível no passado, quando foi implementada junto com o fim do monopólio da Petrobras e a abertura do mercado. Seus índices eram bem mais baixos, com muita comprovação por meio declaratório, um gatilho que fazia com que bens com mais de $60 \%$ de conteúdo nacional fossem considerados $100 \%$ nacionais e a origem de nota, que não permitia que se soubesse exatamente a origem de um determinado bem. A partir das cartilhas de conteúdo local (que foram especificamente mencionadas em duas das entrevistas), se migrou dessa regra de conteúdo local global para uma regra de conteúdo local por sistemas e subsistemas, capaz de avaliar mais precisamente o conteúdo nacional, permitindo que se busque o desenvolvimento de segmentos específicos da indústria. Também foi destacado que o objetivo da política de conteúdo local é desenvolver tecnologia onde é necessário para o Brasil e não procurar alcançar $100 \%$ de conteúdo nacional. Justamente por isso, a partir da $13^{\text {a }}$ ronda se tentaria evitar índices acima de $80 \%$, para evitar uma reserva de mercado, que teria efeitos maléficos para o país.

A necessidade de melhorias na política de conteúdo local também foi mencionada nas três entrevistas. Apesar do aumento que se tem verificado no índice de conteúdo nacional, este aumento não corresponde à expectativa presente na regulação e, devido a isso, a partir da $7^{\text {a }}$ rodada estariam ocorrendo muitas multas. Foi mencionado que a política estava sendo analisada pelos órgãos envolvidos, mais no sentido de aprimorá-la do que no sentido de abandoná-la. Duas entrevistas mencionaram uma conjuntura muito crítica à política de conteúdo local devido à queda do preço do barril e à crise com as empresas da operação Lava Jato, pois não existiriam outras empresas no Brasil capazes de se apropriar dessa oportunidade, de ocupar o lugar das empresas evolvidas. Mesmo com a necessidade de melhorias, foi ressaltado que todos os países que já tiveram alguma indústria desenvolvida se basearam em algum tipo de política de conteúdo local.

O desafio regulatório foi mencionado em duas das entrevistas. Devido às características do setor, a condução da política não deve sofrer mudanças muito radicais, pois aumentariam a incerteza e a complexidade da apuração. Então, dentro do possível, se deveria tentar manter as regras estáveis. Assim, se teria o desafio de corrigir o marco regulatório fazendo o mínimo de mudanças possível. 
Já entre os temas mencionados em apenas uma das entrevistas temos uma série de desvantagens brasileiras, como a produção ter crescido em direção ao mar, onde o custo de exploração é mais alto. As questões tributária, de educação básica e de capacitação técnica também foram levantadas como desvantagens. A falta de capital (até mesmo na Petrobras, devido à queda do preço do barril e à taxa de câmbio desfavorável) seria outra desvantagem. Além dos problemas provenientes do uso da Petrobras como ferramenta de política econômica, como para segurar a inflação. Mesmo assim, foi ressaltado que se tem muita matéria prima. O que falta seria tecnologia, pesquisa e desenvolvimento.

Um aspecto positivo da política que foi mencionado é o fato de ela se basear em uma oferta feita pela própria empresa. Isso deveria motivar o empreendedor a cumprir o índice de conteúdo local prometido. Assim, a política contaria com a boa vontade do empreendedor para contribuir com o desenvolvimento do país.

Apesar dessa característica, a política apresenta dificuldade em beneficiar aquelas empresas que fornecem para os fornecedores da Petrobras, ou seja, os subfornecedores de terceira e quarta camada. Isso porque a indústria de petróleo seria muito transnacionalizada, com empresas centenárias que teriam muito mais capacidade de aprendizado do que as empresas nacionais para se adaptar às necessidades de um cenário de ambiente exploratório tecnologicamente desafiador como o da camada pré-sal. As empresas brasileiras não têm tradição petroleira. Não existe nenhum grande fornecedor brasileiro na cadeia global de fornecedores da indústria de petróleo. Aparecem apenas alguns fornecedores de partes e componentes. $\mathrm{Na}$ área de refino, algumas empreiteiras e prestadoras de serviço participam junto com grandes empresas internacionais. $\mathrm{Na}$ área de exploração e produção existem poucas, como a Queiroz Galvão e a Odebrecht, afretando e operando sondas. Mas serviços mais especializados, como dentro das sondas e dentro das plataformas, são feitos pelas mesmas grandes empresas internacionais de sempre, como Schlumberger, Halliburton e Baker Hughes. Sendo que, nos últimos anos, o fretamento de sondas teria apresentado diárias de aproximadamente seiscentos mil dólares. Ou seja, na área de maior valor agregado da cadeia de fornecedores, não existiria uma inserção de empresas brasileiras.

A política de conteúdo local foi citada como tendo levado a um grande avanço no setor naval, que tinha cerca de dois mil empregados no final da década de 1990 e hoje teria quase oitenta mil. Isso trouxe algumas oportunidades para as empresas do setor. 
Mesmo assim, a inserção de empresas brasileiras se dá de forma subordinada, pois não existe projeto, ou uma estratégia para colocar conteúdo tecnológico na indústria naval. Na década de 1970 e 1980 o Brasil ainda tinha alguns grandes fabricantes no setor, mas depois da década de 1990, pela ausência de uma política industrial para o setor naval, ele teria sumido.

A Noruega foi lembrada como um caso de muito sucesso em aproveitar essa oportunidade para inserir empresas nacionais na cadeia de fornecedores, com uma política de conteúdo local, envolvimento da sociedade e dos políticos, através de um pacto social para aproveitar ao máximo os recursos, com base nos dez mandamentos da indústria de petróleo e gás. Já o Brasil teria uma economia muito diversificada, com um agronegócio muito forte, o que faz com que o debate sobre a indústria de petróleo se limite a discutir sobre a privatização ou não da Petrobras, impedindo uma discussão de geopolítica mais elaborada sobre uma estratégia de política industrial, como fez a Noruega.

O modelo mexicano (que parece ser menos burocrático, com nível de conteúdo local bem mais baixo e não muito transparente sobre como vai ficar a situação da Pemex) foi lembrado como sendo bem mais tímido. Enquanto o modelo brasileiro, bem mais ambicioso, seria muito mais transparente, pois qualquer contrato, de todas as rodadas, e todas as informações, estariam no site da ANP e seria muito claro quais são os órgãos regulatórios intervenientes no processo, o que o México ainda estaria formulando.

Um entrevistado citou que hoje a discussão é sobre se a Petrobras pode ou não ser operadora única. Também se questiona o modelo de partilha. Mas lembrou que o modelo de concessão deve ser utilizado apenas quando a exploração envolve risco, geralmente em um campo novo onde não se sabe se a exploração será viável. Por isso o modelo de concessão não faria muito sentido no pré-sal.

Ainda com relação à política de conteúdo local, foi lembrado que a dificuldade das empresas internacionais em acessar novas reservas e a grande quantidade de reservas que a Petrobras ainda tem para explorar é um contexto geopolítico que não pode ser negligenciado. O interesse das companhias operadoras internacionais é muito forte, fazendo com que essa disputa não seja trivial, o que exige que o cenário seja analisado com muito cuidado. 


\section{b) Associações Empresariais}

O gráfico 2, abaixo, apresenta as respostas dos entrevistados das associações empresariais brasileiras, sobre a avaliação da realidade que serviu de base para a formulação da política industrial de petróleo e gás no país.

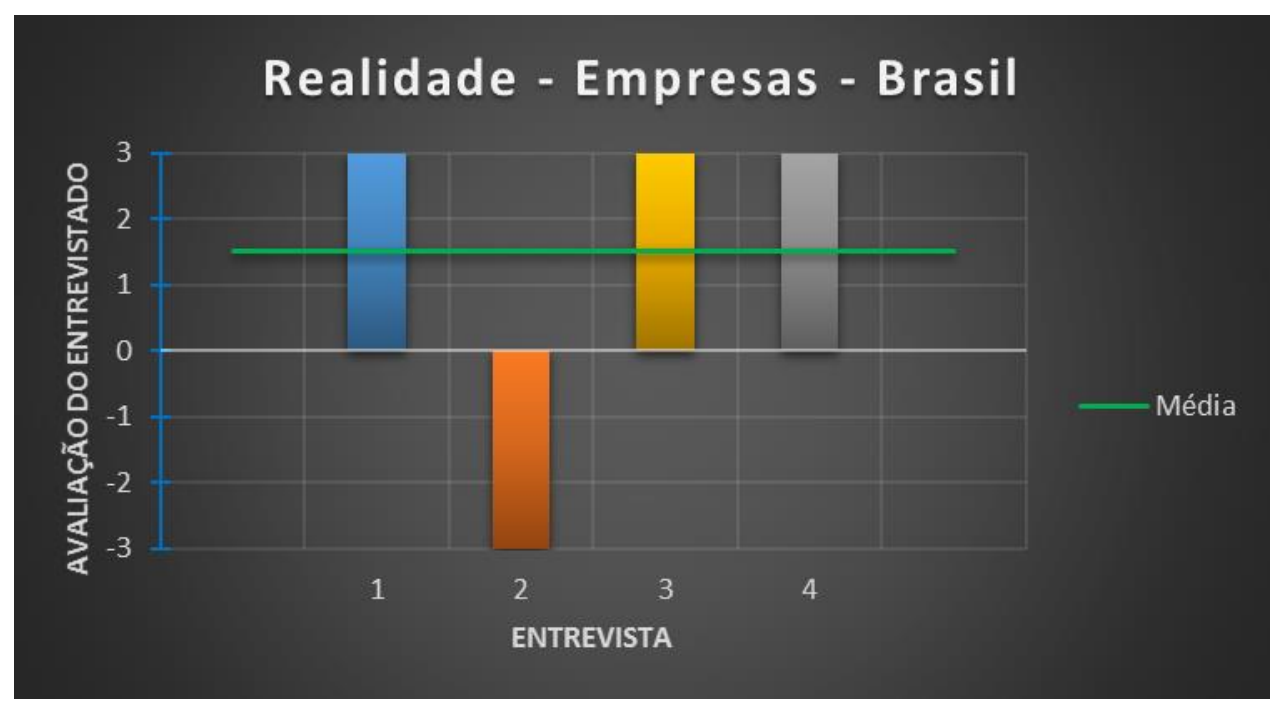

Gráfico 2 - Avaliações dos entrevistados das associações empresariais do Brasil sobre a realidade da indústria que serviu de base para a política industrial do país.

Não houve nenhum tema que tenha sido lembrado em todas as quatro entrevistas. Um dos temas mais recorrentes foi sobre o tamanho das reservas brasileiras, que foi levantado por três entrevistados diferentes. Foi mencionado que as reservas comprovadas tendem a aumentar bastante, por existir muito óleo que ainda não foi declarado como reserva provada. Estas reservas fazem com que o Brasil tenha algo que a maioria dos outros países não tem. O que faltaria para o Brasil seria a capacidade de produção no país e para isso seria necessário a superação de desafios tecnológicos, além do desafio socioeconômico de gerar emprego, competitividade e sustentabilidade no longo prazo.

Outro tema que foi mencionado em três entrevistas foi a política de conteúdo local, que recebeu análises distintas. Houve quem defendeu que a política de conteúdo local brasileira é baseada nas melhores práticas de países como Coréia e Noruega, que foram adaptadas à conjuntura do mercado brasileiro. Já os outros dois entrevistados que mencionaram esta política destacaram que ela não seria, na verdade, uma política, mas sim um elemento contratual, ou simplesmente um indicador. Foi mencionado que 
enquanto os investimentos cresceram de maneira expressiva, a indústria quase não cresceu, o que demonstraria que a indústria nacional não se apropriou de quase nada.

Dois entrevistados chamaram a atenção para o fato de que, efetivamente, não existe uma política industrial brasileira para o setor. Os esforços para aumento do conteúdo nacional não teriam origem no governo, mas sim na própria Petrobras. Foi mencionado que a Inglaterra e a Noruega dividem a exploração no Mar do Norte. Enquanto a Inglaterra optou por uma política industrial visando uma produção rápida, para atender a necessidades econômicas, a Noruega optou por uma política industrial de produção mais lenta, para estimular o desenvolvimento de conteúdo local. Estas seriam duas políticas industriais diferentes, mas nenhuma delas teria acontecido no Brasil.

O fato de que o preço do barril de petróleo é cíclico foi mencionado em duas entrevistas diferentes. Lembrou-se que as previsões sobre este preço sempre erram, fazendo com que qualquer planejamento de longo prazo com base no preço do barril seja um erro. Outro aspecto relacionado ao preço do barril que também foi apontado por dois entrevistados é que a exploração de petróleo na camada pré-sal brasileira seria rentável a partir de quarenta e cinco dólares por barril e seria uma oportunidade para o desenvolvimento de capacidades produtivas no país. Por outro lado, foi lembrado que as explorações no Golfo do México, no Mar do Norte, no oeste da África e no leste brasileiro, assim como qualquer exploração em águas profundas, precisam do preço do barril neste mínimo de quarenta e cinco dólares para serem lucrativas, enquanto a exploração de petróleo no Oriente Médio já seria lucrativa com o barril a dez dólares. Portanto, a indústria do Oriente Médio só não quebra as indústrias dos demais países porque não lhes deve ser interessante.

O sucesso na instalação da indústria de equipamentos subsea no Brasil foi lembrado em duas entrevistas. Ressaltando que se trata de empresas transnacionais que são competitivas, mas não exportam porque suas matrizes, que ficam em outros países, dividem o mercado. Por outro lado, os mesmos entrevistados apontaram para o fato de que o mesmo sucesso não foi obtido em outros setores, como o naval, que não teria conseguido atender a demandas por falta de produtividade, entre outras razões.

Dois entrevistados também levantaram questões sobre os benefícios trazidos pela abertura do setor e pelas mudanças de gestão na Petrobras durante o governo Fernando Henrique Cardoso. Este governo também foi identificado com o início do surgimento do 
conteúdo local, embora o foco fosse apenas sinalizar para as empresas estrangeiras que viriam ao Brasil sobre a existência de uma indústria no país. As mudanças na Petrobras, o alinhando o preço da gasolina ao preço internacional, a subida do preço do petróleo, a capacidade tecnológica que já se tinha para produção em águas profundas e o crescimento do mercado com a abertura teriam contribuído para que a Petrobras se tornasse mais empresa e menos estatal, atingindo níveis bastante razoáveis de competitividade internacional e de tamanho. Estas mudanças teriam servido de base para um crescimento da produção que durou até 2008.

Em 2008 a Petrobras anunciaria a descoberta do pré-sal, que na verdade já teria sido descoberto muito antes (fato citado por dois entrevistados diferentes), mas não teria sido explorado por ser muito caro. Dessa forma, o início da exploração do pré-sal num período onde a produção já apresentava crescimento fez com que o setor adquirisse uma dimensão muito grande. Isto levou ao crescimento da demanda por produtos e serviços no setor, o que também foi apontado em duas entrevistas. Assim, percebeu-se a necessidade de uma indústria montadora no país e para isso seriam necessários estaleiros. Um dos entrevistados disse que Lula teria enxergado aí uma oportunidade de se eleger, pois os estaleiros seriam um grande "celeiro de votos".

De acordo com um dos entrevistados, os investimentos foram transferidos para as plataformas do pré-sal, o que acabou prejudicando a produção já existente e fazendo com que a curva de produção do pós-sal começasse a cair antes do esperado, devido a problemas de manutenção. Dessa forma, mesmo com o crescimento da produção pela exploração da camada pré-sal, a curva de produção nacional parou de crescer e a previsão, que antes era de crescimento da produção, foi revista e agora imagina-se que deva ficar praticamente constante, entre dois milhões e dois milhões me meio de barris.

Problemas relativos à carga tributária foram apontados em duas entrevistas. Além disso, uma série de outros problemas que foram mencionados apenas uma vez, como: o patamar reduzido dos investimentos da Petrobras (mas que continua muito alto quando comparado a outros países, como o México); o alinhamento de uma crise econômica a uma crise política, que assusta os empresários, levando a demissões e corte de investimentos; má gestão; espaço de 8 anos sem leilões; os ciclos econômicos; período inflacionário; crises internacionais cambiais; ineficiência logística; deficiências no 
sistema de educação; e no sistema de inovação. Todos estes fatores teriam contribuído para limitar o desenvolvimento da cadeia fornecedora e da indústria, de um modo geral.

Também foi criticado o foco em serviços, deixando a indústria num segundo plano, o que seria prejudicial tendo em vista que sem indústria não haveria serviços. $O$ Repetro foi mencionado como algo que prejudicou a indústria por ter um viés importador muito grande. E o Prominp como algo que não deu resultado, deixando a política sob responsabilidade da Petrobras.

Foi mencionado que os principais pontos de melhoria estariam ligados a aspectos regulatórios, pois os processos seriam cercados de incertezas. Houve crítica à clausula de operador único e à exigência de participação mínima de 30\% da Petrobras, restringindo a possibilidade de investimentos no setor. Outro entrevistado foi mais enfático, afirmando que o maior problema teria sido o foco em questões como o modelo de partilha, a ideia de que o petróleo é nosso e que deve ser guardado para futuras gerações, concluindo que ele avalia tudo que foi feito como pior do que muito ruim.

Mesmo que a política de atração de estaleiros tenha funcionado, foi mencionada a falta de um indicador, que permita que o governo cobre resultados específicos das empresas como retorno sobre os investimentos feitos. Foi lembrado que uma política industrial precisa saber especificamente no que um setor pode contribuir, o que pode puxar junto com ele e quais legados pode deixar. É preciso que se saiba o que se quer dessa base industrial, pois o leque de possibilidades é enorme e considera-se um erro tentar fazer de tudo, como se tentou fazer no Brasil.

\subsection{2 - Valores da Política}

\section{a) Governo}

O gráfico 3, abaixo, apresenta as respostas dos entrevistados do governo brasileiro, sobre a avaliação dos valores utilizados como base para a formulação da política industrial de petróleo e gás no país. 


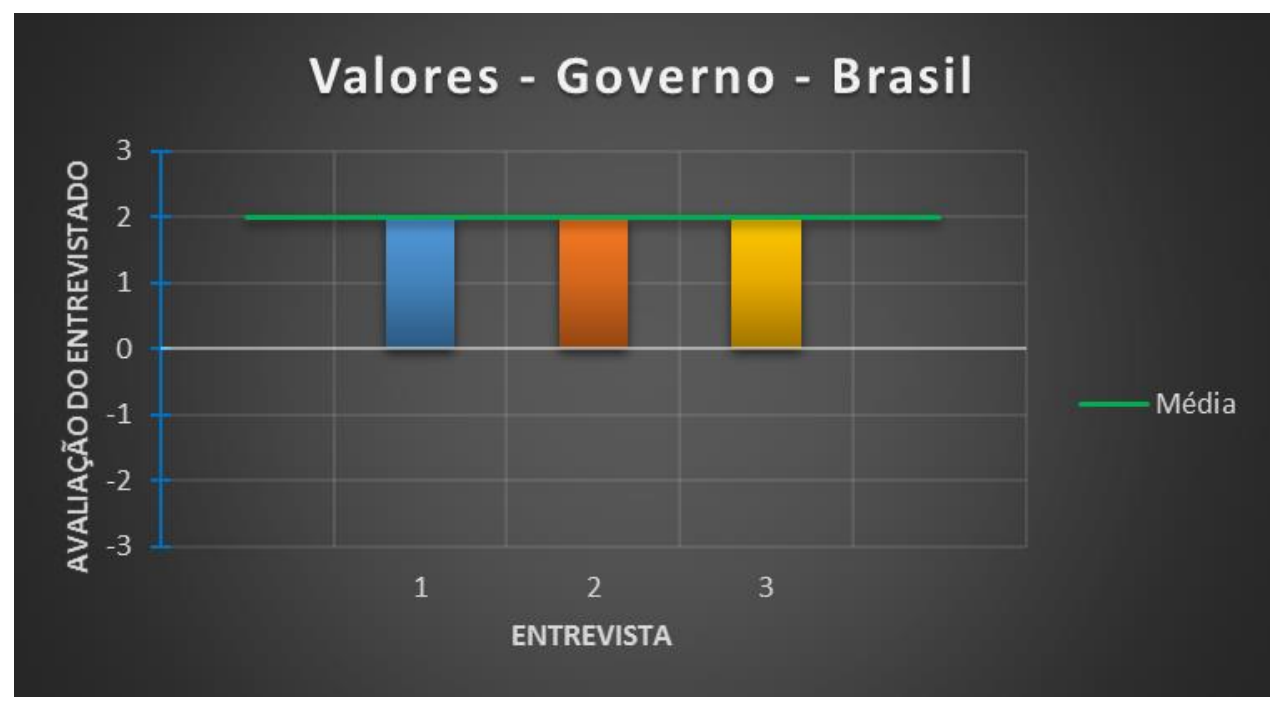

Gráfico 3 - Avaliações dos entrevistados do governo do Brasil sobre os valores da política industrial de petróleo e gás no país.

Mesmo com a indicação de aspectos específicos para serem analisados durante a resposta sobre os valores que basearam a formulação da política industrial, praticamente não houve nenhum tema que tenha sido mencionado em mais de uma entrevista. Enquanto as avaliações objetivas foram exatamente as mesmas entre os três entrevistados, as respostas abertas indicam temas diferentes associados a estas avaliações.

Nenhum tema foi mencionado pelos três entrevistados. Dentre os dois temas que foram mencionados em duas das entrevistas, um foi a reclamação sobre os empresários não terem participado da política industrial como deveriam. Esta seria uma tarefa conjunta para governo e empresários e os empresários não teriam dado a resposta esperada, quando chamados pelo governo. Um dos entrevistados citou a corrupção como uma das possíveis razões para que os investimentos por parte do setor privado tenham decepcionado.

O outro entrevistado mencionou a necessidade de um estudo sobre a capacidade da indústria nacional brasileira devido à baixa participação do empresariado, que talvez se explique pela conjuntura da política macroeconômica, como câmbio baixo, falta de incentivos, taxa de juros, complexidade da tributação e um custo de importação atrativo. Disse ainda que o Brasil não sofre de desindustrialização, mas sim de esvaziamento de cadeias produtivas. Seriam estes sinais macroeconômicos que estariam prejudicando a política industrial e contribuindo para que o setor privado brasileiro não tenha feito os investimentos necessários no desenvolvimento de tecnologia e modernização. Como 
resultado, a inserção da indústria nacional na cadeia de fornecedores acabou não sendo tão efetiva quanto poderia ser.

Ainda neste sentido, foi mencionada a importância de a indústria nacional estar voltada para o mercado externo, citando especificamente o potencial brasileiro para atuar no mercado africano, devido ás características geológicas e de exploração. $\mathrm{O}$ relacionamento com empresas estrangeiras foi considerado importante, mas com o foco em fazer essas empresas começarem a produzir no Brasil. Este foco seria importante para que as tecnologias e os processos ocorram no país, gerando emprego e renda.

O segundo tema mencionado em duas entrevistas foi o fundo social e a educação. Um entrevistado lembrou sobre a importância do fundo social brasileiro, por destinar recursos para a educação e saúde (mesmo que esta discussão tenha levado anos e ainda esteja para ser definida pelo STF). O outro afirmou que não adianta pensar nas gerações futuras sem pensar na geração atual e que, portanto, educação e desenvolvimento tecnológico seriam importantes.

Apesar de cada entrevistado ter utilizado uma perspectiva distinta dos demais, todos abordaram o tema sobre o ritmo de exploração, que era indicado pelo roteiro da entrevista. O primeiro entrevistado disse que o ritmo depende do mercado e que um ritmo alto seria importante para dar continuidade às políticas sociais que recebem recurso do fundo social. Já o segundo disse que o governo deveria dar celeridade ao processo, pois teria passado muito tempo sem rodadas de licitações. Lembrou que a produção é de longo prazo e que um ritmo constante traz previsibilidade para o investimento. Enquanto o terceiro disse que, mesmo que o IBP e a ONIP digam que a falta de leilões é prejudicial à indústria, há que se considerar a necessidade de dosar o ritmo de exploração para que a indústria nacional se desenvolva. Compatibilizar o ritmo da oferta com a capacidade que a indústria nacional tenha de se apropriar das demandas geradas por esta exploração. Mencionou ainda que, de certa forma, a ausência de rodadas de licitação teria contribuído para essa dosagem do ritmo de exploração, mas questionou se isso teria sido feito de forma deliberada ou não.

Dois entrevistados analisaram a questão sobre se a Petrobras deve estar focada na eficiência enquanto empresa ou em servir de ferramenta de desenvolvimento do país. Um deles defendeu que deva ser um meio termo, equilibrando eficiência, pois deve prestar contas aos seus acionistas, com a atuação para o desenvolvimento nacional, por se tratar 
de uma empresa estatal, que deve serviço aos brasileiros. Já o outro disse que a expectativa é de que a Petrobras atue como empresa e dê lucro aos seus acionistas, mas como além de acionista o governo brasileiro também é controlador, ele lembrou que estatais possuem um histórico de utilização para fins políticos.

Uma série de temas foram mencionados em apenas uma entrevista, como o fato de que um dos valores que servem de base para a política industrial brasileira seria a geração de valor na cadeia de produção nacional da indústria de petróleo, citando como exemplo o renascimento a indústria naval. Este mesmo entrevistado lembrou que houve uma discussão muito séria entre governo e Petrobras sobre os dois maiores desafios da indústria de petróleo brasileira, que seriam o desafio tecnológico para exploração na camada pré-sal e como descobrir fornecedores nacionais com a quantidade e a qualidade necessárias para se inserirem na cadeia global de fornecedores.

Também foi mencionada por um entrevistado a ideia de que o aumento que se tem verificado nos custos de produção do setor de petróleo seria decorrente das políticas de conteúdo local que estão sendo adotadas pelo mundo. De qualquer forma, este entrevistado disse acreditar que a questão dos preços explique melhor esse aumento. Outro entrevistado mencionou que o preço do petróleo deve ser internacional, para evitar o estímulo ao uso dessa fonte energética e ajudar a reduzir as emissões e cumprir as metas do país. Apesar de outro entrevistado ter lembrado que a queda dos níveis mundiais das reservas de petróleo estaria relativizada pela exploração de petróleo não convencional. Então, esta questão agora estaria mais ligada ao preço, pois dependendo do interesse, pode-se desenvolver recursos com custos mais elevados.

Em comparação com a Noruega, a política brasileira foi considerada mais legalista, mandatória e baseada em multas. Foi dito que a Noruega não teria abandonado sua política de conteúdo local, mas apenas mudado de nome, pois os noruegueses, que teriam sido mais intervencionistas no princípio, se basearam e ainda se baseiam em planos de trabalho para a transferência de tecnologia de empresas escolhidas pelo Estado. Com a OMC e os acordos com a União Europeia isso teria mudado um pouco, mas a lógica do plano de trabalho seria a mesma, assim como no Reino Unido.

Plano de trabalho seria uma rota, que a empresa que recebe uma concessão apresenta, indicando os fornecedores que pretende utilizar, e isso conta pontos na disputa pelo bloco. O governo verifica se a maioria das empresas são norueguesas e discute a 
situação de forma personalizada com cada empresa. De acordo com o entrevistado, isso seria muito difícil no Brasil, devido ao arcabouço jurídico nacional.

A Noruega teria fatiado o seu desenvolvimento e utilizado suas vantagens comparativas como base para desenvolver sua indústria nacional. Para os noruegueses estava muito claro que a indústria pesqueira, e a indústria naval como um todo, eram o trampolim para o desenvolvimento da indústria, mas no Brasil não estaria muito claro qual seria esse trampolim. Não se sabe ao certo qual setor brasileiro teria alguma vantagem comparativa para se aproveitar da oportunidade que se está tendo. Existe a indústria naval, mas ela estava parada fazia muito tempo. Outra característica seria um histórico de parceria com japoneses, que estaria sendo retomado. Em questão de segurança da exploração e questões ambientais, o Brasil seria uma referência, por produzir em águas ultraprofundas, de três mil a cinco mil metros de profundidade, sem acidentes e sem vazamentos.

De acordo com um entrevistado, o Brasil deveria tentar criar sua vantagem a partir da grande demanda que será gerada. Nos próximos vinte a trinta anos, por exemplo, o Brasil irá demandar mais da metade da produção mundial de árvores de natal molhada, que é um equipamento subsea importante. A FMC, que produz árvore de natal para o mundo inteiro, está produzindo no Brasil e desenvolveu uma rede de fornecedores nacionais importante. Além de algumas características únicas do pré-sal que fazem com que a empresa traga inovações e desenvolvimento tecnológico para dentro do país. Nos últimos anos, o Brasil teria conseguido atrair investidores e desenvolver um pouco sua cadeia de produção, então o desafio agora seria o de criar essa vantagem comparativa e se tornar competitivo internacionalmente.

\section{b) Associações Empresariais}

O gráfico 4, abaixo, apresenta as respostas dos entrevistados das associações empresariais brasileiras, sobre a avaliação dos valores utilizados como base para a formulação da política industrial de petróleo e gás no país. 


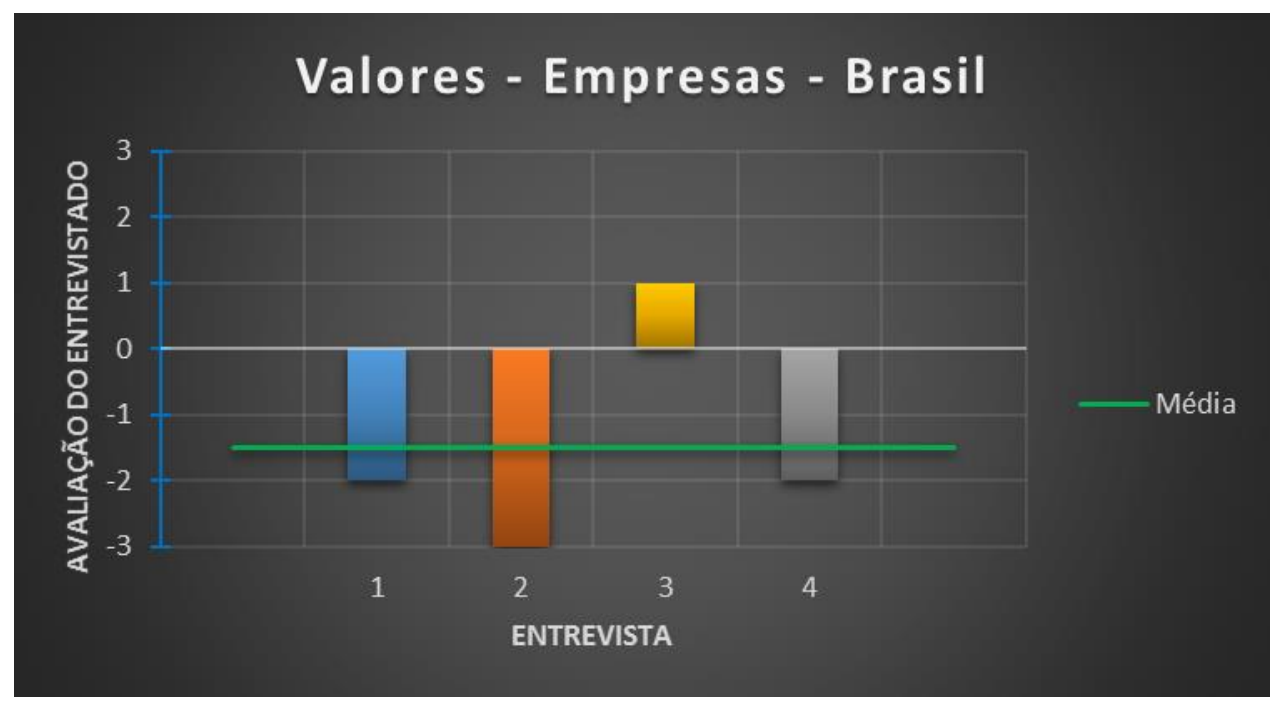

Gráfico 4 - Avaliações dos entrevistados das associações empresariais do Brasil sobre os valores da política industrial de petróleo e gás no país.

Neste bloco não ocorreu de nenhuma perspectiva ser mencionada em mais de duas entrevistas. Uma das perspectivas que apareceu na fala de dois dos entrevistados foi o entendimento de que no Brasil não existe política industrial. Não haveria uma clara definição sobre se os objetivos seriam a geração de fundos para a educação, ou a geração de emprego e renda, ou o desenvolvimento tecnológico, ou ainda o adensamento das cadeias produtivas. Essa falta de foco fez com que se tentasse um pouco de tudo, mas considera-se muito difícil atingir todos esses objetivos ao mesmo tempo. Portanto, a política deveria ser focada no desenvolvimento das atividades que tenham maior valor agregado e conteúdo tecnológico, para que sirva de instrumento indutor de uma transformação estrutural da economia na direção de atividades mais produtivas.

Um outro tema que foi mencionado por dois dos entrevistados foi a influência de interesses eleitorais no direcionamento da política industrial. Um dos entrevistados alegou que o crescimento do ritmo de exploração após o anúncio do descobrimento do pré-sal teria sido uma estratégia eleitoral e não uma política industrial, pois havia uma eleição presidencial se aproximando e se tentou passar a impressão de que o Brasil seria uma nova Arábia Saudita. Outro entrevistado disse que o maior problema do modelo adotado seria um plano paralelo de manutenção de poder, onde os líderes políticos dariam mais importância para o princípio da eleição do que para o progresso do país. 
Outra questão levantada em duas entrevistas diferentes foi a crítica à cláusula que obriga a Petrobras a ser operadora única na área do pré-sal. Esta cláusula revelaria a adoção de um valor equivocado por parte do governo, por impor limites à capacidade de investimento no setor e limitar a demanda para os fornecedores de bens e serviços. Seria uma forma de leilão onde alguém é obrigado a arrematar todos os lances, o que foi considerado uma "burrice" e uma "idiotice" sem tamanho. Acostumar os fornecedores a vender apenas para a Petrobras também não seria interessante por não expor estas empresas às normas e aos padrões internacionais, o que acabaria viciando essas empresas em serem capazes de trabalhar apenas com a Petrobras. Por isso o projeto do senador José Serra para acabar com a obrigação da Petrobras como operadora única foi especificamente mencionado como um acerto, pois não chegaria nem a mexer no modelo de partilha. O Brasil poderia ganhar dinheiro com ou sem a Petrobras. Lembrando que sem produção não haveria fundo social, nem verba para educação e saúde.

O modelo de partilha também chegou a ser criticado por um dos entrevistados, que considerou "burrice" a sua adoção, pois o Brasil teria condições de controlar a produção das empresas estrangeiras, deixando elas produzirem apenas o que fosse do interesse do país. Assim, seria melhor deixar as empresas estrangeiras produzirem e cobrar $20 \%$, por exemplo, pois assim se evitaria os custos de produção. De acordo com este mesmo entrevistado, o modelo de partilha seria normalmente adotado por países de baixa estrutura, com baixos mecanismos de gestão e com instituições fracas. Já países mais fortes, mais organizados, iriam preferir o modelo de concessão, porque seria muito mais fácil e o modelo de partilha não teria vantagem nenhuma.

De acordo com um dos entrevistados, o ritmo de exploração não poderia ficar esperando a indústria nacional ter condições de ofertar o que se precisa, pois a visão de que um dia o Brasil será capaz de produzir tudo seria uma ilusão. O país não pode se transformar numa ilha que só expande a produção conforme essa capacidade interna. Não seria a política industrial que deveria determinar o ritmo de exploração, mas sim o contrário, pois o ritmo de exploração faz parte de uma estratégia nacional macroeconômica.

Dois dos entrevistados demonstraram a mesma visão de que se deve procurar encontrar um equilíbrio na atuação da Petrobras. Não se pode ignorar o papel da Petrobras como alavanca de desenvolvimento industrial da cadeia de fornecedores, assim como a 
Statoil foi na Noruega. Mas também não pode ser apenas ferramenta de desenvolvimento do país e esquecer do papel perante seus sócios acionistas. Afinal, a União também é sua maior acionista, fazendo com que a sociedade inteira seja parte interessada na eficiência da Petrobras em gerar lucro. Além de ser necessário que ela possa se manter enquanto empresa, para que possa ser utilizada como ferramenta de desenvolvimento. Outro ponto importante mencionado sobre a utilização da Petrobras como instrumento de política econômica é que seria um erro controlar o preço da gasolina para segurar a inflação, comprometendo o fluxo de caixa da empresa e diminuindo sua rentabilidade, especialmente levando em conta que a Petrobras teria um dos maiores planos de investimento do mundo. A redução das receitas faria a empresa não conseguir financiar a si mesma, aumentando o endividamento e fazendo com que a empresa pague mais juros para financiar seu plano de investimentos. Tudo isso acabaria sendo ruim para a Petrobras e também para o Brasil.

Um quinto tema que foi tratado em duas entrevistas foi a necessidade de que a rede de fornecedores nacionais seja internacionalmente competitiva. Um dos entrevistados defendeu que se deve investir naquilo que se é bom e não em tudo ao mesmo tempo, caso contrário jamais se será terá competitividade internacional em nada. Para ele, no momento seria muito melhor importar tudo, pois com a crise devido ao preço do barril de petróleo, estaria sobrando sondas e outros equipamentos, fazendo com que tudo esteja mais barato. Foi lembrado que para vender para a Petrobras é necessário fazer parte do seu cadastro de fornecedores, que apresenta mais exigências do que outros países, o que faria com que as empresas que vendem para a Petrobras estejam aptas para vender fora do Brasil também. De qualquer forma, outro entrevistado disse que não se tem tido sinais de que o país pretende se tornar uma base exportadora de determinados segmentos da cadeia produtiva de petróleo e gás.

A propriedade do subsolo foi apontada como sendo, por característica, do Estado em todos os países e um dos entrevistados afirmou que não conhece nenhum país onde a propriedade do subsolo seja privada. O que existiria seria a possibilidade de leiloar o óleo que está no subsolo para a iniciativa privada, mas não o subsolo em si. Outro entrevistado disse que esta questão sobre o subsolo ser de propriedade privada ou estatal não influencia no resultado de uma política industrial, pois seria uma questão de política energética. 
Sobre guardar os frutos da indústria para gerações futuras, houve quem disse que nunca se pensou nisso no Brasil e lembrou da doença holandesa, afirmando que ela não ocorreu no Brasil pois muita gente teria ganhado dinheiro. Outro entrevistado disse que o petróleo tem que ser monetizado de forma inteligente, preservando para gerações futuras, mas dando vida para as gerações atuais. Se não, se morreria hoje e nem se chegaria no amanhã. Ele também afirmou que a ideologia é cega e que se deveria tentar ser mais equilibrado, pois nem tudo que é de direita está certo, assim como nem tudo que é de esquerda está certo. Um deveria tentar aproveitar o que o outro tem de bom, mas a esquerda nunca aproveitaria isso. De acordo com ele, no limite, o melhor seria o capitalismo, apesar de ser difícil o capitalismo incluir todo mundo. Em países pequenos seria mais fácil fazer um capitalismo social como na Noruega. Este mesmo entrevistado explicou que nos Emirados Árabes ninguém paga nenhum tipo de imposto, com exceção de um imposto de importação, e que eles estariam usando o dinheiro do petróleo para se transformarem numa grande Las Vegas, atraindo turismo com praias e neve artificiais. Esse tipo de visão seria uma posição de meio termo e não uma ideologia pura como a ideia de guardar os frutos do petróleo para os nossos netos e bisnetos, pois precisa-se sobreviver até chegar lá. Ele complementa indicando que assistencialismo sem alguma forma de contrapartida acaba gerando vagabundos. Como no caso de 500 mulheres da Bahia que receberam treinamento de costureiras, mas optaram por não trabalhar para não perderem o Bolsa Família, mesmo sendo a metade do que receberiam trabalhando, pois assim poderiam ficar em casa sem fazer nada.

Ainda sobre guardar recursos para as próximas gerações, numa das entrevistas foi mencionado que existem diferentes ciclos de políticas industriais. Desde políticas de substituição de importações, simplesmente devido à escassez de recursos para importar, até uma política que possa ser de fato considerada uma estratégia de desenvolvimento industrial, que seria uma visão mais recente, onde se inclui a perspectiva sobre gerações futuras. Segundo este entrevistado, haveria alinhamento entre o governo e as empresas com relação ao valor de se estabelecer uma base industrial sólida e sustentável, pensando em gerações futuras que não terão mais o petróleo para explorar e vão precisar do legado que essa oportunidade pode deixar. Mas esta questão deveria ser problematizada e colocada sob a perspectiva da estratégia energética nacional, de comercio exterior, de balança comercial e da necessidade de investimentos para o desenvolvimento. 
Um dos entrevistados citou que, com exceção da definição do ritmo de exploração com base em interesses políticos, não existe política industrial no Brasil, então não se tem como enxergar os valores que serviriam de base. Outro entrevistado disse que a Petrobras precisa de planejamento com base em indicadores e não em receitas milagrosas. Haveria uma falta de visão do governo com relação às cadeias de fornecimento e se deveria aproveitar o mercado interno para vender pra fora.

Foi apontado que poucos países da OPEP estão entre os mais ricos do mundo, enquanto muitos dos países mais ricos do mundo dependem da importação de petróleo. Então esse valor também seria relativo. Outra questão levantada foi que países como Noruega, Reino Unido e Estados Unidos terceirizam os produtos de menor valor agregado e que requerem menos capacitação para outros países. Já o Brasil poderia adotar uma estratégia diferente, pois possui uma África e uma Europa dentro de seu território, seja no que se refere a clima, seja com relação ao desenvolvimento. O interior de São Paulo e o sul do país seriam espetaculares. Por isso, não adiantaria fazer estaleiros em todos os estados do país, pois estados como o Ceará deveriam focar em embarcações menores e barcos de apoio. Quando se tem encomendas muito empacotadas, se abriria a possibilidade de criação de cartéis, como seria o caso da Lava Jato, onde de dez a quinze empresas que mandam no Brasil pagariam palestras e outras coisas para Lula. Uma opção seria ter tudo liberado como nos Estados Unidos, onde o que manda é a lei do mercado. Mas num modelo fechado como o brasileiro isso acaba gerando cartel e corrupção, sendo o pior modelo que se pode ter.

Também foi mencionado que alguns dos valores do governo estão em posição invertida, como o ritmo de exploração e o uso da Petrobras como ferramenta de desenvolvimento, mas essa inversão seria apenas com relação ao equilíbrio desses papéis e não com relação a quais papéis deveriam ser assumidos. Um outro problema seria o fato de que alguns mecanismos que são criados para serem utilizados durante um prazo determinado acabam se tornando permanentes. Como o caso do Repetro, que teria sido uma medida inteligente para atrair empresas para o país, mas que não seria mais necessário depois da descoberta das reservas da camada pré-sal. 


\subsection{3 - Normatização da Política}

\section{a) Governo}

O gráfico 5, abaixo, apresenta as respostas dos entrevistados do governo brasileiro, sobre a avaliação da normatização que serve de base para a política industrial de petróleo e gás no país.

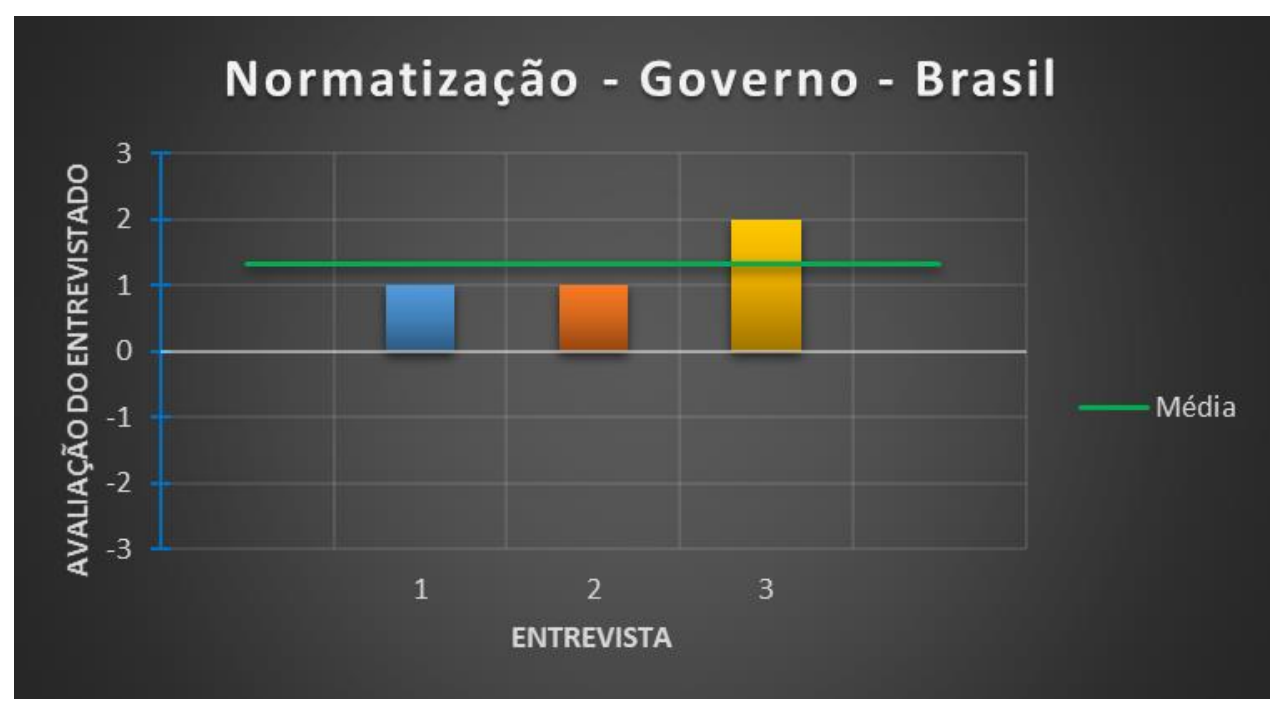

\section{Gráfico 5 - Avaliações dos entrevistados do governo do Brasil sobre a normatização da política industrial de petróleo e gás no país.}

Nenhum tema foi lembrado por todos os três entrevistados, mas dois deles mencionaram o fato de que apesar de existir em lei, o conteúdo local seria uma questão contratual, definida pelas licitações, através dos contratos da ANP com as operadoras. Dois entrevistados também ressaltaram que os compromissos de conteúdo local são declaratórios, com base numa oferta do próprio concessionário, o que deveria contribuir para o seu cumprimento.

Com relação à flexibilidade das normas brasileiras, houve um entrevistado que disse que as normas não são suficientemente flexíveis, ocorrendo muitas reclamações por parte das operadoras e muita utilização de wavers. O aumento da demanda teria gerado gargalos que levaram à aplicação de muitas multas, e muitas mais ainda estariam por vir. Foi ressaltada a importância da sensibilidade que existiria no governo para impedir a aplicação de multas excessivas que possam prejudicar a indústria. Outro entrevistado 
disse que apesar da cláusula de waver dar alguma flexibilidade para a regra, ainda seriam necessários ajustes para atrair o interesse do concessionário na exploração. Já em outra entrevista foi mencionado que as regras brasileiras seriam muito rígidas, voltadas para o controle e a fiscalização, sem dialogar com uma estratégia de desenvolvimento de longo prazo, com muito foco na punição e sem nenhum foco no incentivo.

Dois entrevistados lembraram sobre a falta de recompensas para esforços feitos por algumas empresas. Os exemplos citados foram o atingimento de um índice de conteúdo local acima do comprometido e o esforço feito pela Petrobras para atrair empresas para o Brasil, como o caso da Rolls-Royce, produzindo turbinas a jato. Isto seria resultado da política de conteúdo local, mas executada pela Petrobras e não pelo governo.

Em uma das entrevistas foi mencionado que a Noruega possuía um mecanismo para premiar as operadoras que tenham mais conteúdo local com um bônus que poderia ser usado na licitação seguinte. Essa avaliação sobre a utilização de fornecedores noruegueses seria feita dentro do Ministério de Energia norueguês, de forma ad hoc. De acordo com o entrevistado, se isso fosse feito no Brasil, os envolvidos poderiam acabar sendo presos. O regime jurídico brasileiro seria muito complicado, pois qualquer tentativa de melhoria poderia ser vista como ingerência demasiada do governo ou tentativa de favorecer alguém.

A necessidade de mecanismos de diálogo entre os setores público e privado foi mencionada como uma forma de se promover ajustes na política. Alguns aprimoramentos seriam necessários devido à perversidade na exigência de que o concessionário saiba, já no momento da oferta no leilão, exatamente o peso de bens e serviços, para apresentar o projeto de exploração. Qualquer necessidade de alteração durante a execução do projeto pode gerar a necessidade de investimentos maiores em determinadas áreas que dificultem o atingimento da meta de conteúdo local acordado. Apesar disso, a realização de mudanças nas regras de leilões já realizados seria complicada, pois abriria espaço para que os demais participantes da licitação se sintam prejudicados. Ajustes também seriam necessários para reforçar o interesse de empresas no desenvolvimento de tecnologia, ou na importação de tecnologia para ser implementada no Brasil. Outro aprimoramento necessário seria a adoção de mais incentivos e estímulos e menos punições.

A legislação da área de inovação foi lembrada por dois entrevistados, que criticaram o demasiado foco em centros tecnológicos e universidades e não em empresas. 
Estariam acontecendo muitos casos onde a Petrobras utilizaria seus recursos de P\&D para desenvolver um produto ou serviço junto com empresas que estão dentro de universidades, mas seria obrigada a fazer licitação para contratar o fornecimento deste produto ou serviço destas empresas. Na licitação, essa empresa estaria em desvantagem com relação às grandes empresas estrangeiras e acabavam não sendo contratadas. Um dos entrevistados citou que a nova revisão do marco de inovação seria um avanço, por permitir que a Petrobras contrate sem licitação nesses casos. Existiriam mais de 10, ou 15 empresas nesta situação, que seriam o embrião de uma indústria nacional com base tecnológica, que seja capaz de se inserir na cadeia global de petróleo. No modelo anterior, essas empresas eram absorvidas por empresas transnacionais, de capital estrangeiro.

Dentre os pontos citados por apenas um dos entrevistados, pode-se citar a afirmação de que as empresas nacionais seriam todas a favor da política de conteúdo local. Em alguns casos, haveria crítica a alguns níveis considerados ambiciosos demais, sem considerar a curva de aprendizagem, que faz com que não se possa esperar das empresas brasileiras os mesmos níveis que empresas asiáticas, por exemplo, pois as brasileiras estariam no início do processo de aprendizagem. Antes da queda do preço do petróleo seria mais fácil repassar os custos da política de conteúdo local. Hoje isso seria muito mais difícil. Mesmo assim, um dos entrevistados disse não conhecer exemplos de países que não tenham alguma forma de exigência de conteúdo local. Até mesmo a legislação de petróleo e gás dos Estados Unidos seria muito intervencionista.

O principal problema da política brasileira seria a falta de definição e foco sobre os objetivos a serem alcançados. Se o valor a ser adotado for o da geração de emprego e renda deve-se seguir por um caminho distinto do que se o valor adotado for o do desenvolvimento de setores tecnologicamente mais avançados. Se houvessem tentado desenvolver toda cadeia de fornecedores da indústria aeronáutica no Brasil, teriam quebrado com a Embraer, pois a imposição de barreiras aumentaria os custos e diminuiria a competitividade. No setor de petróleo, como os contratos são de longo prazo, a falta de foco da política de hoje traria reflexos para as próximas décadas. Além disso, nossa política teria perdido dinamicidade e se tornado estanque, uma vez que só verifica o cumprimento dos índices acordados após 5 ou 6 anos da assinatura do contrato. Em países que adotam rotas e planos de trabalho, existiria uma verificação frequente. 


\section{b) Associações Empresariais}

O gráfico 6, abaixo, apresenta as respostas dos entrevistados das associações empresariais brasileiras, sobre a avaliação da normatização que serve de base para a política industrial de petróleo e gás no país.

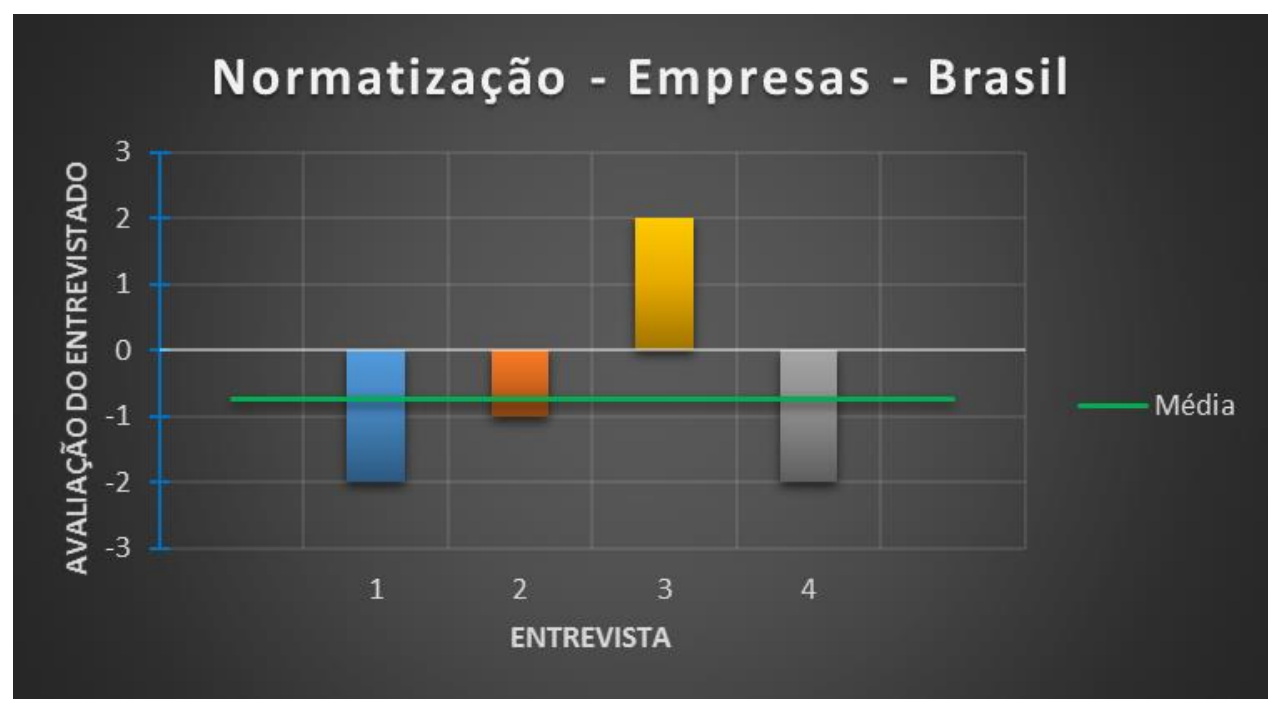

\section{Gráfico 6 - Avaliações dos entrevistados das associações empresariais do Brasil sobre a} normatização da política industrial de petróleo e gás no país.

Não houve nenhum tema tratado por todos os quatro entrevistados, nem mesmo por três deles. Uma das questões que apareceram em duas entrevistas diferentes foi o fato da OMC estar processando o Brasil por adotar políticas de conteúdo local. Foi lembrado que este processo não teria abordado o conteúdo local da indústria de petróleo, porque esse teria sido bem feito. O conteúdo local não seria uma lei, mas uma obrigação assumida por uma empresa, em um contrato.

Dois entrevistados mencionaram que as regras brasileiras seriam muito rígidas e complexas. Esse modelo não seria o mais adequado para ser aplicado num horizonte de longo prazo, que inclui grandes variações tecnológicas, econômicas e de mercado.

Variou bastante a análise sobre a participação dos atores na definição das normas. Um dos entrevistados disse que a participação existiria, mas não daria resultados, pois a ANP rejeitaria todas as propostas oferecidas. Para outro entrevistado, a ANP seria muito participativa, especialmente com a questão da consulta pública, chegando a reunir os 
atores mais representativos para uma conversa, numa espécie de pré-consulta pública. Já em outra entrevista a participação dos atores foi classificada como errática, havendo momentos com participação e momentos sem participação. Apesar de ultimamente estar havendo uma certa participação, seria grande a dificuldade em se fazer adequações, devido a existência de uma estrutura muito consolidada. A interação entre os atores seria feita a varejo, através de conversas individuais, com diferentes grupos de interesse e sem um debate amplo com a presença de todos. Isso faria aumentar as tensões e reforçar as diferenças, ao invés de estimular alinhamentos e convergências.

Entre as questões levantadas em apenas uma entrevista, apareceu a preferência dos governantes por políticas de governo, em detrimento de políticas de Estado. Como os resultados da política industrial de petróleo só aparecem no longo prazo, não seria possível para um governante ver esses resultados ainda durante o seu governo. Para que a política seja de Estado, foi dito que ela teria que estar acima dos ministérios e não no MME. Teria que ser algo como um conselho superior no nível da presidência da república, um órgão da Casa Civil específico para política industrial, ou ainda o BNDES.

Algumas pessoas defendem que as regras de conteúdo local mais atrapalham do que ajudam, pois aumentariam os custos de produção e inibiriam o desenvolvimento de fornecedores. Outras dizem que essas regras são muito importantes para o desenvolvimento da indústria nacional. Um dos entrevistados disse que sua associação considera o conteúdo local um sucesso. Outro disse que a aplicação de multas demonstra que a aplicação das normas nos casos concretos não tem sido muito boa. E ainda houve um entrevistado que disse que o problema seria haver conteúdo local apenas para a área de exploração e produção e não para os segmentos de downstream, refinarias e oleodutos.

Houve menção à necessidade de se considerar a curva de aprendizado para a formação de competência, pois nenhuma indústria seria competitiva num primeiro momento. O problema seria a forma como isto estaria sendo feito. Dentre as melhorias possíveis estaria a correção dos índices referentes a alguns equipamentos. Deveria se procurar uma fórmula mais realista que não onere tanto os estaleiros e a Petrobras, mas que possa garantir o desenvolvimento dos fornecedores nacionais. Um dos entrevistados mencionou que a definição dos índices teria sido feita pela própria indústria. O governo teria enviado uma planilha, com uma lista de equipamentos, e cada setor deveria preencher dizendo o quanto de conteúdo local poderia atender para cada equipamento. 
A punição foi vista como necessária para fazer as empresas cumprirem suas metas de conteúdo local, pois elas só se comprometeriam pelo risco de perdas financeiras. Foi mencionado também que o empresariado brasileiro se utiliza muito da proteção oferecida pela política de conteúdo local como reserva de mercado, aproveitando para aumentar seus preços e sua lucratividade. Um dos entrevistados disse que empresas chegam a cobrar até 6 vezes mais do que o concorrente internacional. Por isso, propôs que quem utiliza o conteúdo local para ganhos abusivos deveria ser penalizado, assim como se penaliza quem não atinge as metas de conteúdo local.

Também foi ressaltado que não seria possível analisar as regras que regem a política industrial, pois não haveria política. Se estaria tratando aqui de normas que regem questões de conteúdo local e que são definidas pela ANP. A política de conteúdo local deveria servir aos objetivos de uma política industrial com foco na competitividade, inserção internacional e sustentabilidade. Isso exigiria uma comparação e exposição a competidores internacionais, mas como as empresas nacionais ainda não estariam num estágio de competitividade necessário para esta exposição, se utilizaria mecanismos de proteção de conteúdo local. Que seriam legítimos, mas que deveriam estar focados em pontos estratégicos para a captura de valor socioeconômico. Também deveriam ser temporários, já que depois de algum tempo se deveria atingir o grau necessário de competitividade. Esses mecanismos deveriam ser suficientes para viabilizar a indústria local, mas sem serem excessivamente protecionistas, a ponto de caracterizar uma reserva de mercado. Isso seria colocar empresas em uma zona de conforto, o que seria a antítese da busca por ganhos de eficiência e competitividade. Por não ter foco, nem uma visão sobre o que seria estratégico para o país, ou quais seriam as vantagens a serem aproveitadas, a regra de conteúdo local brasileira deixaria de ser um instrumento de política industrial e passaria a ter um fim em si mesma.

\subsection{4 - Implementação da Política}

\section{a) Governo}

O gráfico 7, abaixo, apresenta as respostas dos entrevistados do governo brasileiro, sobre a avaliação da forma de implementação da política industrial de petróleo e gás no país. 


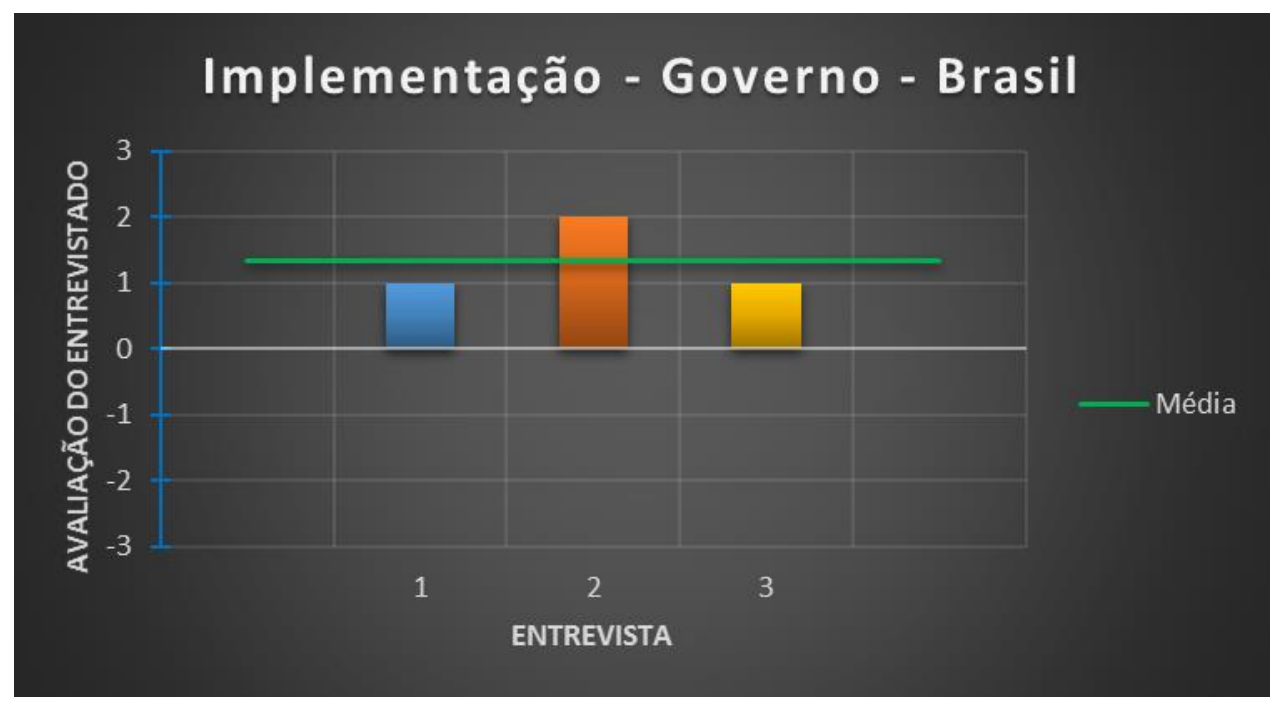

Gráfico 7 - Avaliações dos entrevistados do governo do Brasil sobre a implementação da política industrial de petróleo e gás no país.

Neste bloco nenhum tema foi tratado pelos três entrevistados, mas muitos temas apareceram em duas entrevistas. Houve destaque para o sucesso do cluster da indústria naval em Rio Grande, que estaria conseguindo superar os desafios impostos pela crise do preço do petróleo e pela crise da operação Lava Jato. Neste caso, as empresas teriam se reunido numa organização social que inclui estaleiro, fornecedores, universidade, governo do estado e as quatro prefeituras da região. O modelo de formação de clusters na Noruega é mais sofisticado e sistemático que o brasileiro, e conta com uma participação mais ativa do governo, mas serviu de base para clusters nacionais como o de Rio Grande, que conseguiu aproximar fornecedores e aproveitar a sinergia. Já outros clusters brasileiros estariam sofrendo mais com a situação, por não terem apresentado uma capacidade tão grande de articulação.

Dois entrevistados citaram o os arranjos produtivos locais, a política de aumento de participação de pequenas e médias empresas na cadeia de petróleo e o Plano Brasil Maior como exemplos de interação da política industrial com outras políticas, além da destinação de recursos para a educação, que foi citada por um entrevistado. Os arranjos produtivos locais teriam sido um sucesso, apesar da falta de foco devido à influência de questões políticas. O Plano Brasil Maior seria muito semelhante ao seu equivalente no Reino Unido, mas teria tido o defeito de elencar muitos itens, pois poucos teriam sido atendidos. Deveria ser repensado o modelo de governança da política industrial (e das 
políticas públicas em geral), porque muitas vezes é melhor utilizar um modelo que inclua menos ações, mas tenha mais foco. O modelo de governança do PBM não seria razoável, pois teria inúmeras instâncias, conselhos e níveis decisórios, que acabam dificultando a tomada de decisão e paralisando o projeto. $\mathrm{O}$ modelo britânico seria muito mais enxuto.

Outro programa que foi citado em uma das entrevistas foi o Inovapetro, que teria sido importante por indicar produtos de base tecnológica e de alto valor agregado para empresas nacionais interessadas em inovar. Também houve uma discussão sobre o impacto socioeconômico dos grandes investimentos da Petrobras, utilizando a metodologia do projeto de entornos do BNDES, que inclui questões de planejamento urbano, desenvolvimento territorial, formação de mão de obra, impacto na cadeia produtiva e impacto na governança das regiões.

O Brasil teria um déficit na implementação de qualquer política, porque o órgão que formula e monitora uma política não é necessariamente o mesmo que implementa essa política. Existiria uma tentativa de articulação para uma atuação coordenada entre os ministérios. Lembrando que a política de conteúdo local deveria ficar no MDIC, mas como está diretamente ligada aos blocos exploratórios, acabou ficando no MME.

A corrupção foi considerada um balde de água fria por um dos entrevistados, mas ele considera que a indústria possa sair mais fortalecida e com menos espaços para a corrupção. Outro entrevistado disse que a análise sobre corrupção deveria ser colocada de lado, por não se tratar de um elemento da política.

A rodada de licitações foi considerada bem transparente, assim como a prestação de contas das empresas operadoras perante a Petrobras. A forma como a ANP coloca os contratos também foi considerada transparente, mesmo com a agência sendo vista como impositiva e mandatória.

As metas e objetivos foram considerados claros e bem definidos. Existiria um diálogo amplo e aberto, com interação entre os atores. Enquanto as operadoras cobrariam desburocratização e flexibilidade no processo, as empresas fornecedoras seriam contra. A participação das associações empresariais foi lembrada, assim como a realização de consultas públicas antes de cada rodada de licitação. Parcerias com universidades e centros de pesquisa seriam feitas pela ANP, através da destinação de $1 \%$ da verba para $\mathrm{P} \& \mathrm{D}$, além de várias empresas terem seus próprios centros de pesquisa. O longo tempo sem a implementação de uma política industrial faria com que surgissem dificuldades 
para a retomada. E foi mencionado que, mesmo quando existe algum interesse político permeando uma discussão, existiria um esforço para que as decisões sejam baseadas em critérios técnicos.

\section{b) Associações Empresariais}

O gráfico 8, abaixo, apresenta as respostas dos entrevistados das associações empresariais brasileiras, sobre a avaliação da forma de implementação da política industrial de petróleo e gás no país.

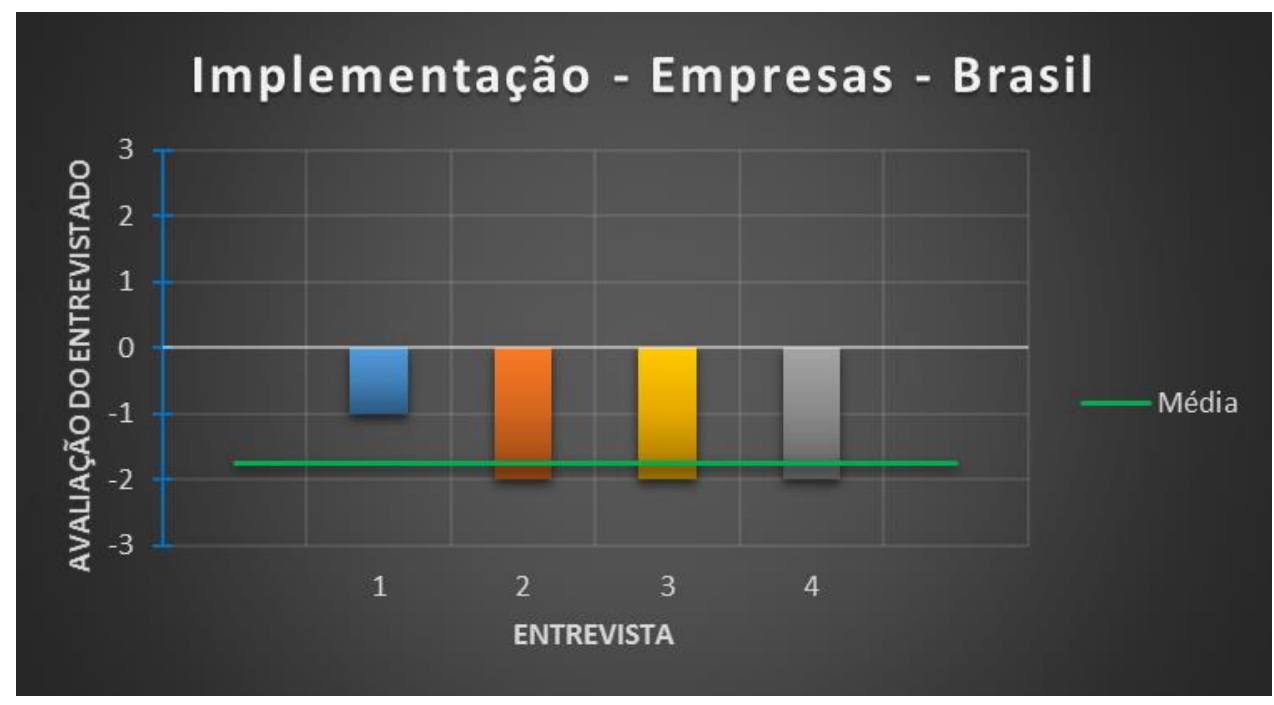

Gráfico 8 - Avaliações dos entrevistados das associações do Brasil sobre a implementação da política industrial de petróleo e gás no país.

Não houve nenhuma questão levantada em todas as quatro entrevistas, mas três entrevistados consideraram que a corrupção não seria tão relevante. Para um deles o pior seria a má gestão, pois mecanismos de controle serviriam para diminuir a corrupção. Para outro, a corrupção não seria uma regra, mas uma consequência de um ambiente de reserva de mercado. Um terceiro entrevistado disse que a corrupção não seria determinante para o sucesso ou fracasso da política, pois entraria como parte do negócio de uma indústria que estaria envolvida na deflagração de guerras, invasão de países e manipulação de preços para controlar o mercado.

A crítica à relação entre os atores foi mencionada também em três entrevistas. Seja por ser feita através de negociações a varejo, que teriam gerado distorções, tensões e 
arraigamento de posições, ou pela mera necessidade de uma melhor interação entre os setores público e privado, para o estabelecimento de políticas mais eficazes. Houve um entrevistado que classificou esta relação como uma briga de gato e rato, devido ao conflito de interesses diversos. As operadoras estariam interessadas em comprar onde seja mais barato, os fornecedores gostariam que as operadoras comprassem tudo no Brasil e os subfornecedores gostariam de passar a fornecer para as grandes empresas transnacionais. Então o diálogo seria bastante confuso, algumas vezes inexistente e com poucos resultados práticos.

As parcerias com universidades e centros de pesquisa também foram mal avaliadas por três entrevistados, mas por diferentes razões. Um deles afirmou que as universidades não saberiam enxergar a realidade da indústria. Outro entrevistado disse a relação com as universidades e centros de pesquisa foi tratada em separado, fazendo com que as regras de $\mathrm{P} \& \mathrm{D}$ não conversem com as regras de conteúdo local, que não conversam com a política industrial, gerando ineficiências e não cumprimento de objetivos. Houve quem afirmou que os recursos destinados às universidades foram destinados à construção de prédios e laboratórios e treinamento de pesquisadores, mas muito pouco para a interação com empresas. Por isso, praticamente não teria havido o desenvolvimento de produtos e serviços capazes de substituir produtos e serviços importados. Os produtos que as universidades desenvolvem não conseguem ser passados para as empresas, pela necessidade de licitação para serem contratados. Essa realidade teria prejudicado uma maior participação das universidades. A PUC do Rio de Janeiro, a Unisinos e a PUC do Rio Grande do Sul teriam conseguido desenvolver alguns produtos e até mesmo gerar algumas empresas, mas a relação da Petrobras com a UFRJ, para fazer um centro de tecnologia na Ilha do Fundão, não estaria dando muito certo.

A inexistência de integração com outras políticas foi mencionada também por três entrevistados. Um deles pediu expressamente para que fosse ressaltado que não existe política industrial, mas apenas política de conteúdo local, portanto, não haveria integração com outras políticas, nem nenhum tipo de movimento integrado. Mesmo o conteúdo local seria uma mera relação entre a ANP e as operadoras e não uma política, fazendo com que a geração de resultados para a cadeia produtiva seja um tanto caótica. Outro entrevistado disse que não haveria integração pela falta de uma visão geral. Em outra entrevista, lembrou-se do descolamento entre a política de conteúdo local de petróleo e gás e a política tributária do setor. Uma governança mais eficaz seria necessária, coordenando as 
diferentes agências e orientando os diferentes instrumentos numa mesma direção, para potencializar os seus efeitos.

Enquanto um entrevistado entende que as metas e objetivos não são bem definidos, outro entende que são pouco claros, havendo casos onde o objetivo está explicitamente definido, mas o desenho do instrumento não estaria alinhado com esse objetivo. Outro entrevistado ainda disse que as metas e objetivos seriam bem definidos, pois estariam expressos nos contratos.

Alguns entrevistados apresentaram sugestões de melhorias para a implementação da política, como um encadeamento de forma horizontal, procurando evitar a verticalização, para que se passe demandas para empresas menores. Ele citou o caso da cidade de Aberdeen, no Reino Unido, e de Bergen, na Noruega, que seriam responsáveis por $80 \%$ do mercado mundial de equipamentos subsea, e teriam sua base produtiva em empresas de pequeno e médio porte, mas com alta intensidade tecnológica. Essas empresas teriam uma relação de muita cooperação entre si, enquanto no Brasil a lógica das empresas seria de competição.

Também foi sugerido que a política industrial brasileira deveria ser voltada para o ganho de competitividade da indústria, priorizando empresas que atinjam índices de produtividade maiores. Para isso, seria necessária a criação de métricas de incentivo através de fontes de financiamento para as empresas que alcancem suas metas de produtividade. A associação deste entrevistado teria chegado a fazer um estudo, junto com universidades, para a criação dessas métricas. Após anos de discussão, depois que o projeto foi proposto para o governo, nada foi feito e o projeto não saiu do papel. A execução após o diálogo com os especialistas do setor e com a indústria seria uma carência muito grande do executivo brasileiro. Haveria muito mapeamento e geração de documentos, mas sem resultados que levem à execução prática. O PBM e o Prominp teriam sido muito bem idealizados e discutidos, mas não teriam sido realizados, em função da burocracia. Já a política de conteúdo local, que também teria sido bem idealizada, formulada e desenvolvida, teria as suas ações de aprimoramento e ajuste da política muito mal implementadas.

Considerou-se que há transparência e prestação de contas, apesar de um excesso na necessidade de controles, o que geraria custos e ineficiência. Foi mencionada a falta de um líder para tocar a política e que alguns dos males que prejudicam o Brasil seriam a 
incompetência, a corrupção e a burocracia. Mais uma vez, foi mencionada a necessidade de o governante pensar no Estado e não apenas no seu governo, pois este seria um objetivo de curto prazo e não muito ético, do ponto de vista do papel ocupado pelo governante.

\subsection{5 - Resultados da Política}

\section{a) Governo}

O gráfico 9, abaixo, apresenta as respostas dos entrevistados do governo brasileiro, sobre a avaliação dos resultados alcançados pela política industrial de petróleo e gás no país.

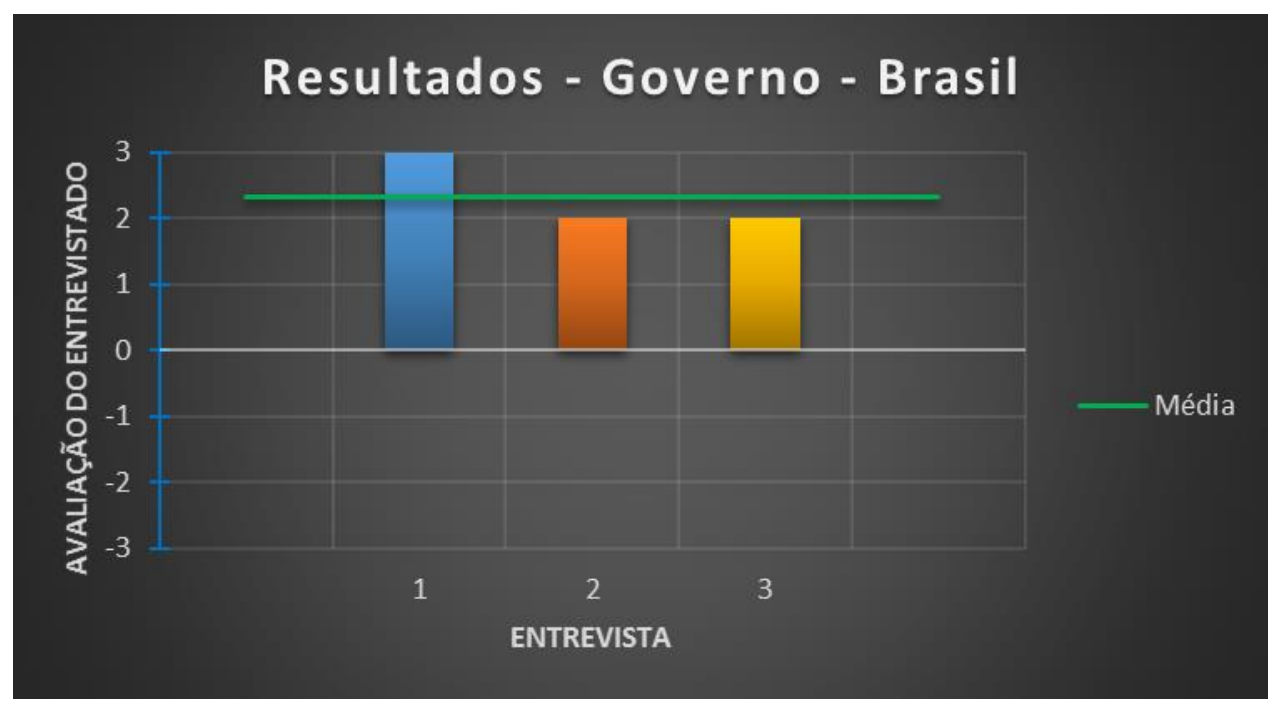

\section{Gráfico 9 - Avaliações dos entrevistados do governo do Brasil sobre os resultados da} política industrial de petróleo e gás no país.

Houve unanimidade entre os três entrevistados sobre os resultados serem todos bons, com exceção das exportações. Estes resultados teriam ficado abaixo do esperado porque a política teria sido ambiciosa demais. A aprendizagem tecnológica também foi especificamente citada em todas as entrevistas como resultado positivo da política, através da atração de empresas de base tecnológica e centros de $\mathrm{P} \& \mathrm{D}$ para produzirem na Ilha do Fundão. O investimento em P\&D teria incluído empresas e universidades, gerando inovação e patentes, principalmente por parte da Petrobras. Alguns exemplos seriam a FPSO, que é uma plataforma flutuante e os raisers flutuantes. 
Dois entrevistados mencionaram que a deflagração da operação Lava Jato teria diminuído os resultados positivos da política, principalmente com relação a empregos e salários na indústria naval. Junto com a queda do preço do petróleo, teria também diminuído a capacidade de investimento da Petrobras, que já estava sendo utilizada para conter o preço da gasolina no mercado interno. Como a Petrobras seria a grande âncora do setor de petróleo nacional, teria havido um enfraquecimento de toda a indústria, e muitos avanços teriam sido perdidos.

Uma das razões para o resultado negativo em exportações seria o plano de negócios da Petrobras ser o maior plano de investimento privado na área de petróleo do mundo, fazendo com que a demanda da Petrobras seja tão grande que as empresas fornecedoras não tenham a necessidade de exportar. Mesmo assim, haveria um movimento visando à bonificação de empresas exportadoras. Isso devido à possibilidade do Brasil se tornar um polo exportador no segmento de equipamentos subsea e exportar para a África, Golfo do México e Ásia. As empresas norueguesas teriam mais de cinco mil engenheiros espalhados pelo mundo, pois a Noruega não teria problemas com a geração de emprego no exterior, como existiria de maneira muito forte no Brasil.

Incentivar as exportações seria também uma forma importante para aumentar a produtividade, através do aumento de escala e redução de custos unitários. Apesar da indústria de petróleo ser muito customizada, pois cada projeto apresenta características específicas, acredita-se numa tendência de padronização de projetos, partes de processos e do sistema de produção, especialmente do sistema de produção submarina. Outro entrevistado também mencionou a replicação de projetos na produção de plataformas como uma forma de se ter ganhos de capacidade produtiva e produtividade.

Alguns resultados foram citados apenas em uma entrevista, como a importância da mobilização de atores, a exemplo do desenvolvimento do catálogo de navipeças, uma ferramenta pública que indica oportunidades para empresas no setor naval offshore. Assim como a política de conteúdo local, que teria feito várias empresas se associarem a estaleiros nacionais para começar a produzir no Brasil. També haveria a previsão de um aumento gradativo do percentual de conteúdo local, como forma de aprimorar a política, tornando os percentuais mais factíveis.

Foi mencionado que os prejuízos com a corrupção iriam além do dinheiro desviado, pois ela geraria também ineficiências no processo, aumento de custos e queda 
de qualidade. Então a corrupção pode ter prejudicado a competitividade da indústria nacional em vender para empresas operadoras em outros países. Todas as empresas nacionais da cadeia de petróleo teriam se especializado em atender à Petrobras e não em trabalhar para o setor. De uma forma geral, os resultados precisariam ser melhorados, por se ter chegado a gargalos que seriam evidentes.

\section{b) Associações Empresariais}

O gráfico 10, abaixo, apresenta as respostas dos entrevistados das associações empresariais brasileiras, sobre a avaliação dos resultados alcançados pela política industrial de petróleo e gás no país.

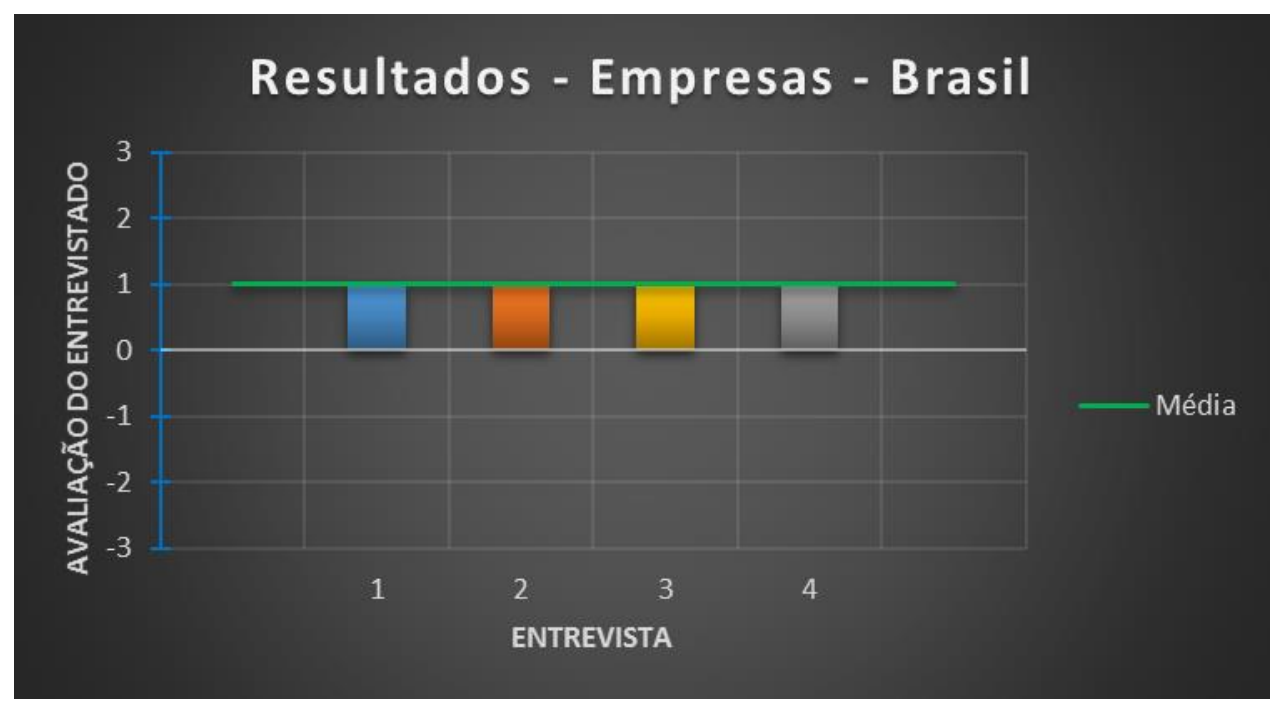

Gráfico 10 - Avaliações dos entrevistados das associações empresariais do Brasil sobre os resultados da política industrial de petróleo e gás no país.

Todos os quatro entrevistados mencionaram o investimento em P\&D em suas respostas, mas apresentaram diferentes avaliações sobre este tema. Enquanto para um deles a cláusula de $\mathrm{P} \& \mathrm{D}$ dentro dos contratos seria responsável por haver muito recurso disponível para desenvolvimento, para outro, a regulação de $\mathrm{P} \& \mathrm{D}$ estaria demonstrando uma capacidade limitada para promover investimentos na cadeia. Já para os outros dois entrevistados, esta questão teria um lado positivo e outro negativo. Por um lado, a iniciativa de investimento em P\&D seria boa e teria recursos abundantes, mas seria 
prejudicada por outros fatores conjunturais, como dificuldades regulatórias e a má utilização dos recursos, que viriam muito mais das próprias empresas do que do governo.

Ao analisar os resultados relativos às exportações, dois entrevistados mencionaram especificamente a empresa WEG, que teria dezessete mil trabalhadores na filial de Jaraguá, teria comprado empresas nos Estados Unidos e na China, e estaria exportando muito, para o mundo inteiro. Essa empresa teria tomado a iniciativa de procurar projetistas do setor de petróleo para apresentar seus equipamentos e tentar incluílos nos pacotes de projetos, que costumam ser vendidos fechados. Esse esforço estaria ajudando a superar diversos obstáculos que as empresas brasileiras encontram ao tentarem exportar, como o cartel das multinacionais, que dividem o mercado conforme seus interesses, e o custo Brasil.

Outro caso de sucesso citado em uma das entrevistas, foi o da Navship, de Edison Chouest, em Santa Catarina, que estaria produzindo embarcações com um nível de competitividade igual ou maior do que nos Estados Unidos. Então, apesar do Brasil ser um país burocrático, com um custo de produção muito alto, mão de obra cara e dificuldades de logística e infraestrutura para o escoamento da produção, existiriam casos de sucesso. De qualquer forma, as empresas brasileiras ainda exporiam muito pouco, aquém do que se poderia. Uma das razões apresentadas para isso seria o fato de que, há pouco tempo atrás, essas empresas estavam atoladas de encomendas do próprio mercado nacional. Para outro entrevistado, a política teria tido alguns poucos resultados, mas nada de exportações, pois tudo teria sido muito voltado para dentro do país.

O índice de conteúdo local foi lembrado por diferentes motivos. Um deles seria que as multas que estariam começando a ser cobradas pelo descumprimento das exigências seriam um indício dos problemas que o modelo apresenta. Para outro, o índice de conteúdo local teria aumentado nos últimos anos, mas ainda se teria muita margem para crescimento. E ainda foi defendido que este índice não serviria para medir o resultado da política, porque é uma métrica que só mede aquilo que sua metodologia manda medir. Como a metodologia teria variado ao longo do tempo, seria muito difícil fazer a comparação. O mero índice de conteúdo local não teria muito significado, por não indicar nada sobre a geração de sustentabilidade, conhecimento, tecnologia, ou competitividade para a indústria. Este entrevistado deu o exemplo de que um copo pode ter muito mais 
conteúdo local do que um avião da Embraer, mas isso não significa que a produção do copo tenha gerado mais benefícios para o país do que a produção do avião.

Enquanto um dos entrevistados disse que o número de empregos poderia ser muito melhor do que é, outro disse que a política de conteúdo local foi muito importante para a geração de emprego e renda no país. Lembrou a indústria naval, que teria mil e novecentas pessoas trabalhando em estaleiros no início dos anos 2000, teria chegado a um pico de oitenta e quatro mil em 2014, e teria a previsão de chegar a cem mil em 2016. O que teria sido atingido até antes, se não fosse toda a crise no setor.

A dificuldade para a obtenção de empréstimos apareceu em duas entrevistas. Numa delas foi dito que isso seria culpa da burocracia e em outra foi dito que essa dificuldade seria ainda mais grave para as pequenas e médias empresas, que costumam ser intensivas em tecnologia no setor de petróleo.

A atração de investimentos também foi analisada por dois dos entrevistados. Estados como o Rio de Janeiro, São Paulo e Rio Grande do Sul conseguiriam atrais bastante investimentos, participando de feiras internacionais e apresentando oportunidades. Muitas empresas que teriam se instalado no Brasil, como a Rolls-Royce, a GE e a Camin, também teriam instalado seus centros tecnológicos no Brasil, principalmente na Ilha do Fundão. Ainda foi mencionado que na Bacia de Campos, $65 \%$ da frota seria norueguesa.

Entre as manifestações que apareceram em apenas uma entrevista, teve a de que o resultado teria sido bom, mas não teria sido perene. Pela falta de um objetivo amplo e da construção de uma base sólida, ultimamente estariam acontecendo retrocessos. De qualquer forma, teria havido desenvolvimento da indústria, com resultados muito bons e resultados muito ruins. O registro de patentes não seria algo muito importante para o setor de petróleo, que tem projetos muito customizados, apesar de haver um movimento recente por uma maior padronização. Apesar de ter tido dificuldades para atender algumas demandas quando o mercado estava agitado, o Brasil teria uma boa capacidade produtiva e um exemplo positivo seria o vale do aço, em Minas Gerais. Existiria uma carência muito grande de recursos e um apagão generalizado na educação, afetando todas as áreas. Um dos problemas seria os sistemas de treinamento, que não consideram as necessidades do mercado e aqueles treinamentos mais tecnológicos, que deveriam ser realizados dentro das próprias indústrias e não em salas de aula. 
A política de conteúdo local, que já existia desde a primeira rodada, mas foi ganhar força realmente a partir da implementação da cartilha, em 2007, já teve tempo de produzir resultados. Para um dos entrevistados, esses resultados aconteceram em algumas áreas, mas foram abaixo do que poderiam ser. Os resultados mais expressivos teriam ocorrido nos setores onde se verificou um envolvimento mais estratégico da Petrobras com os seus fornecedores, como no caso da construção naval e do setor subsea. Um dos entrevistados disse que os resultados seriam bastante questionáveis e necessitariam de um estudo mais aprofundado. De acordo com ele, deve-se questionar se os resultados são efetivamente resultados da política, ou se seriam uma mera consequência de uma estratégia de governo passada para as decisões de compras da Petrobras.

\subsection{6 - Avaliação da Política}

\section{a) Governo}

O gráfico 11, abaixo, apresenta as respostas dos entrevistados do governo brasileiro, sobre a avaliação dos mecanismos de monitoramento e avaliação da política industrial de petróleo e gás no país.

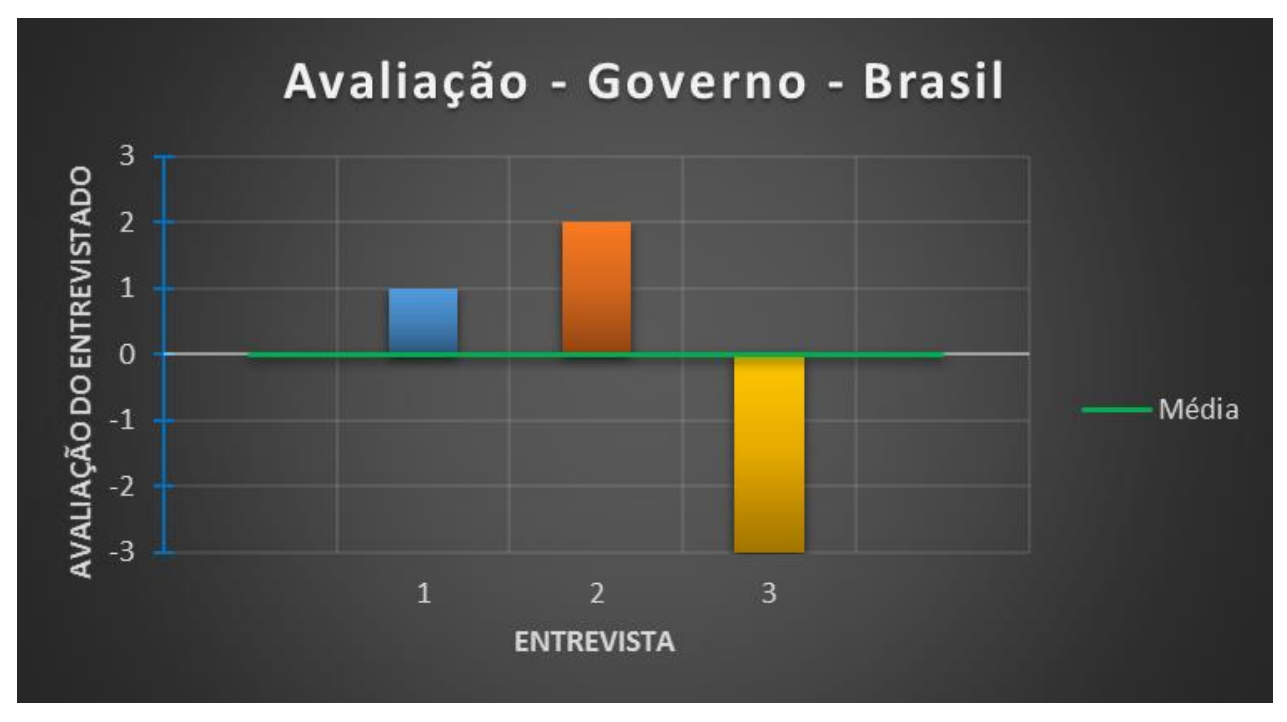

Gráfico 11 - Avaliações dos entrevistados do governo do Brasil sobre a avaliação da política industrial de petróleo e gás no país. 
Neste bloco, não houve absolutamente nenhum tema que tenha sido tratado em mais de uma entrevista. Para um dos entrevistados, não existiria uma estrutura de referência utilizada por todos os atores. A ANP seria a única instituição que teria mecanismos para avaliar a política de conteúdo local, pois somente eles teriam os números com relação aos certificados de conteúdo local. Poderia haver mecanismos mais transparentes para a publicação desses números, mas se tem dúvidas sobre se a ANP teria interesse em que esse processo fosse mais transparente. Esses mecanismos não seriam transparentes nem mesmo para quem é do próprio governo, que muitas vezes precisariam recorrer a dados secundários, pois mesmo no resumo da avaliação feita pela ANP que é enviado para outros órgãos do governo, haveria questões de sigilo, com acesso apenas aos números macro. Também há dúvidas sobre quem poderia ser responsável por esses mecanismos de avaliação. O CNPE poderia ter uma câmara técnica para isso, ou a ANP poderia ter um comitê. De qualquer forma, deveria haver um processo mais frequente de discussão entre os órgãos do governo.

Em uma outra entrevista, foi mencionado que existem diferentes mecanismos de avaliação, que seriam a auditoria da ANP em projetos já conduzidos, a expectativa pela contratação de uma avaliação da capacidade da indústria como um todo, e a cada rodada seriam feitas reuniões com outros atores para que se tenha a percepção do mercado. Não haveria muita integração, porque cada avaliação seria referente a uma etapa diferente do processo. Como não se trata de um estudo que se faça de uma hora para a outra, pois há a necessidade de ir a campo e verificar na prática o que dizem os atores, se estaria fazendo até agora o que seria possível, devido à falta de recursos.

Outro entrevistado disse que, de uma forma geral no Brasil, a avaliação seria um problema, um ponto crítico. Seria necessária a criação de mecanismos que permitam que se tenha mais foco e que se atinjam resultados melhores. Para se fazer uma política industrial, seria necessário que se cobre das empresas o atingimento de certos indicadores de performance. Afinal, se está criando benefícios para algumas empresas, ou certos grupos econômicos, através da utilização de recursos públicos. Por isso, seria fundamental a prestação de contas para a sociedade, de forma transparente.

A Coréia do Sul teria feito isso muito bem, mas o Brasil teria esse problema de conceder benefícios através da política industrial, sem ter como avaliar os resultados desses benefícios depois. Faltam indicadores razoáveis e que sejam aderentes à política. 
Não se soube dizer se a Noruega teria esses mecanismos de avaliação, mas acredita-se que eles devam ter uma percepção do seu sucesso pela quantidade de empresas que eles criaram e que estão no mercado, como a Aker e a Subsea 7.

\section{b) Associações Empresariais}

O gráfico 12, abaixo, apresenta as respostas dos entrevistados das associações empresariais brasileiras, sobre a avaliação dos mecanismos de monitoramento e avaliação da política industrial de petróleo e gás no país.

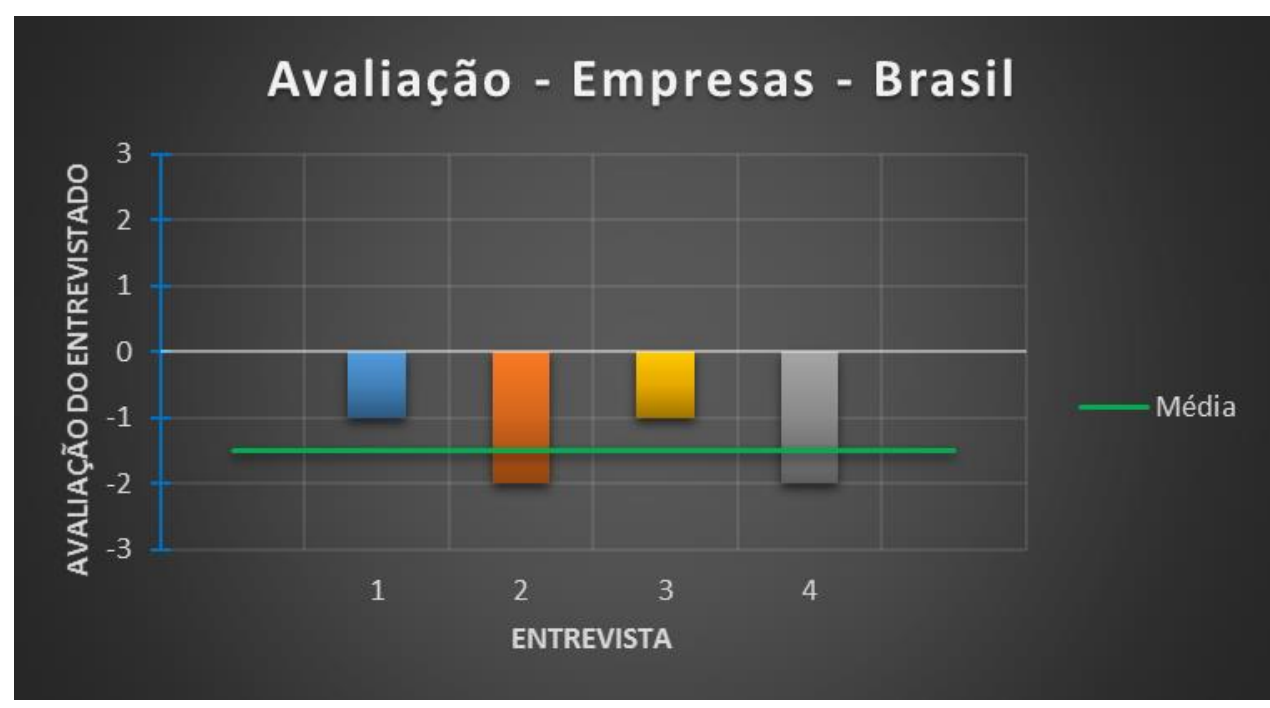

Gráfico 12 - Avaliações dos entrevistados das associações empresariais do Brasil sobre a avaliação da política industrial de petróleo e gás no país.

Não houve nenhum tema que tenha sido tratado pelos quatro entrevistados, mas três deles afirmaram expressamente que não existe um mecanismo de avaliação e monitoramento da política industrial. Seria neste ponto onde o conflito iniciaria, pois cada um faria sua própria avaliação, gerando resultados diferentes. Um dos entrevistados disse que, mesmo não se recordando de nenhum mecanismo, acredita que o governo, a ANP, ou a própria Petrobras tenham alguma ferramenta de gestão para medir o desenvolvimento da indústria nacional.

Foram citadas diversas fontes de monitoramento ou avaliação, como o monitoramento do índice de conteúdo local feito via certificadoras, que geraria um custo a mais para o empresário, mas seria interessante. A ANP saberia sobre o que está 
acontecendo através das audiências públicas, que seriam seu mecanismo de avaliação. $\mathrm{O}$ IBGE, o Banco Central, a CNI e as associações também avaliariam, cada uma, uma parte diferente da política, mas para avaliar a política como um todo, seria necessária a junção disso tudo, o que ainda não teria sido feito. O IPEA também teria publicado um livro, com alguns dados com base em estatísticas oficiais e alguns parâmetros contestáveis, fugindo um pouco da realidade, mas apresentando algumas métricas.

Dois entrevistados disseram que o monitoramento e a avaliação seriam feitos muito a nível de conversa, sem nada concreto que se possa visualizar. Foi dito que talvez os mecanismos não funcionem muito bem por serem pouco robustos, seletivos, por não interagirem, não se integrarem. Faltaria um mecanismo que monitore objetivamente o resultado desejado. Dois entrevistados lembraram que, para isso, seria necessária uma definição muito clara sobre qual o resultado desejado.

Em uma das entrevistas foi mencionado que, devido a sua origem em sindicatos, o PT gostaria de realizar muitas assembleias, de ter muita conversa, mas sem chegar a nenhuma definição. Ou quando ocorre alguma definição, não seria necessariamente aquilo que teria sido discutido. Existiria abertura e existira diálogo, mas a decisão final seria com base em ideias predefinidas.

\subsection{7 - Reação aos Resultados da Política}

\section{a) Governo}

O gráfico 13, abaixo, apresenta as respostas dos entrevistados do governo brasileiro, sobre a avaliação da reação aos resultados encontrados pelos mecanismos de monitoramento e avaliação da política industrial de petróleo e gás no país. 


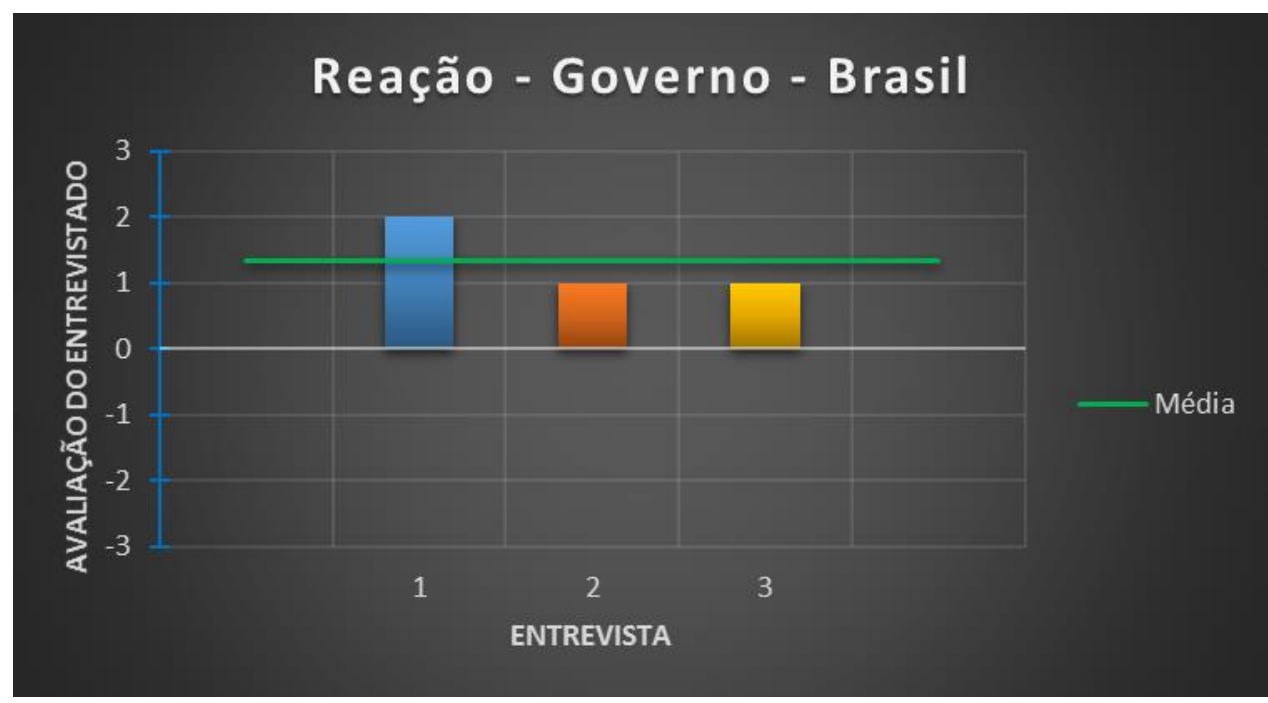

\section{Gráfico 13 - Avaliações dos entrevistados do governo do Brasil sobre a reação aos resultados da avaliação da política industrial de petróleo e gás no país.}

Não houve tema que tenha sido tratado nas três entrevistas. A única questão que apareceu na fala de dois entrevistados foi que a orientação da política seria uma questão política. Um dos entrevistados disse que existiria hoje a possibilidade de se propor algumas melhorias, mas que a questão política dificultaria a implementação dessas melhorias. Outro entrevistado informou que mesmo não havendo um mecanismo formal de avaliação da política, os atores de dentro do governo teriam suas avaliações. Estas avaliações não seriam baseadas em dados, mas numa leitura do contexto. Seria algo qualitativo, que se percebe no dia a dia, na conversa com empresários, com associações empresariais, ouvindo suas reclamações. Desta forma, pode-se considerar que existem mecanismos de avaliação para a orientação da política industrial, mas trata-se de mecanismos políticos, não mecanismos técnicos, sistematizados.

Foi lembrada a existência de avaliações feitas ad hoc sobre problemas específicos na indústria, mas isso não seria algo sistemático. Também foi dito que a política de conteúdo local terá um problema a enfrentar, pois logo aparecerão multas de alguns bilhões de dólares. Devido a isso, se estaria tentando discutir como de não deixar essas multas destruírem a indústria e aperfeiçoar a política ao mesmo tempo.

Outro entrevistado afirmou que dados seriam uma coisa complicada. Faltaria clareza sobre o que teria sido alcançado pela política e sobre o que ainda se precisaria evoluir. A falta de informação sobre isso demonstraria a necessidade de reorientação da 
política, pela dificuldade que ela apresenta em enxergar essas questões. Existiriam dados sobre empregos, investimentos e conteúdo local, mas faltaria dados mais refinados. $\mathrm{O}$ aprimoramento da política passaria justamente pelo acesso a dados melhores, que possam servir de base para a reflexão sobre esse aprimoramento. Seria uma questão de organização de dados que já existem, mas estariam muito difusos. A ANP teria todos esses dados, mas teria dificuldade de organização devido à burocracia da política, ao excesso de notas fiscais e à não informatização dos processos. Apesar da difusão destes dados, hoje a capacidade de diagnóstico seria maior.

\section{b) Associações Empresariais}

O gráfico 14, abaixo, apresenta as respostas dos entrevistados das associações empresariais brasileiras, sobre a avaliação da reação aos resultados encontrados pelos mecanismos de monitoramento e avaliação da política industrial de petróleo e gás no país.

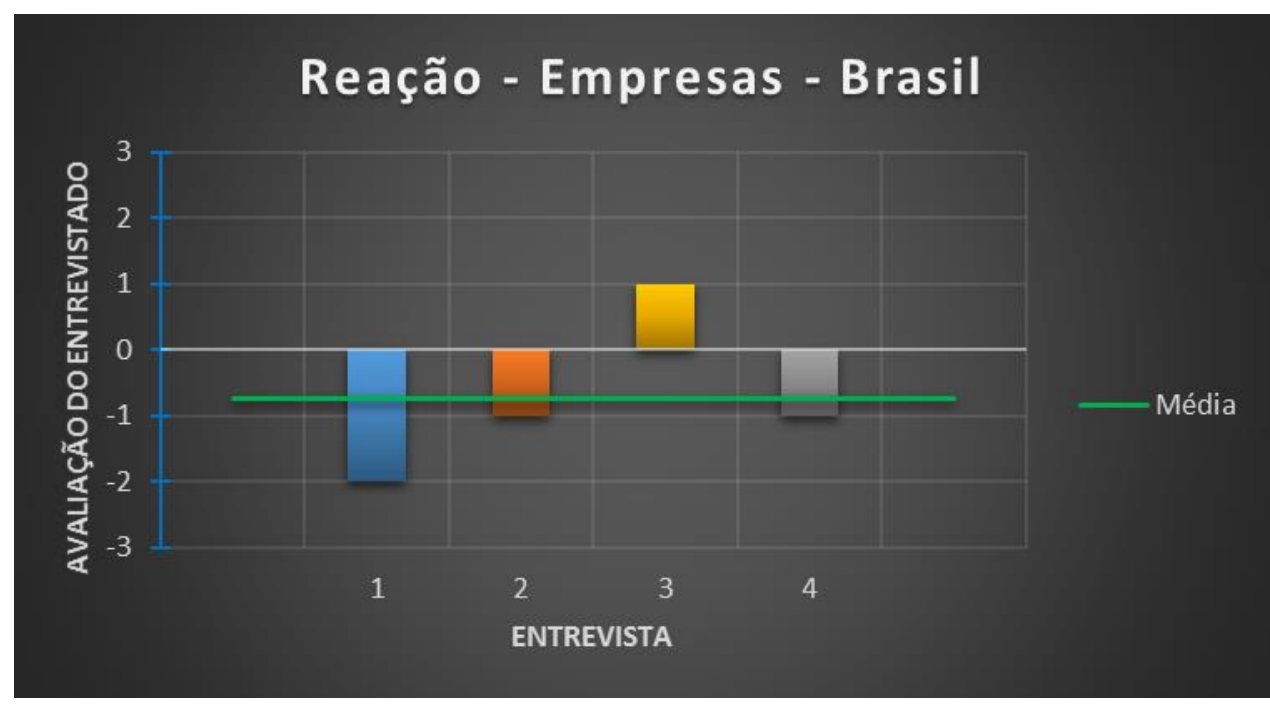

Gráfico 14 - Avaliações dos entrevistados das associações empresariais do Brasil sobre a reação aos resultados da avaliação da política industrial de petróleo e gás no país.

Neste bloco não houve nenhum tema que tenha sido mencionado por todos os quatro entrevistados e nem mesmo por três deles. A única questão que apareceu em duas entrevistas foi a direta relação entre a orientação da política industrial e os interesses do governo. No Brasil, a falta de mecanismos claros de avaliação, desde o lançamento das políticas, dificultaria o monitoramento tempestivo e a correção de rumos. As políticas 
industriais brasileiras teriam a característica de acompanharem os prazos dos mandatos presidenciais, sendo comuns rupturas na passagem de um governo para outro, limitando o processo de aprendizagem e a correção de rumos ao longo do tempo. Um exemplo seria o PBM, cuja área de petróleo e gás estaria tendo reuniões mensais até as eleições de 2014 , e depois não teria ocorrido mais nada, chegando ao ponto de não se saber se o que estava sendo discutido ainda existe.

De acordo com um dos entrevistados, o que falta seria uma certa abertura para o debate, que não estaria sendo feito de forma ampla, no sentido institucional. O debate existiria, seria aberto e intenso, utilizando a imprensa e o parlamento, mas de uma forma muito desorganizada, sem gerar resultado algum. Não existiria uma liderança procurando encontrar um núcleo comum de alinhamento. Deveria se estabelecer metas claras e uma metodologia de avaliação, cujo acompanhamento seria feito em parceria pelos setores público e privado, através de uma governança que permita validar diagnósticos e medidas corretivas.

Foi mencionado que a existência de muitos interesses envolvidos não seria necessariamente ruim, pois seria saudável para o debate que se tenha vários interesses legítimos, cada um dentro do seu grupo de atuação. Um dos entrevistados considerou haver acesso aos dados sobre o monitoramento e a avaliação, mas como não haveria política, não seria nada organizado, nem encadeado. Enquanto na Noruega os atores seriam muito próximos e trabalhariam num contexto de cooperação, no Brasil os atores estariam muito separados e cada um querendo tocar o seu próprio projeto. Se conseguissem juntar todos os atores que, de alguma forma, recebem recursos do governo, muita coisa poderia ser feita. Porém, nenhum deles trabalha em conjunto com o outro, mesmo que alguns sejam do mesmo ministério.

\subsection{8 - Resultado das Avaliações}

\section{a) Governo}

Os gráficos 15, 16 e 17, abaixo, apresentam as respostas objetivas sobre todas as etapas da política industrial brasileira de petróleo e gás, apresentadas pelos três entrevistados do governo brasileiro. 


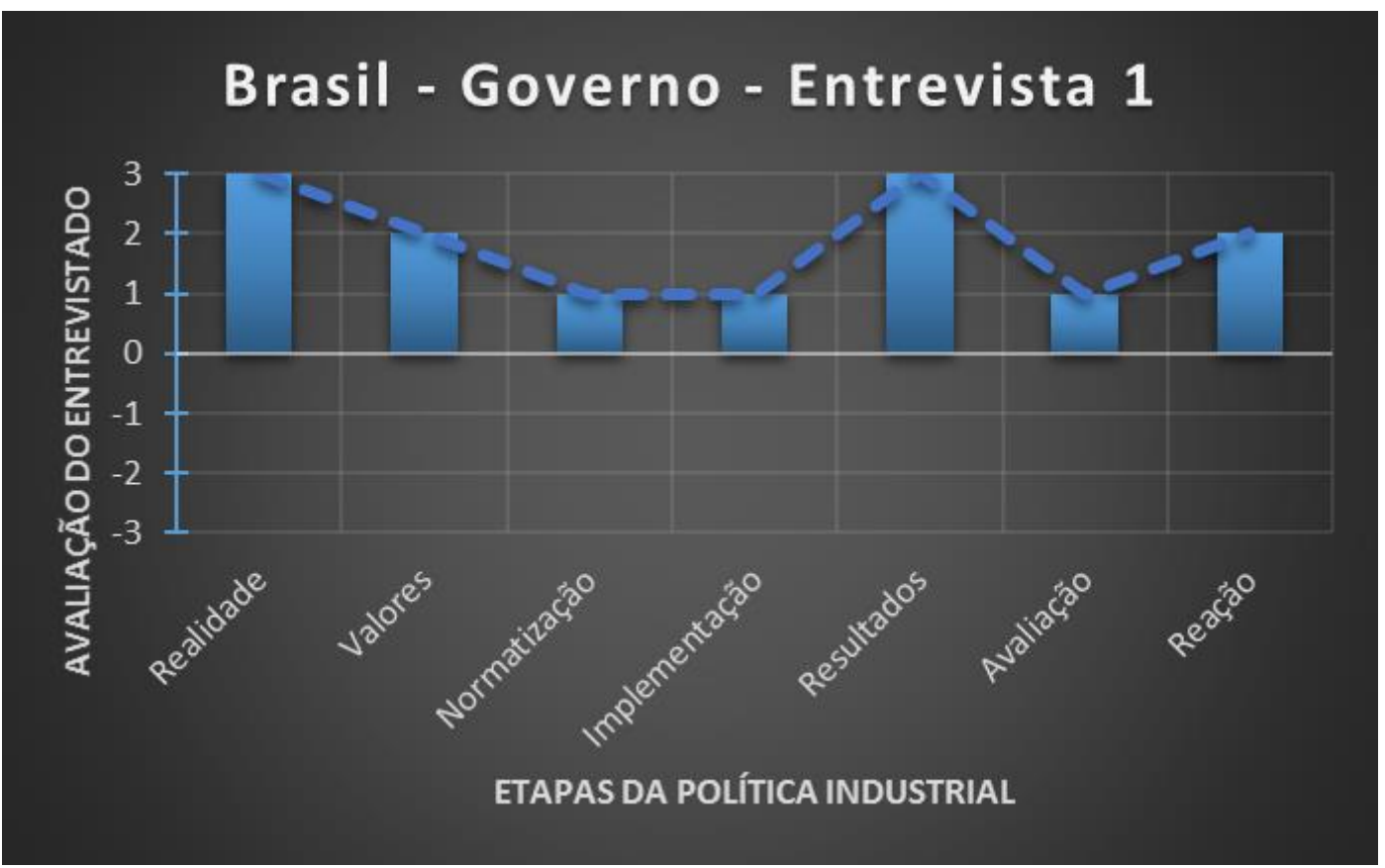

Gráfico 15 - Avaliação sobre as diferentes etapas da política industrial de petróleo e gás no país, pela entrevista 1 do governo do Brasil.

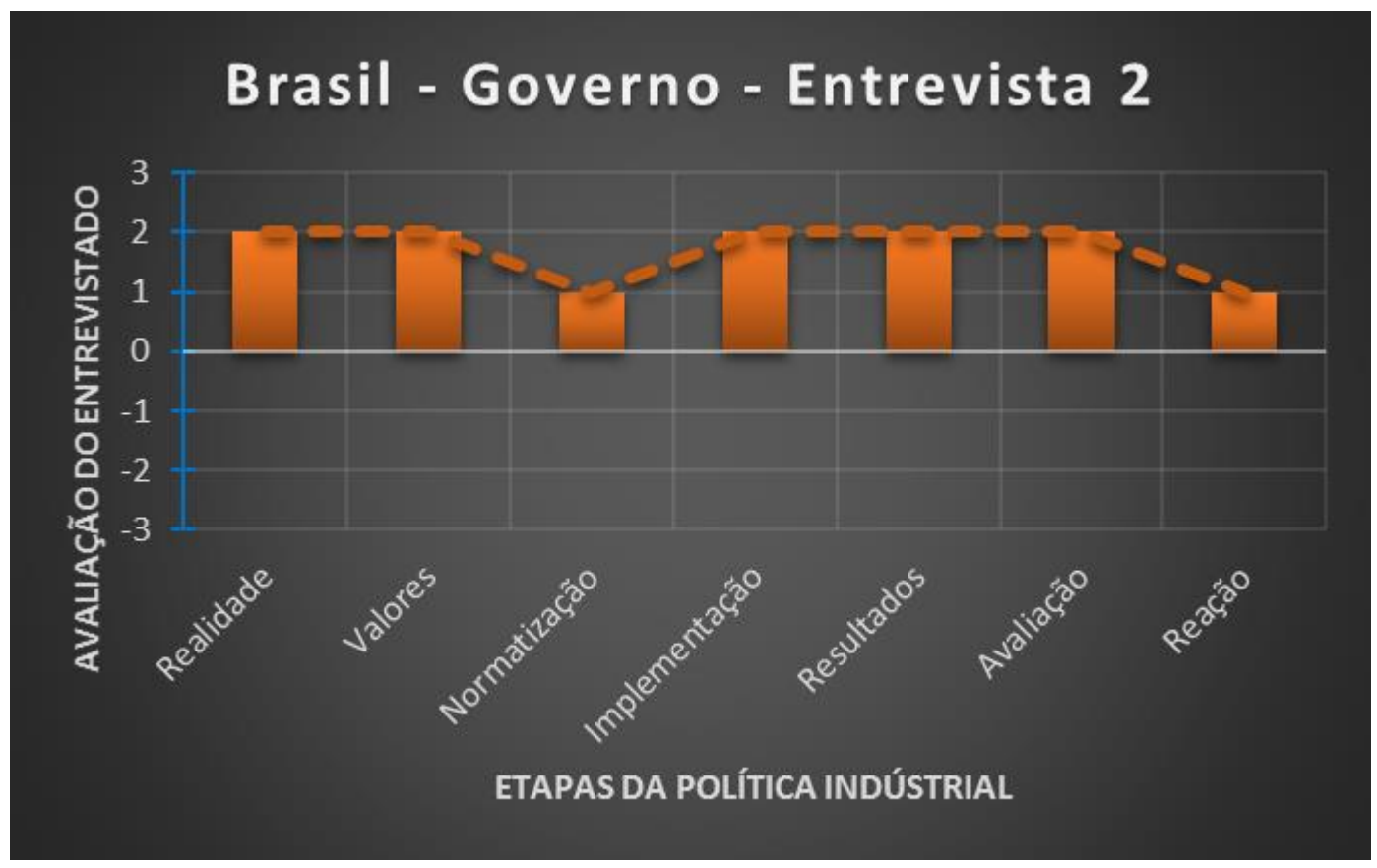

Gráfico 16 - Avaliação sobre as diferentes etapas da política industrial de petróleo e gás no país, pela entrevista 2 do governo do Brasil. 


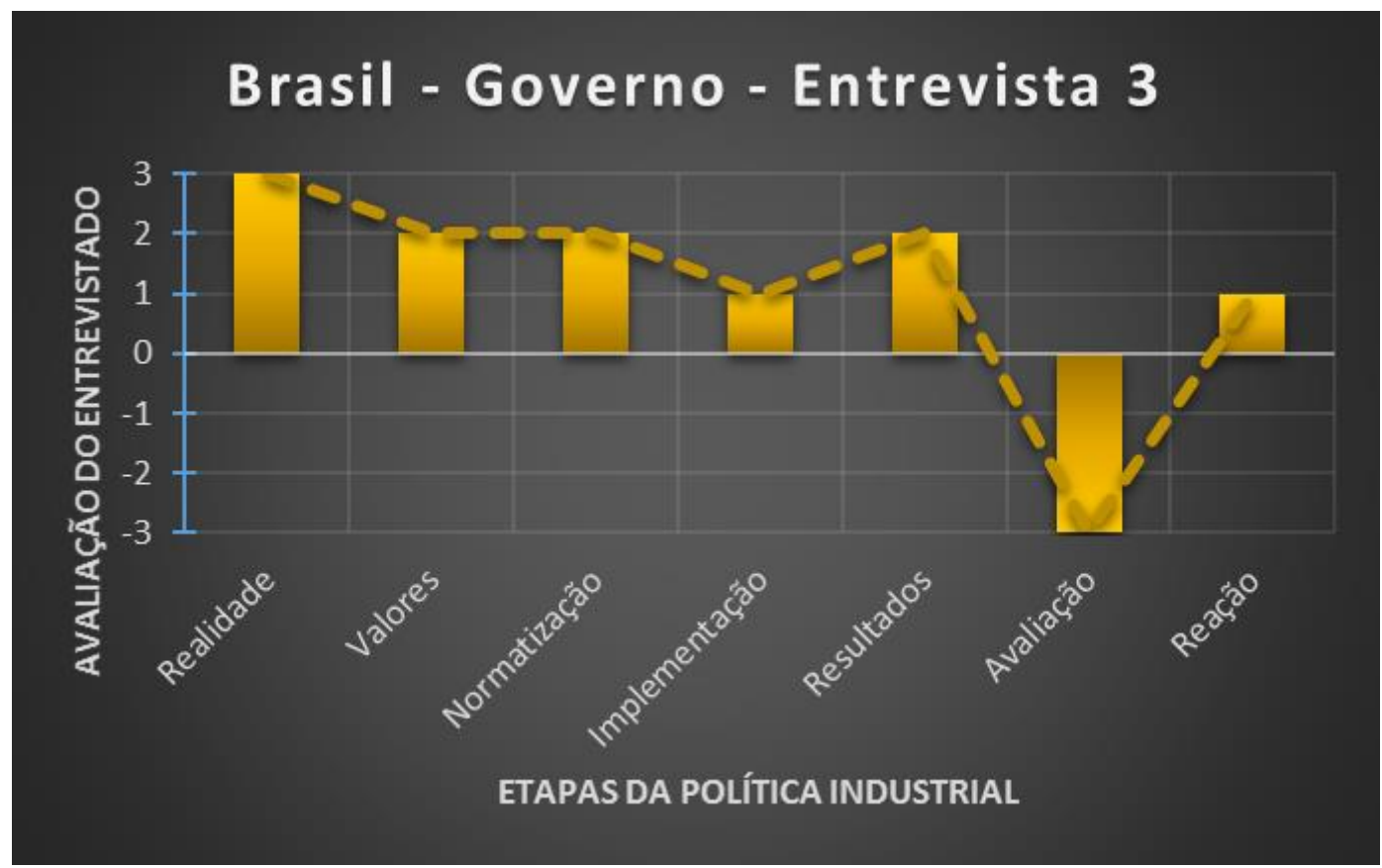

Gráfico 17 - Avaliação sobre as diferentes etapas da política industrial de petróleo e gás no país, pela entrevista 3 do governo do Brasil.

\section{b) Associações Empresariais}

Os gráficos 18, 19, 20 e 21, abaixo, apresentam as respostas objetivas sobre todas as etapas da política industrial brasileira de petróleo e gás, apresentadas pelos quatro entrevistados das associações empresariais brasileiras.

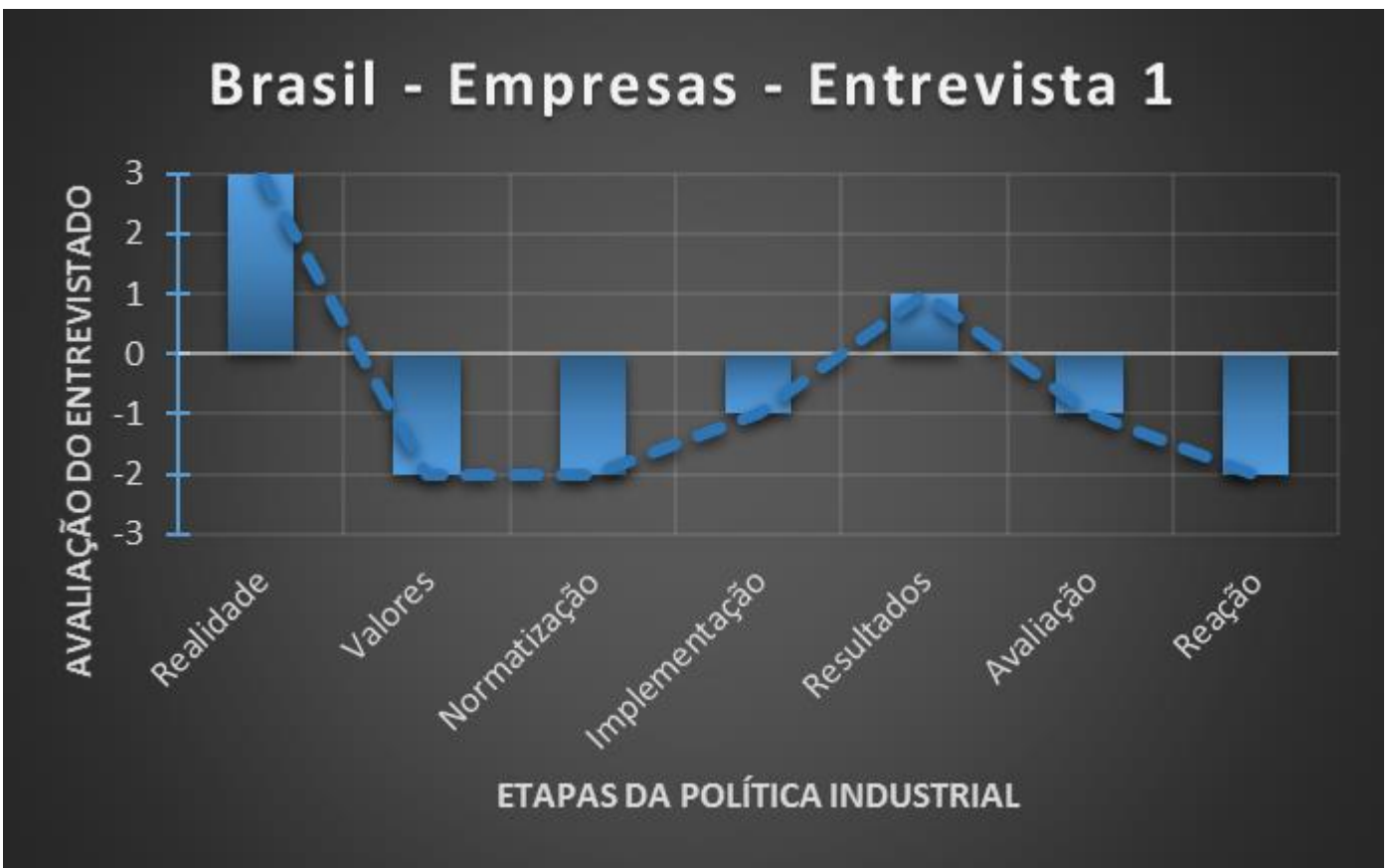

Gráfico 18 - Avaliação sobre as diferentes etapas da política industrial de petróleo e gás no país, pela entrevista 1 das associações empresariais do Brasil. 


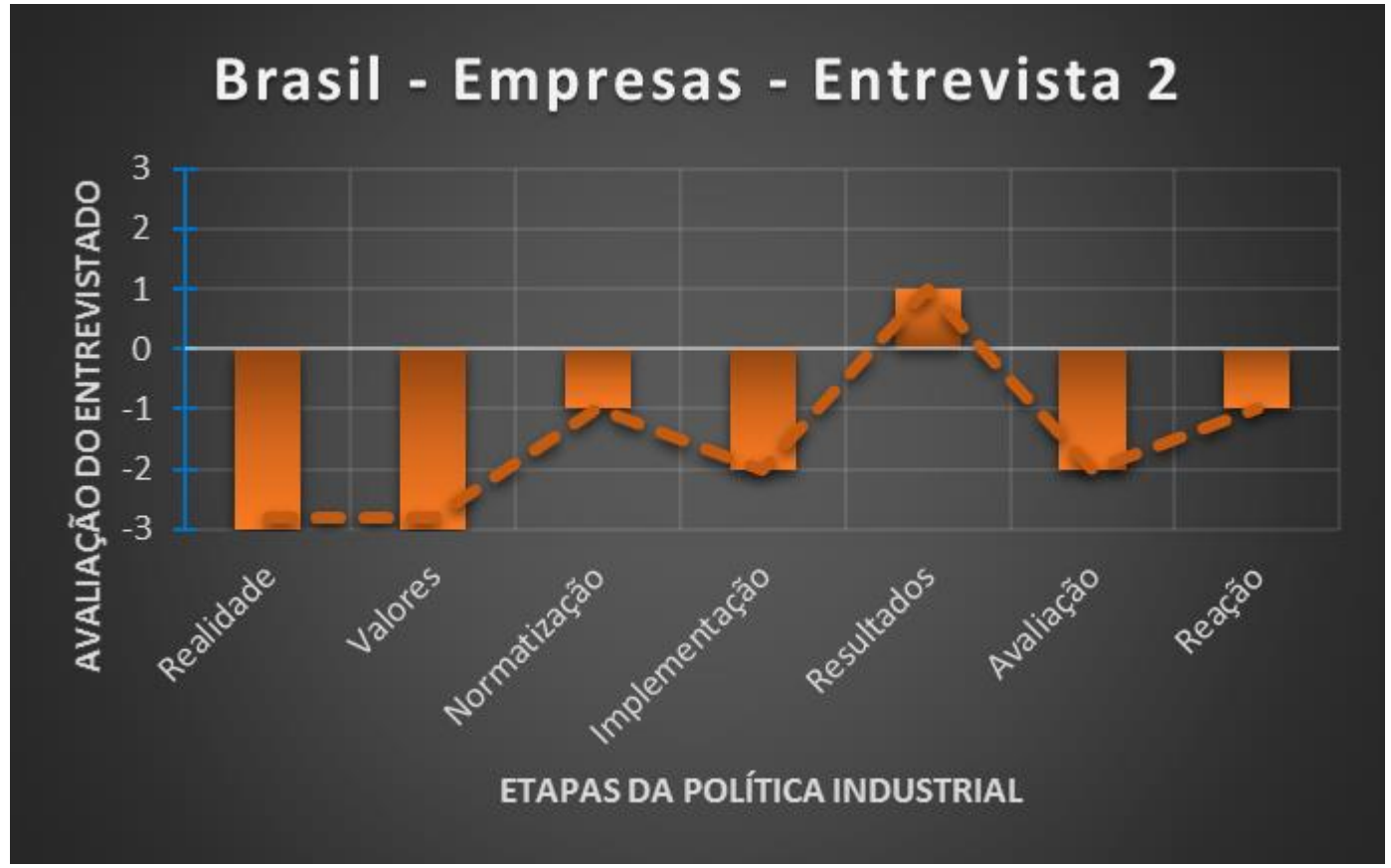

Gráfico 19 - Avaliação sobre as diferentes etapas da política industrial de petróleo e gás no país, pela entrevista 2 das associações empresariais do Brasil.

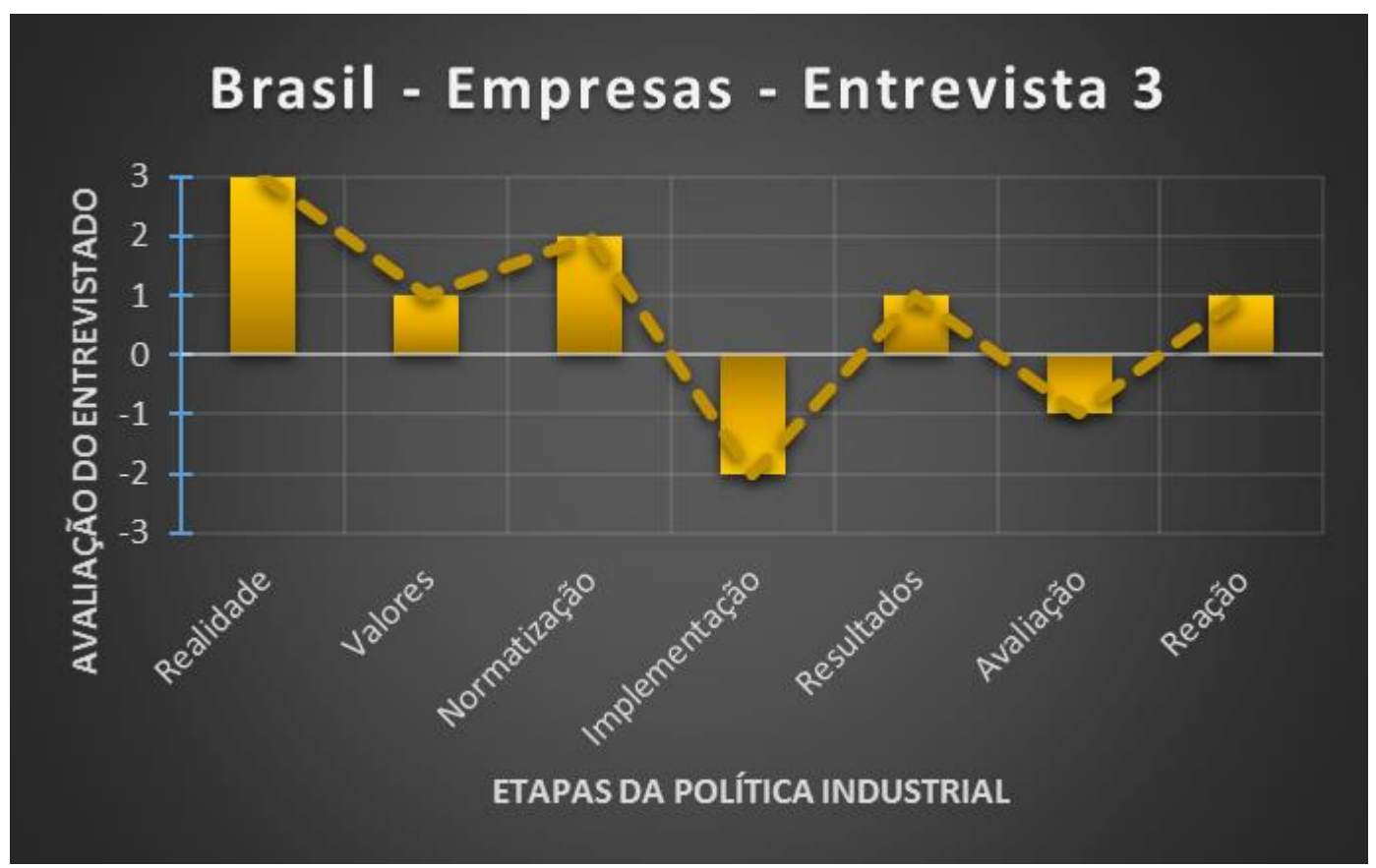

Gráfico 20 - Avaliação sobre as diferentes etapas da política industrial de petróleo e gás no país, pela entrevista 3 das associações empresariais do Brasil. 


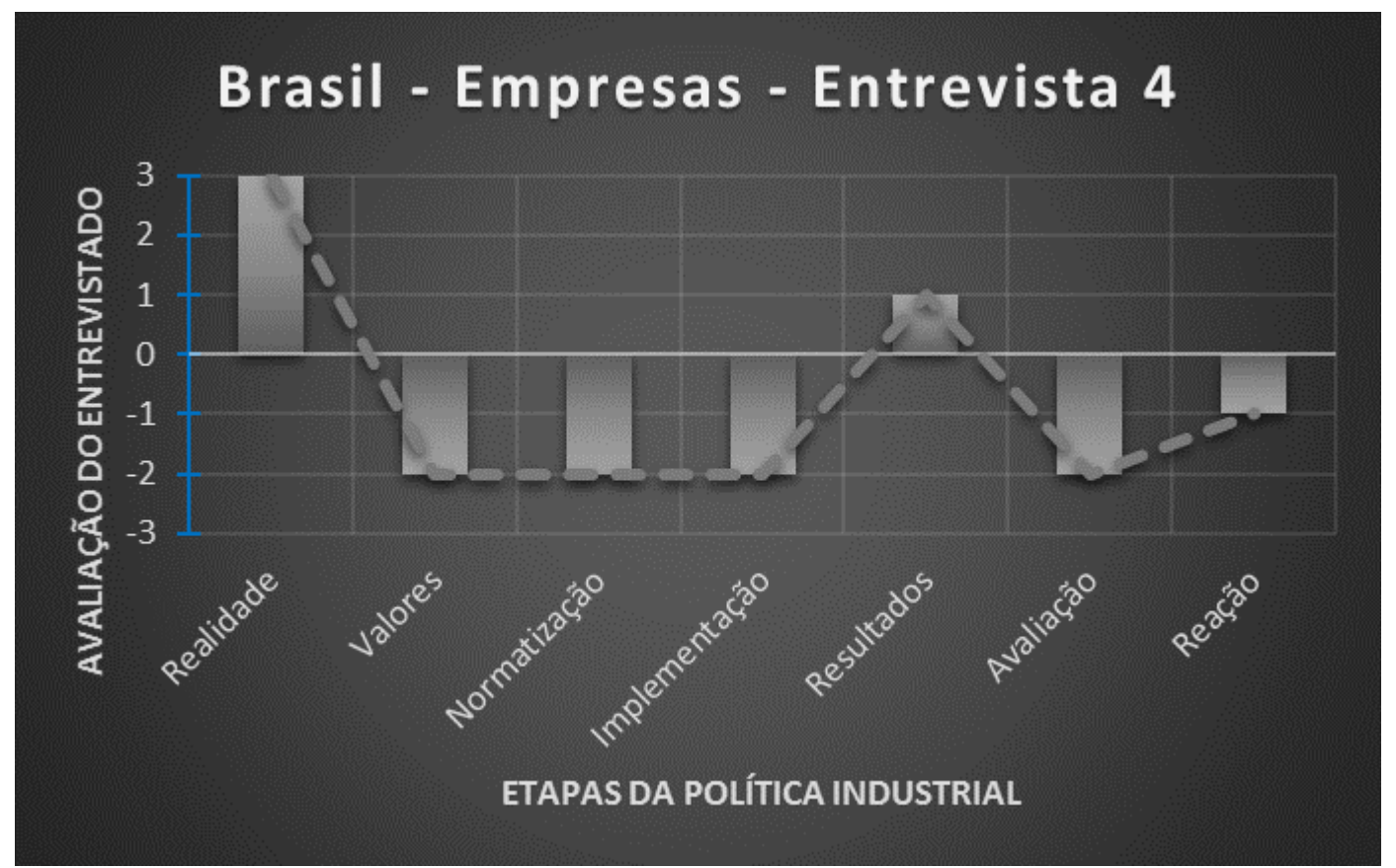

Gráfico 21 - Avaliação sobre as diferentes etapas da política industrial de petróleo e gás no país, pela entrevista 4 das associações empresariais do Brasil.

\subsection{9 - Relação Entre Atores}

\section{a) Governo}

O gráfico 22, abaixo, apresenta o percentual de menções positivas e negativas nas respostas dos entrevistados do governo sobre a relação entre os atores para a orientação da política industrial brasileira para petróleo e gás. 


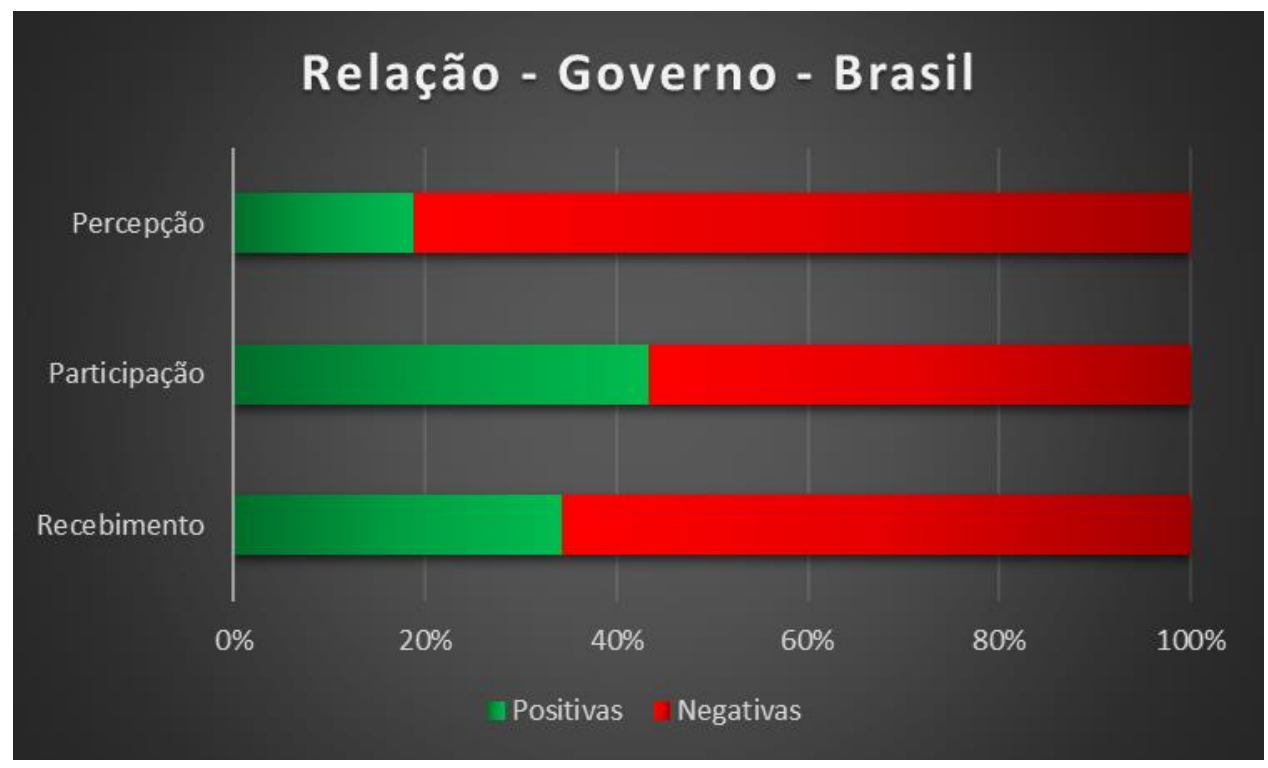

Gráfico 22 - Percentual de menções positivas e negativas nas respostas do governo sobre a relação entre os atores na orientação da política industrial brasileira.

\section{a.1) Percepção sobre as Associações Empresariais}

Com relação à percepção que os entrevistados do governo têm sobre as associações empresariais brasileiras, apareceram apenas duas menções positivas, dizendo que as associações teriam se manifestado e influenciado a mudança de regras na política.

Foram feitos cinco comentários que reuniam uma menção positiva e uma negativa sobre o mesmo tema. O comportamento das empresas foi considerado instável, porque alguns segmentos elogiariam a política, ao mesmo tempo que outros segmentos a criticam. Também haveria casos de empresas que elogiam num momento, mas criticam em outro, como empresas que criticam o marco regulatório, mas gostam da exigência de conteúdo local. A participação delas também foi considerada um tanto dúbia, porque alguns segmentos teriam participado ativamente, enquanto outros não. E algumas tentativas de investimento por parte de empresas teriam sido prejudicadas pela corrupção.

Em dezessete momentos foram feitos comentários negativos a respeito da percepção que os entrevistados de governo têm das associações empresariais. Em nove deles foi mencionado que as empresas reclamam da política industrial, seja por dificuldades no processo, por não ter acesso ao mercado, pela política favorecer outros atores, pelos objetivos da política serem ambiciosos demais e por quererem sempre 
aumentar o percentual de exigência de conteúdo local. Outras oito menções foram feitas a respeito de críticas ou dúvidas com relação às associações empresariais. Foi dito que o ponto de insatisfação das associações empresariais não está muito claro, que não se sabe o que as empresas pensam sobre determinados temas, que operadores e fornecedores teriam objetivos distintos, que as empresas teriam mais informações sobre a indústria do que o governo, que se teria mais dificuldade o quanto mais se desce nos elos da cadeia de fornecedores, e que os sindicatos, além de serem muito críticos, defendem algumas questões apenas para garantir a manutenção da atividade deles.

\section{a.2) Participação do Governo}

Sobre a participação de cada órgão do governo nas discussões sobre a política industrial de petróleo e gás brasileira, foram feitas doze menções positivas. Em oito delas os entrevistados dizem que os órgãos onde trabalham participaram do debate, seja através de trabalhos conjuntos, pela disposição em aperfeiçoar e discutir melhorias, ou por provocar discussões e apresentar propostas. Duas dessas menções ressaltaram que essa participação foi bastante ativa, em outra foi dito que se participa de tudo e em outra que se participa sempre. Em outros quatro momentos foi mencionada a existência de diálogo entre governo e associações empresariais. Ainda que esteja no início, ou que ainda não seja pleno, este diálogo teria o objetivo de aprimorar e dar estabilidade para a política, evitando fortes retrocessos.

Dois comentários foram intermediários. Um disse que não cabia àquele órgão participar da discussão de um determinado tema. Outro afirmou que seu órgão participa da coordenação e monitoramento, mas não da implementação da política.

Em dezesseis oportunidades foram feitos comentários negativos sobre a participação do governo. Cinco disseram que não participaram, seja porque a discussão estaria muito centrada em outros órgãos do governo, por não se conseguir uma efetiva participação no debate, ou por não se ter o protagonismo desejado. A dificuldade para essa participação estaria relacionada ao longo período que se passou sem a implementação de uma política industrial. Outras cinco menções ligadas a tentativas falhas de participar, quase todas ligadas a falta de influência nessa participação e apenas uma falando de maneira geral sobre as tentativas não darem certo. E ainda, outros seis comentários foram relacionadas à problemas internos ao governo que teriam atrapalhado 
essa participação, como a definição da política sem muito diálogo entre os ministérios, a existência de uma disputa entre órgãos do próprio governo, o fato da política estar centrada no MME e na ANP, a necessidade de criação de mecanismos de diálogo entre o setor público e o setor privado para aprimorar a política, a falta de dados precisos e completos para embasar as discussões, dificuldade em levar assuntos para as instâncias superiores decidirem e em se encontrar espaço para discutir internamente sobre melhorias devido às agendas dos superiores serem muito atribuladas.

\section{a.3) Recebimento pelas Associações Empresariais}

Cinco comentários positivos foram feitos sobre o recebimento das ações governamentais pelas associações empresariais. Nestas situações, mencionou-se trabalhos em conjunto, um bom relacionamento e a ausência de críticas por parte das associações empresariais.

Houve apenas uma menção intermediária sobre o recebimento, dizendo que se espera que as associações façam a sua parte para o sucesso do país.

Foram dez os comentários negativos sobre a forma como as associações recebem as ações do governo brasileiro. Quatro deles afirmavam que as tentativas do governo são mal recebidas e todos se basearam na mesma razão: a resistência das associações às propostas de mudanças na política, mesmo quando se trata de aprimoramentos. Existiria uma reclamação generalizada para que não se altere a política de conteúdo local, o pessoal ficaria receoso com mudanças por desconhecerem os desdobramentos decorrentes e os temas seriam politicamente delicados, especialmente na situação atual. As outras seis menções afirmaram que as empresas poderiam ter participado e investido mais, para contribuir com o sucesso da política. Foi dito que quando o mercado era fechado havia mais participação das empresas, que as empresas poderiam ter investido mais em treinamentos, sido mais parceiras, feito um esforço maior, demonstrado mais interesse em mecanismos de avaliação e mais comprometimento, pois teriam dito que tinham a capacidade de produzir muito mais do que realmente eram capazes, apenas para garantir a exigência de um índice de conteúdo local mais alto para o seu segmento. 


\section{b) Associações Empresariais}

O gráfico 23, abaixo, apresenta o percentual de menções positivas e negativas nas respostas dos entrevistados das associações empresariais sobre a relação entre os atores para a orientação da política industrial brasileira para petróleo e gás.

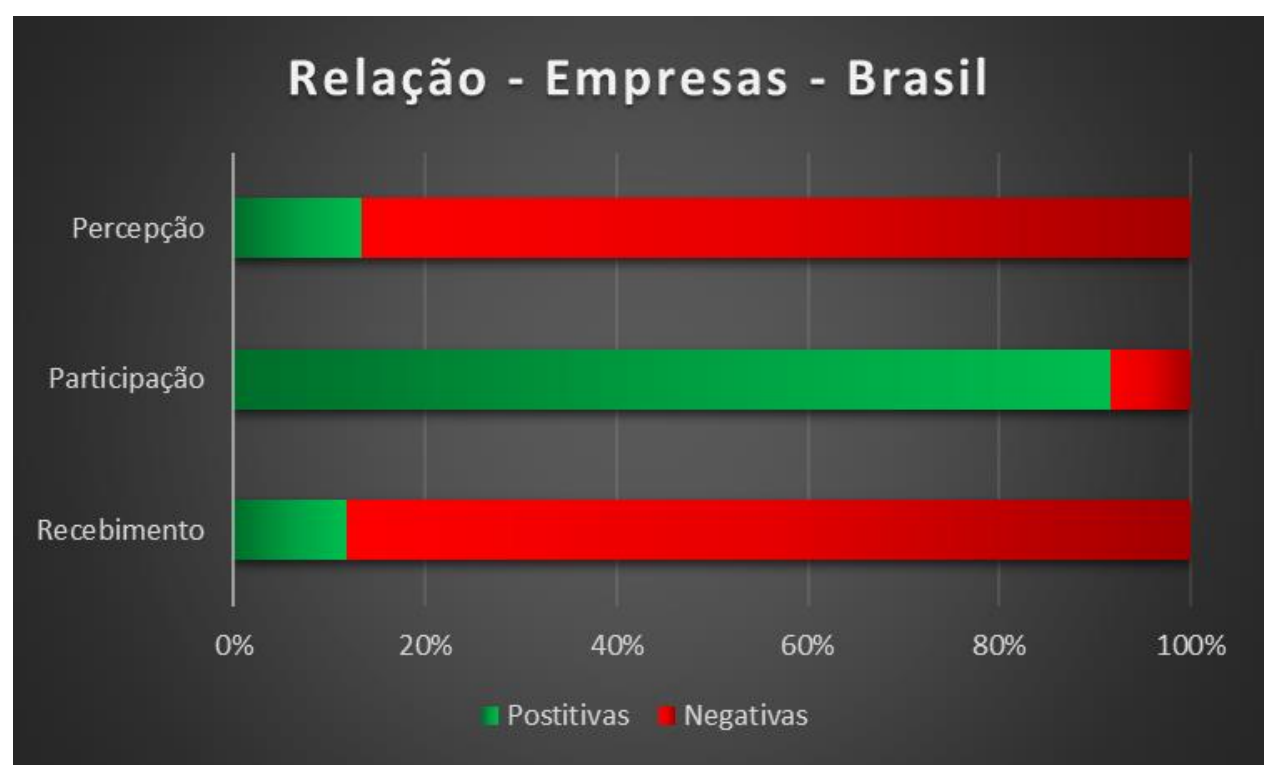

Gráfico 23 - Percentual de menções positivas e negativas nas respostas das associações empresariais sobre a relação entre os atores na orientação da política industrial brasileira.

\section{b.1) Percepção sobre o Governo}

Nas respostas das associações empresariais foram feitas apenas duas menções positivas ao governo brasileiro. Uma dizia que a ideia de exigir um mínimo de conteúdo local para desenvolver fornecedores nacionais deveria ser a única coisa de boa que o governo teria feito. Em outra foi dito que mesmo dentro do governo já existiria uma parcela significativa de pessoas que acreditam que as regras deveriam ser modificadas.

Já comentários negativos foram treze, sendo que quatro destes mencionaram a incapacidade do governo em enxergar as falhas da política. Esta incapacidade estaria relacionada a alguns segmentos do governo, ou aos membros do governo com uma visão mais nacionalista e existiria um excessivo foco na questão global do conteúdo local. $\mathrm{O}$ governo teria a intenção de fazer uma política industrial, mas por alguma razão teria dificuldades para isso. Algumas razões poderiam ser a total falta de coordenação dentro do governo (pois haveria uma variação muito grande de visões sobre a política de um 
ministério para o outro) e o fato do governo não saber como implementar a política de conteúdo local. Haveria uma supervalorização dos resultados alcançados e os resultados divulgados seriam questionáveis, uma vez que o governo os utilizaria como propaganda e o plano seria ganhar as eleições, mesmo que fosse necessário mentir. O governo teria feito campanha criticando as propostas da oposição, mas depois de eleito teria colocado em prática essas mesmas propostas, só que não soube fazer direito como a oposição saberia fazer. O governo estaria pensando apenas como governo e não como Estado. Não haveria discussões baseadas em métricas e instrumentos que foram criados para serem utilizados de forma temporária acabariam sendo utilizados de forma permanente, mesmo quando não fossem mais necessários, como o caso do Repetro, que seria uma medida inteligente para atrair empresas para o país, mas depois da descoberta do pré-sal esse programa não seria mais necessário, mas continuaria sendo utilizado.

\section{b.2) Participação das Associações Empresariais}

Foram feitas vinte e duas menções positivas sobre a participação das associações empresariais na orientação da política industrial. Em uma dessas menções o entrevistado contou que o governo definiu os índices de conteúdo local solicitando que as associações participassem preenchendo uma planilha com uma lista de equipamentos, indicando quanto de conteúdo local as empresas conseguiriam atender para cada equipamento e que sua associação teria participado dessa forma. Outras diversas formas de participação foram mencionadas, como a apresentação de uma proposta de política industrial e de propostas para as eleições de 2014, a coordenação de grupos de trabalho, mapeamento de fornecedores, interação com associações, governo e estaleiros e o desenvolvimento de uma metodologia de fornecimento sistemista. Foi mencionado também que houve participação conjunta com outras associações e com o governo, tentando aproximar empresas. Em quatro momentos foi dito que se participa sempre das discussões sobre a política, três vezes foi dito que se participa de tudo e houve uma menção à participação ativa nesse debate.

Dois comentários negativos foram feitos sobre a participação das associações, sendo que em ambas situações foi dito que essa discussão ficaria mais a nível de governo, ou entre governo e Petrobras. Também houve quem comentou que nunca participou de nenhuma discussão baseada em métricas. 


\section{b.3) Recebimento pelo Governo}

As duas menções positivas sobre o recebimento da participação das associações empresariais brasileiras pelo governo mencionavam a existência de uma boa relação entre os dois e que teriam sido bem recebidos assim como toda classe que participa é recebida.

Já os comentários negativos foram quinze no total. Quatro desses comentários foram de que, mesmo existindo a participação, nada seria colocado em prática pelo governo. A ANP negaria mudanças e não aceitando praticamente nenhuma sugestão das associações para a $13^{\mathrm{a}}$ rodada. Um projeto apresentado teria virado papel e não teria tido nenhum desdobramento. E a proposta de uma política industrial teria sido considerada muito boa e todos teriam concordado que aquele deveria ser o caminho, mas nada teria sido implementado. Em outras quatro menções se percebe questões relacionadas ao conflito de interesses dentro do governo e entre governo e empresas. Quando se propõe algo para estimular a indústria, se as associações empresariais são a favor, o governo seria contra, e se o governo é a favor, as associações seriam contra. Um dos entrevistados das associações empresariais teria sido recriminado durante um projeto com o Prominp e a ANP, por levar uma proposta diretamente para a ANP, sem passar antes pelo Prominp, pois haveria outros interesses envolvidos na questão. Nessas situações de conflito de interesses que impedem avanços da política, faltaria uma presença mais firme do governo para bater o martelo. Muito do não funcionamento da política estaria relacionado à ineficiência das pessoas, que não se engajariam como deveriam, por se preocuparem mais com questões pessoais do que com o atingimento de objetivos para a política e para o país. Dois comentários afirmaram que a receptividade dependeria do ministério, do interlocutor e até mesmo do momento em questão. Mesmo que se consiga participar, não se teria muita influência na parte de monitoramento e pós-monitoramento. Não se pode considerar que as associações sejam bem recebidas pelo governo, mesmo que ele sempre receba com cordialidade, porque não estaria efetivamente aberto para o diálogo. As sugestões que teriam sido utilizadas não teriam sido bem orquestradas, pois o governo não teria feito isso em conjunto com as associações. Se o governo tivesse participado mais, utilizando uma lógica mais de país, teria havido mais crescimento. E as associações teriam tentado participar, fazendo reuniões e influenciando na orientação da política, mas a decisão final daria sempre a impressão de que já estaria pré-definida. 


\section{Capítulo 4 - Estudo de Caso: México}

Neste capítulo serão apresentados os resultados do estudo de caso sobre a política industrial de petróleo e gás mexicana. Assim como no capítulo anterior, num primeiro momento, utiliza-se uma breve contextualização histórica, procurando relacionar os instrumentos de política industrial de petróleo e gás adotados por cada governo com a estratégia de desenvolvimento nacional que serviu de base para cada um desses governos. Em seguida, também serão apresentadas as informações obtidas durante as entrevistas em profundidade com representantes do governo e das associações empresariais.

\section{1 - Contextualização Histórica}

A partir da primeira Lei de Petróleo, de 1901, que permitia ao presidente da república outorgar permissões para que empresas e particulares explorassem terrenos de propriedade da nação, diversas companhias estrangeiras começaram a expandir suas atividades pelo México. No início da década de 1910, essas empresas já haviam iniciado exportações para os Estados Unidos e diversos países da Europa e América Latina (GRACIDA ROMO, 1994). Em 1917, foi promulgada a constituição mexicana que, através de seu artigo vinte e sete, restituiu à nação a propriedade sobre os recursos do subsolo (VIZCAÍNO, 2004) e, em 1933, a Compañía Mexicana del Petróleo El Águila descobriu reservas de petróleo com grande potencial de exploração na cidade de Poza Rica, no estado de Veracruz (LLÓRENTE et al., 1988).

O presidente Lázaro Cárdenas del Rio, do Partido Nacional Revolucionario. decreta a expropriação da indústria petroleira em 18 de março de 1938 e cria a empresa estatal Petróleos Mexicanos (Pemex). A população apoia o presidente moral e economicamente, chegando a levar joias e outros pertences para o Palacio de Bellas Artes, no dia 12 de abril do mesmo ano, para ajudar com o pagamento às empresas expropriadas (CÁRDENAS, 1938; RIPPY, 1972). Logo em seguida, foi adotado o modelo de partilha da produção, permitindo apenas a participação de empresas mexicanas. Em 1941, tendo que lidar com a Segunda Guerra Mundial, os Estados Unidos aceitaram tacitamente que o petróleo em território mexicano era propriedade do México e o governo do presidente Manuel Ávila Camacho, do Partido de la Revolución 
Mexicana, chegou a um acordo para o pagamento da dívida pela expropriação, com valores bem abaixo do que havia sido cobrado inicialmente pelas empresas (MEYER, 1968). Durante o governo do presidente Cárdenas, o Partido Nacional Revolucionario havia se transformado no Partido de la Revolución Mexicana, já em janeiro de 1946, o presidente Camacho transformou o Partido de la Revolución Mexicana no Partido Revolucionario Institucional (PRI).

Com a saída dos investimentos estrangeiros do país, havia dúvidas sobre a capacidade mexicana de manter uma indústria nacional de petróleo autossuficiente, uma vez que não se tinha no país os recursos necessários. Neste contexto, governo do presidente Miguel Alemán Valdés (PRI), adotou uma política nacionalista no final da década de 1940, que falhou na tentativa de industrialização através da substituição de importações. Durante o governo de Adolfo Ruiz Cortines (PRI), no começo da década de 1950, se conseguiu um aumento de quase $50 \%$ da produção de petróleo mexicana, tendo como objetivos exportar esse recurso e desenvolver a capacidade tecnológica da indústria petroleira nacional. Ele manteve a política nacionalista do governo anterior, encerrando a possibilidade do modelo de partilha e estabelecendo o monopólio estatal no setor de petróleo (MORENO-BRID; ROS, 2009).

O governo do presidente Adolfo López Mateos (PRI) seguiu a mesma linha e nacionalizou a indústria elétrica, criando a Comisión Federal de Eletricidad (CFE). Estimulou o desenvolvimento da indústria através da concessão de crédito de origem nacional, pois considerava fundamental que a indústria nacional, especialmente a de petróleo, fosse de capital mexicano. Por isso, convocou inclusive o capital privado, para que ajudasse o Estado a desenvolver as capacidades da indústria mexicana. Manteve o estímulo à produção de petróleo do governo anterior e estimulou a indústria petroquímica nacional para diminuir as importações e aumentar as exportações de derivados. No governo seguinte, durante o final da década de 1960, o presidente Gustavo Díaz Ordaz (PRI) implementou um plano para estabilizar a economia, que havia ficado extremamente endividada após o governo anterior. Ele também propôs o desenvolvimento tecnológico da indústria petroquímica mexicana, para que fosse possível exportar derivados como forma de levantar a economia do país (RUIZ NAUFAL, 1988). Em agosto de 1965 foi criado o Instituto Mexicano del Petróleo, com o objetivo de integrar a indústria petroleira.

No início da década de 1970, o governo do presidente Luis Echeverría Álvarez (PRI), colocou o foco no aumento da produtividade (GÁLVEZ, 1988). A indústria de 
petróleo serviu de base para o chamado "milagre mexicano", tendo resultados não apenas nas exportações, mas também no estímulo à construção de infraestrutura, que acabou beneficiando outros setores da indústria mexicana (BERMÚDEZ, 1976). Em 1973, ele afirmou que a subordinação dos investimentos e da técnica estrangeiras às leis do país deveria ser a base de um nacionalismo econômico (VIZCAÍNO, 2004). Apesar do sucesso do milagre mexicano, o país enfrentava uma enorme dívida externa. Por isso, o principal objetivo do governo de José López Portillo y Pacheco (PRI) foi dobrar a produção de petróleo, para que se tivesse mais exportações e, assim, ajudasse a melhorar a economia do país. No final da década de 1970, os Estados Unidos demonstraram interesse em construir um gasoduto ligando os dois países, mas o governo mexicano não aceitou, pois iria exportar seu gás apenas após satisfeitas as suas necessidades domésticas. Neste contexto, as tensões com os Estados Unidos estavam crescendo, pois os norte-americanos achavam que o México entraria na OPEP para ter mais autonomia (GÁLVEZ, 1988).

Ainda durante o governo de Portillo, em 1976, iniciou-se a exploração de poços submarinos no Golfo do México, que levam ao descobrimento do complexo de Cantarell, a maior reserva já descoberta em território mexicano. O Plan Global de Desarollo de 1980, foi uma política industrial que acabou levando a economia mexicana a uma excessiva dependência do petróleo (VILLAFAÑE, 2006). Já em 1982, com a queda do preço do petróleo, a moeda mexicana foi desvalorizada e houve a nacionalização dos bancos (WEISS, 1996).

Com a mudança de governo, no final de 1982, começam reformas importantes na economia mexicana, abandonando políticas de proteção da indústria nacional e deixando que a competência estrangeira substitua a política doestado para a indústria (VILLAFAÑE, 2006). Durante o governo de Miguel de la Madrid Hurtado (PRI), questões internacionais como a guerra entre o Irã e o Iraque levaram à queda na demanda internacional por petróleo, prejudicando bastante a economia mexicana (SERRANO, 1992). Em 1985, as receitas de exportação de petróleo sofrem uma grande queda, fazendo com que o setor de petróleo enfrente grandes dificuldades. Nesse mesmo ano, ocorre um enorme terremoto na Cidade do México, matando dezenas de milhares de pessoas (LOHMANN, 1990). Em janeiro de 1986, o México iniciou um processo de abertura econômica, desregulação, descentralização e privatização de empresas estatais (MIDDLEBROOK, 2004) e consegue ser aceito pelo General Agreement on Tariffs and Trade (GATT) (KNIGHT, 1996; VIZCAÍNO, 2004). 
No final da década de 1980, a Guerra do Golfo gerou instabilidade, aumentando o preço do petróleo e beneficiando o México, pois com os preços do petróleo em alta, foi possível uma melhora com relação à dívida pública e o setor de petróleo voltou a ser a base da economia nacional. Neste contexto que inicia o governo de Carlos Salinas de Gortari (PRI) que, juntamente com o presidente Miguel de la Madrid, são considerados os pais do neoliberalismo mexicano (GORTARI, 1988). No governo de Salinas foi firmado o acordo de livre comércio com os Estados Unidos e o Canadá (NAFTA) (KNIGHT, 1996), que deixou de fora o setor de petróleo que seguia fechado, mas realizou diversas privatizações de estatais como a empresa de telecomunicações, Telmex (LEVY, 2001). Foi dito que a geografia estava substituindo a política industrial, por se acreditar que bata abrir a fronteira com os Estados Unidos para que o desenvolvimento do México aconteça (VILLAFAÑE, 2006).

Em dezembro de 1994, com o início do mandato do presidente Ernesto Zedillo Ponce de León (PRI), foi adotada a livre flutuação do câmbio entre o peso mexicano e o dólar americano. Isso teria levado a uma grave crise econômica no país, fazendo com que não fosse possível realizar o investimento planejado na indústria de petróleo. Os Estados Unidos impuseram algumas medidas, como a retenção de receitas para garantir o pagamento da dívida, gerando uma recessão em 1995. Essa crise foi resolvida obtendo um empréstimo junto aos Estados Unidos, então governados pelo residente Bill Clinton (VANDEN; PREVOST, 2002).

Após décadas de governo do PRI, em dezembro de 2000, houve uma alternância no partido que governa o país. Durante o governo do presidente Vicente Fox Quesada, do Partido Acción Nacional (PAN), foram feitas mudanças no setor de petróleo, procurando uma maior abertura. Houve uma tentativa de estabelecer uma reforma energética (DRESSER, 2008), mas a falta de recursos no país não permitiu que se alcançasse o nível de desenvolvimento tecnológico necessário para que o setor pudesse ser mais competitivo. Ele foi seguido pelo governo de Felipe Calderón Hinojosa (PAN), que extinguiu a companhia estatal de energia elétrica, Luz y Fuerza del Centro. No início de 2008, ele enviou ao congresso uma proposta de reforma para o setor energético do país, especialmente com relação à Pemex. Após uma série de discussões no senado, a reforma foi aprovada, e publicada em dezembro de 2008 (VALDÉS, 2011).

Em dezembro de 2012 o PRI retorna ao governo do México com o presidente Enrique Peña Nieto. Ele colocou em prática seu plano para uma transformação no país 
(PEÑA NIETO, 2012), através de mais de dez reformas estruturais, incluindo as áreas de energia, fazenda e educação. No setor de petróleo, ele abriu o mercado para o investimento privado (nacional e estrangeiro), o que significou o fim do monopólio da Pemex. Em outubro de 2015, o México firmou um acordo de livre-comércio estabelecido entre doze países banhados pelo Oceano Pacífico (Trans-Pacific Partnership).

\section{2 - Entrevistas em Profundidade}

Dos dez atores mexicanos que foram contatados, oito atenderam à pesquisa e responderam às entrevistas em profundidade. Um dos casos em que não foi possível a realização da entrevista foi o Instituto Mexicano del Petróleo, um órgão público descentralizado, que tem como objetivo incentivar o desenvolvimento tecnológico do setor de petróleo mexicano, através do fomento à pesquisa e da formação de recursos humanos. O outro caso onde a entrevista não foi possível foi a AMIPE (Asociación Mexicana de la Industria del Petróleo), uma associação que reúne pessoas da iniciativa privada, setor público, acadêmico e sociedade civil, com o objetivo de consolidar programas que fomentem o desenvolvimento da indústria petroleira e de seus atores. Em ambos os casos, se conseguiu contato com as instituições, que demonstraram interesse em participar da pesquisa. As entrevistas não aconteceram somente porque, durante o período em que as entrevistas foram realizadas, o Instituto Mexicano del Petróleo estava de férias e o responsável pela AMIPE não se encontrava na Cidade do México. Ambos se ofereceram para responder a entrevista posteriormente, mas as respostas acabaram não sendo solicitadas, uma vez que o número ideal de entrevistas já havia sido atingido nos dois grupos de atores.

Desta forma, serão analisadas quatro entrevistas de representantes do governo mexicano e quatro entrevistas de representantes de associações empresariais mexicanas do setor de petróleo e gás. As entrevistas foram realizadas entre os dias 28 de julho e 05 de agosto de 2015 e as respostas devem ser compreendidas levando em consideração o contexto presente neste período.

Antes mesmo de iniciar as perguntas relativas ao roteiro das entrevistas em profundidade, como uma forma de comentário prévio, foram feitas observações por alguns dos entrevistados. Na primeira entrevista realizada no México, o representante de uma associação empresarial disse que, além de atrair investimentos e aumentar o índice 
de conteúdo local, o fortalecimento da Pemex também seria um objetivo da política industrial mexicana. Outro entrevistado das associações ressaltou que seria importante a adoção de novas práticas operativas no setor, porque a Pemex não estaria mais conseguindo cumprir seu papel de monopólio, abastecendo o mercado interno de combustíveis. Ela estaria precisando de ajuda, pois sua operação estaria sendo financeiramente deficitária, sem demonstrar sinais de melhora. A produção de petróleo, gás e refinados estaria caindo, chegando a haver desabastecimento de produtos como gasolina, em alguns estados. Um terceiro entrevistado ainda disse que o momento para realizar esta pesquisa no México seria muito oportuno, por ser um caso onde se poderá ver algo parecido com o que aconteceu no Brasil há alguns anos, apesar da realidade mexicana estar fortemente relacionada com uma simbiose e uma tensão que existiria entre México e Estados Unidos.

Os entrevistados do governo mexicano também fizeram comentários prévios às perguntas do roteiro das entrevistas em profundidade. Um deles comentou a afirmação do primeiro entrevistado das associações empresariais, sobre um dos objetivos da política industrial mexicana ser o fortalecimento da Pemex. Para este entrevistado, os principais objetivos da política seriam aumentar a capacidade mexicana de produção e oferecer ao país recursos energéticos de forma contínua, com qualidade e preços eficientes. Atração de investimentos e aumento do índice de conteúdo local seriam elementos da política, mas não seus principais objetivos. Outro entrevistado do governo explicou que, diferentemente de um sistema consuetudinário, o direito codificado de tradição romana faria com que tudo tenha que estar previsto em lei, para que possa ser feito. Nesse sentido, a Ley de Hidrocarburos (especialmente seu artigo 43) e a Ley de Órganos Reguladores Coordinados en Materia Energética (especialmente seu artigo 39) seriam as leis que estabelecem com claridade o que se espera da abertura de mercado e qual a função de cada instituição. Os princípios dessas leis devem ser observados para a criação de todo marco regulatório do setor, e o governo mexicano estaria realizando exatamente esta etapa do processo.

Ainda entre os comentários prévios feitos pelos entrevistados do governo mexicano, foi dito que a reforma energética obrigaria a Pemex a competir, pois passaria a ser apenas mais uma permissionária, competindo em igualdade de condições com as empresas privadas. A intenção disso seria apoiar à Pemex, o que se poderia verificar em medidas como: a ronda zero, que permitiu à Pemex escolher os campos que ela gostaria 
de manter para sua exploração; não se ter obrigado a Pemex a vender nada do que possuía (com exceção dos dutos de gás natural, que agora são propriedade da $\mathrm{CNH}$ ); oferecer a ela um marco legal que lhe permita associar-se com outras empresas; dar mais liberdade operativa para a Pemex; ter a cooperação do governo para que as decisões na Pemex se tornem mais parecidas com as decisões que se tomam em empresas privadas; e o congresso ter dado um ano para que a Pemex repense o seu contrato coletivo de trabalho. Por outro lado, a Pemex não seria competitiva por estar atrasada em relação à estrutura e à capacidade de seus competidores e teria um custo laboral gigantesco. Uma transformação na Pemex passaria por uma mudança na cultura institucional existente, que não estaria alinhada com uma cultura corporativa, com competência, nem com livre mercado. Alguns funcionários teriam mais de vinte ou trinta anos de trabalho na empresa e teriam se formado numa mentalidade completamente diferente, onde não havia necessidade de se gerar rentabilidade para os investimentos que eram feitos na empresa. De acordo com esse entrevistado, esses funcionários não saberiam nem sobre o que se está falando quando se fala em rentabilidade. Eles precisariam entender que o jogo anterior acabou e que agora se está em um outro mundo. Como até então a Pemex tinha o monopólio do setor energético mexicano, seria inevitável que ela venha a perder mercado com a entrada no livre mercado. Sua única opção seria aceitar a perda de receitas e se tornar mais eficiente. Esse seria o grande desafio de transformação da Pemex. Foi ressaltado que o mundo dos negócios seria algo vivo, em evolução, onde algumas empresas teriam que morrer para depois renascer, como o caso mexicano do Grupo Alfa, que hoje é uma potência. Se isso já aconteceu com outras empresas, também seria possível para a Pemex. A maior dificuldade seria fazer essa transformação com os mesmos funcionários, acostumados à realidade anterior. Os mexicanos seriam culturalmente muito parecidos com os brasileiros e, por isso, não iriam fazer nada até se sentirem ameaçados. Isso só iria acontecer quando a Pemex começar a perder mercado e eles forem obrigados a confrontar a realidade. A queda do preço do petróleo seria uma forma triste, dolorosa e politicamente duríssima de acelerar esse processo, porque mesmo que queira, o governo mexicano não terá como ajudar à Pemex. Se teria dado tempo suficiente para a Pemex se adequar, pois a abertura da gasolina será apenas em 2018 e a abertura das importação em 2017. Mas a prova de fogo seria em 2016, com a abertura do mercado de gás LP. A Pemex poderia ser facilmente substituída em toda fronteira norte e nas penínsulas de Iucatã e da Baixa Califórnia, por serem muito isoladas e porque já existem portos e infraestrutura privada nesses locais. Então, foi reforçado que o objetivo da 
política não seria o de ajudar à Pemex, mas sim de fazer ela competir como qualquer outra empresa privada. Isso seria uma realidade dura, mas que teria que ser vivida.

\subsection{1 - Realidade da Indústria}

\section{a) Governo}

O gráfico 24, abaixo, apresenta as respostas dos entrevistados do governo mexicano, sobre a avaliação da realidade que serviu de base para a formulação da política industrial de petróleo e gás no país.

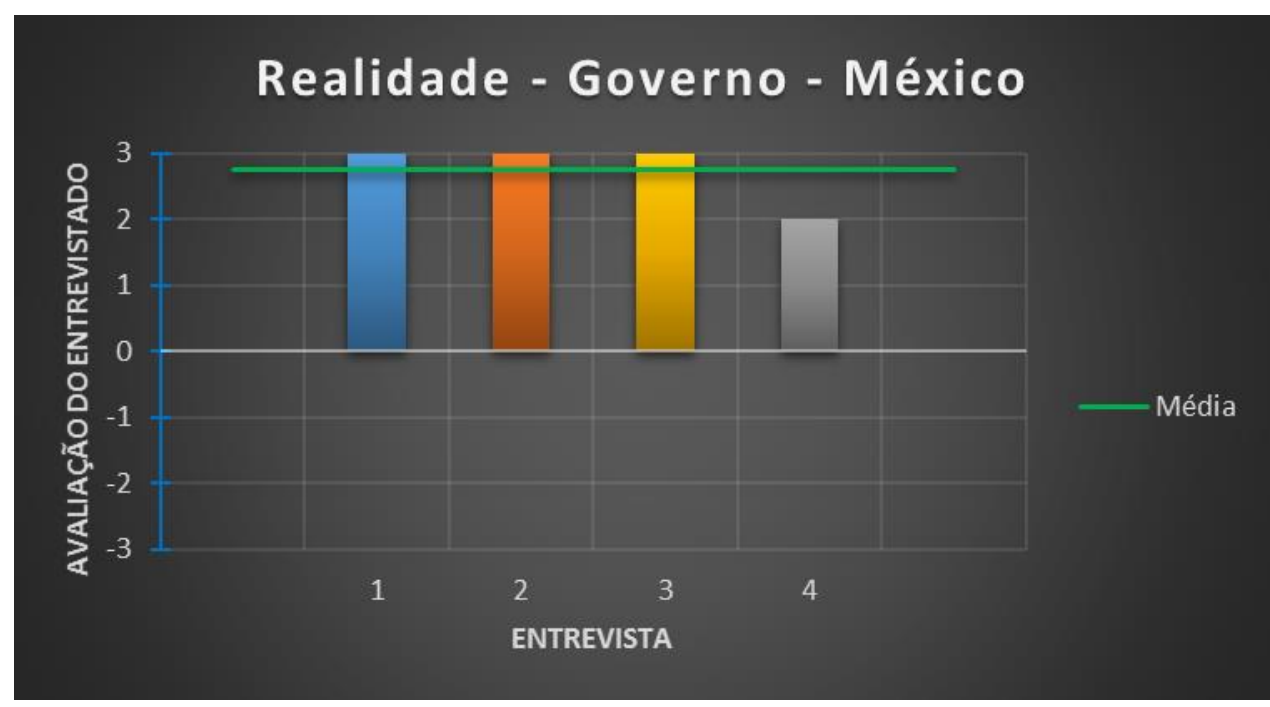

\section{Gráfico 24- Avaliações dos entrevistados do governo do México sobre a realidade da} indústria que serviu de base para a política industrial do país.

Não houve nenhum tema deste bloco que tenha sido tratado por todos os quatro entrevistados do governo mexicano. Duas perspectivas se repetiram em três entrevistas diferentes. Uma delas foi a valorização do potencial do setor de petróleo e gás mexicano, que seria gigante, imenso. A importância de suas reservas foi destacada por dois entrevistados. Um deles disse que as reservas mexicanas estariam entre as dez maiores do mundo, enquanto outro disse que, segundo a Agência Internacional de Energia, o México teria a sexta maior reserva mundial de petróleo e a oitava maior de gás. A queda na produção mexicana durante os últimos anos seria por falta de novos descobrimentos, que não estariam acontecendo pela falta de novas explorações. A reforma estaria trazendo 
elementos úteis para o desenvolvimento do país, colocando o México entre os países mais atrativos do mundo. Um desses elementos seria a permissão para que empresas de sísmica estrangeiras passem a desenvolver trabalhos de exploração e avaliação no território mexicano. Como apenas $20 \%$ do território mexicano já teria sido explorado, haveria ainda muito recurso para ser desenvolvido. Mesmo que seja um setor mais especializado, onde é mais difícil a entrada de uma nova empresa, o potencial da indústria de petróleo e gás mexicana, devido ao seu tamanho, seria muito maior do que o potencial do setor aeroespacial, ou mesmo do setor automotivo, que seria o caso de maior sucesso da indústria no México.

O quarto entrevistado manifestou não acreditar que no curto prazo o México tenha vantagens comparativas com relação a outros países que tenham tido seus processos de liberalização e abertura há mais tempo. Disse que existe potencial, mas que ainda levaria alguns anos para que o México possa ter um papel preponderante no cenário internacional da indústria de petróleo. Mas provavelmente não deva chegar aos níveis de Venezuela (pelas reservas), Colômbia, Canadá, ou Estados Unidos (pelo gás de xisto). Apesar da reforma ser vista como muito boa e como tendo saído melhor do que muita gente esperava, o problema do México seria o timing, pois a reforma teria sido feita tarde demais. A Rússia já teria tudo sob controle, a Colômbia estaria fazendo as coisas muito bem, e até mesmo o Brasil, com todos seus problemas. O México estaria em desvantagem quando comparado com qualquer um desses países. Apesar disso, mais do que competir com outros países, o objetivo do México deveria ser um desenvolvimento saudável, uma indústria saudável, que forneça as vantagens que o país precisa.

A segunda perspectiva trazida por três dos entrevistados foi sobre problemas macroeconômicos que estariam prejudicando a indústria de petróleo mexicana no curto prazo. O preço do barril de petróleo foi citado nessas três entrevistas, assim como o acordo firmado entre Estados Unidos e Irã. A desaceleração econômica chinesa foi mencionada em duas dessas entrevistas. As influências da OPEP no mercado e a situação da Grécia foram mencionadas em apenas uma entrevista, completando essa lista de questões macroeconômicas que estariam afetando a expectativa do mercado com relação à capacidade de desenvolvimento da indústria de petróleo mexicana. Tudo isso estaria fazendo os investimentos de capital serem muito mais seletivos, o que poderia ser verificado nos resultados da primeira ronda. Portanto, o México deveria fazer os ajustes necessários, já que o diretor geral da Pemex teria dito que o custo médio de extração no 
país seria de vinte e três dólares o barril, o que mesmo nos preços atuais seria um elemento de atração. Foi destacada a necessidade da adoção de medidas claras e concretas para tentar ajustar as expectativas do mercado, porque até o momento a impressão seria de que estão sendo tomadas medidas reativas, ao invés de medidas proativas e de precaução, que seriam as mais indicadas.

Os instrumentos regulatórios foram abordados sob diferentes perspectivas. Um entrevistado apontou que a segurança jurídica seria um fator indispensável para a atração de investimentos. Os critérios necessários estariam em processo de elaboração, sujeitos a consultas públicas. Atendendo ao que o mercado diz, seria possível resolver as dúvidas dos investidores, para que se tenha a segurança jurídica necessária. Em outra entrevista, foi dito que o sistema mexicano teria origem na tradição espanhola, fazendo com que seja estruturalmente rígido. Se estaria tentando flexibilizar um pouco esse sistema, principalmente pelo nível da regulação, pois seria fundamental para a realização dos ajustes que venham a ser indicados pela realidade, pelas expectativas e pelo mercado. Outro entrevistado criticou a pressa na criação dos instrumentos regulatórios, especialmente quando se deseja levar em consideração todos os atores envolvidos.

Os demais temas não apareceram em mais do que uma entrevista, como a existência de um atraso tecnológico e a falta de estrutura (exceto na produção em águas rasas, onde a Pemex teria posição destacada). O desenvolvimento dessas tecnologias e dessa infraestrutura seriam uma oportunidade gigantesca para empresas privadas. Tendo isso em vista, a legislação mexicana estaria prevendo obrigações para os contratos, que não seriam apenas de conteúdo local, mas sim medidas para transferência de tecnologia e conhecimento. A simples exigência de índices mínimos de conteúdo local, por si só, não seria muito útil. Esta estratégia estaria sendo adotada (e dando certo) em muitos outros países. O Brasil foi lembrado como um exemplo, onde a utilização de políticas muito específicas de conteúdo local teria chegado a ser prejudicial. Outro tema que foi trazido por apenas um entrevistado foi a questão da segurança, pois seriam crescentes os casos de roubo de combustível no México. Para combater esse fenômeno, os mexicanos estariam se espelhando em modelos como o peruano e o colombiano, que utilizam softwares para registro das transações, o que teria ajudado muito.

Quando se quer liberar um mercado, a existência até então de um monopólio estatal seria um problema, porque todo o know-how, toda informação, têm que ser 
aprendidos com o processo já em andamento. Por outro lado, a entrada de novos operadores deverá trazer outras características para o setor, como novas tecnologias, novos bens, novos investimentos e novas formas de fazer negócios.

Transformar o setor, fazendo com que ele deixe de ser um mero fornecedor da Pemex, para que seja um fornecedor da cadeia global, seria muito mais difícil do que apenas atrair novos atores, mas este seria o objetivo final da política. Por isso, essa atração de novos atores e novos investimentos seria tão importante, uma vez que serão eles que poderão ajudar a reformar toda indústria. Foi indicado que hoje não deve haver mais do que 5 empresas mexicanas operando globalmente na indústria de petróleo, enquanto empresas da Malásia e da Tailândia operam em todo o mundo.

Para uma das pessoas entrevistadas, o México deveria dar um passo à frente e aproveitar os compromissos assumidos para a mudança climática, já que também seria uma potência em fontes renováveis de energia. Essa seria uma outra forma de gerar competitividade para a indústria. De qualquer forma, para o México já estaria muito clara a lição de que ter muitos recursos não é o mesmo que ser rico.

\section{b) Associações Empresariais}

O gráfico 25, abaixo, apresenta as respostas dos entrevistados das associações empresariais mexicanas, sobre a avaliação da realidade que serviu de base para a formulação da política industrial de petróleo e gás no país.

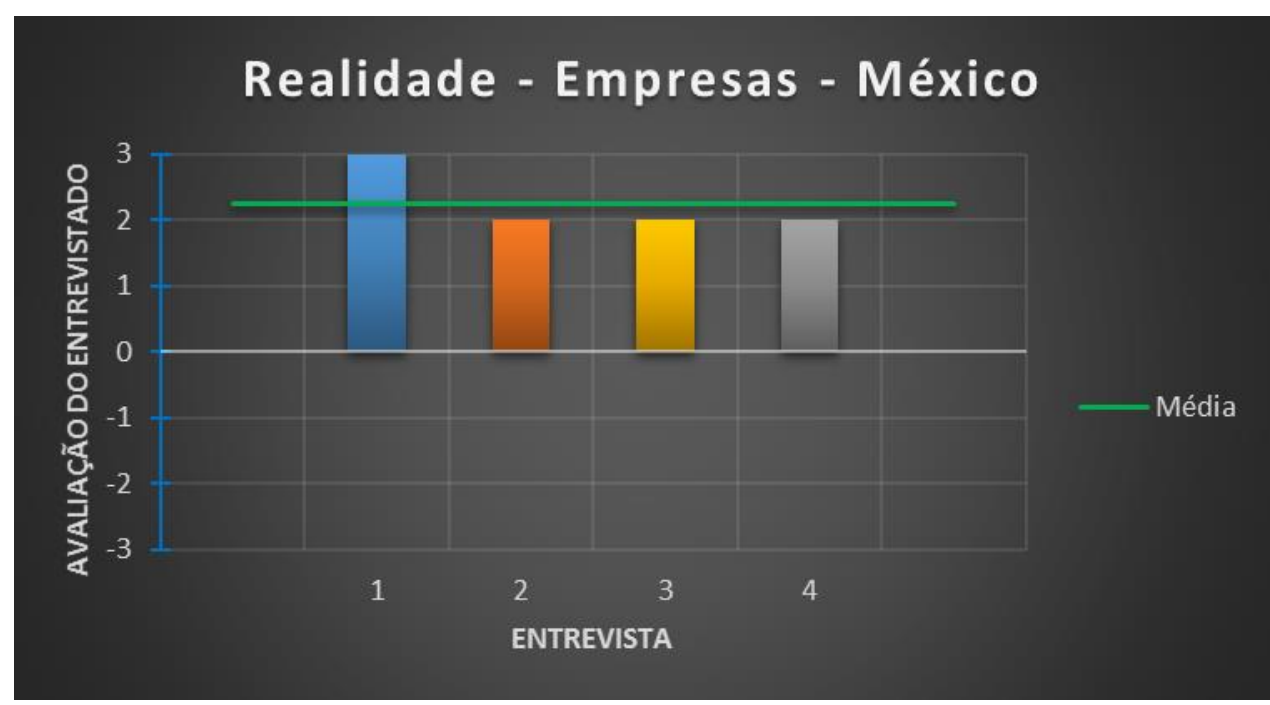

Gráfico 25 - Avaliações dos entrevistados das associações empresariais do México sobre a realidade da indústria que serviu de base para a política industrial do país. 
De alguma forma, todos os quatro entrevistados manifestaram nesse bloco a ideia de que não se pode falar na existência de uma indústria nacional de petróleo no México. Até então, haveria apenas um ator participando do setor, já que a Pemex teria o monopólio de toda cadeia de produção, desde a exploração, passando pelo desenvolvimento, distribuição, venda, refino, transporte, até a exportação. Devido a isso, o setor seria pouco competitivo, pouco eficiente e teria pouca competência. Mesmo que o petróleo tenha sustentado o país durante os últimos quarenta anos, de acordo com um dos entrevistados, a única preocupação do governo, até então, teria sido com o quanto a venda de petróleo poderia gerar. Outro entrevistado atribuiu à Pemex a falha por não ter desenvolvido uma indústria nacional enquanto tinha o monopólio.

Com a reforma, a Pemex deve começar a interagir com outros atores, investimentos e alianças estariam começando a ser feitos e estaria sendo preparada a formação de uma indústria. Haveria uma indústria mexicana incipiente, se formando através de empresas com muito capital, sendo citado o exemplo do senhor Slim que, assim como outros, estaria interessado em participar do setor. A criação de uma indústria nacional de serviços para o setor de petróleo e gás poderia vir a ser uma consequência interessante da abertura. Foi lembrado que nos anos 1950 e 1960 o México tinha uma indústria importante de serviços, como construção de plataformas. Como acabou ficando mais barato comprar da China, ou de outros lugares, teria se deixado essas empresas para trás, por não serem competitivas.

Dois entrevistados mencionaram expectativas positivas com relação à reforma energética. Ela deve permitir a entrada de novos atores para participarem da parte de exploração e produção, enquanto a parte de serviços poderia ser, mais ou menos, abastecida pela indústria mexicana. Devido à geração de demanda, a reforma seria uma grande oportunidade para um país pouco desenvolvido. Os novos atores também devem contribuir para o aumento da produção, gerando maiores ingressos para o Estado. A reforma energética, a reforma constitucional e a abertura de mercado não seriam uma grande fórmula, ou algo revolucionário. O México simplesmente teria entrado em um mercado no qual não havia demonstrado interesse de entrar até então. Se deveria aprender com casos como o brasileiro, que já adotou essa medida e poderia ensinar o que foi feito de bom, o que foi feito de ruim, e o que se pode melhorar. 
Um dos principais objetivos da reforma, de acordo com um dos entrevistados, seria ajudar a Pemex a se fortalecer, a ser mais competitiva, mais eficiente como empresa, mesmo que continue sendo controlada pelo Estado. Um desafio para isso seria o declínio dos níveis das reservas no complexo de Cantarell, que foi citado em duas entrevistas. Esse declínio e a falta de recursos para poder operar seriam as principais razões para a queda de produção da Pemex. Além de ter poucos recursos, ela ainda estaria restringida quanto à sua capacidade de se endividar, por já ter chegado ao limite de endividamento estabelecido pelo congresso mexicano. Com tudo isso, a Pemex se limitou às áreas onde já possuía alguma experiência, como exploração em águas rasas e onshore, e acabou não podendo fazer muito em águas profundas.

Existiriam diversos desafios tecnológicos para que o México possa ser capaz de produzir em águas profundas, ou produzir gás de xisto. Porém, dois entrevistados mencionaram que a capacidade tecnológica teria sido deixada para trás. As empresas mexicanas estariam acostumadas a fornecerem apenas para a Pemex, os recursos humanos seriam muito limitados e não haveria investimento em pesquisa e desenvolvimento. Empresas estrangeiras como a Schlumberger só teriam começado a fornecer para o México a partir de 2000, quando a Pemex já havia ficado muito para trás. Durante o boom do petróleo, empresas como a Petrobras teriam tido a preocupação de modernizarem-se, mas o México não. Se uma plataforma mexicana estava produzindo petróleo, não se via razão para mudar nada nela. Hoje haveria plataformas que ainda utilizam tecnologia de quarenta anos atrás, mesmo já existindo novas tecnologias que oferecem muito mais precisão, que utilizam aços muito mais especializados, e plataformas que podem perfurar profundidades muito maiores. De acordo com um entrevistado, há apenas três ou quatro anos a Petrobras teria começado a passar parte de sua tecnologia, para que os mexicanos consigam retirar petróleo de profundidades muito grandes, de onde não estavam conseguindo retirar mais nada. Como grande parte das reservas mexicanas são no Golfo do México, haveria a necessidade de novas plataformas, que possam produzir em águas profundas.

Em outra entrevista, foi mencionada a expectativa de que as regras de conteúdo nacional (para os contratos de exploração e produção) possam desenvolver uma indústria mexicana. A exigência de utilização de uma parcela de bens e funcionários mexicanos deve influenciar para que todas empresas que venham a operar no México contribuam, incentivando os produtores nacionais. Mesmo assim, os fornecedores nacionais ainda 
precisariam se institucionalizar, pois vários teriam plantas muito pequenas, ou empresas familiares. Deveria haver uma seleção muito mais severa desses fornecedores para fazer eles crescerem, começando com coisas muito simples, de baixa qualidade, para depois ir avançando. Assim, se poderia fazer com que os fornecedores de hoje cresçam e possam, até mesmo, se tornar fornecedores internacionais. Seria assim que outros países, como a Noruega, teriam feito. Para que isso possa ser colocado em prática, seria necessário um esforço do governo, dos fornecedores e das empresas operadoras.

Foi mencionado que, na ronda zero, a Pemex escolheu ficar com pouco mais de $80 \%$ do que ela tinha em produção ou em perspectiva de produção. O restante estaria sendo licitado pelo governo, de forma muito transparente, nas rondas subsequentes. A fase um da ronda um havia acontecido há poucos dias, com resultados decepcionantes no que se refere ao número de campos adjudicados. Para a fase dois da ronda um, que seria em setembro de 2015, o governo mexicano deveria aprender sobre os diferentes fatores relacionados ao processo de licitação, para que houvesse mais interesse. Enquanto na fase um foram ofertados campos para exploração, na fase dois seriam campos para desenvolvimento, com reservas já provadas. Em seguida viria a terceira fase, que seria a mais interessante para a indústria nacional, por se tratar de campos onshore. Depois seriam campos em águas profundas. Por último, seriam não convencionais, como gás xisto. Após essas rondas iniciais, a ideia seria fazer uma ronda a cada ano, ou ano e meio, conforme a participação do mercado.

Os Estados Unidos foram citados em duas entrevistas, relacionados à definição do preço do barril, seja por causa do acordo com o Irã (que poderia entrar no mercado com todo o seu petróleo) ou porque seriam a razão para a OPEP estar influenciando o mercado e mantendo o preço baixo. O panorama da indústria mundial estaria muito incerto nesse momento, com o dólar alto demais e a possibilidade de o Brasil retirar a obrigatoriedade de participação exclusiva da Petrobras nos campos da camada pré-sal. Essas mudanças estariam afetando, ou poderiam vir a afetar o interesse que as empresas estrangeiras venham a ter no México, especialmente por ser um momento onde as empresas internacionais estariam diminuindo seus novos investimentos. A queda do preço do barril também poderia estar relacionada a uma questão de demanda, como resultado dos Estados Unidos estarem se movendo para outros sistemas de produção. 
O México, portanto, deveria aproveitar aquilo que ele é bom, como gás natural, por exemplo. As reservas mexicanas de gás de xisto estariam entre as quatro ou cinco maiores reservas do mundo, e os Estados Unidos seriam um vizinho com grandes reservas de gás. Por outro lado, fazer uma refinaria seria muito caro, exigiria muito investimento e ofereceria uma margem de lucro muito pequena. Essa seria a razão da decisão de parar de utilizar as refinarias mexicanas e passar a importar gasolina, pois sairia muito mais barato. Mesmo sendo um problema de infraestrutura, se poderia deixar para resolver isso no longo prazo. O setor privado poderia se oferecer para construir uma refinaria em troca de algo para explorar, como um campo de gás xisto.

Outro exemplo de possível melhoria mencionado por um entrevistado foi a questão da qualidade do serviço oferecido para o consumidor, para a população. No setor de energia elétrica, o ex-presidente Felipe Calderón teria extinguido uma empresa pública, chamada Luz y Fuerza, colocando a Comisión Federal de Eletricidad no seu lugar. Essa transição teria sido feita com a criação de centros de serviço, onde as contas de luz poderiam ser pagas de maneira muito mais fácil. Anteriormente, só era possível realizar o pagamento das contas em escritórios da Luz y Fuerza, onde o pagamento tinha que ser feito na quantia exata, pois muitas vezes o troco não era devolvido. Isso teria feito a população ficar insatisfeita, mesmo que o serviço de prestação de eletricidade estivesse sendo bem feito. Essa parte do serviço, de marketing e atenção com o cliente, que teria acabado com a empresa.

Em outros momentos, o governo mexicano já teria tido dificuldades para superar o sindicato de trabalhadores da Pemex, que teria o hábito de não permitir a implementação de mudanças dentro da empresa, caso não visse nisso algum ganho para si. Muitos investimentos e muitos projetos teriam sido prejudicados por isso. Portanto, para que a reforma funcione, além da participação do setor privado, seria preciso que a Pemex continue controlando seu sindicato.

Sobre o tamanho das reservas conhecidas, um entrevistado disse que a Pemex jamais iria dizer o que sabe para o setor privado. Notícias sobre novos descobrimentos seriam as únicas pistas que se tem, e fazem esse entrevistado acreditar que possa existir petróleo suficiente para mais uns trinta ou quarenta anos. Foi considerado difícil que o México consiga incrementar sua produção consideravelmente ainda durante este governo, que já se encontrava na metade dos seus seis anos de mandato. Poderia haver um 
incremento não mais do que modesto nesse período. Já as perspectivas de médio e longo prazo seriam muito positivas, pois a intensa atividade encontrada no lado norte-americano do Golfo do México faz com que seja muito provável que haja o mesmo do lado mexicano. A falta de recursos não seria o problema, mas sim como e quando retirar esses recursos. O objetivo seria chegar aos níveis de produção que se tinha há alguns anos, entre três milhões e três milhões e meio de barris. Como se estaria produzindo apenas dois milhões e trezentos mil barris, seria preciso recuperar muito do que foi perdido. Também foi mencionada a necessidade de se começar a fazer a transição para outros meios, que utilizem energias renováveis e sustentáveis.

\subsection{2 - Valores da Política}

\section{a) Governo}

O gráfico 26, abaixo, apresenta as respostas dos entrevistados do governo mexicano, sobre a avaliação dos valores utilizados como base para a formulação da política industrial de petróleo e gás no país.

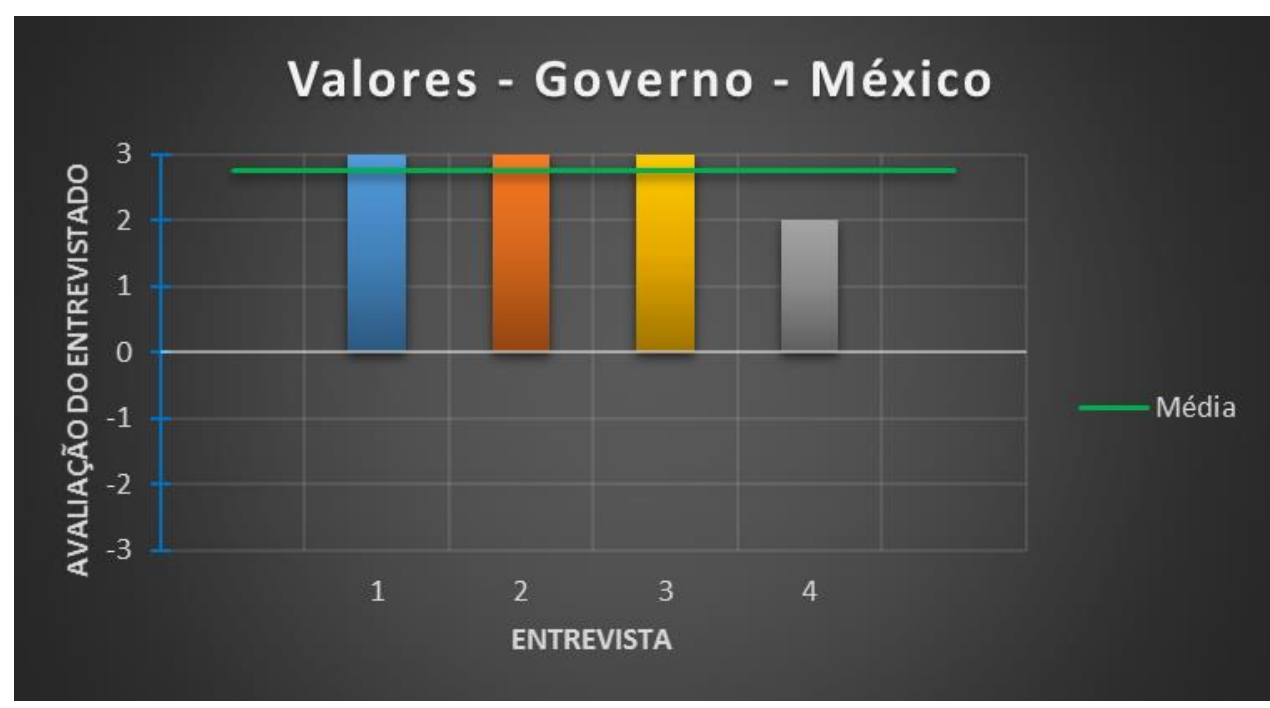

Gráfico 26 - Avaliações dos entrevistados do governo do México sobre os valores da política industrial de petróleo e gás no país.

Não houve nenhum tema que tenha sido tratado por todos os quatro entrevistados, nem por três deles. Uma das opiniões que apareceram em duas entrevistas foi a de que os 
valores adotados seriam consequência do aprendizado que se teve com experiências anteriores, como uma reforma realizada em 2008, que teria servido de ensaio e preparativo para a reforma atual. Estes valores estariam bem alinhados com a realidade mexicana do passado, com a atual e com os objetivos para o futuro, se espelhando nas melhores práticas internacionais. A outra perspectiva que foi utilizada por dois entrevistados diz respeito à propriedade dos recursos do subsolo serem do Estado, pois isto estaria em lei. Mesmo que compartilhe parte da produção ou dos lucros, somente o Estado decidiria quem pode e quem não pode explorar no seu território.

A questão sobre a nacionalização ou internacionalização da cadeia de fornecedores foi analisada por três entrevistados, mas cada um apresentou uma visão diferente. Numa entrevista foi dito que não se deveria pensar na nacionalização ou internacionalização da cadeia de fornecedores (pois passa a ideia de serem excludentes), mas sim em eficiência e vantagens comparativas. A abertura da cadeia de fornecimento seria para atrair as melhores empresas, sejam elas internas ou externas. No sentido oposto, outro entrevistado disse que o desenvolvimento nacional seria sim um dos valores adotados pela política. Por isso que ela incluiria elementos de conteúdo local e de transferência de conhecimento e tecnologia. Já um terceiro entrevistado destacou que o objetivo mexicano seria nacionalizar, para depois internacionalizar. Construir uma indústria nacional, formada por uma cadeia produtiva de empresas mexicanas, e que eventualmente, seja capaz de se tornar global, exportando para o mercado internacional. A abertura para que todos possam participar, competindo por um contrato, seria muito importante, tendo em vista que até então todo o setor era operado apenas pela Pemex e que ninguém saberia ao certo como era feita essa operação.

O ritmo de exploração foi abordado por um entrevistado como sendo uma ciência importantíssima, que dependeria dos preços, do potencial, do tipo de solo e da geopolítica. Para outro entrevistado, o ritmo de exploração estaria relacionado com o objetivo da política de aproveitar o maior volume possível de recursos no longo prazo, independentemente do preço do barril. Haveria uma eterna tensão entre extrair a maior quantidade de óleo para colocar no mercado, não importando o desperdício de gás natural (que muitas vezes acaba sendo queimado), ou reduzir o ritmo de exploração, para conseguir aproveitar o máximo de gás. A Noruega seria o exemplo perfeito de como resolver esta questão, mostrando que, independentemente da relação entre o preço do óleo e do gás, com planejamento adequado pode-se maximizar o aproveitamento de todos os 
recursos. O México teria claramente adotado na sua legislação o modelo norueguês, obrigando empresas, inclusive a Pemex, a ter o maior aproveitamento possível de gás natural. Essa maximização do aproveitamento de gás estaria relacionada também com o objetivo de se utilizar uma fonte de energia mais limpa e barata.

Outros pontos foram indicados por apenas um entrevistado, como o fato dos valores que servem de base para a política já estarem em lei, faltando apenas uma regulação que harmonize a realização desses valores. O Estado mexicano teria adotado o sistema de pesos e contrapesos, dividindo entre diferentes agências os distintos papéis e funções que o Estado deve cumprir e balancear. Esta divisão estaria muito bem definida, sendo muito claro para cada órgão o que cabe a ele, o que não lhe cabe e o que cabe aos demais. Com a adoção desse sistema, se teria a vantagem de que cada órgão só precisaria cuidar daqueles valores que lhe correspondem.

Em uma das entrevistas foi mencionado que, quando uma empresa tem como foco ser eficiente, naturalmente acabaria se convertendo em uma ferramenta de desenvolvimento para o país. O desenvolvimento, assim como a eficiência, só seriam possíveis de se alcançar no longo prazo. Portanto, se a Pemex tivesse se centrado em ser uma empresa eficiente dez anos atrás, hoje poderia ser uma ferramenta de desenvolvimento. Os valores adotados teriam objetivos de médio e longo prazo, mas existiria sempre uma pressão política para que se tenha resultados de curto prazo.

Foi lembrada a importância de guardar parte dos frutos da indústria para gerações futuras, apontando que seria para isso que o fundo de petróleo teria sido criado. Outro valor fundamental seria o dos direitos humanos, fazendo com que se leve em conta uma avaliação sobre o impacto social de qualquer projeto que se queira implementar no setor energético. Em questões relativas à negociação sobre terras, por exemplo, pode haver a necessidade de uma consulta indígena. $\mathrm{O}$ tema social seria uma preocupação dos investidores e estaria sendo muito controvertido em todo mundo, devido a essa necessidade de consulta às comunidades locais. Caso uma comunidade se posicione contra a realização de determinado projeto, haveria uma situação complicada, onde seria necessário decidir o que se considera mais importante. A intenção dessa obrigatoriedade de consulta seria forçar o governo a ouvir as comunidades, tentar atender às suas demandas e procurar a melhor forma para colocar o projeto em prática. Algumas questões não poderiam jamais ser violadas, como o meio ambiente e zonas sagradas para algumas 
culturas. Entende-se que essa obrigatoriedade de consulta não deve agradar ao grande capital, mas deve agradar aos policy makers.

O mercado foi associado à ideia de competência, e seria a melhor forma para se garantir fornecimento a preços eficientes, mas teria que se ter cuidado com questões envolvendo sustentabilidade e meio ambiente. Nesse sentido, um entrevistado disse acreditar que exista um balanço adequado entre a necessidade de se desenvolver um mercado, atraindo investimentos privados, e a necessidade de não desrespeitar o meio ambiente, os direitos humanos e a indústria nacional.

A governança da atividade petroleira através de planos de trabalho, assim como fazem os noruegueses, também foi mencionada como um valor importante. Brasil e Colômbia não utilizariam o sistema de planos de trabalho e, por isso, teriam contratos muito grandes, tentando incluir neles tudo que é necessário. Já o México estaria adotando um sistema mais equilibrado, parecido com o dos noruegueses, pois exigiria planos de trabalho que teriam que estar alinhados com os objetivos do Estado.

Um dos entrevistados ressaltou bastante a importância da transparência, como um dos principais valores adotados pela política industrial mexicana de petróleo e gás. Um dos exemplos disso seria a primeira ronda, que teria sido um evento totalmente transparente, aberto a todos, televisionado e que todos puderam assistir. Todo regulador teria a necessidade de se fundamentar na transparência, para que tenha credibilidade para construir um modelo de desenvolvimento industrial. Este seria um pilar fundamental e o melhor exemplo de um valor colocado em prática.

\section{b) Associações Empresariais}

O gráfico 27, abaixo, apresenta as respostas dos entrevistados das associações empresariais mexicanas, sobre a avaliação dos valores utilizados como base para a formulação da política industrial de petróleo e gás no país. 


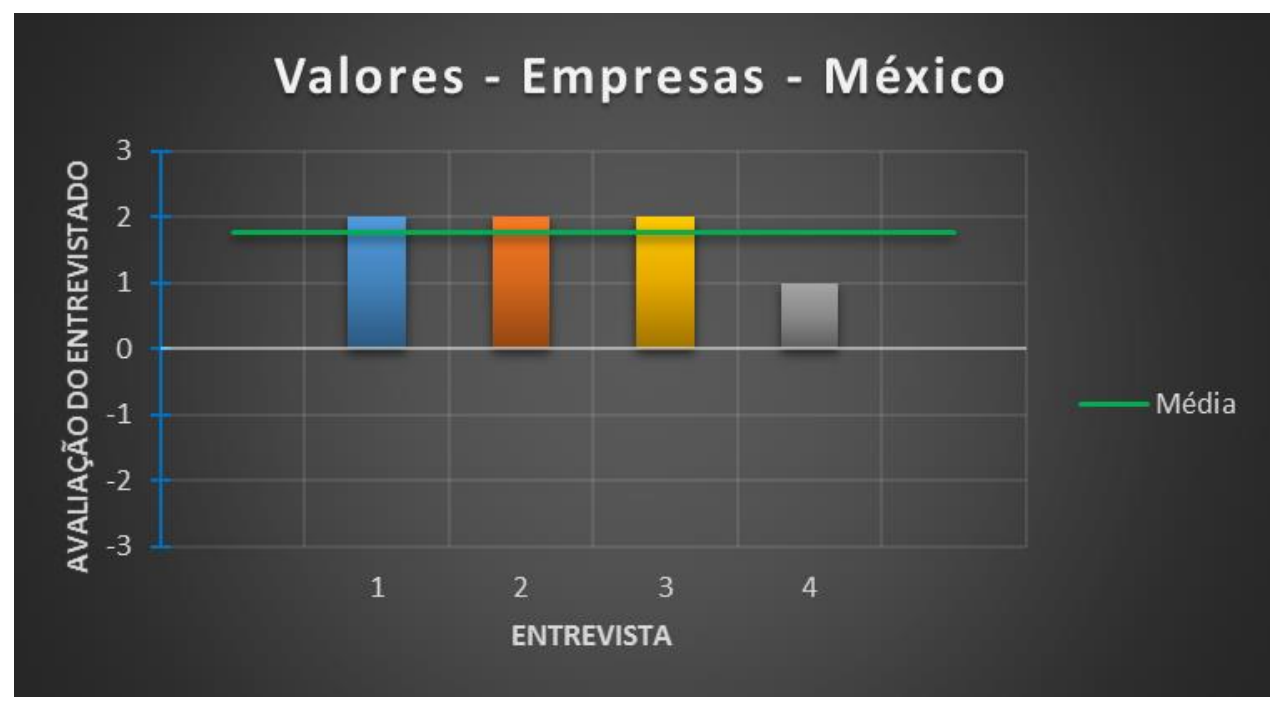

Gráfico 27 - Avaliações dos entrevistados das associações empresariais do México sobre os valores da política industrial de petróleo e gás no país.

Todos os quatro entrevistados ressaltaram a importância de se ter uma indústria de fornecedores nacionais. O objetivo, porém, não seria a nacionalização da rede de fornecedores e sim o máximo aproveitamento das capacidades do país. Todos defenderam a importação e a internacionalização da cadeia, quando necessário. Isso pode ocorrer quando o país não produz algum equipamento importante, que não se possa esperar até começar a ser produzido nacionalmente, ou quando as empresas nacionais não sejam competitivas no mercado internacional. Nessas situações, a melhor solução seria importar e tentar se especializar em outra coisa, que possa ser complementar. Portanto, seria necessária uma política inteligente, capaz de diferenciar o que pode ser produzido no país e o que deve ser importado.

As cadeias produtivas não seriam mais nacionais, e sim globais. Deve-se tentar criar um grande corredor, onde vários países se beneficiem. Para o industrial, não importaria se a cadeia for nacional ou internacional. Mesmo que a empresa venha de fora, teria que construir uma fábrica, que acabaria gerando empregos para os mexicanos e, inevitavelmente, algumas coisas teriam que ser compradas no México (como cimento, por exemplo), pois sairia muito mais caro trazer de outro país. Abrir o setor para a internacionalização seria imprescindível para o país se desenvolver e ter acesso às tecnologias de outros países e outras empresas. O objetivo final seria fazer do México um dos países mais tecnologicamente inovadores neste setor. Mesmo que a Pemex já tenha 
desenvolvido alguma tecnologia e tenha um importante centro de pesquisa e desenvolvimento tecnológico, ultimamente esse não teria sido o foco dos investimentos. Para que se formem joint ventures no México, seriam necessários investimentos. Um dos entrevistados disse duvidar que se consiga resultados importantes de conteúdo nacional, mesmo sabendo dos esforços que estão sendo feitos. De acordo com ele, não se pode forçar algo que não exista, ou que não seja competitivo, pois isso pode gerar outros problemas. Para que se tenha muito conteúdo nacional em algo que não se é competitivo, todos acabam pagando. Como ele não percebe a criação de clusters de desenvolvimento industrial, acredita que esta reforma seja mais uma abertura total, buscando aproveitar as forças do livre mercado.

Em três entrevistas foi mencionado que o atual ritmo de exploração estaria sendo baixo. Isto seria porque se estaria licitando pouco, já que as primeiras fases da ronda um seriam modestas. A definição desse ritmo dependeria de fatores exógenos, como o preço do barril e o interesse das empresas. Estaria havendo uma mudança de valores nesse sentido, e seria importante que o México adotasse um ritmo alto de exploração, pois a situação atual estaria difícil. Necessidades domésticas também poderiam influenciar o ritmo de exploração, especialmente com relação ao gás natural, tendo em vista que o país teria passado por uma transformação industrial para a utilização do gás como fonte energética. Essa transformação teria sido feita de forma equivocada, pois se fez a transformação antes de se ter o recurso. Não existe dúvida sobre as reservas de gás mexicanas serem suficientes para todas as necessidades domésticas, mas sabe-se que para extrair e distribuir esse gás serão necessários grandes investimentos, como a construção de gasodutos. Esses investimentos já estariam sendo feitos, mas os resultados ainda iriam demorar um pouco para aparecer. Por isso, hoje se estaria importando gás, principalmente dos Estados Unidos. De qualquer forma, deverá haver uma grande pressão para que o México desenvolva, explore e tenha infraestrutura para distribuir o seu gás o mais rápido possível. O quarto entrevistado também falou sobre o ritmo de exploração, mas disse apenas que a Pemex deve ter um bom conhecimento sobre as reservas que possui, e que o ritmo depende de quanto ela irá abrir e compartilhar. Ele acredita que, para valorizar o que possuem, irão vender uma parte de suas reservas como se fossem as últimas, depois de vendidas, abrirão a venda de uma segunda parte das reservas, dizendo que estas são as últimas, para depois abrir uma terceira parte como se fosse a última, e assim por diante. 
Três entrevistados também falaram sobre a propriedade das riquezas do subsolo serem do Estado, diferentemente dos Estados Unidos, onde a propriedade é privada. Foi lembrado que houve uma revolução há mais de cem anos, que teria retirado os recursos das mãos de empresas petroleiras internacionais que estavam no México. Depois disso, a constituição teria deixado muito claro que todas as riquezas do subsolo são propriedade estatal. Sempre teria havido concessões do governo para que empresas privadas explorassem minérios, mas não para a exploração de petróleo e gás. Essa realidade teria sido boa até a década de 1970, mas hoje não seria mais operativa. A reforma teria alterado isso, adotando um modelo de licenças, onde o Estado recebe participações e royalties pela propriedade dos recursos explorados pelos privados. Embora hoje essas licenças ainda não existam formalmente, elas serão necessárias para todas empresas, incluindo a Pemex.

Também foram três os entrevistados que destacaram a predominância de valores de curto prazo na definição da política mexicana. O objetivo seria que os frutos dessa indústria tenham um efeito imediato sobre o desenvolvimento do país, gerando empregos e arrecadação de impostos. As empresas também deveriam acabar utilizando esses frutos para necessidades imediatas, pela necessidade de reinvestir esses recursos, para corresponder ao retorno esperado por seus acionistas. A única medida de longo prazo mencionada foi a criação do fundo de petróleo mexicano, citada por dois entrevistados. Mesmo assim, um deles disse achar difícil que se mude dos valores de curto prazo para os de longo prazo. Por isso, mesmo com relação ao fundo, acredita que as necessidades imediatas irão prevalecer.

A ineficiência da Pemex foi mencionada em duas entrevistas diferentes. Ela foi considerada uma das international oil companies mais ineficientes do mundo, devendo estar melhor apenas que a PDVSA, que já teria sido uma das empresas mais eficientes do mundo, mas hoje estaria pior que o México. O que faria a Pemex ter uns dos índices mais baixos de produtividade do mundo seria seu recente histórico de monopólio, a falta de recursos suficientes para melhorar sua eficiência, ser parte do Estado e empregar gente demais. Estes dois entrevistados disseram que a Pemex deveria pensar como uma empresa privada, ser competitiva, eficiente e diminuir seus riscos operacionais. Sua contribuição para o desenvolvimento do país seria, assim como as demais empresas do setor, através da realização de sua atividade. Não deveria mais ser utilizada como ferramenta de desenvolvimento do país, pois isso já teria sido feito e não teria dado certo. Outro entrevistado disse que não acredita que a Pemex corra o risco de quebrar, mas deve 
diminuir sua participação no mercado para uns $60 \%$ ou $40 \%$, nos próximos dez ou quinze anos, e para uns $10 \%$, em aproximadamente cinquenta anos. Se conseguir convencer seu sindicato a renunciar a muitos privilégios, pode ser que a Pemex consiga investir mais, desenvolver mais e crescer mais.

Entre os comentários feitos por apenas um dos entrevistados, foi dito que a indústria sempre vai se interessar por um energético que seja barato, pois precisa de energia para funcionar. Então, mesmo que leve dez ou quinze anos para recuperar seus investimentos nessa área, as empresas provavelmente farão esse investimento sem muita resistência, por saberem da importância de investir em um energético barato. Uma das poucas empresas mexicanas que estariam participando da exploração de gás de xisto no país seria o Grupo Alfa, que fica em Monterrey, e seria uma grande corporação, incluindo os ramos de alimentos, tubos e cabos, por exemplo. Devem ser grandes incorporadoras como essa que irão participar do setor e não empresas solitárias. Outro exemplo seria o Grupo Carso, de Carlos Slim, que certamente deve participar. Esse negócio não estaria sendo visto apenas como uma forma de se ganhar dinheiro no curto prazo, mas como um projeto de longo prazo, para que gere a sustentabilidade necessária. Por isso, apenas empresas muito grandes devem ter condições de suportar esses enormes investimentos, que irão demorar para começar a dar retorno.

Foi mencionado um teórico mexicano chamado Macario Schettino, que desenvolveu uma teoria chamada Análise da Realidade. Nela ele defende que o problema de países em desenvolvimento, como o México, seria o fato de seus cidadãos não obedecerem às leis, não respeitarem o Estado democrático de direito, nem participarem como devem e terem uma classe com muitos privilégios, fazendo com que não haja produção, nem crescimento. Já em países mais desenvolvidos, como os europeus, não haveria tantos privilégios, tudo seria mais equitativo, as pessoas cumpririam as leis e cobrariam dos outros que também cumprissem, fazendo com que o pais funcione. Tudo se resumiria à criação de riquezas e à distribuição dessas riquezas. Nos países em desenvolvimento, problemas políticos antigos ainda não teriam sido resolvidos, enquanto novos problemas continuariam a surgir. Os países ricos seriam ricos por terem um Estado forte, limitado por lei, responsável com seus cidadãos, que se valoriza a criação de riquezas e menospreza a existência de privilégios. 
No México, assim como no Brasil, haveria um debate há muitos anos sobre se existiria ou não uma política industrial de governo. Certa vez um ministro de economia mexicano teria dito que a melhor política industrial seria a não política, deixar que o setor privado e o mercado desenvolvam o que tem que desenvolver. Todavia, o entrevistado colocou em dúvida essa ideia, por entender que existem indícios claros de que políticas industriais mexicanas e decisões de políticas públicas tomadas pelo governo teriam gerado resultados que até então não existiam no México. Seria o caso da indústria aeroespacial, que não existia há dez anos e hoje teria mais de duzentas empresas, contribuindo com dois bilhões de dólares para o produto interno mexicano. Isso seria resultado direto da atração de investimentos e do oferecimento de incentivos, que teriam permitido o desenvolvimento dessa indústria no país. Outro exemplo seria a indústria automobilística, que também teria tido êxitos e resultados através de uma firme política do governo para a atração investimentos para esta indústria.

O ideal seria uma política criativa, saudável, que não seja protecionista e que fomente setores onde o México não esteja atuando, ou não esteja sendo competitivo. Assim, os valores adotados estariam bem alinhados com um país que adota uma economia de mercado aberta, com apoio governamental a certos setores, mas sem deixar que a economia passe a ser dirigida pelo governo.

\subsection{3 - Normatização da Política}

\section{a) Governo}

O gráfico 28, abaixo, apresenta as respostas dos entrevistados do governo mexicano, sobre a avaliação da normatização que serve de base para a política industrial de petróleo e gás no país. 


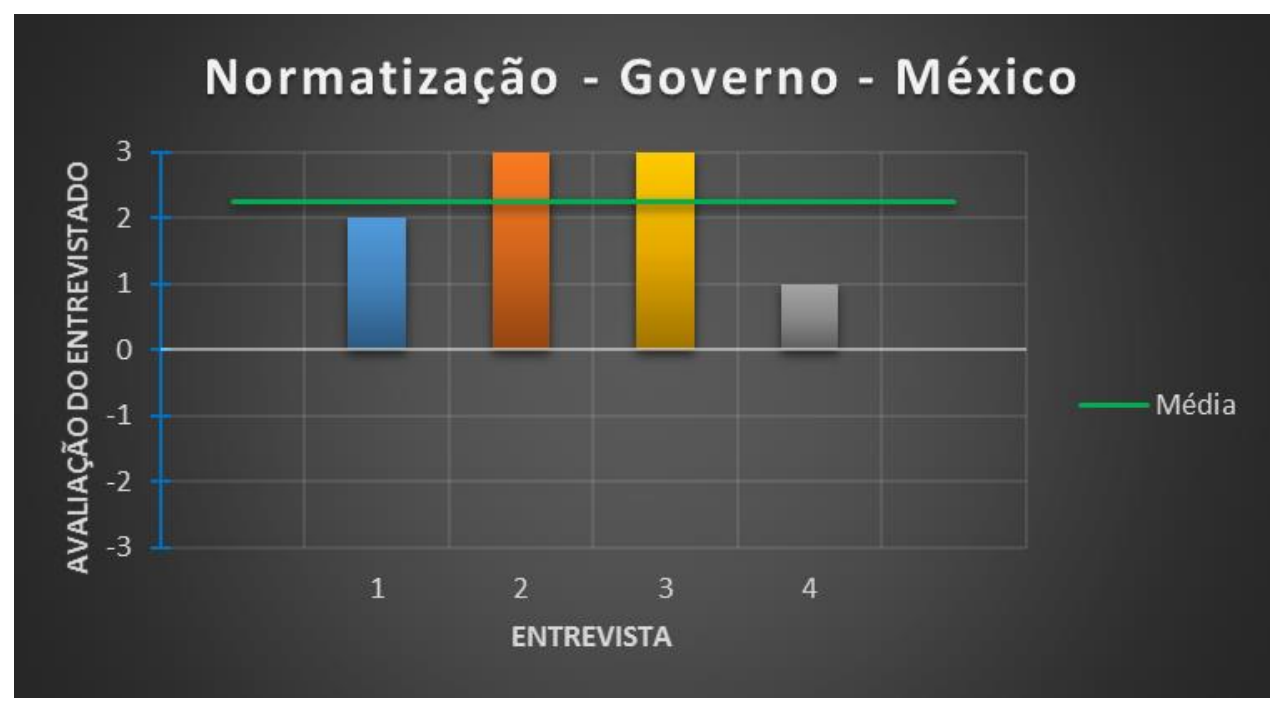

\section{Gráfico 28 - Avaliações dos entrevistados do governo do México sobre a normatização da política industrial de petróleo e gás no país.}

Neste bloco, não houve nenhuma perspectiva que tenha sido levantada em todas as quatro entrevistas. Três entrevistados destacaram que a flexibilidade das normas foi um dos principais objetivos dos legisladores, que teriam tido o cuidado para que as leis não criassem o comprometimento com nada que não pudesse ser ajustado ou excluído posteriormente. Vários critérios e instrumentos não foram especificados pela lei, para que fossem definidos posteriormente, em normas e regulamentos. Assim, não seria preciso ir ao congresso para alterar esses critérios e instrumentos. Essa flexibilidade facilitaria a mudança, permitindo que os critérios sejam ajustados, melhorados ou reorientados com base nos resultados obtidos e na evolução do mercado, contribuindo para que se implemente a política mais adequada.

A lei teria apenas fixado alguns objetivos nacionais, estabelecendo metas (como $35 \%$ de conteúdo nacional), mas dando flexibilidade para a forma de se atingir essas metas. Por outro lado, um dos entrevistados destacou que houve a tentativa de que a lei não estabelecesse nenhum percentual e trabalhasse caso a caso, o que poderia dar ainda mais flexibilidade. Apesar disso, o governo teria incluído um mínimo de conteúdo local buscando vantagem política, pois assim estaria dando algo para a indústria, deixando este setor mais tranquilo. O modelo flexível permitiria que essa exigência de conteúdo local não signifique necessariamente a participação dos mesmos grupos de sempre. 
Outro tema tratado em três entrevistas foi a utilização de consultas para a criação das novas normas que seriam necessárias para atualizar as normas anteriores, que continuam valendo até serem substituídas. O processo de criação de qualquer norma estaria muito bem definido, obrigando toda autoridade a passar por uma instituição chamada Comisión Federal de Mejora Regulatoria, a apresentar uma manifestação de impacto regulatório e a fazer uma consulta pública. Os conselhos consultivos seriam espaços onde o governo apresenta seus objetivos e alguns dos principais atores apresentam propostas. Essas consultas permitiriam participação de toda a sociedade e seriam o espaço para que todos opinem, ajudando o governo a conhecer quais são as preocupações do mercado sobre os assuntos que ele está definindo. Até mesmo a Pemex estaria participando e seria sempre escutada, mesmo que ela e o governo nem sempre estejam de acordo. Ainda sobre a participação dos atores na criação das normas, o quarto entrevistado mencionou apenas que alguns órgãos do governo estariam trabalhando de forma aproximada para que não haja casos de duplicidade nem conflito entre as regulações. Todas as diferentes agências reguladoras estariam participando, teriam interfaces para comunicação entre si e seriam coordenadas por uma única e mesma lei.

Entre as perspectivas trazidas em apenas uma entrevista está o questionamento sobre se as normas devem se adequar à realidade da indústria ou às melhores práticas internacionais. Também foi lembrado que, até o momento, teriam sido mantidas as normas anteriores, para que sirvam como um marco de referência e ofereçam um mínimo de segurança jurídica. Se estaria no meio do processo de desenvolvimento das novas normas que irão substituir as antigas, adaptando-as a um cenário completamente diferente do que se tinha antes da reforma.

Um dos entrevistados destacou que não se deveria falar em política industrial, mas sim em uma política energética, que ainda estaria em construção. A aplicação das normas aos casos concretos vai depender de como os processos serão feitos. Deve haver muito cuidado para que as normas de conteúdo local não acabem gerando custos desnecessários, nem trazendo situações indesejadas, como o enriquecimento de um grupo específico, sem trazer benefícios sociais. Por isso, o melhor seria que a lei nem tivesse estabelecido um percentual mínimo específico.

O governo mexicano teria feito um claro esforço para tentar conciliar os dois modelos opostos que existem no mundo regulatório do setor de petróleo: o da governança 
por contratos e o da governança por lei. A Noruega seria o melhor exemplo de governança pela lei. Os Estados Unidos seriam um caso curioso, utilizando licenças pequenas, mas com uma legislação demasiadamente prescritiva e alguns casos que estariam migrando para um modelo baseado em resultados. O Canadá seria uma mistura, mas também estaria migrando para um modelo com base em resultados. Já Malásia, Brasil e Colômbia teriam a maior parte do conteúdo de suas governanças estabelecido pelos contratos.

O modelo adotado pelo México teria uma tendência maior à regulação, com os contratos abrangendo conteúdos regulatórios específicos, mas vinculados à lei. Dessa forma, casos onde a indústria seja mais forte e esteja melhor desenvolvida serão tratados com uma regulação baseada em resultados, e casos considerados críticos, onde haja necessidade de estabelecer normas e padrões específicos, serão tratados com disposições mais prescritivas. Portanto, o modelo mexicano seria uma mistura, deixando o operador como responsável por elaborar esses padrões, que serão avaliados pelo governo, em função dos objetivos do país.

De qualquer forma, foi lembrado que o governo mexicano está recém começando esse processo e que muito do que deve ser ajustado e corrigido será aprendido ao longo do caminho. Esse aprendizado permitiria um constante melhoramento das normas, regulações, processos e mecanismos envolvidos. Foi levantada dúvida sobre a capacidade dessas normas se manterem adequadas no futuro, pois o ideal seria que houvesse normas, processos, programas e ações mais definias, mais precisas e mais sistemáticas.

\section{b) Associações Empresariais}

O gráfico 29, abaixo, apresenta as respostas dos entrevistados das associações empresariais mexicanas, sobre a avaliação da normatização que serve de base para a política industrial de petróleo e gás no país. 


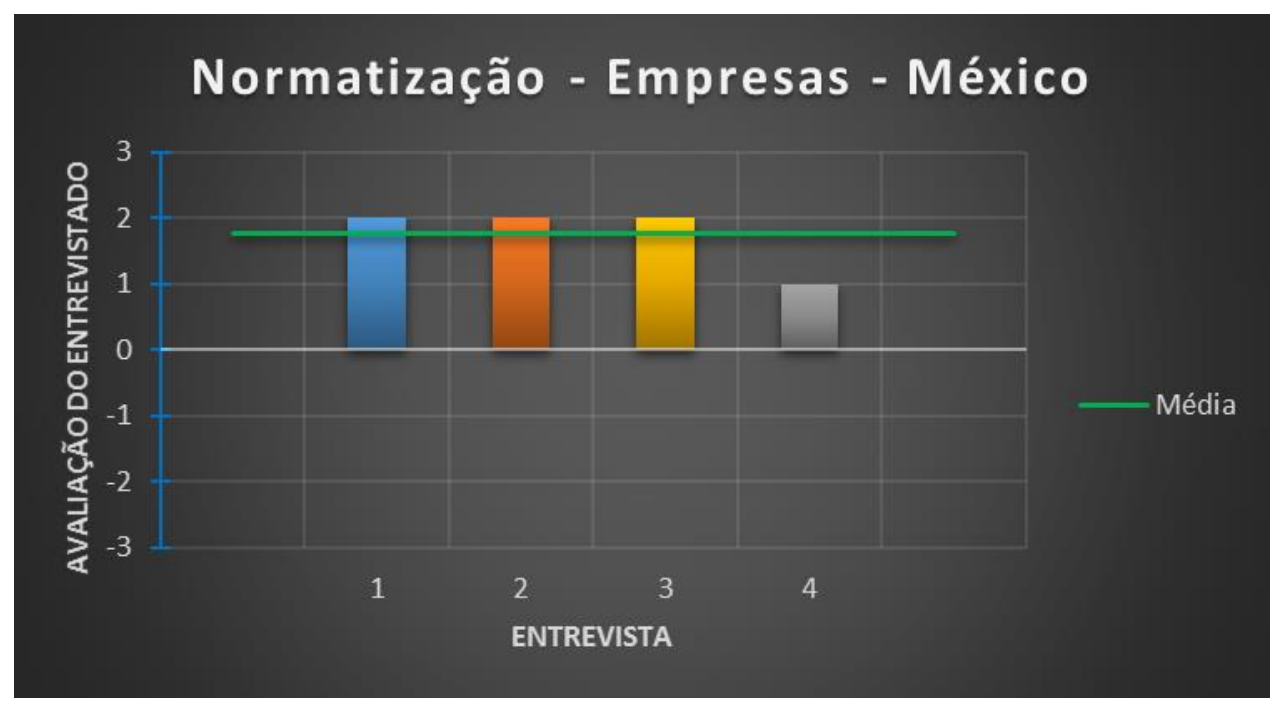

\section{Gráfico 29 - Avaliações dos entrevistados das associações empresariais do México sobre a normatização da política industrial de petróleo e gás no país.}

Todos os quatro entrevistados destacaram a importância da consulta ao setor privado quando o governo pretende criar uma nova norma. Três desses entrevistados acreditam haver uma boa sinergia entre o setor público e o setor privado no México, pois existiria a obrigação de que qualquer norma, antes de se aprovada, deva passar pela Comisión Federal de Mejora Regulatoria (Cofemer), onde se realizam consultas prévias, incluindo consultas públicas. Antigamente, o governo teria o costume de tomar essas decisões sem consultar a ninguém e muitas vezes acabava prejudicando a indústria. Vale lembrar que hoje, mesmo havendo diálogo e a participação plena das partes interessadas, isso não significa que todos saiam sempre satisfeitos. Já o quarto entrevistado disse que, apesar das consultas estarem ocorrendo, os comitês de consulta não estariam operando como deveriam para que se tenha uma participação mais ativa e permanente do setor privado na definição das normas. O governo estaria dizendo que existem muitos mecanismos de participação e consulta, mas a verdade seria que estes mecanismos estariam ainda no papel e não teriam sido colocados em prática. Isso talvez tenha ocorrido porque o governo teve que cumprir com muitas coisas e pode não ter tido tempo para construir os mecanismos de consulta. Por isso, segundo esse entrevistado, não haveria uma relação fluida entre governo e empresas.

Não houve a repetição de nenhuma outra perspectiva entre os entrevistados nesse bloco. Todas as demais visões foram trazidas em apenas uma entrevista, como a questão 
sobre a rigidez ou flexibilidade das normas, que foi tratada por três dos entrevistados, mas trazendo opiniões distintas. Um deles explicou que uma lei geralmente é mais ampla (dizendo simplesmente que se deve utilizar tubos para os dutos de petróleo e gás, por exemplo), sendo complementada por um regulamento (que diz que esses tubos devem atender às condições técnicas necessárias) e especificada por uma norma (que vai dizer exatamente qual a grossura que esse tubo deve ter). Para mudar uma lei, criada por deputados e senadores, seria necessário convencer a todos estes, o que seria muito difícil. Para mudar uma norma ou regulamento que especifica essa lei seria muito mais fácil, pois bastaria convencer um secretário ou o ministro da área correspondente. Em outra entrevista foi dito que as normas seriam rígidas por natureza, mas que, como acontece em muitos países, o enforcement dessas normas nem sempre seria rígido. As leis de conteúdo local brasileiras, por exemplo, seriam muito rígidas, mas quando se cria leis que não podem ser cumpridas, haveria um problema a ser resolvido. Já o México não teria mais o foco de que tudo seja sobre estímulo a conteúdo nacional, como já teria sido feito no passado. A participação no NAFTA teria ajudado para que o México tenha normas suficientemente bem-feitas, que possam ser cumpridas. Acordos com a União Europeia, com o NAFTA e, mais recentemente, com o TPP (Trans-Pacific Partnership) estariam fazendo com que muitas leis sejam flexibilizadas, para permitir o acesso a mercados que o México não exportava até então. Já o terceiro entrevistado disse que as normas seriam muito rígidas, e que mesmo existindo o confronto entre distintos valores, como o de livre mercado e o de desenvolvimento do conteúdo nacional, teria havido um acordo para que não haja políticas de conteúdo local muito agressivas.

Um dos entrevistados destacou que, de maneira geral, as normas seriam adequadas à realidade da indústria. Por outro lado, alguns temas seriam afetados pela participação no NAFTA, como uma tendência da normatização mexicana em buscar uma harmonização com as normas americanas e canadenses. Algumas vezes isso seria feito sem levar em consideração diferenças que existem no México, como tamanho do mercado, sofisticação da tecnologia e o custo que ela representa. Um exemplo disso seria a indústria automobilística, muito integrada entre México, Estados Unidos e Canadá e que estaria discutindo a harmonização de normas relacionadas à emissão de gás carbônico. As autoridades nem sempre entenderiam que essa harmonização seria difícil, devido às diferenças de mercado, como os diferentes incentivos existentes em cada país. Enquanto os Estados Unidos oferecem, por exemplo, um crédito de imposto de 5 mil 
dólares para quem compra um Prius, o único incentivo possível no México seria a não cobrança do imposto sobre automóveis novos, que seria muito pequeno. Essa falta de incentivos do governo mexicano quando comparado a outros países poderia estar ligada a uma diferença entre a visão adotada por um país em desenvolvimento e a visão adotada por um país desenvolvido.

Um exemplo de problema relativo à aplicação das normas nos casos concretos seria a lei de transição energética, que procura estimular o uso de energias limpas, cobrando um imposto de quem segue utilizando energias fósseis. O problema seria porque poucas empresas no México teriam condições de pagar por um parque eólico ou de células fotovoltaicas. Mesmo assim, foi dito que as mudanças nas leis teriam sido boas. O que faltaria agora seriam as mudanças nas regulamentações. Em comparação com o Brasil, as fronteiras mexicanas estariam mais expostas e desprotegidas contra agressões de comércio internacional de outros países, permitindo a entrada de todo tipo de material.

Também foi apontado que o tempo parece ter sido curto para a criação de toda regulamentação para o setor de petróleo e que, por isso, não teria sido possível encontrar soluções mais adequadas. Se teria tentado criar uma fórmula de avaliar a implementação da reforma, mas que acabou não funcionando, pois era muito difícil fazer as empresas fornecerem informações especificadas sobre sua produção e seus custos.

\subsection{4 - Implementação da Política}

\section{a) Governo}

O gráfico 30, abaixo, apresenta as respostas dos entrevistados do governo mexicano, sobre a avaliação da forma de implementação da política industrial de petróleo e gás no país. 


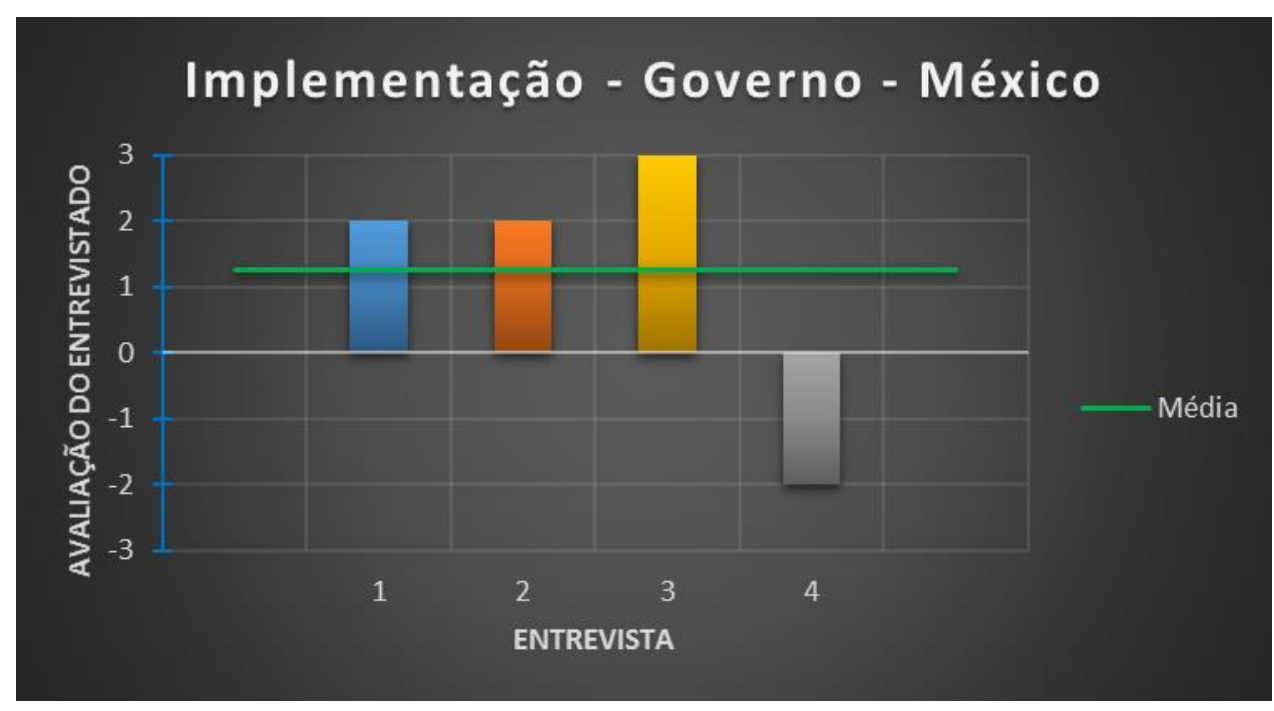

Gráfico 30 - Avaliações dos entrevistados do governo do México sobre a implementação da política industrial de petróleo e gás no país.

Neste bloco, nenhuma perspectiva foi levantada por todos os quatro entrevistados. Em três entrevistas houve a menção de que ainda seria muito cedo para avaliar a implementação da política, pois esta fase ainda estaria em construção. Destes três entrevistados, dois disseram que entendem a implementação como positiva até aqui. Para o primeiro deles, governo mexicano estaria muito avançado no processo de definição de metas e objetivos mais precisos, linhas de ação, mecanismos de transparência, indicadores de desempenho, participantes, responsabilidades, funções e a forma de interação com instituições como universidades e centros de pesquisa. Tudo isso estaria sendo feito de forma muito ordenada, construindo um método, uma plataforma, um mecanismo sistemático, onde todas essas questões possam interagir para que tudo funcione. Para o segundo entrevistado, se for analisada a quantidade de trabalhos e documentos que estão sendo liberados, o resultado seria extraordinário, mas analisando os preços cobrados do consumidor, a quantidade de investimentos recebidos e o desenvolvimento econômico alcançado, o resultado seria inexistente. Essas seriam expectativas criadas pela população, que teria dificuldade de entender que ainda não seria o momento para que se tenha esses resultados.

O terceiro entrevistado também disse que, se for medido o desempenho dos atores com base no esforço feito por eles, seria dada nota máxima, mas medindo com base nos resultados, estes seriam inexistentes. Todavia, ao contrário do segundo entrevistado, essas 
mesmas razões levaram o terceiro entrevistado a avaliar a implementação como negativa. Internamente, não se teria percebido resultados como geração de empregos ou aumento de competitividade. Externamente, os fundos de investimento não estariam "contentes" com o desempenho apresentado. Muito disso seria consequência da pressa que se teria tido para realizar as licitações. Ainda não se teria as instituições necessárias, nem a quantidade necessária de pessoas trabalhando para que as rondas sejam possíveis. Apenas no órgão deste entrevistado, haveria mais de cinquenta disposições para serem feitas até o final do ano, relacionadas com armazenamento, transporte, distribuição por dutos, por rondas, por tarifas, entre outros. Sem saber como o transporte do petróleo será feito, não haveria como uma ronda ter resultados positivos.

A transparência e a prestação de contas foram apontadas como elementos fundamentais da reforma por dois entrevistados. A preocupação com transparência teria sido impecável, criando-se a obrigação de se estabelecer códigos de ética vinculantes para o setor e impossibilitando os funcionários das comissões de atenderem diretamente seus regulados em assuntos de sua competência. Essas reuniões teriam que ser feitas por meio de audiência, que teria que ser gravada, para que fosse apresentada uma minuta pública. Mesmo para a realização da entrevista desta pesquisa, teria sido necessário bater em várias portas, pois não seria permitido se reunir com ninguém sem que haja uma autorização. No final do processo de regulação ou de implementação de políticas, haveria ainda a necessidade de se passar por uma revisão integral pelo congresso. Todos os anos, processos exaustivos avaliariam o que foi feito, como foi feito, porque foi feito, quem participou, entre outras coisas. A nomeação dos comissionados seria feita através de ratificação pelo senado, que escolheria o nome a partir de uma lista tríplice oferecida pelo presidente da república. Isso deveria ajudar os comissionados a terem mais independência e autonomia técnica sobre os políticos. Apesar do governo estar sendo muito aberto, a transparência não serviria para tornar o governo invulnerável, mas ajudaria para que todos sejam mais cautos, observadores e cuidadosos naquilo que fazem ou deixam de fazer. Já um terceiro entrevistado disse que não existiria prestação de contas, pois muitos agiriam como se estivessem numa empresa familiar, mesmo se tratando de funcionários públicos.

Também foram dois os entrevistados que disseram haver um bom diálogo e interação entre os atores. Isso seria perceptível em todos os procedimentos, pois não haveria nenhuma limitação e o governo poderia receber a todos. Com exceção de alguns tomadores de decisão da Secretaría de Energía, praticamente todos os atores seriam os 
mesmos de antes da reforma. O que teria mudado seria apenas a lei, a constituição. A interação com os atores deveria ser de respeito, equilibrando ao mesmo tempo cautela com a imposição de respeito. O governo estaria também recebendo retroalimentação de todos os atores do setor. Todos os processos teriam a obrigação de serem convertidos em documentos públicos, para serem publicados na Gaceta Oficial. Antes disso, ainda teriam que passar por um processo consultivo e uma consulta pública aberta, o que fortaleceria ainda mais a transparência e faria com que toda sociedade estivesse envolvida. Todas as regulações devem ficar ao menos vinte dias úteis no site da Cofemer, que teria a obrigação legal de atender e responder a todo comentário que fosse feito. Então, as ferramentas e os mecanismos de consulta estariam disponíveis, mas a efetiva utilização deles pela população estaria fora do controle do governo. Um terceiro entrevistado defendeu haver necessidade de uma definição mais precisa sobre a implementação da política. Seriam muitos os atores envolvidos, que querem participar, que devem ser consultados e receber espaço, fazendo com que seja muito importante o alinhamento de suas direções. Já o quarto entrevistado rebateu a afirmação feita em outras entrevistas dizendo que, se um cidadão entrar na página da Cofemer para acompanhar a sessão se perguntas, descobrirá que na verdade ela não existe. O entrevistado disse acreditar que esse mecanismo ainda não tenha sido desenvolvido porque eles também teriam estado muito ocupados.

A aliança com universidades e centros de pesquisa foi considerada um dos pontos fortes da implementação da política em duas entrevistas. Além de um programa para desenvolvimento de capital humano, que seria o principal gargalo da economia mexicana, haveria uma interação com instituições nacionais e internacionais para que o governo receba uma retroalimentação sobre as decisões que são tomadas, sobre as regulações emitidas e sobre propostas em geral. Já numa terceira entrevista foi dito que não estaria havendo tempo para alianças. Mesmo existindo interesse de ambas as partes, cada pessoa que trabalha no governo estaria encarregada de tantas coisas que não sobraria tempo nem para fazer um memorando para dar início a uma aliança.

Também foram dois os entrevistados que destacaram a gravidade da corrupção como um problema nacional que se verifica por todos os lados. Para um desses entrevistados, a única coisa que o governo poderia fazer seria dar atenção à transparência e prestação de contas, o que já estaria sendo feito. Já o segundo entrevistado se recusa a aceitar a ideia de que a corrupção faça parte do sistema, ou a justificativa de que esse problema viria desde os tempos em que o México foi colonizado pelos espanhóis e que, 
portanto, nada poderia ser feito para mudar. Segundo ele, vai ser chave para a reforma que sua implementação detenha ou pelo menos crie obstáculos para toda essa corrupção. Parece haver uma mudança no discurso, o que poderia ser um primeiro passo. Situações antes tratadas como normais, hoje estariam sendo questionadas por evolver questões como conflito de interesses. A operação de combate à corrupção na Petrobras agradou esse entrevistado, pois prisões assim só ocorreriam no México por motivações políticas e não porque alguém tenha feito algo de errado. Um exemplo disso seria a representante do sindicato de educação, que teria crescido demais e deixado de ser uma interlocutora desejável, então teria acabado sendo presa.

Outros temas foram trazidos por apenas um entrevistado, como a existência de metas e objetivos bem definidos e a existência de integração com outras políticas, como a ambiental, a social, a econômica e a educacional, entre outras. Além disso, o caso brasileiro foi citado como sendo um dos que mais serviram de base para a definição da reforma energética mexicana, seja por apontar elementos que o México deveria tentar adaptar para a sua realidade, ou seja por apontar elementos que deveriam ser evitados. $\mathrm{O}$ exemplo brasileiro, assim como o colombiano, também serviu de referência com relação à tentativa de expropriação dos bancos de dados, mas isso não teria funcionado muito bem no México. De um modo geral, mais do que Estados Unidos e Reino Unido, os principais modelos utilizados pelos mexicanos teriam sido o brasileiro, o colombiano, o norueguês e o canadense. Se procurou retirar elementos úteis de todos esses modelos, para que fosse possível construir um modelo mexicano.

\section{b) Associações Empresariais}

O gráfico 31, abaixo, apresenta as respostas dos entrevistados das associações empresariais mexicanas, sobre a avaliação da forma de implementação da política industrial de petróleo e gás no país. 


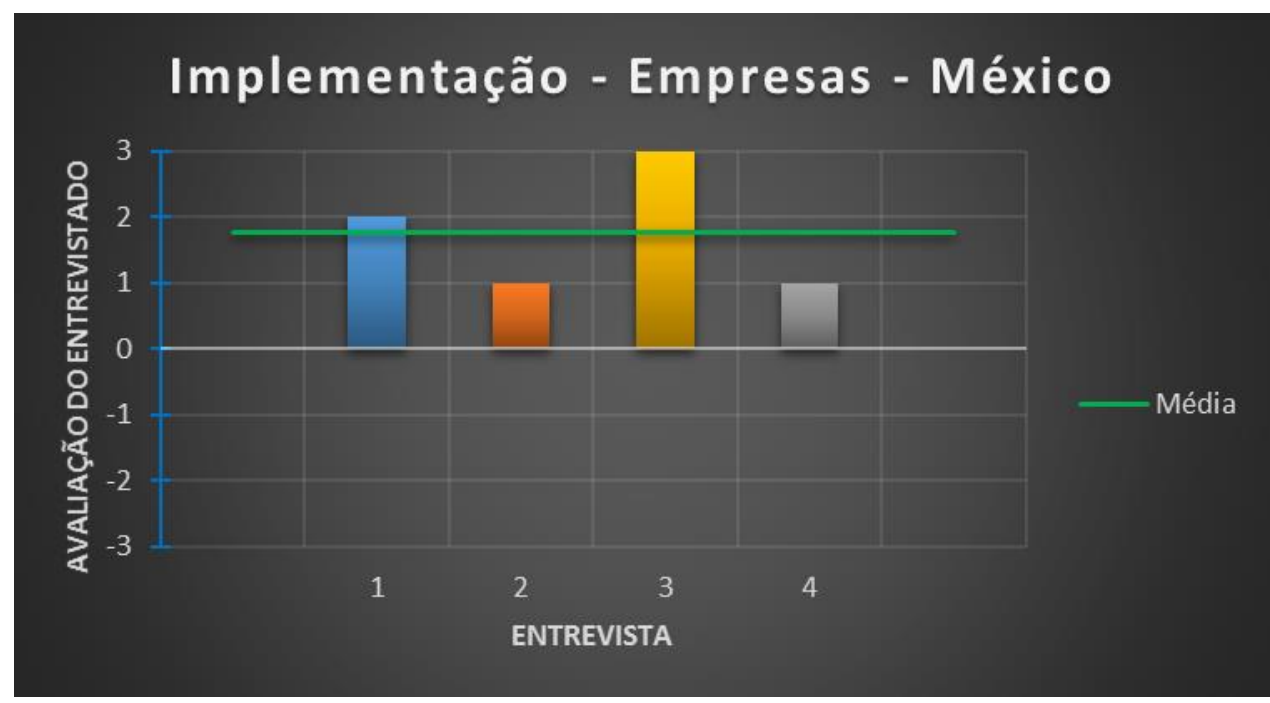

\section{Gráfico 31 - Avaliações dos entrevistados das associações empresariais do México sobre a implementação da política industrial de petróleo e gás no país.}

Nenhuma perspectiva foi levantada por todos os quatro entrevistados, nem mesmo por três deles. Por outro lado, diversas visões foram repetidas em duas entrevistas, como o entendimento de que hoje existe um bom diálogo entre os atores. Para a preparação dos contratos, a CNH e a Secretaría de Energía teriam escutado à indústria nacional e especialmente a estrangeira, para aproveitar experiências de todo o mundo. Se conversou muito com a Petrobras, Statoil, Exxon, BP e Shell. A partir dessas conversas foram feitas modificações nos contratos e, devido aos resultados da primeira ronda, essa experiência deve prosseguir. O México era um país que não tinha o hábito de consultar diretamente para fazer políticas públicas, pois se aplicava o que a lei decidia. A escola de políticas públicas no México seria recente (aproximadamente vinte anos), mesmo já estando na sua terceira geração, o que tem obrigado o governo a se adaptar. Hoje existiria muito mais participação do setor público, que seria muito mais transparente e aberto. Não que isso seja necessariamente por desejo do governo ou do setor privado, mas sim porque a tecnologia atual obriga a isso, pela facilidade que se tem para fazer gravações e tirar fotos. Em todos os comitês ou mesas que um dos entrevistados teria participado, existiria o cuidado para que sempre haja alguém da sociedade civil. O governo também estaria sendo mais participativo, em comparação com o passado, onde não seria possível nem se fazer uma crítica ao presidente. Hoje, existiriam opiniões negativas, charges e "memes" criticando o presidente diariamente. 
Por outro lado, haveria a necessidade de mudança da cultura de políticos que têm entre sessenta e setenta anos de idade, criados na lógica de sigilo e segredo, sem a necessidade de oferecer muitas explicações ou informações, para uma cultura onde se tem que ser muito mais hábil, muito mais visto e compartilhar muito mais informações. De acordo com um dos entrevistados, ao se dizer as coisas como elas realmente são, de maneira clara, muitas vezes acaba se ganhando mais e tendo menos problemas do que quando se tenta ser opaco e não dividir. Então haveria uma mudança para uma cultura de midiatização e de uso de redes sociais, que estaria sendo bem-feita pelo governo e estaria funcionando bem. Outras culturas seriam mais difíceis de serem mudadas, como o pessoal que trabalha há trinta ou quarenta anos na Pemex e na CFE, e que não querem se modernizar. Eles não querem que coloquem nos seus lugares pessoas capazes de utilizar ferramentas tecnológicas que eles não são capazes e que, consequentemente, sejam muito mais produtivos. Já um terceiro entrevistado apontou que o diálogo entre os atores estaria sendo prejudicado por regras muito rígidas, que têm o objetivo da transparência, mas que estariam fazendo com que se perca agilidade na interlocução entre os atores. Até seria possível conseguir falar com um comissionado, com o presidente de uma comissão, ou com o diretor geral, mas essas audiências teriam o costume de demorar muito para acontecerem. Depois dessas audiências, o governo não teria o hábito de dar nenhum feedback, ou retroalimentação, e quando isso ocorre, já seria muito tarde.

Outros pontos que foram trazidos por dois entrevistados foram a existência de metas e objetivos bem definidos (havendo inclusive índices específicos de conteúdo nacional) e a existência de atos de corrupção (que devem diminuir devido à ênfase em transparência, participação cidadã, abertura, e exposição na internet). A existência de alianças com universidades e centros de pesquisa também foi mencionada em duas entrevistas, explicando que estaria havendo mais envolvimento nesse processo e que, devido a um déficit de engenheiros no mercado mexicano, se estaria fazendo parcerias para a criação de novas carreiras e a formação de pessoal e capacidade humana para o setor de petróleo e gás.

A transparência foi analisada por dois entrevistados, mas cada um ofereceu uma visão completamente distinta sobre o tema. Um deles ressaltou a importância da transparência e o desejo por uma prestação de contas realmente sólida. Chegou a dizer que houve um exagero do governo com a transparência da primeira ronda, uma vez que governo, congresso e opinião pública querem que o setor de petróleo sirva de paradigma, 
já que o passado do México não teria bons exemplos no que se refere a transparência e prestação de contas. Já o outro entrevistado afirmou que a transparência e a prestação de contas do governo mexicano seriam péssimas. Muitas vezes haveria apenas a aparência de que se está sendo transparente, mas na verdade existiriam outros processos ocorrendo por trás, como reuniões privadas, por exemplo. Também haveria o caso de audiências que não são gravadas, ou que são gravadas, mas não são públicas. Seria possível saber que houve uma reunião entre um determinado órgão e um determinado ator sobre um determinado tema, mas o conteúdo da audiência não estaria sendo revelado. Então, ainda faltaria muito a ser feito sobre transparência.

No mesmo sentido, dois entrevistados discordaram entre si na análise sobre a integração com outras políticas. Um deles disse haver uma coerência geral da política de petróleo e gás com as demais políticas. A diferença de interesses seria normal, pois a Secretaría de Hacienda certamente vai querer arrecadar o máximo possível, enquanto a Secretaría de Energía cuida dos recursos naturais e a Secretaría de Economía quer atrair investimentos estrangeiros. Então, não estariam todos completamente alinhados, mas haveria sim uma política governamental geral para o setor. Já o segundo entrevistado denunciou que não existiria a integração de outras políticas com a política industrial, porque esta seria muito desarticulada e não seria congruente. Haveria, por exemplo, um problema de timing no setor acadêmico, como no caso de um programa nuclear para desenvolvimento do setor elétrico que não conta com nenhuma universidade que tenha engenheiros físico-nucleares. Assim como não existiria nenhuma universidade com cursos especializados no setor de petróleo.

Na fala de apenas um dos entrevistados foi dito que todos esses elementos já estariam em lei, mas ainda não teriam sido implementados. Também foi lembrado que, como o setor privado foi impedido de participar dessa indústria por muitos anos, teria se criado um mito de que o mundo inteiro estaria apenas esperando o México abrir o seu mercado para que viessem todos roubar e explorar com voracidade os recursos mexicanos. Tanto por razões internas quanto externas, a realidade teria demonstrado não ser bem assim. Então, se estaria trabalhando para diminuir as expetativas sobre essa entrada massiva de investimentos no país. 


\subsection{5 - Resultados da Política}

\section{a) Governo}

O gráfico 32, abaixo, apresenta as respostas dos entrevistados do governo mexicano, sobre a avaliação dos resultados alcançados pela política industrial de petróleo e gás no país.

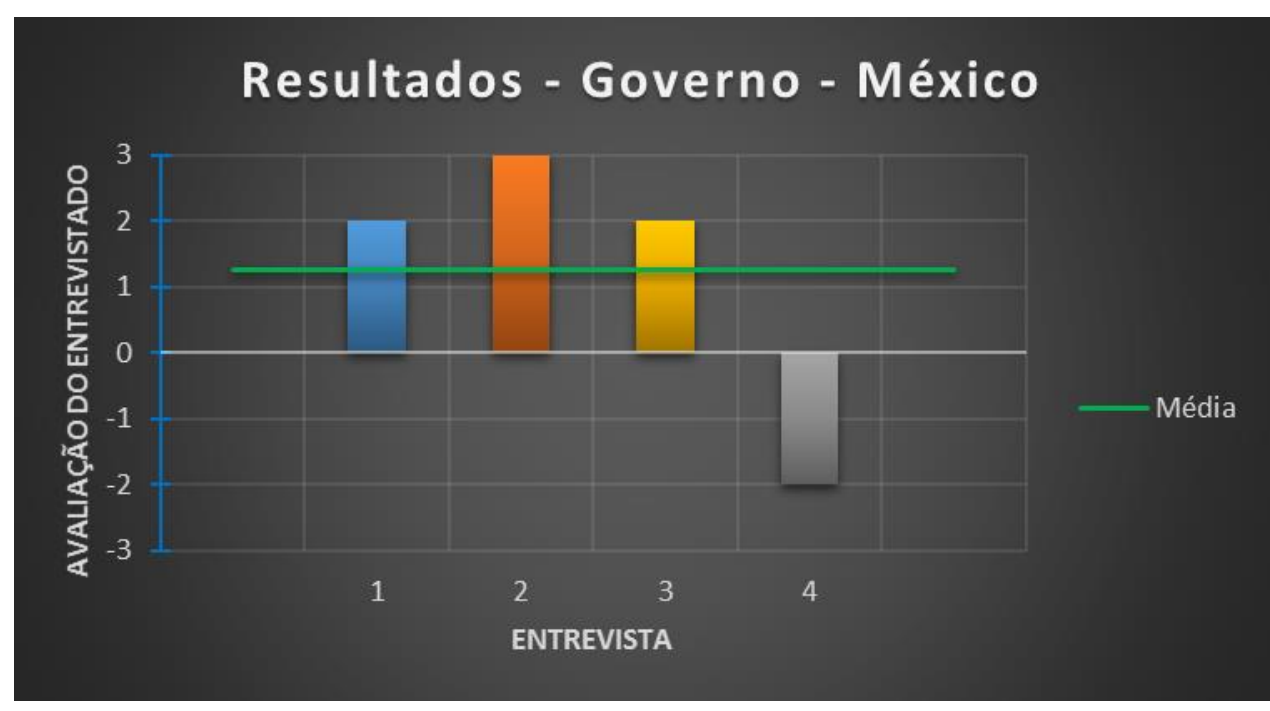

\section{Gráfico 32 - Avaliações dos entrevistados do governo do México sobre os resultados da} política industrial de petróleo e gás no país.

Houve unanimidade entre os quatro entrevistados ao mencionarem que a política industrial mexicana de petróleo e gás ainda não teria apresentado resultados. Dois desses entrevistados disseram que ainda não seria o momento para que se tenha resultados, pois eles virão mais para frente. Os indicadores de desempenho estariam sendo construídos para medir resultados ligados ao número de empresas participando da cadeia, à quantidade de campos leiloados, ao desenvolvimento científico e tecnológico e às exportações. Apesar disso, até agora não seria possível perceber nada de geração de empregos, atração de investimentos ou crescimento econômico, que são os resultados que se espera de uma política industrial. Com relação à atração de empregos, foi lembrado que a política da indústria automobilística mexicana seria um exemplo de sucesso. A adoção de processos de aprendizagem estaria sendo iniciada e questões como registro de patentes e aumento da capacidade produtiva e da produtividade seriam resultados 
desejados pela reforma. Foi considerado que a Pemex possa aumentar suas exportações, apesar de ainda não ter competência suficiente para isso, pois a reforma teria lhe retirado uma obrigação implícita de abastecer o mercado interno mexicano. Também foi dito que teria sido uma sorte não ter havido muita discussão ou polêmica sobre conteúdo nacional no México, pois poderiam ter conseguido porcentagens mais altas, e o certo seria o que foi feito, uma abertura para todos.

Um dos entrevistados apontou a emissão de critérios regulatórios como um resultado que poderia ser considerado, mesmo que eles só venham a ser concluídos no final de 2015. Outro resultado que já poderia ser verificado seriam os estudos de sísmica, que estariam ajudando a incrementar o conhecimento do potencial do setor de petróleo mexicano. Também já se poderia considerar o desenvolvimento de capacidades e o processo de aprendizagem tecnológica, que estariam dependendo de memorandos firmados com agentes e autoridades de outros países, para intercâmbio de conhecimento, melhores práticas e tecnologias. Em uma entrevista foi dito que teria havido muito investimento em pesquisa, fazendo com que alguns pesquisadores e consultores tenham ficado ricos. Mesmo que seja muito cedo para que se tenha um diagnóstico claro, para três dos entrevistados não haveria dúvidas de que esse resultado estaria sendo positivo e que, com o tempo, essa percepção ficaria mais clara. Já o quarto entrevistado entendeu que essa falta de resultados até aqui deveria ser considerada como negativa.

Em três entrevistas foi defendido que o governo teria uma ideia muito clara de que a política industrial se trata de um processo gradual de aprendizagem. Foi mencionado que o governo teria uma relação muito boa com as operadoras e com as empresas. O primeiro objetivo da política já teria sido alcançado, pois não teria havido conflito ou controvérsias sobre as etapas da política implementadas até aqui. Além disso, o governo estaria tentando passar uma mensagem de que a responsabilidade pelo desenvolvimento da indústria não seria uma obrigação exclusiva do governo, nem exclusiva das empresas, mas sim um trabalho colaborativo. Todos estariam entendendo muito claramente essa mensagem e respondendo muito bem. Mecanismos de colaboração estariam sendo criados pelo governo, para que se tenha um processo sistemático e definido de esforço compartilhado, pois isso permitiria que se tenha resultados positivos de forma rápida.

Um dos entrevistados comparou as diferentes fases adotadas pela política industrial norueguesa, que teriam fases mais protecionistas e fases mais de abertura. 
Nesse sentido, o Brasil seria um país muito fechado, protecionista, enquanto o México, desde os anos 1990, estaria se abrindo, adotando a liberalização comercial. Os mexicanos não teriam o objetivo de adotar uma política de estímulo ao conteúdo nacional depois dessa fase inicial de atração de investimentos. O objetivo seria que a atração de investimentos crie empregos, gerando desenvolvimento. Se estaria pensando em um mundo globalizado e não em nacionalização da cadeia. Não haveria o plano de adotar uma política protecionista daqui dez anos, nem de se tornar uma Noruega no longo prazo. Os noruegueses teriam uma realidade muito diferente da que se tem em países como México e Brasil, que deveriam tratar de simplesmente aplicar as melhores práticas internacionais e não "tropicalizar" essa aplicação, pois isso seria o mesmo que desvirtuar essas práticas. Portanto, a reforma mexicana não teria o objetivo de competir em exportações de petróleo com outros países, mas sim os de tornar o país mais eficiente, desenvolver uma indústria que pague royalties e utilizar o gás como um motor de competitividade, oferecendo uma energia barata para a indústria mexicana.

\section{b) Associações Empresariais}

O gráfico 33, abaixo, apresenta as respostas dos entrevistados das associações empresariais mexicanas, sobre a avaliação dos resultados alcançados pela política industrial de petróleo e gás no país.

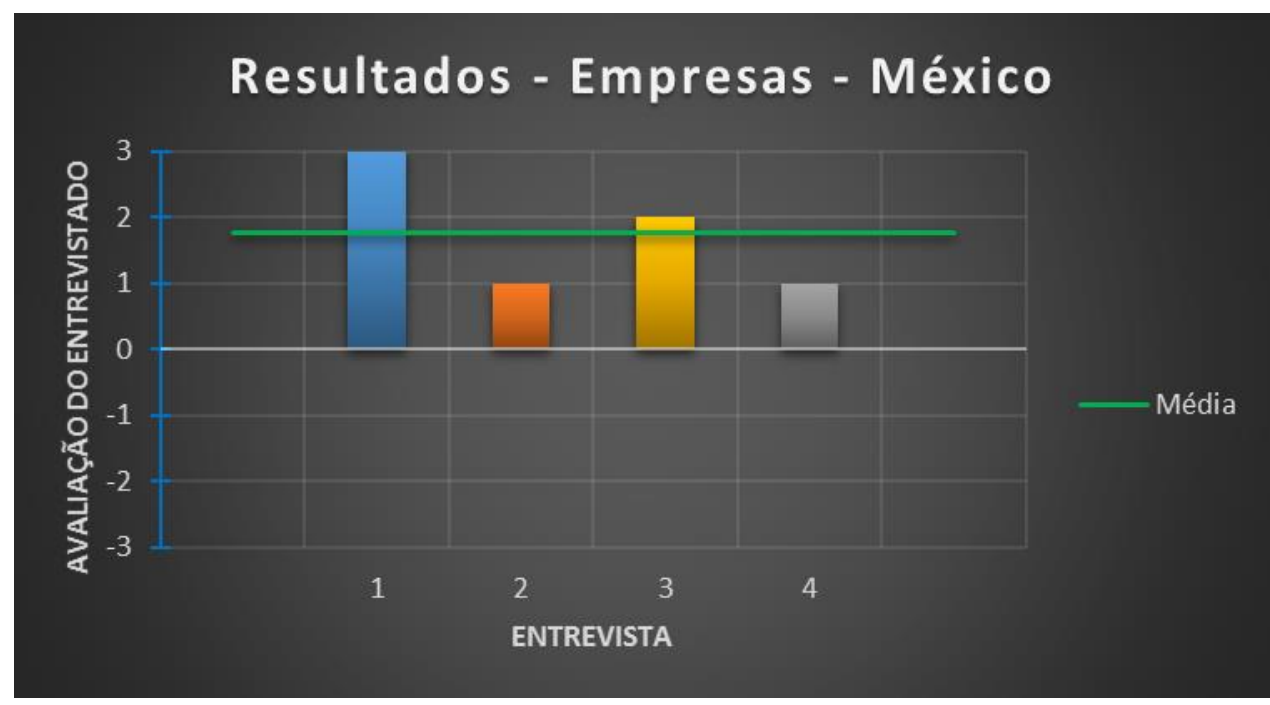

Gráfico 33 - Avaliações dos entrevistados das associações empresariais do México sobre os resultados da política industrial de petróleo e gás no país. 
Neste bloco, todos os quatro entrevistados mencionaram que ainda seria muito cedo para que se tenha resultados da atual política industrial mexicana. Houve quem disse que se deve esperar alguns anos para que os primeiros resultados apareçam, que a política foi bem discutida, mas que ainda falta apresentar resultados, ou ainda que os resultados que se tem até aqui teriam sido muito baixos.

Foi mencionado em três entrevistas que o registro de patentes seria muito pequeno no México, mesmo quando comparado a países como o Brasil. Isso seria devido à falta de competitividade, produtividade e de recursos destinados para P\&D. Por isso, todos os temas ligados a inovação e tecnologia ainda devem demorar para apresentarem resultados. Dois dos entrevistados mencionaram a falta de melhorias na capacidade produtiva e nas exportações, que não devem ter um incremento no curto prazo. A demanda nacional seria crescente e o mais importante seria garantir que o país não volte a ser um importador de petróleo.

Também foram dois os entrevistados que disseram que a geração de emprego e renda não estaria ocorrendo como deveria. De acordo com um deles, os resultados estariam aparecendo de forma muito lenta. Para outro, seria ainda pior, pois hoje estariam ocorrendo problemas de desemprego em centros petroleiros como os de Campeche e de Tabasco. Esse aumento do desemprego deve ser resultado de fatores internacionais, pois estaria acontecendo também em Aberdeen e no Brasil.

Algumas empresas estariam buscando pessoal com experiência, mas para isso, estariam tendo que contratar funcionários das empresas estatais. A Pemex teria muita gente trabalhando, com salários altos demais e muitos benefícios. Historicamente, o sindicato dos petroleiros teria sido relativamente combativo, e seria claramente oposto à abertura. Por outro lado, questões relacionadas à política sindical mexicana na área de educação (que seria outra parte das reformas do governo Peña Nieto) teriam baixado as pretensões sindicais e a sua militância. Por isso, hoje em dia, o sindicato petroleiro não estaria representando uma oposição aberta e forte ao que se tem feito na reforma energética. Ao contrário, se teria conseguido convencer os trabalhadores de que o fortalecimento da Pemex, que era o único empregador até agora, irá trazer benefícios no longo prazo, além de que haverá mais oportunidades de emprego em outras empresas. 
O México teria uma força de trabalho muito boa, que só precisaria de investimento em qualificação. Um exemplo disso seria a planta da Ford em Hermosillo, na região de Sonora, que seria considerada pela Ford sua planta mais produtiva e eficiente em todo o mundo, incluindo os Estados Unidos. Isso seria fruto da dedicação de tempo, esforços e recursos para a capacitação do pessoal. O mesmo aconteceria com os investimentos japoneses feitos no país. A necessidade desse investimento em capacitação seria uma das razões para a reforma, uma vez que a Pemex não teria recursos para isso. Os mexicanos seriam uma potência industrial, pois cerca de $80 \%$ do seu PIB viria da indústria manufatureira, o que seria muito diferente do Brasil. O governo teria muito interesse em que a política tenha como resultados uma maior eficiência e uma maior participação da força de trabalho que já está empregada, além da criação de novos empregos. Para isso, estariam sendo iniciados processos de aprendizagem tecnológica através de alianças com centros de pesquisa e universidades privadas e públicas. Foi lembrado o exemplo dos casos de violência do final dos anos 1990 e início dos anos 2000, quando houve sequestros e mortes, e os estudantes tinham um perfil penalista e estudavam criminologia, pois essa era a realidade. Agora, estaria havendo um perfil da classe universitária voltado para a produção, formando engenheiros e técnicos que se envolvam nas áreas de energia, tecnologia e inovação. Dois entrevistados disseram ser necessário que a população assimile essa ideia e que se espere cinco anos para que se veja o resultado final, quando os primeiros graduados começarão a sair dessas instituições e a trabalhar nas fábricas. Por enquanto ainda seria muito cedo para que se fale nesses resultados.

Em duas entrevistas foi dito que o índice de conteúdo local de 35\% estabelecido pela lei seria perfeitamente factível. A ideia de que haveria uma influência de interesses externos que poderia estar levando empregos para fora do país foi rechaçada por um dos entrevistados, que entende que, diferentemente da Nigéria, o México teria uma indústria forte, mesmo que a Pemex não tenha utilizado essa indústria da melhor maneira possível. Nunca teria havido uma política clara e uma estratégia de conteúdo nacional, de apoio aos fornecedores, como existiria agora. Isso deverá ajudar a incorporar paulatinamente a indústria nacional na cadeia de fornecedores do setor. Já para outro entrevistado, esse índice de conteúdo local seria uma preocupação para o setor privado mexicano, pois ele gostaria de seguir fornecendo, e acredita que pode acabar perdendo esse mercado. Por isso, espera que haja a exigência de que as empresas que venham produzam nas mesmas condições que as empresas mexicanas, para que a competição seja possível. Por outro 
lado, esse mesmo entrevistado também disse que os industriais sempre querem um índice de conteúdo local maior, mas não entendem que um índice mais alto não necessariamente significa que eles irão fornecer mais. Caso uma licitação exija 35\% de conteúdo local e o máximo que se ofereça seja 34\%, a licitação seria cancelada e seria feita uma licitação pública internacional. Então, seria melhor deixar a licitação exigir apenas $15 \%$ ou 20\%, e depois subir para $25 \%$ ou $30 \%$. Assim, os fornecedores e os licitantes poderiam cumprir suas metas e haveria uma sinergia muito melhor entre eles. Por isso, esse entrevistado gostaria que o conteúdo local fosse um pouco mais aberto. Ainda houve uma terceira opinião sobre o conteúdo local, apresentada pelo quarto entrevistado, que acredita que o índice de conteúdo local exigido seja bem agressivo, pois o que se tinha até então era muito pouco. Ressaltou que esse índice não chegou nem sequer a ser medido, mas que ele não tem percebido sinais de que tenha havido algum progresso.

As opiniões sobre os resultados na atração de investimentos também foram diversas. Um dos entrevistados disse entender que não houve um acréscimo de investimentos no setor, ainda mais nesse momento de falta de orçamento e redução de gastos públicos devido à queda do preço do barril e à falta de crescimento econômico conforme esperado. De qualquer forma, espera-se que haja investimentos, que eles venham de fora do país e que se invista também em desenvolvimento tecnológico e de capacidades humanas. Já outro entrevistado disse que entende que tenha havido atração de investimentos, pois existem projetos como muitos oleodutos que estariam sendo construídos. O problema seria a ocorrência de um lapso de uns seis ou sete meses, onde não estava definido qual o papel que seria assumido pela Pemex. Essa falta de decisão teria feito com que os contratos ficassem praticamente parados durante esse tempo. Já um terceiro entrevistado defendeu que o grande interesse de investidores estrangeiros seria um sinal de um potencial sobre o qual talvez nem mesmo os mexicanos teriam consciência, mas que outros países estariam enxergando com clareza.

Toda reforma teria se baseado na ideia de que haveria resultados relativamente rápidos na queda do custo da energia e na geração de empregos, mas se estaria passando pelo problema da migração de um modelo para o outro. A Pemex teria reduzido seu orçamento em decorrência da queda de suas receitas. Como ela não estaria mais gastando o mesmo que antes, os contratos que ela tinha com a indústria já não estariam acontecendo no mesmo ritmo, nem com a mesma quantidade. Esses contratos ainda não teriam sido substituídos pelas empresas operadoras privadas que vão entrar no mercado mexicano, 
fazendo com que se esteja no pior dos mundos. Seria um momento muito difícil para a indústria, pois teria que esperar a Pemex regularizar a sua operação nos níveis que vinha tendo, e começar a aparecer os efeitos dos investimentos do setor privado, que ainda não foram vistos. Seja como for, com a vontade ou sem a vontade dos mexicanos, seria inevitável o crescimento, a adoção de novas tecnologias e a mudança nas políticas. Essa mudança na política industrial mexicana não seria mensurável no curto prazo e seria preciso um acompanhamento do que venha a acontecer nos próximos anos para que essa mensuração seja possível. As próprias empresas diriam que não tomam suas decisões com base no preço atual do petróleo, mas sim com base em um cenário de vinte ou trinta anos adiante. Isso é o que se deveria fazer para avaliar os resultados da política. A reforma seria ainda muito recente e teria sido feita muito rapidamente, podendo aparecer erros que tenham que ser corrigidos. Então, deve-se ter meios de ajuste da política, para que os resultados possam ser convergentes.

\subsection{6 - Avaliação da Política}

\section{a) Governo}

O gráfico 34, abaixo, apresenta as respostas dos entrevistados do governo mexicano, sobre a avaliação dos mecanismos de monitoramento e avaliação da política industrial de petróleo e gás no país.

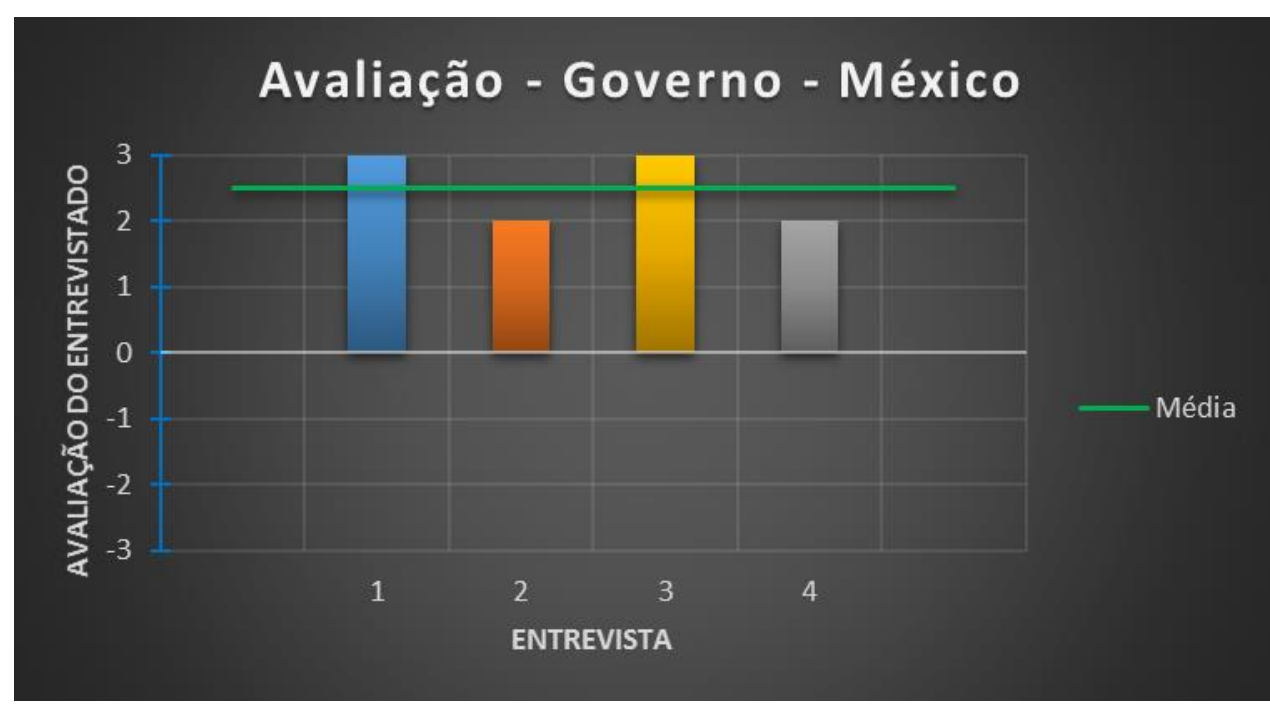

Gráfico 34 - Avaliações dos entrevistados do governo do México sobre a avaliação da política industrial de petróleo e gás no país. 
Neste bloco nenhuma perspectiva foi levantada por todos os quatro entrevistados, nem mesmo por três deles. Dois dos entrevistados disseram acreditar que existem mecanismos de monitoramento e avaliação da política mexicana. Como em qualquer programa do governo, esses mecanismos incluiriam avaliações próprias constantes feitas dentro do governo, que às vezes seriam muito estritas, completas e exaustivas. $\mathrm{O}$ congresso faria avaliações frequentes, onde seria necessário reportar praticamente tudo que se faz no dia a dia do trabalho. No interior de cada órgão haveria uma parte de acompanhamento através da controladoria interna deste órgão, que seria responsável por avaliar o cumprimento de metas e objetivos. A Secretaría de Hacienda também imporia um controle de obtenção de metas com base no orçamento disponibilizado, relacionando a quantidade de recursos solicitados com os resultados que se compromete em obter. Isso tudo poderia ser visto como um fardo, mas já estaria praticamente automatizado e disponível de forma pública na internet. Então, seria possível acompanhar cada processo de obtenção de autorização, ou algum outro processo, pois tudo estaria online. Seria possível acompanhar diariamente o que está sendo feito em cada área, como as definições de cada órgão do governo e todas as resoluções. Esta seria uma forma de se demonstrar como é feita a retroalimentação para a definição dos temas. Outro mecanismo de avaliação seriam os fóruns de consulta, servindo de mecanismos de acompanhamento, vigilância e controle, que não são obrigatórios por lei, mas que permitem uma avaliação em termos de objetivos substantivos. Teria faltado apenas dar a capacidade de decidir algo para estes conselhos consultivos, pois só lhes teria sido dada a possibilidade de opinar. Também existiria uma inter-relação entre os setores de economia, fazenda e energia em distintos fóruns, que deveriam discutir e garantir os mecanismos através dos quais se irá ouvir a indústria nacional ou estrangeira.

Haveria ainda um outro mecanismo de avaliação que estaria sendo criado, por iniciativa de um dos entrevistados, e que seria um tipo de organismo externo, como uma universidade. Seria como um observador externo, que esteja sempre avaliando e dizendo o que está sendo alcançado e o que não está sendo, que possa ter acesso a tudo que é feito no órgão, que avalie de forma externa, sem nenhum tipo de agenda, nem compromisso, nem político, nem legal, nem nada. O maior problema para isso seria a forma de financiamento. Dentro do governo existiriam vários mecanismos de controle e acompanhamento, que fazem vistorias e exigiriam prestações de contas todos os meses, 
da mesma forma que é feito com a indústria automobilística. Particularmente ao setor de petróleo, se deveria buscar essa forma de avaliação que não tenha agenda de nenhum tipo. Sabe-se que é muito difícil encontrar esse tipo de observador, que seja neutro e que não seja político. Não é fácil, porque alguns tendem a se empoderar demais, enquanto outros tendem a cair no clientelismo. No México, não haveria esse tipo de organismo exógeno, externo, que permita ao governo se expor e ter essas avaliações.

Já para os outros dois entrevistados, ainda não haveria mecanismos de monitoramento e avaliação, nem ninguém que esteja planejando fazer isso de forma integrada. A política teria previsto indicadores precisos de desenvolvimento, infraestrutura, crescimento econômico e criação de empregos. Alguns órgãos também teriam criado uma área de planejamento, com o objetivo de gerar indicadores regulatórios, que permitam saber se o órgão está funcionando bem e se está atingindo suas metas. Existiriam também elementos como o plano quinquenal de upstream, ou o plano quinquenal de gás natural. Mas não haveria nenhum instrumento de avaliação previsto para o que foi feito até aqui. Por isso, os elementos de avaliação dessa fase seriam muito ruins. Haveria a previsão de se medir os resultados, mas não dessa fase, mesmo que o cumprimento de metas na outorga dos serviços e a emissão de documentos também devam ser medidos. O que se vendeu para a sociedade teria sido a queda do preço das tarifas de energia, que efetivamente baixaram, mas devido à queda do preço do barril de petróleo e não devido à política. Os resultados tangíveis da política ainda não estariam postos e teria que se esperar ainda mais alguns anos para que se possa medi-los.

\section{b) Associações Empresariais}

O gráfico 35, abaixo, apresenta as respostas dos entrevistados das associações empresariais mexicanas, sobre a avaliação dos mecanismos de monitoramento e avaliação da política industrial de petróleo e gás no país. 


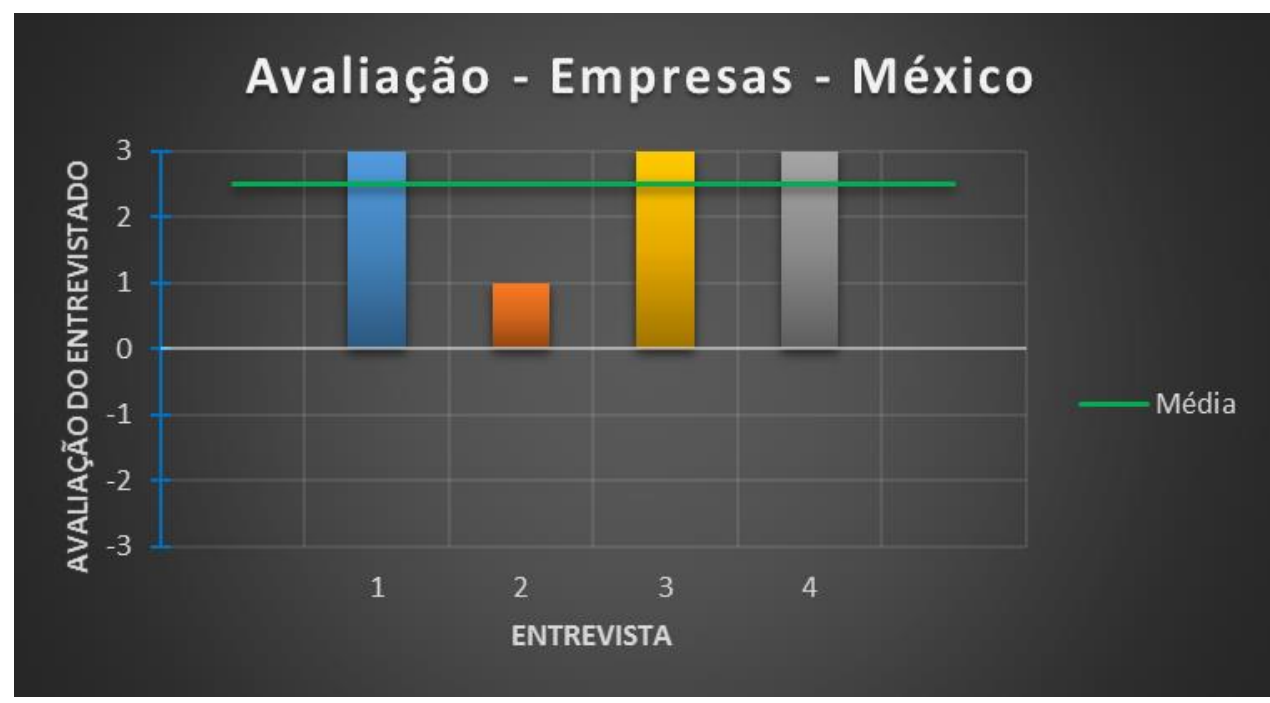

\section{Gráfico 35 - Avaliações dos entrevistados das associações empresariais do México sobre a avaliação da política industrial de petróleo e gás no país.}

Nenhum tema foi tratado em todas as quatro entrevistas, nem mesmo em três delas. Dois dos entrevistados demonstraram entender que a reforma energética teria criado todas as normas e medidas necessárias para a sua avaliação. Teriam sido criados os comitês de consulta, acompanhamento e avaliação, com a participação de muitos especialistas. Se teria criado organismos públicos (financiados com recursos públicos) e independentes (compostos por cidadão que pensam como conselheiros). Então se trata de órgãos colegiados, onde não seria apenas uma pessoa a responsável por tomar decisões, mas sim um corpo de seis ou sete pessoas. Haveria também o monitoramento permanente da opinião pública, das empresas e de analistas das empresas. Lembrando que devem existir no mundo por volta de uma dúzia de empresas de consultoria e análise que se dedicam a isso e que, em termos gerais, estariam sendo favoráveis ao que se tem feito no México. Haveria a impressão de que o México tem feito um muito bom trabalho até agora. Antes de se desenvolver toda a política, foram criados os mecanismos necessários para que ela funcione bem. Caso contrário, seria mais um caso de uma política que nasce sem nenhuma forma de controle. Mesmo que a avaliação seja positiva, sabe-se que serão necessários ajustes e flexibilizações ao longo do caminho, conforme for se adquirindo mais experiência.

Já os outros dois entrevistados defenderam que seria muito cedo para que se tenha mecanismos de monitoramento e avaliação. O governo não teria começado a desenvolver 
esses mecanismos, pois estaria recém fazendo os primeiros contratos. Um desses entrevistados disse não conhecer esses mecanismos para o setor de petróleo, nem sequer saber se eles estariam sendo feitos por alguém, apesar de conhecer mecanismos assim no setor elétrico mexicano. Até agora, não haveria uma posição muito clara do governo com relação a quais serão os elementos para avaliação da política. No México haveria muito desse problema de não se ter mecanismos claros de avaliação das políticas em geral. Mesmo assim, isso não seria preocupação dos governos.

Foi lembrado em uma das entrevistas que se essa avaliação for feita no curto prazo, será uma avaliação falsa, pois deve-se avaliar esta política no médio e longo prazo. Devese, portanto, resistir à tentação de se dizer que a fase um teria sido um desastre, por ter arrematado apenas dois dos quatorze blocos oferecidos, uma vez que a avaliação deve considerar um lapso temporal muito maior.

\subsection{7 - Reação aos Resultados da Política}

\section{a) Governo}

O gráfico 36, abaixo, apresenta as respostas dos entrevistados do governo mexicano, sobre a avaliação da reação aos resultados encontrados pelos mecanismos de monitoramento e avaliação da política industrial de petróleo e gás no país.

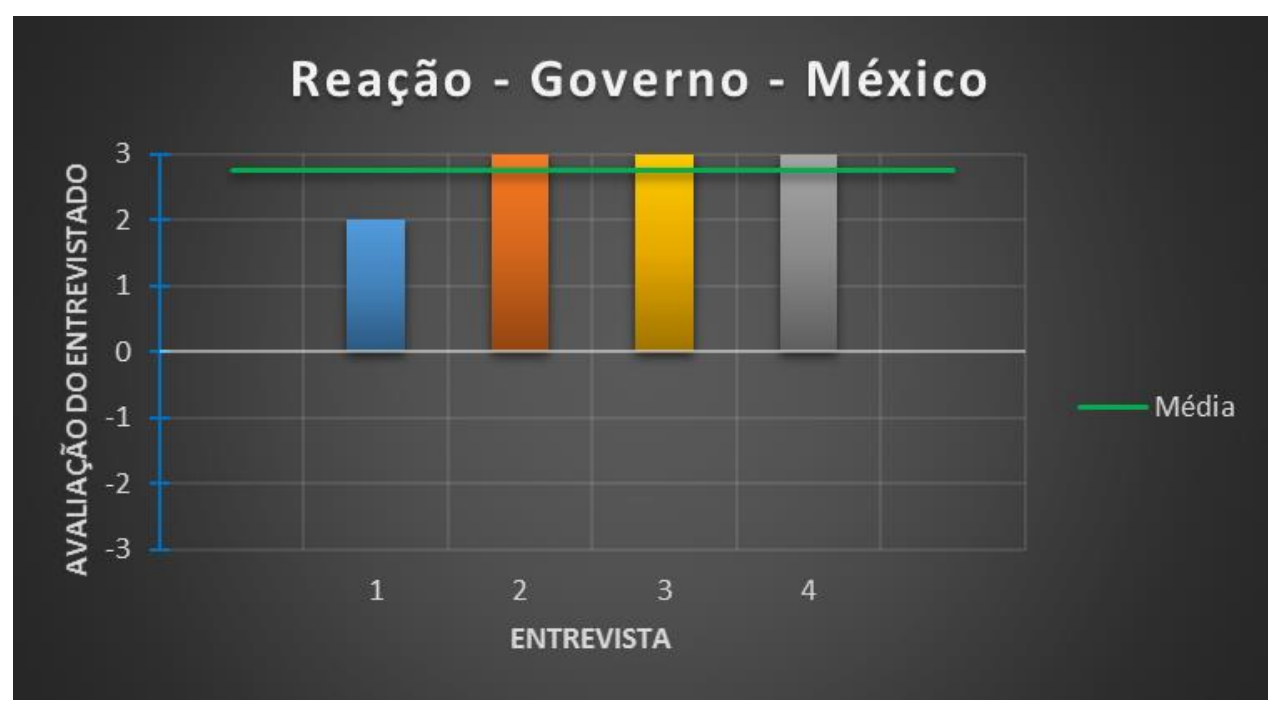

Gráfico 36 - Avaliações dos entrevistados do governo do México sobre a reação aos resultados da avaliação da política industrial de petróleo e gás no país. 
Não houve nenhuma perspectiva que tenha sido levantada por todos os quatro entrevistados. Em três entrevistas foi ressaltado que os resultados obtidos na primeira fase da ronda um teriam obrigado o governo a repensar toda a política e fazer uma autocrítica e análise. Um dos entrevistados mencionou que ainda não seria o momento para que se faça essa revisão da política, pois se estaria ainda no começo de todo o processo. Outro entrevistado disse que foram recebidos comentários e observações, que irão servir de base para que se assimile, de forma conjunta, quais ajustes serão necessários. Haveria também um processo de fiscalização feito por uma auditoria superior que, quando necessário, poderia exigir um plano de trabalho corretivo. No ano seguinte, haveria uma fiscalização para saber se tudo teria sido cumprido e, caso contrário, o assunto poderia ser levado para instâncias administrativas adicionais. Para o terceiro entrevistado, quando os resultados de uma ronda não são bons, devem ser repensados para as rodas seguintes. Seria melhor parar o que está sendo feito do que seguir fazendo as coisas do mesmo jeito, pois já se sabe que isso não trará os resultados desejados. O governo parece estar tentando fazer essa análise e autocrítica, o que daria esperança de que se estaria tentando fazer a reforma de uma maneira bem-feita. O único resultado que se tem até agora seria a primeira fase da ronda um. Como esse resultado foi muito ruim, o que não era esperado pelos analistas, a reação do governo de recuar foi considerada muito boa.

Em uma das entrevistas foi dito que, se o governo conseguir baixar o custo da energia, não seria necessário alterar a política. No longo prazo podem ser criados outros indicadores como o desenvolvimento de infraestrutura, a entrada de investimentos e a capacitação de novos recursos humanos. Mas num primeiro momento, o objetivo seria apenas o de baixar o custo da energia.

Foi mencionado que quando se trata de ser transparente - dizendo para todos o que se está fazendo, o que se vai fazer, porque se está fazendo dessa forma, para onde se pretender ir, o que se tem até aqui, onde está o que se persegue - se teria uma melhor reação e um melhor entendimento dos demais atores. Porém, ainda não estaria ocorrendo nenhum tipo de debate ou uso de dados para a orientação da política. Essa orientação deveria acontecer nas mesas de discussão que estão sendo estabelecidas. A informação gerada por um órgão deve ser propriedade de todos, para que esse debate possa gerar uma retroalimentação. 
O fato de todos estarem inteirados do que está acontecendo serviria como uma blindagem para o governo. Com todo mundo participando, não haveria surpresas para ninguém, pois seria resultado do trabalho de todos. Como teria participado e ajudado a construir, o setor privado teria a "sensação" de que a política seria também resultado do trabalho deles. Estaria havendo a utilização dos dados da avaliação para a definição da política de uma forma muito aberta. Essas informações devem estar acessíveis a todos, pois outros atores podem ter alguma informação melhor ou diferente, que deve ser sempre bem-vinda. Como a indústria de petróleo é muito especializada, poderia ocorrer um centro isolamento e, por isso, quanto mais a sociedade estiver envolvida no processo de definição da política, melhor. O objetivo seria construir uma "caixa de cristal”, que ofereça clareza e certeza para investidores, sociedade e governo, de que os objetivos estão sendo alcançados. Um processo que seja aberto e transparente teria muito mais chances de sucesso. No caso do México, os atores estariam em uma espécie de "lua de mel”, onde todos participam, cooperam e tudo funciona bem. A vinculação entre resultados, princípios, objetivos e fiscalização estaria perfeitamente alinhada.

Um dos entrevistados disse que acredita que sempre existam outros interesses envolvidos na definição da política industrial de petróleo e gás. Ele acredita que, através da mudança na lei, a reforma estaria procurando fazer com que esses interesses tenham menos influência negativa na indústria do que tinham até então. Para isso, teriam criado a figura de conselheiros independentes e conselheiros de administração. Mesmo que a influência desses interesses realmente diminua, o entrevistado acredita que jamais irão desaparecer, pois as empresas públicas seriam muito poderosas. Além de serem uma fonte de recursos financeiros, a definição das tarifas energéticas, por exemplo, teria grande importância política para as eleições.

\section{b) Associações Empresariais}

O gráfico 37, abaixo, apresenta as respostas dos entrevistados das associações empresariais mexicanas, sobre a avaliação da reação aos resultados encontrados pelos mecanismos de monitoramento e avaliação da política industrial de petróleo e gás no país. 


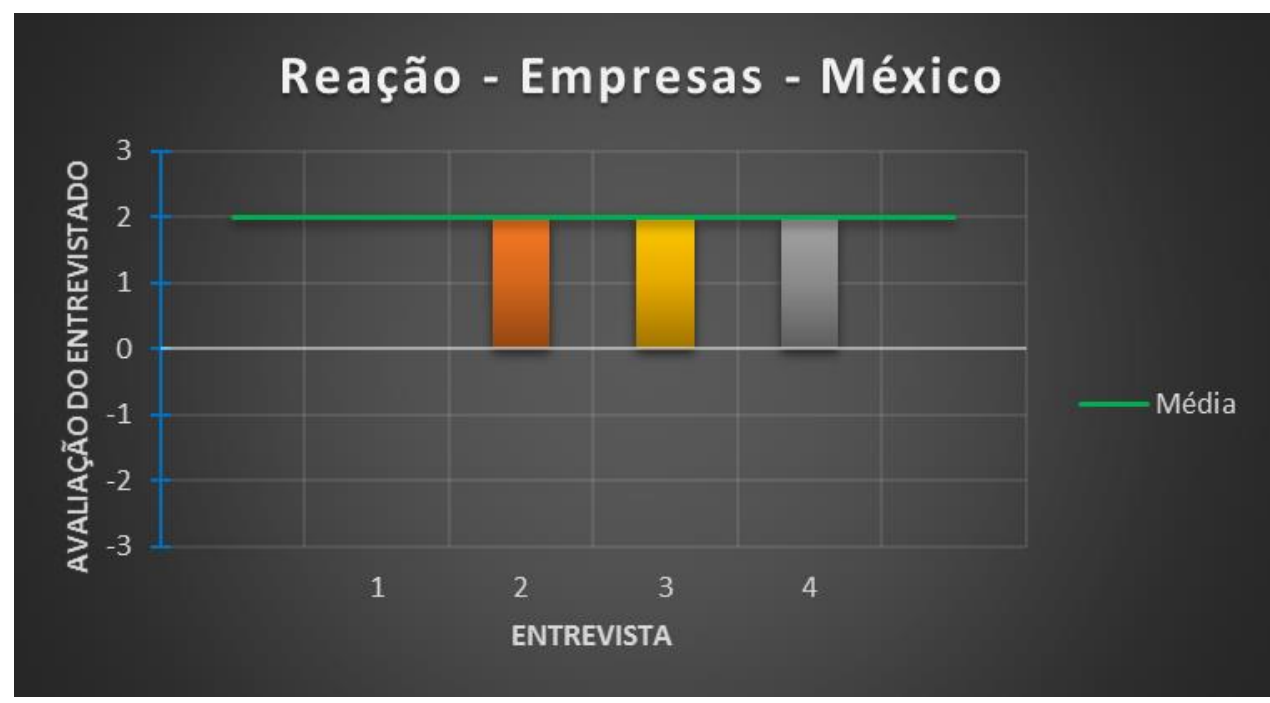

\section{Gráfico 37 - Avaliações dos entrevistados das associações empresariais do México sobre a reação aos resultados da avaliação da política industrial de petróleo e gás no país.}

Todos os quatro entrevistados manifestaram, de alguma forma, a ideia de que ainda seria muito cedo para que se possa avaliar a reação aos dados obtidos pela avaliação da política mexicana. Para um dos entrevistados, como não haveria uma política muito clara sobre os mecanismos de avaliação, não seria possível haver uma reação a essa avaliação e, por isso, ele não apresentou uma resposta objetiva. Existiria acesso aos dados do governo e o processo de assinatura de contratos e permissões deve ser bastante transparente, mas a avaliação estaria prejudicada porque a política ainda não teve resultados. Outro entrevistado disse que não estaria havendo debates com muitos setores da sociedade e haveria gente pedindo que esse debate seja mais aberto. Mas isso não teria sido feito porque o debate no México costuma servir para revoltas e manifestações, e haveria grupos de interesse e controle por trás dos manifestantes. Um terceiro entrevistado defendeu que o que se teria até aqui seria apenas uma reação retórica e política que não se baseia em resultados. Enquanto o quarto entrevistado disse que, mesmo sendo cedo para se analisar a reação, os mecanismos de avaliação já estariam presentes e se teria a expectativa de que eles funcionem bem.

Em três entrevistas houve menção ao fato de que, no passado, os interesses políticos pareciam influenciar mais a orientação da política. Já esse governo daria a impressão de estar sendo muito proativo e de estar escutando muito ao setor privado, permitindo que ele participe da definição da política. O crescimento da participação e a 
consolidação da indústria nesse setor estaria ajudando a fazer com que a opinião e a presença da indústria sejam cada vez mais importantes. Para um desses entrevistados, a política ainda não seria baseada na realidade, mas sim em setenta anos de um mito e de um tabu histórico. Haveria um fervor nacionalista muito forte, e mudar essa percepção e essa cultura seria muito difícil. Os mexicanos estariam acostumados a governos mais totalitaristas e autoritários, e os políticos do atual governo estariam habituados a esse tipo de práticas. Então, para eles teria sido muito difícil essa questão de terem que ser abertos, transparentes e com foco na prestação de contas. Mas mesmo que essa tenha sido a parte mais difícil para o governo colocar em prática, hoje em dia isso seria indispensável. Além disso, o México teria chegado a uma situação de bipartidarismo que seria o que os Estados Unidos sempre desejaram. Dessa forma, eles podem negociar com um grupo e, quando houver algum desgaste, passar a negociar com outro. Ao mesmo tempo, a existência de apenas duas opções diminuiria a instabilidade política.

Uma questão trazida por dois dos entrevistados foi a ideia de que a população estaria sempre mais interessada em obter resultados imediatos. Um cidadão normal mexicano não entenderia muito bem a diferença entre uma política de Estado e uma política de governo. Teria dificuldade em entender que a construção de uma refinaria, ou a licitação de um campo petrolífero toma muito tempo. Por isso, a reforma energética não deveria ter sido utilizada como plataforma de campanha eleitoral, como teria sido feito por um candidato municipal, que disse que a reforma traria mais empregos e reduziria preços. Isso teria feito a população criar expectativas e deixar de entender que este é um processo que leva anos para apresentar resultados.

Houve a manifestação de um entrevistado no sentido de que com a segunda fase da ronda um seria possível que se verifique se as autoridades aprenderam com a experiência da primeira fase. Na licitação de três dos blocos que foram oferecidos, por exemplo, algumas empresas foram descartadas por oferecerem abaixo do mínimo exigido. Como a diferença entre o mínimo exigido e o oferecido seria de menos de 5\%, seria necessário um pouco mais de flexibilização neste ponto na próxima ronda, para que em casos de diferenças muito pequenas como essa, seja possível que a empresa faça uma nova oferta imediatamente.

Também foi mencionado que não se pode medir a reação a esta política de forma isolada dos demais fatores que influenciam o país. O governo mexicano não teria uma 
aprovação generalizada e a população estaria cética com a reforma, sem entender muito bem porque houve mudança na política. Para os mexicanos, a Pemex estaria cumprindo com seu papel, por estar garantindo a gasolina necessária para o mercado interno. A esquerda do país sempre teria feito oposição à abertura do setor, especialmente na pessoa de López Obrador, que será novamente candidato à presidência em 2018, e disse que a reforma era um presente que o México estaria oferecendo para outros países. Mas isso não passaria de parte da retórica esquerdista mexicana. O cidadão comum estaria vendo também as notícias de que o resultado da ronda um teria sido um fracasso, mesmo que os meios especializados digam que não. A opinião pública da não-elite mexicana, daquelas pessoas que não são bem informadas, reagiria conforme o que sente no seu bolso. Por isso, teria bons olhos para a reforma dos setores elétrico e de comunicações, já que ambos baixaram seus preços depois da reforma. A reação à entrada do México no NAFTA também teria sido negativa no começo, com a ideia de que isso acabaria com a indústria mexicana. Hoje, o "mexicano médio" estaria satisfeito com isso, pela maior variedade de produtos que ele tem a sua disposição, pelos preços mais baixos, pela qualidade maior e pelo ganho de competitividade. De qualquer maneira, o que venha a acontecer nos próximos anos será importante para formar a opinião pública sobre se a política trouxe desenvolvimento econômico, se ajudou a criar empregos, se ajudou a crescer o produto interno mexicano e se, de uma maneira geral, beneficiou o cidadão comum.

\subsection{8 - Resultado das Avaliações}

\section{a) Governo}

Os gráficos 38, 39, 40 e 41, abaixo, apresentam as respostas objetivas sobre todas as etapas da política industrial mexicana de petróleo e gás, apresentadas pelos quatro entrevistados do governo mexicano. 


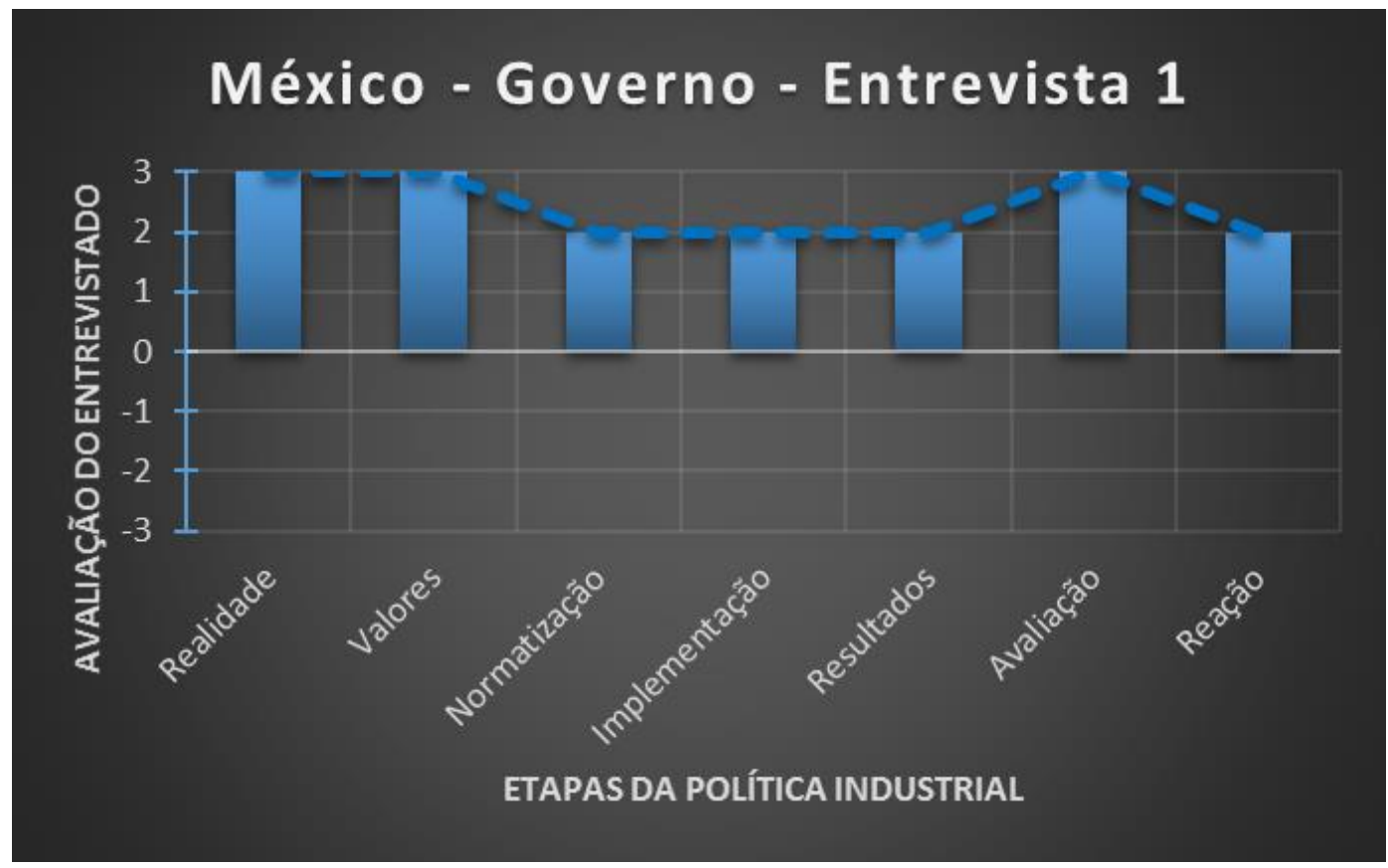

Gráfico 38 - Avaliação sobre as diferentes etapas da política industrial de petróleo e gás no país, pela entrevista 1 do governo do México.

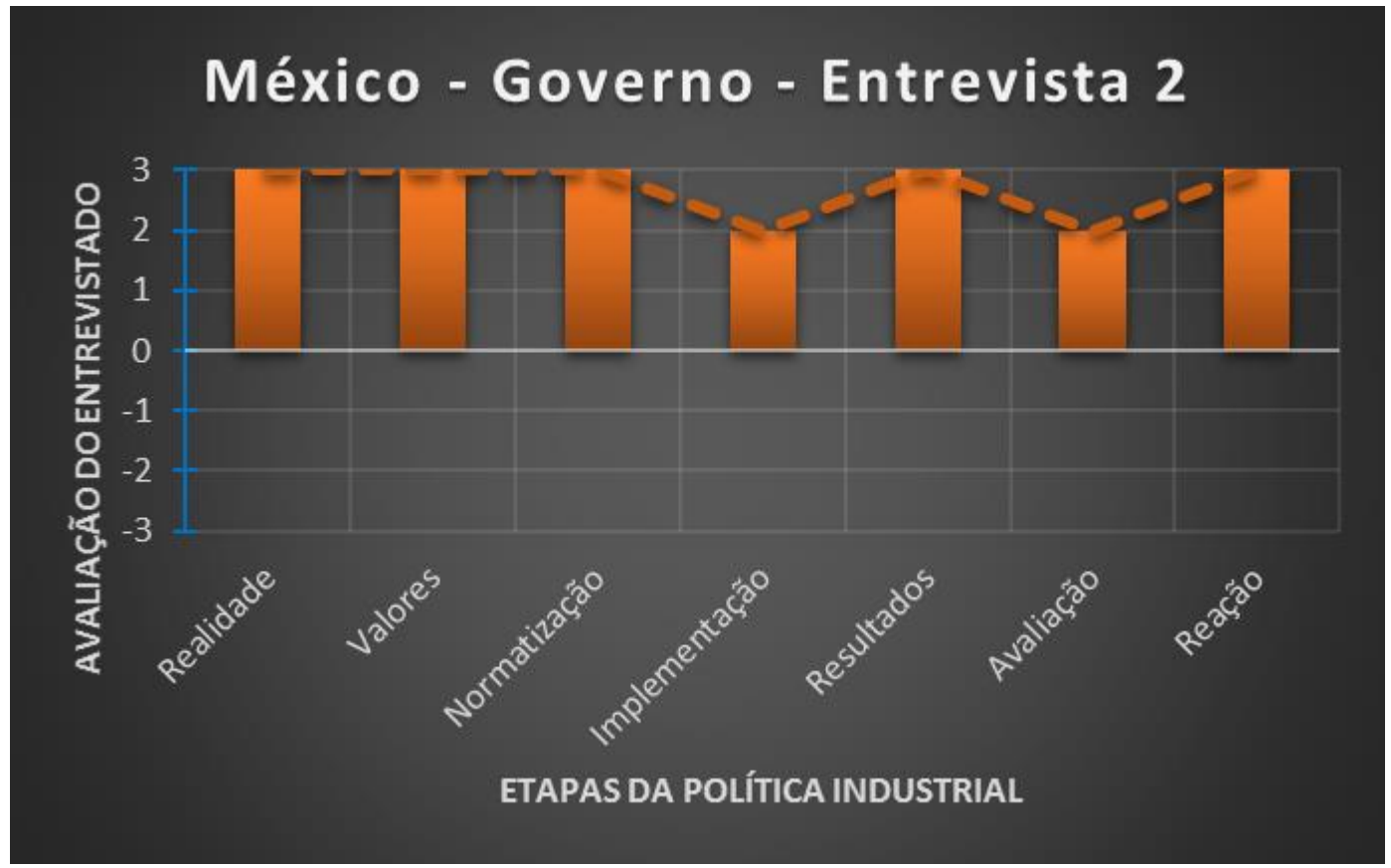

Gráfico 39 - Avaliação sobre as diferentes etapas da política industrial de petróleo e gás no país, pela entrevista 2 do governo do México. 


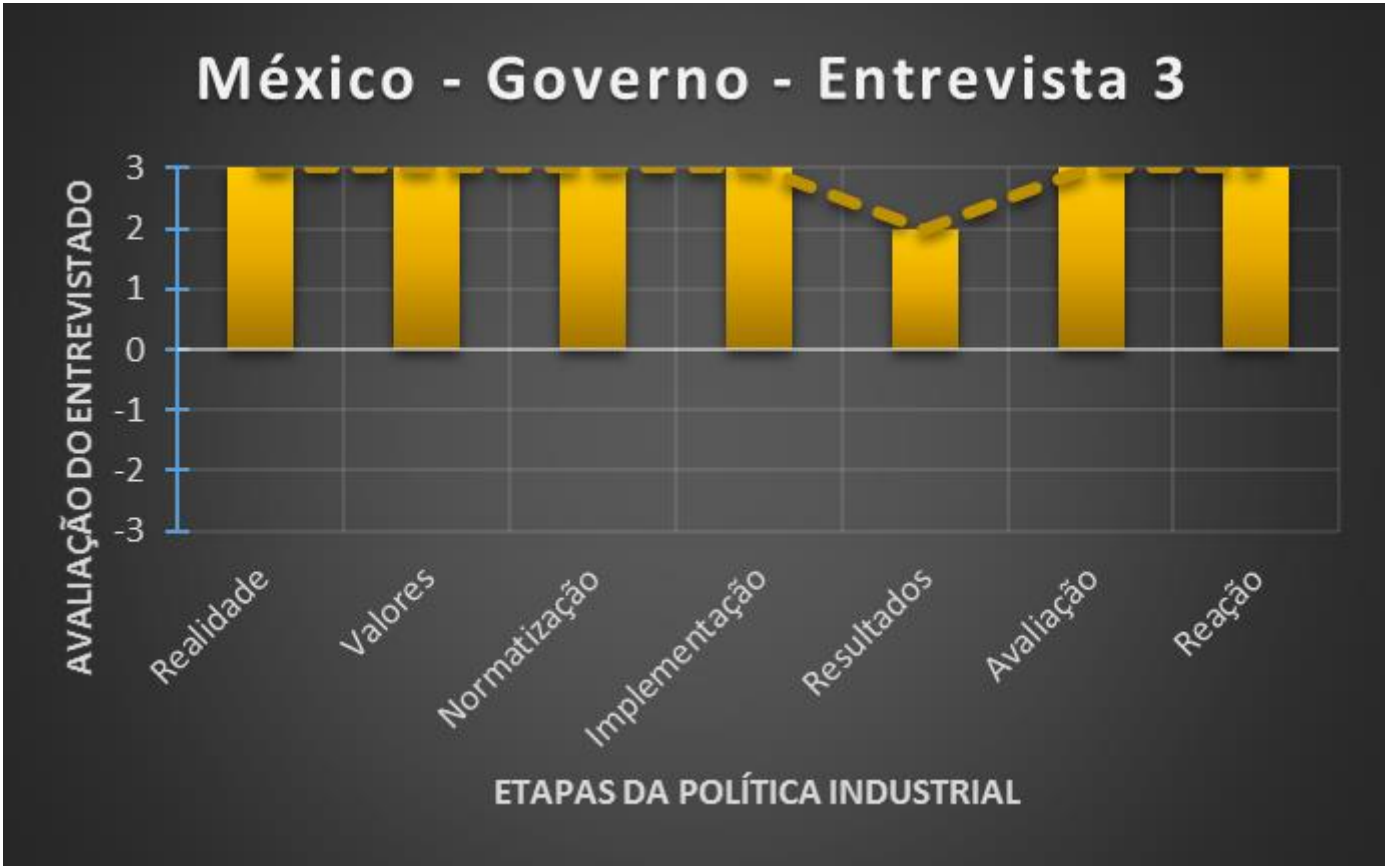

Gráfico 40 - Avaliação sobre as diferentes etapas da política industrial de petróleo e gás no país, pela entrevista 3 do governo do México.

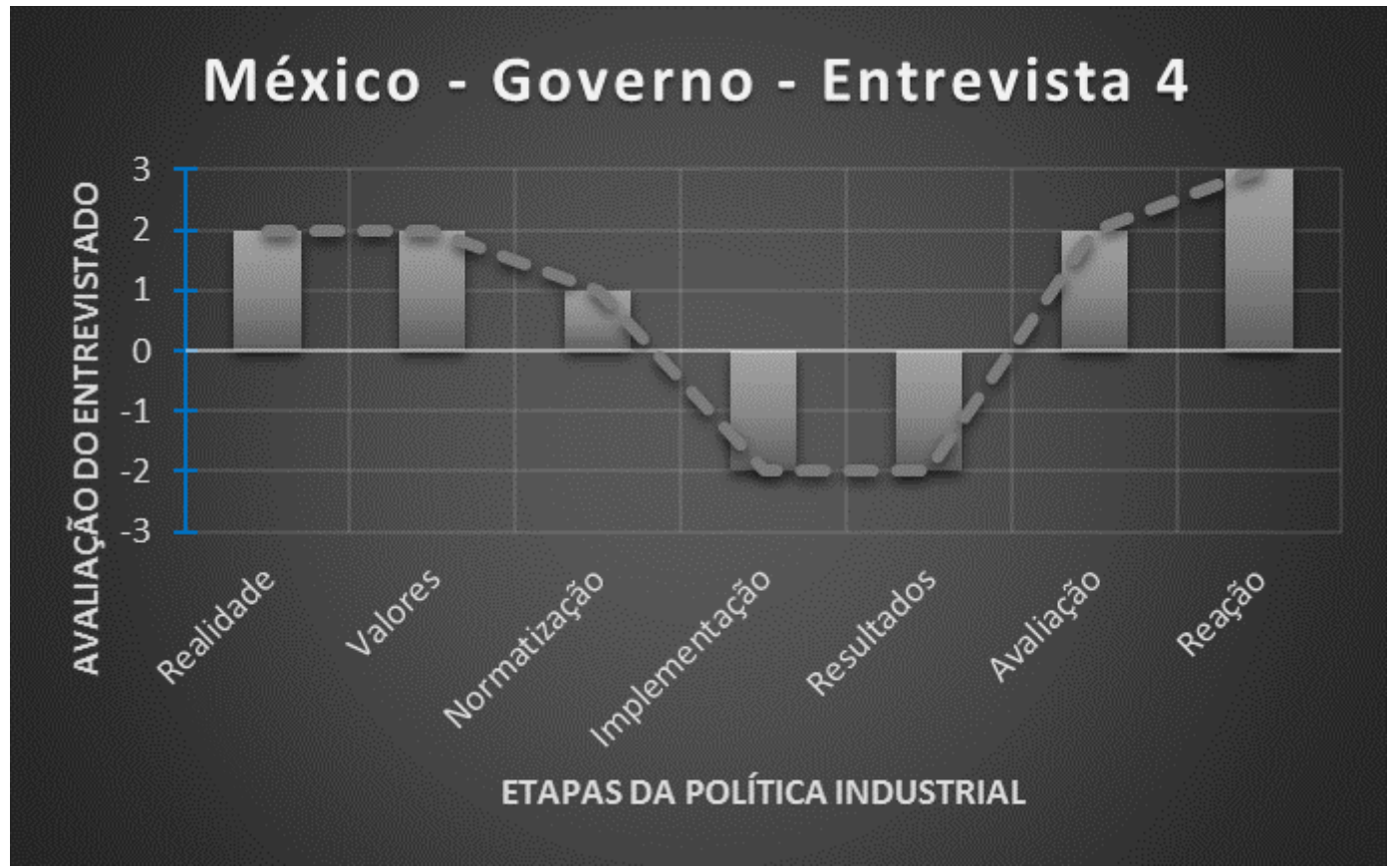

Gráfico 41 - Avaliação sobre as diferentes etapas da política industrial de petróleo e gás no país, pela entrevista 4 do governo do México. 


\section{b) Associações Empresariais}

Os gráficos 42, 43, 44 e 45, abaixo, apresentam as respostas objetivas sobre todas as etapas da política industrial mexicana de petróleo e gás, apresentadas pelos quatro entrevistados das associações empresariais mexicanas.

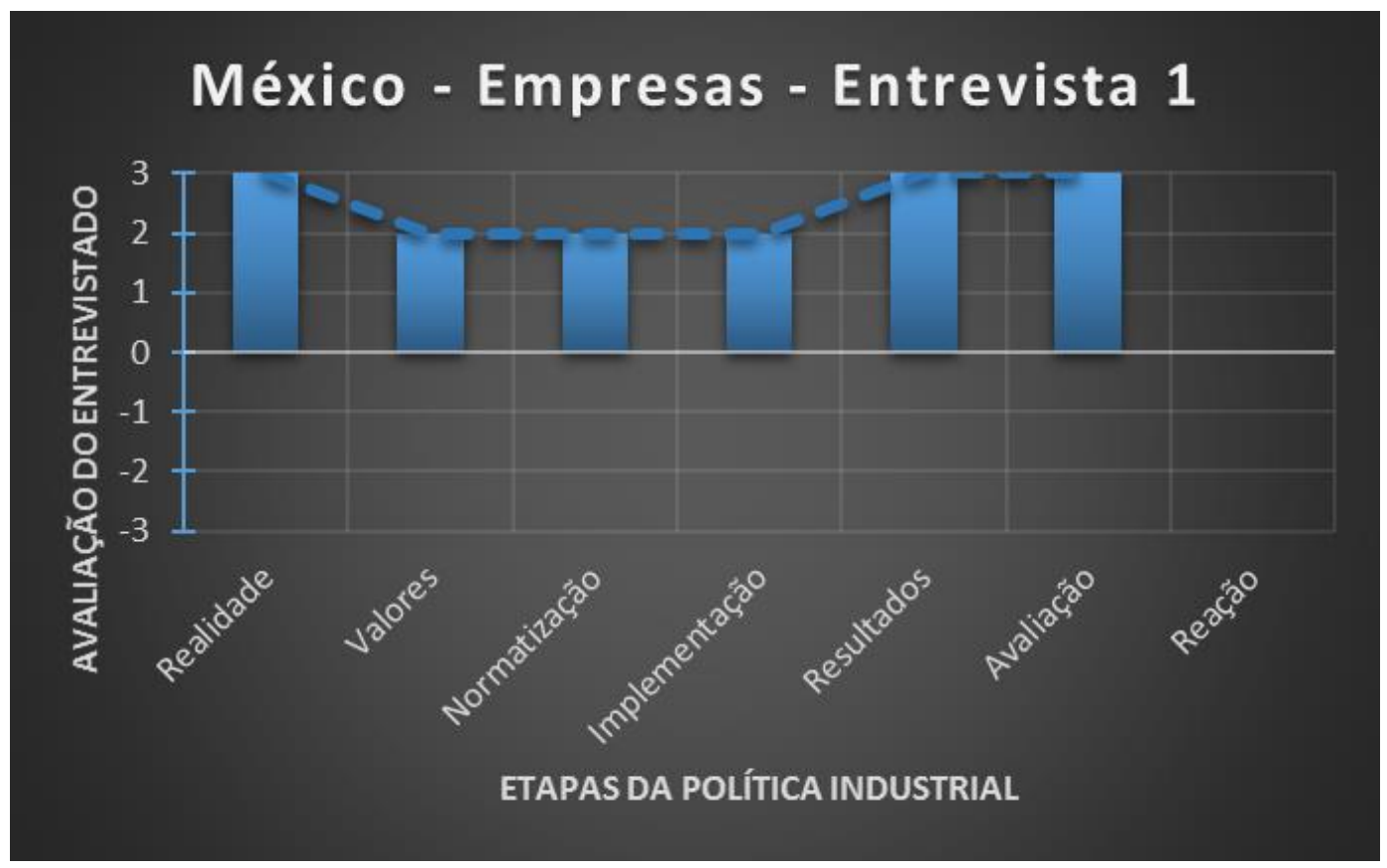

Gráfico 42 - Avaliação sobre as diferentes etapas da política industrial de petróleo e gás no país, pela entrevista 1 das associações empresariais do México.

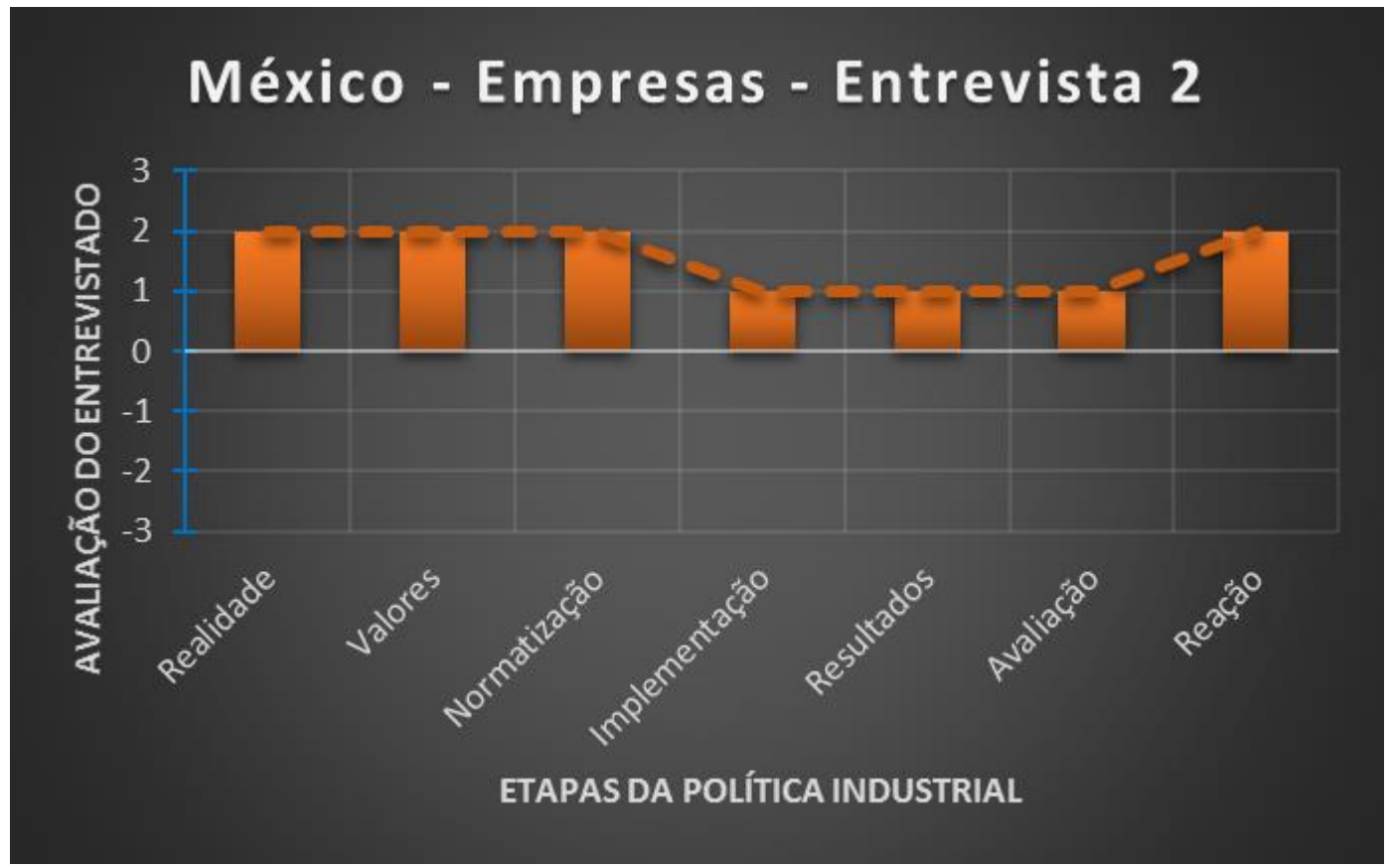

Gráfico 43 - Avaliação sobre as diferentes etapas da política industrial de petróleo e gás no país, pela entrevista 2 das associações empresariais do México. 


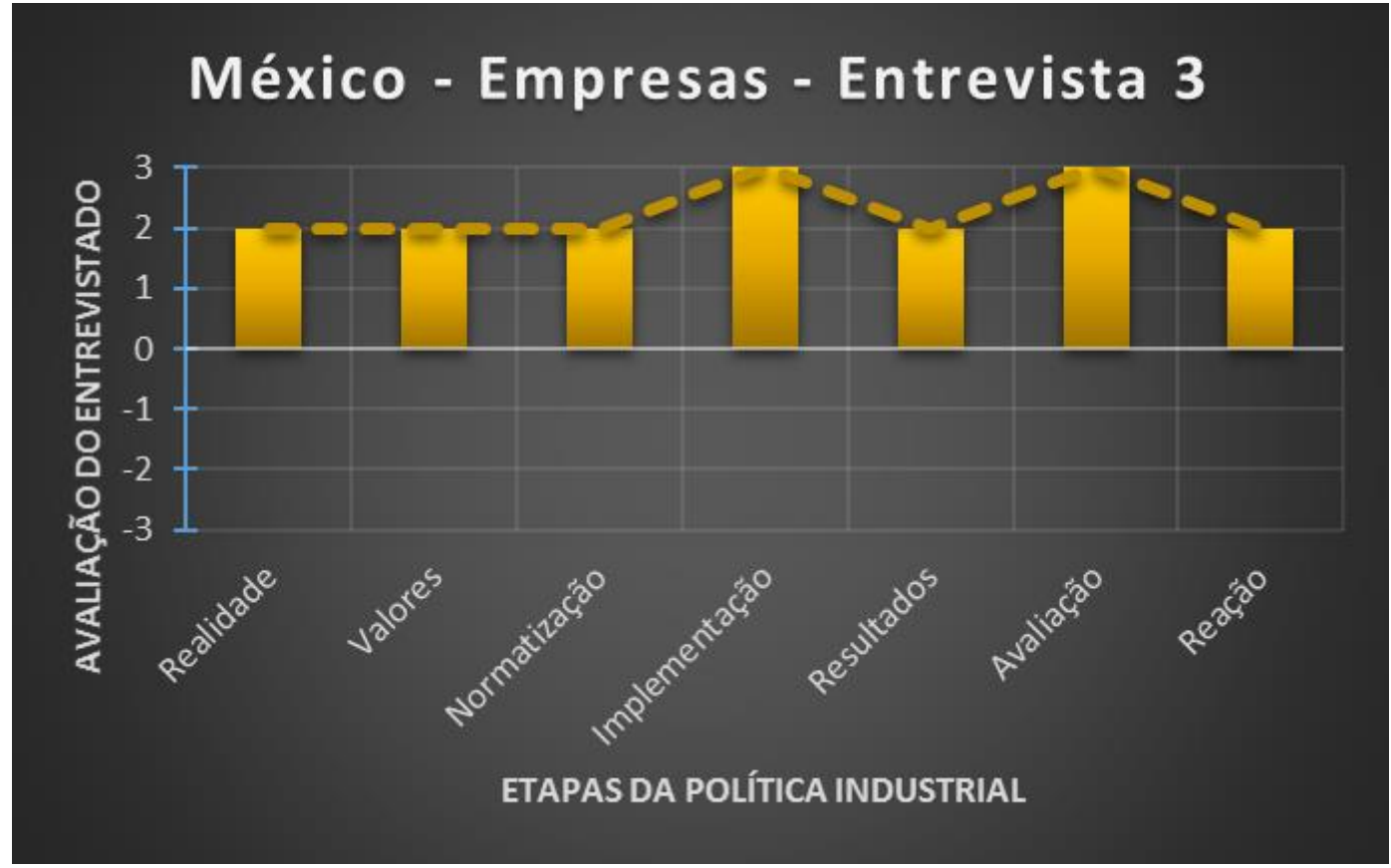

Gráfico 44 - Avaliação sobre as diferentes etapas da política industrial de petróleo e gás no país, pela entrevista 3 das associações empresariais do México.

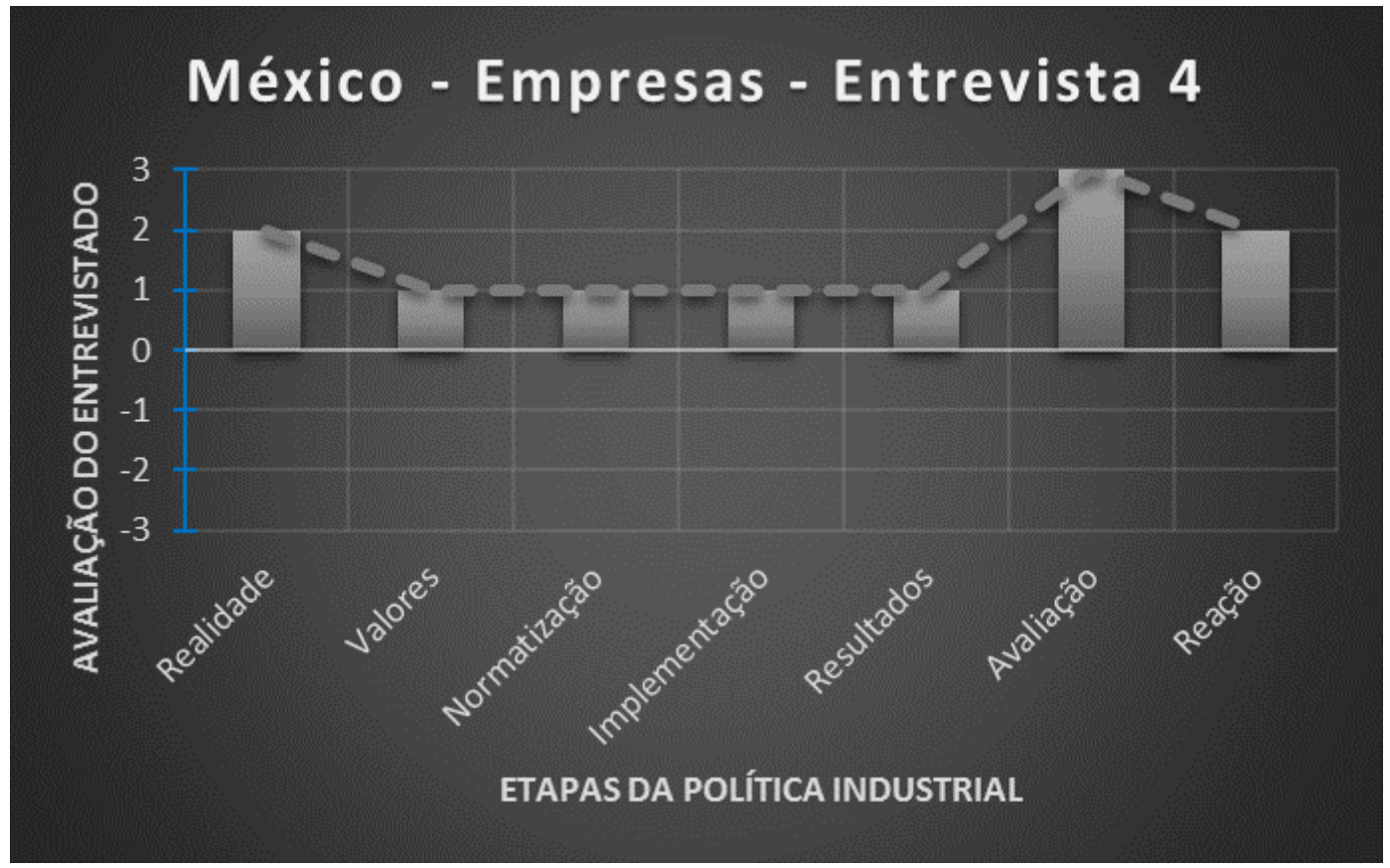

Gráfico 45 - Avaliação sobre as diferentes etapas da política industrial de petróleo e gás no país, pela entrevista 4 das associações empresariais do México. 


\subsection{9 - Relação Entre Atores}

\section{a) Governo}

O gráfico 46, abaixo, apresenta o percentual de menções positivas e negativas nas respostas dos entrevistados do governo sobre a relação entre os atores para a orientação da política industrial mexicana para petróleo e gás.

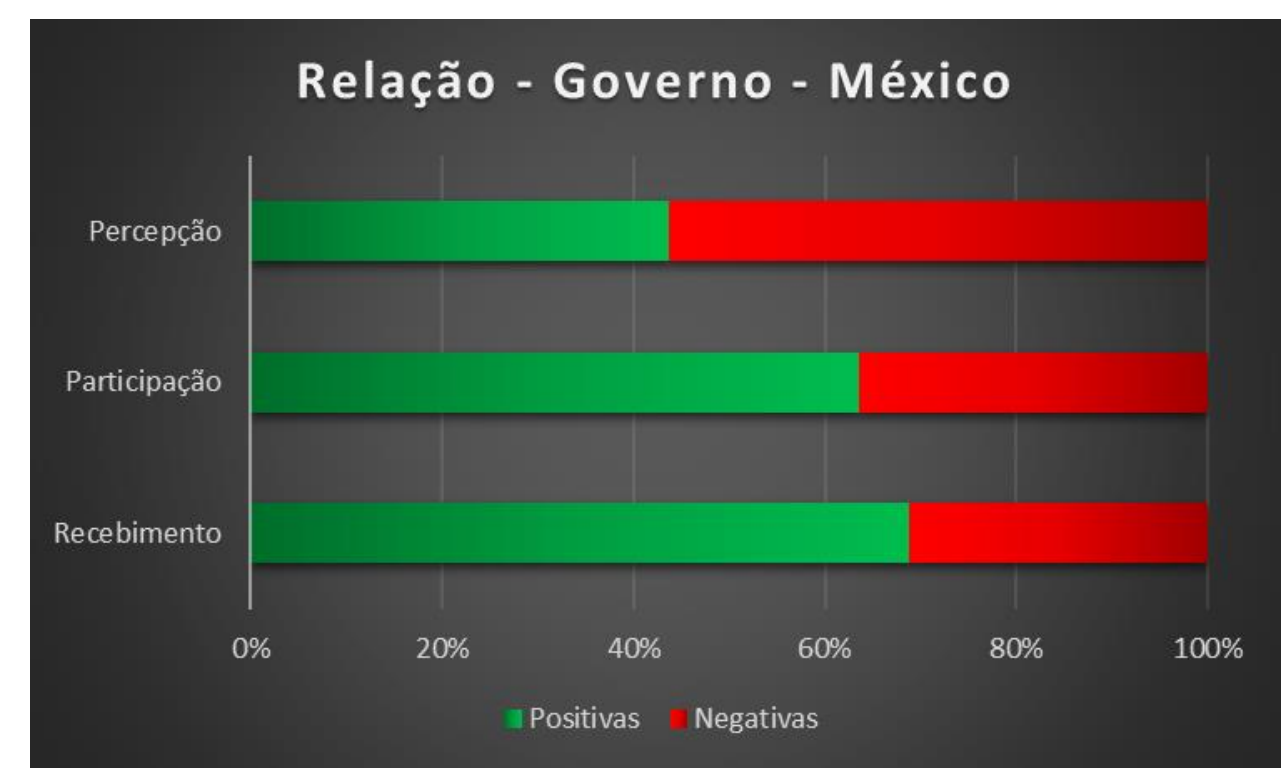

Gráfico 46 - Percentual de menções positivas e negativas nas respostas do governo sobre a relação entre os atores na orientação da política industrial mexicana.

\section{a.1) Percepção sobre as Associações Empresariais}

Com relação à percepção que os entrevistados do governo têm sobre as associações empresariais mexicanas, foram feitos dez comentários positivos. Em quatro desses comentários foi dito que as empresas estariam "felizes", "contentes" ou "entusiasmadas", mencionando inclusive a constante presença de representantes das empresas nos órgãos do governo. Elas estariam se apresentando para participar de projetos e desenvolvendo suas capacidades e seu potencial, por estarem confiantes num processo ascendente e incremental de adaptação, para o desenvolvimento integral de toda cadeia. Então, as associações empresariais teriam a consciência de que a política 
industrial se trata de um processo e de que o governo estaria trabalhando bastante para resolver os problemas e apresentar os critérios necessários. Em duas ocasiões foi mencionado que já haveria uma certa base industrial no México e que não se estaria começando do zero, pois se trata de um país petroleiro há mais de setenta e cinco anos, que já teria o fornecimento de serviços nacionais. O México seria o país mais exitoso do mundo na exploração em águas rasas, com uma imensa maioria de fornecedores nacionais, e teria ao menos três empresas mexicanas trabalhando, junto com a Pemex, na exploração de águas profundas e não-convencionais. Todos os atores estariam de acordo sobre a necessidade de se criar uma indústria nacional, que eventualmente seja internacional, como teria sido feito na indústria automobilística, que adotaria uma atuação global, importando e exportando, e seria a política industrial mexicana de maior sucesso. Também foi elogiada a participação conjunta de capital privado mexicano e internacional nas rondas e o estabelecimento de um período de adaptação para o atingimento dos objetivos de conteúdo nacional. Diferentemente do Brasil, que teria imposto objetivos muito altos, o governo mexicano teria a consciência de que as empresas iriam precisar de um tempo para que possam acreditar na política.

Oito comentários foram feitos com menções tanto positivas quanto negativas. $\mathrm{O}$ potencial de desenvolvimento dos fornecedores pequenos e médios estaria diretamente relacionado com o sucesso ou fracasso da Pemex, que dependeria da sua participação na exploração em águas profundas. Também disseram que a Pemex seria agora apenas mais um jogador e que não teria preferência de nenhuma forma. Ainda teria a desvantagem de as normas não estarem baixando os padrões de exigência para se adaptar às capacidades da Pemex, mas também não estariam sendo impostas cargas adicionais ou distintas das que serão colocadas para qualquer outro operador. Então o grande desafio da Pemex seria o de se adaptar à nova realidade, mas esse também seria um desafio para o governo e para os fornecedores nacionais. A percepção sobre as empresas dependeria, pois alguns grupos estariam "contentes" por terem se sentido beneficiados, enquanto outros não. As empresas estariam recém começando a conhecer as novas leis, mas também devem estar preocupadas com a falta de mecanismos de avaliação. Em outro momento, foi dito que o direito à expropriação sempre existiu na constituição mexicana e que a reforma não o teria modificado, mas apenas estabelecido um processo para que se busque uma solução antes que a expropriação seja utilizada, porque este seria um processo pouco eficiente. Não haveria problema em as empresas terem opiniões diferentes das opiniões do governo 
sobre direitos humanos, ou questões ambientais. Isso seria até natural, pois caberia ao governo e não às empresas proteger e maximizar o interesse público.

Em quatorze oportunidades foram feitos comentários negativos sobre as empresas e associações empresariais mexicanas. Quatro dessas menções foram sobre preocupações das empresas, como o fato de elas estariam com medo dos resultados, ou a necessidade de desenvolvimento maior em águas profundas e não-convencionais, que seriam temas de fronteira para os mexicanos. Os privados teriam preocupação com o foco em temas sociais, ambientais e toda carga burocrática, como a necessidade de permissões para atividades que outros países não costumam exigir permissão. Haveria muita reclamação por um excesso de burocracia que não havia antes, mas isso seria uma consequência da abertura, pela necessidade de reorganização institucional, dividindo decisões e responsabilidades, para que não se fique dependente de apenas uma entidade, ou de uma pessoa. Em duas situações foi levantada a necessidade de uma mudança de mentalidade, pois, durante as conversas entre governo e empresas, ainda haveria um foco muito grande na Pemex. Os fornecedores nacionais teriam o desejo de continuar sendo fornecedores da Pemex e teriam dificuldade de internalizar o potencial que poderiam ter vendendo para empresas como Exxon, ou BP, simplesmente por estarem acostumados à situação anterior. Um outro problema enfrentado pelos mexicanos seria com alguns fornecedores nacionais que sempre estariam presentes e sempre teriam que estar satisfeitos, como o ramo de aço e o de plásticos. Isso seria algo que também faria parte da realidade brasileira, e o desejo seria de que o mercado seja repartido entre os melhores e não entre os de sempre. Foram feitas duas menções sobre a obrigatoriedade de consultas às comunidades locais quando são afetadas por algum projeto do setor de energia. Por um lado, o grande capital certamente não estaria satisfeito com essa obrigatoriedade, pois lhes seria mais cômodo passar por cima dessas questões, ou procurar formas alternativas de investimento. Por outro lado, a esquerda estaria se opondo a essa obrigação dizendo ser uma perda de tempo, pois a reforma teria mantido a possibilidade de expropriação contra a vontade das comunidades. As empresas estariam impacientes, querendo ver resultados, enquanto o governo estaria tentando balancear o objetivo de se ter bons resultados com o de desenvolver uma infraestrutura adequada. Mesmo que os fornecedores entendam isso, querem que seja feito logo e rápido. As empresas não teriam interesse na parte de monitoramento e avaliação, pois isso seria algo ligado a pessoas que trabalham com políticas públicas. Qualquer política pública seria algo muito complicado, pois seria 
sempre difícil conciliar o objetivo de maximizar o bem-estar social e o bem-estar individual, pois estes seriam praticamente contrários um ao outro. Com isso, as empresas constantemente reclamariam de que o governo não lhes permite maximizar suas próprias rendas, enquanto o governo alega estar tentando não deixar ninguém desprotegido. A visão do Estado seria mais de longo prazo, enquanto as empresas teriam necessidades mais imediatas e mediatas.

\section{a.2) Participação do Governo}

Sobre a participação dos órgãos de governo nas discussões sobre a política industrial de petróleo e gás mexicana, foram feitas vinte e uma menções positivas. Em onze delas os entrevistados dizem ter participado de alguma forma desse debate. Participaram na formulação de leis e no debate para melhorias. Houve colaboração para a inclusão de obrigações de conteúdo local, de consulta social e de respeito ao meio ambiente. Também relataram a participação em vários fóruns, mecanismos de consulta e em uma discussão constante, tanto dentro do governo como com empresas e outras instituições, para que se receba uma retroalimentação do que se tem feito. Em cinco oportunidades foram mencionadas características positivas sobre a relação entre os diferentes órgãos do governo, que teriam suas competências muito bem definidas, deixando muito claro para cada órgão qual a responsabilidade de cada um. Haveria comunicação e uma excelente relação entre esses órgãos, que trabalhariam muito próximos uns aos outros. Haveria uma interface para a comunicação entre esses órgãos, que estariam sob uma única e mesma lei, que coordenaria e permitiria a participação de todos. A liderança na definição de pontos importantes da política foi mencionada em duas situações. As regras seriam claras e abertas, e toda contratação passaria por uma análise de competência econômica, para que não haja barreiras de entrada, de permanência, nem de saída. A lei de transparência e acesso à informação obrigaria o governo a responder qualquer pergunta feita pelos cidadãos. E o governo estaria criando mecanismos de participação que iriam permitir que se tenha resultados positivos muito rapidamente, através de um processo sistemático e definido para que se tenha um esforço compartilhado.

Os comentários negativos sobre a participação do governo na definição da política industrial foram doze. Quatro deles diziam simplesmente que o órgão não havia 
participado de alguma etapa da política. Também foi dito que haveria muito pouca comunicação institucional, que se estaria correndo tanto que não teria havido tempo para planejamento e que, como ainda não teria desenvolvido todas normas que deveria, o governo seria coparticipe nos resultados negativos. Todos no governo estariam muito “ensimesmados", pois haveria muita coisa para ser feita em pouco tempo. Estaria faltando uma cabeça que coordene a implementação da reforma, reunindo todos os atores pelo menos uma vês por mês, para saber como as coisas estão andando. Alguns órgãos não estariam tendo a independência que deveriam ter, e acabariam sendo obrigados a realizar suas funções conforme a orientação de outros órgãos, gerando resultados indesejados. Como a reforma energética seria o pilar do atual governo, o encarregado dela deveria estar na chefia de gabinete da presidência, pois assim estaria acima de todos os secretários. Muitas vezes a Pemex e a CFE ficariam acima dos seus órgãos reguladores.

\section{a.3) Recebimento pelas Associações Empresariais}

Foram feitos onze comentários positivos sobre o recebimento das ações governamentais pelas associações empresariais mexicanas. Cinco menções foram feitas sobre a existência de uma relação muito boa entre governo e empresas, que incluiria um diálogo através de contato direto, onde as empresas sempre teriam a oportunidade de expressar seus pontos de vista, que seriam sempre escutados. Em nenhum outro setor haveria tanta abertura para que as empresas participem do desenho da política, como no caso do setor energético. Não teria havido conflito, nem controvérsias, sobre as etapas implementadas até aqui e todos estariam entendendo tudo muito claramente. A mensagem do governo de que a responsabilidade pelo desenvolvimento da cadeia de fornecedores não seria uma obrigação exclusiva do governo, nem exclusiva das empresas, mas sim um trabalho colaborativo, teria sido muito bem recebida pelas empresas. A segunda fase da ronda um teria sido desenhada especialmente para empresas pequenas, como resultado de um debate com associações. Os mecanismos institucionais de retroalimentação já estariam prontos e seriam públicos. Na página da Cofemer estariam todos os anteprojetos, assim como todo processo consultivo, e haveria a possibilidade de ver todos os comentários que houvessem sido feitos até aqui. A inexistência de comentários negativos ou críticas até aqui foi mencionada em dois momentos. Também foi manifestada a crença de que as empresas entendam que isso não se trata apenas de um discurso político. 
Por outro lado, foram feitos cinco comentários negativos sobre esse recebimento. Dois deles disseram que existe diálogo, mas que este diálogo não é colocado em prática. Em outros dois momentos foi mencionado que muito poucas empresas mexicanas participaram diretamente do desenvolvimento de infraestrutura, mas que não haveria nada na lei dizendo que apenas empresas grandes poderiam participar. Também foi dito que o regulador geralmente seria visto como uma "pedra no sapato", obstruindo e atrapalhando os investimentos. Isso aconteceria porque o objetivo do governo seria o de gerar para o país desenvolvimento (que não seria o objetivo das empresas, muito menos da Pemex) e competitividade (que não seria interessante para as empresas estrangeiras).

\section{b) Associações Empresariais}

O gráfico 47, abaixo, apresenta o percentual de menções positivas e negativas nas respostas dos entrevistados das associações empresariais sobre a relação entre os atores para a orientação da política industrial mexicana para petróleo e gás.

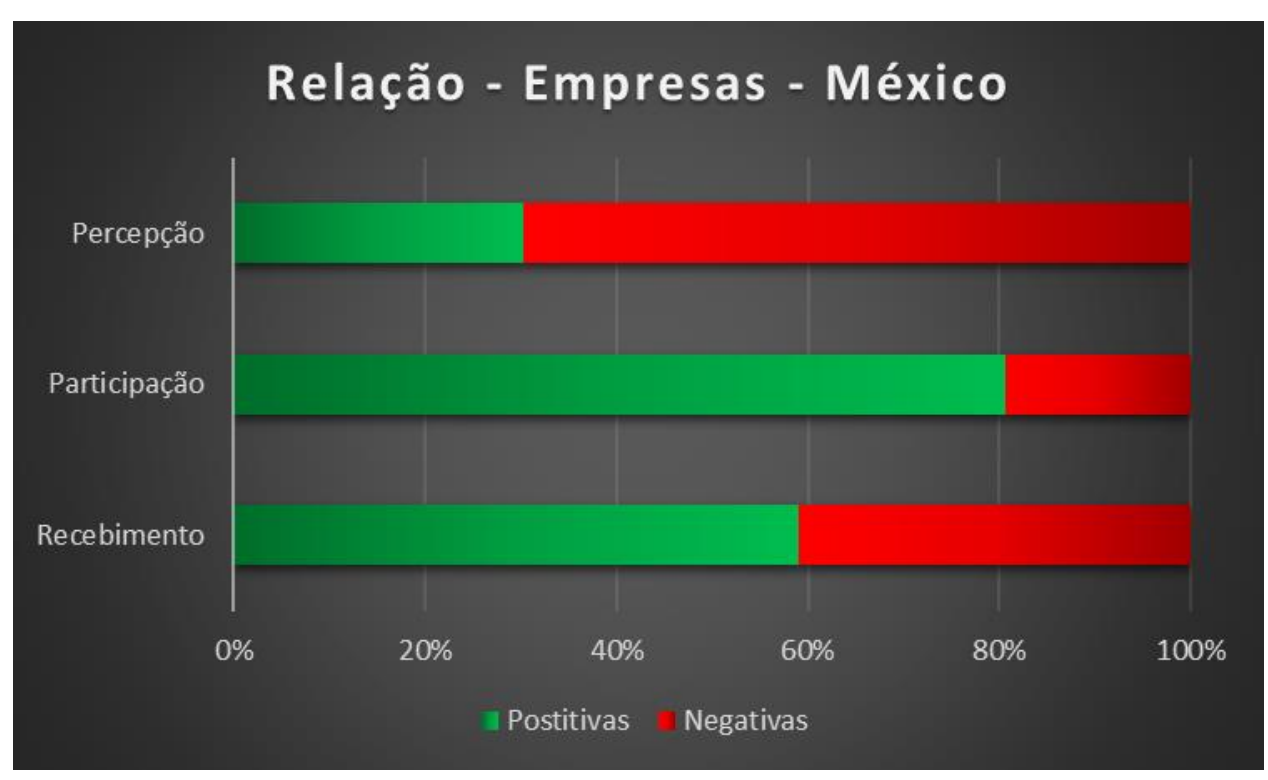

Gráfico 47 - Percentual de menções positivas e negativas nas respostas das associações empresariais sobre a relação entre os atores na orientação da política industrial mexicana.

\section{b.1) Percepção sobre o Governo}

Nas respostas dos entrevistados das associações empresariais foram feitas dez menções positivas sobre o governo mexicano. A percepção de que o governo estaria 
sendo mais transparente, apareceu três vezes, mesmo que seja relacionada a um espírito de transparência, ou a um desejo de ser transparente. Antigamente os contratos seriam muito obscuros, então o governo estaria estabelecendo mecanismos de transparência para que não o acusem de nada. Também em três oportunidades apareceu a impressão de que o governo estaria bastante envolvido, sempre informando as empresas sobre o que está acontecendo e sempre aberto a sugestões de melhorias. A capacidade de percepção do governo foi lembrada três vezes de forma positiva. Após os resultados decepcionantes da primeira fase, haveria consciência da necessidade de flexibilizar as normas para atrair o interesse das empresas. Saberia da necessidade de aumentar o conteúdo nacional, com a condição de que as empresas nacionais tenham a capacidade e a escala necessárias para cumprir com tudo que se comprometerem. O governo também teria a "sensação" de que a política energética, junto com a de telecomunicações, seriam as duas mais exitosas, entre as onze reformas que o atual governo colocou em prática nos seus primeiros anos de governo. A reforma da educação, por exemplo, estaria passando por uma grande crise. Foi destacado que, mesmo que todo governo goste de resultados imediatos, uma das principais mudanças que teriam ocorrido no México durante os três ou quatro últimos governos (ou seja, nos últimos vinte e cinco anos) teria sido a substituição de políticas de governo por políticas de Estado. Enquanto políticas de governo seriam de curtíssimo prazo, políticas de Estado seriam de médio e longo prazo. Mesmo que siga querendo resultados rápidos, o atual governo pareceria entender que muitas das decisões tomadas hoje terão seus resultados reais apenas em governos posteriores.

Já os comentários negativos foram vinte e três. A falta de diálogo e transparência apareceu em seis oportunidades. Foi dito que o governo talvez não diga publicamente o que realmente pensa, porque eles têm que parecer sempre muito otimistas. Haveria dúvidas sobre se a política adotada é $100 \%$ do governo mexicano, pois há quem acredite que ela seja fruto da influência de interesses dos Estados Unidos para que o mercado mexicano fosse aberto. O governo não saberia ouvir a todos, nem fazer uma consulta mais transparente, pois se ouvisse as associações elas teriam manifestado interesse em ter mais claridade sobre a situação dos campos mexicanos, para que os investidores nacionais tivessem a oportunidade de uma melhor avaliação. O governo estaria dizendo que é transparente, mas ele não seria $100 \%$ transparente. Foi dito que, antes mesmo das consultas prévias, já havia questões definidas, que não tinham possibilidade de mudança. Então, o ponto de partida não era o zero. Também aconteceria de o governo pedir para os 
privados se manifestarem sobre qualquer problema, mas depois diriam que não teria mais espaço para algumas correções, pois o momento já haveria passado. Não se percebe um interesse do governo em estabelecer compromissos, nem na questão do conteúdo nacional, nem do desenvolvimento da indústria nacional. $\mathrm{O}$ fato de existir um processo constante de aprovação de novas normas seria um sinal de que o governo não estaria satisfeito com as normas atuais. Não bastaria criar os regulamentos e se esquecer de implementar o que foi feito. O governo talvez ainda não tenha feito tudo que deve fazer por falta de tempo ou falta de pessoal, porque assumiram muitas obrigações. Toda reforma teria se baseado na ideia de que haveria resultados relativamente rápidos, como a queda do custo da energia e o aumento de empregos. Isso não estaria ocorrendo como esperado, o que estaria preocupando o governo que, apesar dos resultados negativos, estaria esperando uma melhora. Essa preocupação com os resultados estaria fazendo com que o desenvolvimento de mecanismos de avaliação seja deixado para depois. Na verdade, foi dito que esse governo não estava acostumado a ser supervisionado e que não gostava de ter esse controle, mas devido à pressão social, será obrigado a criar esses mecanismos. O governo também teria percebido que, no longo prazo, esses mecanismos permitiriam que as empresas o ajudem a justificar aquilo que for feito pela política. Além da visão negativa sobre o governo, houve menção negativa sobre a Pemex e seus sindicalistas. Haveria muita corrupção no uso da Pemex como ferramenta do Estado, sem que haja um controle adequado, e isso seria prejudicial para uma international oil company. A Pemex também teria dado a impressão de saber muito bem onde ela gostaria que houvesse uma sinergia com os demais atores, para que se faça negócios, e onde ela não quer essa sinergia. Alguns sindicalistas estariam dizendo que a abertura seria uma forma de o México se vender para os Estados Unidos, mas a verdade seria que o maior interesse estaria na participação de empresas europeias, que teriam muitos bônus de carbono e dinheiro para investir numa fonte de energia mais barata. Teria que se interpretar tudo o que é dito por um sindicalista, pois muitos seriam contra a reforma apenas porque ela acabaria com benefícios que existem há muitos anos. Muitos líderes sindicais teriam mais dinheiro do que alguns empresários e seriam mal vistos pela população, pois ficariam do lado que mais lhes convêm, e não necessariamente do lado daquelas pessoas que eles deveriam estar representando. 


\section{b.2) Participação das Associações Empresariais}

Foram feitas vinte e cinco menções positivas sobre a participação das associações empresariais na orientação da política industrial. Em vinte e um desses casos houve referência apenas à participação da associação, seja através de grupos de trabalho, publicação de estudos, ou propostas de política. Mesmo em situações onde o governo não tenha aberto espaço para o diálogo, as associações teriam reagido muito bem. A participação das associações na definição das normas seria importante porque, em muitos casos, os legisladores não entenderiam sobre os procedimentos e critérios técnicos envolvidos. Outra função que estaria sendo desempenhada pelas associações seria a de diminuir a expectativa de uma entrada massiva de investimentos privados no país. O monopólio durante tantos anos teria ajudado a criar um mito de que o mundo todo estaria esperando o México se abrir para investir no seu mercado, mas a realidade já estaria demonstrando não ser bem assim. De acordo com um dos entrevistados, haveria poucos atores do setor como o IMCO (Instituto Mexicano de la Competitividad) e o CIDAC (Centro de Investigación para el Desarollo), que seriam think-tanks mexicanos, e o CIDE (Centro de Investigación y Docencia Económicas) e o TEC (Instituto Tecnológico de Estudios Superiores de Monterrey), da área acadêmica, mas haveria uma aceitação geral sobre uma mistura de economia aberta, de livre mercado, com algumas políticas de apoio ao desenvolvimento de novos setores no México.

Seis comentários negativos foram feitos a respeito da participação das associações. Quatro deles mencionaram apenas a não participação das associações na definição da política industrial de petróleo e gás mexicana. Num outro momento disseram não fazer ideia da opinião que o governo teria sobre uma determinada etapa da política. E também foi dito que as associações empresariais estariam mantendo, mesmo que de uma forma menos evidente, o hábito histórico de defender a manutenção de uma política de proteção às empresas nacionais, com base em apoios e privilégios protecionistas.

\section{b.3) Recebimento pelo Governo}

As menções positivas sobre o recebimento da participação das associações empresariais por parte do governo mexicano foram treze. Nove delas mencionaram diferentes formas de perceber que a participação das associações teria sido levada em conta, como a adoção de muitos dos elementos sugeridos pelas associações, a realização 
de encontros e a influência na mudança de pensamento. Em duas situações houve apenas a menção de que teriam sido bem recebidos. Foi dito que o governo e as empresas estariam muito integrados, porque as associações dariam respaldo para o governo no caso um ator reclamar de algo. Se isso ocorrer, o governo poderia questionar esse ator dizendo que ele teria sido consultado e teria participado de tudo. Essa consulta feita pelo governo seria prática e não apenas teórica.

Já os comentários negativos foram nove no total. Seis desses comentários diziam, de uma forma ou de outra, que o governo sempre acaba tendo a última palavra. O governo teria sido mandatório com relação a algumas questões, sobre as quais as associações não foram consultadas, ou não foi aberto espaço para negociação. Isso teria dado a impressão de que o governo já teria toda a informação que gostaria e já teria começado com toda estratégia predefinida. Foram feitas duas menções de que ouvir seria uma coisa, mas implementar seria outra, muito mais difícil de acontecer. Haveria a impressão de que a participação teria ocorrido mais por uma iniciativa das associações de buscar o governo para conversar sobre algo que não estava funcionando, do que pelo governo ter tomando a iniciativa de consultar as associações. 


\section{Capítulo 5 - Estudo de Caso: Noruega}

Neste capítulo serão apresentados os resultados do estudo de caso sobre a política industrial de petróleo e gás norueguesa. Assim como nos capítulos anteriores, num primeiro momento, utiliza-se uma breve contextualização histórica, procurando relacionar os instrumentos de política industrial de petróleo e gás adotados por cada governo com a estratégia de desenvolvimento nacional que serviu de base para cada um desses governos. Em seguida, também serão apresentadas as informações obtidas durante as entrevistas em profundidade com representantes do governo e das associações empresariais.

\section{1 - Contextualização Histórica}

Einar Gerhardsen, do partido trabalhista norueguês, era o primeiro ministro do país, desde 1955, quando três representantes da Phillips (uma companhia petrolífera norte-americana) chegaram a Oslo, no dia 29 de outubro de 1962. Eles sabiam que a Exxon e a Shell estavam fazendo perfurações na região do Mar do Norte e pela costa holandesa, assim como outras empresas na Alemanha Ocidental e Dinamarca. Por isso, foram ao escritório do ex-secretário-geral da ONU, Trygve Lie, solicitando permissão para uma concessão monopolista de toda a costa norueguesa (ANDERSEN, 1993).

Em maio de 1963 a Noruega declarou a propriedade do país sobre sua plataforma continental e o decreto governamental de 09 de abril de 1965 foi a pedra fundamental para o regime de concessões norueguesas. As empresas esperavam que o governo fixasse royalties de 12,5\%, mas eles foram fixados em 10\% para atrair o interesse de empresas estrangeiras. Ao mesmo tempo, se utilizou o princípio do confisco, que estabelece que a posse e o controle dos campos adquiridos nas licitações voltam para o Estado após alguns anos (RYGGVIK, 2014). Além disso, em 1965, o parlamento aceitou redução fiscal para companhias petrolíferas (RYGGVIK, 2015) e foi feita a maior rodada de concessões da história da indústria norueguesa. Ou seja, foram adotadas condições muito atrativas para a participação de empresas estrangeiras, com base na ideia de que o país estava competindo com outros países produtores na atração do investimento feitos pelas empresas. Para que se tenha uma ideia de quão atrativas eram essas condições iniciais, os 
ganhos do governo norueguês seriam entre $50 \%$ a $60 \%$ menores do que os do governo britânico, que era um de seus concorrentes. Dos oitenta e um blocos dessa primeira rodada de concessão, apenas vinte e um tiveram alguma participação (modesta e minoritária) de empresas norueguesas. Grandes empresas norueguesas fizeram oposição, pois queriam ter uma participação maior, mas foram desencorajadas pelo Estado norueguês, pois ainda não havia sido encontrado petróleo no território do país. Então, a operação ainda era considerada de alto risco, com economistas keynesianos temendo por uma maior perda de divisas (RYGGVIK, 2014).

Em outubro de 1965 inicia o governo do primeiro-ministro Per Borten, de uma coalizão entre os partidos de centro-direita. Na véspera de Natal de 1969, pela primeira vez é encontrado petróleo no campo de Ekofisk, o primeiro campo grande o suficiente para ser desenvolvido comercialmente (AUSLAND, 1979). Logo em seguida, entre 1970 e 1971, foi apresentada a Declaração do Comitê Industrial do Parlamento norueguês com os dez mandamentos da indústria de petróleo, que expressavam os meios para que a exploração desse recurso pudesse beneficiar toda a sociedade norueguesa. Esses princípios defendiam: a) a necessidade de assegurar a governança e o controle nacionais sobre todas as operações na plataforma norueguesa; b) a necessidade do pais se tornar independente no fornecimento de petróleo bruto; c) a necessidade de desenvolvimento de um novo setor industrial, ligado ao petróleo; d) que esse desenvolvimento deve levar em consideração os negócios já existentes e a proteção ambiental, quando necessário; e) a proibição da queima de gás aproveitável; f) a necessidade de levar o petróleo para solo norueguês, como regra geral; g) a necessidade de contribuição do Estado para o desenvolvimento de um ambiente integrado na indústria de petróleo do país; h) a necessidade de criação de uma empresa estatal de petróleo; i) a necessidade de um padrão de operações adaptado às necessidades especiais da região ao norte da latitude 62; e j) a necessidade de novas tarefas de política externa (RYGGVIK, 2014).

Entre março de 1971 e outubro de 1973, os noruegueses saíram de um governo de centro-direita para um governo do partido trabalhista, passaram por um governo de centro e voltaram para um governo do partido trabalhista. Foi durante este período que ocorreu o planejamento e a criação da Statoil, com o parlamento concordando com a sua criação em junho de 1972. Seus principais mentores foram Finn Lied e Jens C. Hauge, que foram os dois primeiros líderes do conselho da empresa, entre 1972 e 1984, e teriam sido os responsáveis pelo gerenciamento da política de petróleo norueguesa. Eles não tinham uma 
visão socialista de que a propriedade estatal fosse um fim em si mesma, e não trabalhavam nesse sentido no início da década de 1960, mas a perspectiva de encontrar petróleo em território norueguês mudou isso. Eles acreditavam que a Statoil deveria ser propriedade do Estado pela importância única da indústria de petróleo, política e economicamente. A Statoil tinha dois objetivos principais: garantir uma maior parte da renda do petróleo para o Estado e não para as empresas estrangeiras; e apoiar a criação de uma indústria nacional privada forte. Esses dois objetivos continuaram sendo a base da empresa até 1988, com a saída de Arve Johnson do cargo de CEO da empresa (RYGGVIK, 2015).

Em setembro de 1972, os noruegueses votam pela não adesão à antiga Comunidade Econômica Europeia (atual União Europeia). Em agosto de 1973, a Statoil recebe controle acionário de 50\% do campo de Statfjord. Muitos achavam que 50\% era muita coisa para a Statoil, e que isso poderia afastar as empresas estrangeiras. Um ano depois, se descobriu que esse campo era muito maior do que o imaginado. Assim, as empresas ficaram muito satisfeitas e a posição dominante da Statoil nesse campo foi decisiva para o desenvolvimento da empresa e de uma rede de fornecedores nacionais (RYGGVIK, 2014). Entre 1972 e 1985, a licença para atividades de exploração e produção era concedida isoladamente à Statoil, ou para outras empresas que formassem parceria (joint ventures) com a Statoil. Devido a isso, esses anos ficaram conhecidos como o período de “casamentos forçados" (AGÊNCIA BRASILEIRA DE DESENVOLVIMENTO INDUSTRIAL, 2011).

O governo do primeiro ministro Trygve Bratteli, do partido trabalhista, começou em outubro de 1973 e em fevereiro do ano seguinte foi apresentado o relatório técnico número 25, com o título “O Papel das Atividades Petrolíferas na Sociedade Norueguesa". Este documento defende que as riquezas geradas pelo setor de petróleo devem ser utilizadas para desenvolver uma sociedade qualitativamente melhor, com uma maior igualdade nos padrões de vida, para que se evitem problemas sociais, destacando a importância de o governo controlar todas as questões ligadas à política industrial de petróleo, e concluindo que a Noruega deveria ter um ritmo moderado de exploração. Em 1974 houve aumento dos impostos cobrados, o que gerou reclamações das empresas estrangeiras, que tiveram que aceitar, por saberem que caso resolvessem sair do país, esse mercado poderia ser desenvolvido com a atividade da Statoil. No ano seguinte houve a suspensão temporária da imigração, que ficou vinculada à obtenção de um visto de trabalho. Criaram uma comissão especial para avaliar os casos de contratações para a 
indústria de petróleo, chamada de "Comitê de Stavanger", que foi uma importante ferramenta protecionista utilizada em 1975 pelos noruegueses (RYGGVIK, 2014).

O parágrafo cinquenta e quatro, do Decreto Real de dezembro de 1972, já declarava que “...nos casos em que mercadorias e serviços noruegueses forem competitivos, ambos em qualidade, serviço, prazo de entrega e preço, esses devem ser utilizados". Mas devido à pressão dos armadores noruegueses, esse decreto fícou suspenso durante o primeiro ano, sendo colocado em prática apenas quando a crise atingiu a indústria de construção naval, em 1974, e alterou o equilíbrio de forças. Em 1976, durante o governo de Odvar Nordli, do partido trabalhista, esse protecionismo levou ao uso de empresas de concreto norueguesas para a construção de plataformas (ENGEN, 2009). Já em 1978, a garantia de equiparação dos salários de empregados estrangeiros, que haviam entrado em greve, acabou servindo de ferramenta protecionista. Isso porque a equiparação salarial acabou com a vantagem econômica que se tinha ao contratar estrangeiros, que tinham salários mais baixos que os noruegueses. A Empresa Borwn and Root, por exemplo, que havia se especializado em utilizar trabalhadores de língua espanhola, nunca mais foi contratada (RYGGVIK, 2014).

Em 1979, houve a alteração do texto do parágrafo cinquenta e quatro do Decreto Real, colocando a necessidade de oferecer oportunidades reais aos fornecedores noruegueses. O recém-criado Ministry of Petroleum and Energy passou a ter a possibilidade de orientar a forma de implementação desse parágrafo, através de regulamentos e licenças individuais. De acordo com esses regulamentos, as licitações deveriam ser enviadas a um número razoável de fornecedores noruegueses, especificações de prazo e condições de entrega não poderiam servir para excluir empresas norueguesas, o uso de subfornecedores noruegueses devia ser considerado e deveria ser informado ao ministério a porção norueguesa final em cada contrato. No início de 1980, uma outra forma de protecionismo foi criada pela Statoil e pela Universidade de Bergen, que iniciaram um projeto para utilizar a língua norueguesa no ambiente de trabalho e nos contratos do setor de petróleo, obrigando as empresas estrangerias a se adaptarem (RYGGVIK, 2014).

Dois meses após ter tomado posse, no final de 1981, o primeiro ministro Kåre Willoch, do partido conservador, e defensor de que a economia norueguesa desse um papel maior para os mecanismos de mercado, convoca representantes das operadoras 
estrangeiras para uma reunião. Nessa reunião ele solicitou que as empresas passassem a fazer parte do sistema tripartite norueguês, que servia de base para as relações de trabalho no país. Antes das eleições, o partido de Willoch tinha criticado aspectos negativos da relação entre o governo norueguês anterior (do partido trabalhista) e os sindicatos. Havia uma tendência internacional de combate aos sindicatos, seguindo os governos conservadores norte-americano, de Ronald Reagan, e britânico, de Margareth Thatcher. Mas Willoch deu uma clara demonstração de que, independente da corrente política que estivesse no poder, as autoridades norueguesas não queriam apenas aumentar a participação norueguesa nos contratos, mas utilizar os padrões noruegueses também nas relações de trabalho (RIGGVIK, 2014).

A operação de corte de asas da Statoil, em abril de 1984, retirou da empresa alguns direitos de propriedade. Em campos onde a produção já havia sido iniciada esses direitos foram mantidos, mas em campos como o grande campo de Troll, parte de suas participações foram tomadas. O objetivo era dividir o envolvimento estatal nas atividades petrolíferas entre a Statoil e o controle direto do Estado através do instrumento SDFI (State's Direct Financial Interest), que foi institucionalizado em 2001, com a estatal Petoro, cujo objetivo era o de restringir o poder financeiro da Statoil (AGÊNCIA BRASILEIRA DE DESENVOLVIMENTO INDUSTRIAL, 2015; RYGGVIK, 2015).

Entre a quinta (1981) e a décima rodada (1986), das quarenta e três concessões feitas, trinta e uma foram para empresas norueguesas. Então a participação do Estado permaneceu forte mesmo depois da divisão entre a Statoil e o SDFI. O texto de alteração do decreto de 1979 só foi aprovado em 1985, incluindo a necessidade de que todas empresas que fossem desenvolver um campo na Noruega fossem obrigadas a apresentar um plano de envolvimento de fornecedores locais, pois o ministério havia percebido que a forma mais eficaz para que houvesse participação da indústria norueguesa era utilizando o poder de negociação que se tinha durante a fase de concessão de novos campos. As empresas que apresentavam uma contribuição maior à nacionalização eram beneficiadas nas concessões seguintes (RYGGVIK, 2014). O colapso dos preços do barril, em 1986, é visto como o evento individual mais importante para a mudança no sentido de uma política mais aberta. Neste cenário ruim, as empresas estrangerias estavam ameaçando sair do país, caso não fossem oferecidas melhores condições. Apesar de elas já terem feito essa ameaça antes, quando foram ignoradas pelo governo, dessa vez a ameaça foi levada à sério pelas autoridades norueguesas (AL-KASIM, 2006). 
No final da década de 1980, os noruegueses saíram de um governo conservador (que manteve as políticas protecionistas e ainda pressionou empresas estrangeiras pela adoção das condições de trabalho norueguesas), e voltaram para um governo socialdemocrata (que iniciou o processo de enfraquecimento do sistema protecionista). $\mathrm{O}$ governo da primeira ministra Gro Harlem Brundtland, do partido trabalhista, se baseou na criação do mercado interno da comunidade europeia e na capacidade alcançada pela indústria nacional para iniciar um processo de abertura econômica no país. Estes dois governos seriam exemplos práticos de que o que orienta a política norueguesa não é o partido que está no poder, mas sim as condições, externas e internas, enfrentadas pela indústria (RYGGVIK, 2014).

A participação norueguesa no setor de petróleo foi de $18 \%$ a $25 \%$ até 1975 e de mais de 50\% de 1977 em diante. Em 1987, a empresa norueguesa Aker construiu a plataforma para o grande campo de Gullfaks, atingindo o maior índice de conteúdo local jamais alcançado pela indústria nacional, com $80 \%$ do total de horas trabalhadas. A partir de 1984 o Ministry of Petroleum and Energy parou de divulgar os índices de conteúdo local, pois as empresas estariam exagerando nos números da nacionalização fazendo os dados ficarem imprecisos, e para que o governo se prevenisse da acusação da prática de protecionismo. A partir de 1986, com o governo de Gro Harlem Brundtland, o governo aprova desonerações para empresas estrangeiras e extingue a regra de que as empresas estrangeiras deveriam arcar com as despesas do Estado na fase de exploração. Em janeiro de 1988, o parlamento aprova permissão para autoridades limitarem o desenvolvimento em descobertas comprovadas, estabelecendo um limite para investimentos, pois acreditava-se que taxas constantes de investimento poderiam ajudar a evitar grandes oscilações na indústria. Em maio do mesmo ano, devido à crise financeira no país, o governo libera a empresa Saga para o desenvolvimento do campo de Snorre, com o objetivo de estimular a criação de novos empregos (RYGGVIK, 2014).

Em 1989, a Noruega e outros membros europeus da Associação Europeia de Livre Comércio realizam um processo de negociação comum com a União Europeia, que levou à adaptação da regulamentação norueguesa às exigências esperadas para a entrada no mercado interno, alterando elementos centrais da Lei de Petróleo de 1985. A exigência de que as empresas estrangeiras criassem filiais norueguesas foi flexibilizada para a possibilidade de o registro dessas filiais serem na Zona Econômica Europeia, qualquer trabalhador dessa zona poderia trabalhar na Noruega, a exigência de prestação de contas 
sobre a cooperação com fornecedores noruegueses foi retirada e se enfraqueceu o direito à exigência de que o petróleo e o gás fossem levados para território norueguês. Além de mudanças legais, foi abolido o regime especial para os acordos tecnológicos, que funcionava como mais um imposto para as empresas estrangeiras, que eram obrigadas a investir em pesquisa e desenvolvimento no país (RYGGVIK, 2014). Em agosto de 1990, o novo líder da Statoil, Harald Norvik, anunciou uma associação da Statiol com a BP em uma aliança estratégica global, para atuarem juntas em diversos países, o que implicava na BP treinar a Statoil para ser uma empresa internacional de petróleo (LERPOLD, 2003).

O projeto britânico CIRNE (Cost Reduction for the New Era), tinha o objetivo de reduzir custos no setor (PORTER, 1990). Inspirado neste projeto, o Ministry of Petroleum and Energy norueguês anuncia, em 1993, a criação do NORSOK, que seria a versão norueguesa do CIRNE britânico. A redução de custos seria feita através da padronização e da utilização sistemática de longos contratos de EPC (Engineering, Procurement, Construction). Ambos os projetos, mesmo não discriminando a nacionalidade das empresas, davam vantagem aos subfornecedores locais. A partir desse modelo do NORSOK, foi criada a INTSOK, com o objetivo de fortalecer a indústria norueguesa nos mercados internacionais. Logo em seguida, em novembro de 1994, a maioria dos noruegueses novamente decide que o país não deve fazer parte da União Europeia.

O governo do primeiro ministro Thorbjørn Jagland, do partido trabalhista, iniciou em outubro de 1996, e no mês seguinte, foi aprovada a lei ${ }^{\circ}$. 72, que adotou o modelo de concessões para o setor de petróleo norueguês (BAIN \& COMPANY; TOZZINIFREIRE ADVOGADOS, 2009). No mesmo sentido, o governo do primeiro ministro Jens Stoltenberg, também do partido trabalhista, teve início no ano 2000, e em 2001 a Statoil teve seu capital aberto. A empresa permaneceu sob controle estatal, que manteve mais de $67 \%$ de suas ações, mas o governo incluiu uma cláusula determinando que não poderia utilizar a sua posição de acionista majoritário para interferir nas atividades da companhia (RYGGVIK, 2015).

A Innovation Norway foi criada em 2004, com o objetivo de ajudar as empresas norueguesas a se estabelecerem no mercado externo, oferecendo empréstimos de baixo custo e subvenções para pesquisa, desenvolvimento e inovação. A organização da indústria em clusters também foi considerada uma forma de protecionismo, mas esse seria um novo tipo de política industrial, adaptada às exigências de uma economia globalizada 
e aberta. Nesse mesmo sentido, a fusão entre Statoil e Norsk Hydro, em 20007, teve como principal objetivo a criação de mais capacidade para a expansão internacional (RYGGVIK, 2015).

\section{2 - Entrevistas em Profundidade}

Dos nove atores noruegueses que foram contatados, todos atenderam à pesquisa. Todavia, os representantes de dois órgãos do governo não responderam ao roteiro de entrevista em profundidade. O Norwegian Ministry of Foreign Affairs é encarregado de promover internacionalmente os interesses noruegueses, mas não tem um departamento específico para a indústria de petróleo e gás. A Petroleum Safety Authority Norway é um regulador governamental independente, específico da indústria de petróleo norueguesa, responsável pelo ambiente de trabalho, segurança e preparação para emergências, mas sem ligação direta com questões de política industrial. Em ambos os casos os entrevistados confirmaram que suas instituições não trabalham diretamente com a política industrial de petróleo e gás norueguesa e que as únicas instituições governamentais norueguesas que poderiam responder sobre estas questões seriam os outros dois órgãos (Norwegian Ministry of Petroleum and Energy e Norwegian Petroleum Directorate), que responderam aos roteiros de entrevista. Mesmo não seguindo o roteiro, os entrevistados atenderam à pesquisa com muita atenção e interesse, utilizando suas experiências no setor para trazerem diferentes elementos e novas perspectivas. Como ambos possuem importante atuação acadêmica, suas informações, comentários e sugestões também contribuíram bastante para a definição do desenho de pesquisa e uma melhor compreensão do caso norueguês.

Houve uma mudança com relação à entrevista com o representante da NORAD (Norwegian Agency for Development Cooperation), que tem como principais objetivos assegurar que os fundos noruegueses de apoio ao desenvolvimento sejam gastos da melhor maneira possível e informar sobre as práticas que apresentam melhores resultados. A NORAD tem um programa chamado Oil for Development Programme, que oferece assistência para países em desenvolvimento realizarem a gestão de seus recursos petroleiros de forma sustentável. Mas apesar de ser uma agência governamental, ligada ao Norwegian Ministry of Foreign Affairs, o entrevistado preferiu responder ao roteiro de entrevista como um representante do mercado e não como um representante do governo. 
Isso porque a agência não trabalha diretamente com questões ligadas à política industrial norueguesa e o entrevistado possui mais de trinta anos de experiência trabalhando em empresas e associações empresariais do setor de petróleo e gás.

Dessa forma, serão analisadas duas entrevistas de representantes do governo norueguês e quatro entrevistas de representantes de associações empresariais norueguesas do setor de petróleo e gás. As entrevistas foram realizadas entre os dias 03 e 11 de novembro de 2015 e as respostas devem ser compreendidas levando em consideração o contexto presente neste período.

Antes mesmo de iniciar as perguntas relativas ao roteiro das entrevistas em profundidade, como uma forma de comentário prévio, um dos entrevistados do governo informou que existe um aplicativo para celulares, gratuito e público, chamado Oil Facts, que apresenta todas as informações sobre uma grande variedade de questões ligadas à indústria de petróleo norueguesa. Dois entrevistados das associações empresariais também fizeram comentários prévios. Um deles disse que o desenvolvimento da indústria norueguesa teria mudado bastante nos últimos anos. Por ser membro da Organização Mundial do Comércio e devido ao acordo com a União Europeia, hoje a Noruega não poderia mais adotar as mesmas medidas que tomou há trinta anos. Mesmo assim, essa questão continuaria sendo discutida em trabalhos de cooperação com outros países, que ainda tenham mais liberdade para adotar essas medidas. Foi dito que a Statoil estaria passando por uma mudança geracional de seus funcionários, pois os novos estariam trabalhando numa lógica diferente daquela utilizada pelos funcionários mais antigos. Quando questionado sobre se haveria na Statoil a mesma dificuldade encontrada pela pesquisa para ter acesso a informações sobre empresas fornecedoras da Petrobras, um dos entrevistados disse que esse tipo de segredo não deveria mais existir no Brasil, pois provavelmente essa prática esteja relacionada aos problemas que a Petrobras vem enfrentando ultimamente. Já outro entrevistado ressaltou que, além do objetivo de exportar bens e serviços, a política industrial norueguesa também teria o objetivo de aprender com o mercado internacional. Para que seja competitiva, adquira novas tecnologias e possa fornecer para mercados fora do país, a indústria norueguesa faria também um movimento no sentido contrário, levando competências de fora para dentro da Noruega. 


\subsection{1 - Realidade da Indústria}

\section{a) Governo}

O gráfico 48, abaixo, apresenta as respostas dos entrevistados do governo norueguês, sobre a avaliação da realidade que serviu de base para a formulação da política industrial de petróleo e gás no país.

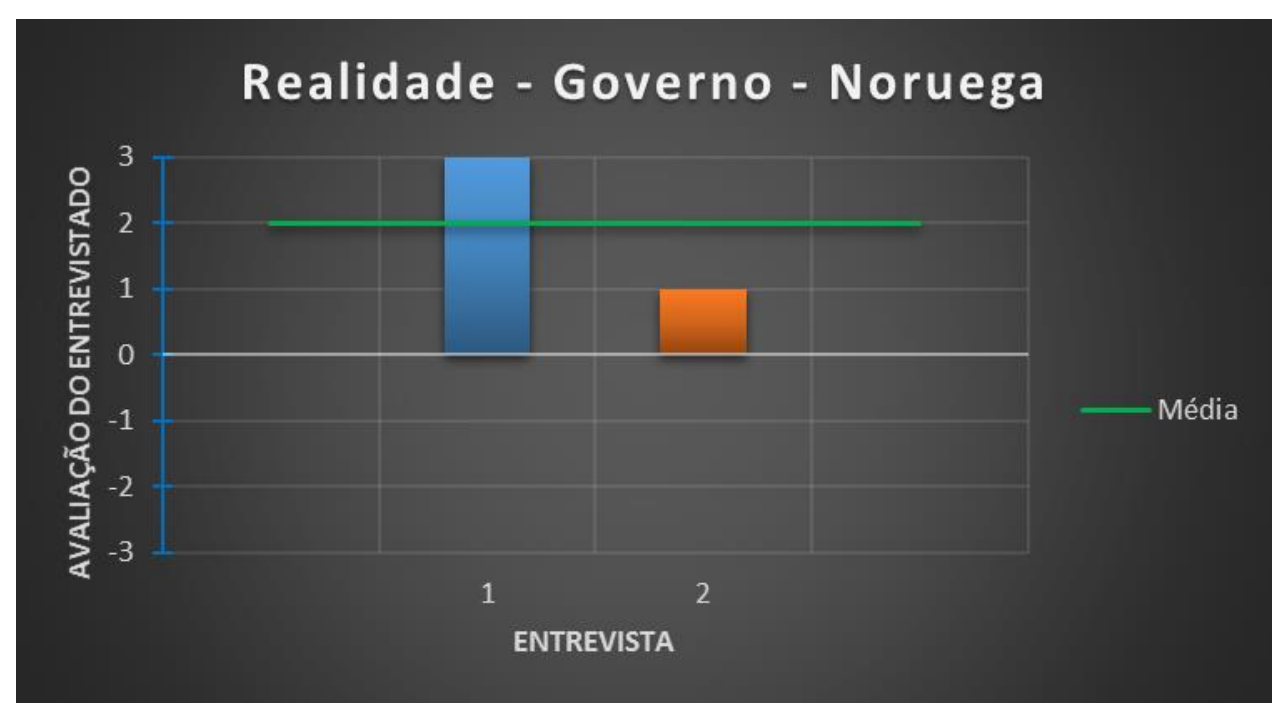

Gráfico 48 - Avaliações dos entrevistados do governo da Noruega sobre a realidade da indústria que serviu de base para a política industrial do país.

Os dois entrevistados lembraram do alto custo de produção da indústria norueguesa, como uma desvantagem da Noruega, com relação a outros países. Um dos entrevistados mencionou esse alto custo de produção devido à Noruega ser um país extremamente caro de uma maneira geral, pois seria um Estado de bem-estar social, com salários altos. Já o outro entrevistado citou esse alto custo devido à produção norueguesa ser offshore. Mesmo tendo um potencial de reservas enorme, se comparado ao tamanho do seu território, a produção norueguesa estaria caindo desde 2001 aproximadamente. Como a maior parte da produção viria de campos já maduros, o custo de produção teria uma tendência a ser cada vez maior, fazendo com que a questão do preço do barril ganhe ainda mais importância. No momento, o custo de produção já estaria mais alto do que o preço de venda do barril, fazendo com que as previsões para o futuro estejam muito incertas. A produção de gás ainda estaria estável, mas o preço também seria um desafio. 
Como vantagem, a indústria de petróleo norueguesa teria tido um início muito confortável, de acordo com um dos entrevistados. A Noruega já seria um país industrializado desde os anos 1960, com uma grande indústria naval, uma das três maiores frotas mercantes do mundo e experiência com um sistema de gestão de recursos naturais (a partir das concessões de recursos hídricos). Teria sido a existência prévia de um sistema regulatório e de governança de recursos que permitiu o sucesso na concessão da exploração de recursos naturais para empresas privadas. Desde cedo também teria havido uma conversão natural de outros setores, como a indústria naval, para começarem a fornecer para o setor de petróleo.

A setor que mais exporta na Noruega seria o de petróleo e gás, chegando a quase $50 \%$ do PIB, e o segundo que mais exporta seria o de bens e serviços para a indústria de petróleo e gás de outros países. Portanto, com relação às perspectivas e à realidade da indústria nacional, os noruegueses devem ter feito algo de correto. Não haveria muitos outros exemplos de empresas nacionais de petróleo que tenham desenvolvido, a partir de sua atividade, toda uma indústria de fornecedores para o mercado internacional. De acordo com o entrevistado, na Noruega não existe nenhum objetivo particular de promover bens e serviços noruegueses internacionalmente, nem mesmo de dar preferência na contratação local desses serviços. Esse desenvolvimento teria ocorrido de forma independente, através da própria indústria de fornecedores. Desde 1994, com a assinatura do acordo com a União Europeia, não haveria nenhuma forma de tratamento especial para as empresas norueguesas e se teria percebido que essas empresas podem desempenhar um ótimo papel competindo no mercado internacional. A única coisa que estaria segurando as empresas norueguesas nesse momento, não seria problemas de $\mathrm{P} \& \mathrm{D}$ ou falta de novas soluções, mas sim uma desaceleração geral do mercado.

\section{b) Associações Empresariais}

O gráfico 49, abaixo, apresenta as respostas dos entrevistados das associações empresariais norueguesas, sobre a avaliação da realidade que serviu de base para a formulação da política industrial de petróleo e gás no país. 


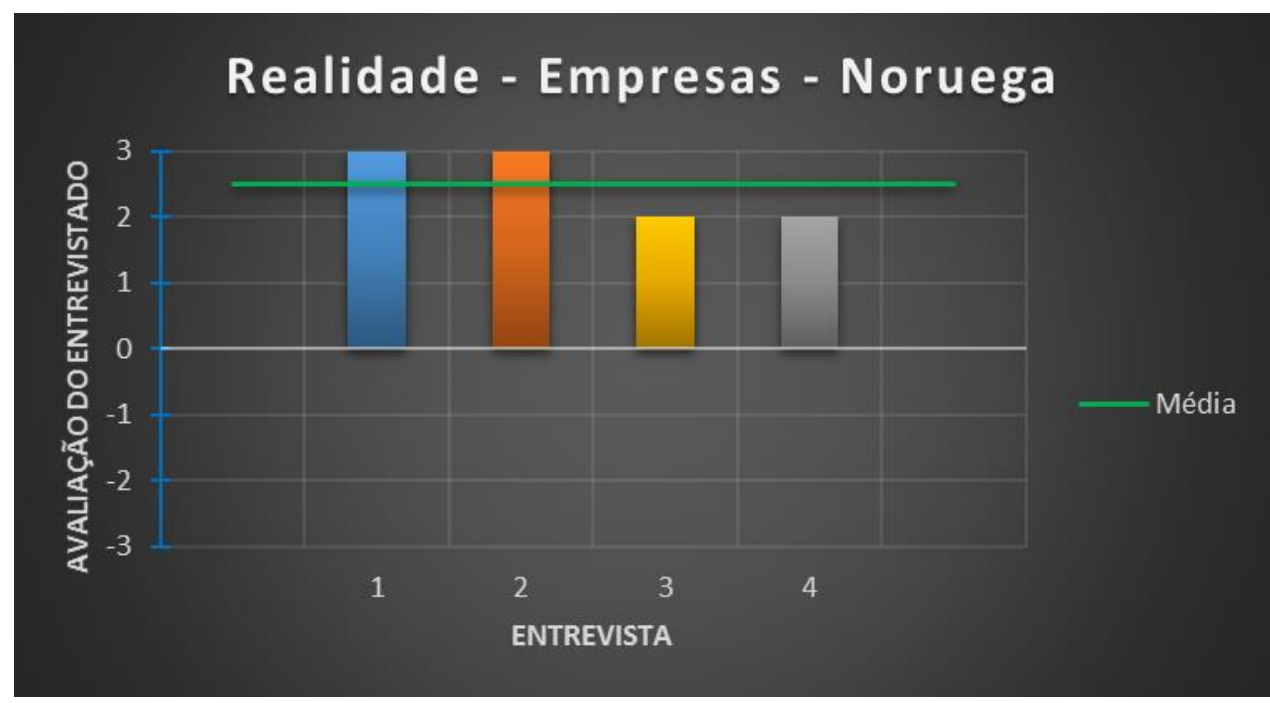

\section{Gráfico 49 - Avaliações dos entrevistados das associações empresariais da Noruega sobre a realidade da indústria que serviu de base para a política industrial do país.}

Nenhum tema foi tratado por todos os quatro entrevistados, nem mesmo por três deles. Dois entrevistados ressaltaram a postura equilibrada do governo norueguês como uma das principais razões para o sucesso da indústria nacional. Um desses entrevistados lembrou especificamente do diálogo entre o embaixador Trygve Lie e o presidente da Phillips Petroleum, Vard Dunn, em 1962. A Noruega teria conseguido desenvolver uma indústria sustentável de petróleo e gás, devido a uma colaboração trilateral única entre governo, atores da indústria e sindicatos de trabalhadores. Para outro desses entrevistados, o governo e a indústria estariam cientes da necessidade de um desenvolvimento industrial equilibrado, pois mesmo que a indústria de petróleo tenha se tornado dominante, se deveria ter cuidado para que ela não acabe prejudicando outras indústrias, criando um desequilíbrio entre a indústria de terra firme e a indústria voltada para o alto mar.

Em duas entrevistas foi mencionado que a Noruega teria poucas desvantagens, ou quase nenhuma, quando comparada com outros países produtores. Nesse sentido, foi mencionada uma escassez cíclica de acesso a recursos humanos e o sobe e desce do preço do barril de petróleo. Outro entrevistado apontou como desvantagem a necessidade de investimentos em infraestrutura para permitir a exploração em áreas de fronteira. Já um quarto entrevistado disse que seriam muitas as desvantagens, como o alto custo de produção (devido a um alto padrão de segurança e respeito ao meio ambiente) e que, 
mesmo sendo o maior mercado offshore do mundo, as reservas norueguesas não seriam tão grandes.

Em uma entrevista foi dito que os noruegueses teriam explorado menos de metade dos seus potenciais recursos, pois mesmo que algumas áreas já estejam maduras, se estaria explorando novas áreas de fronteira, como no caso da $23^{\mathrm{a}}$ ronda de concessões, em áreas como o Mar de Barents. Mesmo nas áreas maduras ainda se estaria conseguindo encontrar algumas novas reservas, e existiriam algumas áreas consideradas proibidas, onde haveria algum tipo de disputa política para que se faça a abertura dessas áreas para exploração. No início dessa indústria, haveria um certo receio, mas depois se teria percebido que existiria uma ampla gama de bens e serviços da indústria de petróleo que beneficiam outros setores. Quem se especializa num determinado bem ou serviço da indústria de petróleo poderia fazer modificações para servir a outros mercados.

Um dos entrevistados manifestou a ideia de que mesmo as desvantagens norueguesas poderiam ser vistas como vantagens. Apesar do alto custo de produção, a exploração offshore teria permitido a aquisição de experiência na produção de reservas complicadas. O alto custo no país teria obrigado a indústria a ser inovadora. Com tudo isso, a Noruega teria desenvolvido sua indústria de forma sustentável, não apenas no curto, mas também no longo prazo. Não se poderia nem falar em potencial de desenvolvimento da indústria de petróleo norueguesa, porque suas empresas teriam aproximadamente $10 \%$ do mercado mundial de bens e serviços para a indústria de petróleo. Além disso, os noruegueses teriam adotado um modelo de compartilhamento muito bom, fazendo alguns projetos dentro do país e outros fora. Não seria possível fazer tudo na Noruega, pois a população é de apenas cinco milhões de pessoas. Por isso, tevese que aprender a ser muito bom no trabalho em conjunto.

\subsection{2 - Valores da Política}

\section{a) Governo}

O gráfico 50, abaixo, apresenta as respostas dos entrevistados do governo norueguês, sobre a avaliação dos valores utilizados como base para a formulação da política industrial de petróleo e gás no país. 


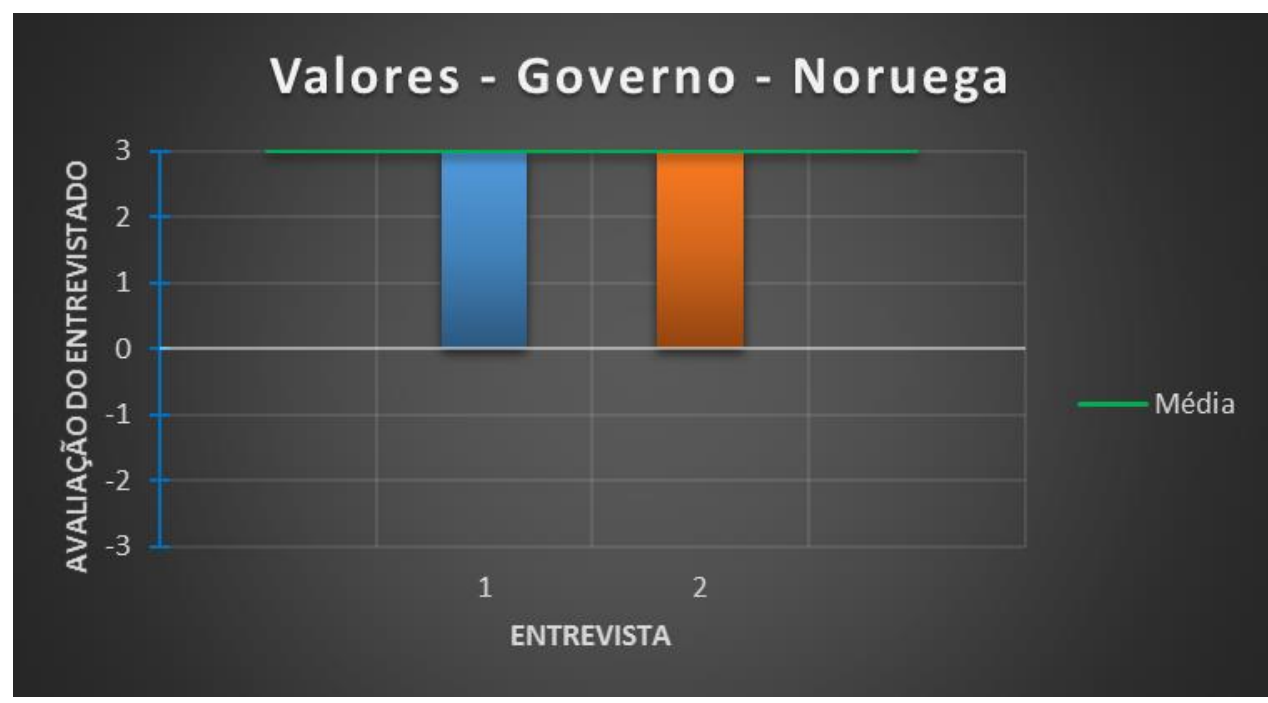

Gráfico 50 - Avaliações dos entrevistados do governo da Noruega sobre os valores da política industrial de petróleo e gás no país.

Neste bloco, os dois entrevistados mencionaram que as riquezas de petróleo e gás pertencem ao povo norueguês, enquanto as reservas são propriedade do Estado e a indústria recebe licenças para fazer a extração desses recursos. A responsabilidade por vender e exportar esses recursos seria das empresas. A Noruega exporta todo gás e quase todo petróleo que produz, pois estaria bem abastecida com sua energia hídrica.

Nas duas entrevistas foi lembrada a existência de um fundo estatal de investimentos. Seriam cobradas altas taxas das empresas que exploram os recursos noruegueses, e todas as renda do setor seriam diretamente direcionadas para esse fundo, que estaria próximo de alcançar um trilhão de dólares e seria uma salvaguarda para o futuro. A receita obtida pela indústria de petróleo e gás seria tão grande, em comparação com o tamanho da população do país, que não se poderia gastar tudo agora, pois isso iria destruir a economia nacional. Por isso, teria sido criado esse fundo de pensão, que foi estabelecido em 1991, teria recebido as primeiras receitas em 1996. Apenas uma parte dos juros obtidos pelas aplicações desse fundo podem ser utilizadas para equilibrar o orçamento e o parlamento seria muito disciplinado nesse ponto.

Os dois entrevistados também defenderam que a Statoil deva ser exclusivamente focada no lucro. Ambos lembraram que a empresa era originalmente 100\% estatal, mas que já nos anos 1980 teria ficado claro que ela não poderia ser um prolongamento do governo. Não deveria ter tarefas da administração governamental e deveria se concentrar 
na sua atividade comercial. Em 2001 ela teria sido parcialmente privatizada, e hoje o governo teria $67 \%$ das ações da empresa, mas jamais interferiria nas suas operações cotidianas. A Statoil não teria influência nos licenciamentos e precisaria solicitar permissões e aprovações ao governo, como todas as demais empresas. Em território norueguês, nenhuma atividade seria feita por apenas uma empresa, então a Statoil sempre estaria participando de joint ventures, o que seria positivo para todas partes envolvidas. Isso ajudaria a demonstrar que a Statoil se baseia em deliberações comerciais e não representaria visões governamentais, o que estaria diretamente ligado à credibilidade da empresa. Essa característica seria parte da cultura norueguesa, que teria o hábito de separar completamente a administração governamental e atividades comerciais. Então, mesmo em empresas $100 \%$ estatais, seria proibido que funcionários públicos ocupem cargos de diretoria, pois essas funções deveriam estar sempre muito bem separadas. $\mathrm{Na}$ Statoil, o governo só apareceria nas assembleias gerias anuais, caso tenha algo a dizer como proprietário. Os noruegueses teriam tido muita consciência com a Statoil, para separar os papeis de produtor, ator comercial e regulador, diferentemente de países em desenvolvimento, que costumam misturar esses papéis, como os brasileiros, com a Petrobras, e os mexicanos, com a Pemex.

Um dos entrevistados disse que se teve uma filosofia de exploração muito bem planejada, no sentido de se dar um passo de cada vez, de forma gradual. Nesse sentido, só se faria a exploração de uma área geológica por vez e, com isso, se teria encontrado relativamente bastante recursos com poucas explorações. Também seria importante para a indústria e para o governo que se tenha um ritmo estável de novas explorações, pois permitiria um melhor planejamento do uso dos recursos humanos e dos equipamentos. $\mathrm{E}$ sobre a nacionalização ou internacionalização da cadeia de fornecedores, foi citada uma organização chamada INTSOK, que promoveria a internacionalização de bens e serviços noruegueses, mas caberia a cada empresa, e não ao governo, a decisão sobre abrir uma filial em outro país ou não.

\section{b) Associações Empresariais}

O gráfico 51, abaixo, apresenta as respostas dos entrevistados das associações empresariais norueguesas, sobre a avaliação dos valores utilizados como base para a formulação da política industrial de petróleo e gás no país. 


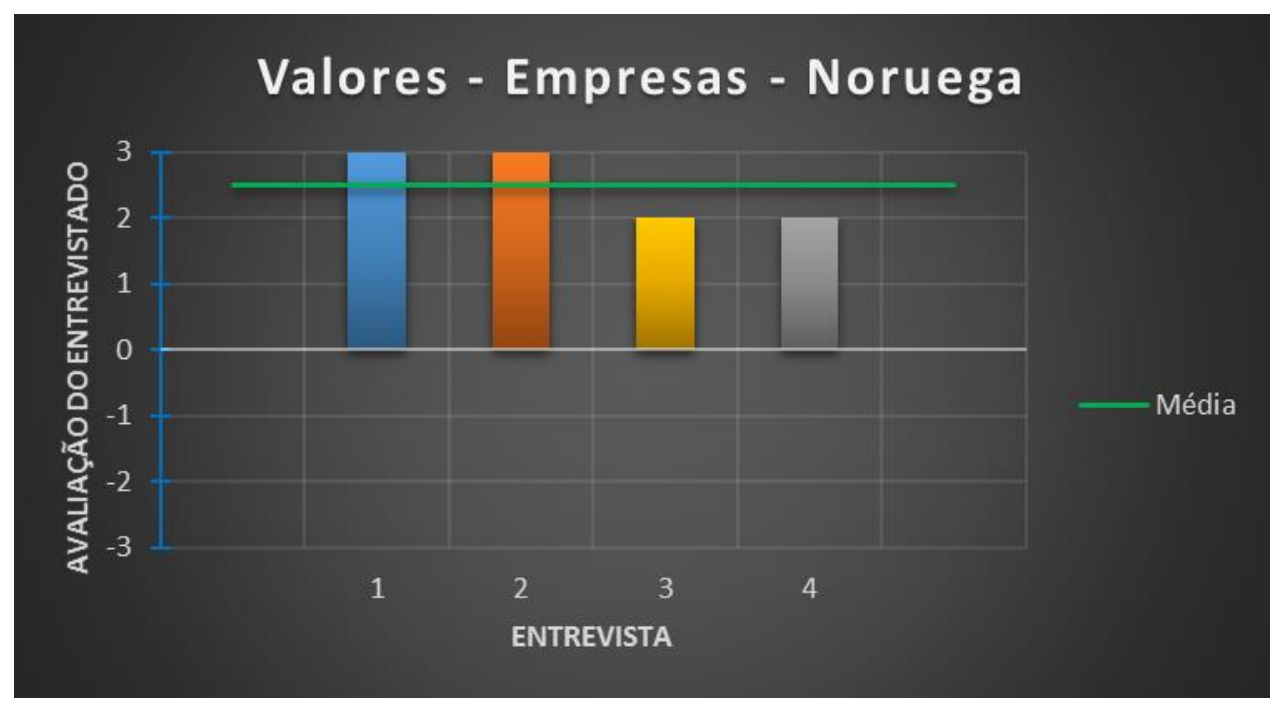

Gráfico 51 - Avaliações dos entrevistados das associações empresariais da Noruega sobre os valores da política industrial de petróleo e gás no país.

Neste bloco não houve nenhuma perspectiva que tenha sido levantada por todos os quatro entrevistados, mas muitas questões foram mencionadas em três diferentes entrevistas. A propriedade do Estado sobre os recursos de petróleo e gás foi apontada por três entrevistados. Esses recursos seriam do povo norueguês e a empresa petroleira seria o agente que desenvolve esse ativo, através da utilização de um sistema de licenças. A condição para qualquer empresa operar na plataforma continental norueguesa seria realizar essa operação em nome do povo e do Estado norueguês.

O direcionamento da indústria norueguesa para necessidades futuras também foi apontado em três entrevistas. A ideia seria converter os ativos que estão no subsolo em ativos financeiros para as gerações futuras. Trinta anos atrás, a maior parte da receita com impostos da indústria de petróleo era utilizada para necessidades imediatas. Hoje, com uma produção muito alta e uma economia pequena, se estaria adotando uma postura mais balanceada, utilizando uma pequena parte para necessidades imediatas, mas guardando a maior parte para gerações futuras. O fato de se ter o maior fundo soberano do mundo, com quase um trilhão de dólares, seria uma prova disso. $\mathrm{O}$ valor depositado nesse fundo deve ser mantido fora do orçamento ordinário, podendo-se utilizar parte dos juros para necessidades imediatas., mas não o principal. Mesmo que as receitas provenientes desse setor tenham decaído, em decorrência do baixo preço do barril e da maturação dos campos 
noruegueses, um dos entrevistados disse acreditar haver recursos suficientes para um período de cinquenta a cem anos, especialmente gás.

Foram três também os entrevistados que defenderam a ideia de que a Statoil deva ter seu foco na obtenção de lucro. Lembraram que inicialmente a empresa era $100 \%$ estatal, mas que hoje teria reduzido para $67 \%$ a participação das ações estatais. Essa propriedade do Estado seria representada pelo ministro de petróleo e energia, mas o governo não teria nenhum diretor no conselho da empresa, que seria tratada como qualquer outra empresa do mercado. Inicialmente, teria havido a intenção de que a Statoil tivesse competidores nacionais, mas todos acabaram sendo comprados por ela (como a Saga Petroleum e a Norsk Hydro), que hoje seria uma empresa dominante no mercado norueguês. O ideal seria que houvesse competição, pois quando uma empresa domina um mercado, acabaria ficando muito relaxada. Um desses entrevistado disse que, mesmo que o foco tenha que ser na eficiência e geração de lucro, a Statoil também deveria se preocupar com o desenvolvimento do país no longo prazo, pois como $80 \%$ de suas operações seriam em território nacional, esta questão a afetaria diretamente. Além disso, ela seria uma empresa grande demais para se preocupar apenas com lucro.

A importância da internacionalização da cadeia de fornecedores também foi destacada em três entrevistas. O governo norueguês sempre teria tido essa intenção de expandir sua indústria para fora do país. Hoje a Noruega teria uma economia muito aberta, mas trinta ou quarenta anos atrás o foco do país era a defesa do interesse nacional. Hoje, com todos os acordos comerciais que foram firmados, teria se tornado uma indústria internacionalizada. Essa transição de uma política nacionalista para uma política voltada à internacionalização da cadeia teria se dado com base em muita discussão entre os atores envolvidos e um forte direcionamento do governo para desenvolver a indústria nacional. O governo não se contentava em ficar apenas com os impostos cobrados pela extração dos recursos, pois queria também desenvolver sua indústria, aproveitando ao máximo os frutos de seus recursos naturais. Essa indústria de fornecedores seria muito grande e precisaria ser independente do desenvolvimento da plataforma continental norueguesa, devido a seu objetivo de competir no mercado global. Em 2014, enquanto as exportações de petróleo e gás teriam ficado entre oitocentos e novecentos bilhões de coroas norueguesas, a indústria de fornecedores, que seria a segunda maior exportadora do país, teria exportado entre cento e sessenta e duzentos bilhões de coroas, e a indústria de frutos do mar, em terceiro lugar, teria exportado a metade disso, entre cinquenta e cem bilhões. 
Percebe-se assim a verdadeira dimensão e importância do desenvolvimento dessa indústria para o país. Também foi apontado que a internacionalização seria importante por ser uma forma de aprendizado. Os desafios do futuro e as novas tecnologias provavelmente não serão desenvolvidos na Noruega, mas sim por situações encontradas em outros países. Seria muito importante que as empresas que atuam no exterior levassem de volta para a Noruega novos achados, novos aprendizados e novas descobertas. Além disso, o investimento em $\mathrm{P} \& \mathrm{D}$ e em novas tecnologias seria muito barato no país, pois um $\mathrm{PhD}$ provavelmente ganhe mais no Brasil do que na Noruega, onde competência seria relativamente barata, alta competência seria extremamente barata e baixa competência seria extremamente cara.

A questão sobre o ritmo de exploração foi abordada por diferentes perspectivas. Sempre teria havido um debate político sobre a necessidade de um ritmo de exploração balanceado, pois ao se desenvolver muito rapidamente não se daria chance para as pequenas empresas nacionais participarem e se perderia muito da possibilidade de aprendizado com cada etapa realizada. Teria se estabelecido que devem haver uma ou duas rodadas a cada ano, durante os próximos trinta anos. Isso ajudaria muito, dando segurança para aqueles que desejam investir no país. O ritmo também estaria relacionado ao preço do barril de petróleo, então estaria havendo uma queda nas explorações devido ao baixo preço.

Um dos entrevistados lembrou que muitos dos países que possuem reservas de petróleo enfrentam problemas como guerras civis e questões ambientais, e por isso, procurariam utilizar a experiência norueguesa como exemplo a ser seguido. Para que se compreenda o exemplo norueguês seria necessário entender que o país já possuía uma base industrial considerável no setor offshore, com experiência na exploração de ambientes marinhos muito difíceis. Também já possuía uma das maiores indústrias navais do mundo, estava desenvolvendo grandes projetos de energia hídrica, e tinha muitos geólogos trabalhando com mineração. Então tudo isso teria facilitado a entrada do país no setor de petróleo e gás. Nos primeiros dez a vinte anos, havia uma política industrial de cooperação com a indústria internacional, que foi convidada a participar do desenvolvimento de campos na Noruega. Esse convite seria vinculado a requerimentos, como a necessidade de formação de joint ventures com empresas norueguesas, através das quais os noruegueses teriam aprendido muito rapidamente. Também teriam sido impostas condições sobre como a indústria deveria operar, especialmente com relação a 
questões ambientais e de segurança no trabalho. Os equipamentos de perfuração que vinham dos Estados Unidos causavam muitos acidentes, mas os norte-americanos não levavam isso tão a sério quanto as autoridades norueguesas, que determinaram que esses aparelhos deveriam ser controlados automaticamente, para evitar acidentes. Essa condição não poderia ser atendida nos primeiros vinte anos, mas após vinte ou trinta anos, a indústria desenvolveu tecnologia para isso. O mesmo teria sido feito com relação a equipamentos que necessitavam da operação por mergulhadores, pois muitos teriam morrido realizando esses serviços. A imposição de condições com relação a segurança, automação e proteção do meio ambiente teria ajudado a Noruega a ter hoje as maiores indústrias mundiais de subsea e de equipamentos de perfuração. Isso teria sido uma combinação entre a atuação do governo e da indústria. A sociedade também teria participado através do sindicato de trabalhadores e do setor educacional, que passou a ser orientado para as necessidades da indústria de petróleo. Todos esses valores de abertura e cooperação seriam a base para uma boa política, e a experiência demonstraria que boas políticas levam a bons resultados.

A questão mais importante de todas seria que não existem grandes conflitos de interesse entre os objetivos políticos para a indústria e os objetivos comerciais para a indústria, pois estes trabalhariam juntos. Obviamente, existiria disputa acerca de certas posições, mas ambos pensariam da mesma forma com relação aos objetivos principais. Esse alinhamento estaria relacionado com a Noruega ser um país pequeno, de cinco milhões de habitantes, com uma economia pequena e aberta, um Estado de bem-estar social muito dependente do comércio internacional, com a necessidade de exportar muito e com a possibilidade de vender todo petróleo e gás encontrado no território norueguês, pois o país conseguiria satisfazer suas necessidades energéticas apenas com seus recursos hídricos. Teria sido essa necessidade de comércio exterior que teria levado a Noruega a assinar os acordos que foram feitos coma União Europeia, mesmo que o país não seja um membro do bloco. Em comparação com outros países, teria sido mais fácil para a Noruega estabelecer princípios e valores adequados para sua política industrial de petróleo e gás porque inicialmente ninguém se importava com isso, pois não acreditavam que houvesse petróleo e gás no país. Com isso, a política pôde ser estabelecida sem nenhuma pressão e com muita discussão com diversos atores envolvidos.

Muitos daqueles países que demonstram interesse em seguir o modelo norueguês, na verdade, não seguiriam os exemplos deixados pela experiência norueguesa. Eles 
estariam preocupados em colher os frutos dessa indústria antes mesmo de terem criado as instituições necessárias para que se possa adotar uma política voltada para resultados de longo prazo. Se deveria garantir que a indústria tenha capacidade e competência, o que a Noruega teria levado trinta anos para desenvolver. O problema da maioria desses países seria querer alcançar os resultados para amanhã. Durante mais de vinte e cinco anos, os noruegueses teriam investido muito, e reinvestido todos os recursos obtidos pela indústria, antes de terem um fluxo de caixa positivo. Então, se hoje essa indústria gera muito dinheiro, seria pela adoção dessa visão de longo prazo, com o objetivo de investir para colher no futuro.

Uma outra percepção equivocada que os demais países teriam a respeitos dos noruegueses seria que muitos deles teriam a ideia de que não se pode falar abertamente sobre os problemas do seu país, pois isso seria como assumir uma posição de inferioridade. Mas na verdade, os noruegueses se baseariam na ideia de que o que torna alguém forte seria, justamente, a sua capacidade de admitir que não sabe algo e de perguntar para outras pessoas. Se teria a impressão de que, por serem líderes no seu setor, os noruegueses deveriam saber a resposta para tudo que esteja relacionado a isso, mas o princípio básico para que se seja o melhor em algo seria justamente não acreditar que se possa saber a resposta de antemão, pois essa seria única maneira de se encontrar qualquer resposta.

\subsection{3 - Normatização da Política}

\section{a) Governo}

O gráfico 52, abaixo, apresenta as respostas dos entrevistados do governo norueguês, sobre a avaliação da normatização que serve de base para a política industrial de petróleo e gás no país. 


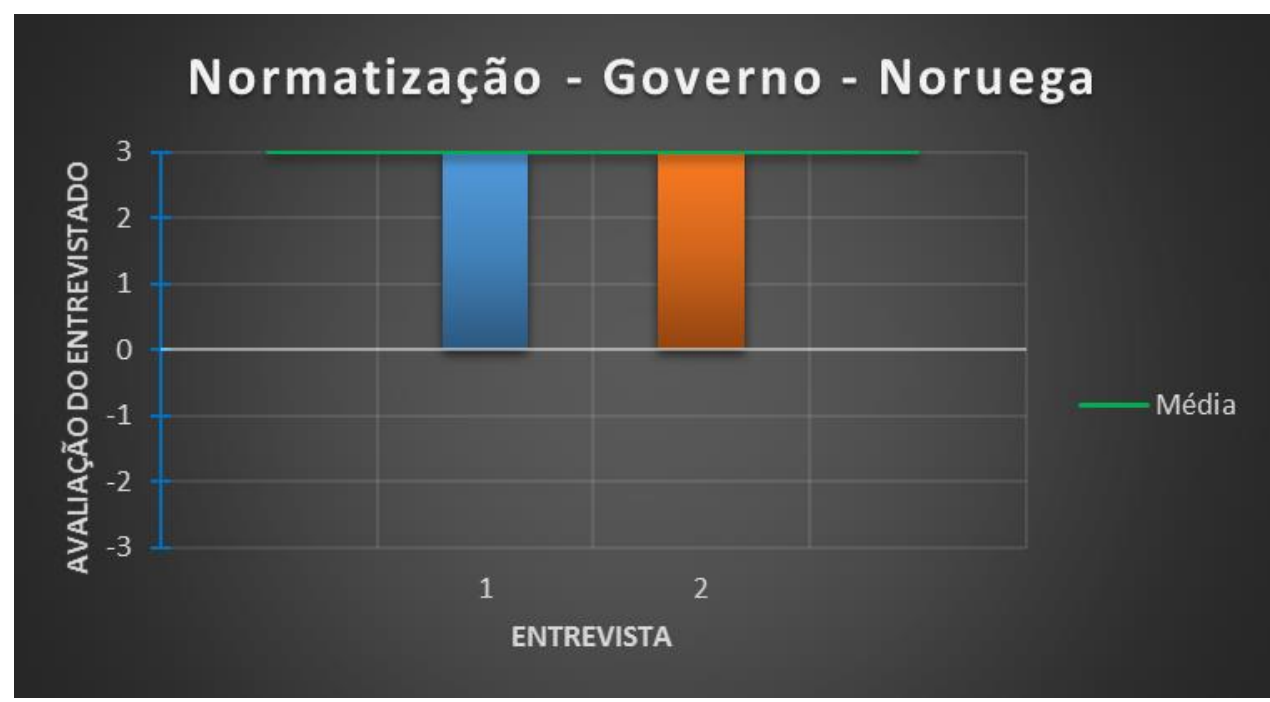

Gráfico 52 - Avaliações dos entrevistados do governo da Noruega sobre a normatização da política industrial de petróleo e gás no país.

Neste bloco, há que se destacar que ambos os entrevistados informaram terem participado diretamente da formulação das normas do setor de petróleo e gás norueguês. A participação da indústria nesse processo de desenvolvimento do sistema regulatório também foi apontada por ambos entrevistados. A lei de petróleo norueguesa, de 1996, teria sido desenvolvida por um comitê que contou com a participação de membros de indústria, pois seria muito mais fácil uma pessoa obedecer a uma lei que ela tenha ajudado a criar. O processo de desenvolvimento e atualização do sistema regulatório seria muito transparente e teria o objetivo de servir como uma ferramenta prática e operacional, que as pessoas possam entender e se relacionar. Como consequência, a lei teria sido bem recebida tanto pelo governo como pela indústria.

Outro tema que apareceu nas duas entrevistas foi a boa reputação que o sistema regulatório norueguês teria em outros países. A Noruega teria dedicado bastante tempo para desenvolver esse sistema e muitos países em desenvolvimento estariam demonstrando interesse em aprender e se espelhar no exemplo regulatório norueguês.

Um dos entrevistados mencionou que, de certa forma, a lei seria rígida, pois não poderia ser alterada frequentemente. Nesse sentido, a indústria apresentaria uma curiosidade, pois desejaria ao mesmo tempo flexibilidade e previsibilidade. Por isso, a lei norueguesa seria previsível e muito estável, mas também teria introduzido uma certa folga, para que essa mesma lei possa ser aplicada de formas diferentes ao longo do tempo, 
caso o governo ou a indústria vejam necessidade para isso. Dessa forma, a lei não seria uma camisa-de-força, sendo equilibradamente flexível sem que se torne aleatória. Além disso, essas normas seriam efetivamente aplicadas nos casos concretos.

\section{b) Associações Empresariais}

O gráfico 53, abaixo, apresenta as respostas dos entrevistados das associações empresariais norueguesas, sobre a avaliação da normatização que serve de base para a política industrial de petróleo e gás no país.

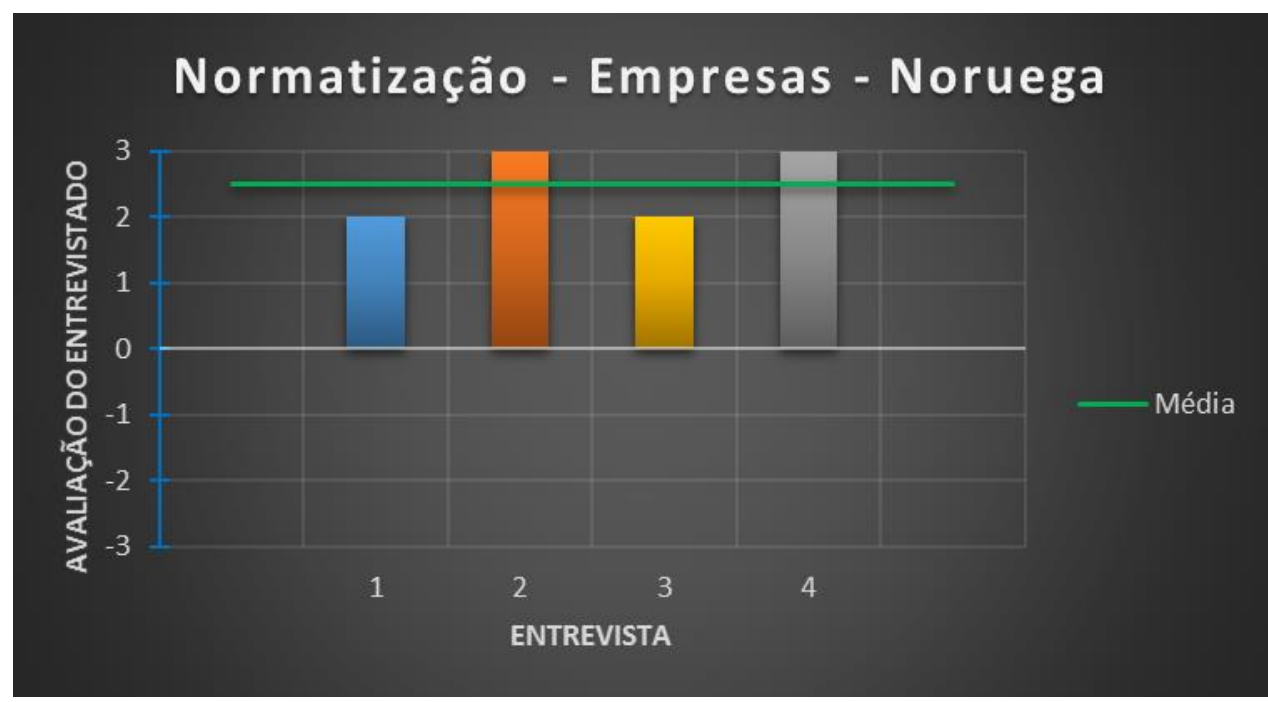

Gráfico 53 - Avaliações dos entrevistados das associações empresariais da Noruega sobre a normatização da política industrial de petróleo e gás no país.

Houve unanimidade entre os entrevistados ao destacarem o papel da relação de diálogo estabelecida entre o governo e a indústria. Isso teria ajudado na participação dos atores para a definição das regras, na adequação das normas à realidade e na flexibilidade da legislação, permitindo que se tenha um sistema regulatório balanceado. As regras deveriam ser transparentes e abertas, incluindo questões de política industrial, de sustentabilidade e de responsabilidade social das empresas, além de cuidar da segurança do trabalho, do meio ambiente e de inovações, ao mesmo tempo que deve ser inclusiva com as relações de trabalho. Mesmo que possam existir conflitos no dia a dia, de forma geral, governo e empresas trabalhariam de forma alinhada, através de uma cooperação construtiva, para a qual a indústria daria total apoio. A indústria, o sindicato, a academia, 
os legisladores e os políticos ajudariam um a balancear a atuação do outro. Cada um teria a sua responsabilidade, mas também seriam responsáveis por ouvir os demais, antes de tomarem uma decisão, para que se estabeleça uma relação de mão dupla. Além disso, haveria uma forte base na competência, tendo em vista que todos esses atores seriam muito competentes nas suas funções.

Em duas entrevistas foi defendido que as normas teriam uma combinação de rigidez e flexibilidade. A rigidez teria sido importante por ter forçado a indústria a se adaptar e desenvolver novas tecnologias, especialmente com relação à segurança no trabalho e proteção ao meio ambiente. Por outro lado, em outros momentos o governo teria tido que recuar e flexibilizar sua posição, para que se siga os princípios de uma boa gestão de recursos, que servem de fundamento para políticas justas e sustentáveis. Um terceiro entrevistado disse entender que algumas regras sejam muito rígidas, pois os objetivos da regulamentação não estariam conectados com os custos dela, como no caso da obrigação do uso de barcos salva-vidas, que traria custos que estariam fora da realidade. Assim, a grande prioridade de extrair os recursos da forma mais segura possível estaria refletida na legislação.

O Mar do Norte teria sido um laboratório para o desenvolvimento de tecnologia, tanto do lado do Reino Unido quanto do lado da Noruega, e as regras teriam se desenvolvido em paralelo com esse desenvolvimento tecnológico. Haveria uma relação dinâmica, onde as normas teriam que ser adaptadas constantemente e, por isso, o diálogo seria sempre importante. Além disso, hoje em dia as normas e regulamentações seriam muito internacionalizadas e a indústria teria se desenvolvido a ponto de adotar as melhores práticas em todo o mundo. Haveria muita padronização sendo colocada em prática. Na maior parte do mundo as empresas petroleiras seriam as mesmas, os fornecedores seriam os mesmos e os governos trabalhariam em conjunto.

Já em algumas questões, os padrões noruegueses seriam diferentes dos estabelecidos em outros países. Desde o começo, nos anos 1970, a Noruega teria proibido a queima de gás associado, exigindo seu aproveitamento. Se a mesma medida tivesse sido adotada em todo mundo, quatrocentos milhões de toneladas de gases de efeito estufa poderiam ter sido evitados a cada ano. A Noruega também teria fixado um imposto sobre a emissão de dióxido de carbono desde 1991. A experiência do país teria mostrado que a cobrança de valores teria reduzido essas emissões, estimulando o uso de tecnologias e 
operações mais eficientes. Como resultado, os noruegueses teriam alcançado um dos mais baixos níveis mundiais de emissão por unidade de óleo produzida. Como apenas $28 \%$ das reservas de gás do país teria sido produzido, a Noruega deverá continuar sendo um exportador de gás natural por muitos anos.

Também foram dois os entrevistados que mencionaram que muitos países tentam seguir o modelo regulatório norueguês. O problema seria que, na maioria desses países, esse modelo acabaria gerando corrupção, pois nele todos falam com todo mundo, marcariam reuniões e pediriam favores. Seria a existência de um sistema muito transparente que permitiria esse tipo de interação sem que sirva como uma oportunidade para atos de corrupção.

\subsection{4 - Implementação da Política}

\section{a) Governo}

O gráfico 54, abaixo, apresenta as respostas dos entrevistados do governo norueguês, sobre a avaliação da forma de implementação da política industrial de petróleo e gás no país.

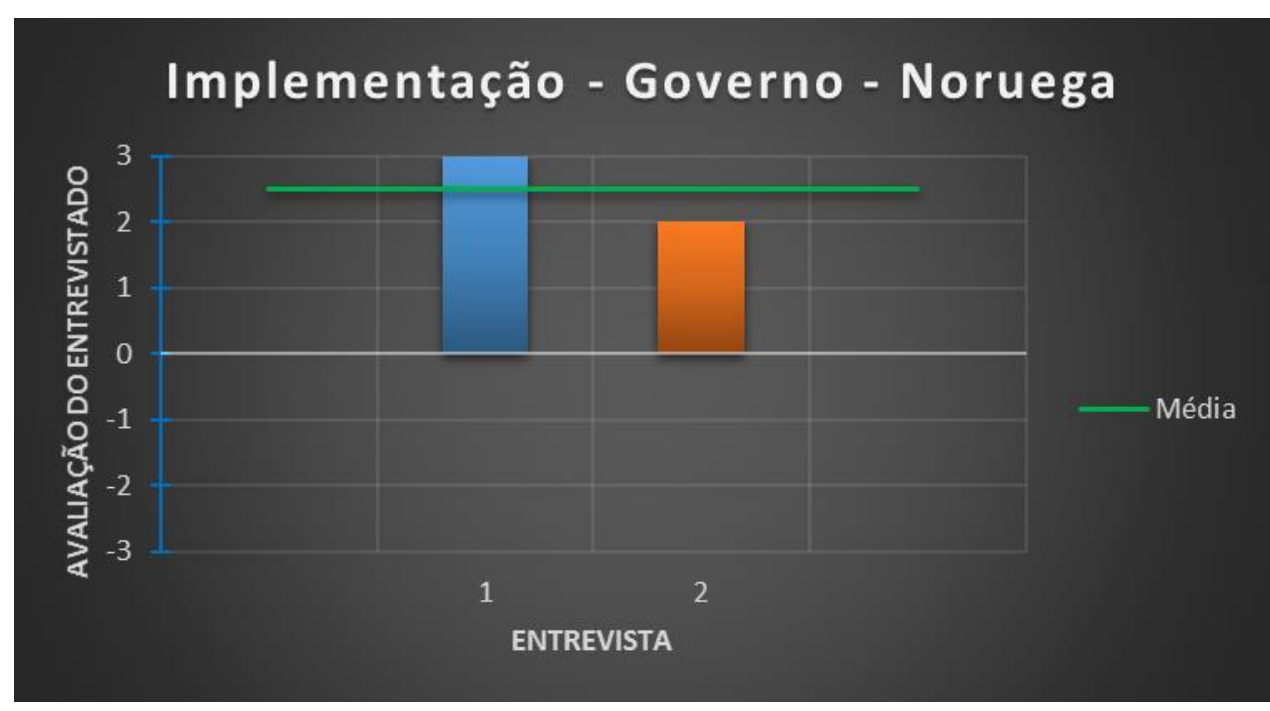

Gráfico 54 - Avaliações dos entrevistados do governo da Noruega sobre a implementação da política industrial de petróleo e gás no país. 
Os dois entrevistados disseram haver uma boa participação dos atores envolvidos, pois haveria transparência, e todos seriam sempre muito bem-vindos para manifestarem suas opiniões. Seria necessário que haja esse espaço para que se ouça outros atores, para evitar que sejam perdidas diferentes e importantes questões, visões ou nuances. O grupo de atores envolvidos com a política seria muito grande. Por exemplo, mas questões legais, haveria os advogados do governo, os advogados das empresas, os procuradores e a academia. Duas vezes por ano, todos esses quatro grupos, representados por aproximadamente cento e vinte pessoas, se reuniriam durante alguns dias para discutir questões legais, garantir que não haja nenhum mal-entendido e que ninguém esteja insatisfeito. Essas reuniões seriam permanentes e não apenas em momentos problemáticos. Também seriam feitos encontros com as associações empresariais, anualmente, na cidade de Hammerfest. O conteúdo de todas essas conversas seria tornado público.

Um dos entrevistados disse não perceber nenhum elemento da política que não tenha sido implementado, nem conhecer reclamações sobre isso. A política seria muito bem implementada com base em um acordo geral, um consenso, dentro do parlamento norueguês. Também haveria cooperação com universidades e centros de pesquisa. Além disso, haveria um programa chamado DEMO 2000, de apoio à P\&D e ao desenvolvimento industrial. Esse seria um sistema onde o Estado fornece uma verba inicial para programas de desenvolvimento de novas tecnologias e novas soluções por parte da indústria. A ideia seria o Estado contribuir com o desenvolvimento até que ele se torne comerciável. Esse seria um arranjo bastante popular. Haveria outros arranjos onde seriam oferecidas reduções fiscais e diversas outras formas de incentivos, que funcionariam muito bem.

Já o outro entrevistado disse que não acredita na existência de atos de corrupção. Ao menos no centro do governo, seria absolutamente inexistente qualquer chance de que haja corrupção. Uma atitude dessas não iria durar, pois o responsável seria imediatamente excluído. Quando os noruegueses aconselham outros países esse seria um dos pontos destacados, pois se não for resolvida a questão da corrupção, qualquer política estaria fada a dar errado. 


\section{b) Associações Empresariais}

O gráfico 55, abaixo, apresenta as respostas dos entrevistados das associações empresariais norueguesas, sobre a avaliação da forma de implementação da política industrial de petróleo e gás no país.

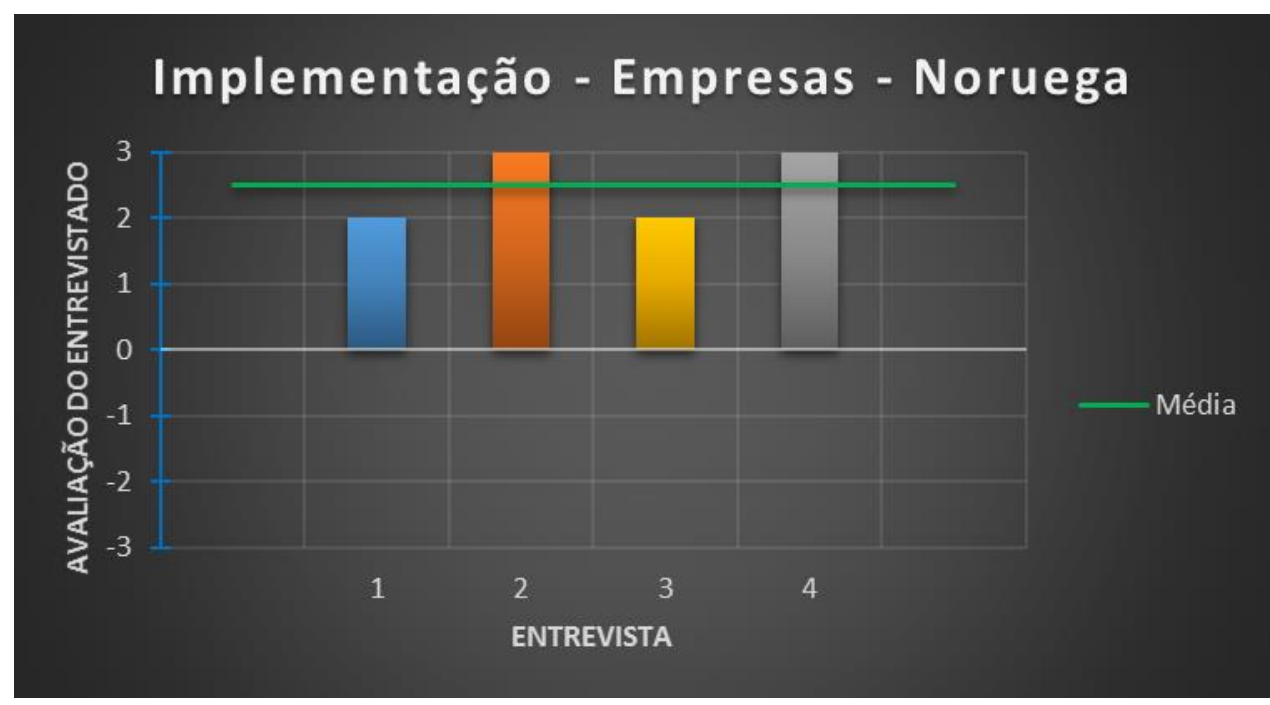

Gráfico 55 - Avaliações dos entrevistados das associações empresariais da Noruega sobre a implementação da política industrial de petróleo e gás no país.

Não houve nenhuma perspectiva levantada por todos os quatro entrevistados. $\mathrm{O}$ estabelecimento de metas e objetivos bem definidos foi mencionado em três entrevistas. Os noruegueses teriam tido a sorte de terem bons líderes na época em que o setor de petróleo chegou ao país. Quando a empresa norte-americana, Phillips, quis comprar toda plataforma continental norueguesa em um único bloco, alguém teria se dado conta de que seria importante haver competição e um bom planejamento, para que se pudesse ter um desenvolvimento gradual de longo prazo. Com base nisso, em 1974, foram criados os dez mandamentos da indústria de petróleo e gás que servem de base para a política e a legislação até hoje.

Também foram três os entrevistados que mencionaram a transparência na implementação da política industrial norueguesa. Foi apontado que existe um grupo de atores que se reúnem na EITI (Extractive Industry Transparent Initiative), que seria um grupo internacional anticorrupção. A Lei Dodd-Frank, dos Estados Unidos, também seria uma referência para a transparência nas contas púbicas. A ideia seria evitar a corrupção 
dando transparência para os valores que as empresas pagam para os governos. De um lado, as empresas teriam que declarar o quanto pagam, enquanto do outro, os governos teriam que declarar quanto recebem. Além disso, fazer parte da indústria global e contar com a participação de diferentes órgãos do governo, das empresas operadoras, das empresas fornecedoras, das associações empresariais e dos sindicatos de trabalhadores seria a forma mais adequada para que se tenha transparência e prestação de contas.

A existência de poucos casos de corrupção na história do país foi outra perspectiva trazida por três dos entrevistados. Alguns casos de corrupção já teriam acontecido na Noruega, mas o país seria muito transparente e a maioria dos envolvidos teria sido presa. Existiriam casos de pessoas ou empresas corruptas, mas comparado com outras áreas do mundo seria algo mínimo. Por tratar de negócios envolvendo valores muito altos, o sistema adotado para evitar corrupção no setor de petróleo seria muito estrito. Por isso, outros setores noruegueses como o naval e o de pesca, provavelmente tenham mais casos de corrupção do que o setor de petróleo. Nos velhos tempos, com exceção de alguns jantares caros e algumas viagens pelo mundo, as pessoas do governo não devem ter recebidos quaisquer outros privilégios. Hoje em dia, a corrupção seria muito pequena, algo mínimo. Muito focado em indivíduos e algumas empresas que atuam internacionalmente, mas não algo sistemático como seria o caso do Brasil e do México. Um dos entrevistados citou um exemplo, fazendo a ressalva de que não chegaria a ser um ato de corrupção, mas que a Statoil, devido à sua competência e poder, teria um papel muito dominante e teria mais voz do que os demais atores, com relação à política e junto a políticos e legisladores.

O diálogo e a interação entre os atores envolvidos com a política industrial foram lembrados em duas entrevistas. Na região de Stavanger, existiriam clusters da indústria de petróleo, criando competência para o desenvolvimento de aprimoramentos técnicos, junto com instituições de pesquisa e universidades. Um dos requerimentos impostos pelo governo às empresas seria o de que, para que se receba uma licença, se deveria participar do desenvolvimento de uma determinada tecnologia, junto com a indústria nacional, universidades e centros de pesquisa. Nestas relações também teria havido uma cooperação muito boa.

Já com relação à integração da política industrial com outras políticas, foram apresentadas diferentes visões. Foi mencionado que haveria integração com outras 
políticas, mas que a indústria de petróleo e gás seria dominante. Também foi dito que essa integração teria sido feita utilizando a experiência da indústria de petróleo e gás em outras áreas. Um exemplo disso seria que mais de $50 \%$ das pessoas que perderam seus empregos no setor de petróleo teriam conseguido emprego em outros setores. Outra perspectiva apresentada foi a influência que um setor pode ter em outro. Haveria uma política para tentar fazer com que a indústria de petróleo não prejudique outras indústrias, como a indústria pesqueira. Por isso, antes que uma empresa tenha seu plano de exploração aprovado, ela deve apresentar uma avaliação de impacto ambiental, que inclui o impacto social, no meio ambiente e em outras indústrias. Neste ponto também teria havido um diálogo muito bom entre os atores envolvidos.

\subsection{5 - Resultados da Política}

\section{a) Governo}

O gráfico 56, abaixo, apresenta as respostas dos entrevistados do governo norueguês, sobre a avaliação dos resultados alcançados pela política industrial de petróleo e gás no país.

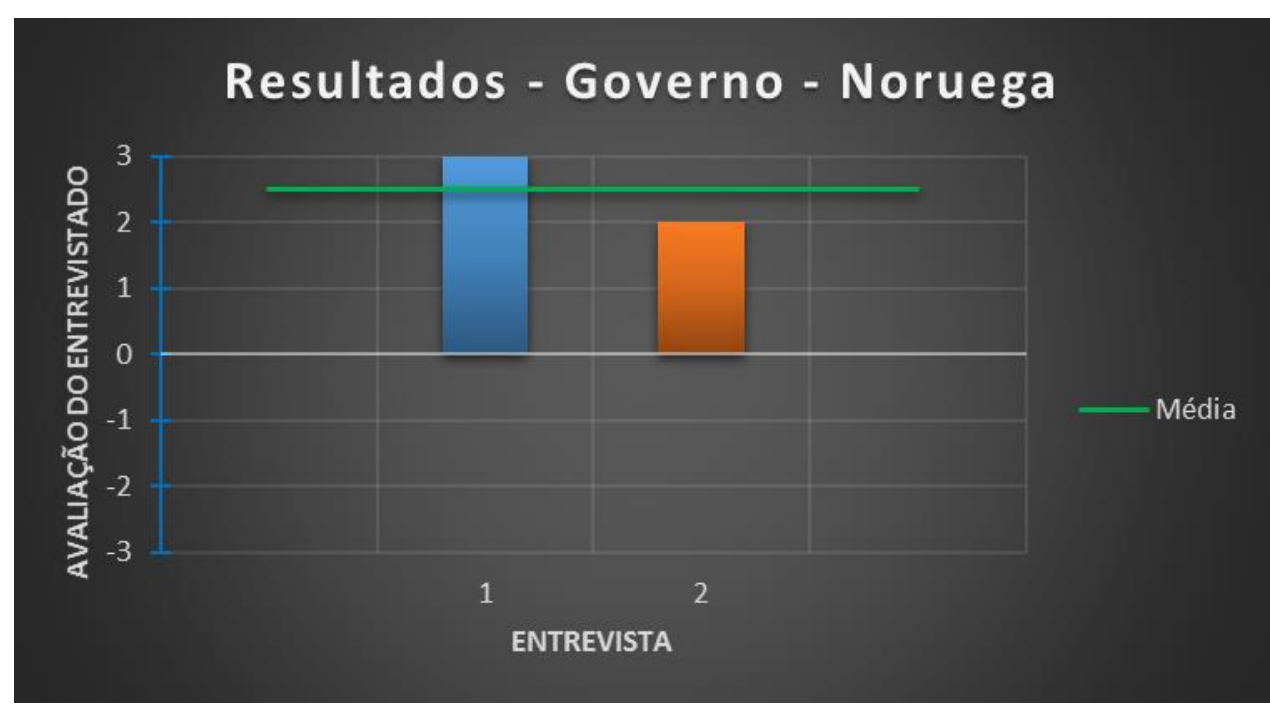

Gráfico 56 - Avaliações dos entrevistados do governo da Noruega sobre os resultados da política industrial de petróleo e gás no país. 
Nas duas entrevistas foi mencionado que o setor de petróleo e gás teria uma contribuição significativa para o emprego na Noruega. Mesmo não sendo um setor intensivo em mão-de-obra, dos cinco milhões de habitantes do país, duzentos e quarenta mil trabalhariam no setor de petróleo e gás. Então seria muita gente. Os salários seriam acima da média, o que causaria desafios em alguns casos. Períodos de grande crescimento no setor poderiam gerar evasão de talentos de outros setores para o de petróleo, além de os salários altos colocarem pressão sobre o salário de outros setores.

A não adoção de políticas de conteúdo local foi destacada nas duas entrevistas. Inicialmente o índice de conteúdo local seria um objetivo claro e expresso da política, mas hoje existiriam limites à proteção que se poderia adotar, devido à associação com a União Europeia, que teria tornado essa prática ilegal. Mas mesmo que a Noruega não tenha mais nenhuma política nesse sentido muitos fornecedores seriam noruegueses.

Os dois entrevistados também disseram que haveria muita exportação de bens e serviços. Isso seria algo muito importante, pois demonstraria que se é internacionalmente competitivo e que o país conta com ferramentas, equipamentos e processos de alto desempenho.

Em uma das entrevistas foi dito que, mesmo sendo muito conservadora, a indústria de petróleo e gás norueguesa teria tido processos de aprendizagem tecnológica, como a tecnologia de perfuração em poços horizontais, desenvolvida no campo de Troll. O governo também ofereceria uma verba inicial para o desenvolvimento de projetos de $\mathrm{P} \& \mathrm{D}$, formando joint ventures com a indústria, com o desenvolvimento de muitos subfornecedores de diferentes áreas. Haveria uma boa capacidade produtiva e o fato de ser competitivo, mesmo com altos salários, seria uma demonstração de eficiência. A atração de investimentos seria estimulada pela existência de um sistema político estável e previsível. E, de uma maneira geral, os resultados atuais seriam muito melhores do que o que se esperava alguns anos atrás.

\section{b) Associações Empresariais}

O gráfico 57, abaixo, apresenta as respostas dos entrevistados das associações empresariais norueguesas, sobre a avaliação dos resultados alcançados pela política industrial de petróleo e gás no país. 


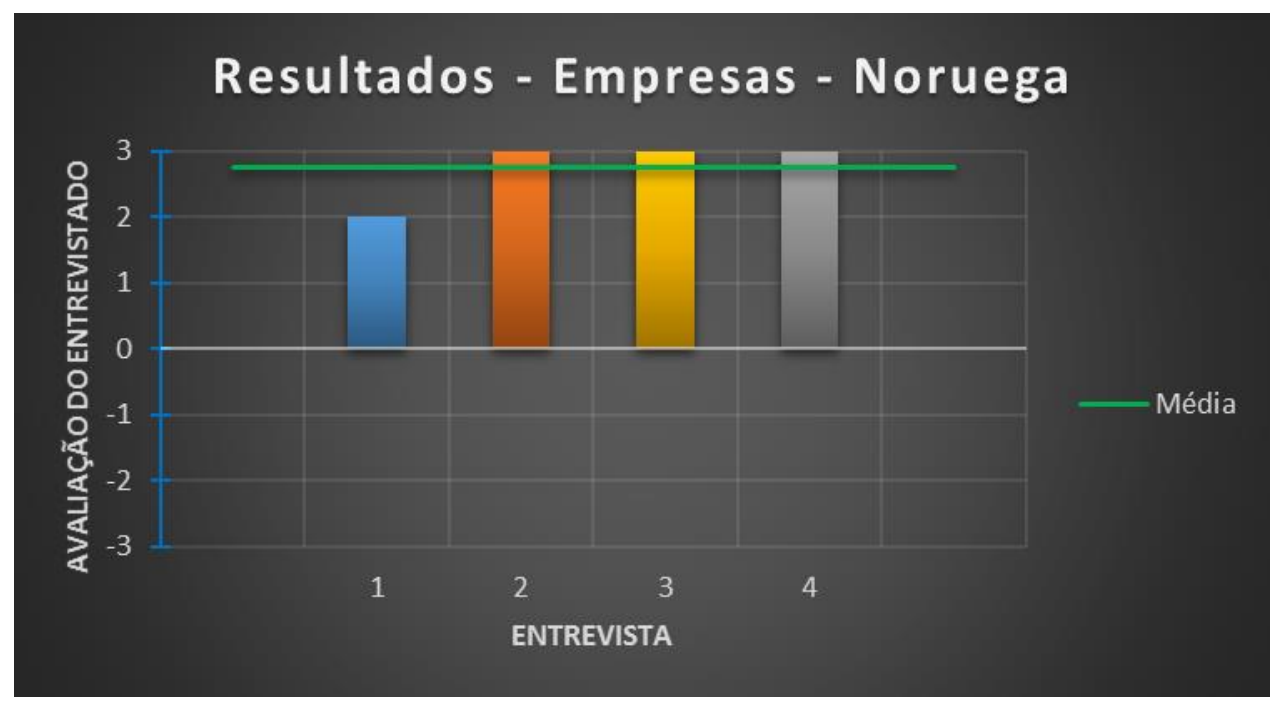

Gráfico 57 - Avaliações dos entrevistados das associações empresariais da Noruega sobre os resultados da política industrial de petróleo e gás no país.

Neste bloco não houve nenhum tema levantado por todos os quatro entrevistados. Muitos temas foram trazidos em três das entrevistas, como o grande número de empregos gerados pelo setor, mesmo se tratando de uma indústria de capital intensivo. Não se poderia reclamar dos resultados, pois a indústria de petróleo norueguesas teria $10 \%$ do mercado mundial, duzentos e cinquenta mil pessoas empregadas direta ou indiretamente, sendo a maior indústria do país. Para um país tão pequeno, ter alcançado tantos resultados seria excelente e seria fruto de um muito bom gerenciamento da política, que pode ter ocorrido por sorte ou por competência dos noruegueses. O nível salarial seria muito alto, o que, além de aumentar os custos para a indústria de petróleo, aumentaria o salário em outras partes da economia, sendo um desafio para a competitividade do país.

Também foram três os entrevistados que falaram sobre os bons resultados em desenvolvimento tecnológico e investimentos em $\mathrm{P} \& \mathrm{D}$, incluindo parcerias com muitas universidades e institutos de pesquisa, especialmente nas regiões de Stavanger, Bergen e Trondheim. Haveria investimentos privados em $\mathrm{P} \& \mathrm{D}$, vindos de exigências nos contratos de licenças, assim como investimentos públicos. Haveria muitos processos de aprendizagem tecnológica e desenvolvimento de tecnologias que depois seriam utilizadas em outros setores.

Outro tema mencionado em três das entrevistas foi a necessidade de uma alta produtividade e de tecnologia para compensar os altos custos no país, como os altos 
salários. No momento se estaria abaixo da capacidade produtiva, devido ao preço baixo do barril, mas a produtividade seria altíssima na Noruega. Haveria uma variação da produtividade de acordo com a tendência do momento. Quando o preço do barril está alto, a capacidade produtiva seria maximizada, e a produtividade competitiva seria reduzida. Mas com o preço baixo, haveria demissões, maior competição e um aumento da competitividade.

Bons resultados com relação à atração de investimentos também foram lembrados por três dos entrevistados. A estabilidade e previsibilidade das condições oferecidas no país seriam elementos importantes para essa atração de investimentos.

Dois dos entrevistados relativizaram a importância do registro de patentes para os noruegueses. A indústria seria aberta e transparente, não adiantando muito tentar se proteger através de patentes, pois os concorrentes encontrariam outros meios. A melhor forma de se proteger seria colocando a invenção no mercado.

Em duas entrevistas foi mencionado que quando essa indústria teria começado na Noruega, em 1967, teria se adotado medidas de proteção, como políticas de conteúdo local, mas hoje isso não existiria mais. No começo se tinha a ideia de que a propriedade norueguesa das empresas seria algo importante, mas depois teria se percebido que o mais importante seria que a atividade fosse realizada na Noruega, para que a criação de empregos e o desenvolvimento de inovações sejam feitos no país. Ser o dono da indústria não seria tão importante. Então, nos últimos vinte a trinta anos uma grande parte da indústria norueguesa teria se tornado propriedade de complexos industriais internacionais, assim como muitos desses complexos teriam sido adquiridos por empresas norueguesas. Para os noruegueses, conteúdo local seria a criação de valor no país e não a propriedade nacional das empresas.

A importância das exportações para o país também foi destacada por dois entrevistados. O país seria dependente de exportações, exportando $98 \%$ do gás produzido no país, além de outras commodities. Por não haver a necessidade do uso dos recursos de petróleo e gás noruegueses para abastecer o mercado interno, praticamente todos esses recursos seriam exportados. 


\subsection{6 - Avaliação da Política}

\section{a) Governo}

O gráfico 58, abaixo, apresenta as respostas dos entrevistados do governo norueguês, sobre a avaliação dos mecanismos de monitoramento e avaliação da política industrial de petróleo e gás no país.

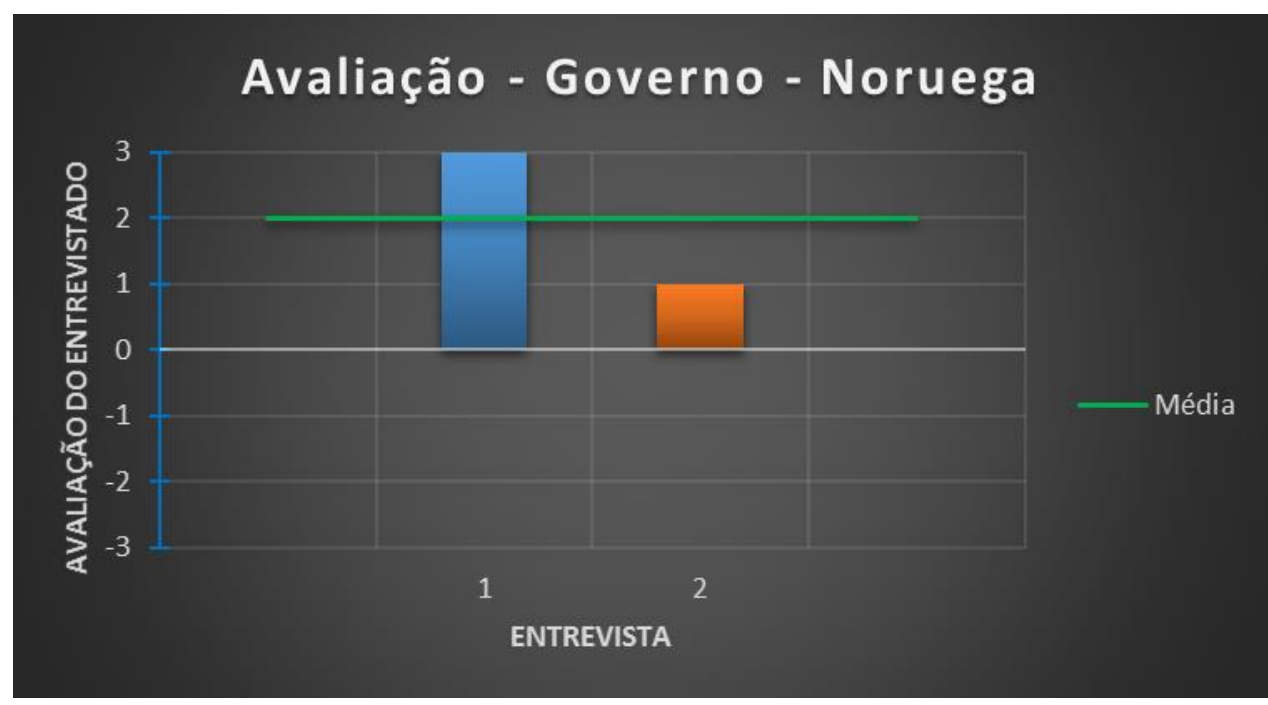

\section{Gráfico 58 - Avaliações dos entrevistados do governo da Noruega sobre a avaliação da} política industrial de petróleo e gás no país.

Neste bloco não houve nenhum tema que tenha sido tratado pelos dois entrevistados. Um deles disse entender que o único instrumento real de monitoramento que as autoridades teriam seria o sistema de licenciamento. Porque depois de dada a licença não haveria mais muito que o governo poderia fazer. Ele também defendeu que os políticos talvez tenham a impressão de terem mais poder para monitorar a política do que eles realmente teriam.

Já o outro entrevistado explicou que os mecanismos de monitoramento e avaliação noruegueses não estariam integrados de uma maneira sistemática. $\mathrm{O}$ desenvolvimento, $\mathrm{o}$ monitoramento e a avaliação da política seriam feitos através de um processo dinâmico. De tempos em tempos o governo teria que apresentar a política ao parlamento. Para essa apresentação, teria que se fazer uma espécie de análise. Essa análise seria uma forma de 
monitoramento. E, como parte desse monitoramento, seria necessário avaliar a política. Todo esse processo consumiria muito tempo e ocuparia muitas capacidades do governo.

Na Noruega, todas as informações seriam muitos transparentes e de fácil acesso. Haveria dois aplicativos para celulares cheios de informações. A legislação norueguesa seria muito estrita com relação a que tudo que seja feito pelo governo tenha que ser tornado público. Mas se algo é desenvolvido como sigilo comercial ou segredo industrial, não haveria essa obrigação de tornar público. Assim como alguns memorandos e cartas, que seriam considerados correspondência interna. Mas fora isso tudo seria muito aberto, com fácil acesso à informação, que estaria prontamente disponível. Isso seria bom para manter o governo alerta de que se deve prestar contas para a opinião pública sobre tudo que se faça e por aumentar o nível de conhecimento disponível para aqueles que se interessarem em adquirir essa informação.

Os noruegueses teriam um sistema onde seria muito difícil que alguém possa impor suas decisões. Não que tudo seja consenso, nem nada parecido. Quem tem que decidir, deve tomar as decisões. Mas tudo ficaria muito mais fácil com estruturas de incentivo e motivação, que levem a uma propriedade compartilhada, não apenas dos resultados, mas também dos processos. Fazer com que os atores participem do processo ajudaria a fazer com que eles, posteriormente, compreendam melhor os resultados.

\section{b) Associações Empresariais}

O gráfico 59, abaixo, apresenta as respostas dos entrevistados das associações empresariais norueguesas, sobre a avaliação dos mecanismos de monitoramento e avaliação da política industrial de petróleo e gás no país. 


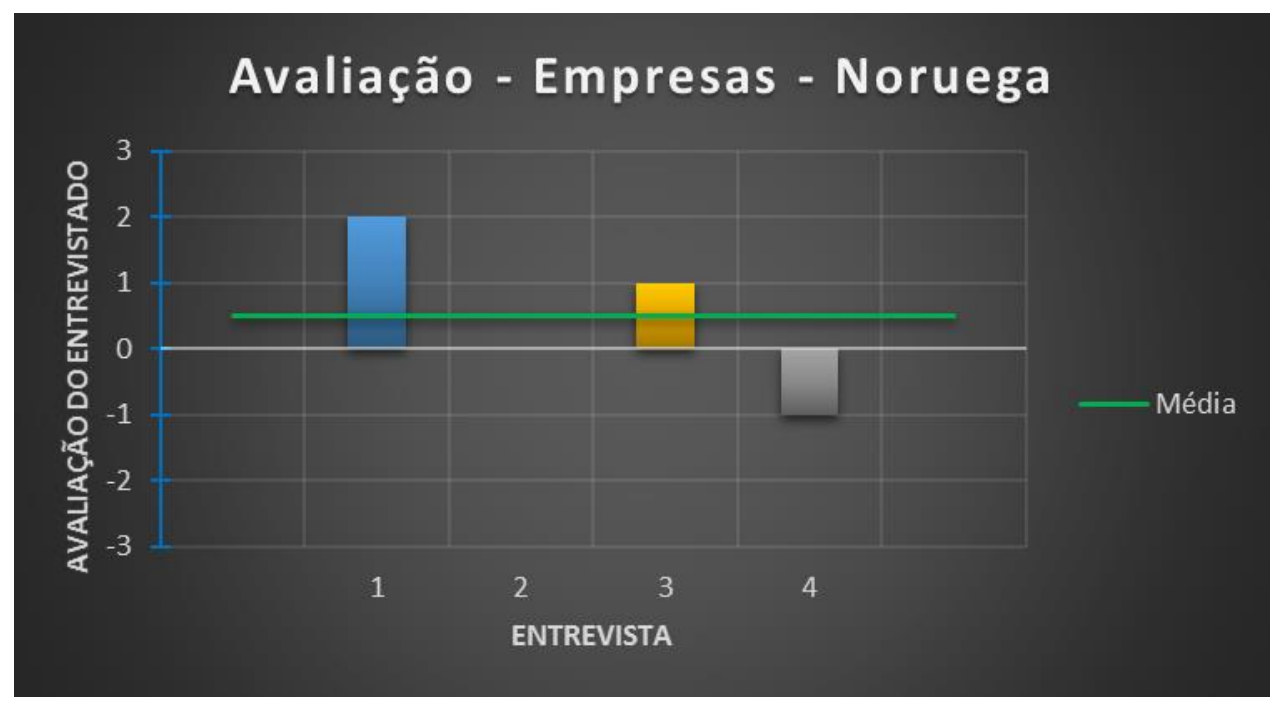

Gráfico 59 - Avaliações dos entrevistados das associações empresariais da Noruega sobre a avaliação da política industrial de petróleo e gás no país.

Um dos entrevistados preferiu não responder às perguntas deste bloco, por entender que caberia apenas ao governo se manifestar sobre essas questões. Entre os outros três entrevistados, não houve nenhuma perspectiva que tenha se repetido em mais de uma entrevista.

Um dos entrevistados disse que provavelmente exista alguma forma de monitorar e avaliar a política, mas que este seria um ponto fraco da política norueguesa, para o qual se deveria ter dado mais atenção. Nesse sentido, se poderia ter sido mais eficiente para explicar o que foi feito. Por exemplo, quando houve a fusão entre a Hydro e a Statoil, essa decisão teria sido justificada com base numa expetativa de atingimento de alguns objetivos. Mas não se viu uma avaliação sobre o que aconteceu depois da fusão, analisando se os resultados desejados foram alcançados, ou o que teria levado ao não atingimento de algum objetivo. Também não teria se visto nenhuma avaliação da política.

Toda empresa teria que reportar dados para o governo. Mas o governo não ofereceria acesso a esses dados. Por uma questão de confidencialidade, só se daria acesso a informações em bases agregadas. Nesse mesmo sentido, associações contratariam empresas de consultoria, que fariam declarações de confidencialidade, para terem acesso aos dados das empresas associadas, que serão necessários para a apresentação de relatórios ao governo. Esses relatórios apresentariam as empresas de forma anônima e os dados também seriam apresentados de forma agregada. Não seria nada fácil conseguir 
dados em bases individuais. Portanto, segundo um dos entrevistados, facilitar de todas as formas possíveis o acesso a esses dados do governo seria um dos elementos que poderiam ser aprimorados nessa política.

Comparando com quarenta anos atrás, hoje os políticos noruegueses não poderiam mais fazer muitas das coisas que faziam, pois agora fazem parte de tratados internacionais. Seriam obrigados a garantir que a indústria norueguesa esteja competindo no mercado internacional e que a educação do país siga padrões internacionais. Conforme um dos entrevistados, estaríamos nos tornando um mundo globalizado também no que se refere a políticas, monitoramentos e controles de qualidade. Numa visão mais ampla, se poderia dizer que os noruegueses seriam monitorados pelos resultados obtidos pelas exportações da sua indústria.

Além disso, de uma forma geral, haveria um alto nível de monitoramento no país. A política norueguesa não seria mais feita por um pequeno grupo de pessoas numa sala fechada. Isso seria resultado da participação de instituições fortes, sindicatos, imprensa, indústria e opinião pública. Toda a política, a legislação e as decisões seriam monitoradas muito de perto por todos esses atores, através do diálogo que existe entre eles. Também foi lembrada a existência de um mecanismo central, chamado "Riksrevisjonen", que seria uma autoridade de controle, uma grande organização, como um auditor geral, que controla ministérios e seus secretários para saber se estão realizando corretamente as suas funções. A presença de uma imprensa muito independente e livre também seria um importantíssimo mecanismo de monitoramento, além de se tratar de uma sociedade muito transparente como um todo. Instituições internacionais de consultoria foram apontadas como tendo muito boa reputação, citando exemplos como a Wood Mackenzie e a Mackenzie and Deloy.

Muitos países perguntam sobre o modelo norueguês, mas qualquer resposta que se dê seria mal compreendida, porque eles não conseguiriam ter a percepção correta dos elementos sobre os quais se está falando. Poucos estariam dispostos a passar vinte e cinco anos investindo, esperar vinte e cinco anos para poder retirar algum lucro, correr riscos, falar sobre questões envolvendo petróleo, deixar a indústria internacional entrar no país para que se aprenda com ela e não impor fortes requerimentos de conteúdo local, para não prejudicar a competência e a capacidade da sua indústria no longo prazo. Ninguém estaria disposto a fazer isso. Eles só estariam interessados em ter o dinheiro que os 
noruegueses têm. Mas isso seria algo que eles começaram em 1967. Não seria possível começar em 2016 e achar que terá os mesmos resultados no ano seguinte.

\subsection{7 - Reação aos Resultados da Política}

\section{a) Governo}

O gráfico 60, abaixo, apresenta as respostas dos entrevistados do governo norueguês, sobre a avaliação da reação aos resultados encontrados pelos mecanismos de monitoramento e avaliação da política industrial de petróleo e gás no país.

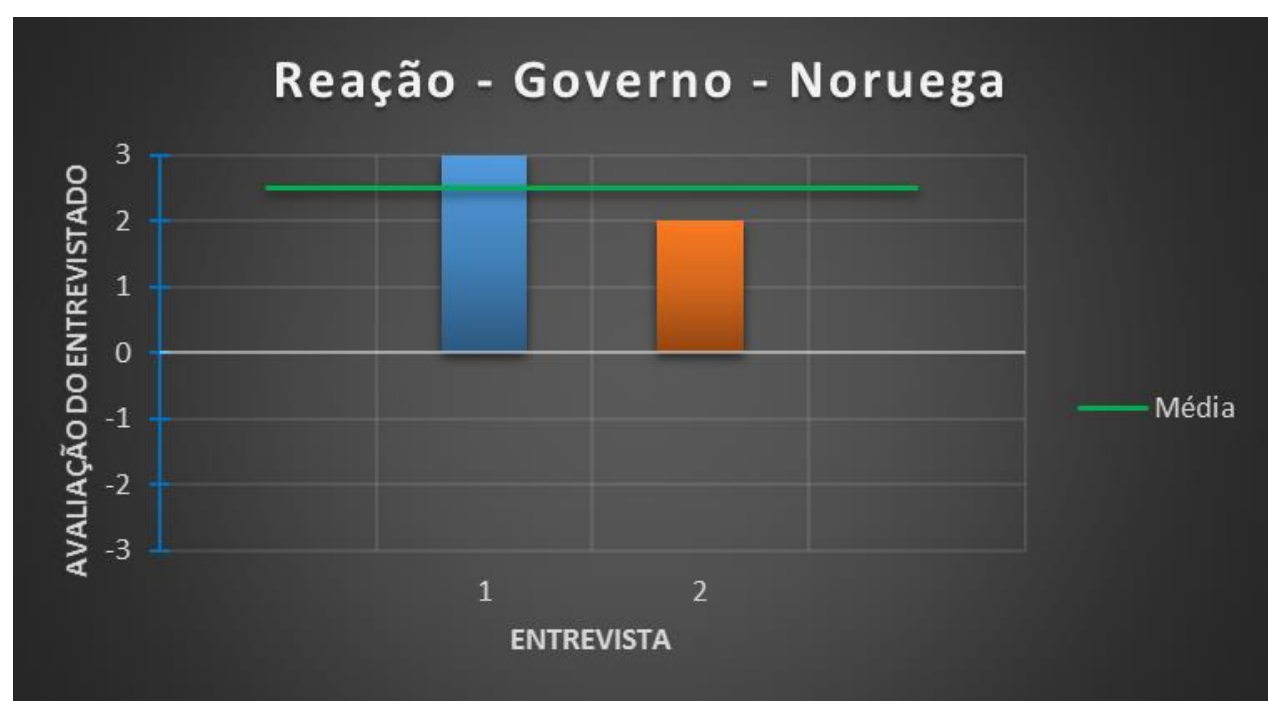

\section{Gráfico 60 - Avaliações dos entrevistados do governo da Noruega sobre a reação aos} resultados da avaliação da política industrial de petróleo e gás no país.

Neste bloco não houve nenhuma informação que tenha sido mencionada nas duas entrevistas. Foi dito que o debate no parlamento não tem como ser mais público do que é. O governo seria bastante bom em ouvir, e não estaria ouvindo apenas para parecer educado. Estaria realmente interessado em saber o que pensam os demais atores. Isso porque existiriam coisas que um não consegue enxergar, mas outros conseguiriam. De acordo com esse entrevistado, pensar qualquer coisa diferente disso seria excessivamente arrogante. Sobre a existência de outros interesses que possam influenciar as decisões sobre a política industrial norueguesa, um entrevistado mencionou apenas os interesses dos movimentos ambientais e da indústria pesqueira.

O governo teria algumas informações que seriam disponíveis para a indústria e para instituições de pesquisa, mas essa disponibilidade seria muito regulada. Para 
proteger os investidores, dados sobre explorações, por exemplo, só seriam disponibilizados após certos anos. Um exemplo disso teria acontecido no norte do país, onde Noruega e Rússia dividem fronteira. A parte sul do lado norueguês dessa fronteira teria sido anunciada como parte da próxima ronda de licitações. Mas antes dessa rodada, o governo teria coletado e processado dados sísmicos dessa região, para serem analisados e avaliados. Essas análises a avaliações teriam servido de base para a decisão política sobre abrir licitações nessa região ou não. Após tomarem a decisão de realizar essas licitações, os dados coletados foram disponibilizados para serem vendidos para a indústria. A ideia por trás disso seria fazer com que a obtenção desses dados seja realizada sem gerar custos para o governo. Então, se estabeleceria um preço para cada pacote de dados, que as empresas podem comprar e utilizar como base para sua análise sobre se devem aplicar para essas licitações. Com isso, não haveria a necessidade de proteger essas informações por serem propriedade do governo, mas essas informações não seriam disponibilizadas antes do governo ter feito suas próprias avaliações. De acordo com o entrevistado, isso tudo estaria funcionando muito bem.

\section{b) Associações Empresariais}

O gráfico 61, abaixo, apresenta as respostas dos entrevistados das associações empresariais norueguesas, sobre a avaliação da reação aos resultados encontrados pelos mecanismos de monitoramento e avaliação da política industrial de petróleo e gás no país.

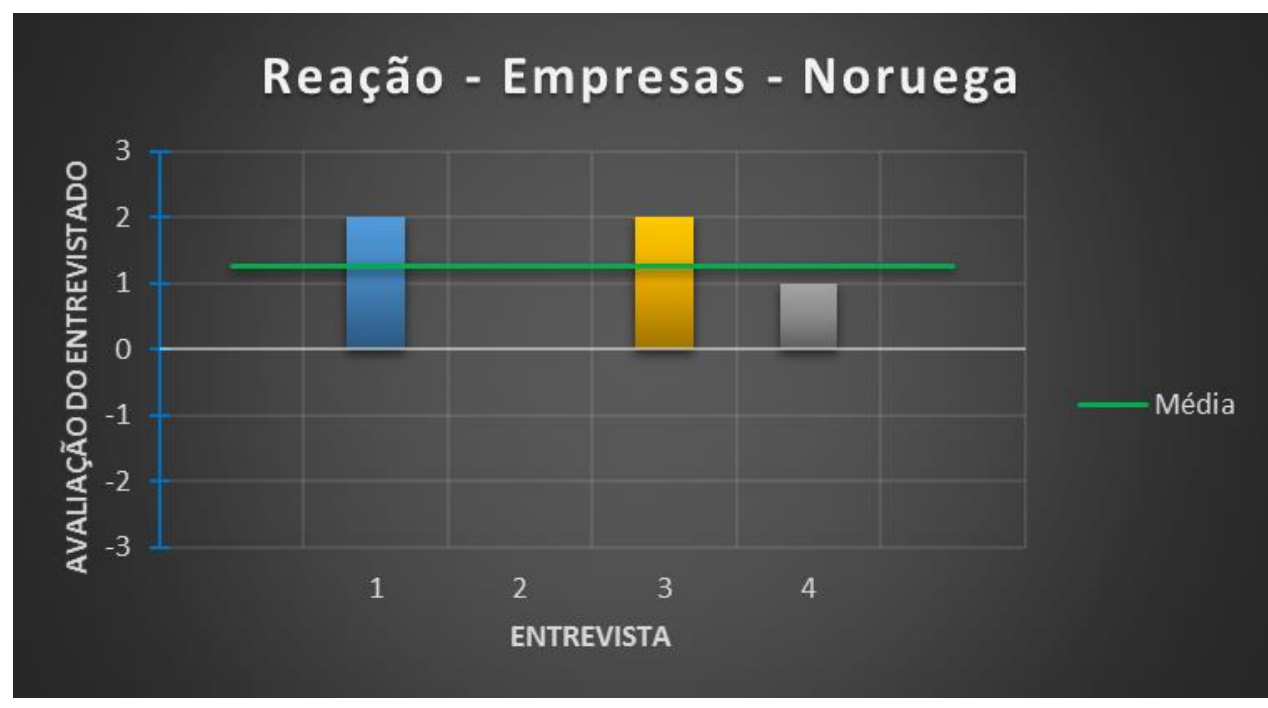

Gráfico 61 - Avaliações dos entrevistados das associações empresariais da Noruega sobre a reação aos resultados da avaliação da política industrial de petróleo e gás no país. 
Um dos entrevistados preferiu não responder às perguntas deste bloco, por entender que caberia apenas ao governo se manifestar sobre essas questões. Todos os outros três entrevistados disserem entender que haveria transparência e diálogo na definição dessa reação. Para um desses entrevistados, todo o monitoramento e avaliação seriam públicos. Então seria fácil para que qualquer pessoa possa ver o que foi avaliado, quais os resultados, e quais os planos para correções. Para outro entrevistado, faltaria um pouco com relação aos mecanismos de avaliação e haveria um certo debate sobre a reação a essa avaliação, mas todos estariam de acordo que a política foi um sucesso. Estaria clara a adoção de um objetivo de longo prazo e a importância da relação entre governo, forneceras, operadoras e academia. Já o terceiro entrevistado disse entender que, não se teria como manipular os dados quando eles são objetivos e transparentes. Por isso, esse entrevistado acredita que não exista uma agenda oculta por aqueles que fazem a política, com o objetivo de que se tenha um resultado que não seja transparente.

Poderia se usar um exemplo de uma outra área para a análise dessa reação. No começo dos anos 1990, teria sido feita uma reforma fiscal, que demandou um enorme trabalho de análise sobre a reação aos efeitos das propostas feitas pelo governo. Nesse processo, infelizmente uma grande parte das discussões acabou virando uma disputa sobre os tipos de dados que deveriam ser utilizados como base para as análises. Isso teria prejudicado muito a obtenção de resultados construtivos através desse debate. Assim, se teria passado a tarefa para que consultores desenvolvessem um modelo analítico que pudesse ser utilizado. Isso teria sido feito de forma externa ao governo, com um consultor independente, pois tinha que se ter cuidado com a questão da integridade, para que se pudesse mudar o foco das discussões anteriores. Assim, se teria conseguido tirar o foco da discussão sobre o tipo de dados utilizados e se concentrar na análise de resultados.

De acordo com um dos entrevistados, na Noruega não seria natural levantar muitas das questões trazidas por essa pesquisa. O pano de fundo dessas perguntas seria uma sociedade onde essas atividades não sejam muito abertas, como o caso do Brasil. Seria perceptível que essas perguntas foram feitas por alguém que vem de uma sociedade diferente da norueguesa, onde as coisas sejam mantidas distantes do público geral. Esse entrevistado disse ter certeza de que o governo e o público no Brasil irão reagir muito seriamente com relação ao que foi descoberto. O nível de corrupção na Petrobras seria tão grande que os brasileiros seriam obrigados a uma reação firme, para que não se tenha mais esse tipo de resultado. $\mathrm{O}$ setor brasileiro teria certamente que se abrir, caso queira 
se tornar internacional e participar do mercado global. Essa questão sobre abertura seria diferente em cada país do mundo. Enquanto a Noruega estaria num extremo, por ser muito aberta, outros países estariam no outro extremo, por serem muito fechados.

Também foi dito que não haveria dúvidas de que o caso norueguês foi um sucesso, mas haveria dúvidas sobre a possibilidade desse modelo ser replicado por algum outro país. Então, não seria tão fácil para que um outro país possa dizer que irá fazer o mesmo. A Noruega era um país pobre em 1967 e os noruegueses não estavam acostumados com muito dinheiro. Eles não tinham internet e não viam na televisão a riqueza de outros países a sua volta. Então, quando se passou a ter muito dinheiro, não se gastou tudo de uma só vez. Já os brasileiros, quando viram que a indústria de petróleo estava indo para o Brasil, começaram a usar o dinheiro muito antes de receberem esse dinheiro. Por outro lado, foi feita uma ressalva sobre que seria sempre mais fácil escrever a história depois que já se sabe os resultados. Como a história é sempre escrita pelos vencedores, obviamente, os noruegueses estariam escrevendo a história como desejam.

\subsection{8 - Resultado das Avaliações}

\section{a) Governo}

Os gráficos 62 e 63, abaixo, apresentam as respostas objetivas sobre todas as etapas da política industrial norueguesa de petróleo e gás, apresentadas pelos dois entrevistados do governo norueguês. 


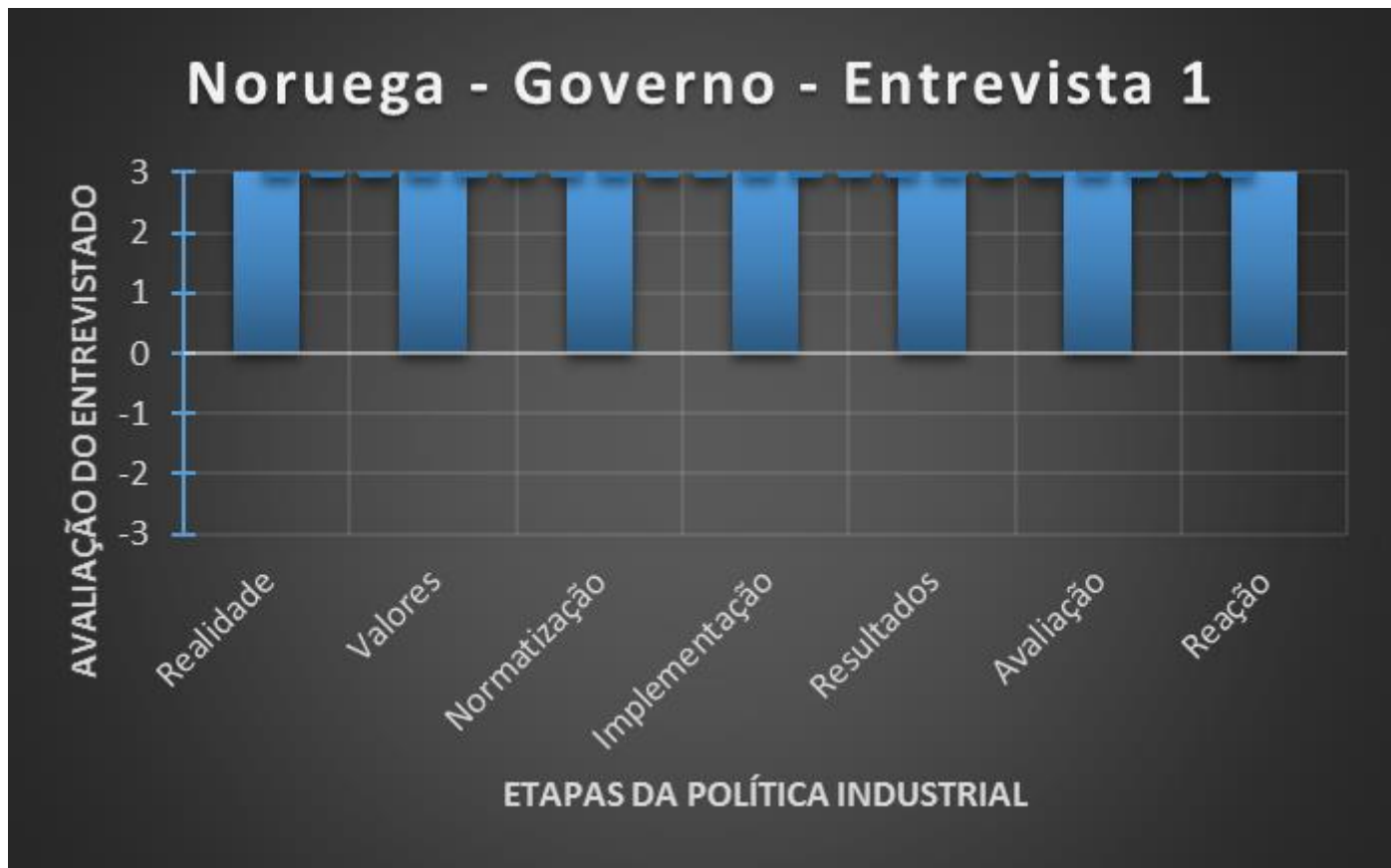

Gráfico 62 - Avaliação sobre as diferentes etapas da política industrial de petróleo e gás no país, pela entrevista 1 do governo da Noruega.

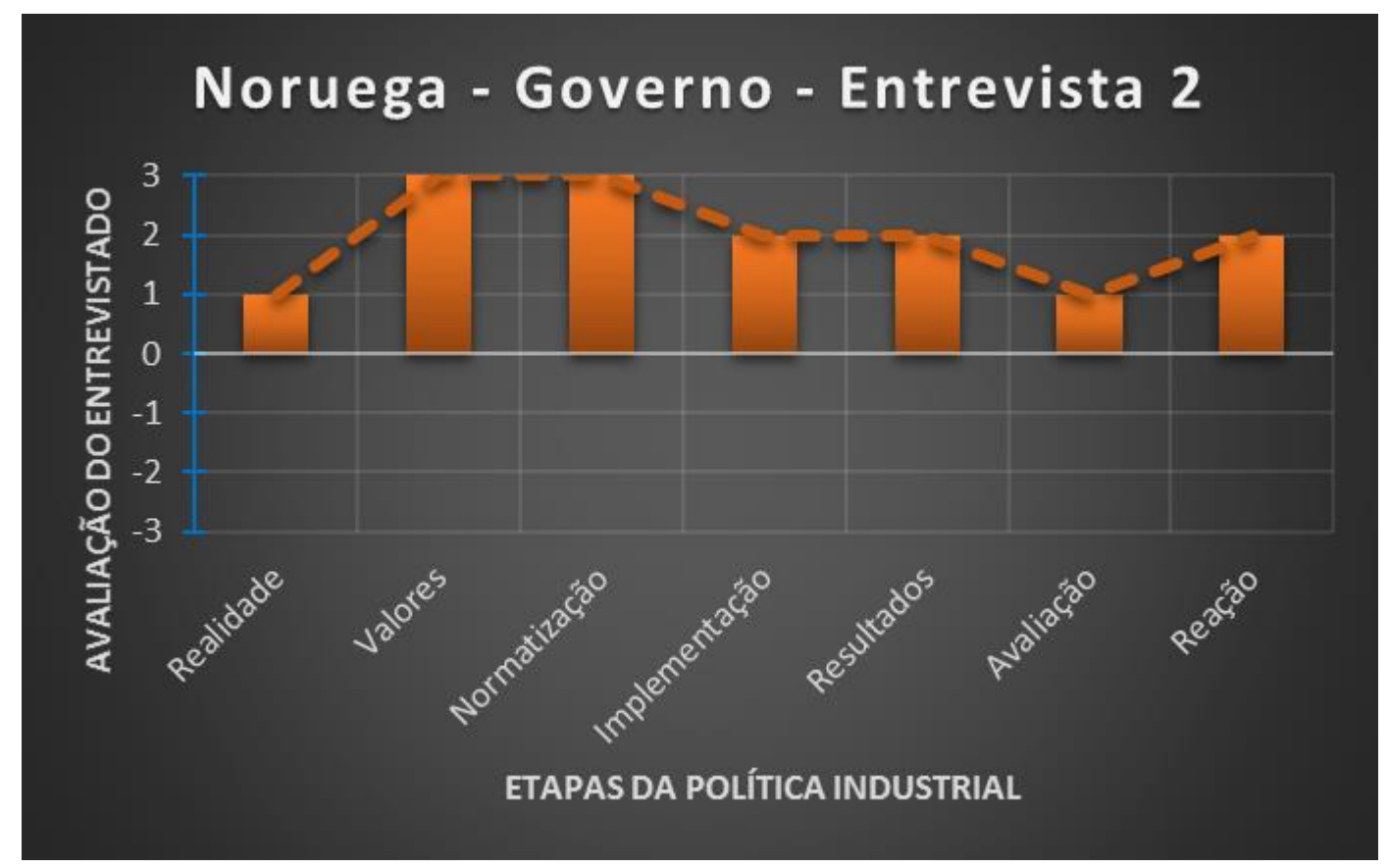

Gráfico 63 - Avaliação sobre as diferentes etapas da política industrial de petróleo e gás no país, pela entrevista 2 do governo da Noruega. 
b) Associações Empresariais

Os gráficos 64, 65, 66 e 67, abaixo, apresentam as respostas objetivas sobre todas as etapas da política industrial norueguesa de petróleo e gás, apresentadas pelos quatro entrevistados das associações empresariais norueguesas.

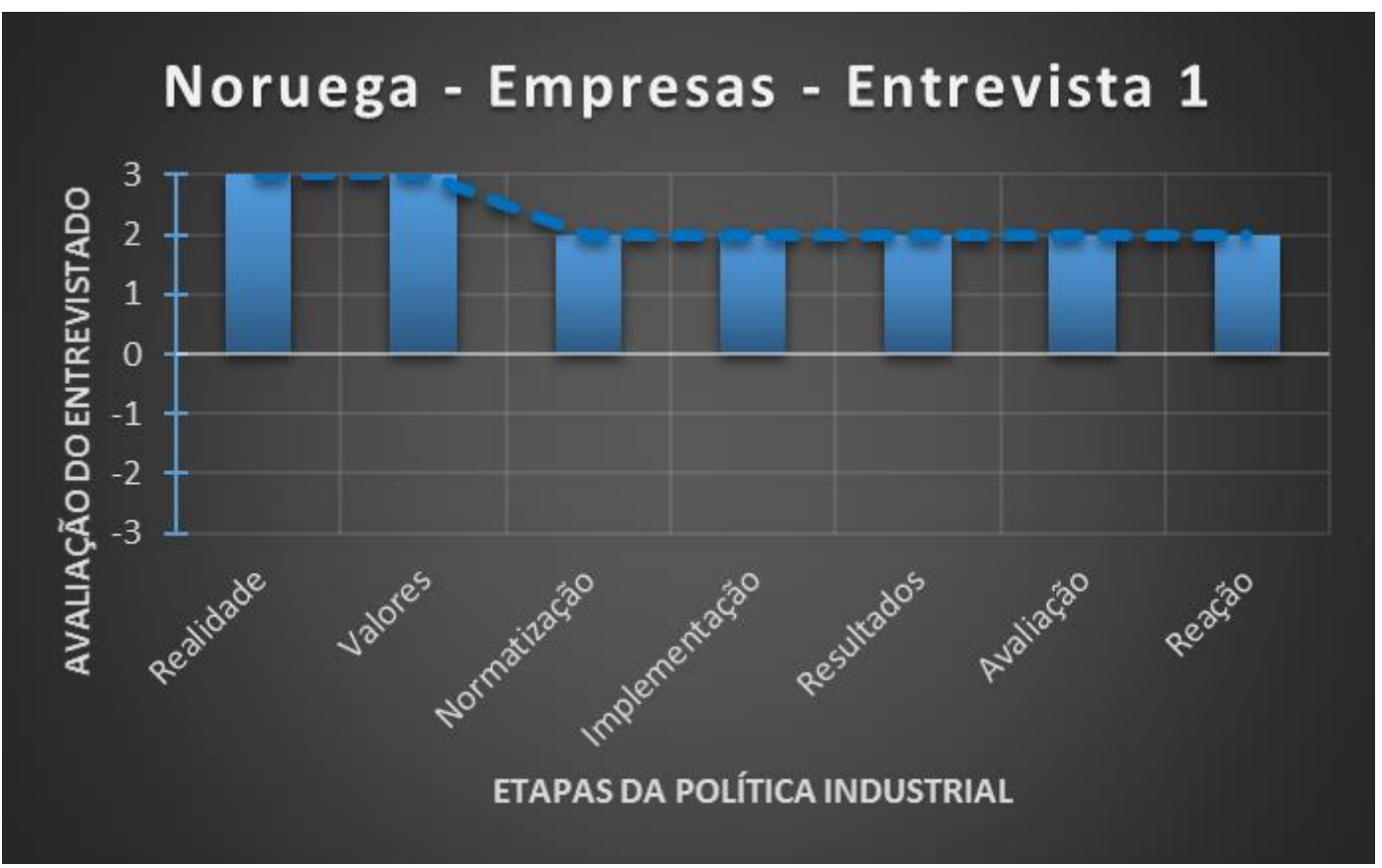

Gráfico 64 - Avaliação sobre as diferentes etapas da política industrial de petróleo e gás no país, pela entrevista 1 das associações empresariais da Noruega.

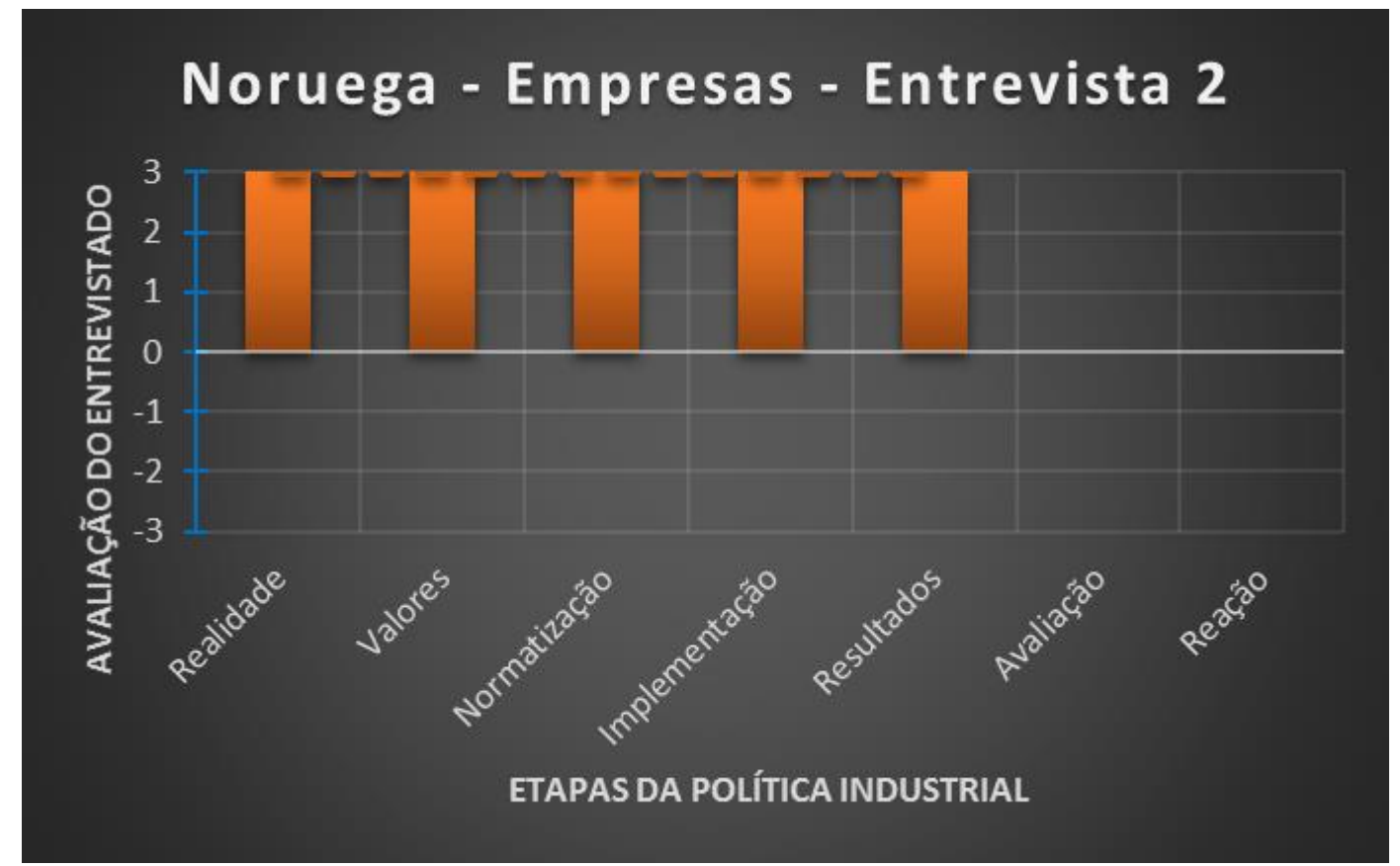

Gráfico 65 - Avaliação sobre as diferentes etapas da política industrial de petróleo e gás no país, pela entrevista 2 das associações empresariais da Noruega. 


\section{Noruega - Empresas - Entrevista 3}

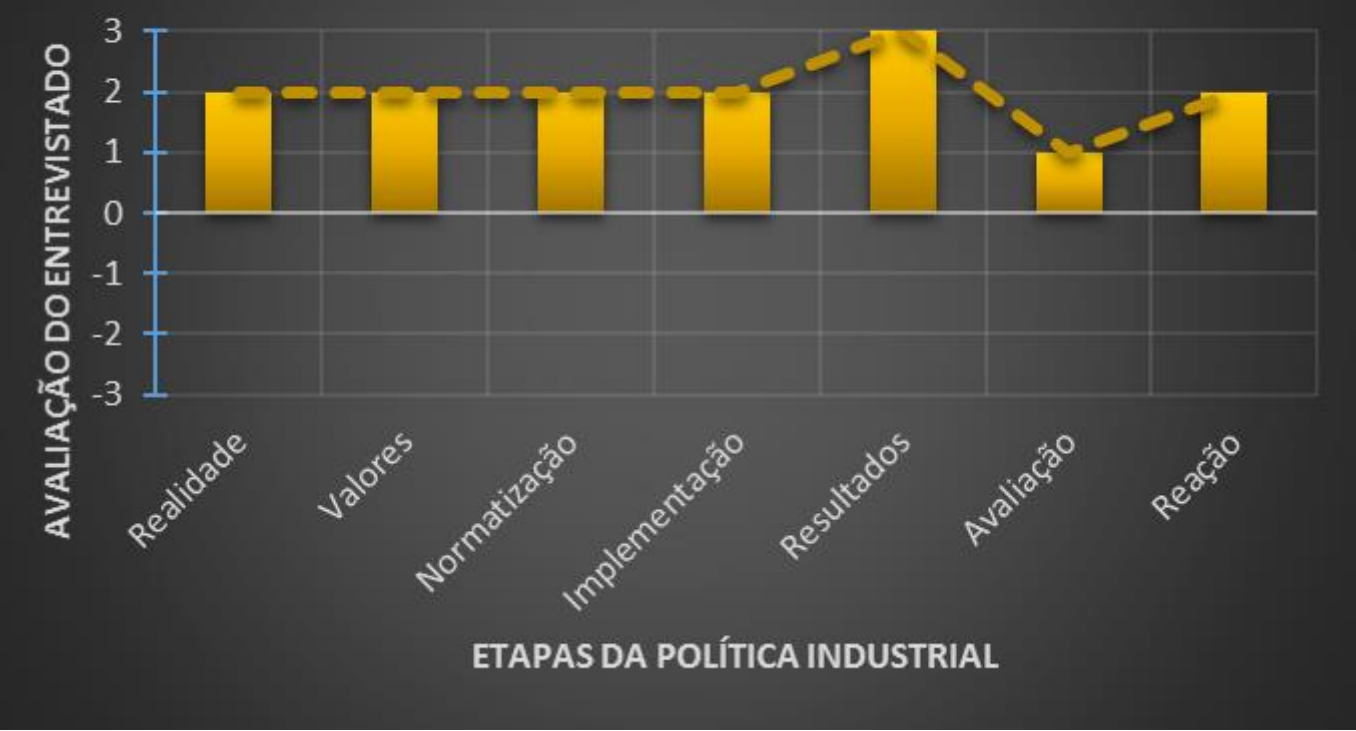

Gráfico 66 - Avaliação sobre as diferentes etapas da política industrial de petróleo e gás no país, pela entrevista 3 das associações empresariais da Noruega.

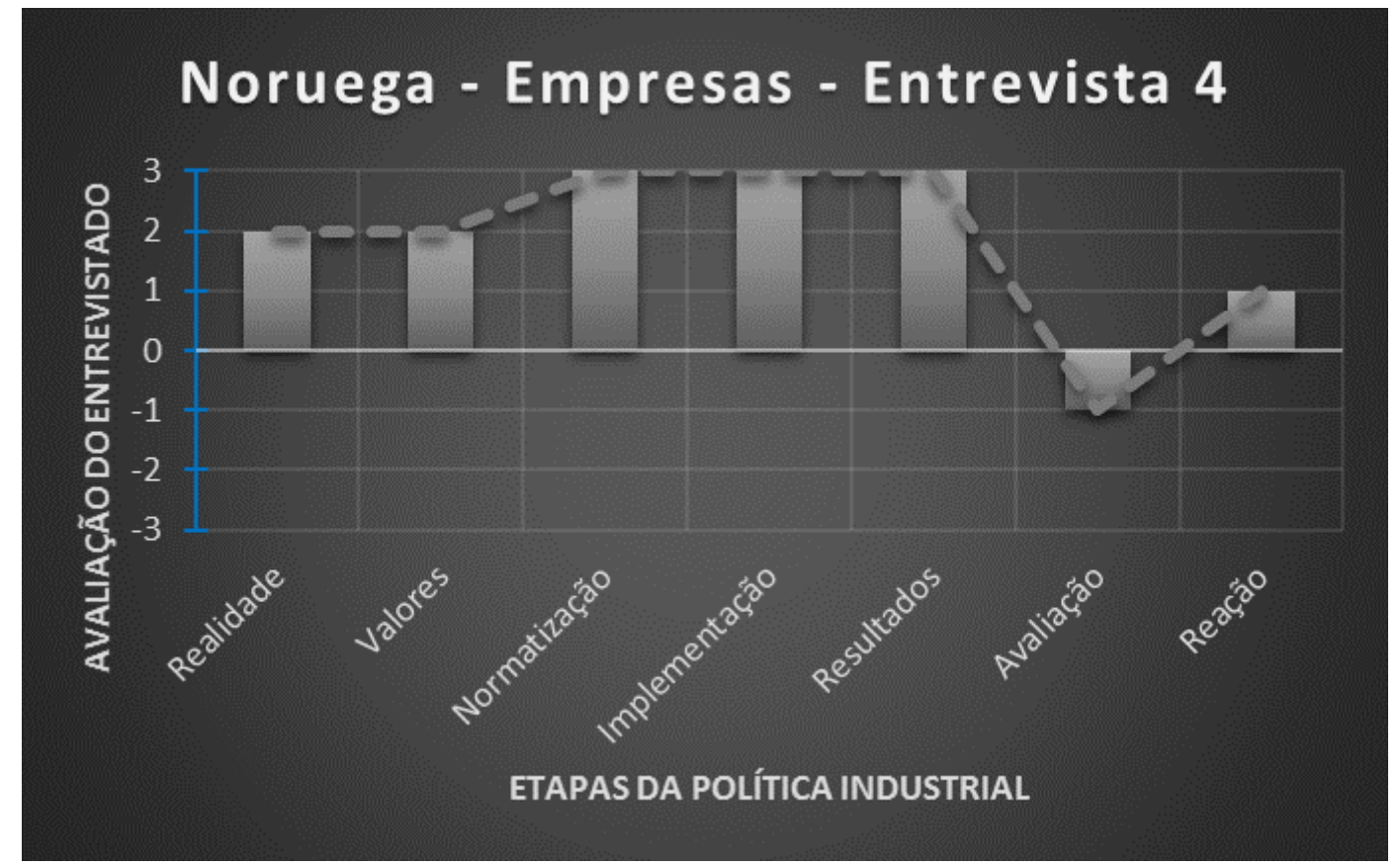

Gráfico 67 - Avaliação sobre as diferentes etapas da política industrial de petróleo e gás no país, pela entrevista 4 das associações empresariais da Noruega. 


\subsection{9 - Relação Entre Atores}

\section{a) Governo}

O gráfico 68, abaixo, apresenta o percentual de menções positivas e negativas nas respostas dos entrevistados do governo sobre a relação entre os atores para a orientação da política industrial norueguesa para petróleo e gás.

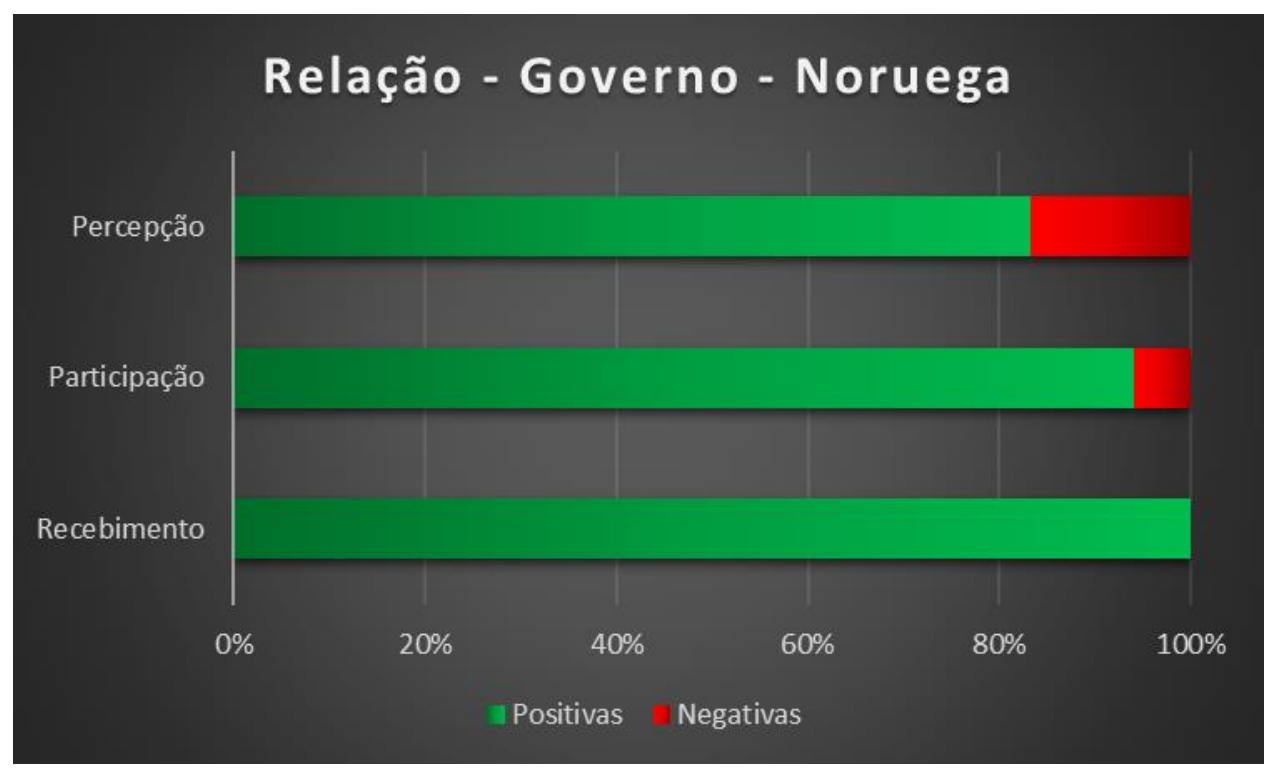

Gráfico 68 - Percentual de menções positivas e negativas nas respostas do governo sobre a relação entre os atores na orientação da política industrial norueguesa.

\section{a.1) Percepção sobre as Associações Empresariais}

Com relação à percepção que os entrevistados do governo têm sobre as associações empresariais norueguesas, foram feitos nove comentários positivos. Em três desses comentários foi dito que as empresas fornecedoras nacionais deveriam estar bastante "contentes". Mesmo com casos onde grandes projetos de desenvolvimento acabaram sendo feitos fora da Noruega e as empresas nacionais teriam pedido mais proteção, ou com a atual desaceleração do mercado, que as teria feito pedir pacotes de incentivo ao governo, as empresas estariam satisfeitas e otimistas. Foram feitas duas menções sobre o baixo índice de reclamações por parte das empresas. Numa delas foi dito que as reclamações eram poucas. Em outra, o entrevistado disse que nunca teria ouvido reclamações por parte das empresas. Também foram duas as menções à existência de um acordo político muito amplo, ou um grande consenso, entre o governo e as empresas. Foi 
mencionado que as empresas teriam participado da formulação de leis e que elas teriam um bom diálogo com o governo.

Em dois comentários foram apresentados aspectos que não foram considerados nem positivos, nem negativos. Foi dito que todos os atores envolvidos acreditam haver espaço para melhorias na política e que o que estaria segurando as empresas nacionais atualmente não seriam necessidades de $\mathrm{P} \& \mathrm{D}$ ou de novas soluções, mas sim a desaceleração geral do mercado.

Houve apenas um comentário considerado negativo, onde o entrevistado disse que as empresas sempre querem mais do governo.

\section{a.2) Participação do Governo}

Sobre a participação dos órgãos de governo nas discussões sobre a política industrial de petróleo e gás norueguesa, foram feitas trinta e duas menções positivas. Em dezoito delas os entrevistados dizem ter participado de alguma forma desse debate. Seja através da apresentação de informes técnicos para o parlamento, dando orientações para outros órgãos do governo, formulando ou aprimorando a legislação, viajando para divulgar as melhores práticas para a indústria, estimulando as empresas a adotarem práticas (como a proibição da queima de gás natural e a cobrança pelas emissões de gás carbônico) que demonstrem suas preocupações com as questões climáticas, coletando informações, atraindo investimentos ou participando de reuniões e cooperações com instituições de pesquisa. Foram feitas três menções ao fato de se ter um papel chave em diferentes questões da política, como a coleta de dados, a definição das áreas para as licenças e sobre as rondas de licitações. Haveria uma estrita e bem aceita compreensão do papel de cada ator, que permitiria que cada um saiba o que serve de base para a posição do outro. E nove comentários foram feitos a respeito da existência de um bom diálogo entre os atores envolvidos com a política. Seria um processo do qual a indústria teria participado desde o começo, com um cenário bem transparente e um sistema aberto e acessível, onde todo mundo fala com todo mundo. Abertura e franqueza seriam muito úteis, pois todo o sistema norueguês seria baseado no diálogo. Se a forma como a política é desenhada, apresentada, administrada e compreendida não for aceitável para a maioria dos atores envolvidos, o sistema acabaria sendo menos eficiente como um todo. Seriam feitas perguntas e as discussões seriam sobre qual a política certa ou errada, e não sobre 
qual a melhor forma para se maximizar a gestão dos recursos e a criação de valor. Quando vai fazer uma rodada de licitações em áreas novas, não maduras, o governo procura perguntar para a indústria quais os blocos que ela teria interesse. Essa seria uma base importante para a definição dos blocos que serão ofertados. Algumas vezes se faria a combinação de ofertas de áreas onde não haja muito interesse em conjunto com áreas onde haja mais interesse.

Foram feitos apenas dois comentários negativos sobre a participação do governo na definição da política industrial. Em ambos os casos foi dito que não se participou de alguma etapa da política.

\section{a.3) Recebimento pelas Associações Empresariais}

Todos os treze comentários sobre o recebimento das ações governamentais pelas associações empresariais norueguesas foram considerados positivos. Em sete deles foi dito simplesmente que se teria sido bem recebido. Também foi dito que a responsabilidade social e a boa governança seriam valorizadas pela agenda tanto das empresas petroleiras quanto das empresas fornecedoras. Haveria apoio da maioria do parlamento com relação à política e o governo não estaria sentado em uma torre de marfim, fazendo com que seja bem avaliado em pesquisas de avaliação sobre órgãos do governo. As maiores empresas fornecedoras teriam escritórios na região de Oslo e estariam sempre interessadas em promover uma maior participação. De uma maneira geral, os laços entre as empresas e o governo seriam muito bons.

\section{b) Associações Empresariais}

O gráfico 69, abaixo, apresenta o percentual de menções positivas e negativas nas respostas dos entrevistados das associações empresariais sobre a relação entre os atores para a orientação da política industrial norueguesa para petróleo e gás. 


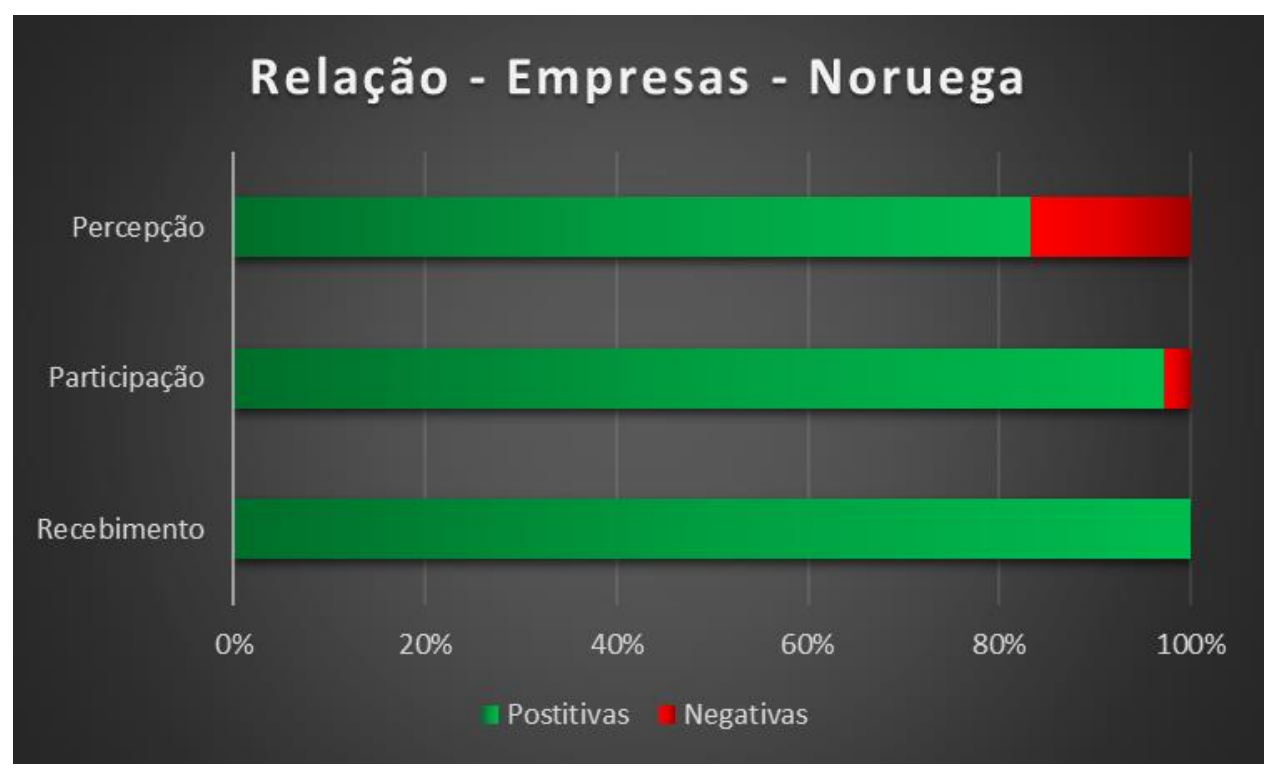

Gráfico 69 - Percentual de menções positivas e negativas nas respostas das associações empresariais sobre a relação entre atores na orientação da política industrial norueguesa.

\section{b.1) Percepção sobre o Governo}

Nas respostas dos entrevistados das associações empresariais foram feitas nove menções positivas sobre o governo norueguês. Em seis dessas menções foi dito que as empresas e o governo compartilham os mesmos valores, visões, objetivos, interesses, compreensões, posições e que ambos estariam indo na mesma direção. Haveria um constante diálogo entre governo e empresas, e até mesmo com outras indústrias, porque o principal interesse de todos seria o mesmo: maximizar a criação de valor na plataforma continental norueguesa e ser internacionalmente competitivo. Também foi dito que o governo teria feito parte de discussões com a indústria e que teria diversas instituições trabalhando de forma adequada. O governo teria a intenção de sustentar o futuro desenvolvimento da indústria de petróleo e gás norueguesa e explorar o potencial tecnológico do país.

Dois comentários foram considerados como positivos e negativos ao mesmo tempo. Um disse que algumas pessoas teriam feito críticas, dizendo que a indústria de petróleo estaria prejudicando o resto da indústria norueguesa. Mas também haveria a percepção de que as experiências obtidas por essa indústria poderão ser aproveitas por outras indústrias. O outro comentário lembrou que existem questões políticas globais, como a configuração da matriz energética mundial para os próximos anos, especialmente 
após a convenção climática, em dezembro de 2015, em Paris. A indústria de petróleo e gás seria a indústria mais importante da Noruega, seja com relação à geração de emprego, criação de valor, geração de receita ou arrecadação de impostos, representando mais de $50 \%$ das exportações, um terço do fluxo de caixa, e entre $20 \%$ e $25 \%$ do PIB. Então, de acordo com esse entrevistado, mesmo que algum ambientalista sonhe em acabar com essa indústria, seja no curto ou no longo prazo, deve-se materializar se essa mudança ecológica terá como repor as perdas que ocorrerão nessas questões. Mesmo que se tenha que considerar os desafios da mudança climática - o que a indústria norueguesa faz com muita seriedade pois, em comparação com outros países, produziria de uma maneira ambientalmente responsável e com um baixíssimo nível de emissões - enquanto o mundo demandar petróleo e gás, a Noruega seguirá produzindo, e cuidando para que seja de uma maneira mais sustentável que os demais. Essa seria a forma de competir norueguesa, e eles conseguiriam ser muito competitivos, mesmo assim. Apesar da crítica aos políticos ambientalistas, foi destacado que os políticos responsáveis teriam a percepção correta sobre essa realidade.

Houve apenas um comentário negativo, onde o entrevistado disse que existem alguns políticos que querem fazer da Noruega uma protagonista em questões ambientais para o resto do mundo. O objetivo seria dar o exemplo reduzindo a produção norueguesa de petróleo e gás. De acordo com esse entrevistado, essa ideia não faria sentido algum.

\section{b.2) Participação das Associações Empresariais}

Foram feitas trinta e quatro menções positivas sobre a participação das associações empresariais na orientação da política industrial. Em dezesseis desses casos houve referência a diferentes formas de participação das associações, seja junto com o governo, auxiliando outros países a desenvolverem suas leis, através do diálogo com outros atores, na transferência de conhecimento e tecnologia, repassando lições aprendidas junto à indústria ou quando se precisa encontrar a solução para algum problema. A indicação do diálogo como um elemento positivo da participação foi feita em doze dessas menções. Haveria uma comunicação muito boa, com cooperação e um diálogo contínuo e aberto entre governo, parlamento, academia, empresas e trabalhadores. O diálogo seria um elemento chave na definição de salários, no desenvolvimento de tecnologia e em questões legais e regulatórias, especialmente nas áreas de segurança do 
trabalho e meio ambiente. As associações sabem que o governo tem a expectativa de que elas apresentem propostas e que sejam ativas nesse diálogo. Essa relação positiva entre governo e empresas seria acima da média mesmo comparada com países europeus. Os britânicos teriam uma cultura parecida com a norueguesa, mas haveria uma diferença cultural com relação a países como Holanda e Espanha, que achariam muito estranho existir um diálogo tão bom. Com a ressalva de que esse ótimo diálogo não deveria jamais ser confundido com corrupção, pois seria um diálogo baseado no profissionalismo. Isso seria possível porque a Noruega é um país pequeno. Mas, também por ser pequeno, a interação entre diferentes competências seria muito fundamental. Seria muito importante que as empresas que atuam no exterior levassem de volta para a Noruega novos achados, novos aprendizados, novas descobertas. Foi mencionado o interesse de que se tenha um sistema regulatório e administrativo transparente e aberto. Sindicato e associações teriam um acordo entre si, para que um ajude a reforçar os interesses do outro junto ao governo. E foi elogiada a atitude do Ministry of Petroleum and Energy em delegar responsabilidades para associações empresariais.

Houve apenas uma menção negativa, onde um entrevistado disse não ter participado de alguma etapa da política industrial.

\section{b.3) Recebimento pelo Governo}

Todos os nove comentários sobre o recebimento da participação das associações empresariais por parte do governo norueguês foram considerados positivos. Em três deles foi dito simplesmente que se teria sido bem, ou muito bem recebido. A indústria sentiria que vale a pena participar, trabalhando bastante nas questões em que se envolve, para produzir seus argumentos, pois o governo realmente se interessaria em ouvir. Isso não seria apenas uma questão de aparência. No diálogo com o governo, as empresas teriam a "sensação" de ter uma voz forte e de que a sua participação é apreciada. Um dos entrevistados explicou que uma coisa é ter voz, outra coisa é ser ouvido e outra coisa é ser compreendido. Quando o governo dá voz, ouve e compreende o que as associações dizem, mas decide fazer diferente, com base na sua competência, as associações teriam que aceitar. Mas o que acontece em outros países lhe parece ser um pouco diferente, pois os governos parecem que já teriam tomado suas decisões antes mesmo de ouvir os demais atores envolvidos na política. 


\section{Capítulo 6 - Comparação entre Governo e Associações Empresariais}

Neste trabalho serão feitas duas formas de análise comparada. A primeira está neste capítulo, e será uma comparação entre as respostas do governo e das associações empresariais de cada estudo de caso, procurando entender melhor a relação entre estes dois grupos em cada um dos países e as características de cada caso estudado. No capítulo seguinte, será apresentada uma análise comparativa entre os três estudos de caso, para que se possa perceber as semelhanças e diferenças entre os países e para que, com isso, se procure responder à pergunta e verificar a hipótese desta tese.

A comparação entre os resultados das entrevistas com representantes do governo e das associações empresariais de cada país será feita através da apresentação de diferentes cruzamentos destes dados. Para cada um dos casos, primeiramente, serão comparados os totais das respostas objetivas de cada grupo, para que se possa verificar como foi a avaliação de cada grupo sobre as diferentes etapas da política industrial de seu país. Em seguida, será apresentado o cruzamento das respostas às perguntas abertas sobre a avaliação de cada uma dessas etapas, onde serão analisadas as semelhanças e diferenças entre as opiniões apresentadas, destacando as opiniões sobre os instrumentos de política industrial adotados e sobre o que serve de base para a definição dessa política industrial de cada país. Posteriormente, serão comparadas as variações das respostas objetivas de cada grupo, para que se verifique o quanto essas avaliações variaram, tanto dentro de cada grupo separadamente, como entre os entrevistados agrupados dos dois grupos. Por último, será apresentado o cruzamento das respostas às perguntas abertas sobre a relação entre os atores de cada país, onde serão comparadas as respostas sobre a percepção que um grupo de atores tem do outro, sobre como cada grupo vê a sua própria participação na política e sobre como cada grupo sente que essa participação é recebida pelos demais atores. 


\section{1 - Brasil}

\subsection{1 - Total das Avaliações Objetivas}

\section{a) Governo}

O gráfico 70, abaixo, apresenta o total das respostas objetivas sobre todas as etapas da política industrial brasileira de petróleo e gás, apresentadas pelos três entrevistados do governo brasileiro.

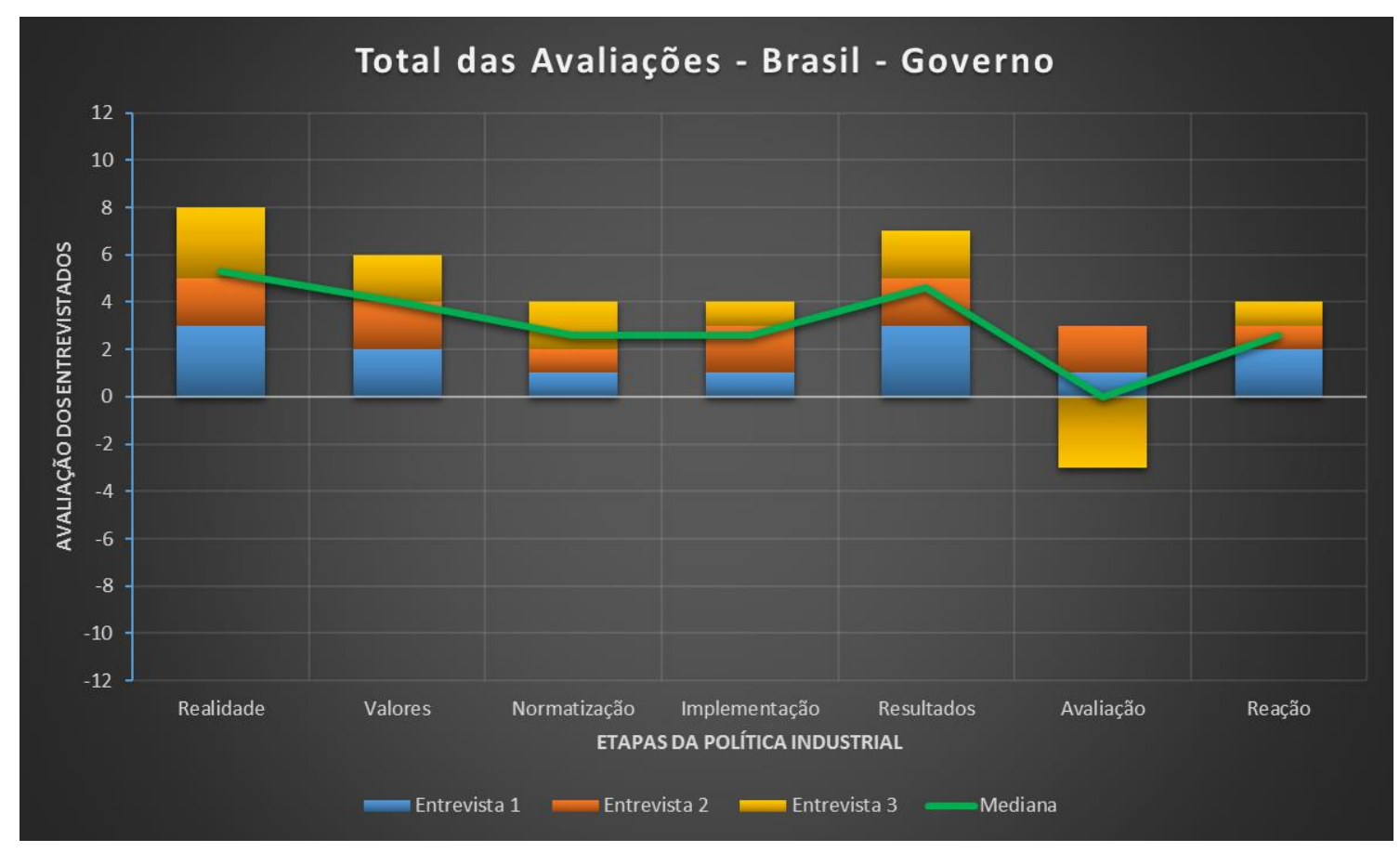

Gráfico 70 - Total das avaliações sobre as diferentes etapas da política industrial de petróleo e gás nas entrevistas do governo do Brasil.

Percebe-se que as avaliações do governo brasileiro sobre as diferentes etapas da política indústria brasileira foram boas, aparecendo apenas uma avaliação negativa e todas as demais positivas. As avaliações sobre a realidade que serviu de base para a atual política industrial de petróleo e gás foram muito boas e começaram a cair um pouco quando trataram dos valores que serviram de base para a formulação da política. Seguiram caindo um pouco mais com relação à normatização que rege a política industrial e seguiram no mesmo patamar quando analisando a forma como a política é implantada. 
Os resultados obtidos pela política foram a segunda etapa melhor avaliada pelos entrevistados do governo, atrás apenas do potencial de indústria, analisado na primeira etapa. Devido àquela única avaliação negativa, os mecanismos de monitoramento e avaliação da política industrial brasileira foram a etapa pior avaliada entre os representantes do governo. Terminando com uma avaliação entre pouco boa e boa, do mesmo nível da normatização e da implementação, sobre a forma de reação aos dados do monitoramento e da avaliação, para definir a orientação da política.

\section{b) Associações Empresariais}

O gráfico 71, abaixo, apresenta o total das respostas objetivas sobre todas as etapas da política industrial brasileira de petróleo e gás, apresentadas pelos quatro entrevistados das associações empresariais brasileiras.

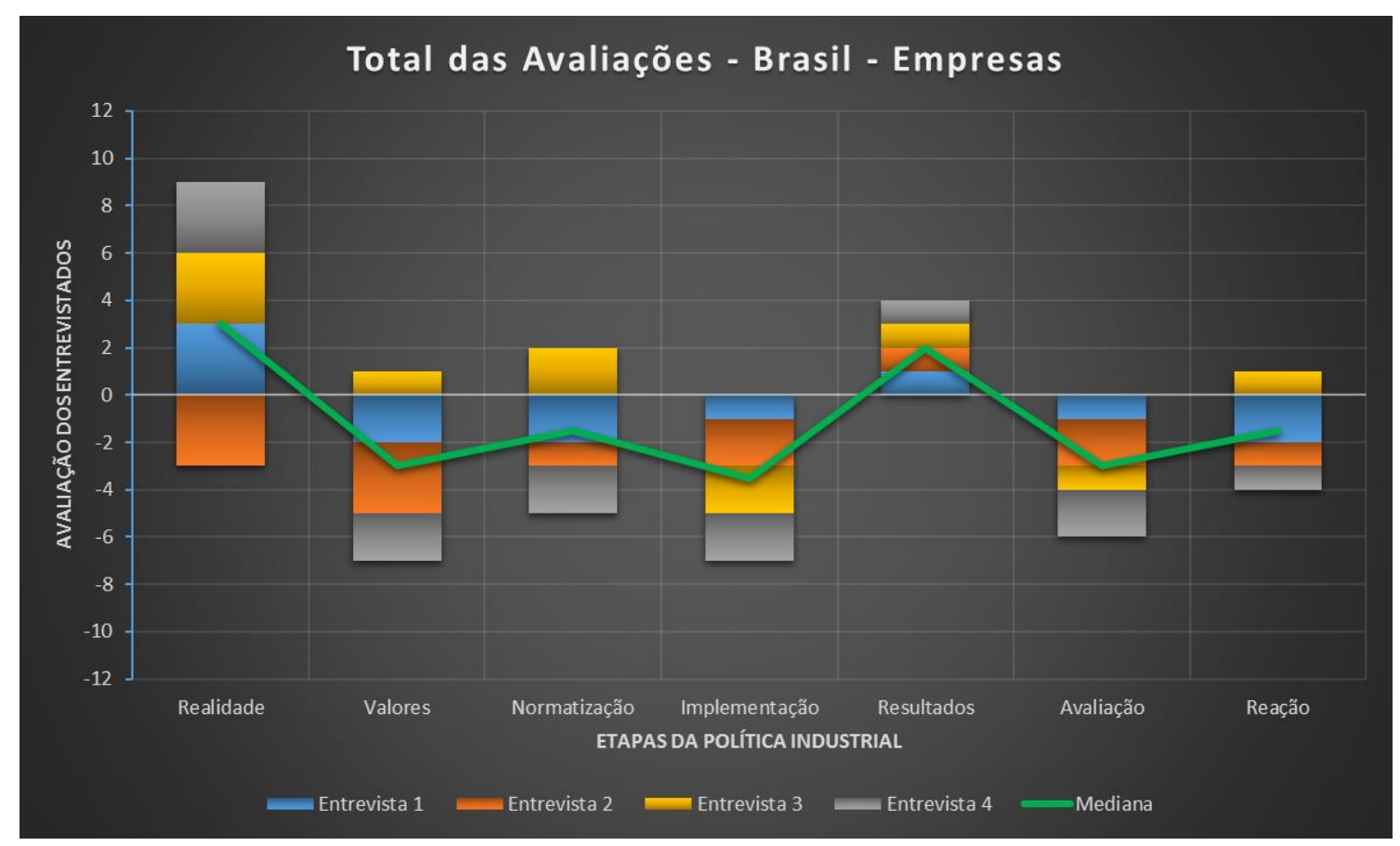

Gráfico 71 - Total das avaliações sobre as diferentes etapas da política industrial de petróleo e gás nas entrevistas das associações empresariais do Brasil.

As avaliações dos representantes das associações empresarias brasileiras sobre as diferentes etapas de política industrial de petróleo e gás do país foram, na sua maioria, negativas. As avaliações sobre o potencial oferecido pela realidade brasileira para o 
desenvolvimento de uma indústria nacional de petróleo e gás ficaram no nível bom. Já as avaliações sobre os valores que serviram de base para a política estiveram entre as piores desse grupo, juntamente com a fase de implementação. A normatização que rege a política, os mecanismos de monitoramento e avaliação e a forma de reação aos dados desses mecanismos ficaram todas no nível ruim. E por último, as avaliações sobre os resultados obtidos, mesmo que todos tenham avaliado com pouco bons, foi a única etapa que não teve nenhuma avaliação negativa.

\section{c) Comparação entre Governo e Empresas}

O gráfico 72, abaixo, apresenta a comparação entre as medianas dos totais das respostas objetivas sobre todas as etapas da política industrial brasileira de petróleo e gás, apresentadas pelos entrevistados do governo brasileiro e pelas associações empresariais brasileiras.

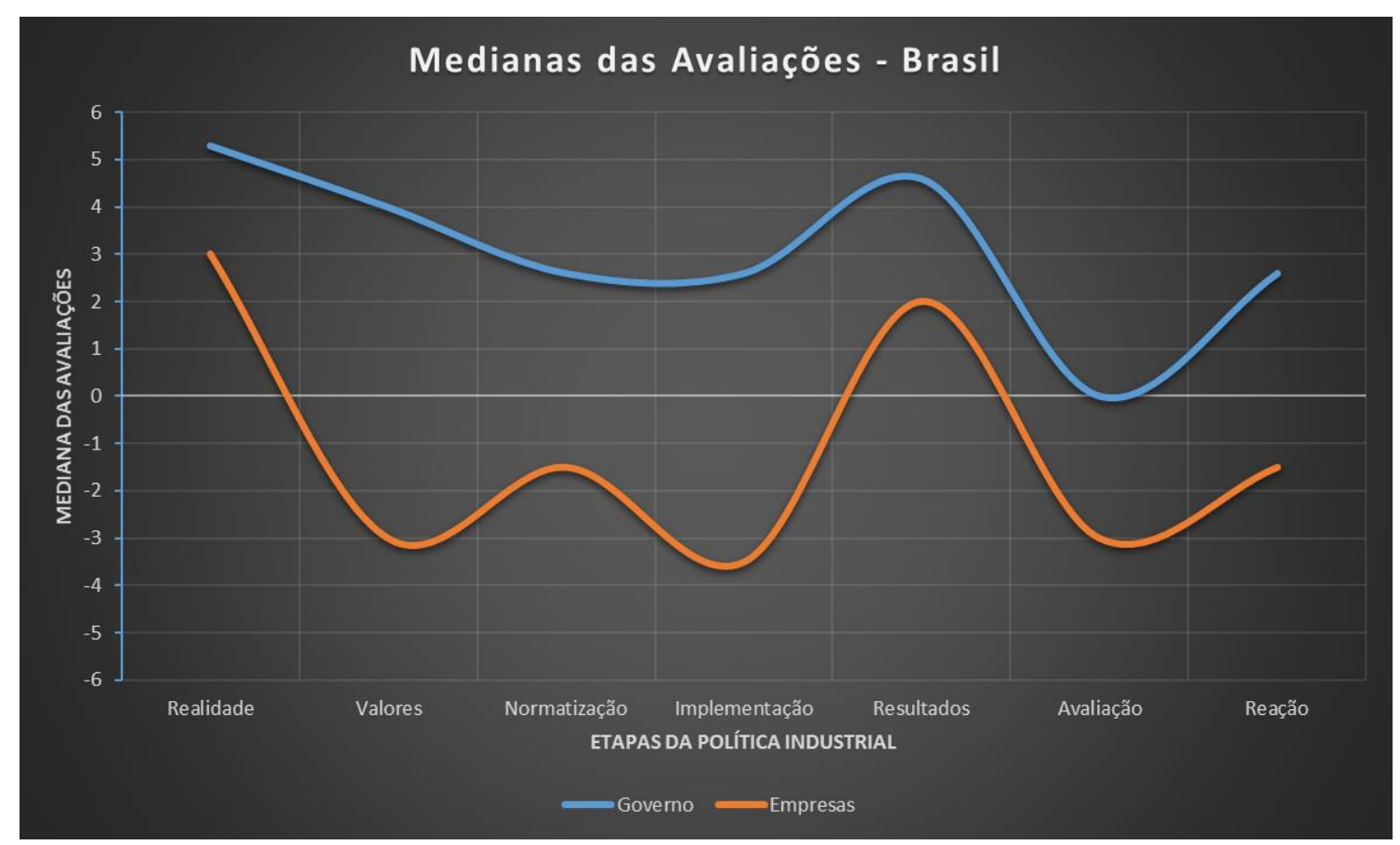

Gráfico 72 - Comparação entre as medianas do total das avaliações sobre as diferentes etapas da política industrial de petróleo e gás no Brasil.

O gráfico acima demonstra que, de uma forma geral, as avaliações do governo e das associações empresariais brasileiras seguiram uma mesma tendência. As avaliações dos representantes do governo foram mais positivas do que as das associações, com 
relação a todas as etapas da política industrial. Parece estar bem marcada uma avaliação positiva dos dois grupos sobre o contexto que serviu de base para a política, mas uma queda na avaliação das etapas posteriores. Os dois grupos apresentaram uma quebra nessa tendência de queda das avaliações quando trataram sobre os resultados obtidos pela política, mas ambos voltaram a apresentar avaliações baixas com relação aos mecanismos de monitoramento e avaliação. Por último, os dois grupos também tiveram uma melhora na avaliação sobre a fase de reação aos dados obtidos pela avaliação, para definir a reorientação da política industrial do país.

\subsection{2 - Temas Levantados}

\section{a) Semelhanças e Diferenças}

Nas respostas às perguntas abertas dos roteiros de entrevista, os entrevistados do governo e das associações empresariais brasileiras apresentaram visões semelhantes em alguns temas. Um deles foi sobre a importância do tamanho das reservas brasileiras que, após as descobertas na camada pré-sal teriam aumentado ainda mais o potencial do país para o desenvolvimento da indústria nacional. A necessidade de superação de desafios tecnológicos para a exploração dos recursos da cama pré-sal também foi apontada pelos dois grupos, que mencionaram também problemas de educação no país que podem prejudicar o desenvolvimento da indústria. Tanto os representantes do governo quanto os das associações defenderam um equilíbrio entre o uso dos frutos da indústria para o atendimento de necessidades imediatas e de longo prazo, pois não adiantaria se preocupar com as gerações futuras e se esquecer da atual. Os dois grupos concordaram com relação às regras serem muito rígidas e complexas, com muito foco na punição e pouco no incentivo, mas ambos também lembraram que o conteúdo local seria definido nos contratos das licitações e não na lei. Ambos ressaltaram a necessidade de uma governança mais eficaz da política industrial, pois o modelo adotado teria muitos problemas. Por outro lado, os dois grupos também defenderam que a corrupção não seria algo muito relevante do ponto de vista da política industrial. Destacaram que, com relação às exportações, os resultados seriam baixos, e que isso poderia estar relacionado com uma alta demanda do mercado interno, gerada pelas atividades da Petrobras, que estariam utilizando toda a capacidade das empresas nacionais. Uma recente tendência à padronização de projetos 
nessa indústria também foi lembrada pelos dois grupos. Por último, houve consenso também com relação à ausência de mecanismos de monitoramento e avaliação para a política industrial de petróleo e gás brasileira.

Com relação a uma questão, houve ao mesmo tempo concordância e conflito de opiniões. Entrevistados dos dois grupos manifestaram entender que existam metas e objetivos bem definidos, mas alguns entrevistados das associações empresariais disseram que entendem que essas metas e objetivos não estariam muito claros.

As divergências entre as opiniões dos entrevistados do governo e das associações empresariais se concentraram na etapa de implementação de política industrial. Enquanto os entrevistados do governo defenderem que existe integração entre a política industrial de petróleo e gás e outras políticas brasileiras, mencionando o exemplo do Plano Brasil Maior, dos arranjos produtivos locais e da participação de pequenas e médias empresas, os entrevistados das associações empresariais disseram entender que essa integração não existe. No mesmo sentido, os atores ligados ao governo mencionaram a existência de diálogo e interação entre os atores, incluindo parcerias com universidades e centros de pesquisa. Já os atores ligados às associações avaliaram que existem diversos problemas na interação entre esses atores, e que o diálogo entre eles seria bastante confuso, quando não inexistente.

\section{b) Instrumentos de Política Industrial}

Sobre os instrumentos adotados pela política industrial brasileira, ambos os grupos manifestaram opiniões de apoio à uma política com viés intervencionista, mas a maioria dessas opiniões vieram de entrevistados do governo. Tanto os entrevistados do governo quanto os entrevistados das associações empresariais disseram que o conteúdo local é um instrumento importante, pois teria gerado muitos empregos e seria um sucesso apoiado por todas as empresas nacionais. Entre os atores do governo foi defendido que um dos principais objetivos da política brasileira seria a geração de valor para a indústria nacional através das demandas criadas pela exploração de petróleo e gás no país. A utilização das cartilhas de conteúdo local, trocaram a medição de conteúdo global pela medição de sistemas e subsistemas foi apontada pelos entrevistados do governo como uma melhoria feita pela política. Os entrevistados desse grupo também disseram que se deveria procurar encontrar soluções para os problemas enfrentados pela política de conteúdo local, ao invés 
de abandoná-la. Ela teria funcionado em outros países, como a Noruega, onde teria sido feita através de um grande pacto social, e não haveria nenhum país desenvolvido que, ao longo de sua história, não tenha utilizado esse tipo de política para se desenvolver. As respostas do governo também mencionaram a importância da diminuição do ritmo de exploração para que a indústria nacional tenha tempo de se desenvolver e da adoção do modelo de partilha para a exploração dos campos da camada pré-sal. Já os entrevistados das associações defenderam o viés punitivo da política de conteúdo local, pois somente assim as empresas se comprometeriam com o atingimento das metas acordadas.

A combinação entre instrumentos de intervenção estatal e de abertura para o mercado foi defendida por representantes do governo e das associações empresariais brasileiras com relação a apenas um ponto. Ao analisar o papel a ser adotado pela Petrobras, ambos os grupos defenderam a ideia de que ela tenha que combinar a eficiência como empresa, para obter lucro para seus acionistas, com o papel de ferramenta de promoção do desenvolvimento da indústria nacional e do país.

Instrumentos de política industrial com um viés liberalizante também foram apoiados por entrevistados dos dois grupos de atores, mas dessa vez a grande maioria dessas opiniões vieram dos entrevistados das associações empresariais. A crítica à política de conteúdo local foi a questão mais recorrente aqui. Sobre isso, foi dito que a proteção oferecida pelo Estado seria prejudicial, pois seria utilizada pelo empresariado nacional como uma espécie de reserva de mercado. A adoção dessa ferramenta estaria ligada à existência à atual situação da Petrobras, à existência de corrupção e a que o país tenha sido processado pela OMC pelo uso indevido dessa prática. A política estaria gerando custos desnecessários e os resultados sido abaixo do esperado, com pouca geração de empregos. Além disso, o conteúdo local seria apenas um índice, que não serviria para medir os resultados da política. Por não ter o foco necessário, deixaria inclusive de ser um elemento de política industrial para ser algo com fim em si mesmo. Já os entrevistados do governo criticaram o conteúdo local por ter adotado índices muito ambiciosos e por não ser como na Noruega, onde não haveria o medo de se gerar empregos em outros países. Ambos os grupos defenderam a necessidade de os fornecedores nacionais serem internacionalmente competitivos, para que possam exportar mais e aumentarem sua produtividade através da exposição à competição. Um exemplo disso seria a indústria naval brasileira, que teria deixado de atender a demandas pela falta de produtividade. Entrevistados do governo e das associações também concordaram com a ideia de que a 
Petrobras deveria ter seu foco na eficiência e no lucro para seus acionistas, ao invés de servir de ferramenta de desenvolvimento para o país. Entre as visões liberalizantes defendidas pelos entrevistados das associações, ainda apareceram críticas à cláusula da Petrobras como operadora única, à adoção do modelo de partilha e à diminuição do ritmo de exploração para desenvolver a indústria nacional. Eles elogiaram os benefícios trazidos para o setor pelo fim do monopólio e pelas mudanças de gestão na Petrobras, que foram medidas adotadas pelo governo FHC. Por último, também defenderam os benefícios da não cobrança de impostos e a ideia de que a adoção de uma política baseada no mercado reduziria os riscos de corrupção.

\section{c) Definição da Política Industrial}

As respostas abertas sobre a avaliação das diferentes etapas da política trouxeram diversos elementos importantes para responder à pergunta sobre o que serve de base para a definição da política industrial de petróleo e gás brasileira. Entrevistados do governo e das associações empresariais destacaram bastante que essa definição seria feita com base em critérios políticos e até ideológicos. Haveria a influência de interesses eleitoreiros do governo, que fariam a política acompanhar os prazos dos mandatos presidenciais, levando a rupturas quando ocorrem trocas de governo. Foi citado especificamente que o ritmo de exploração teria sido definido com base em interesses políticos e que Lula teria visto na política de estímulo aos estaleiros uma oportunidade para se eleger. Com isso, haveria no Brasil a adoção de políticas de governo e não de políticas de Estado. Outro tema que foi levantado por entrevistados dos dois grupos foi a falta do uso de medições, indicadores, critérios técnicos ou avaliações para definir a orientação da política industrial nacional, que seria feita com base em interpretações pessoais e subjetivas acerca do contexto e receitas milagrosas. Haveria a falta de informações claras, organizadas e sistematizadas, além de métricas que permitam que o governo cobre resultados daqueles que recebem benefícios públicos. Ambos os grupos também citaram a necessidade de foco para a política brasileira, que teria sido ambiciosa demais, tentado desenvolver todos os seguimentos da cadeia no país. Não se teria consciência sobre quais sejam as vantagens comparativas do país, para que seja possível estabelecer os objetivos a serem atingidos pela política, que deveriam se concentrar no ganho de competitividade. Faltaria uma base sólida para a política, que teria o desenho de alguns instrumentos desalinhado dos seus 
objetivos e não teria conhecimento mais aprofundado sobre o que cada setor da indústria nacional poderia contribuir para cadeia de fornecimento da indústria de petróleo e gás. Problemas com o modelo de governança foram também mencionados pelos dois grupos de atores. Haveria a necessidade de mais integração e transparência, para que a governança seja mais eficaz. Um dos problemas seria que o órgão que formula a política não seria o mesmo que a implementa. A governança da política deveria estar em algum órgão acima dos ministérios, no nível da presidência da república. Problemas com o diálogo entre os atores foram apontados nas entrevistas do governo e das associações, sendo necessários mecanismos de diálogo e de abertura para o debate. A interação do governo com o setor privado seria feita através de conversas individuais, que estimulam a divergência e o conflito entre eles, pois os interesses de cada grupo de atores seriam diversos um do outro. Ainda foi alertado que, quando ocorre algum diálogo das empresas com o governo, isso não geraria resultados práticos. Muitas vezes as conversas ficariam apenas no papel ou a definição final seria diferente daquilo que havia sido conversado. Foi destacada a impressão de que a tomada de decisão do governo seria feita com base em algo pré-definido. A inexistência de mecanismos de monitoramento e avaliação foi outro elemento levantado por entrevistados do governo e das associações empresariais. Esse seria um problema crítico no Brasil, que afetaria todas as políticas nacionais, que seriam desenvolvidas sem a previsão desses mecanismos, dificultando a correção de rumos quando necessária. Para que essa avaliação possa ser feita seria necessária uma definição sobre os objetivos da política. Os mecanismos que existem seriam muito ruins, pouco robustos, seletivos e não haveria interação entre eles. Somente a ANP teria os dados necessários para realizar a avaliação da política, mas essa avaliação, quando ocorre, seria feita muito no nível da conversa, sem nada de concreto que sirva como base. $\mathrm{O}$ último ponto que foi destacado pelos dois grupos foi a ideia de que a existência de atos de corrupção não seria relevante para a análise da política.

Alguns pontos foram mencionados apenas pelos entrevistados do governo, como o fato de se estar fazendo o possível com o que se tem, mas que haveria falta de recursos para a política. Houve a reclamação de que os empresários brasileiros não teriam participado da forma que se esperava e que a forte presença dos interesses do agronegócio na economia brasileira prejudicaria o estabelecimento de um debate mais aprofundado sobre uma estratégia de política industrial, como feito na Noruega. 
Já entre os pontos levantados apenas pelos representantes das associações empresariais brasileiras, o mais recorrente foi a menção à inexistência de uma política industrial brasileira. A política teria sido deixada a cargo da Petrobras e os índices de conteúdo local teriam sido definidos pelas próprias empresas fornecedoras. Nas entrevistas das associações também apareceu a crítica a instrumentos que foram desenvolvidos para serem utilizados durante um prazo determinado, mas que acabaram sendo utilizados de forma definitiva. Também foi mencionada a falta de um líder que toque a política brasileira, buscando alinhas os diferentes interesses envolvidos. Houve destaque para a prevalência de uma lógica de competição entre os atores envolvidos com a política industrial brasileira, quando o mais adequado seria a existência de uma lógica de cooperação entre eles.

\subsection{3 - Variação das Avaliações Objetivas}

\section{a) Governo}

O gráfico 73, abaixo, apresenta a variação entre as respostas objetivas sobre todas as etapas da política industrial brasileira de petróleo e gás, apresentadas pelos entrevistados do governo brasileiro.

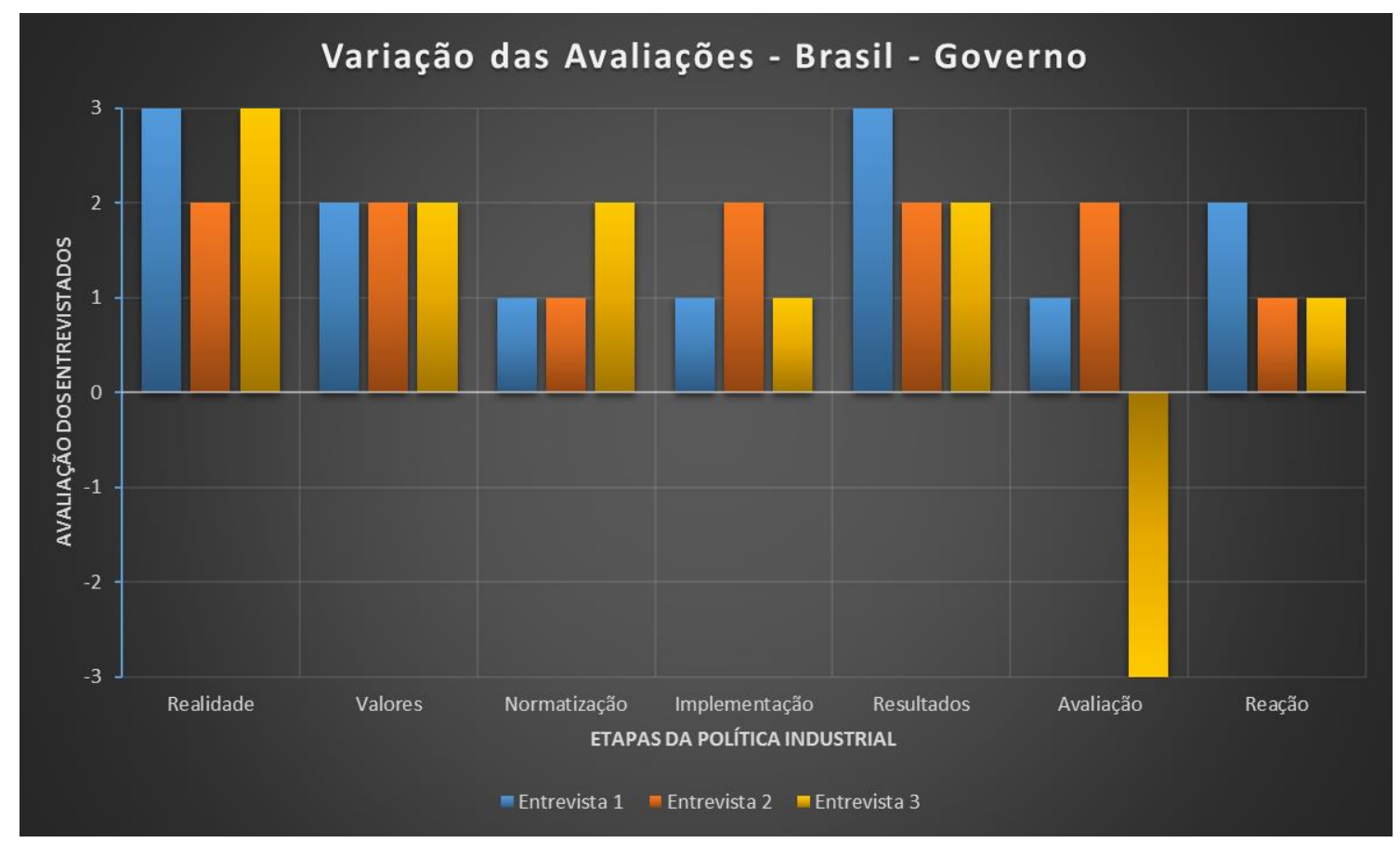

Gráfico 73 - Variação das avaliações sobre as diferentes etapas da política industrial de petróleo e gás nas entrevistas do governo do Brasil. 
Percebe-se que houve uma variação pequena nas respostas da maioria das etapas da política. A realidade que serviu de base para a formulação da política, a normatização que rege a política, a implementação da política, os resultados obtidos e a reação aos dados de avaliação da política tiveram a variação mínima de apenas uma resposta. Houve unanimidade entre os entrevistados do governo brasileiro na avaliação dos valores que guiaram a formulação da política. E a maior variação ocorreu na avaliação dos mecanismos de monitoramento e avaliação da política, onde houve a única avaliação negativa nesse grupo de entrevistados.

O gráfico 74, abaixo, apresenta o total de desvios que as respostas objetivas de cada entrevistado tiveram com relação às médias das avaliações feitas pelos entrevistados do governo brasileiro, sobre as diferentes etapas da política industrial brasileira de petróleo e gás.

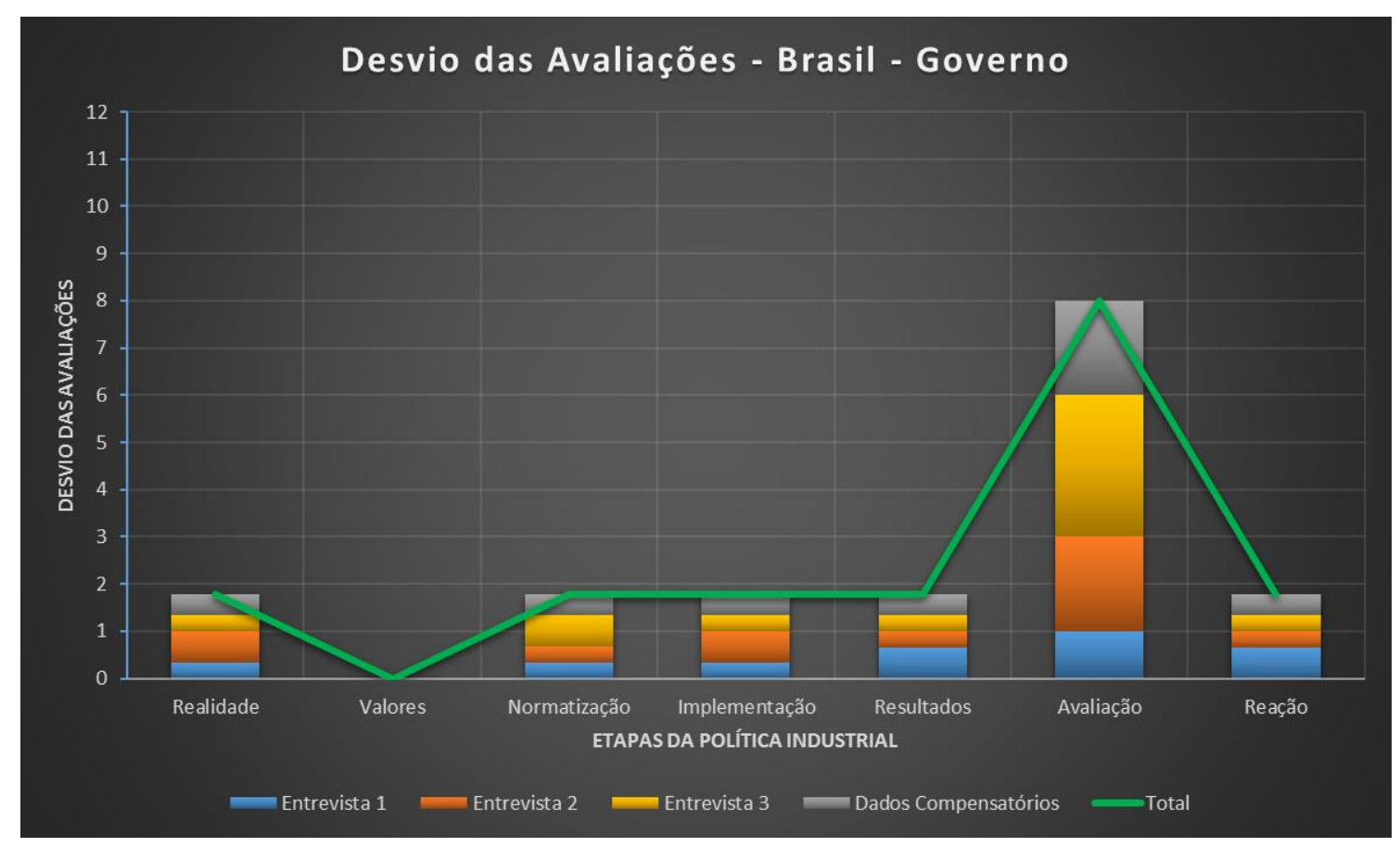

Gráfico 74 - Desvio entre a avaliação de cada entrevistado e a média das avaliações do governo, para cada etapa da política industrial de petróleo e gás no Brasil.

Este gráfico deixa ainda mais claro o baixo índice de desvio nas respostas dos entrevistados do governo brasileiro. Enquanto as respostas sobre a definição de valores não apresentaram desvio algum, quase todas as outras etapas tiveram um desvio muito 
pequeno, com relação à média das respostas desse grupo. A única exceção foi com relação à etapa de monitoramento e avaliação da política, onde os desvios foram bem maiores.

\section{b) Associações Empresariais}

O gráfico 75, abaixo, apresenta a variação entre as respostas objetivas sobre todas as etapas da política industrial brasileira de petróleo e gás, apresentadas pelos entrevistados das associações empresariais brasileiras.

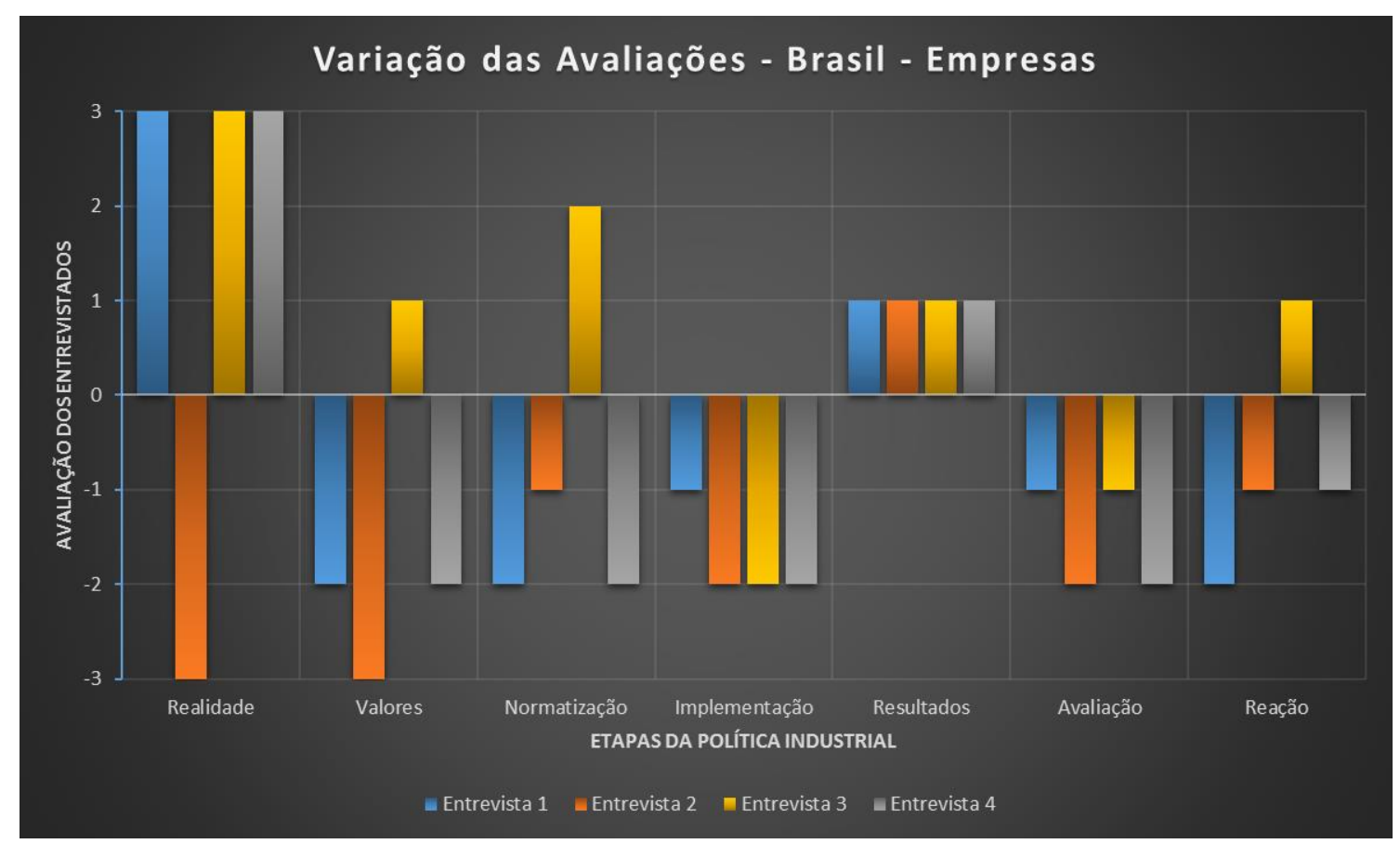

Gráfico 75 - Variação das avaliações sobre as diferentes etapas da política industrial de petróleo e gás nas entrevistas das associações empresariais do Brasil.

Aqui percebe-se que houve uma variação muito maior nas respostas dos entrevistados. A avaliação sobre a realidade da indústria apresentou uma única resposta divergente, mas que variou entre os dois extremos possíveis. A etapa de implementação teve a variação mínima e a avaliação dos resultados obtidos foi a mesma entre todos os entrevistados desse grupo. Todas as demais etapas tiveram uma variação considerável nas respostas objetivas apresentadas.

O gráfico 76, abaixo, apresenta o total de desvios que as respostas objetivas de cada entrevistado tiveram com relação às médias das avaliações feitas pelos entrevistados 
das associações empresariais brasileiras, sobre as diferentes etapas da política industrial brasileira de petróleo e gás.

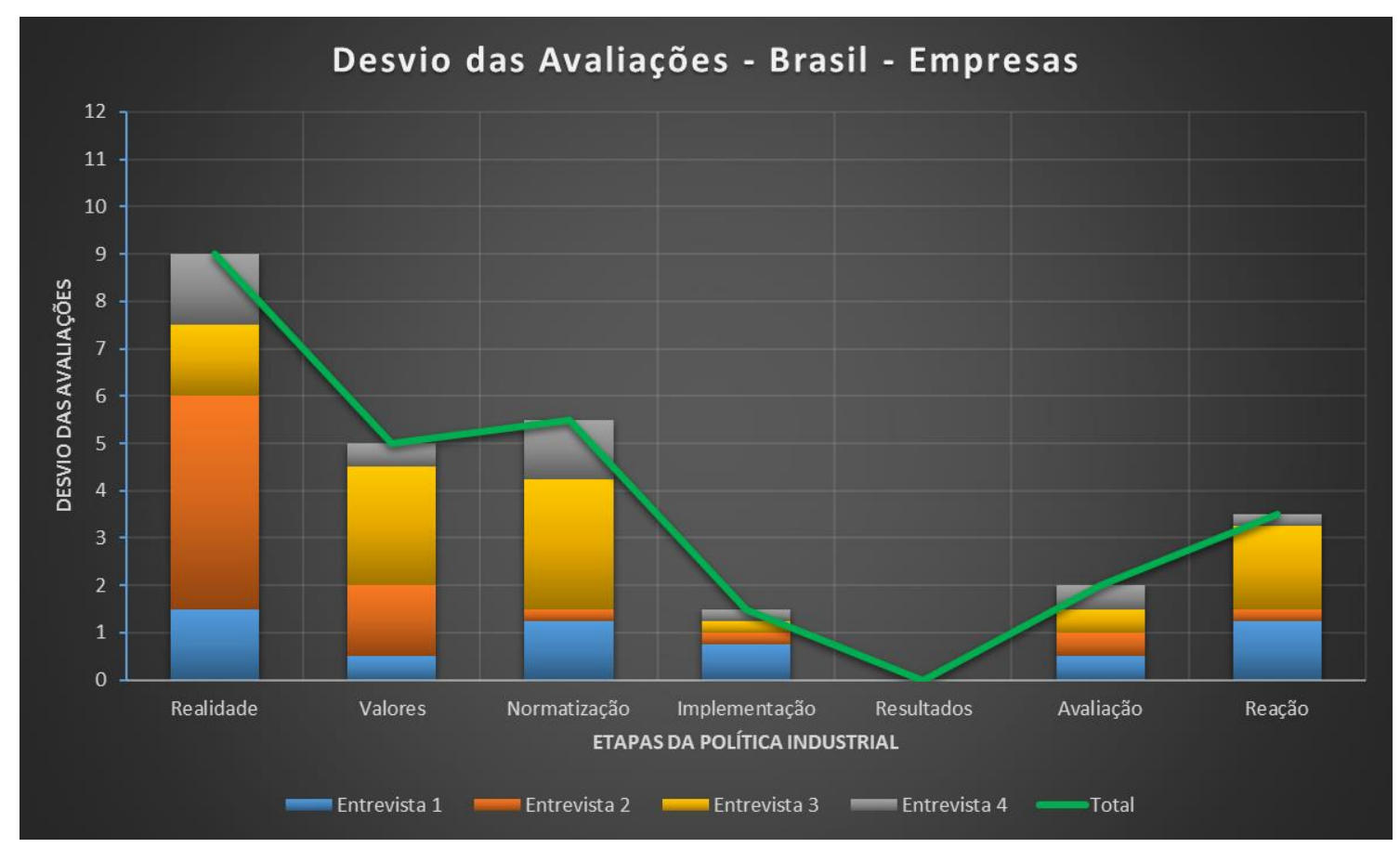

Gráfico 76 - Desvio entre a avaliação de cada entrevistado e a média das avaliações das associações empresariais, para cada etapa da política industrial de petróleo e gás no Brasil.

Este gráfico torna mais clara a diferença entre os desvios nas respostas das entrevistas com representantes das associações empresariais brasileiras. Embora apenas um dos entrevistados tenha apresentado uma resposta diferente dos demais, por ter variado de um extremo ao outro, os maiores desvios foram com relação à avaliação sobre a realidade que serviu de base para a formulação da política industrial. As avaliações sobre os valores da política, sobre as normas que regem essa política e sobre a reação aos dados do monitoramento e da avaliação tiveram níveis médios de desvios. Já a implementação e a avaliação da política tiveram níveis de desvios baixos. Enquanto as respostas sobre os resultados obtidos tiveram desvio zero. 


\section{c) Relação Governo-Empresas}

O gráfico 77, abaixo, apresenta a comparação entre o total de desvios, dentro de cada grupo, com relação às respostas sobre todas as etapas da política industrial brasileira de petróleo e gás, apresentadas pelos entrevistados do governo e pelas associações empresariais brasileiras.

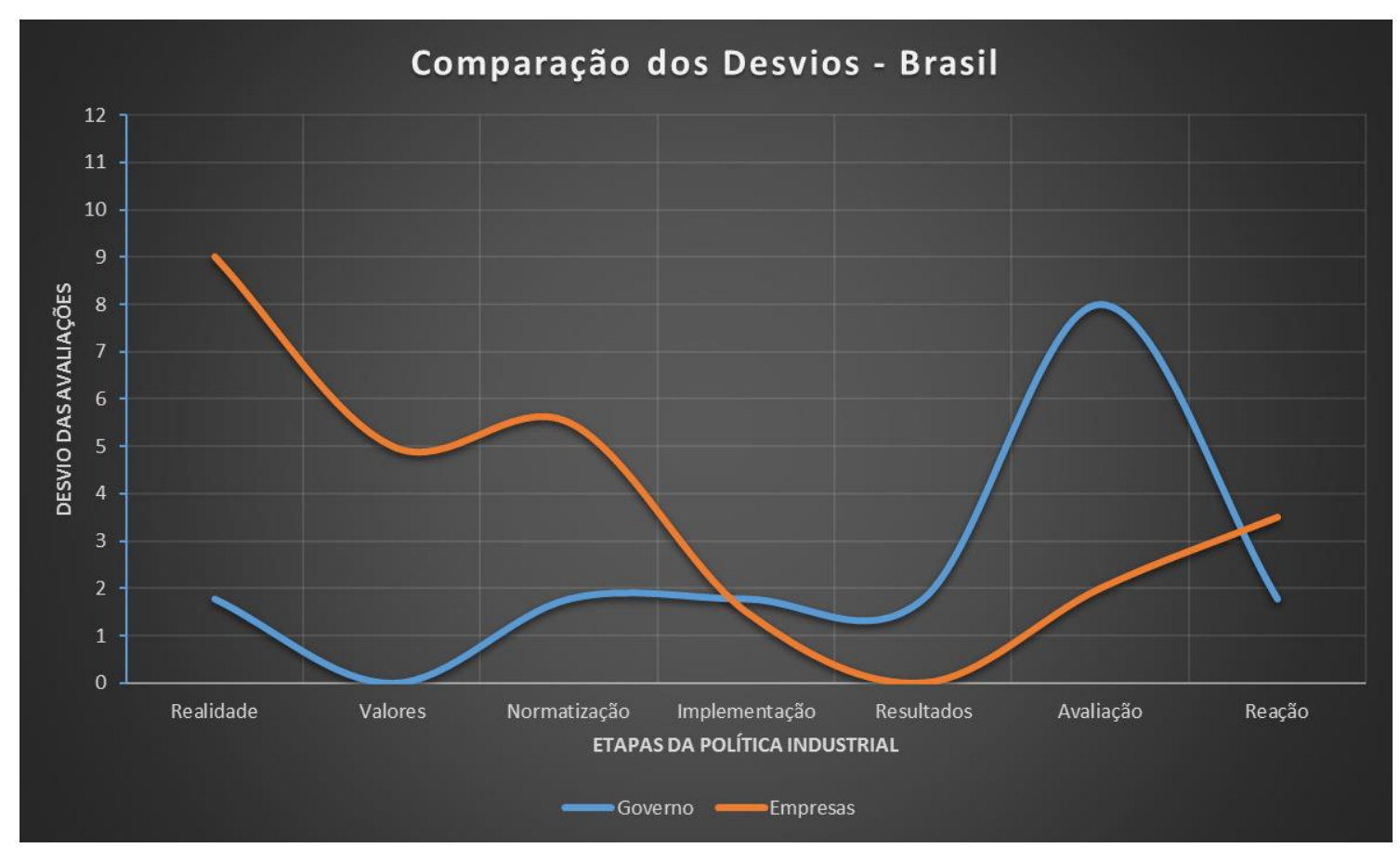

Gráfico 77 - Comparação dos desvios dentro de cada grupo, nas respostas sobre as avaliações de cada etapa da política industrial de petróleo e gás no Brasil.

Nesta comparação fica perceptível que houve uma diferença grande entre as etapas onde ocorrem os desvios nas respostas dos entrevistados do governo e das associações empresariais brasileiras. Enquanto o governo teve uma variação baixa nas respostas das primeiras etapas e mais alta nas etapas finais, as respostas das associações empresariais seguiram a lógica oposta, tendo uma grande variação nas etapas iniciais, mas caindo ao se aproximas das últimas etapas da política. Não houve nenhuma etapa que tenha tido uma variação grande nos dois grupos. As etapas que não tiveram variação nenhuma também foram diferentes nos dois grupos.

O gráfico 78, abaixo, apresenta o percentual de variação nas avaliações dentro de cada um dos grupos, sobre todas as etapas que fazem parte da política industrial brasileira. 


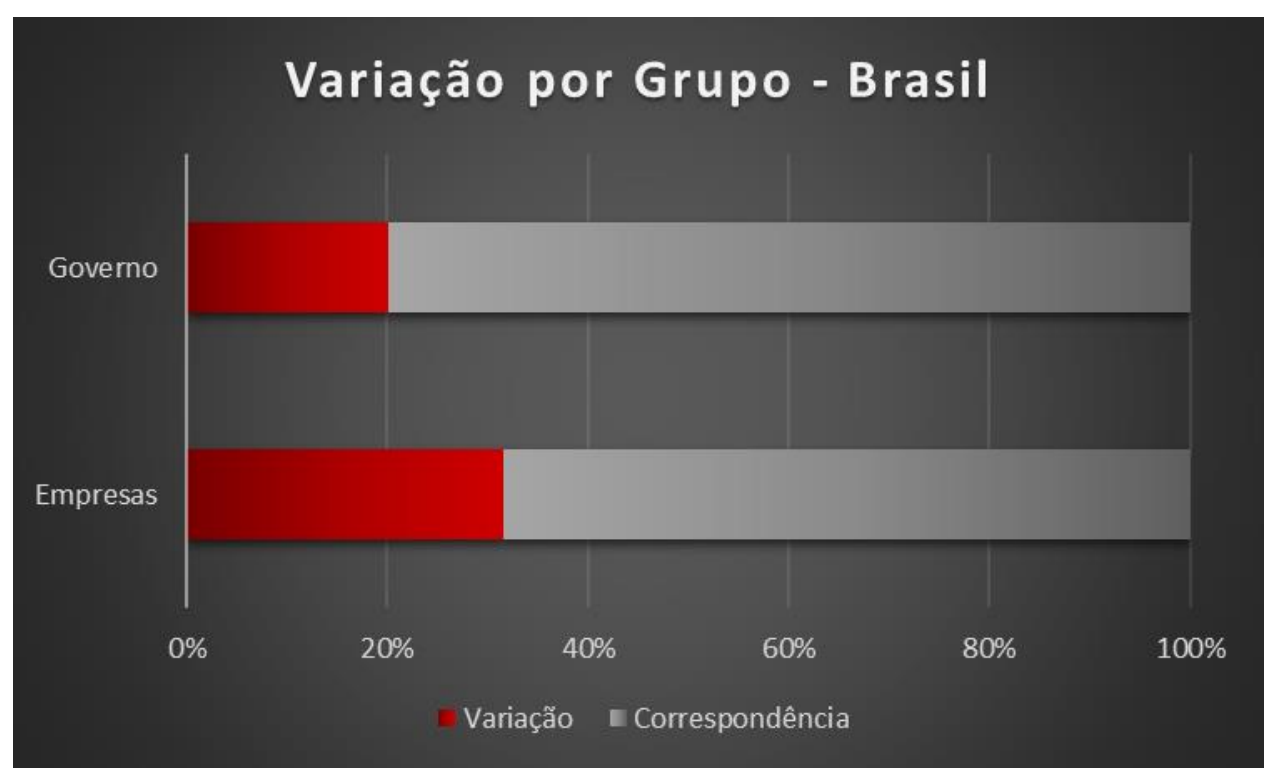

Gráfico 78 - Percentual de variação na avaliação de cada grupo sobre todas as etapas da política industrial de petróleo e gás no Brasil.

Com esse gráfico, fica perceptível que houve uma variação maior entre as avaliações dos entrevistados das associações empresariais brasileiras, do que entre as avaliações dos entrevistados do governo brasileiro. Cabe mencionar que a variação entre as respostas das associações foi aproximadamente 50\% superior à variação das respostas do governo.

O gráfico 79, abaixo, apresenta a soma do total de desvios que as respostas objetivas dos entrevistados de cada grupo tiveram com relação às médias gerais das avaliações feitas por ambos os grupos, sobre as diferentes etapas da política industrial brasileira de petróleo e gás. 


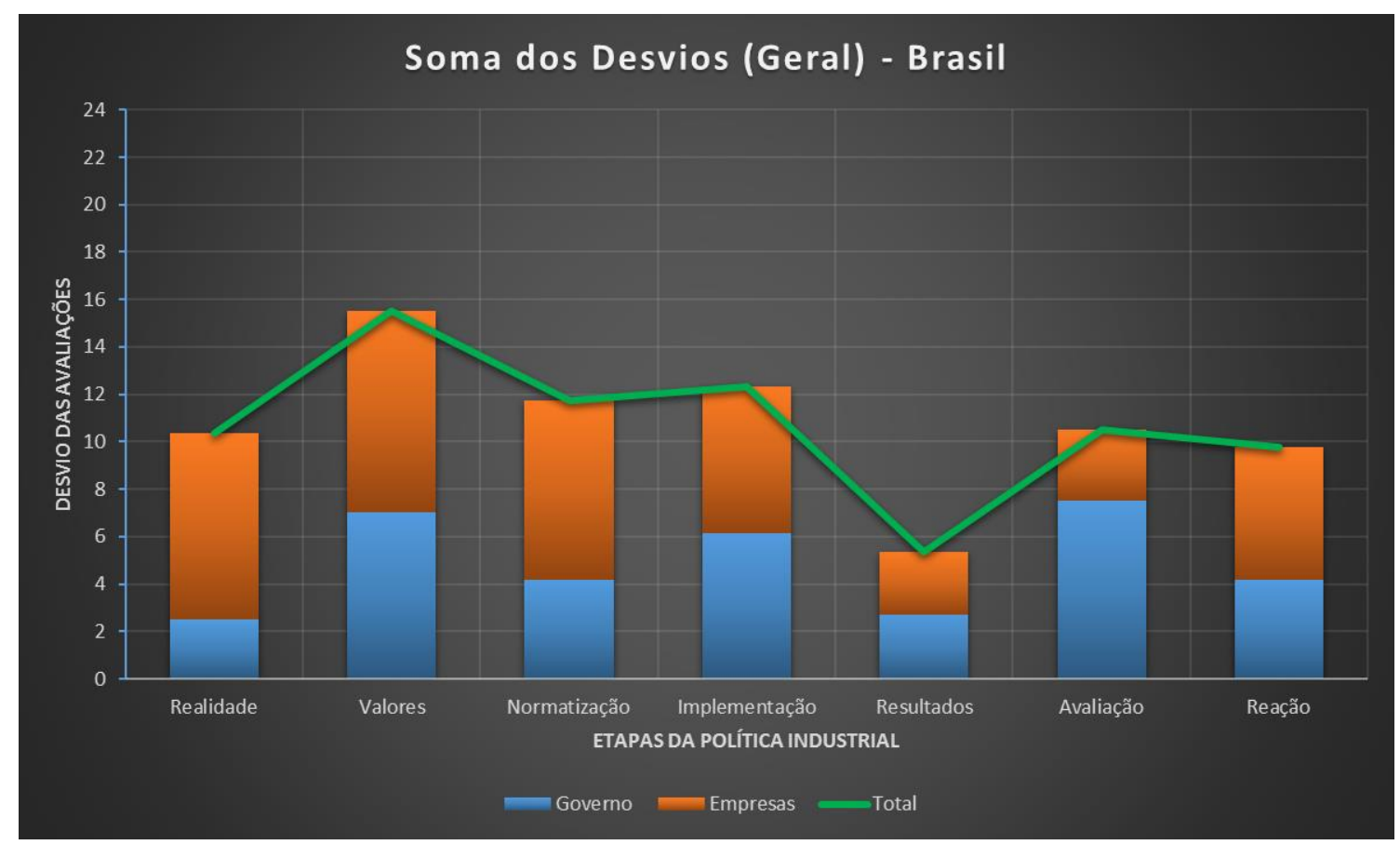

Gráfico 79 - Soma dos desvios entre a avaliação de cada entrevistado e a média das avaliações dos dois grupos, para cada etapa da política industrial de petróleo e gás no Brasil.

No gráfico acima se utiliza a média geral, que considera as respostas dos entrevistados dos dois grupos para fazer o cálculo dos desvios. Essa soma do total de desvios nas respostas dos entrevistados do governo brasileiro com o total de desvios nas respostas dos entrevistados das associações empresariais brasileiras permite que se perceba melhor quais etapas apresentam uma variação maior de respostas entre todos os atores brasileiros. Com isso, fica mais perceptível que houve uma variação considerável na avaliação de quase todas as etapas da política industrial brasileira. Apenas aqui podese perceber que foram os valores da política a maior fonte de discordância entre os entrevistados. A segunda maior variação foi referente à fase de implementação da política, sendo seguida de perto pela normatização, realidade da indústria, mecanismos de avaliação e reação aos dados da avaliação da política, em ordem decrescente de variação. E mais uma vez, aparece aqui que os resultados obtidos pela política foram a etapa onde as respostas menos divergiram. 


\subsection{4 - Relação Entre Atores}

Nesta parte da análise comparativa serão comparadas as avaliações de cada grupo com relação à interação entre os atroes envolvidos com a política industrial de petróleo e gás brasileira. Para isso, serão analisadas as opiniões que os entrevistados de um grupo apresentaram a respeito da sua percepção sobre os atores do outro grupo, sobre como cada grupo percebe a sua própria participação e sobre como cada grupo percebe o recebimento dessa sua participação pelos atores do outro grupo de entrevistados.

\section{a) Percepção do Outro}

O gráfico 80, abaixo, apresenta a comparação entre o percentual de menções positivas e negativas nas respostas dos entrevistados dos dois grupos brasileiros, sobre a percepção que os atores de um grupo têm a respeito dos atores do outro grupo.

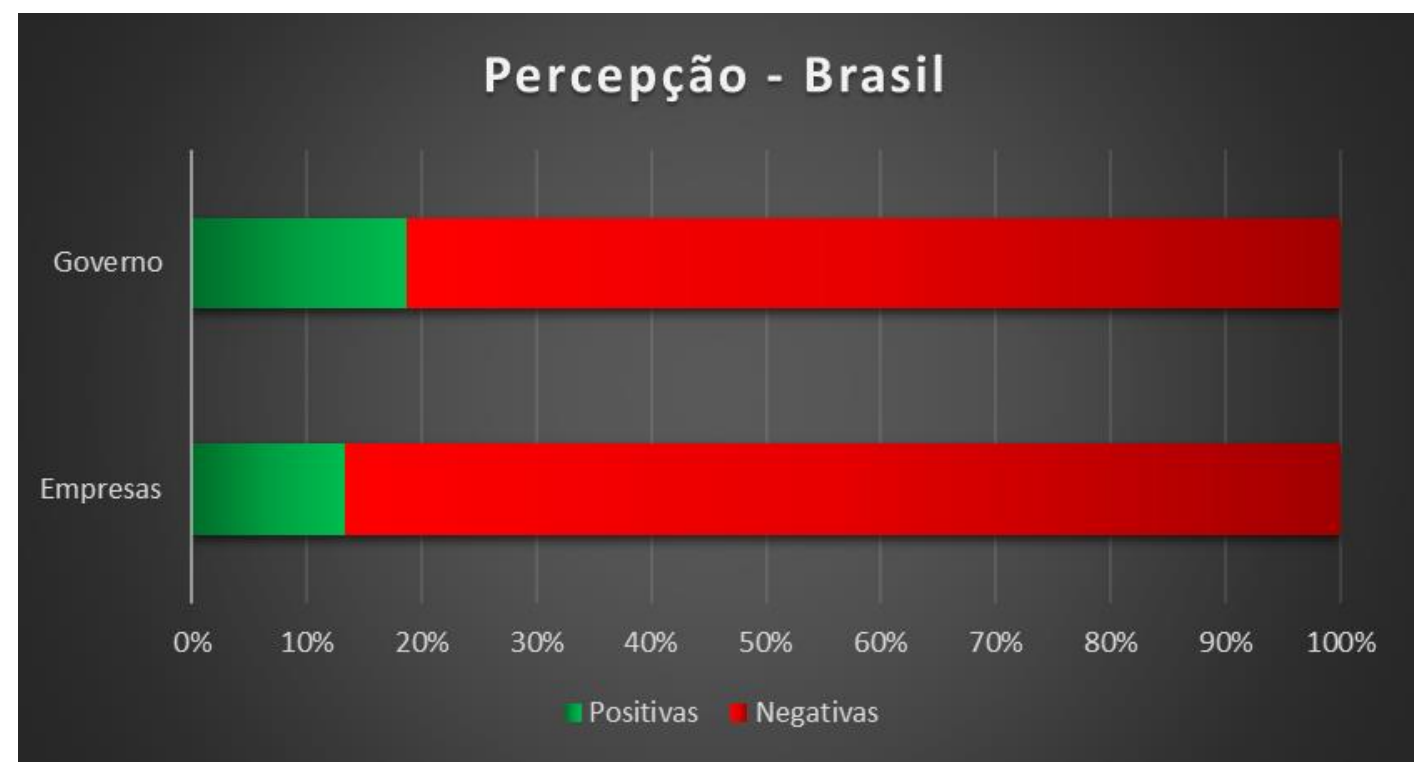

Gráfico 80 - Percentual de menções positivas e negativas nas respostas dos dois grupos brasileiros sobre a percepção que um grupo tem do outro.

Como uma forma de menção positiva sobre as associações empresariais brasileiras, os entrevistados do governo brasileiro disseram que elas teriam se manifestado e influenciado a mudança da política industrial nacional. Já como menções positivas sobre o governo brasileiro, os entrevistados das associações empresariais indicaram que a adoção da política de conteúdo local seria a única coisa boa feita pelo 
governo brasileiro e que algumas pessoas de dentro do governo já estariam admitindo a necessidade de mudanças na política.

Nas entrevistas junto aos representantes do governo foram feitas menções sobre as associações empresariais que não foram consideradas nem positivas nem negativas. Foi dito que algumas empresas participariam da política, enquanto outras não, assim como algumas empresas elogiariam a política, enquanto outras estariam reclamando.

Os comentários negativos dos entrevistados do governo a respeitos das associações empresariais indicaram que as empresas reclamariam muito da política, mas que não estaria muito claro o que elas querem. Empresas fornecedoras e empresas operadoras teriam interesses distintos, além dos sindicatos de trabalhadores, que estariam preocupados em alcançar objetivos próprios. Por outro lado, os comentários negativos das associações empresariais a respeito do governo brasileiro incluíram a menção à dificuldade que o governo teria para desenvolver uma política industrial. O governo teria dificuldades para enxergar as falhas da política, faltariam métricas e instrumentos que sirvam de base para a política e haveria uma supervalorização dos resultados encontrados, que seriam bastante questionáveis. Uma parte das pessoas que integram o governo teria uma visão demasiadamente nacionalista. Como a política seria usada pelo governo para fins eleitoreiros, ele não teria problema algum em mentir sobre seus resultados, ou em fazer como fez nas eleições de 2014, onde teria criticado propostas dos adversários que acabaram sendo utilizadas pelo governo após eleito. De uma maneira geral, haveria a adoção de medidas ligadas a uma política de governo e não a uma política de Estado.

\section{b) Participação}

O gráfico 81, abaixo, apresenta a comparação entre o percentual de menções positivas e negativas nas respostas dos entrevistados dos dois grupos, sobre a participação do seu próprio grupo na política industrial de petróleo e gás brasileira. 


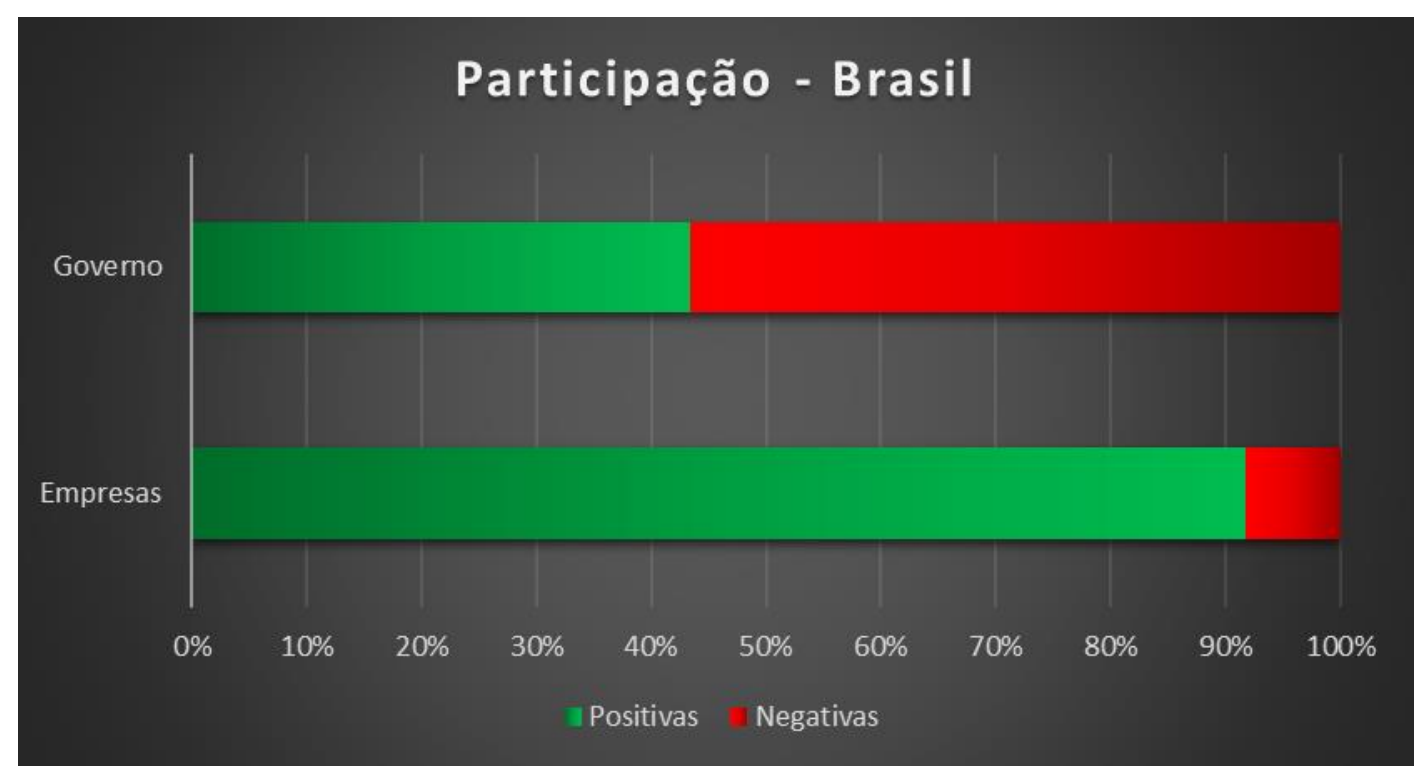

Gráfico 81 - Percentual de menções positivas e negativas nas respostas dos dois grupos sobre a participação do seu próprio grupo na política industrial do Brasil.

Sobre a participação de cada grupo na política industrial de petróleo e gás brasileira, as menções positivas do governo mencionaram sua participação no diálogo com as empresas, enquanto as menções positivas das associações citaram a participação delas na definição dos índices de conteúdo local, na aproximação entre governo e empresas, na apresentação de propostas de política industrial para o governo e na apresentação de propostas para os candidatos à presidência nas eleições de 2014.

Houve apenas um comentário que não foi considerado nem positivo nem negativo, quando um dos entrevistados do governo mencionou que seu órgão participaria da formulação e do monitoramento, mas não participaria da implementação da política.

Os comentários negativos que os representantes do governo fizeram sobre a participação do próprio governo na política industrial nacional trataram sobre a não participação em alguma etapa da política, ou sobre a falta de influência nessa participação. Eles disseram que a política estaria muito centrada no MME e na ANP, que haveria falta de diálogo entre os ministérios para a definição da política e de uma discussão interna sobre melhorias. O longo período sem a utilização de políticas industriais seria um obstáculo para a participação do governo. Além disso, haveria dificuldades dentro do próprio governo para levar assuntos até instâncias superiores do governo e que as pessoas encarregadas das decisões teriam dificuldade para atender outras pessoas do governo, por 
terem suas agendas muito ocupadas. Já os entrevistados das associações empresariais manifestaram nunca terem participado de discussões com o governo que fossem baseadas em métricas. Além disso, disseram que não teriam participado, pois a discussão sobre a política industrial brasileira estaria mais limitada às pessoas de dentro do governo, ou entre governo e Petrobras.

\section{c) Recebimento pelo Outro}

O gráfico 82, abaixo, apresenta a comparação entre o percentual de menções positivas e negativas nas respostas dos entrevistados dos dois grupos, sobre o recebimento da sua participação pelo outro grupo, na definição da política industrial de petróleo e gás brasileira.

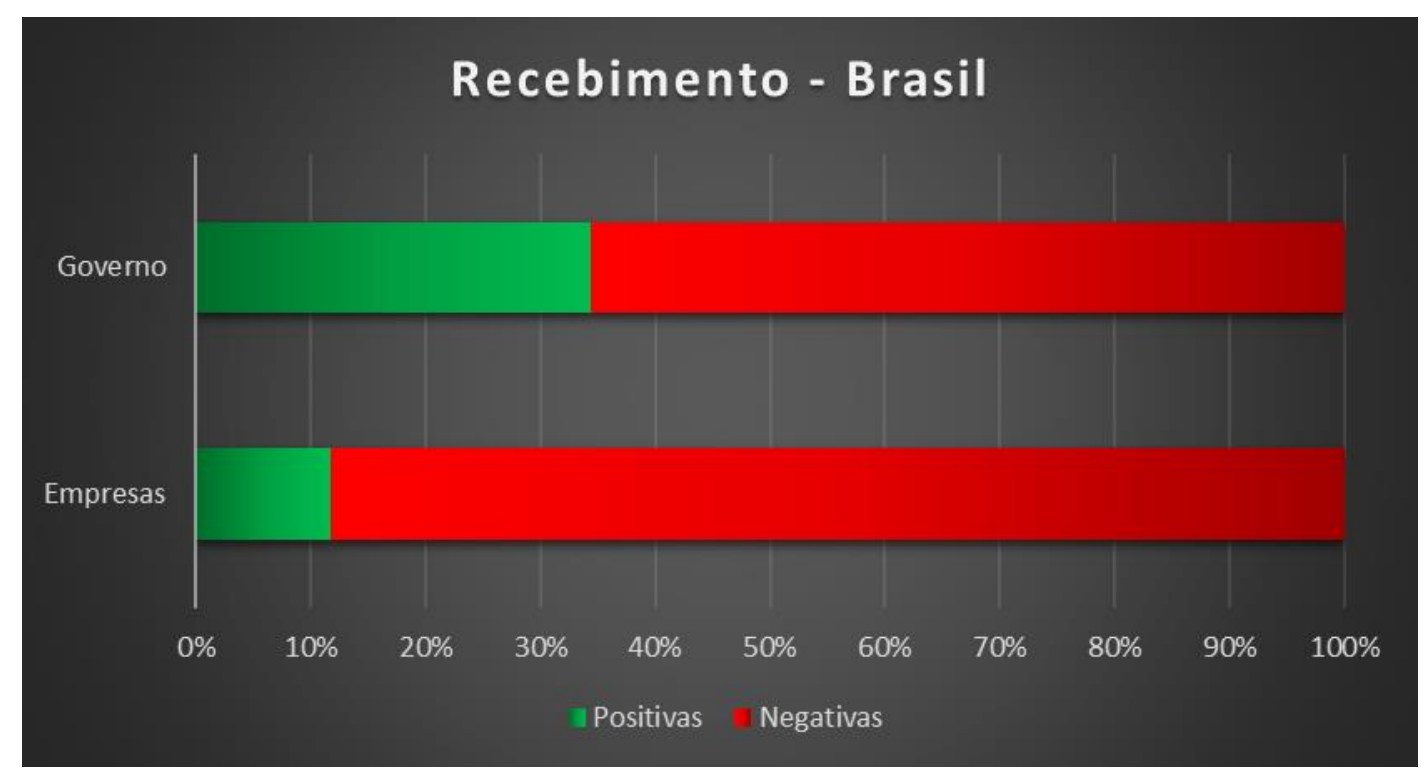

Gráfico 82 - Percentual de menções positivas e negativas nas respostas dos dois grupos brasileiros sobre o recebimento da sua participação pelo outro grupo.

Os entrevistados do governo relacionaram um bom recebimento de suas participações por parte das associações empresariais com trabalhos em conjunto entre governo e empresas e com a falta de críticas por parte das empresas. Do outro lado, as associações empresariais disseram que haveria uma boa relação entre empresas e governo e que elas se sentem bem recebidas pelo governo, mas nada diferentes da forma como o governo recebe a todos. 
Nas entrevistas com os representantes do governo apareceu um comentário que não foi considerado nem positivo nem negativo. Nele foi dito simplesmente que o governo espera que as empresas participem da política fazendo a sua parte.

Já os comentários negativos sobre o recebimento que as associações empresariais oferecem à participação do governo estiveram ligados a uma resistência das associações empresariais às propostas de mudanças para melhorias na política industrial. Sempre que o governo tenha tentado modificar a política de conteúdo local, teria ouvido uma reclamação generalizada das empresas nacionais. Também disseram que as empresas poderiam ter participado e investido mais para contribuir com os resultados da política, pois elas teriam dito serem capazes de produzir mais do que realmente são capazes, para garantirem a exigência de um índice de conteúdo local mais alto. Entre os entrevistados das associações empresariais brasileiras, as menções negativas ao recebimento que tiveram por parte do governo brasileiro disseram que elas seriam mal recebidas por falta abertura do governo ao diálogo. A receptividade seria variável, conforme o ministério ou a pessoa com quem se está falando, mas a ANP, por exemplo, não teria aceito nenhuma das sugestões das associações sobre melhorias para a $13^{\mathrm{a}}$ rodada de licitações e haveria pessoas dentro do governo que estariam mais preocupadas com questões pessoais do que com o sucesso da política ou o desenvolvimento do país. Se sentiria falta de uma presença mais firme do governo, pois haveria muito conflito de interesses, tanto dentro do governo como entre governo e empresas. Quando as empresas participam, haveria a "sensação" de que essa participação não exerce influência sobre as decisões, pois nada seria colocado em prática, ou quando alguma sugestão é aceita, não seria bem implementada, pois o governo não faria essa implementação em conjunto com as empresas. De uma maneira geral, foi dito que as associações tentam participar, mas que ficaria sempre a impressão de que as decisões finais já estão pré-estabelecidas.

\section{d) Interação de Atores}

O gráfico 83, abaixo, apresenta a comparação entre o percentual de menções positivas e negativas nas respostas dos entrevistados dos dois grupos, sobre a interação entre os atores, na definição da política industrial de petróleo e gás brasileira. 


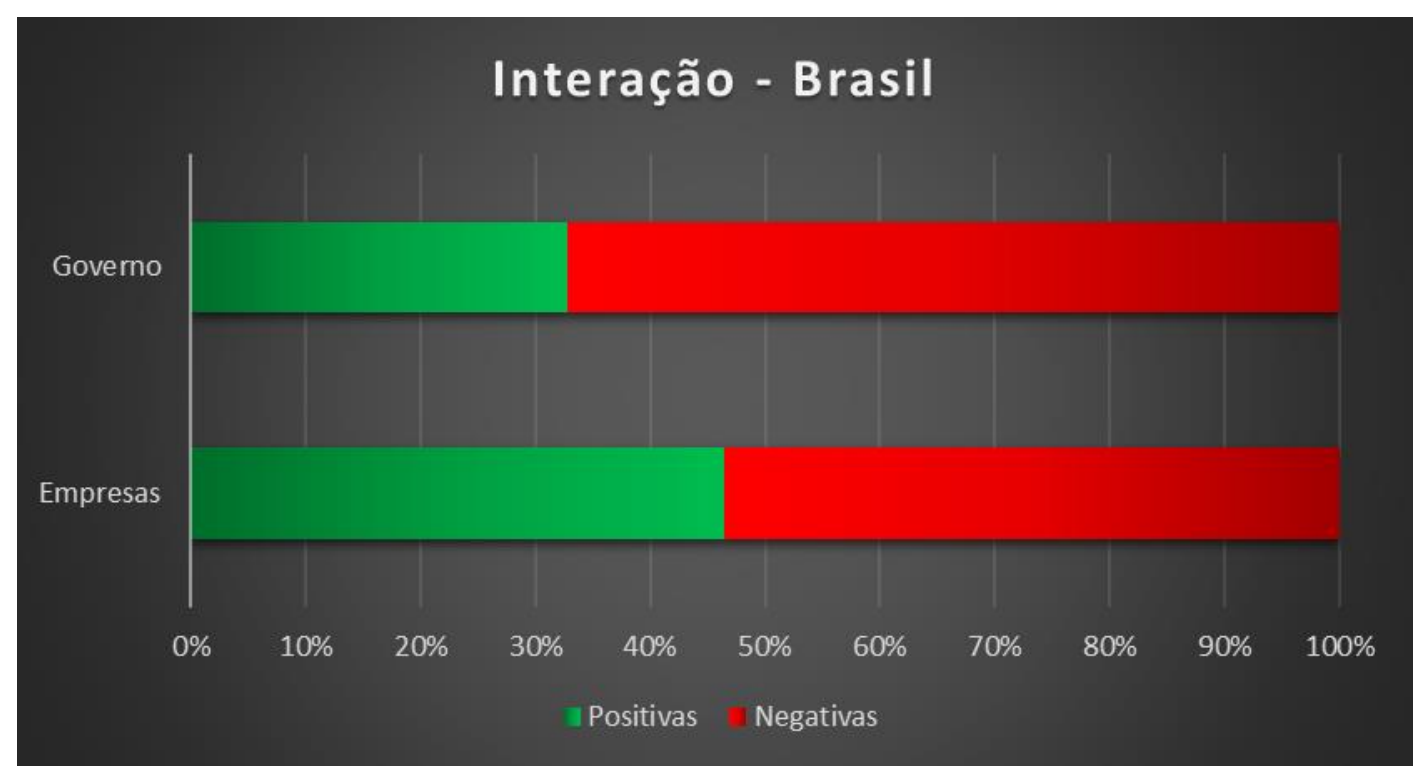

Gráfico 83 - Percentual de menções positivas e negativas nas respostas dos dois grupos sobre a interação dos atores na política industrial brasileira.

Aqui, o percentual foi calculado com base no total de menções realizadas sobre a percepção do outro, a participação e o recebimento e não com base numa média entre esses três elementos. Percebe-se que, considerando todos os elementos anteriores, relacionados à interação entre os atores brasileiros na definição da política industrial de petróleo e gás, as associações empresariais teriam uma visão geral mais positiva dessa relação do que o governo. Uma grande parte dessa diferença está ligada à uma avaliação muito mais positiva das associações com relação à sua própria participação, pois nos outros dois elementos foi o governo quem apresentou uma percepção mais positiva. De qualquer forma, é importante reparar que, no total, os dois grupos tiveram mais menções negativas do que positivas sobre a interação entre os atores brasileiros na definição da política industrial de petróleo e gás nacional. 


\section{2 - México}

\subsection{1 - Total das Avaliações Objetivas}

\section{a) Governo}

O gráfico 84, abaixo, apresenta o total das respostas objetivas sobre todas as etapas da política industrial mexicana de petróleo e gás, apresentadas pelos três entrevistados do governo mexicano.

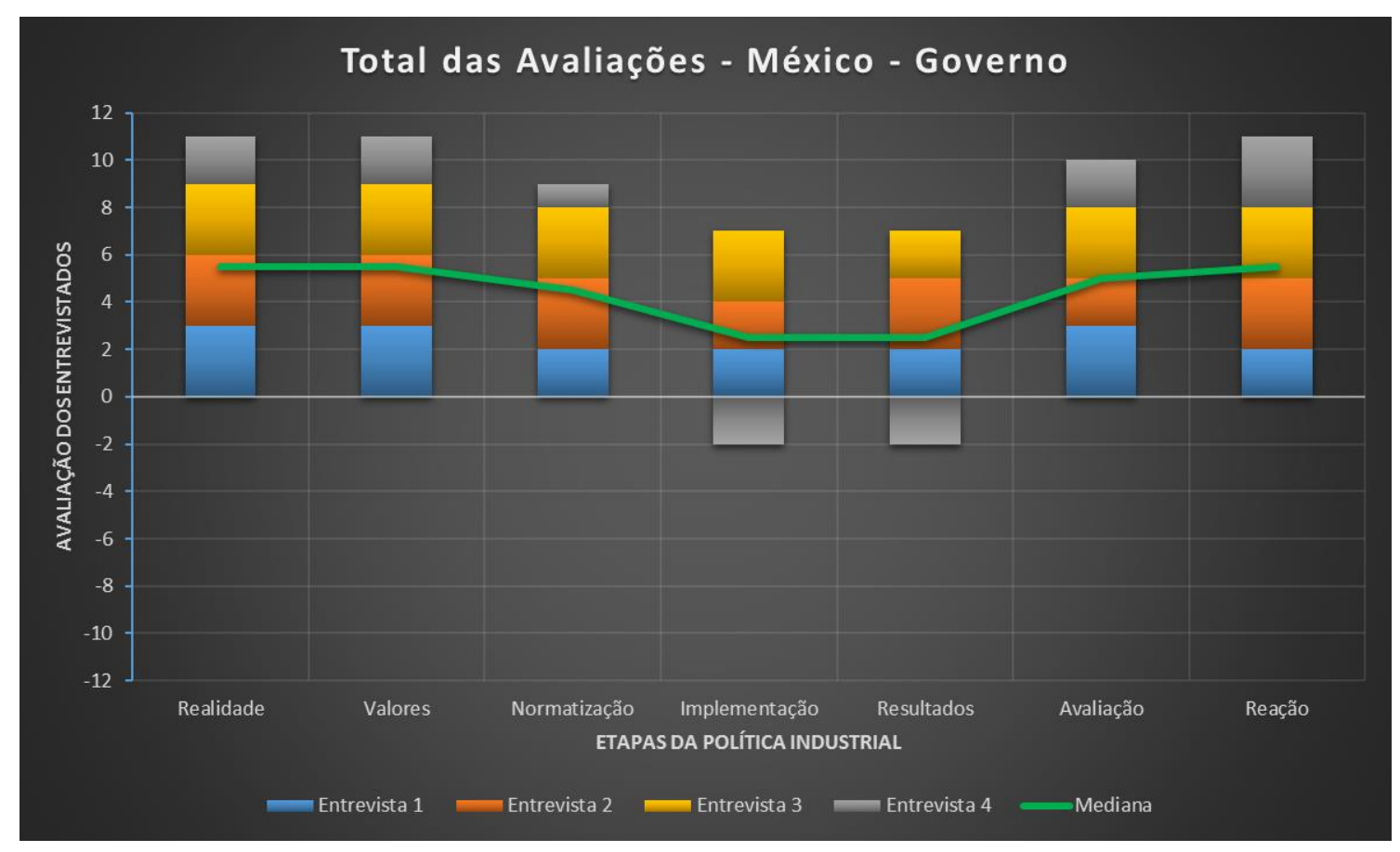

Gráfico 84 - Total das avaliações sobre as diferentes etapas da política industrial de petróleo e gás nas entrevistas do governo do México.

Percebe-se que as avaliações do governo mexicano sobre as diferentes etapas da política indústria mexicana foram boas, aparecendo apenas duas avaliações negativas e todas as demais positivas. As avaliações sobre a realidade que serviu de base para a atual política industrial de petróleo e gás foram muito boas, se mantiveram neste nível quando trataram dos valores que serviram de base para a formulação da política e caíram muito pouco com relação à normatização que rege a política industrial. Já com relação à forma como a política é implantada e aos resultados obtidos pela política houve uma queda um 
pouco maior, sendo as duas etapas pior avaliadas. As duas últimas etapas, referentes aos mecanismos de monitoramento e avaliação da política industrial mexicana e à forma de reação aos dados do monitoramento e da avaliação, para definir a orientação da política, voltaram ao nível muito bom de avaliação que se teve nas primeiras etapas.

\section{b) Associações Empresariais}

O gráfico 85, abaixo, apresenta o total das respostas objetivas sobre todas as etapas da política industrial mexicana de petróleo e gás, apresentadas pelos quatro entrevistados das associações empresariais mexicanas.

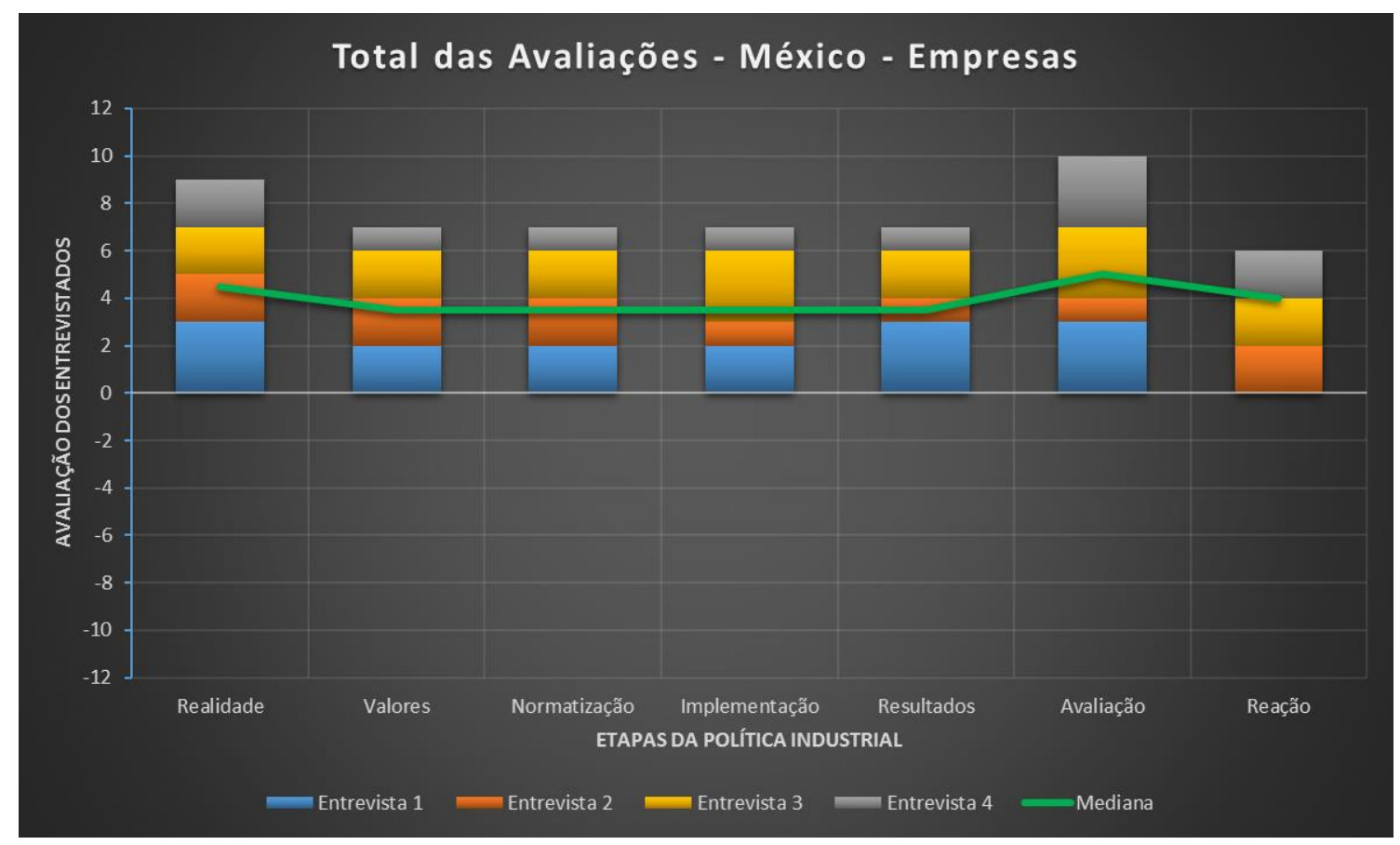

Gráfico 85 - Total das avaliações sobre as diferentes etapas da política industrial de petróleo e gás nas entrevistas das associações empresariais do México.

As avaliações dos representantes das associações empresarias mexicanas sobre as diferentes etapas de política industrial de petróleo e gás do país foram, sem exceção, todas positivas. As avaliações sobre o potencial oferecido pela realidade brasileira para o desenvolvimento de uma indústria nacional de petróleo e gás ficaram entre boa e muito boa. Já as avaliações sobre os valores que serviram de base para a política, juntamente com a normatização que rege a política, a fase de implementação, os resultados obtidos e 
a forma de reação aos dados desses mecanismos ficaram todas num nível bom. Por último, os mecanismos de monitoramento e avaliação foram a fase melhor avaliada pelos entrevistados do governo mexicano.

\section{c) Comparação entre Governo e Empresas}

O gráfico 86, abaixo, apresenta a comparação entre as medianas dos totais das respostas objetivas sobre todas as etapas da política industrial mexicana de petróleo e gás, apresentadas pelos entrevistados do governo mexicano e pelas associações empresariais mexicanas.

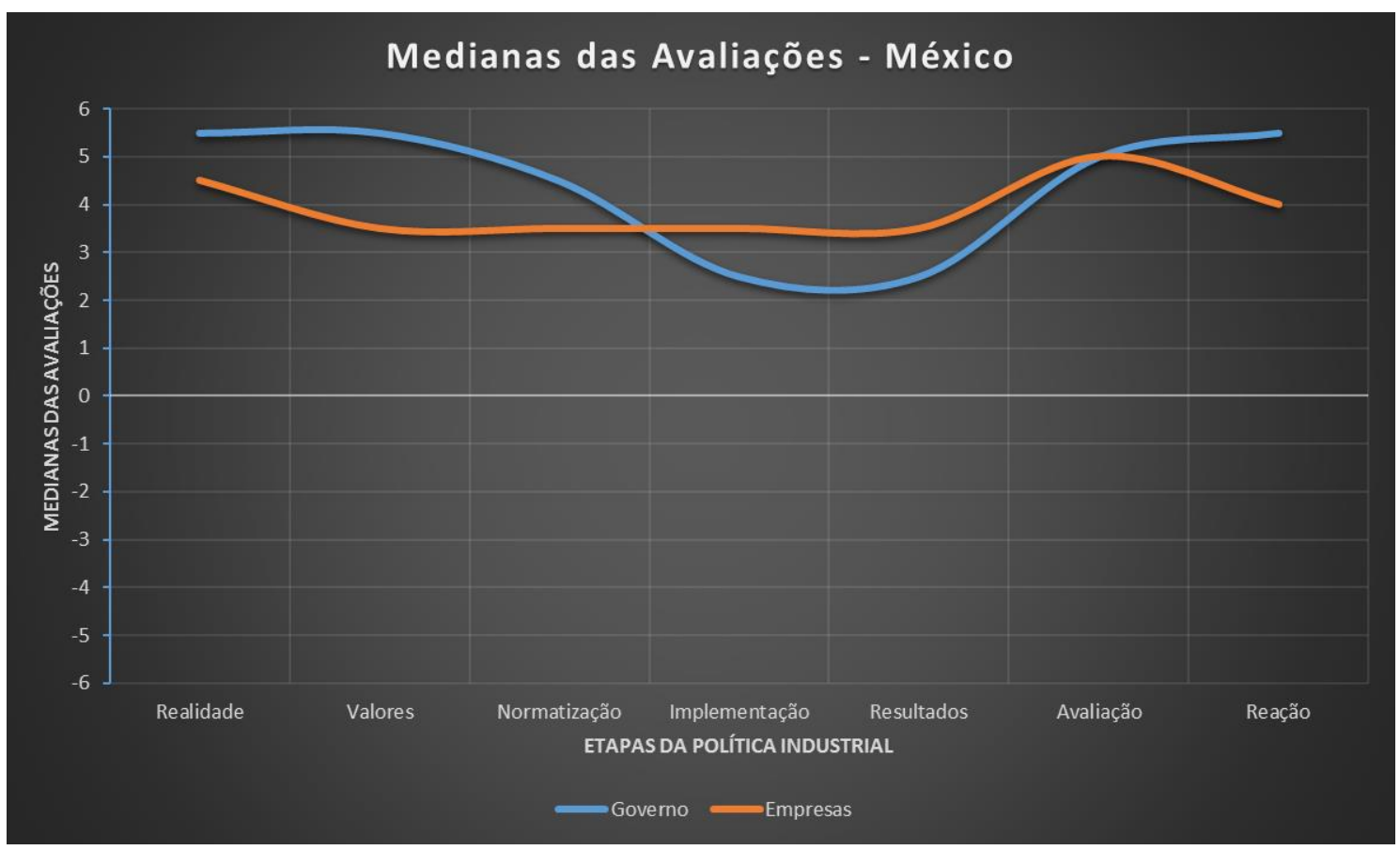

Gráfico 86 - Comparação entre as medianas do total das avaliações sobre as diferentes etapas da política industrial de petróleo e gás no México.

O gráfico acima demonstra que houve uma pequena variação entre as respostas dos dois grupos sobre quase todas as etapas da política mexicana. Em algumas etapas o governo avaliou melhor, em outras foram as associações empresariais que melhor avaliaram. $\mathrm{O}$ governo avaliou um pouco melhor as três primeiras etapas, mas avaliou pior do que as associações empresariais as etapas de implementação e resultados. Muito disso está ligado às respostas de um dos entrevistados do governo, que avaliou como negativo o fato de a política ainda não ter sido implementadas nem gerado resultados. Outros 
entrevistados avaliaram essas situações como positivas, por considerarem ainda ser cedo para que estas etapas tenham sido colocadas em prática. Os dois grupos tiveram o mesmo nível de avaliações sobre os mecanismos de monitoramento e avaliação. Já com relação à fase de reação aos dados obtidos pela avaliação, para definir a reorientação da política industrial do país, o governo voltou a avaliar um pouco melhor do que as associações empresariais mexicanas.

\subsection{2 - Temas Levantados}

\section{a) Semelhanças e Diferenças}

Nas respostas às perguntas abertas dos roteiros de entrevista, os entrevistados do governo e das associações empresariais mexicanas apresentaram visões semelhantes em alguns temas. Ambos valorizaram a importância das reservas mexicanas, mas alertaram para problemas de atraso tecnológico e falta de infraestrutura no país. Os dois grupos lembraram questões macroeconômicas, como o preço do barril de petróleo, que estariam prejudicando o setor. A forte relação com os Estados Unidos também foi lembrada por entrevistados do governo e das associações empresariais. Disseram que no México não haveria uma política industrial de petróleo e gás, mas apenas uma política energética. Ambos disseram que os recursos do subsolo são de propriedade do governo mexicano por lei e que o sindicato de trabalhadores da Pemex seria um obstáculo à realização de mudanças. Os dois grupos também levantaram a necessidade do México começar a fazer sua transição para o uso de energias renováveis, pois o país seria uma potência também nesse tipo de recursos. Eles mencionaram que teria havido pressa na criação das leis, o que poderia ser um problema, mas que ainda seria cedo para que se possa avaliar a implementação, os resultados e à reação aos dados de avaliação da política. Muitos desses elementos já estariam em lei, mas ainda não teriam sido implementados. A existência de metas e objetivos bem definidos e a existência de parcerias com universidades e centros de pesquisa, que estariam iniciando o desenvolvimento de capacidades e processos de aprendizagem tecnológica foi mencionada pelos dois grupos de atores mexicanos. Ambos disseram que a indústria gostaria de contar um energético mais barato. Nas entrevistas do governo e das associações também foi dito que a população mexicana teria dificuldades 
para entender que ainda não é o momento para que se tenha resultados e que a existência de atos de corrupção seria um sério problema nacional.

Em alguns pontos houve ao mesmo tempo concordância e conflito de opiniões. Entrevistados do governo mexicano disseram entender que o ritmo de exploração depende do preço do barril de petróleo e da geopolítica. Entre os entrevistados das associações empresariais, houve quem concordou com isso, mas também houve quem alertasse que o ritmo depende de fatores internos, como as necessidades domésticas de abastecimento de gás natural. Os entrevistados do governo também defenderam que muitos critérios estariam sendo estabelecidos por leis secundarias, o que facilitaria suas alterações, para correção da política com base nos resultados obtidos, entre as associações houve quem defendeu o mesmo e quem disse que as normas são rígidas. Invertendo os papéis, entrevistados das associações manifestaram que acreditam que estejam ocorrendo alianças com universidades e centros de pesquisa, mas entre os entrevistados do governo houve quem concordou e quem discordou, dizendo que estas alianças não estariam acontecendo. Sobre a integração da política industrial com outras políticas, nas entrevistas do governo mexicano foi dito que esta integração estaria ocorrendo, mas nas entrevistas das associações houve quem defendeu o mesmo e quem defendeu o contrário. Já com relação aos resultados obtidos, foram os entrevistados das associações que manifestaram acreditar que os resultados sejam baixos, enquanto entrevistados do governo se dividiram entre aqueles que também consideraram os resultados negativos e aqueles que, mesmo admitindo que os resultados ainda não existem, disseram ter certeza de que serão positivos. Os investimentos feitos no país teriam sido grandes para entrevistados do governo e para alguns das associações empresariais, mas outras associações disseram que não houve acréscimo de investimento ou que por enquanto só existe o interesse de alguns investidores.

Os dois grupos de entrevistados divergiram sobre alguns temas, como o ritmo de exploração, que para os entrevistados do governo seria definido com o objetivo de maximizar o aproveitamento de recursos como o gás natural, mas os entrevistados das associações acreditam que vá haver uma grande pressão para que os mexicanos desenvolvam e explorem esses recursos da forma mais rápida possível. Assim como entrevistados do governo disseram entender que todos os atores mexicanos estejam se relacionando tão bem um com o outro a ponto de comparar essa relação com uma lua de 
mel, mas por outro lado entrevistados das associações dizem que haveria gente pedindo para que essa relação seja mais aberta.

\section{b) Instrumentos de Política Industrial}

Sobre os instrumentos adotados pela política industrial mexicana, ambos os grupos manifestaram muito mais opiniões de apoio a uma política liberalizante do que a uma política intervencionistas ou a uma combinação entre as duas. Com relação a instrumentos intervencionistas, nos dois grupos foi dito que a nacionalização da cadeia de fornecedores seria um objetivo da política, através da adoção de regras de conteúdo local que devem ajudar a desenvolver uma indústria nacional. Os entrevistados das associações disseram que nunca houve uma política de conteúdo local clara a estratégica como agora, mas também disseram que as empresas nacionais estariam preocupadas em perder mercado devido ao baixo índice que foi estabelecido. De acordo com eles, o ideal seria uma política que fomente setores inexistentes ou não competitivos, mas que não seja protecionista. A intervenção de políticas industriais mexicanas teria sido determinante ao gerar resultados que até então eram inexistentes nos setores aeroespacial e automobilístico do país. Nas entrevistas com representantes do governo mexicano foi apontada a necessidade de o governo adotar medidas proativas e de prevenção, e não medidas reativas como estaria tomando até aqui. Também foi destacada a importância da política ter instrumentos para que parte dos frutos gerados pela indústria de petróleo sejam poupados para gerações futuras e da obrigatoriedade de consulta à comunidades locais para a realização de qualquer projeto do setor energético.

A combinação entre instrumentos de intervenção estatal e de abertura para o mercado foi defendida por representantes do governo e das associações empresariais mexicanas com relação a alguns pontos. Os entrevistados das associações empresariais defenderam que é importante que se tenha uma indústria de fornecedores nacionais, mas com a internacionalização da cadeia quando necessário. Deveria haver uma seleção severa dos fornecedores nacionais para selecionar aqueles que serão auxiliados a crescer. Seria necessária uma política inteligente, capaz de diferenciar o que pode ser produzido no país e o que deve ser importado. Os entrevistados do governo ressaltaram que a simples exigência de conteúdo nacional não seria muito útil, pois o importante seria a transferência de tecnologia e de conhecimento. O México deveria também ir além de 
simplesmente competir com outros países e se preocupar em ter uma indústria e um desenvolvimento saudáveis. Nas entrevistas do governo também foi dito que se deveria ter um primeiro momento de nacionalização da cadeia para fortalecer as empresas nacionais, para depois se passar a uma fase de internacionalização dessas empresas. Mais importante do que nacionalizar ou internacionalizar seria o foco em eficiência e vantagens comparativas pois seria com esse foco em eficiência que uma empresa poderia servir como ferramenta de desenvolvimento para o país. Haveria também uma tentativa do governo em passar uma mensagem de que seria necessário um trabalho cooperativo entre governo e empresas e essa mensagem estaria sendo bem recebia pelas empresas.

Instrumentos de política industrial com um viés liberalizante foram os mais apoiados nos dois grupos de entrevistados mexicanos. Ambos disseram que um dos objetivos da política seria fazer a Pemex competir, sendo que entre os entrevistados isso foi considerado uma tentativa de fortalecimento da Pemex, mas entre os entrevistados do governo isso não foi visto como uma tentativa de ajudar a empresa. Nas entrevistas com representantes do governo foi mencionado que o governo estaria apoiando a Pemex a ser mais empresa privada, devendo diminuir o alto custo laboral que tem para que possa ser mais competitiva. Com o fim do monopólio, a Pemex deveria se tornar mais eficiente e adotar uma cultura corporativista, baseada na competência e no livre mercado. De acordo com as entrevistas das associações empresariais, por estar deficitária e ser ineficiente, a mudança no setor seria importante para a Pemex, que deveria pensar como uma empresa privada. Além disso, foi considerada da empresa a culpa por não ter desenvolvido uma indústria nacional mexicana enquanto ainda tinha o monopólio no setor. Os dois grupos de atores concordaram que o monopólio teria sido um problema, pois teria feito o setor ser pouco competitivo, pouco eficiente e pouco competente. Por isso, entrevistados do governo e das associações disseram que a abertura será importante, trazendo novas tecnologias e permitindo a participação de todos, pois a entrada de novos atores deve fazer bem para esse setor. Nas entrevistas do governo foi mencionado que o México teria ficado para trás de outros países que tenham adotado medidas liberalizantes e aberto seus mercados há mais tempo. Os entrevistados das associações empresariais manifestaram ter expectativas positivas com relação à reforma, que estaria ajudando a construir uma indústria no México, através de uma abertura total, que tenta aproveitar ao máximo as forças do livre mercado. Ambos os grupos concordaram na crítica à política de conteúdo local, que já não seria mais o foco da política mexicana, sendo melhor que a lei não tivesse 
nem estabelecido um índice mínimo, para que isso não acabe criando problemas. Contrariando os entrevistados das associações que, conforme dito anteriormente, acreditam que existe uma política de conteúdo muito clara e estratégica, os entrevistados do governo disseram que não existe no México o objetivo de se adotar uma política de estímulo ao conteúdo nacional. Nesse mesmo grupo foi dito que se teve sorte, pois era possível que fossem estabelecidos índices de exigência mais altos. O objetivo da política seria o de atrair investimentos para gerar empregos e desenvolvimento, sem pensar em políticas protecionistas, nem na nacionalização da cadeia, mas sim numa cadeia globalizada. Já os entrevistados das associações divergiram entre si, dizendo que os índices estabelecidos seriam factíveis, mas também que seriam agressivos demais, por estarem muito acima do praticado até então. De acordo com eles, essas regras de conteúdo local não devem gerar resultados positivos, pois quando se força algo que não existe naturalmente acaba se criando outros problemas. Por isso, seria melhor que os índices fossem ainda mais abertos, favorecendo o atingimento das metas pelas empresas fornecedoras e operadoras e estimulando a sinergia entre elas. Voltando às entrevistas do governo mexicano, elas também levantaram a ideia de que o mercado seria sinônimo de competência, por isso o México estaria se abrindo desde os anos 1990 e adotando a liberalização comercial, pois atender às expectativas do mercado pode-se atrair mais investimentos. Nessas entrevistas também foi dito que o objetivo da política industrial mexicana não seria o de competir com outros países, mas apenas o de receber mais royalties, aumentar eficiência e competitividade éter uma fonte de energia mais barata. Além disso, também defenderam que os noruegueses teriam uma realidade bem diferente das realidades mexicana e brasileira, então estes países deveriam parar de tentar adaptar as melhores práticas internacionais às suas realidades, pois isso seria o mesmo que desvirtuar essas práticas.

\section{c) Definição da Política Industrial}

As respostas abertas sobre a avaliação das diferentes etapas da política trouxeram diversos elementos importantes para responder à pergunta sobre o que serve de base para a definição da política industrial de petróleo e gás mexicana. Entrevistados do governo e das associações empresariais destacaram que essa definição seria feita com base em mecanismos de consulta como conselhos consultivos, consultas públicas e a necessidade 
de passar qualquer norma pela Cofemer para que seja aberta à participação de todos. Em contrapartida, nas entrevistas com as associações foi alertado que essas consultas não estariam ocorrendo como deveriam, pois estes mecanismos de consulta não teriam saído do papel. Já os entrevistados do governo apresentaram perspectivas opostas, pois houve quem disse que a página da Cofemer teria um espaço aberto para comentários, mas outros disseram que este espaço não existe.

Em diversos temas os dois grupos concordaram ao discordar, ou seja, ocorreram as mesmas discordâncias internas nos dois grupos. Ambos disseram haver transparência e prestação de contas muito sólidas, sendo estes alguns dos principais valores da política, pois todo regulador dependeria destas características para que tenha legitimidade na construção de um modelo de desenvolvimento industrial. Mas também foram ambos os grupos que disseram entender que a transparência e a prestação de contas seriam péssimas, com funcionários públicos agindo como se estivessem em empresas familiares, e muitas vezes onde haveria uma aparência de transparência encobrindo outros processos mais privados. Os dois grupos disseram acreditar que existe um bom diálogo entre governo e empresas, ajudando a realizar correções na política, mas também disseram que as diferenças entre os atores necessitariam de uma política mais definida e precisa, e que regras muito rígidas de transparência estariam prejudicando a agilidade na relação entre os atores. Entrevistados do governo e das associações também concordaram em discordar sobre a existência de mecanismos de monitoramento e avaliação da política industrial mexicana. Enquanto ambos disseram que estes mecanismos existem, ambos também disseram que eles não existem e que não há nem planos para que sejam criados.

Em dois pontos houve discordância entre os dois grupos de atores mexicanos, como a ideia defendida pelos entrevistados do governo de que, apesar da pressão política por resultados de curto prazo, os valores adotados pela política seriam de médio e longo prazo, mas os entrevistados das associações disseram que esses valores seriam predominantemente de curto prazo. Nas entrevistas do governo foi dito que a reação do governo em recuar devido ao resultado ruim da ronda um teria sido muito boa, enquanto nas entrevistas das associações foi mencionado que somente na segunda ronda se poderia verificar como foi a reação do governo a estes resultados, e que, até aqui, a reação teria sido apenas retórica e política, sem se basear em resultados. 
Entre os elementos que servem de base para a orientação da política mexicana, os entrevistados do governo mencionaram o aprendizado com a reforma realizada em 2008, a adoção do sistema de freios e contrapesos para dividir funções e balancear as relações, os resultados da primeira ronda, comentários e sugestões recebidas pelo governo e o aprendizado com os exemplos brasileiro, norueguês, colombiano e canadense. Foi levantada uma dúvida sobre se a política deveria se basear na realidade do país ou nas melhores práticas internacionais. Como não haveria nenhum instrumento específico previsto para a avaliação da política, foram mencionadas outras formas de avaliação como avaliações próprias feitas dentro do governo, avaliações pelo congresso e pela controladoria interna de cada órgão. Disseram que todas essas informações estariam na internet, mas também foi dito que os mecanismos de monitoramento e avaliação seriam muito ruins. Nas entrevistas com as associações foi destacada a importância de a consulta ao setor privado servir de base para a criação de normas, a criação de organismos públicos e independentes e o monitoramento constante feito pela opinião pública e pelas empresas. Também foi ressaltado que seria comum a falta de mecanismos de monitoramento e avaliação de políticas no país, pois essa não seria uma preocupação dos governos. Ainda de acordo com as associações, se deveria evitar uma avaliação de curto prazo da política, com base nos resultados negativos da primeira ronda, pois esses resultados só serão perceptíveis no longo prazo. O governo teria o interesse de que a política tenha como resultado a geração de empregos, e teria baseado toda a reforma na ideia de que ela traria resultados relativamente rápidos, mas isso não estaria acontecendo. Os entrevistados do governo disseram que, apesar da pressa que houve para a realização das licitações, o governo teria a consciência de que a política é um processo gradual de aprendizagem. Ele estaria criando os indicadores de desempenho necessários para medir os resultados da política, criando mecanismos de colaboração para que se tenha um processo sistemático e definido de esforço compartilhado entre os atores, e haveria planos para a criação de um mecanismo de avaliação externo ao governo. As associações empresariais disseram que o cidadão mexicano não saberia diferenciar uma política de governo de uma política de Estado e teriam sempre o interesse em resultados imediatos. Já os entrevistados do governo disseram que se o governo consegui baixar o custo da energia não haveria necessidade de mudar a política num primeiro momento e se poderia deixar o desenvolvimento de indicadores de desempenho para depois. Nas entrevistas das associações empresariais disseram não haver interesses externos influenciando a política mexicana e que antigamente haveria uma influência muito maior de interesses políticos 
na definição da política industrial mexicana. Até hoje ainda existiriam alguns políticos que seguem uma cultura do sigilo, sem necessidade de prestação de contas, incluindo as pessoas do atual governo, que estariam acostumadas a práticas autoritárias e totalitárias no passado e que hoje, apesar de serem obrigados pelo contexto atual, ainda teriam certa dificuldade para essa abertura à transparência e à prestação de contas. Também foi mencionada a existência de um fervor nacionalista muito forte, que teria feito com que a política tivesse sido baseada num mito de mais de setenta anos e não na realidade. Voltando aos entrevistados do governo mexicano, eles admitiram que devem existir outros interesses envolvidos na definição da política de petróleo e gás do país, e que esses interesses provavelmente existirão sempre, pois empresas públicas como a Pemex seriam muito poderosas, tanto financeira quanto politicamente. A inclusão de um índice mínimo de conteúdo nacional teria sido uma tentativa de buscar vantagem política junto à indústria nacional. Por último, mas não menos importante, foi mencionada a necessidade de que a avaliação da política seja feita sem a influência de nenhum tipo de compromisso político.

\subsection{3 - Variação das Avaliações Objetivas}

\section{a) Governo}

O gráfico 87, abaixo, apresenta a variação entre as respostas objetivas sobre todas as etapas da política industrial mexicana de petróleo e gás, apresentadas pelos entrevistados do governo mexicano. 


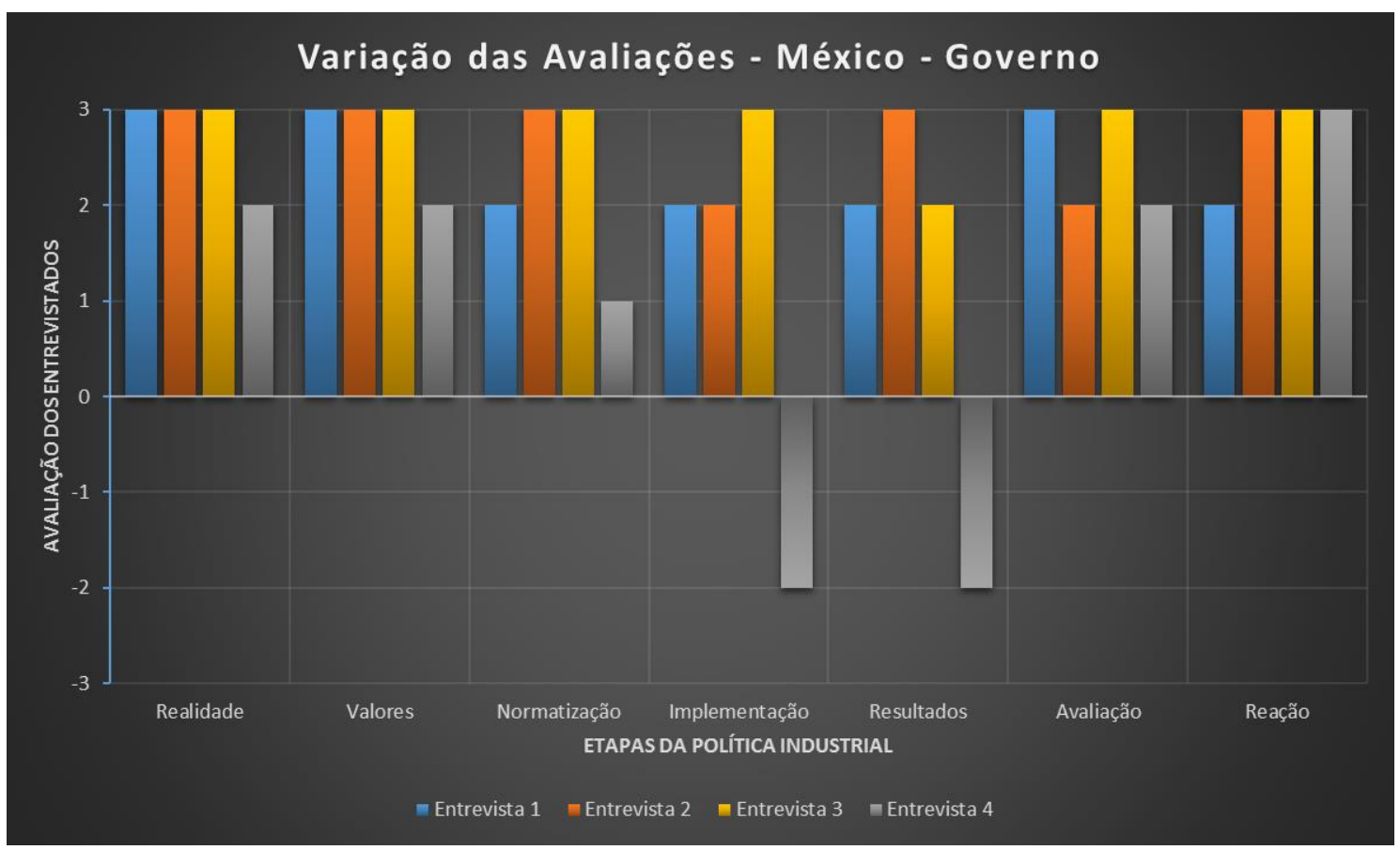

Gráfico 87 - Variação das avaliações sobre as diferentes etapas da política industrial de petróleo e gás nas entrevistas do governo do México.

Percebe-se que houve uma variação pequena nas respostas da maioria das etapas da política. A realidade que serviu de base para a formulação da política, os valores e a reação aos dados de avaliação da política tiveram a variação mínima de apenas uma resposta. A etapa de avaliação da política veio logo atrás, tendo apenas duas respostas com variação mínima e sendo seguida de perto pela normatização. Já as etapas de implementação e resultados obtidos foram as que tiveram a maior variação, e onde ocorreram as duas únicas avaliações negativas.

O gráfico 88, abaixo, apresenta o total de desvios que as respostas objetivas de cada entrevistado tiveram com relação às médias das avaliações feitas pelos entrevistados do governo mexicano, sobre as diferentes etapas da política industrial mexicana de petróleo e gás. 


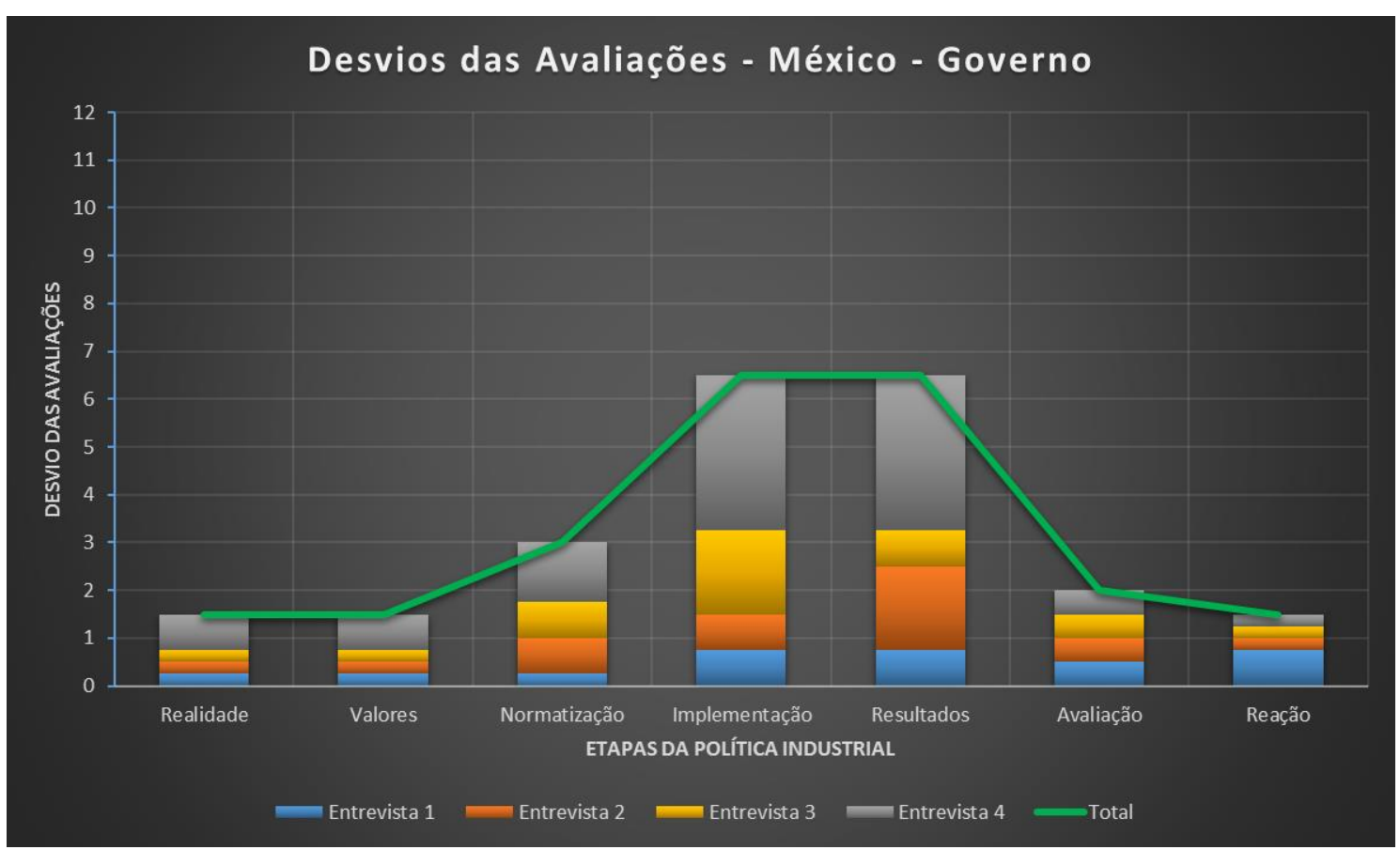

Gráfico 88 - Desvio entre a avaliação de cada entrevistado e a média das avaliações do governo, para cada etapa da política industrial de petróleo e gás no México.

Este gráfico deixa ainda mais claro o baixo índice de desvio nas respostas dos entrevistados do governo mexicano, apesar de não ter havido unanimidade em nenhuma etapa. A realidade, os valores a avaliação e a reação aos dados de avaliação tiveram desvios muito baixos, mas a etapa de normatização já teve um desvio um pouco maior. Enquanto as avaliações sobre a implementação da política e sobre os resultados obtidos foram as que tiveram os desvios mais altos.

\section{b) Associações Empresariais}

O gráfico 89, abaixo, apresenta a variação entre as respostas objetivas sobre todas as etapas da política industrial mexicana de petróleo e gás, apresentadas pelos entrevistados das associações empresariais mexicanas. 


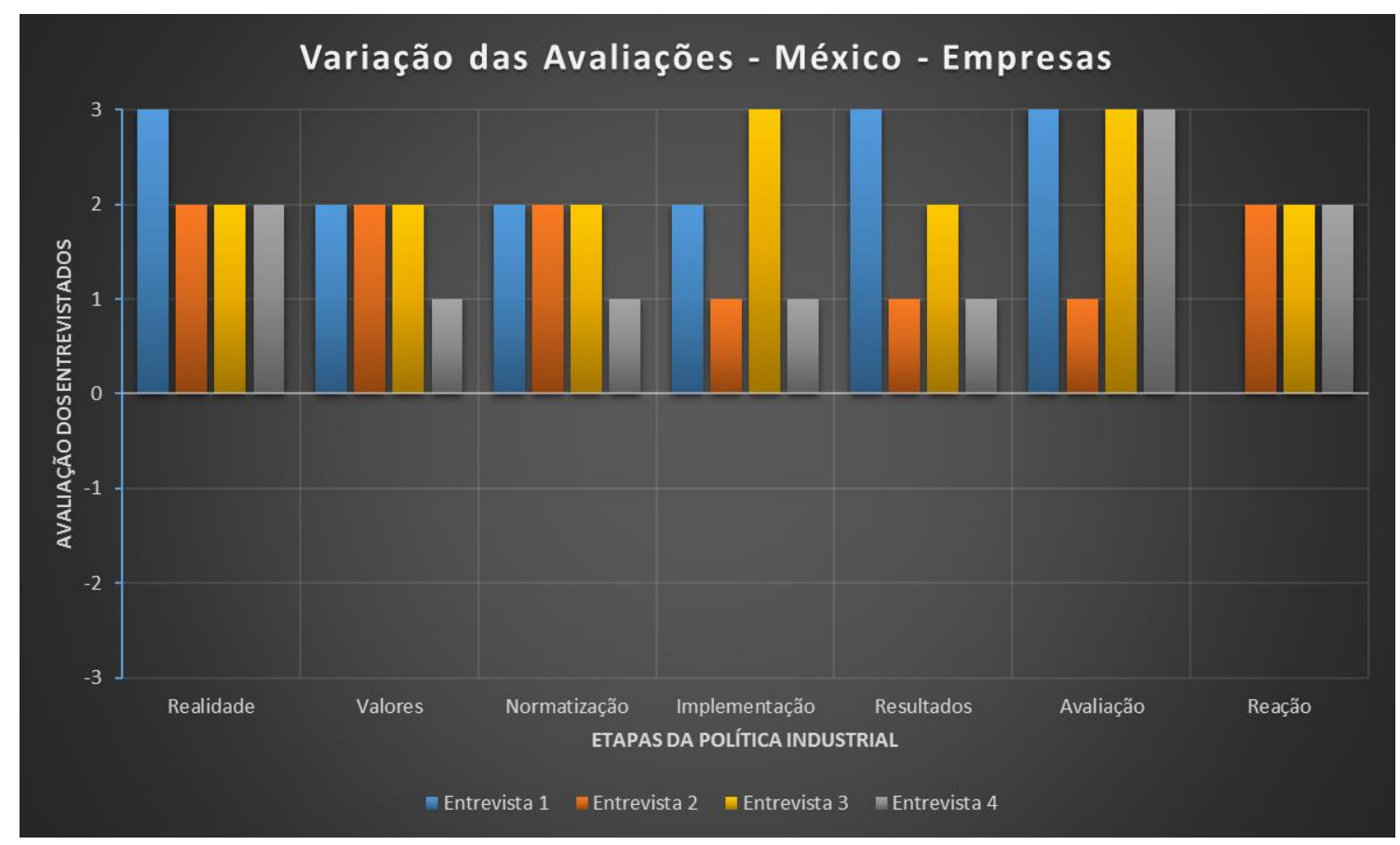

Gráfico 89 - Variação das avaliações sobre as diferentes etapas da política industrial de petróleo e gás nas entrevistas das associações empresariais do México.

Aqui percebe-se que a variação também foi baixa entre as respostas dos entrevistados das associações empresariais mexicanas, destacando-se a ausência de avaliações negativas. Com ressalva de ter tido uma resposta a menos, a última etapa da política teve unanimidade na sua avaliação. As avaliações sobre a realidade, os valores e a normatização tiveram apenas uma resposta com variação mínima, sendo seguidas de perto por uma baixa variação das respostas sobre a etapa de monitoramento e avaliação da política. Já as etapas de implementação e resultados obtidos, mesmo tendo apresentado uma variação baixa, foram as etapas com maior incidência de variação entre as respostas.

O gráfico 90, abaixo, apresenta o total de desvios que as respostas objetivas de cada entrevistado tiveram com relação às médias das avaliações feitas pelos entrevistados das associações empresariais mexicanas, sobre as diferentes etapas da política industrial mexicana de petróleo e gás. 


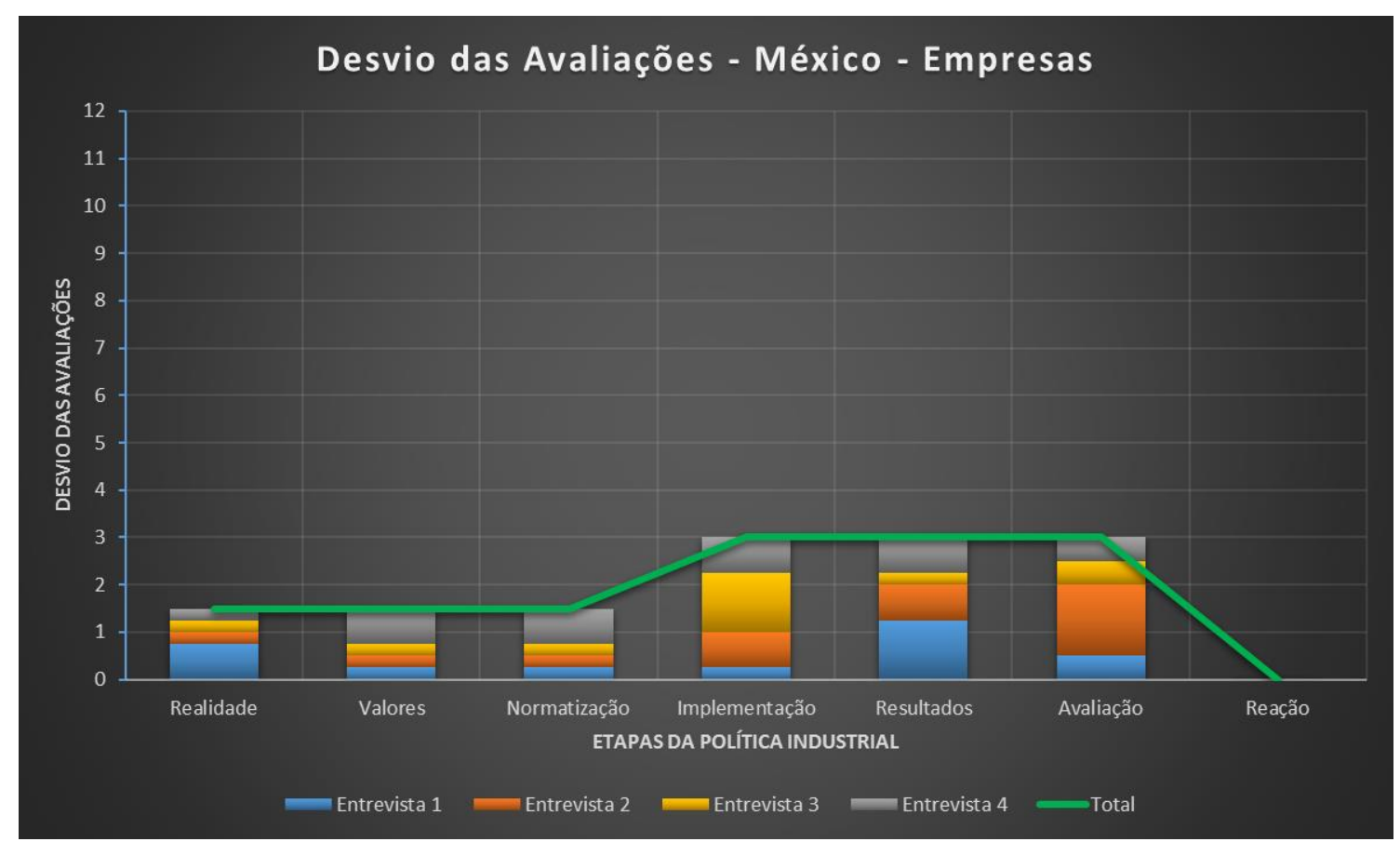

Gráfico 90 - Desvio entre a avaliação de cada entrevistado e a média das avaliações das associações empresariais, para cada etapa da política industrial de petróleo e gás no México.

Este gráfico torna mais claro o quanto foi baixa a variação das respostas dos entrevistados das associações empresariais mexicanas. Enquanto as três primeiras etapas apresentaram um mesmo nível de desvio muito baixo entre as respostas apresentadas, as três etapas seguintes apresentaram um nível um pouco mais elevado, mas ainda considerado baixo. Já a última etapa apresentou desvio zero, com a ressalva de ter tido uma resposta a menos que as demais etapas.

\section{c) Relação Governo-Empresas}

O gráfico 91, abaixo, apresenta a comparação entre o total de desvios, dentro de cada grupo, com relação às respostas sobre todas as etapas da política industrial mexicana de petróleo e gás, apresentadas pelos entrevistados do governo e pelas associações empresariais mexicanas. 


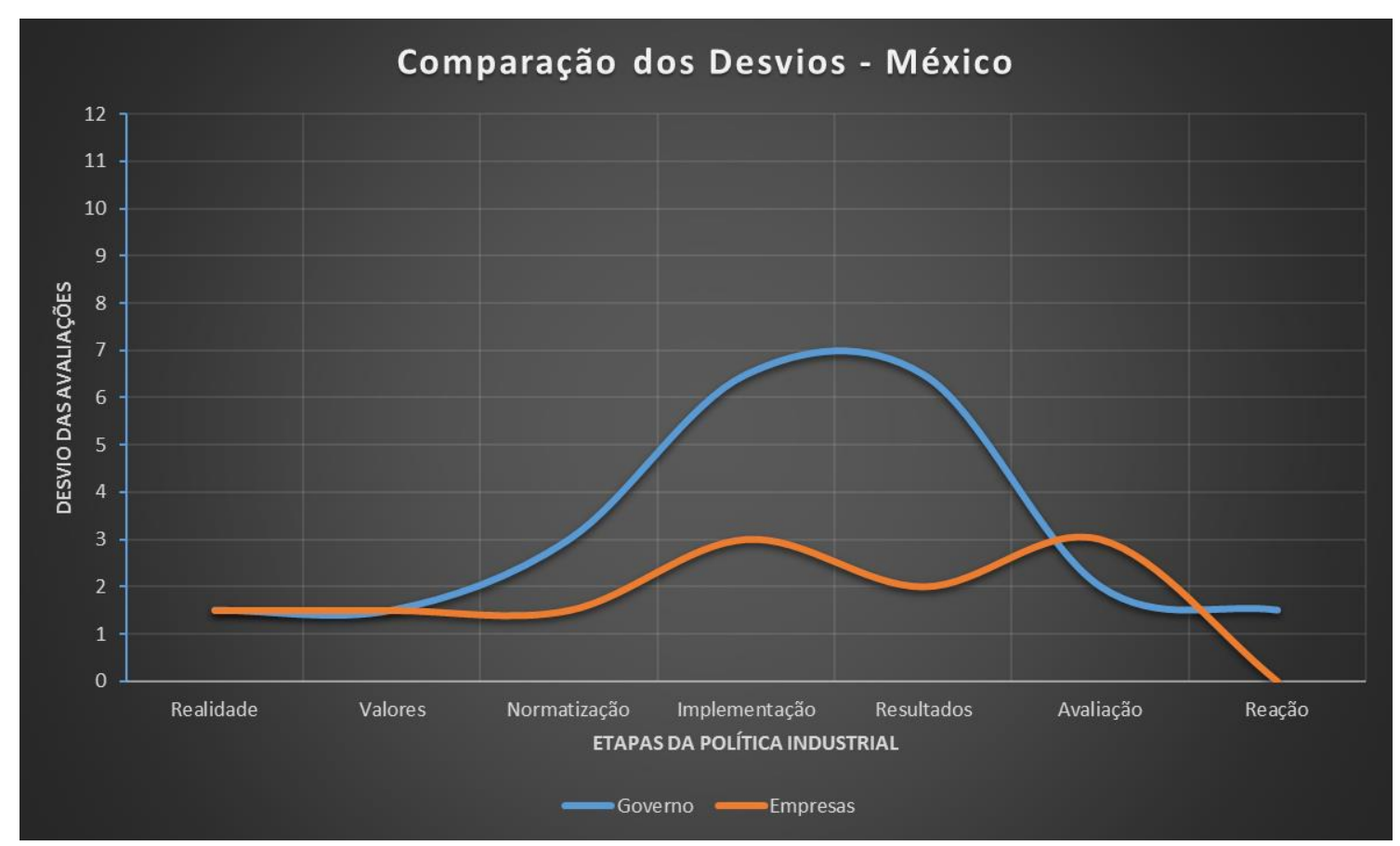

Gráfico 91 - Comparação dos desvios dentro de cada grupo, nas respostas sobre as avaliações de cada etapa da política industrial de petróleo e gás no México.

Nesta comparação fica perceptível que houve uma diferença pequena entre os desvios das avaliações da maioria das etapas da política industrial mexicana. Nas duas primeiras etapas os desvios dos dois grupos foram o mesmo, num nível muito baixo. Na etapa de normatização as avaliações do governo começam a apresentar um desvio maior, até atingirem seu maior índice, e a maior diferença com relação aos desvios entre as respostas das associações, nas etapas sobre a implementação e sobre os resultados obtidos. Cabe lembrar que essa diferença se deve em grande parte a uma diferença nos critérios utilizados para a avaliação dessas etapas pelos entrevistados do governo, pois enquanto alguns consideraram a falta de implementação e resultados como natural, não prejudicando a avaliação das etapas, outros consideraram essa falta como algo negativo, o que baixou bastante a avaliação objetiva que foi feita. Nas duas últimas etapas o governo diminui o índice de desvios entre suas respostas e se aproxima do índice de desvios apresentado pelas empresas.

O gráfico 92, abaixo, apresenta o percentual de variação nas avaliações dentro de cada um dos grupos, sobre todas as etapas que fazem parte da política industrial mexicana. 


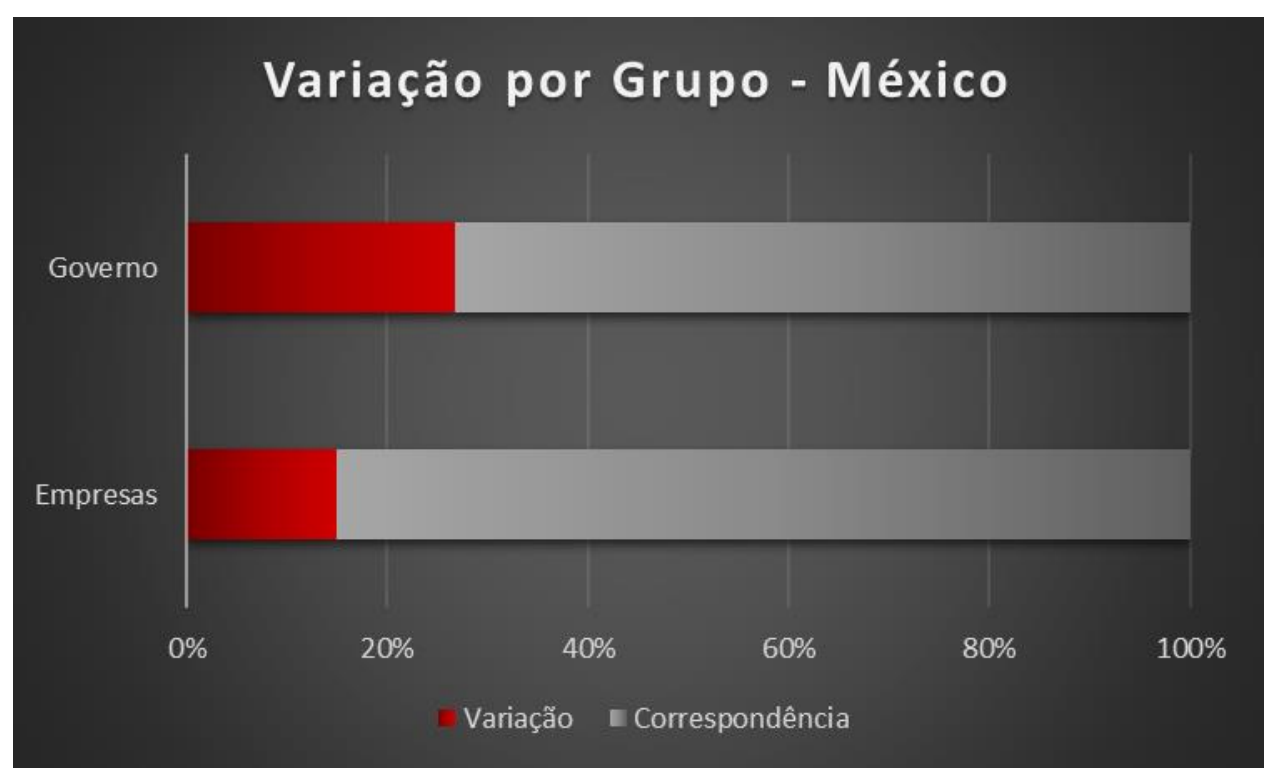

Gráfico 92 - Percentual de variação na avaliação de cada grupo sobre todas as etapas da política industrial de petróleo e gás no México.

Com esse gráfico, fica perceptível que houve uma variação maior entre as avaliações dos entrevistados do governo mexicano, do que entre as avaliações das associações empresariais mexicanas. Cabe mencionar que a variação entre as respostas do governo foi aproximadamente 50\% superior à variação das respostas das associações.

O gráfico 93, abaixo, apresenta a soma do total de desvios que as respostas objetivas dos entrevistados de cada grupo tiveram com relação às médias gerais das avaliações feitas por ambos os grupos, sobre as diferentes etapas da política industrial mexicana de petróleo e gás. 


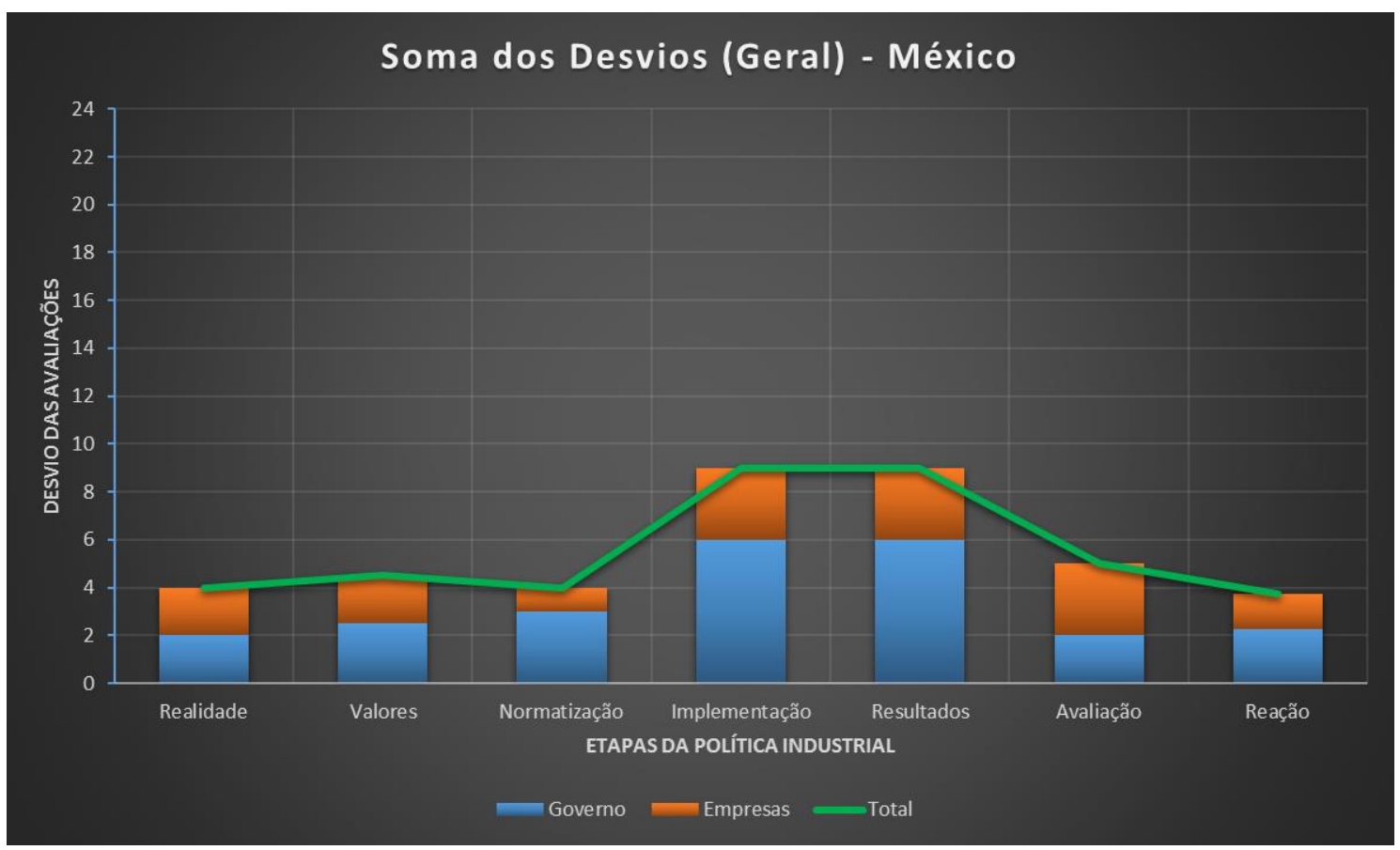

Gráfico 93 - Soma dos desvios entre a avaliação de cada entrevistado e a média das avaliações dos dois grupos, para cada etapa da política industrial de petróleo e gás no México.

No gráfico acima se utiliza a média geral, que considera as respostas dos entrevistados dos dois grupos para fazer o cálculo dos desvios. Essa soma do total de desvios nas respostas dos entrevistados do governo mexicano com o total de desvios nas respostas dos entrevistados das associações empresariais mexicanas permite que se perceba melhor quais etapas apresentam uma variação maior de respostas entre todos os atores mexicanos. Com isso, se reforça a percepção anterior de que houve uma variação muito baixa em quase todas as etapas da política industrial mexicana. Este gráfico confirma que, mesmo considerando os dois grupos reunidos, também são as etapas de implementação e dos resultados obtidos as que apresentam um desvio maior.

\subsection{4 - Relação Entre Atores}

Nesta parte da análise comparativa serão comparadas as avaliações de cada grupo com relação à interação entre os atroes envolvidos com a política industrial de petróleo e gás mexicana. Para isso, serão analisadas as opiniões que os entrevistados de um grupo apresentaram a respeito da sua percepção sobre os atores do outro grupo, sobre como cada 
grupo percebe a sua própria participação e sobre como cada grupo percebe o recebimento dessa sua participação pelos atores do outro grupo de entrevistados.

\section{a) Percepção do Outro}

O gráfico 94, abaixo, apresenta a comparação entre o percentual de menções positivas e negativas nas respostas dos entrevistados dos dois grupos mexicanos, sobre a percepção que os atores de um grupo têm a respeito dos atores do outro grupo.

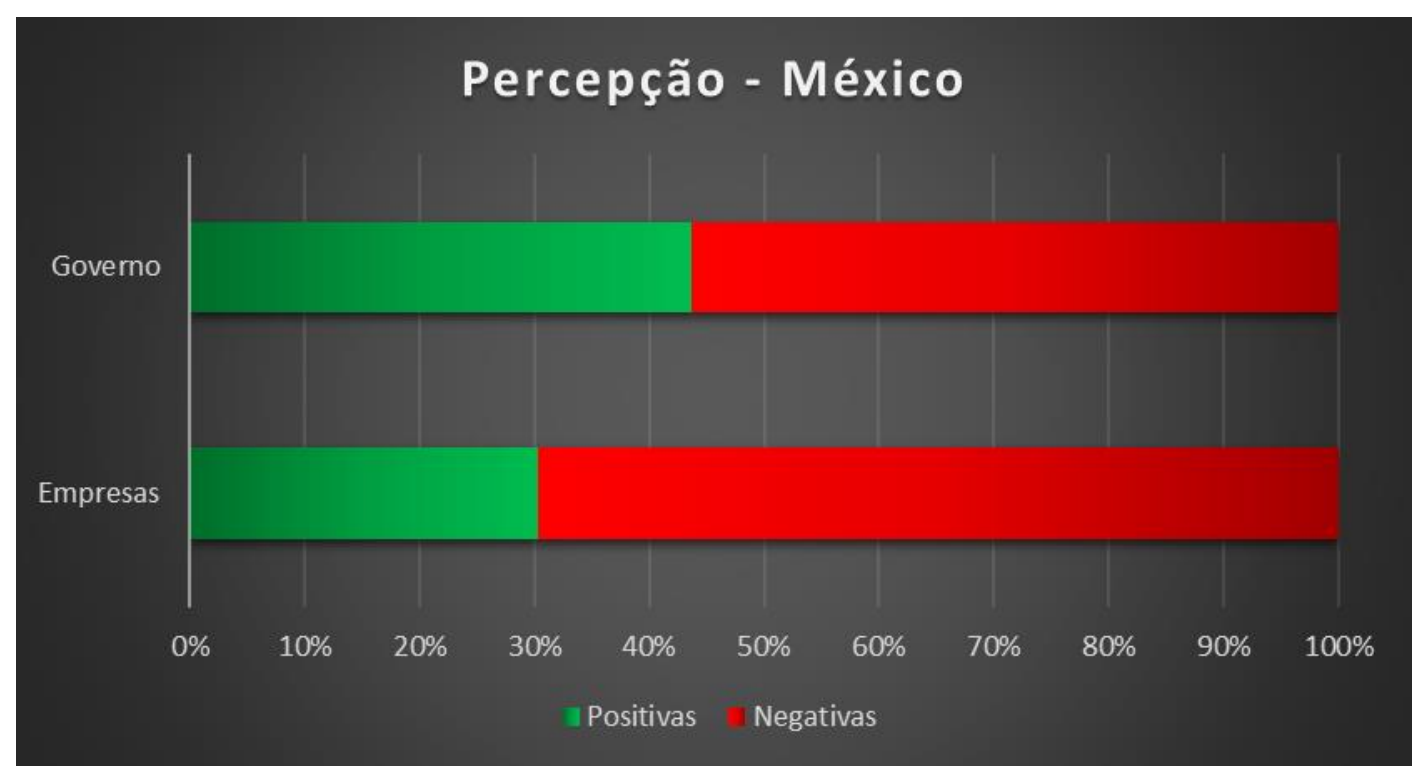

Gráfico 94 - Percentual de menções positivas e negativas nas respostas dos dois grupos mexicanos sobre a percepção que um grupo tem do outro.

Como uma forma de menção positiva sobre as associações empresariais mexicanas, os entrevistados do governo mexicano disseram que já haveria uma certa base industrial no México, que as empresas estariam “contentes" e "entusiasmadas", que elas teriam consciência de que a política é um processo gradual e que todos os atroes estariam de acordo sobre a necessidade de criar uma indústria nacional, que eventualmente seja internacional. Já como menções positivas sobre o governo mexicano, os entrevistados das associações empresariais indicaram que o governo teria uma boa capacidade de percepção da realidade, que estaria bastante envolvido dando informações e recebendo sugestões, que estaria sendo mais transparente que antes e que, nos últimos anos, estaria substituindo políticas de governo por políticas de Estado. 
Nas entrevistas junto aos representantes do governo foram feitas menções sobre as associações empresariais que não foram consideradas nem positivas nem negativas. Foi dito que o potencial de desenvolvimento das empresas fornecedoras estaria vinculado ao sucesso da Pemex na exploração de águas profundas e que a Pemex agora seria um jogador como os demais, sem vantagens nem desvantagens. Além disso, disseram que algumas empresas teriam se beneficiado com a reforma e estariam "contentes", enquanto outras não, e que as empresas estariam recém começando a conhecer as leis que foram criadas. Ainda sobre percepções que não foram consideradas nem positivas nem negativas, os entrevistados do governo disseram que caberia ao governo e não às empresas a maximização do interesse público.

Os comentários negativos dos entrevistados do governo a respeito das associações empresariais indicaram que as empresas estariam preocupadas com os resultados, com a necessidade de desenvolvimento e com o foco em questões ambientais e sociais. O grande capital não estaria satisfeito com a necessidade de consulta a comunidades locais. Haveria também muita reclamação das empresas devido a um excesso de burocracia resultante da abertura. Seria importante que as empresas mudassem sua mentalidade, pois ainda teriam um foco muito grande nas atividades junto à Pemex. O país teria um problema por ter que satisfazer sempre aos interesses de um grupo tradicional de setores mexicanos, como o de aço e o de plásticos. Enquanto o governo estaria tentando balancear o atingimento de resultados com o desenvolvimento de infraestrutura, as empresas estariam impacientes por resultados. Não haveria interesse na arte de monitoramento e avaliação por parte das empresas. Elas também reclamariam sobre o governo não permitir que elas maximizem seus ganhos, porque a maximização do bem-estar individual seria contrária à maximização do bem-estar social. O Estado teria uma visão mais de longo prazo, enquanto as empresas teriam necessidades mediatas e imediatas. Já os entrevistados das associações empresariais mexicanas disseram que faltaria diálogo e transparência para o governo mexicano, que não saberia ouvir e aparentaria já ter questões previamente definidas antes mesmo de conversar com a indústria. Há quem acredite que a política não seja $100 \%$ do governo mexicano, pois haveria interesses dos Estados Unidos na abertura desse setor. Foi cogitada a hipótese de o governo não ter feito o que devia fazer por falta de tempo ou de pessoal, mas também houve a crítica de que o governo não demonstraria interesse em estabelecer compromissos. Os mecanismos de monitoramento e avaliação o governo teria deixado para criar mais tarde, e ele estaria preocupado com os resultados 
até aqui, mas estaria esperando uma melhora. Também foi mencionado que as pessoas desse governo não estariam acostumadas a terem mecanismos de controle, mas devido à pressão social, teriam sido obrigados a aceitar. Teria havido muita corrupção no uso da Pemex como ferramenta de desenvolvimento e haveria a impressão de que a Pemex estaria demonstrando o interesse em desenvolver uma sinergia com outros atores em algumas áreas, mas em outras não. Também houve crítica aos sindicalistas mexicanos, que seriam contra a reforma porque ela acaba com vários benefícios e defenderiam apenas aquilo que lhes convém e não as pessoas a quem deveriam representar.

\section{b) Participação}

O gráfico 95, abaixo, apresenta a comparação entre o percentual de menções positivas e negativas nas respostas dos entrevistados dos dois grupos, sobre a participação do seu próprio grupo na política industrial de petróleo e gás mexicana.

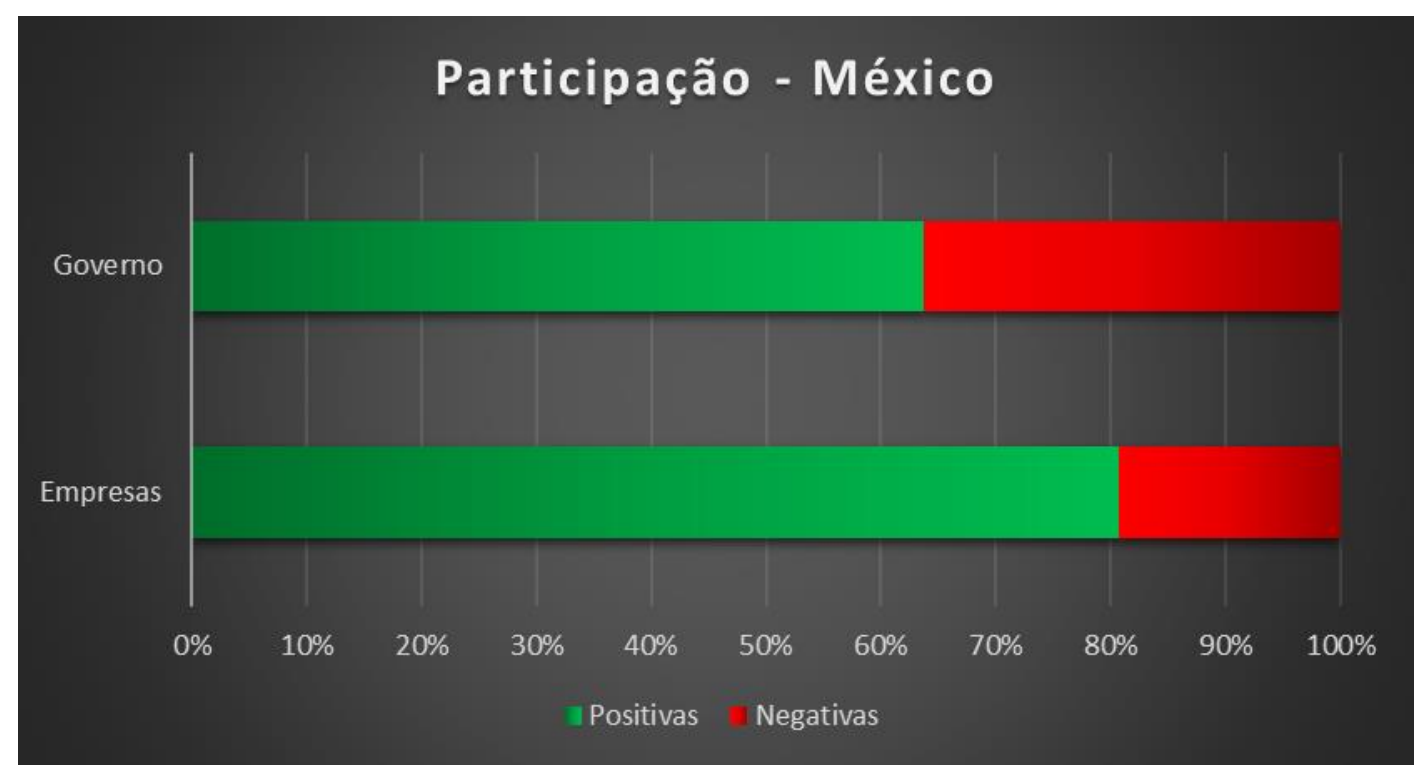

Gráfico 95 - Percentual de menções positivas e negativas nas respostas dos dois grupos sobre a participação do seu próprio grupo na política industrial do México.

Sobre a participação de cada grupo na política industrial de petróleo e gás mexicana, as menções positivas do governo citaram uma participação constante, tanto dentro do governo como com as empresas. Haveria uma boa relação e uma excelente comunicação entre os órgãos de governo, que teriam suas competências muito bem 
definidas e a liderança na definição de pontos importantes da política. O governo estaria criando mecanismos de participação para que se tenha um esforço compartilhado entre empresas e governo. As regras seriam claras e abertas, e haveria a obrigação por lei de o governo responder a todas perguntas que lhe são feitas. Nas entrevistas junto aos representantes das associações empresariais foi dito que a participação seria feita através de grupos de trabalho, divulgação de estudos, apresentação de propostas de políticas e ajudando a diminuir as expectativas com relação a uma entrada massiva de investimentos no país. Mesmo quando o governo não abre muito espaço para participação, as associações estariam se envolvendo bem e tiveram uma importante participação na definição das normas. Entre todos os atores haveria uma aceitação geral sobre a adoção de uma mistura entre uma economia aberta de livre mercado e algumas políticas de apoio ao desenvolvimento de novos setores.

Os comentários negativos que os representantes do governo fizeram sobre a participação do próprio governo na política industrial nacional trataram sobre a não participação em alguma etapa da política e a existência de pouca comunicação institucional. Tudo teria sido feito tão rápido que o governo não teria tido tempo para planejamento. O governo teria culpa pelos resultados negativos, pois ainda não teria cumprido com todas as suas obrigações, e todos no governo estariam muito "ensimesmados", por terem muitas coisas para fazer. Estaria faltando uma cabeça para coordenar a implementação da reforma, que deveria estar acima de todos os ministérios, e ainda haveria alguns órgãos que não estariam tendo a independência que deveriam ter. Já os entrevistados das associações empresariais manifestaram não terem participado da definição da política e não conhecerem a opinião do governo sobre certos temas ligado à política industrial. Além disso, algumas associações ainda estariam defendendo uma política de proteção às empresas nacionais, através de privilégios protecionistas.

\section{c) Recebimento pelo Outro}

O gráfico 96, abaixo, apresenta a comparação entre o percentual de menções positivas e negativas nas respostas dos entrevistados dos dois grupos, sobre o recebimento da sua participação pelo outro grupo, na definição da política industrial de petróleo e gás mexicana. 


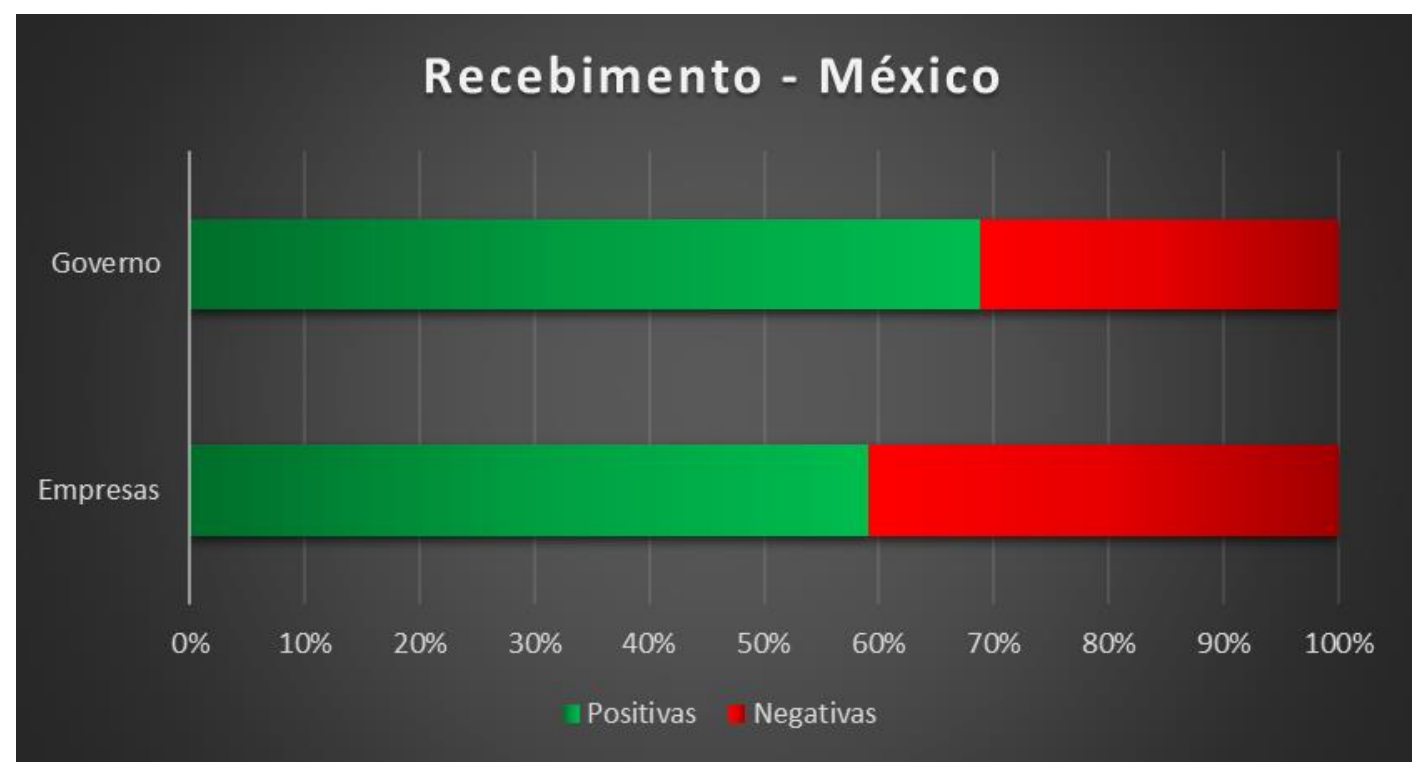

Gráfico 96 - Percentual de menções positivas e negativas nas respostas dos dois grupos mexicanos sobre o recebimento da sua participação pelo outro grupo.

Os entrevistados do governo relacionaram um bom recebimento de suas participações por parte das associações empresariais com uma relação muito boa e a existência de diálogo entre governo e empresas. Até aqui não haveria controvérsias, comentários negativos e nem críticas. Um debate com associações teria levado ao desenho da segunda ronda, que tem foco em empresas menores. O governo estaria tentando passar uma mensagem sobre a necessidade de uma participação colaborativa entre governo e empresas e essa mensagem teria sido bem recebida pelas empresas, que saberiam que não se trata apenas de discurso político. Em nenhum outro setor mexicano haveria tanta abertura para a participação. Entre as entrevistas com as associações empresariais mexicanas foi dito que elas teriam a impressão de que sua participação é levada em conta, pois muitas de suas sugestões foram adotadas, influenciando na mudança de pensamento do governo. Governo e empresas estariam muito bem integrados, fazendo com que as empresas se sintam bem recebidas pelo governo.

Já os comentários negativos sobre o recebimento que as associações empresariais oferecem à participação do governo estiveram ligados a pouca participação das empresas e ao fato de que mesmo quando existe diálogo entre eles, esse diálogo não seria colocado em prática. Também disseram que o regulador geralmente é visto como uma "pedra no sapato" para os investidores. Do outro lado, as associações empresariais disseram que o 
governo teria sido mandatório em algumas questões, sem consultar as empresas ou sem abrir para o debate. Haveria a impressão de que quando ocorre a participação das associações seria fruto de iniciativas dessas associações e não de uma iniciativa do governo em consultar suas opiniões. Foi destacada que ouvir é diferente de implementar, o que seria muito mais difícil de acontecer. Além disso, o governo passaria a impressão de ter toda a informação que gostaria, de já ter uma estratégia pré-definida e de ter sempre a última palavra.

\section{d) Interação de Atores}

O gráfico 97, abaixo, apresenta a comparação entre o percentual de menções positivas e negativas nas respostas dos entrevistados dos dois grupos, sobre a interação entre os atores, na definição da política industrial de petróleo e gás mexicana.

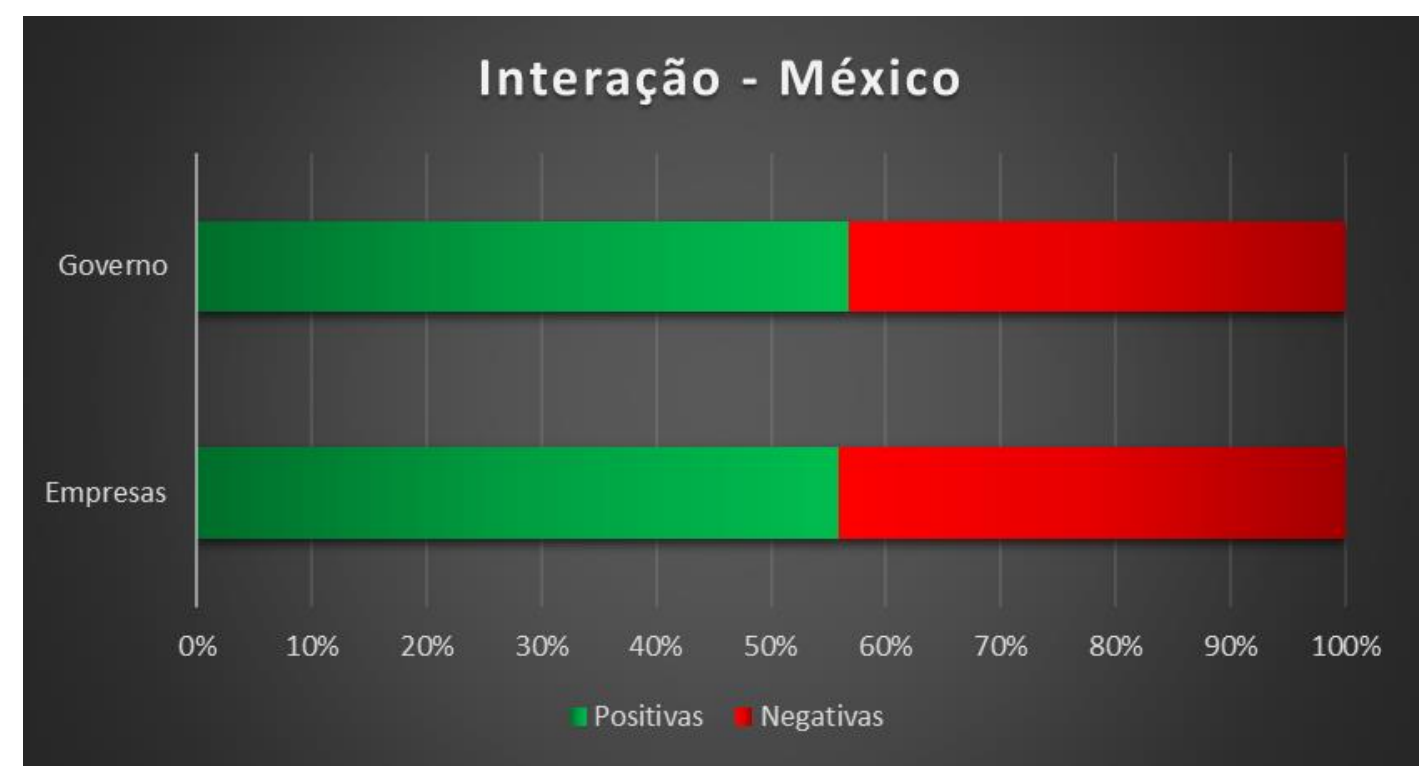

\section{Gráfico 97 - Percentual de menções positivas e negativas nas respostas dos dois grupos} sobre a interação dos atores na política industrial mexicana.

Aqui também, o percentual foi calculado com base no total de menções realizadas sobre a percepção do outro, a participação e o recebimento e não com base numa média entre esses três elementos. Percebe-se que, considerando todos os elementos anteriores, relacionados à interação entre os atores mexicanos na definição da política industrial de petróleo e gás, governo e associações empresariais teriam uma visão muito semelhante. 
Haveria uma diferença mínima, apontando para uma visão levemente mais positiva do governo, mas essa diferença seria tão pequena que deveria ser desconsiderada. Esse equilíbrio entre as visões dos dois grupos é resultado de um equilíbrio também com relação a visão sobre os três elementos anteriores. E é importante reparar que os dois grupos tiveram mais menções positivas do que negativas em todos esses elementos, com exceção da percepção sobre o outro grupo.

\section{3 - Noruega}

\subsection{1 - Total das Avaliações Objetivas}

\section{a) Governo}

O gráfico 98, abaixo, apresenta o total das respostas objetivas sobre todas as etapas da política industrial norueguesa de petróleo e gás, apresentadas pelos três entrevistados do governo norueguês.

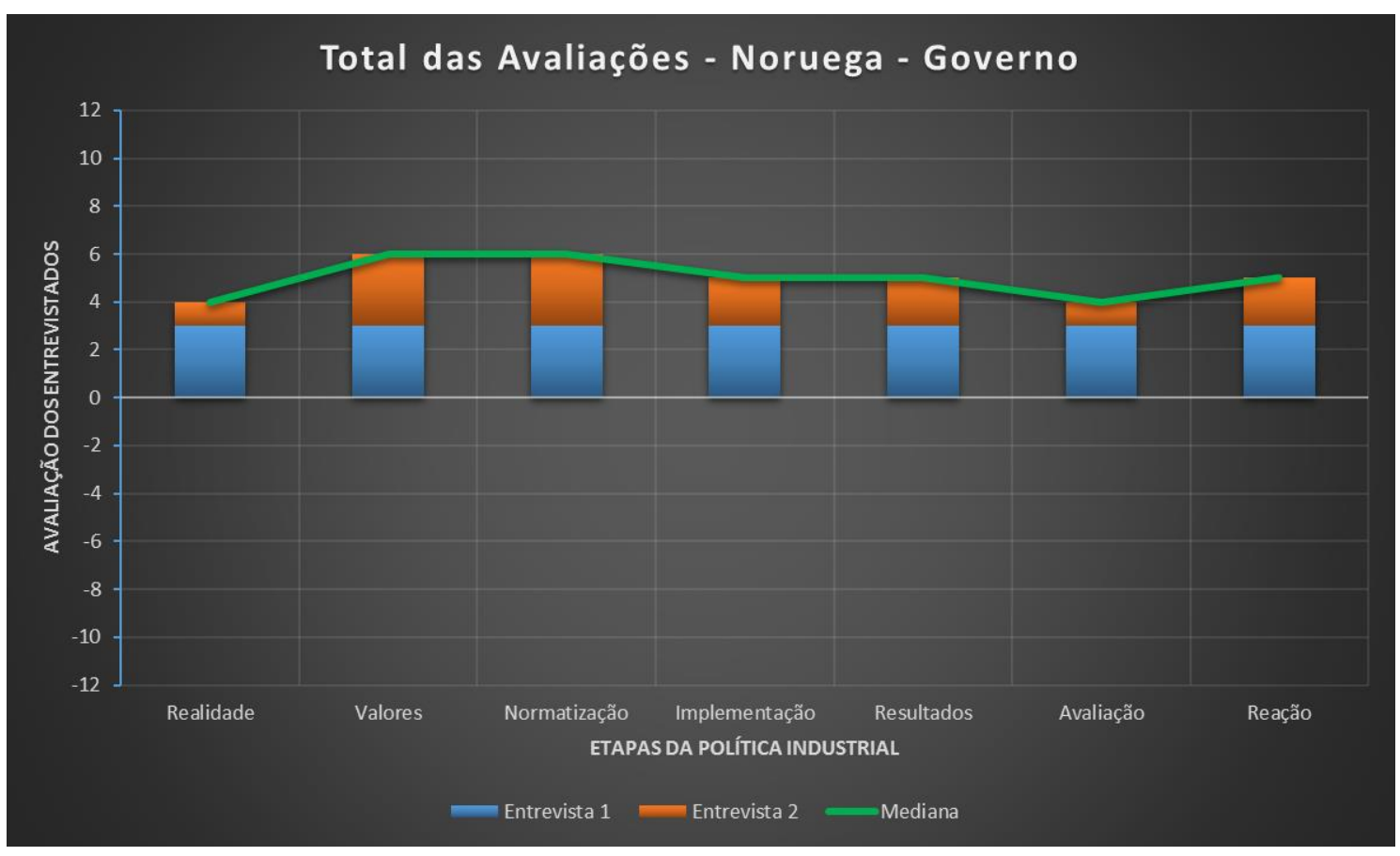

Gráfico 98 - Total das avaliações sobre as diferentes etapas da política industrial de petróleo e gás nas entrevistas do governo da Noruega. 
Percebe-se que as avaliações do governo norueguês sobre as diferentes etapas da política indústria norueguesa foram muito boas, não havendo nenhuma avaliação negativa. As avaliações sobre a realidade que serviu de base para a atual política industrial de petróleo e gás foram boas e subiram para a melhor avaliação possível quando trataram dos valores que serviram de base para a formulação da política. Continuaram com uma avaliação de nível máximo sobre a normatização que rege a política industrial e depois ficaram entre bom e muito bom, quando trataram das etapas de implementação e de resultados obtidos pela política. Os mecanismos de monitoramento e avaliação foram avaliados como bons e, junto com a primeira etapa, receberam as avaliações mais baixas de toda política. Por último, com uma avaliação entre boa e muito boa sobre a forma de reação aos dados de monitoramento e avaliação, para definir a orientação da política.

\section{b) Associações Empresariais}

O gráfico 99, abaixo, apresenta o total das respostas objetivas sobre todas as etapas da política industrial norueguesa de petróleo e gás, apresentadas pelos quatro entrevistados das associações empresariais norueguesas.

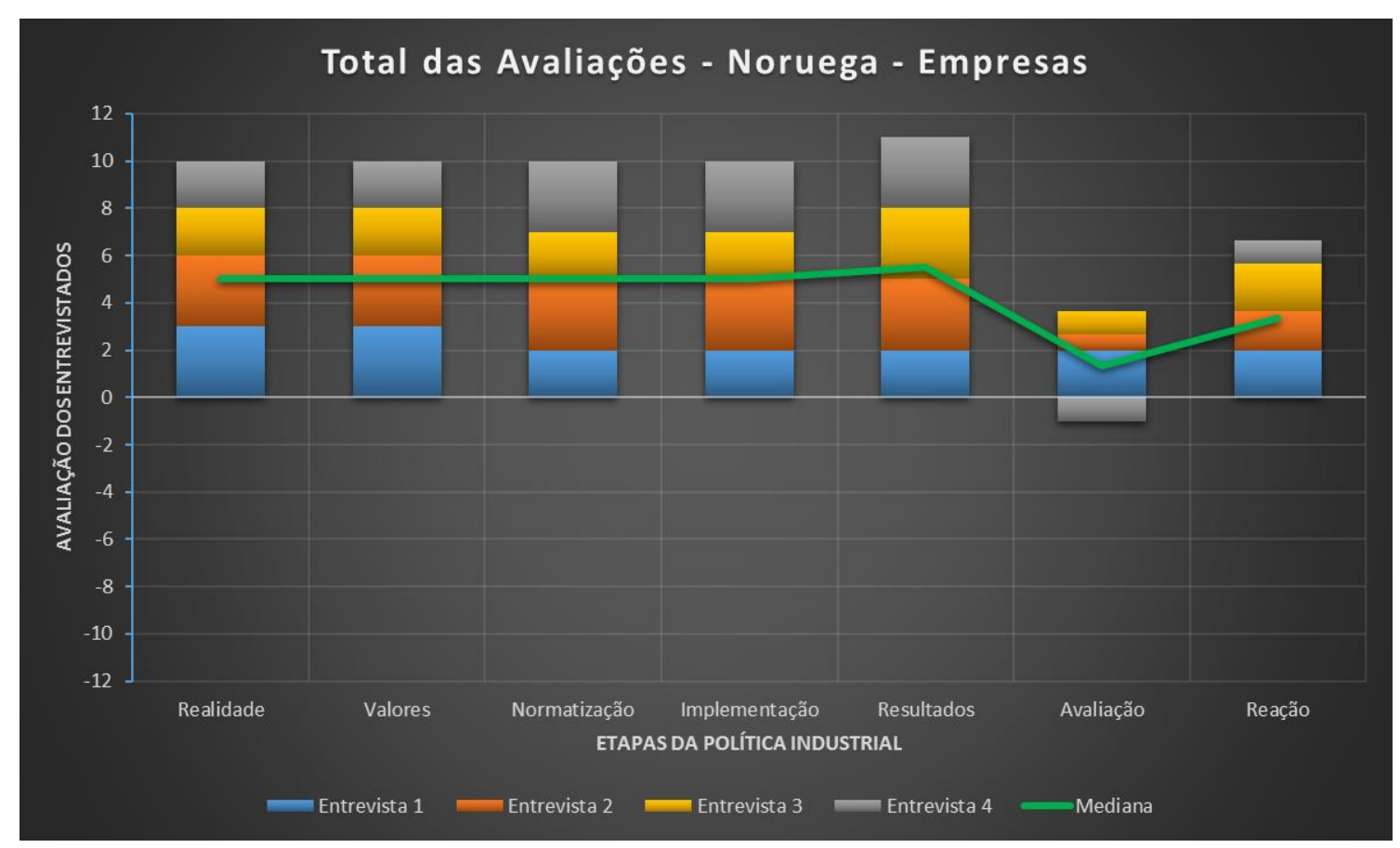

Gráfico 99 - Total das avaliações sobre as diferentes etapas da política industrial de petróleo e gás nas entrevistas das associações empresariais da Noruega. 
As avaliações dos representantes das associações empresarias norueguesas sobre as diferentes etapas de política industrial de petróleo e gás do país foram, na sua maioria, muito boas, havendo apenas uma avaliação negativa. As avaliações sobre o potencial oferecido pela realidade brasileira para o desenvolvimento de uma indústria nacional de petróleo e gás ficaram entre boa e muito boa. Se mantiveram neste mesmo patamar ao analisarem os valores adotados, as normas que regem a política e a forma de implementação da política. Deram uma leve subida ao avaliarem os resultados obtidos, mas ainda sem chegar ao nível máximo. Já os mecanismos de monitoramento e avaliação foram a etapa pior avaliada, ficando entre média e pouco boa. As avaliações sobre a etapa de reação subiram um pouco, mas ainda ficaram abaixo do patamar apresentado pelas cinco primeiras etapas.

\section{c) Comparação entre Governo e Empresas}

O gráfico 100, abaixo, apresenta a comparação entre as medianas dos totais das respostas objetivas sobre todas as etapas da política industrial norueguesa de petróleo e gás, apresentadas pelos entrevistados do governo norueguês e pelas associações empresariais norueguesas.

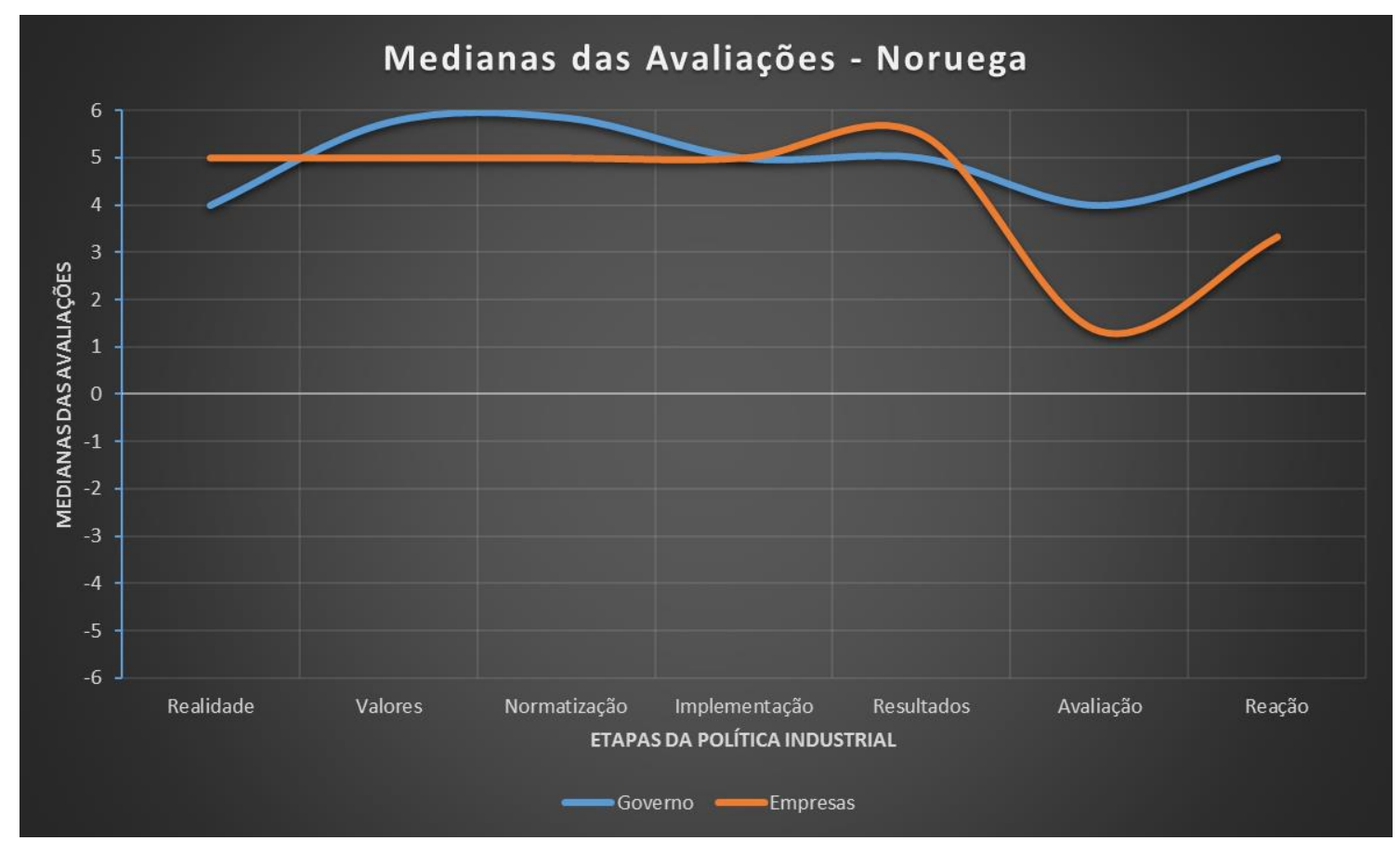

Gráfico 100 - Comparação entre as medianas do total das avaliações sobre as diferentes etapas da política industrial de petróleo e gás na Noruega. 
O gráfico acima demonstra que houve uma pequena variação entre as avaliações do governo e das associações empresariais norueguesas. Houve alternância entre os grupos que apresentaram as avaliações mais positivas. As associações começaram com avaliações levemente mais positivas que as do governo, quando trataram da realidade que serviu de base para a política. Nas duas etapas seguintes, sobre os valores e a normatização, foi o governo quem foi mais otimista, chegando a uma avaliação máxima nos dois casos. Os dois grupos tiveram a mesma avaliação sobre a forma de implementação da política e as associações voltaram a apresentar uma avaliação levemente mais positiva sobre os resultados obtidos. A diferença maior foi com relação aos mecanismos de monitoramento e avaliação. Ambos apresentaram uma queda na avaliação dessa etapa, mas a queda na avaliação das associações foi mais brusca. Na última etapa, ambos os grupos apresentaram uma melhora nas avaliações. Aqui também a subida na avaliação das associações foi mais brusca do que a subida na avaliação do governo, mas não o suficiente para aproximá-las novamente como antes.

\subsection{2 - Temas Levantados}

\section{a) Semelhanças e Diferenças}

Nas respostas às perguntas abertas dos roteiros de entrevista, os entrevistados do governo e das associações empresariais norueguesas apresentaram visões semelhantes em muitos temas. Um deles foi sobre o alto custo de produção na Noruega ser uma desvantagem, especialmente com relação aos altos salários. Mas como vantagem, o país teria o fato de que quando o setor de petróleo iniciou sua atividade no país, os noruegueses já tinham uma base industrial desenvolvida, uma grande frota naval e experiência na gestão de recursos. Hoje a indústria de petróleo e gás seria a que mais exporta na Noruega e a indústria de serviços de petróleo e gás seria a segunda maior exportadora do país. Os noruegueses exportariam praticamente todo o petróleo e todo o gás produzidos no país, pois teriam suas necessidades energéticas satisfeitas com recursos hídricos. Ambos os grupos expressaram que as riquezas da indústria de petróleo são do povo norueguês, a propriedade dos recursos do subsolo é do Estado e a licença para explorar e produzir esses recursos são das empresas. Também disseram que o processo de desenvolvimento e atualização do sistema regulatório seria muito aberto e transparente, lembrando que este 
sistema teria boa reputação em outros países, que tentariam seguir o modelo norueguês. Tanto os entrevistados do governo como das associações empresariais disseram que acreditam que haja transparência e prestação de contas na implementação da política, com participação, diálogo e interação entre os atores envolvidos e cooperação com universidades e centros de pesquisa. Também manifestaram que acreditam na existência de poucos ou mesmo nenhum ato de corrupção que, caso ocorram, são situações individuais e não algo sistemático, como no Brasil e no México. Os dois grupos elogiaram os resultados obtidos com relação ao número de empregos, que disseram envolver aproximadamente duzentos e cinquenta mil trabalhadores, que teriam salários acima da média do país, o que causaria problemas para outras áreas da economia norueguesa. Destacaram os bons resultados em exportações, a adoção de processos de aprendizagem tecnológica, a existência de boa capacidade produtiva, eficiência e competitividade, para superar os obstáculos com o alto custo de produção, e um sistema normativo e político estável, que ajuda na atração de investimentos para o país. Eles também mencionaram que praticamente tudo que o governo faz tem a obrigação de ser tornado público, com exceção de questões de sigilo comercial, que devido à confidencialidade, o governo apresenta apenas através de dados agregados.

Com relação a uma questão, houve ao mesmo tempo concordância e conflito de opiniões. Entrevistados dos dois grupos manifestaram entender que as leis norueguesas são estáveis e previsíveis, mas conseguem ter ao mesmo tempo alguma folga, que lhe dão certa flexibilidade, fazendo com que o sistema regulatório seja balanceado. Mas alguns entrevistados das associações empresariais norueguesas afirmaram acreditar que algumas regras seriam rígidas demais, por estarem desconectadas dos custos que elas acarretam, citando o exemplo da obrigatoriedade de botes salva vidas em embarcações.

Só houve divergência entre as opiniões dos entrevistados do governo e das associações empresariais com relação e um tema. Enquanto entrevistados do governo disseram que as informações no país seriam muito transparentes e de fácil acesso, entrevistados das associações empresariais disseram que facilitar o acesso aos dados seria uma forma de se melhorar a política norueguesa. 


\section{b) Instrumentos de Política Industrial}

Sobre os instrumentos adotados pela política industrial brasileira, ambos os grupos manifestaram algumas poucas opiniões de apoio a instrumentos de política industrial intervencionista ou liberalizante. Mas a grande maioria das opiniões foram alinhadas com uma política que combine estes dois tipos de instrumentos. Entre os instrumentos intervencionistas, ambos os grupos destacaram a importância da existência do maior fundo soberano do mundo para evitar danos para a economia do país, e o fato de $67 \%$ das ações da Statoil ainda serem de propriedade estatal. Os entrevistados das associações ainda lembraram que a rigidez de algumas normas foi importante para forçar a indústria a realizar adaptações e desenvolver tecnologias para atender aos requisitos legais. A Noruega teria exigências mais severas que os demais países em questões como a proibição da queima de gás associado, a obrigatoriedade do seu aproveitamento e a cobrança de um imposto sobre emissões de gás carbônico.

Sobre instrumentos de política industrial com viés liberalizante, entrevistados dos dois grupos defenderam que a Statoil deva ser exclusivamente focada na eficiência e obtenção de lucro. Para os entrevistados do governo, a empresa não deveria assumir responsabilidades da administração governamental, nem ser um prolongamento do governo, pois sua credibilidade como empresa estaria diretamente ligada à sua capacidade de demonstrar que não representa interesses governamentais. Ainda entre os atores do governo, foi dito que não houve um interesse específico em promover empresas norueguesas internacionalmente, e que isso teria sido feito por iniciativa das próprias empresas fornecedoras. Já os entrevistados das associações manifestaram entender que a indústria adote as melhores práticas internacionais, e que estaria havendo cada vez mais padronização de normas entre os países. Eles também relativizaram a importância do registro de patentes para os noruegueses, pois eles acreditariam que a melhor forma de se proteger uma inovação seja sendo aberto e transparente, colocando o produto no mercado.

A combinação entre instrumentos de intervenção estatal e de abertura para o mercado foi a perspectiva mais defendida por entrevistados dos dois grupos. De diferentes maneiras, repetiram diversas vezes a ideia de que hoje a Noruega não poderia mas adotar as medidas de proteção, que adotou há trinta anos, e não haveria mais nenhuma forma de tratamento diferenciado para as empresas norueguesas. Inicialmente, o foco teria sido no interesse nacional e o conteúdo local seria um objetivo expresso e claro, mas os acordos 
internacionais de hoje colocariam limites para estes instrumentos. De acordo com os entrevistados das associações, o mais importante não seria que a propriedade da indústria seja norueguesa, mas sim que as atividades sejam desenvolvidas em território nacional, para que gerem empregos e desenvolvam inovações no país. Portanto, o importante do conteúdo local seria a geração de valor, e não a propriedade nacional das empresas. Os dois grupos de atores defenderam a necessidade de um ritmo de exploração balanceado, para que seja feita uma exploração gradual e planejada, para não prejudicar outros setores da economia do país. Também foi lembrado que no início, todos os recursos gerados pela indústria eram utilizados para necessidades imediatas, mas que agora haveria um balanceamento, utilizando um pouco agora, mas poupando a maior parte para o futuro. Entrevistados do governo e das associações explicaram que faz parte da cultura norueguesa uma completa separação entre a administração governamental e atividades comerciais, fazendo com que funcionários públicos não ocupem cargos de diretoria, nem na Statoil, nem em empresas que sejam 100\% estatais. Também foi dito que, mesmo que o foco da Statoil deva ser o lucro, ela deveria se preocupar com o desenvolvimento do país no longo prazo, pois seria uma empresa muito grande para se limitar à obtenção de lucro. Ambos os grupos mencionaram requerimentos e condições impostas pelo governo, com a colaboração da indústria e da sociedade, que teriam ajudado a desenvolver a indústria do país. Para a concessão de licença seria exigido o desenvolvimento de alguma tecnologia junto com a indústria nacional, universidades e centros de pesquisa. A indústria internacional foi convidada a participar, mas com a obrigatoriedade de formação de joint ventures com empresas nacionais, através das quais os noruegueses teriam adquirido grande parte de suas atuais capacidades. Os contratos de licenças teriam a exigência de investimentos privados e públicos em projetos de $\mathrm{P} \& \mathrm{D}$. Os entrevistados do governo disseram ainda que a indústria demandaria uma legislação que seja ao mesmo tempo flexível, mas estável e que o governo faria a coleta de dados sobre áreas de exploração para serem analisadas e depois vendidas, como pacotes de informação, para as empresas, fazendo com que essas informações possam ser obtidas sem custos para o governo. Por último, nas entrevistas com as associações empresariais foi dito que o governo norueguês não se contentaria apenas com a arrecadação dos impostos gerados pela indústria de petróleo, pois teria também o interesse de desenvolver a indústria nacional e maximizar o aproveitamento dos recursos. Além de exportar, a política industrial norueguesa teria também o objetivo de aprender com o mercado internacional, por isso os noruegueses teriam projetos dentro e fora do país, para que haja o maior 
compartilhamento possível de trabalhos em conjunto. Também foi mencionado que a produtividade estaria relacionada com o preço do barril, pois quando o preço do barril está alto, haveria a maximização da capacidade produtiva e a consequente queda de produtividade, mas quando o preço está baixo, haveria demissões, maior competição e aumento da produtividade.

\section{c) Definição da Política Industrial}

As respostas abertas sobre a avaliação das diferentes etapas da política trouxeram diversos elementos importantes para responder à pergunta sobre o que serve de base para a definição da política industrial de petróleo e gás norueguesa. Entrevistados do governo e das associações empresariais destacaram repetidamente que essa definição seria feita com base no diálogo entre os atores envolvidos com a política. Haveria algo como um acordo geral, uma colaboração entre governo, indústria e sindicatos de trabalhadores, onde todos estariam alinhados numa forma de cooperação construtiva. Indústria, sindicatos, academia, legisladores e políticos ajudariam um a balancear a atividade do outro. O governo seria bom em ouvir e não faria isso apenas para parecer educado, pois realmente se interessaria pela opinião dos demais atores. Isso porque ele entenderia que possa ser mais fácil para que outros enxerguem o que é difícil para ele enxergar. Qualquer pensamento contrário a isso seria uma forma de arrogância. Assim, a indústria teria participado da formulação das normas e o debate no parlamento não teria como ser mais transparente. Quando os atores participam de todo processo, eles conseguiriam entender melhor os resultados. Como as regras do setor se modificam em paralelo ao desenvolvimento tecnológico, esse diálogo seria fundamental para que seja possível acompanhar essa constante necessidade de adaptação. Mesmo a transição de uma política com viés nacionalista para uma política com foco na internacionalização teria sido feita com base no debate entre os atores envolvidos e num forte direcionamento do governo. A grande questão aqui seria a inexistência de conflitos entre os interesses políticos para o setor e os interesses comerciais para o setor. Os entrevistados das associações mencionaram diversos valores que servem de base para a política norueguesa, começando pelos dez mandamentos do setor de petróleo e gás que servem de base para a política até hoje, passando pela flexibilidade do governo para seguir princípios de boa gestão, valores de abertura e cooperação e a necessidade de competição e planejamento para um 
desenvolvimento gradual e de longo prazo. Além disso, uma das principais razões de sucesso da política norueguesa, segundo os entrevistados das associações empresariais, seria a postura equilibrada do governo norueguês. Entre os entrevistados do governo foi dito que na política norueguesa ninguém conseguiria impor suas decisões, pois seriam utilizadas estruturas de incentivo e motivação, que procuram desenvolver uma propriedade compartilhada dos resultados e dos processos envolvidos. Outro ponto analisado por entrevistados dos dois grupos foram os problemas com os mecanismos de monitoramento e avaliação, que foram considerados o ponto fraco da política norueguesa, merecendo receber uma maior atenção. Os políticos teriam a impressão de terem mais capacidade de monitorar a política do que realmente têm. Foi dito que o sistema de licenciamento seria o único instrumento de monitoramento da política e que não haveria uma integração sistemática dos mecanismos de monitoramento e avaliação. Por outro lado, também foi mencionado a existência de um alto nível de monitoramento na sociedade norueguesa. Diferentes formas de monitoramento seriam a apresentação da política que o governo tem que fazer de tempos em tempos para o parlamento, a existência de aplicativos públicos e gratuitos para celulares com muitas informações disponíveis sobre o setor, uma autoridade de controle que funciona como um auditor geral, chamada "Riksrevisjonen", a presença de uma imprensa livre e independente, a participação de instituições internacionais de consultoria, e uma sociedade muito transparente como um todo. A política também seria monitorada pelos resultados obtidos pelas exportações, que serviriam de indicador sobre a competitividade internacional da indústria e através do diálogo entre instituições fortes, sindicatos, imprensa, indústria e opinião pública. Foi lembrado especificamente o exemplo sobre a reforma fiscal, onde foi necessária a contratação de uma empresa de consultoria externa e independente, para retirar o foco das discussões que estava sobre o tipo de dados que seriam utilizados e passar a focar na análise de resultados. Os dois grupos também defenderam que a transparência seria um dos elementos que servem de base para a definição da política industrial norueguesa, mencionando que todo monitoramento seria público, permitindo que qualquer pessoa acompanhe seus resultados e os planos de correção propostos. Não haveria como manipular os dados devido a essa transparência e disseram não acreditarem na existência de agendas ocultas, disfarçando interesses daqueles que fazem a política. Os únicos interesses que foram mencionados aqui seriam os interesses de grupos ambientalistas e da indústria pesqueira. $\mathrm{O}$ fácil acesso às informações seria uma forma de manter o 
governo prestando contas sobre suas atividades e aumentar o nível de informação disponível para quem se interesse em adquirir essa informação.

Para terminar, foram apresentados alguns elementos relacionados à forma dos noruegueses entenderem sua relação com a política industrial que seriam importantes para que se compreenda alguns outros elementos que servem de base para essa política. Entrevistados das associações manifestaram uma visão onde desvantagens são interpretadas como vantagens, como no caso dos altos salários criarem a necessidade de inovação e as dificuldades da exploração em alto mar terem desenvolvido capacidades que não teriam sido desenvolvidas em ambientes mais fáceis de se trabalhar. Uma outra perspectiva fundamental seria a de que a única maneira de se encontrar uma resposta é não acreditando de antemão que já se sabe essa resposta. Por isso seria muito importante a capacidade de se admitir que não se sabe algo e saber perguntar para aprender. Uma explicação para o sucesso norueguês que apareceu mais de uma vez foi vincular esse sucesso a trabalho e sorte. Como os noruegueses não estavam acostumados a terem muito dinheiro, quando a indústria de petróleo começou a gerar muito lucro, eles optaram por tratar esse dinheiro com cautela, para não acabar prejudicando a economia de todo país. Em outros países como o Brasil, as pessoas teriam o costume de começar a gastar esse dinheiro antes mesmo de ter ele. Mencionaram também que estava claro que o roteiro das entrevistas tinha sido desenvolvido por alguém de fora da Noruega, pois os temas tratados estariam relacionados a sociedades não muito abertas. Disseram expressamente que não deveria mais haver segredos nas relações da Petrobras e do governo brasileiro, pois essa teria sido a razão que levou aos problemas que estão sendo enfrentados. Os entrevistados do governo também disseram que sem resolver problemas de corrupção, qualquer política estaria fadada ao fracasso. Os noruegueses, com a Statoil, teriam separado muito bem as funções de produtor, ator comercial e regulador, diferentemente de países em desenvolvimento como o Brasil, com a Petrobras, e o México, com a Pemex, onde estas funções estariam mal separadas. E nas entrevistas das associações, foi alertado para a dúvida sobre se seria possível replicar o sucesso do caso norueguês em outros países. 


\subsection{3 - Variação das Avaliações Objetivas}

\section{a) Governo}

O gráfico 101, abaixo, apresenta a variação entre as respostas objetivas sobre todas as etapas da política industrial norueguesa de petróleo e gás, apresentadas pelos entrevistados do governo norueguês.

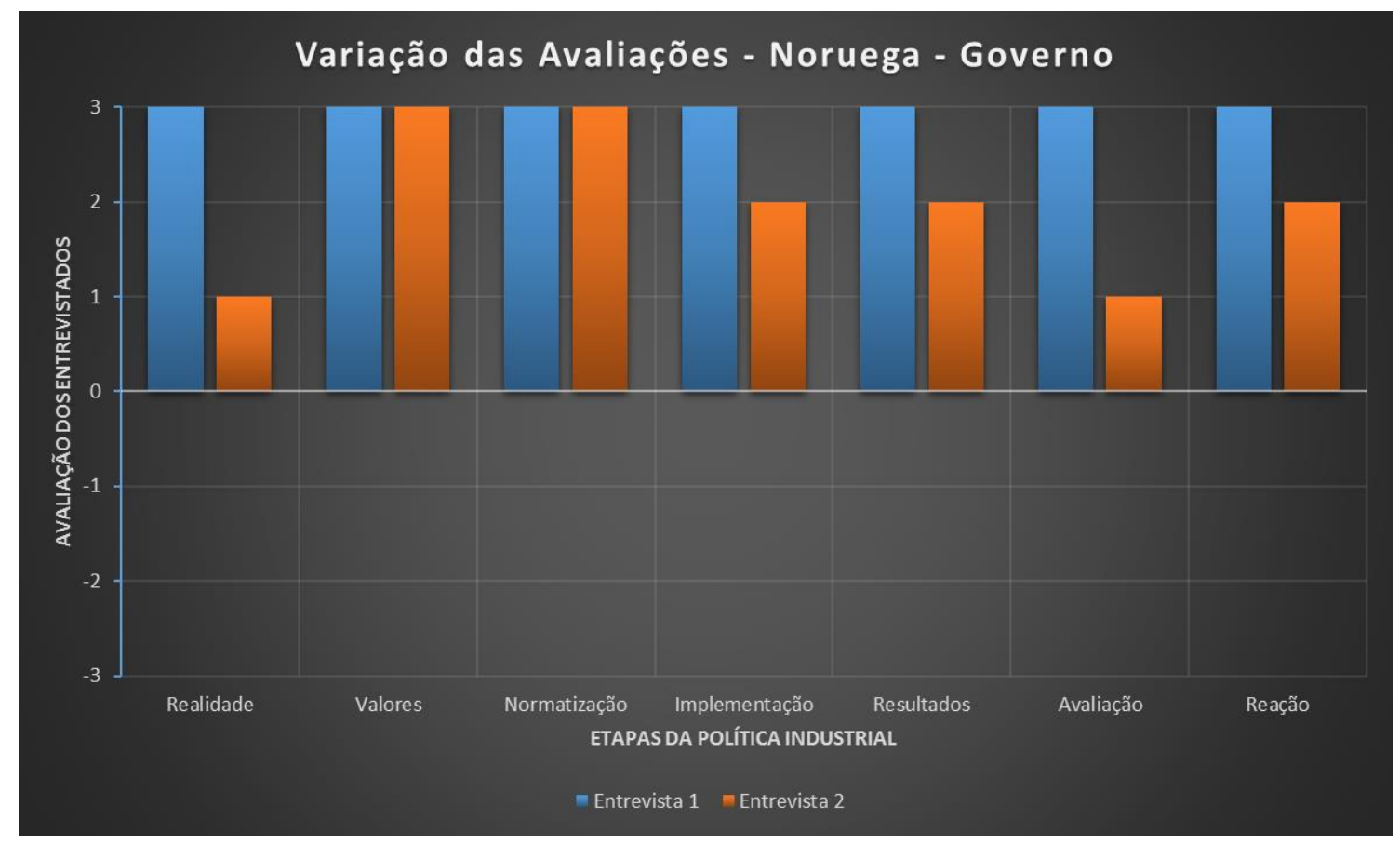

Gráfico 101 - Variação das avaliações sobre as diferentes etapas da política industrial de petróleo e gás nas entrevistas do governo da Noruega.

Percebe-se que houve uma variação pequena nas respostas da maioria das etapas da política, mas com a ressalva de que a comparação de apenas duas entrevistas nesse grupo ajuda a diminuir a probabilidade de uma variação maior. Nas avaliações sobre os valores e sobre a normatização, ambos entrevistados deram a mesma resposta. Sobre as etapas de implementação, dos resultados obtidos e da reação aos dados do monitoramento e da avaliação, verificou-se uma variação mínima entre as duas respostas. As etapas sobre a realidade que serviu de base para a política e sobre os mecanismos de monitoramento e avaliação foram as duas com as maiores variações entre as respostas, mas mesmo assim tiveram uma variação pequena. 
O gráfico 102, abaixo, apresenta o total de desvios que as respostas objetivas de cada entrevistado tiveram com relação às médias das avaliações feitas pelos entrevistados do governo norueguês, sobre as diferentes etapas da política industrial norueguesa de petróleo e gás.

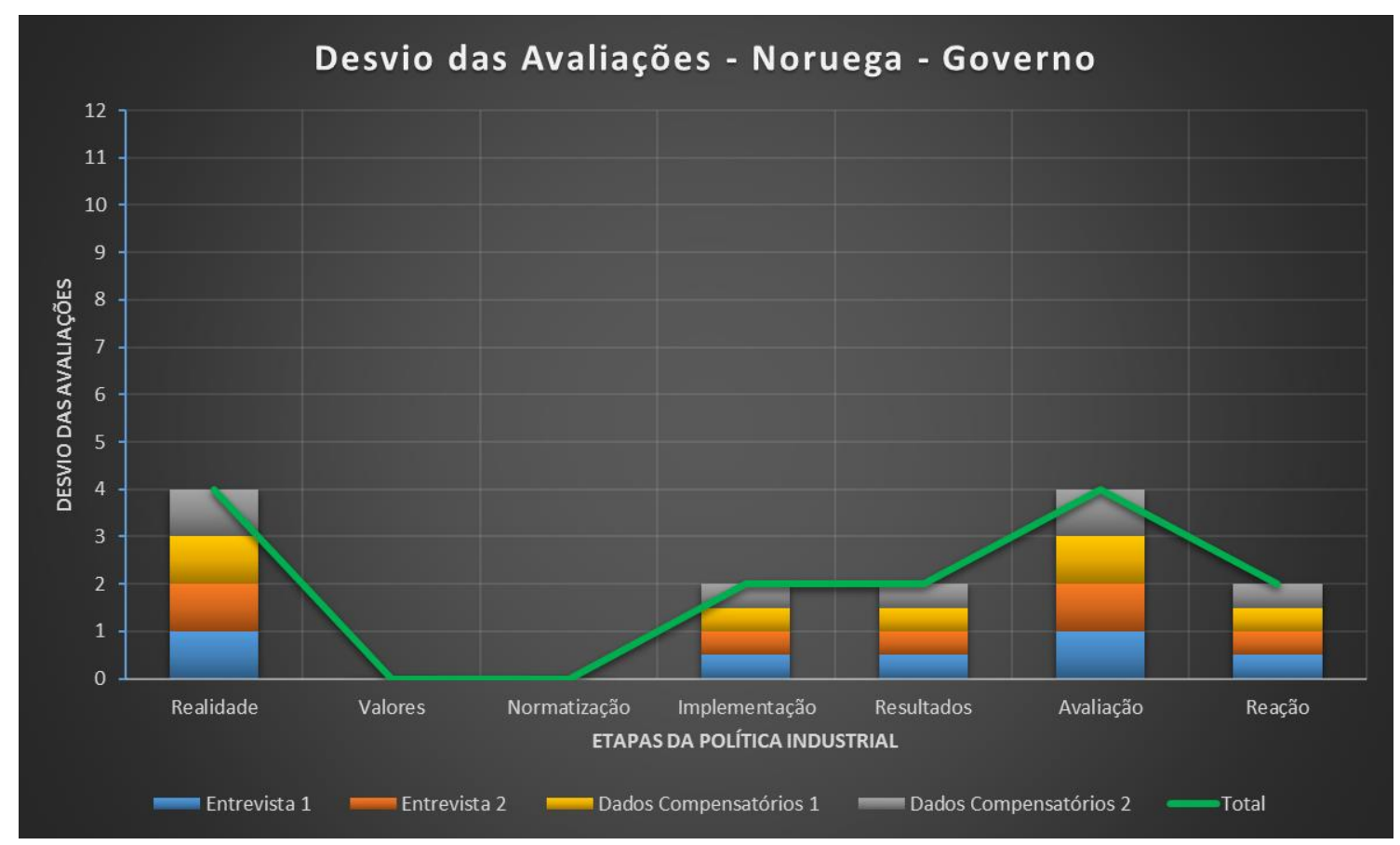

\section{Gráfico 102 - Desvio entre a avaliação de cada entrevistado e a média das avaliações do} governo, para cada etapa da política industrial de petróleo e gás na Noruega.

Este gráfico deixa ainda mais claro o baixo índice de desvio nas respostas dos entrevistados do governo norueguês. Enquanto as etapas sobre a realidade e os mecanismos de monitoramento e avaliação apresentaram um nível baixo de desvio, as avaliações sobre a implementação da política industrial, sobre os resultados obtidos pela política e sobre a reação aos dados de monitoramento e avaliação tiveram índices de desvio muito baixos. Já as etapas sobre os valores adotados e sobre a normatização da política, apresentaram desvio zero.

\section{b) Associações Empresariais}

O gráfico 103, abaixo, apresenta a variação entre as respostas objetivas sobre todas as etapas da política industrial norueguesa de petróleo e gás, apresentadas pelos entrevistados das associações empresariais norueguesas. 


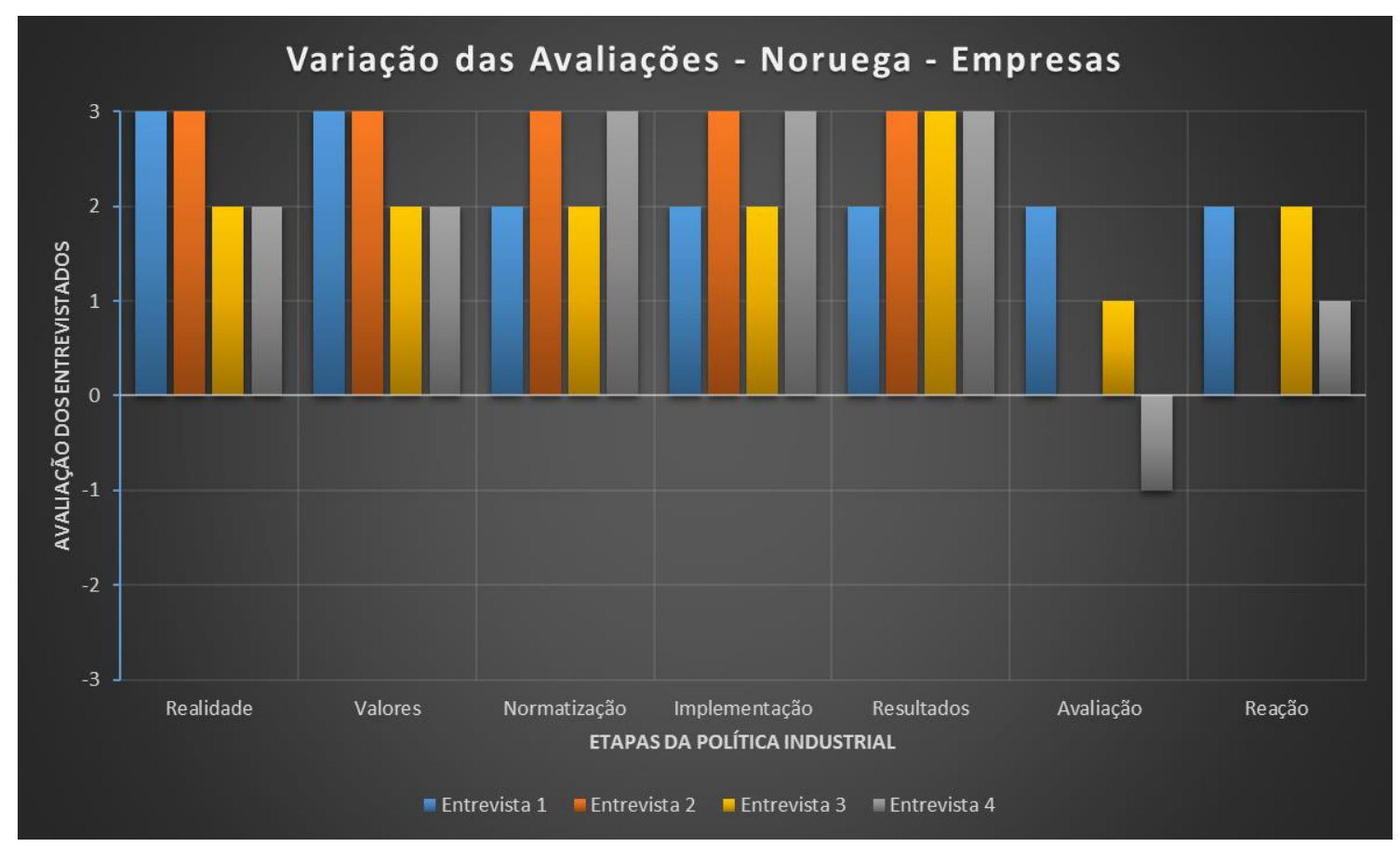

Gráfico 103 - Variação das avaliações sobre as diferentes etapas da política industrial de petróleo e gás nas entrevistas das associações empresariais da Noruega.

Aqui também se percebe uma baixa variação nas respostas dos entrevistados, com exceção da etapa sobre o monitoramento e a avaliação. As avaliações sobre os resultados obtidos e sobre a reação para orientação da política industrial apresentaram uma variação mínima. Logo em seguida, com uma variação ligeiramente maior, aparecem as quatro primeiras etapas, sobre a realidade, os valores, a normatização e a implementação da política. Já a etapa sobre os mecanismos de monitoramento e avaliação, mesmo contando com uma resposta a menos do que as etapas anteriores, apresentou uma variação consideravelmente maior, sendo a etapa com a maior variação entre as respostas desse grupo de entrevistados.

O gráfico 104, abaixo, apresenta o total de desvios que as respostas objetivas de cada entrevistado tiveram com relação às médias das avaliações feitas pelos entrevistados das associações empresariais norueguesas, sobre as diferentes etapas da política industrial norueguesa de petróleo e gás. 


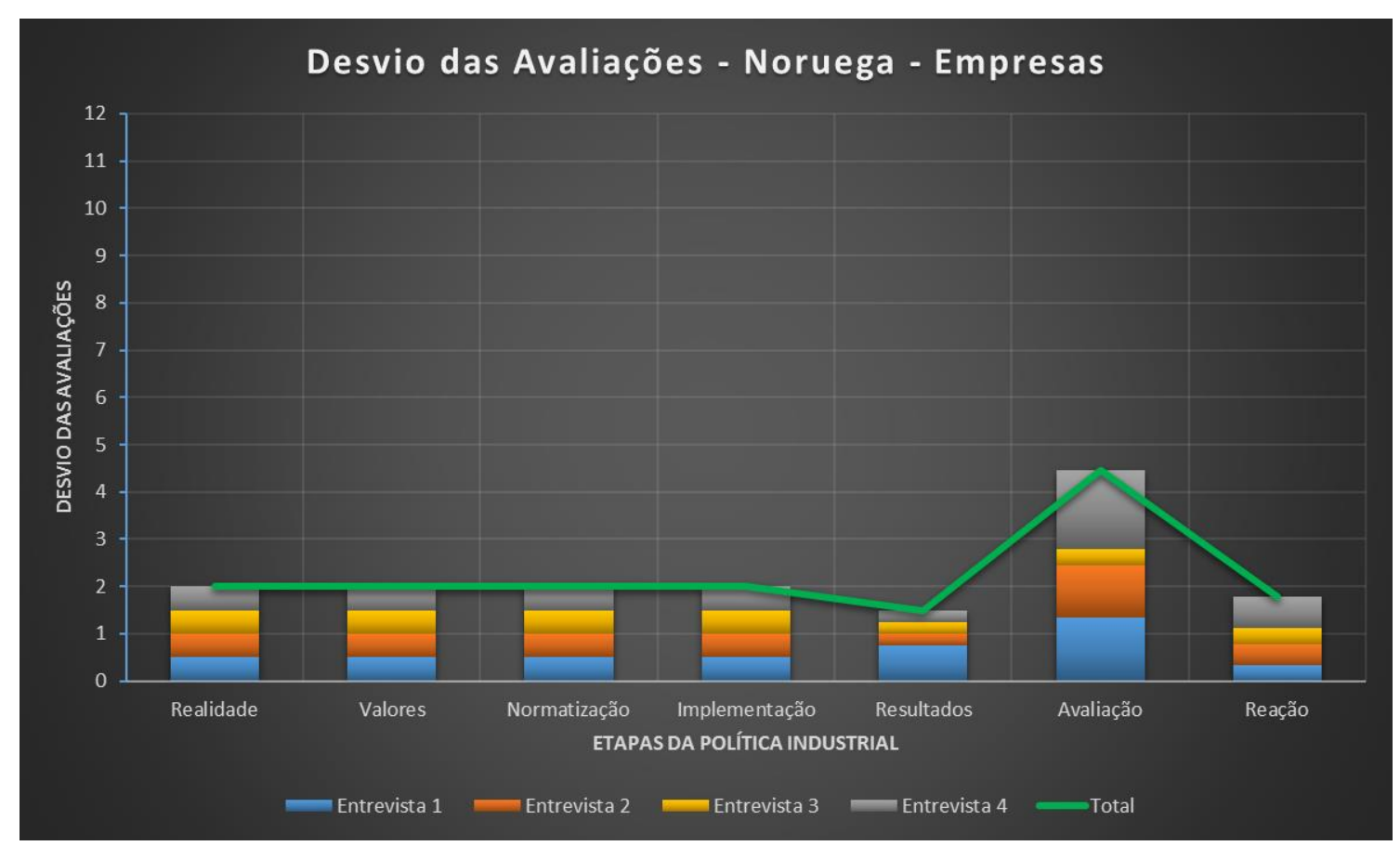

Gráfico 104 - Desvio entre a avaliação de cada entrevistado e a média das avaliações das associações empresariais, para cada etapa da política industrial de petróleo e gás na Noruega.

Este gráfico confirma que os desvios nas respostas dos representantes das associações empresariais norueguesas foram muito baixos, com exceção da etapa sobre os mecanismos de monitoramento e avaliação, que ficou com um desvio entre baixo e médio. Todas as demais etapas apresentaram um desvio muito baixo, sendo ainda um pouco mais baixos quando tratando sobre os resultados obtidos pela política ou sobre a reação aos dados obtidos pelos mecanismos de monitoramento e avaliação da política.

\section{c) Relação Governo-Empresas}

O gráfico 105, abaixo, apresenta a comparação entre o total de desvios, dentro de cada grupo, com relação às respostas sobre todas as etapas da política industrial norueguesa de petróleo e gás, apresentadas pelos entrevistados do governo e pelas associações empresariais norueguesas. 


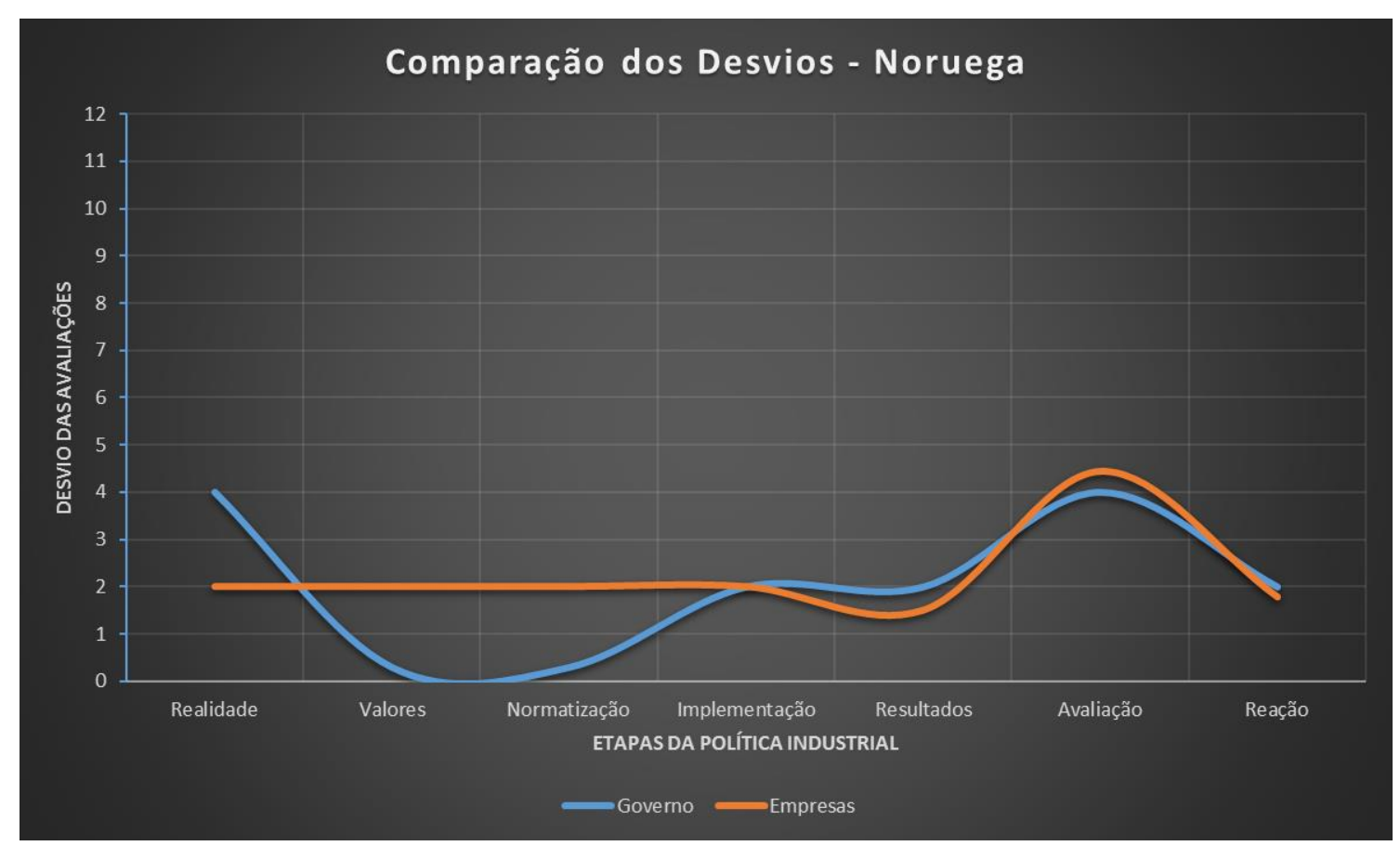

Gráfico 105 - Comparação dos desvios dentro de cada grupo, nas respostas sobre as avaliações de cada etapa da política industrial de petróleo e gás na Noruega.

Nesta comparação fica perceptível que as respostas dos entrevistados do governo e das associações empresariais norueguesas apresentaram uma diferença de desvios pequena nas três primeiras etapas, mas uma semelhança bastante grande nos índices de desvios das etapas posteriores. Os desvios nas respostas sobre a realidade que serviu de base para a política foram maiores entre os entrevistados do governo. O oposto ocorreu com relação aos valores e à normatização da política, onde os desvios das associações foram maiores que os do governo. Na etapa sobre a implementação da política os dois grupos apresentaram o mesmo índice de desvios. Nas três etapas seguintes os níveis de desvios foram quase os mesmos entre entrevistados do governo e das associações empresariais. As etapas sobre os resultados obtidos e sobre a reação para direcionamento da política tiveram níveis mais baixos de desvios do que aqueles apresentados nas avaliações sobre os mecanismos de monitoramento e avaliação da política.

O gráfico 106, abaixo, apresenta o percentual de variação nas avaliações dentro de cada um dos grupos, sobre todas as etapas que fazem parte da política industrial norueguesa. 


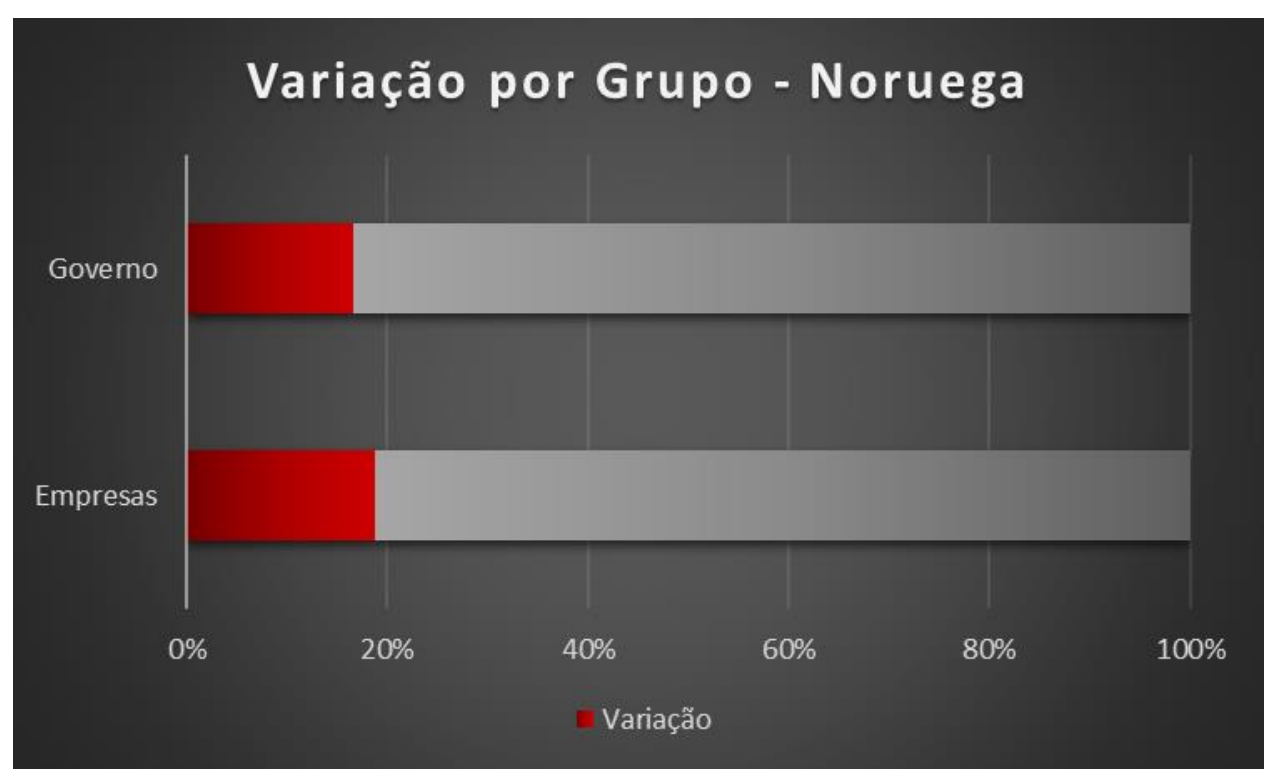

Gráfico 106 - Percentual de variação na avaliação de cada grupo sobre todas as etapas da política industrial de petróleo e gás na Noruega.

Com esse gráfico, fica perceptível que a variação foi praticamente a mesma entre as avaliações dos entrevistados das associações empresariais norueguesas e as avaliações dos entrevistados do governo norueguês. Cabe mencionar que a variação entre as respostas das associações foi ligeiramente superior à variação das respostas do governo, mesmo assim, essa variação não chegou nem a $20 \%$ em nenhum dos dois grupos.

O gráfico 107, abaixo, apresenta a soma do total de desvios que as respostas objetivas dos entrevistados de cada grupo tiveram com relação às médias gerais das avaliações feitas por ambos os grupos, sobre as diferentes etapas da política industrial norueguesa de petróleo e gás. 


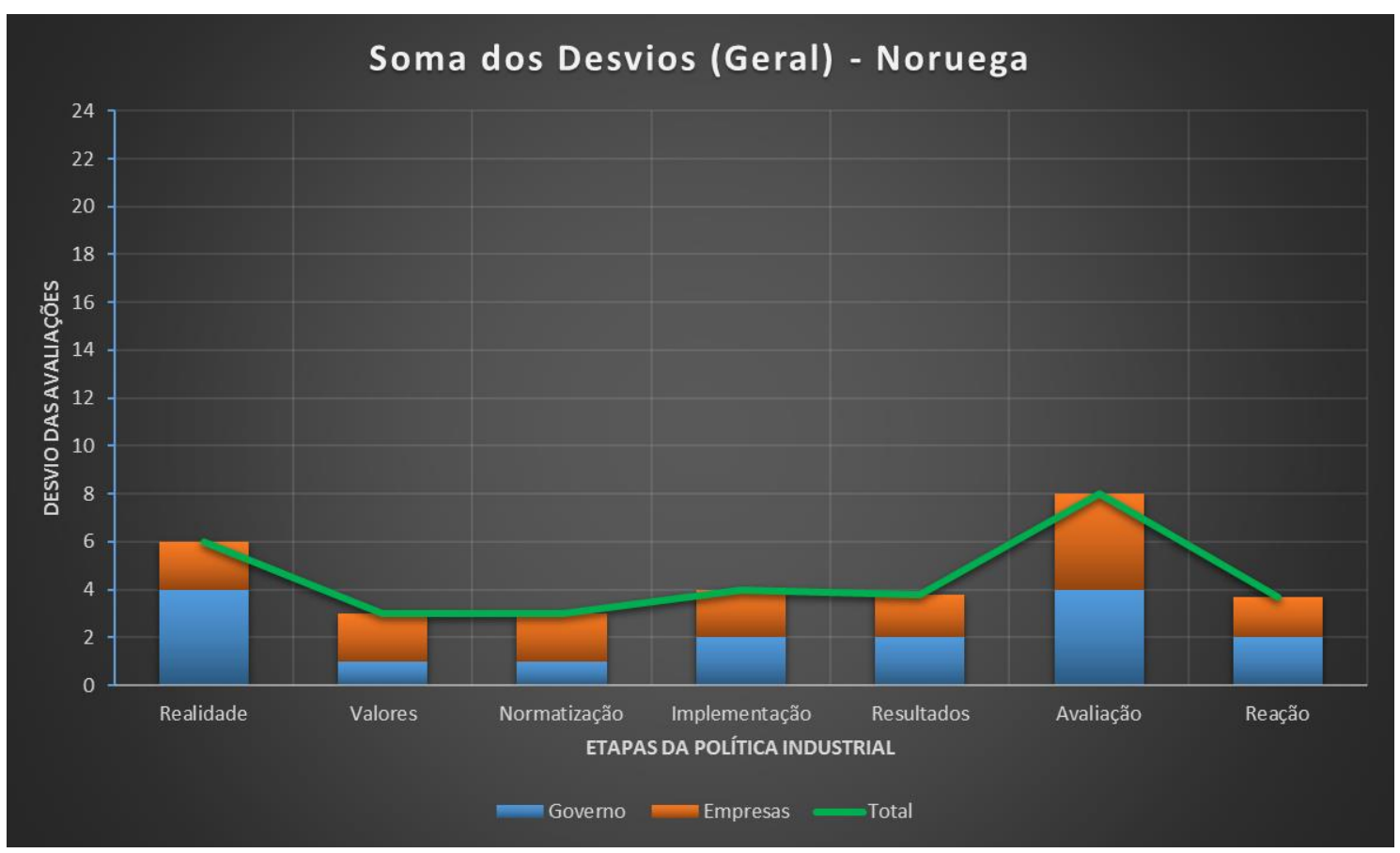

Gráfico 107 - Soma dos desvios entre a avaliação de cada entrevistado e a média das avaliações dos dois grupos, para cada etapa da política industrial de petróleo e gás na Noruega.

No gráfico acima se utiliza a média geral, que considera as respostas dos entrevistados dos dois grupos para fazer o cálculo dos desvios. Essa soma do total de desvios nas respostas dos entrevistados do governo norueguês com o total de desvios nas respostas dos entrevistados das associações empresariais norueguesas permite que se perceba melhor quais etapas apresentam uma variação maior de respostas entre todos os atores noruegueses. Com isso, se reforça a percepção anterior de que houve uma variação muito baixa em quase todas as etapas da política industrial norueguesa. Este gráfico confirma que, mesmo considerando os dois grupos reunidos, também são as etapas sobre a realidade que serviu de base para a política e sobre os mecanismos de monitoramento e avaliação as que apresentam um desvio maior entre as avaliações de todos os entrevistados noruegueses.

\subsection{4 - Relação Entre Atores}

Nesta parte da análise comparativa serão comparadas as avaliações de cada grupo com relação à interação entre os atroes envolvidos com a política industrial de petróleo e gás norueguesa. Para isso, serão analisadas as opiniões que os entrevistados de um grupo 
apresentaram a respeito da sua percepção sobre os atores do outro grupo, sobre como cada grupo percebe a sua própria participação e sobre como cada grupo percebe o recebimento dessa sua participação pelos atores do outro grupo de entrevistados.

\section{a) Percepção do Outro}

O gráfico 108, abaixo, apresenta a comparação entre o percentual de menções positivas e negativas nas respostas dos entrevistados dos dois grupos noruegueses, sobre a percepção que os atores de um grupo têm a respeito dos atores do outro grupo.

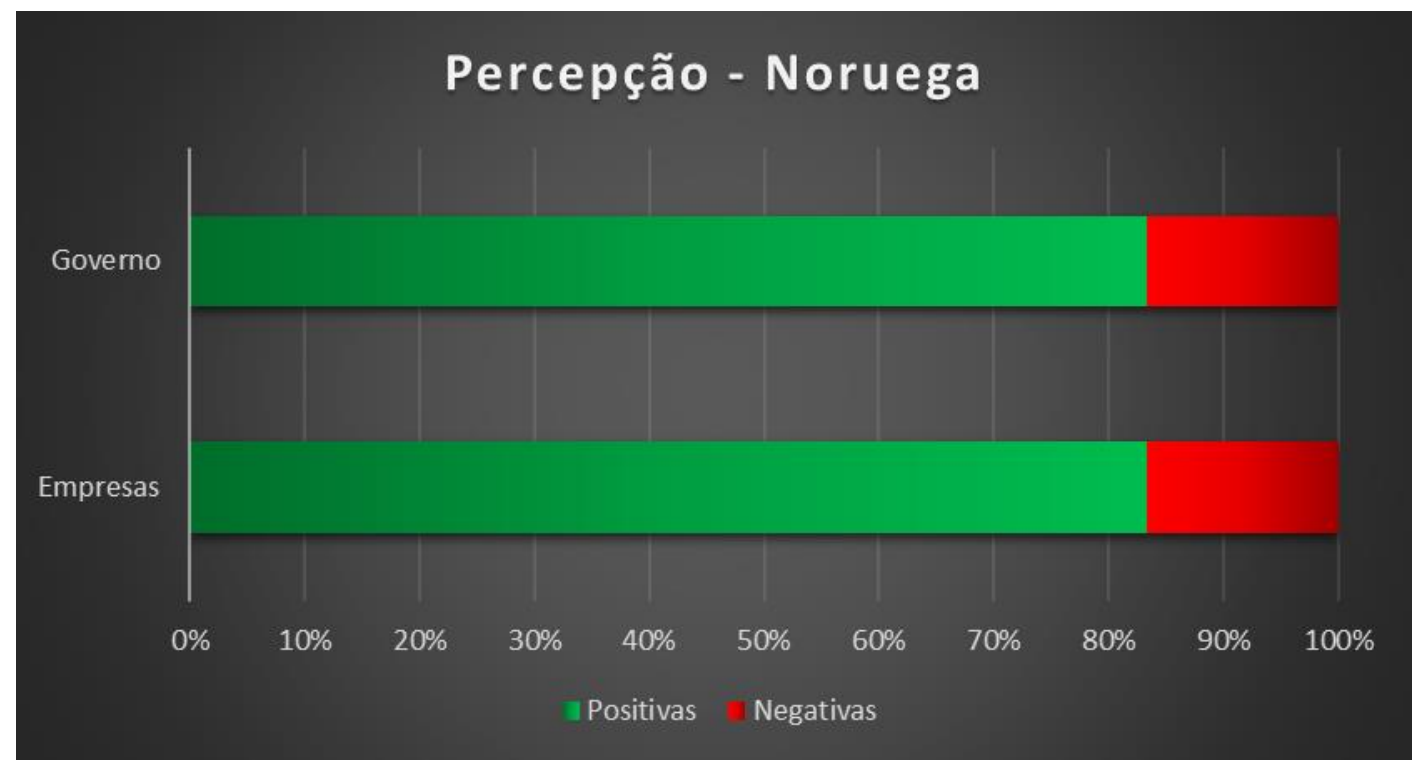

Gráfico 108 - Percentual de menções positivas e negativas nas respostas dos dois grupos noruegueses sobre a percepção que um grupo tem do outro.

Como uma forma de menção positiva sobre as associações empresariais norueguesas, os entrevistados do governo norueguês disseram que elas estariam bastante "contentes", apresentando baixos índices de reclamações. De acordo com eles, haveria um acordo muito amplo entre governo e empresas, com um bom diálogo entre eles e com a participação das empresas na definição da política. Já como menções positivas sobre o governo norueguês, os entrevistados das associações empresariais também indicaram que haveria um bom e constante diálogo com o governo, que estaria trabalhando de forma adequada. Elas também disseram que compartilham com o governo os mesmos interesses, valores, visões e posições, pois ambos estariam caminhando na mesma direção. Tanto o 
governo como as empresas teriam como principais objetivos a maximização da criação de valor na plataforma continental norueguesa e a competitividade internacional.

Nas entrevistas dos dois grupos foram feitas menções sobre o outro grupo que não foram consideradas nem positivas nem negativas. Nas entrevistas com representantes do governo foi dito que todos os atores envolvidos acreditam haver espaço para melhorias na política e que a desaceleração do mercado internacional estaria segurando as atividades das empresas norueguesas. Já nas entrevistas dos representantes das associações empresariais foi dito que as atividades do setor de petróleo poderiam estar prejudicando outros setores noruegueses, mas estes outros setores poderiam estar aproveitando o desenvolvimento de capacidades que ocorre no setor de petróleo. Também indicaram a existência de ambientalistas que teriam o desejo de acabar com o setor de petróleo, sem considerar as perdas que seriam geradas com relação a empregos, impostos, criação de valor, exportações e participação no PIB, por exemplo, mas haveria políticos responsáveis se opondo a esta proposta.

Os comentários negativos dos entrevistados do governo a respeito das associações empresariais indicaram apenas que as empresas sempre querem mais do governo. Já os comentários negativos das associações sobre o governo norueguês mencionaram apenas à crítica a alguns políticos que teriam o objetivo de fazer da Noruega um exemplo para o mundo em questões ambientais, através da redução da produção de petróleo e gás no país.

\section{b) Participação}

O gráfico 109, abaixo, apresenta a comparação entre o percentual de menções positivas e negativas nas respostas dos entrevistados dos dois grupos, sobre a participação do seu próprio grupo na política industrial de petróleo e gás norueguesa. 


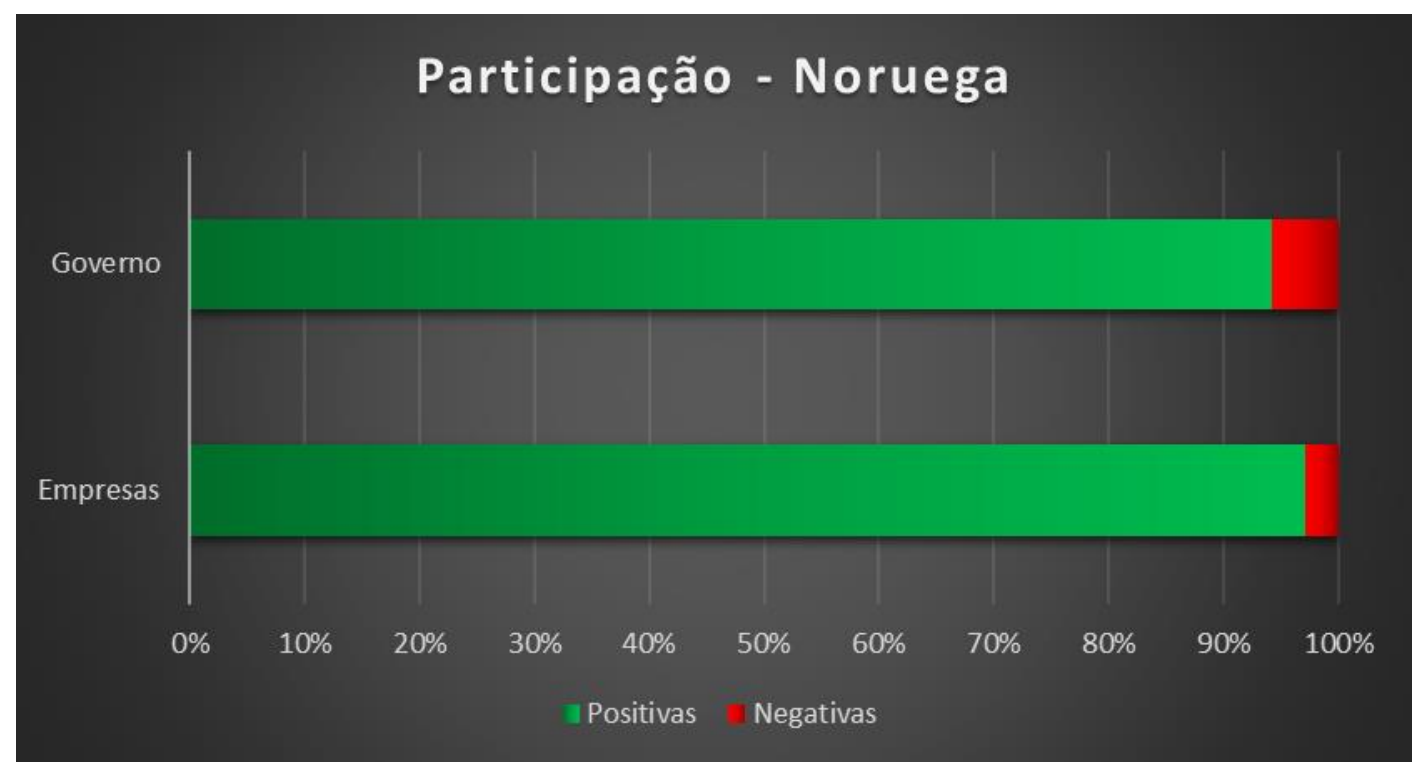

Gráfico 109 - Percentual de menções positivas e negativas nas respostas dos dois grupos sobre a participação do seu próprio grupo na política industrial da Noruega.

Sobre a participação de cada grupo na política industrial de petróleo e gás norueguesa, as menções positivas do governo mencionaram sua participação na apresentação de informes técnicos, dando orientações, formulando e aprimorando leis, divulgando as melhores práticas, coletando informações, atraindo investimentos e participando de reuniões e de cooperações com instituições de pesquisa. Estes entrevistados também manifestaram a "sensação" de terem um papel chave em diferentes questões da política. Haveria uma estrita e bem aceita compreensão do papel de cada ator na política, existindo também um bom diálogo entre eles, pois a abertura e franqueza seriam fundamentais para que a política seja eficiente e não se precise perder tempo fazendo correções na relação entre os atores. Já os entrevistados das associações disseram que participam junto com o governo, conversando com outros atores, transferindo conhecimento e tecnologia, repassando lições, ajudando outros países e contribuindo com soluções para situações problemáticas. O diálogo também foi mencionado como um elemento positivo nessa participação e estaria acima da média mesmo comparado com os padrões europeus. A existência de um amplo diálogo entre os atores não deve ser confundida com a prática de corrupção, como acontece em outros países, mas sim como um diálogo com profissionalismo. Foi mencionada a existência de um acordo entre associações empresariais e sindicatos de trabalhadores para que um ajude a promover os interesses do outro junto ao governo, além de elogiar a prática do Ministry of Petroleum 
and Energy em delegar responsabilidades para as associações empresariais. Também houve menção ao fato de que as empresas que atuam no exterior adquirem aprendizados que depois são levados para dentro do país.

Os comentários negativos que os representantes do governo e das associações empresariais fizeram sobre as suas próprias participações na política industrial nacional trataram apenas sobre a não participação em alguma etapa da política.

\section{c) Recebimento pelo Outro}

O gráfico 110, abaixo, apresenta a comparação entre o percentual de menções positivas e negativas nas respostas dos entrevistados dos dois grupos, sobre o recebimento da sua participação pelo outro grupo, na definição da política industrial de petróleo e gás norueguesa.

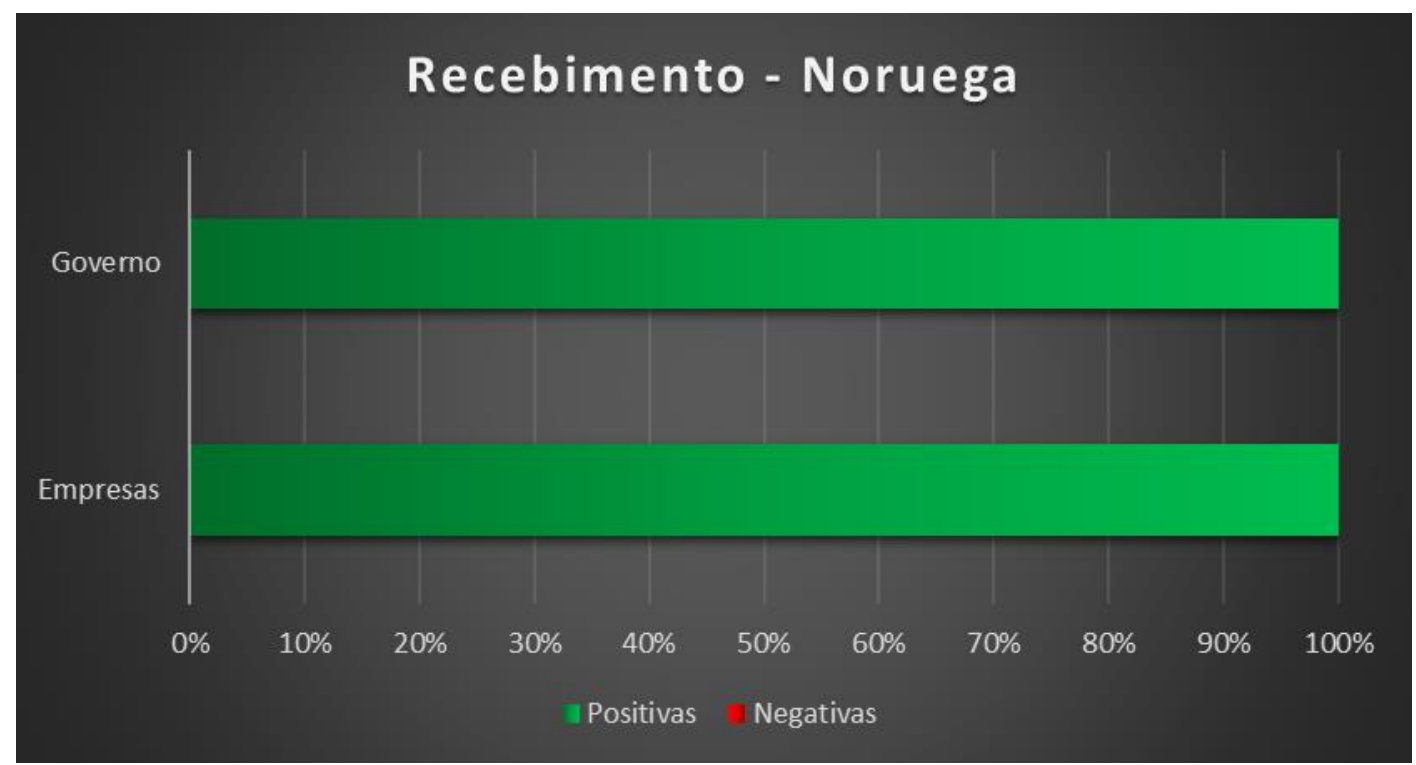

\section{Gráfico 110 - Percentual de menções positivas e negativas nas respostas dos dois grupos noruegueses sobre o recebimento da sua participação pelo outro grupo.}

Os entrevistados do governo relacionaram um bom recebimento de suas participações por parte das associações empresariais com laços muito bons entre governo e empresas de uma maneira geral. Haveria apoio da maioria do parlamento e o governo seria sempre muito bem avaliado em pesquisas de opinião, sendo um indício de que ele não estaria isolado dos demais atores. Foi dito que as agendas de empresas produtoras e fornecedoras valorizam a boa governança e a responsabilidade social, além de as 
principais empresas fornecedoras terem sede em Oslo e estarem sempre interessadas em aumentar a sua participação no setor. Já os entrevistados das associações empresariais norueguesas disseram que se sentem bem ou muito bem recebidos pelo governo. As empresas teriam a "sensação" de terem voz forte no diálogo com o governo e que vale a pena participar, pois haveria um interesse real do governo em ouvir a opinião delas e a demonstração de apreço por essa participação. Foi feita a ressalva de que existem situações onde o governo dá voz às empresas, ouve e compreende a posição delas, mas mesmo assim decide diferente. Essa situação seria normal e aceitável, pois faz parte da interação entre os atores, mas o que não seria normal é acontecer como ocorre em outros países, onde os governos parecem já terem tomado suas decisões antes mesmo de ouvirem os demais atores envolvidos na política industrial.

Há que se destacar que não houve absolutamente nenhum comentário negativo de nenhum dos grupos noruegueses sobre a forma como suas participações são recebidas pelo outro grupo.

\section{d) Interação de Atores}

O gráfico 111, abaixo, apresenta a comparação entre o percentual de menções positivas e negativas nas respostas dos entrevistados dos dois grupos, sobre a interação entre os atores, na definição da política industrial de petróleo e gás norueguesa.

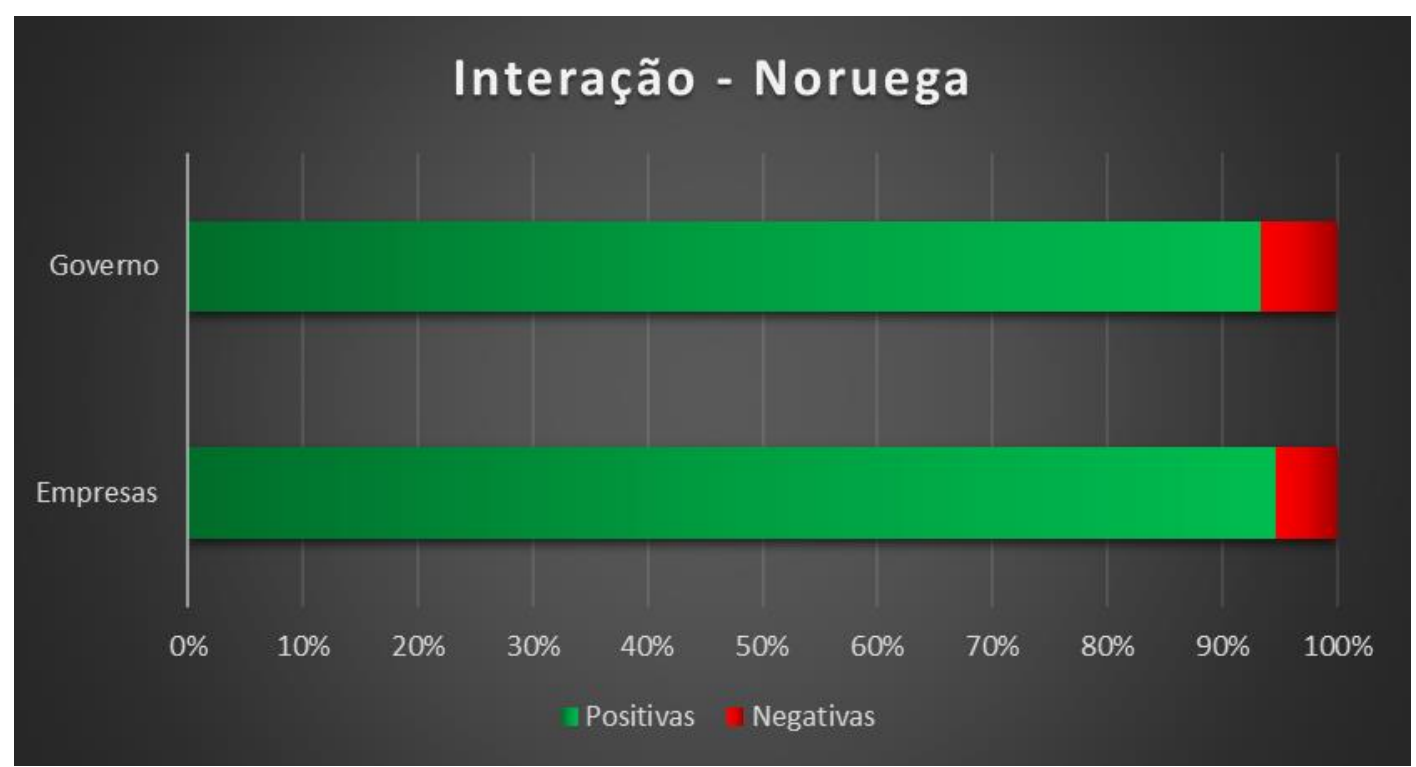

Gráfico 111 - Percentual de menções positivas e negativas nas respostas dos dois grupos sobre a interação dos atores na política industrial norueguesa. 
Aqui, o percentual foi calculado com base no total de menções realizadas sobre a percepção do outro, a participação e o recebimento e não com base numa média entre esses três elementos. Percebe-se que, considerando todos os elementos anteriores, relacionados à interação entre os atores noruegueses na definição da política industrial de petróleo e gás, as associações empresariais teriam uma visão geral ligeiramente mais positiva dessa relação do que o governo. Essa semelhança se explica pelo fato de que em todos os três elementos considerados sobre essa interação, houve um equilíbrio muito grande entre as opiniões dos dois grupos. Merecendo o destaque ao percentual de menções positivas gerais terem ficado acima dos $90 \%$ tanto entre os entrevistados do governo como entre os entrevistados das associações empresariais norueguesas. 


\section{Capítulo 7 - Comparação entre Brasil, México e Noruega}

Neste capítulo, será apresentada a comparação entre os três estudos de caso, para que se possa perceber as semelhanças e as diferenças entre os três países e para que, com isso, se procure responder à pergunta da pesquisa e verificar a hipótese desta tese. Para fundamentar esta comparação, será utilizada a base teórica apresentada no primeiro capítulo deste trabalho.

\section{1 - Mudanças os Instrumentos de Política Industrial}

A análise sobre os contextos históricos dos países oferece uma importante perspectiva para a verificação da hipótese deste trabalho. Através dela que é possível verificar como se dá a variação da relação entre as estratégias de desenvolvimento de cada governo e os instrumentos de política industrial adotados por cada um ao longo da história de cada país.

Para a realização desta análise, foram selecionados instrumentos de política industrial considerados relevantes para o contexto de cada país. Em seguida, estes instrumentos foram classificados como tendo um viés intervencionista (destacados em vermelho) ou liberalizante (destacados em azul). Esta divisão foi feita com base na literatura sobre estratégias de desenvolvimento e sobre políticas industriais, que apresentam a característica de serem polarizadas entre a predominância do papel do Estado ou do mercado. Em alguns casos, essa classificação não se demonstra tão evidente, então foi adotado o critério de comparação com a política anterior. Quando o instrumento representa uma mudança no sentido de uma maior abertura para o mercado, o instrumento foi considerado liberalizante. Quando se tratou de um processo de aumento da intervenção do Estado na indústria ou na economia, considerou-se um instrumento intervencionista. Outra questão importante para esta classificação foi o quanto cada instrumento serviu como afronta aos interesses do grupo oposto. Com base nas entrevistas, entende-se que muitas políticas foram adotadas apenas como uma forma de satisfação política, mas sem efeitos relevantes para a disputa de forças entre Estado e setor privado. Por exemplo, quando o governo brasileiro de Fernando Henrique Cardoso adota uma política de conteúdo local, no final da década de 1990, essa política não representa uma efetiva 
tensão entre os interesses dos dois grupos, pois utilizava uma forma de medição falha e tinha uma exigência de índices muito baixos. O mesmo parece ocorrer com relação à política de conteúdo local adotada pelo México, no atual governo. Outro exemplo importante de política que não foi utilizada para esta comparação foi a estratégia desenvolvimentista brasileira que levou à criação do CENPES, criado na década de 1970 com um forte viés de intervencionismo estatal para o desenvolvimento de competências tecnológicas, mas sem representar um objeto de disputa entre Estado e setor privado. A adoção de medidas que gerem tensões por representarem uma disputa de interesses, ou mais precisamente, aquela disputa pela "renda da terra" mencionada por David Ricardo (1982), foram as escolhidas para a realização desta comparação.

Com relação às estratégias de desenvolvimento adotadas, os governos foram divididos entre aqueles que se fundamentam em estratégias de desenvolvimento com foco no papel do Estado (em vermelho) ou do mercado (em azul). Aqui também foram encontrados casos onde esta classificação não era tão óbvia. Nestes casos, procurou-se adotar uma combinação variada de critérios para definir essa classificação, incluindo a história pessoal de cada governante, o partido político de cada governo, as plataformas apresentadas durante as campanhas e as medidas adotadas durante os governos.

Não é demais destacar que tanto a classificação sobre os instrumentos de política industrial, quanto a classificação sobre as estratégias de desenvolvimento adotadas por cada governo, não são classificações absolutas. Algumas variações podem ser encontradas, em diferentes governos dos três países, mas de uma forma geral, entende-se que a divisão adotada pela classificação desta pesquisa atende às necessidades de comparação para os fins deste trabalho.

Na tabela 3, abaixo, são apresentados os instrumentos de política industrial selecionados e os respectivos governos que os utilizaram, ao longo da história da indústria de petróleo no Brasil. 


\begin{tabular}{|c|c|c|}
\hline Ano & Presidente & Instrumento de Política Industrial \\
\hline $\mathbf{2 0 1 6}$ & Michel Temer & Atual \\
\hline $\mathbf{2 0 1 6}$ & Michel Temer & Proposta de retirada da obrigatoriedade da Petrobras como operadora única \\
\hline $\mathbf{2 0 1 1}$ & Dilma Rousseff & Plano Brasil Maior (PBM) \\
\hline $\mathbf{2 0 1 0}$ & Luis Inácio Lula da Silva & Modelo de partilha, operadora única, participação mínima 30\% e Fundo Social \\
\hline $\mathbf{2 0 0 8}$ & Luis Inácio Lula da Silva & Política de Desenvolvimento Produtivo (PDP) \\
\hline $\mathbf{2 0 0 7}$ & Luis Inácio Lula da Silva & CNPE retira pré-sal da 9a rodada \\
\hline $\mathbf{2 0 0 5}$ & Luis Inácio Lula da Silva & Adoção da Cartilha de Conteúdo Local \\
\hline $\mathbf{2 0 0 4}$ & Luis Inácio Lula da Silva & Política Industrial, Tecnológica e de Comércio Exterior (PITCE) \\
\hline $\mathbf{2 0 0 3}$ & Luis Inácio Lula da Silva & Criação do PROMINP \\
\hline $\mathbf{1 9 9 7}$ & Fernando Henrique Cardoso & Abertura de capital da Petrobras e adoção do modelo de concessão \\
\hline 1995 & Fernando Henrique Cardoso & Abertura do mercado e fim do monopólio da Petrobras \\
\hline $\mathbf{1 9 9 0}$ & Fernando Collor de Melo & Programa Nacional de Desestatização \\
\hline $\mathbf{1 9 5 3}$ & Getúlio Vargas & Criação da Petrobras e estabelecimento do monopólio estatal \\
\hline
\end{tabular}

Tabela 3 - Relação entre os instrumentos de política industrial utilizados e as estratégias de desenvolvimento de cada governo, ao longo da história brasileira.

Nesta tabela, percebe-se que existe uma correspondência entre os instrumentos de política industrial adotados e as estratégias de desenvolvimento de cada governo, ao longo de toda a história brasileira. Instrumentos de política industrial intervencionistas são sempre adotados por governos cujas estratégias têm foco no papel do Estado como promotor do desenvolvimento. Já instrumentos de política industrial liberalizantes são sempre adotados por governos cujas estratégias têm foco no papel do mercado como promotor de desenvolvimento. Esta tabela indica a materialização daquela lógica positivista que fundamenta praticamente todas as teorias sobre estratégias de desenvolvimento. A crença dos governos na ideia de que a sua estratégia de desenvolvimento seja uma verdade absoluta, faz com que todos os governos adotem instrumentos de políticas industriais que sigam a mesma orientação dessa estratégia. A realidade enfrentada pelo setor, ou diferentes momentos em que o mercado possa se encontrar, não parecem influenciar a definição da política industrial de petróleo e gás brasileira, que apresenta fortes indícios de que seja definida com base na estratégia adotada por cada governo.

Na tabela 4, abaixo, são apresentados os instrumentos de política industrial selecionados e os respectivos governos que os utilizaram, ao longo da história da indústria de petróleo no México. 


\begin{tabular}{|c|c|c|}
\hline Ano & Presidente & Instrumento de Política Industrial \\
\hline $\mathbf{2 0 1 6}$ & Enrique Peña Nieto & Atual \\
\hline $\mathbf{2 0 1 3}$ & Enrique Peña Nieto & Refoma energética com abertura do mercado \\
\hline $\mathbf{2 0 0 8}$ & Felipe Calderón Hinojosa & Reforma energética de 2008 \\
\hline $\mathbf{1 9 9 2}$ & Carlos Salinas de Gortari & México entra no NAFTA \\
\hline $\mathbf{1 9 8 6}$ & Miguel de la Madrid Hurtado & México entra no GATT e começa um processo de abertura econômica \\
\hline $\mathbf{1 9 7 9}$ & José López Portillo y Pacheco & Governo nega proposta de gasoduto dos EUA e adota o Plan Global de Desarollo \\
\hline $\mathbf{1 9 6 2}$ & Adolfo López Mateos & Estímulo à indústria petroquímica \\
\hline $\mathbf{1 9 6 0}$ & Adolfo López Mateos & Nacionalização da indústria elétrica e criação da CFE \\
\hline $\mathbf{1 9 5 8}$ & Adolfo Ruiz Cortines & Extinção da partilha e estabelecimento do monopólio estatal \\
\hline $\mathbf{1 9 4 7}$ & Miguel Alemán Valdés & Substituição de importações \\
\hline 1941 & Miguel Alemán Valdés & Acordo com o governo dos EUA para pagamento da dívida pela expropriação \\
\hline $\mathbf{1 9 4 0}$ & Lázaro Cárdenas del Rio & Partilha só com empresas mexicanas \\
\hline $\mathbf{1 9 3 8}$ & Lázaro Cárdenas del Rio & Expropriação da indústria de petróleo e criação da Pemex \\
\hline
\end{tabular}

Tabela 4 - Relação entre os instrumentos de política industrial utilizados e as estratégias de desenvolvimento de cada governo, ao longo da história mexicana.

Aqui também se percebe a existência de uma correspondência entre os instrumentos de política industrial adotados e as estratégias de desenvolvimento de cada governo, ao longo de toda a história mexicana. Assim como no Brasil, instrumentos de política industrial intervencionistas são sempre adotados por governos cujas estratégias têm foco no papel do Estado como promotor do desenvolvimento. Da mesma forma, instrumentos de política industrial liberalizantes são sempre adotados por governos cujas estratégias têm foco no papel do mercado como promotor de desenvolvimento. A mesma lógica positivista que parece estar presente na definição da política industrial brasileira, também aparece nesta tabela sobre a política mexicana. Parece que os dois países apresentam indícios importantes no sentido de que sejam as estratégias de desenvolvimento adotadas por cada governo que sirvam de base para a definição da política e dos instrumentos de política industrial mexicanos para o setor de petróleo e gás.

Na tabela 5, abaixo, são apresentados os instrumentos de política industrial selecionados e os respectivos governos que os utilizaram, ao longo da história da indústria de petróleo na Noruega. 


\begin{tabular}{|c|c|c|}
\hline Ano & Presidente & Instrumento de Política Industrial \\
\hline $\mathbf{2 0 1 6}$ & Erna Solberg & Atual \\
\hline $\mathbf{2 0 0 7}$ & Jens Stoltenberg & Fusão entre Statoil e Norsk Hydro \\
\hline $\mathbf{2 0 0 0}$ & Jens Stoltenberg & Abertura de capital da Statoil \\
\hline $\mathbf{1 9 9 7}$ & Thorbjørn Jagland & Adoção do modelo de concessão \\
\hline $\mathbf{1 9 9 4}$ & Gro Harlem Brundtland & Noruega assina tratado de livre circulação de bens e serviços com União Europeia \\
\hline $\mathbf{1 9 8 9}$ & Gro Harlem Brundtland & Alterações na lei para atender às exigências de entrada no mercado comum europeu \\
\hline $\mathbf{1 9 8 8}$ & Gro Harlem Brundtland & Mudança de objetivos na administração da Statoil \\
\hline $\mathbf{1 9 8 7}$ & Gro Harlem Brundtland & Empresas estrangeiras deixam de ser responsáveis pelas despesas com exploração \\
\hline $\mathbf{1 9 8 6}$ & Gro Harlem Brundtland & Desonerações para empresas estrangeiras \\
\hline $\mathbf{1 9 8 5}$ & Kåre Willoch & Lei do Petróleo entra em vigor, alterando Decreto Real de 1979 \\
\hline $\mathbf{1 9 7 9}$ & Odvar Nordli & Decreto Real estabelece exigencia de conteúdo local \\
\hline $\mathbf{1 9 7 8}$ & Odvar Nordli & Exigência de 50\% dos custos com pesquisa e treinamento pagos pela empresa \\
\hline $\mathbf{1 9 7 4}$ & Trygve Bratteli & Aumento de impostos com participação de 80\% do governo no setor \\
\hline $\mathbf{1 9 7 3}$ & Lars Korvald & Decreto Real exige conteúdo local e Statoil fica com 50\% do campo de Statfjord \\
\hline $\mathbf{1 9 7 2}$ & Trygve Bratteli & Criação da Statoil e adoção do modelo de licenças vinculadas a joint ventures \\
\hline $\mathbf{1 9 7 0}$ & Per Borten & Dez mandamentos da indústria de petróleo \\
\hline $\mathbf{1 9 6 5}$ & Einar Gerhardsen & Royalties baixos, redução fiscal e a maior rodada de concessões \\
\hline $\mathbf{1 9 6 2}$ & Einar Gerhardsen & Noruega declara propriedade sobre a plataforma continental \\
\hline
\end{tabular}

Tabela 5 - Relação entre os instrumentos de política industrial utilizados e as estratégias de desenvolvimento de cada governo, ao longo da história norueguesa.

Já nesta tabela, percebe-se uma diferença fundamental entre o caso norueguês e os casos brasileiro e mexicano. Não existe uma correspondência entre os instrumentos de política industrial adotados e as estratégias de desenvolvimento de cada governo, ao longo de toda a história norueguesa. Instrumentos de política industrial intervencionistas foram utilizados por governos que adotam estratégias com base no papel do Estado, assim como por governos que adotam estratégias com foco no papel do mercado. Já os instrumentos de política industrial liberalizantes selecionados foram adotados todos por governos cujas estratégias se baseiam no papel do Estado como promotor de desenvolvimento. Essa relação parece confirmar dois elementos trazidos pela literatura analisada no primeiro capítulo. Por um lado, a utilização de políticas liberais por governos intervencionistas, assim como a utilização de políticas intervencionistas por governos liberais, aponta para a verificação de um exemplo prático sobre e realidade de que trata a teoria sobre o novo desenvolvimentismo. A combinação entre o papel do Estado e do mercado na promoção do desenvolvimento nacional e produtivo se apresenta aqui de forma concreta, onde fica evidente a importância que é dada para estas duas orientações, e o resultado parece apontar que este seja um elemento fundamental para a adoção de uma política efetivamente equilibrada, que não se limite ao discurso teórico. Por outro lado, a marcante diferença que se verifica entre o padrão das relações entre as estratégias de 
desenvolvimento e as políticas industrias nos países latino-americanos, quando comparados com o padrão encontrado entre os noruegueses, pode servir de reforço para a ideia estruturalista utilizada pela CEPAL, que aponta para diferenças fundamentais e estruturantes entre países de centro, como é o caso da Noruega, e de periferia, como é o caso do Brasil e do México.

Com isso, percebe-se que, nos casos brasileiro e mexicano, a hipótese levantada por esta pesquisa não foi negada, pois os instrumentos de política industrial parecem estar diretamente relacionados com as estratégias de desenvolvimento de cada governo. Já no caso norueguês, a hipótese pode ser negada, abrindo espaço para que a definição da política industrial na Noruega seja feita com base em outros elementos.

\section{2 - Total das Avaliações Objetivas}

O gráfico 112, abaixo, apresenta a comparação entre as médias das medianas dos totais das respostas objetivas sobre todas as etapas da política industrial de petróleo e gás, apresentadas pelos entrevistados do governo e das associações empresariais nos três países.

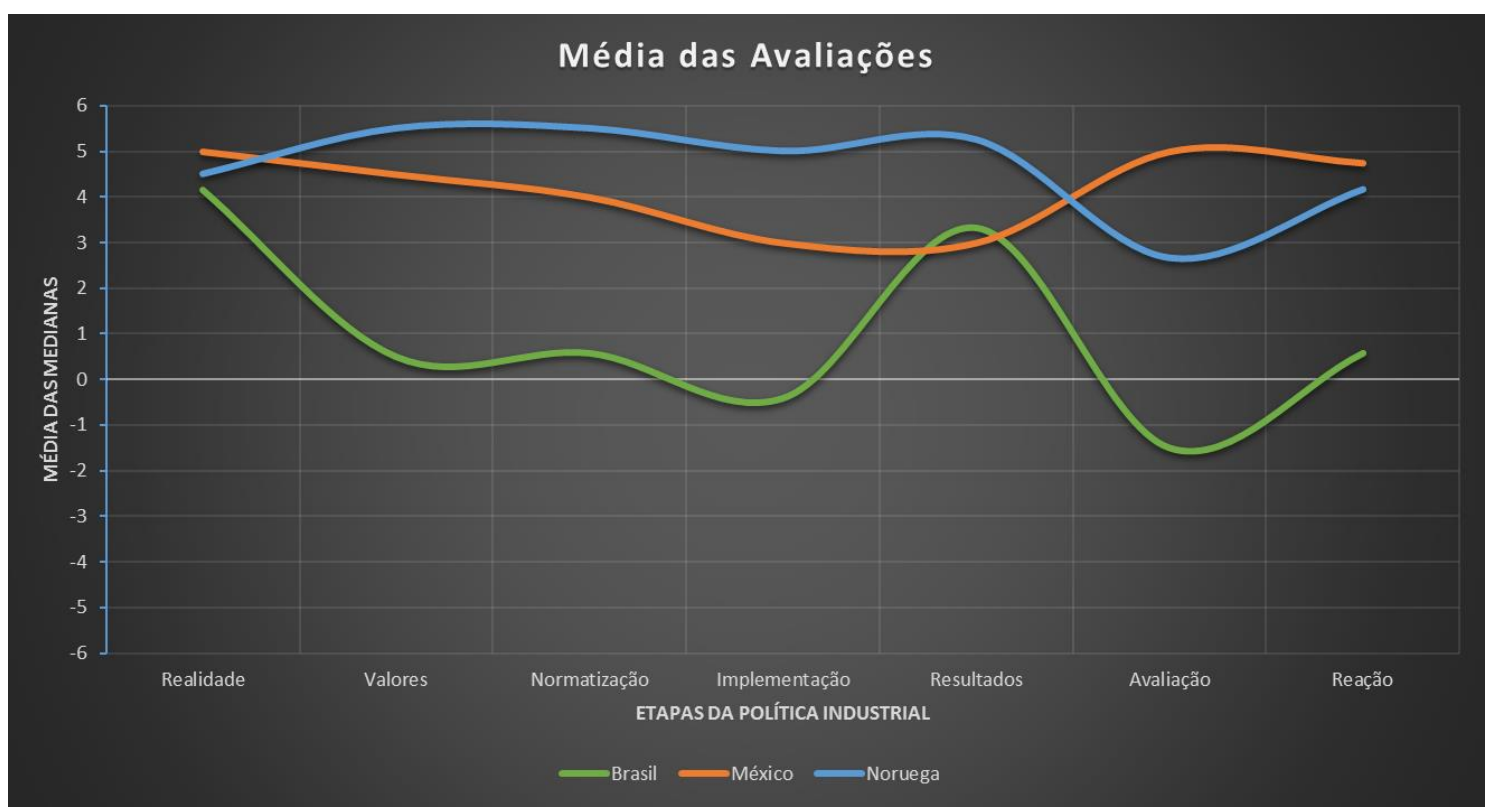

Gráfico 112 - Comparação entre a média do total das avaliações de ambos os grupos, sobre as diferentes etapas da política industrial de petróleo e gás dos três países. 
Este gráfico resume as avaliações feitas em todas respostas objetivas dos três estudos de caso. Percebe-se que os três países começam com uma avaliação muito boa sobre a realidade que serve de base para a política industrial. Na fase seguinte, sobre os valores que fundamentam a política, o Brasil apresenta uma forte queda na avaliação dos entrevistados, enquanto o México tem uma leve queda e a Noruega uma leve alta. Estas avaliações seguem aproximadamente esta mesma tendência ao longo das etapas sobre normatização e implementação da política. Com relação aos resultados obtidos, tanto Brasil quanto Noruega apresentam uma alta nas avaliações, enquanto o México tem uma leve queda. Os mecanismos de monitoramento e avaliação da política foram mal avaliados, em comparação com as demais etapas, no Brasil e na Noruega e se recuperaram na avaliação sobre a reação para a orientação da política. Enquanto o México apresentou uma melhor avaliação sobre os mecanismos de monitoramento e avaliação e manteve o mesmo patamar na avaliação da reação.

Mesmo que não sirva para responder à pergunta desta pesquisa, nem para verificar a hipótese adotada, este gráfico é importante por comparar o quão bem ou o quão mal cada etapa de cada política é avaliada. Entende-se que boas avaliações sobre as etapas de uma política representam satisfação com os resultados concretos alcançados pela política em cada uma dessas fases, e que a qualidade desses resultados pode estar relacionada com a forma de definição da política industrial de cada país. Já seguindo a abordagem sistêmica, esta satisfação dos atores com relação às políticas serve como um indicativo sobre aquela relação levantada pela abordagem das arenas políticas, uma vez que seriam as políticas que definiriam a configuração da relação entre os atores nessas arenas (LOWI, 1972; 1985; EASTON, 1953; 1957).

O gráfico 113, abaixo, apresenta a comparação entre o percentual de aprovação de todas as fases de cada política industrial, nas respostas dos entrevistados dos dois grupos nos três países. 


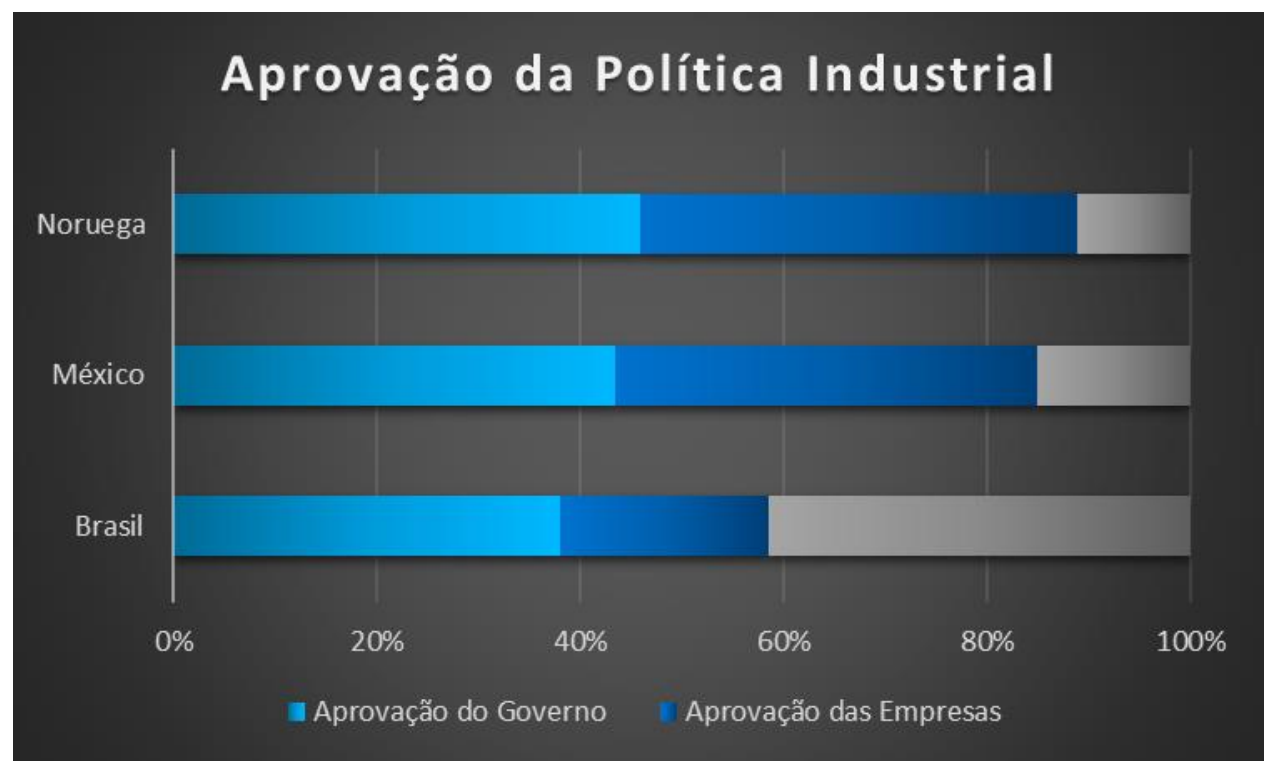

Gráfico 113 - Percentual de aprovação na avaliação de cada grupo, sobre todas as etapas da política industrial de petróleo e gás, em cada um dos três países.

Aqui fica muito clara a diferença entre as avaliações das políticas norueguesa e mexicana para a avaliação da política brasileira. A política da Noruega foi a melhor avaliada, mas a política do México foi quase tão bem avaliada quanto. Há que se utilizar as informações de outras análises deste trabalho para que se compreenda que esta semelhança de aprovação não representa necessariamente uma semelhança na qualidade dos resultados apresentados por cada política.

Conforme explicado no gráfico anterior, quanto maior a satisfação dos atores com a política, maior será o indício de que a relação entre os atores nas suas arenas de disputas políticas seja realizada de uma forma mais colaborativa e eficiente. Quanto menor a satisfação dos atores, maior será o indício de que existam problemas, não apenas com relação à política passada, que já está sendo avaliada pelos atores, mas também com relação àquela política que ainda está por vir, como resultado dessa relação entre os atores envolvidos (LOWI, 1972; 1985; EASTON, 1953; 1957).

As respostas abertas deixam claro que as avaliações mexicanas, a partir da fase de implementação, foram muito baseadas nas expectativas que se tem com relação a resultados futuros, enquanto as avaliações norueguesas se baseiam em resultados sólidos, que a política do país já apresenta há alguns anos. O percentual de aprovação geral da política brasileira ficou muito abaixo dos outros dos países, em boa parte devido à uma muito baixa avaliação por parte das associações empresariais. Aqui também há que se 
fazer uma ressalva porque, mesmo existindo uma forte crítica à política industrial brasileira, parte dessa baixa avaliação pode estar relacionada com o contexto de mudanças no governo do país e com o conflito entre visões opostas a respeito da orientação da política industrial nacional.

\section{3 - Temas Levantados}

Entre os entrevistados brasileiros, ambos os grupos defenderam a necessidade de equilibrar a destinação dos frutos da indústria para necessidades imediatas com sua poupança para gerações futuras. Reclamaram de normas rígidas e complexas, que têm foco na punição e não no incentivo. Apontaram a necessidade de uma governança mais eficaz da política e a ausência de mecanismos de monitoramento e avaliação. Governo e associações empresariais também concordaram ao defender que a corrupção não seria um elemento importante para a política industrial. Já entre os entrevistados mexicanos, os dois grupos apontaram para a importância da forte relação que a política mexicana tem com os Estados Unidos, e a existência de um atraso tecnológico e falta de infraestrutura na indústria de petróleo do México. Foi apontado o objetivo de que se tenha uma fonte energética mais barata no país e que se inicie uma transição para o uso de recursos renováveis. Ainda seria cedo para que se possa avaliar a implementação, os resultados e a avaliação da política, mas representantes do governo e das associações disseram entender que não exista uma política industrial para o setor de petróleo e gás mexicano. Nas entrevistas com os atores noruegueses, foi lembrado o alto custo de produção no país, especialmente por causa dos altos salários, mas a existência de bons resultados em exportações. Ambos os grupos disseram que a política norueguesa apresenta transparência, prestação de contas, diálogo e parcerias, e que existe pouca ou nenhuma corrupção nesta indústria.

Com relação às discordâncias entre os grupos, o governo brasileiro e as associações empresariais do país discordaram com relação à existência de integração entre a política industrial de petróleo e outras políticas, assim como sobre a existência de diálogo entre os atores brasileiros. O governo e as associações empresariais mexicanas também discordaram sobre a existência de uma boa relação entre os atores no país, além de divergirem com relação à forma de definição do ritmo de exploração. Já os noruegueses divergiram apenas com relação à facilidade de acesso à alguns dados. 
Nos três países houve menção positiva a políticas intervencionistas, mas foi no Brasil onde essa defesa foi mais marcante, com os entrevistados destacando a importância da política de conteúdo local. Entre os mexicanos, foi defendido que a nacionalização da cadeia de fornecedores seria um dos objetivos da política e que a intervenção do governo com políticas industriais teria sido fundamental para o desenvolvimento de outros setores no país. Os entrevistados noruegueses destacaram a importância da criação do fundo soberano, de algumas regras mais rígidas que teriam obrigado empresas a se adaptarem a certas exigências e da manutenção de $67 \%$ das ações da Statoil em poder do Estado.

O apoio a políticas liberalizantes também ocorreu nos três países, mas foi no México onde este apoio teve mais destaque. Entre os brasileiros, a defesa destes instrumentos foi feita na maior parte por entrevistados das associações empresariais e incluíram a crítica à política de conteúdo local, a ideia de que a Petrobras deva ter foco exclusivo na eficiência empresarial e a necessidade dos fornecedores nacionais se tornarem internacionalmente competitivos. Os entrevistados mexicanos também defenderam que a Pemex deve competir, sendo mais empresa privada, com foco em eficiência e competitividade e também criticaram a política de conteúdo local, que não seria o foco da política do país. Expressaram a opinião de que mercado seria sinônimo de competência, e que a abertura do mercado mexicano seria importante, pois o monopólio teria criado muitos problemas para o país. Já os entrevistados noruegueses apoiaram a adoção das melhores práticas e a padronização de normas internacionais. Também defenderam que a Statoil deva ter foco exclusivo na obtenção de lucro e destacaram que as empresas norueguesas teriam se promovido no mercado internacional por inciativa própria, e não do governo norueguês.

O foco na combinação de instrumentos de política intervencionistas com instrumentos de política liberalizantes também apareceu nas entrevistas dos três países, mas foi notadamente predominante na Noruega. Os brasileiros combinaram estas duas modalidades de instrumentos apenas ao defender que a Petrobras tenha foco na eficiência e lucro, mas também na atuação como ferramenta de desenvolvimento para o país. Os mexicanos apontaram um pouco mais de exemplos nesse sentido, como a importância da nacionalização da indústria, mas sem se fechar para a possibilidade de contratar empresas estrangeiras quando necessário. Num primeiro momento, seria importante que ocorresse uma nacionalização da cadeia, incluindo mais empresas mexicanas, mas juntamente com objetivos de transferência de tecnologia e conhecimentos, para que estas empresas 
possam se internacionalizar num segundo momento. Já os noruegueses lembraram que os instrumentos adotados pela política deles no passado não podem mais ser utilizados atualmente. Disseram que a Statoil seria grande demais para ter foco apenas no lucro, e que deveria se preocupar também para o desenvolvimento do país. Mais importante do que a propriedade norueguesa das empresas seria a geração de empregos e o desenvolvimento de inovações em território norueguês. É importante que a legislação seja estável, mas ao mesmo tempo flexível e que se tenha um ritmo de exploração moderado, que permita uma exploração gradual e planejada. Os entrevistados da Noruega também lembraram a abertura de sua política para a participação de empresas estrangeiras, mas sob a condição de formação de joint ventures com empresas norueguesas e com a obrigação da realização de investimentos em $\mathrm{P} \& \mathrm{D}$ no país. E além de exportar produtos e serviços, um dos objetivos da política seria o de aprender com o mercado internacional.

Esta análise parece corroborar com a análise histórica, pois indica um ambiente mais favorável à uma política industrial intervencionista no Brasil, cuja política foi implementada por um governo com estratégia de desenvolvimento baseada no papel do Estado. Da mesma forma, o ambiente mexicano, onde a política foi implementada por um governo com estratégia de desenvolvimento baseada no mercado, parece mais favorável a uma política industrial liberalizante. Já os noruegueses demonstram ter uma percepção menos excludente de um tipo de política com relação ao outro, mas sem que isso signifique uma posição de meio termo. Apesar de os instrumentos de política industrial noruegueses não estarem diretamente relacionados com as estratégias de desenvolvimento de seus governantes, a política industrial da Noruega teve orientações muito bem definidas, ora com a predominância de políticas intervencionistas e ora com a predominância de políticas liberalizantes.

A forte atuação do Estado, mesmo nos períodos liberalizantes, e a permanente consideração aos interesses do mercado, mesmo nos períodos protecionistas, parece ter facilitado a adoção de políticas mais equilibradas, que apresentam características de intervenção combinadas com características de liberalização. Parece forte o início de que a adoção de políticas liberalizantes por governos intervencionistas e a adoção de políticas intervencionistas por governos liberalizantes seja um dos principais fatores por trás da qualidade da política industrial norueguesa. 
A comparação entre as menções sobre as formas de definição da política de cada país é uma das análises que, de maneira mais direta, irá ajudar a responder à pergunta desta pesquisa. Os entrevistados brasileiros disseram que o que serve de base para a definição da política industrial brasileira são critérios políticos e ideológicos. A definição da política não seria baseada no uso de medições, indicadores, avaliações e critérios técnicos. O diálogo com entre governo e empresas não parece ser um dos elementos utilizados para essa definição, pois há reclamações sobre este diálogo não gerar resultados práticos. O governo acha que as empresas não participam e as empresas acham que o governo não tem uma política industrial de verdade. Haveria falta de foco para a política e a necessidade de integração e transparência para uma governança mais eficaz. Predominaria uma lógica de competição e não a de cooperação, e as tomadas de decisão do governo parecem ser feitas com base em posicionamentos pré-definidos. Os mexicanos discordaram entre si com relação à utilização de mecanismos de consulta para a definição da política, pois alguns atendem que estes mecanismos funcionem muito bem, outros dizem que eles estão sendo criados e outros dizem que estes mecanismos não existem. Até a conclusão desta tese, a seção para sugestões no site da Cofemer informava que esta comissão não possui mecanismos ou ações de participação cidadã. Também houve discordância com relação a existência de transparência, prestação de contas, diálogo e mecanismos de monitoramento e avaliação da política. Sobre estes mecanismos, também foi destacada a necessidade de que eles não tenham compromissos políticos de nenhuma natureza. Disseram que empresas públicas como a Pemex seriam fonte de muito poder, tanto econômico quanto político, e levariam ao envolvimento de outros interesses na definição da política. Além disso, a adoção de um índice mínimo de conteúdo local teria sido uma forma do governo obter vantagem política junto às empresas nacionais.

Percebe-se a predominância de elementos políticos e ideológicos, sem a utilização de critérios técnicos, falta de transparência e com problemas de interação entre os atores, nas formas de definição da política no Brasil e no México. Já com relação à definição da política norueguesa, os entrevistados apontaram o excelente diálogo entre os atores como o principal elemento. De uma maneira geral, não haveria conflitos entre os interesses do governo e das empresas norueguesas, e o governo seria muito bom em ouvir os demais atores, pois seria verdadeiramente interessado em opiniões diferentes das suas. A postura equilibrada do governo norueguês e o foco no incentivo e na motivação, ao invés da punição, seriam outros elementos importantes para a orientação da política. Até hoje, os 
dez mandamentos criados na década de 1970 ainda serviriam de base para a indústria de petróleo e gás da Noruega. A transparência do governo seria fundamental para que não haja outros interesses na definição da política, mas os entrevistados concordaram ao afirmar que a falta de mecanismos integrados de monitoramento e avaliação seria o ponto fraco da política no país. Alguns valores mais amplos também foram apresentados e parecem estar relacionados com a forma norueguesa de definir sua política industrial. A tendência a interpretar desvantagem como oportunidade permite que obstáculos sejam vistos como uma chance para o desenvolvimento de capacidades. De acordo com os entrevistados, os noruegueses se baseiam na ideia de que para que se possa encontrar a reposta para qualquer questão, não se pode achar que já se sabe essa reposta de antemão e, por isso, seria fundamental perguntar para aprender. Outro ponto que indica uma postura de humildade entre os noruegueses foi a vinculação do sucesso da política do país à uma certa dose de sorte. A separação entre o governo norueguês e a Statoil seria outro elemento fundamental para a orientação da política, diferentemente dos governos brasileiro e mexicano, que não teria uma separação clara com relação às atividades da Petrobras e da Pemex, respectivamente. Uma diferença importante mencionada por entrevistados da Noruega foi a relação de cada país com a perspectiva de crescimento de suas receitas devido às atividades da indústria de petróleo. Em países como o Brasil, haveria o uso e comprometimento destas receitas antes mesmo de elas serem geradas, mas os noruegueses teriam adotado uma postura de cautela. Os entrevistados noruegueses também enfatizaram o fato de que a existência de corrupção faz com que qualquer política

seja fadada ao fracasso e levantaram dúvida sobre a possibilidade de replicação da experiência norueguesa em outros países.

\section{4 - Variação das Avaliações Objetivas}

O gráfico 114, abaixo, apresenta a comparação dos desvios entre a avaliação de cada entrevistado e a média das avaliações dos dois grupos de cada país, em cada uma das etapas da política industrial de petróleo e gás dos três estudos de caso. 


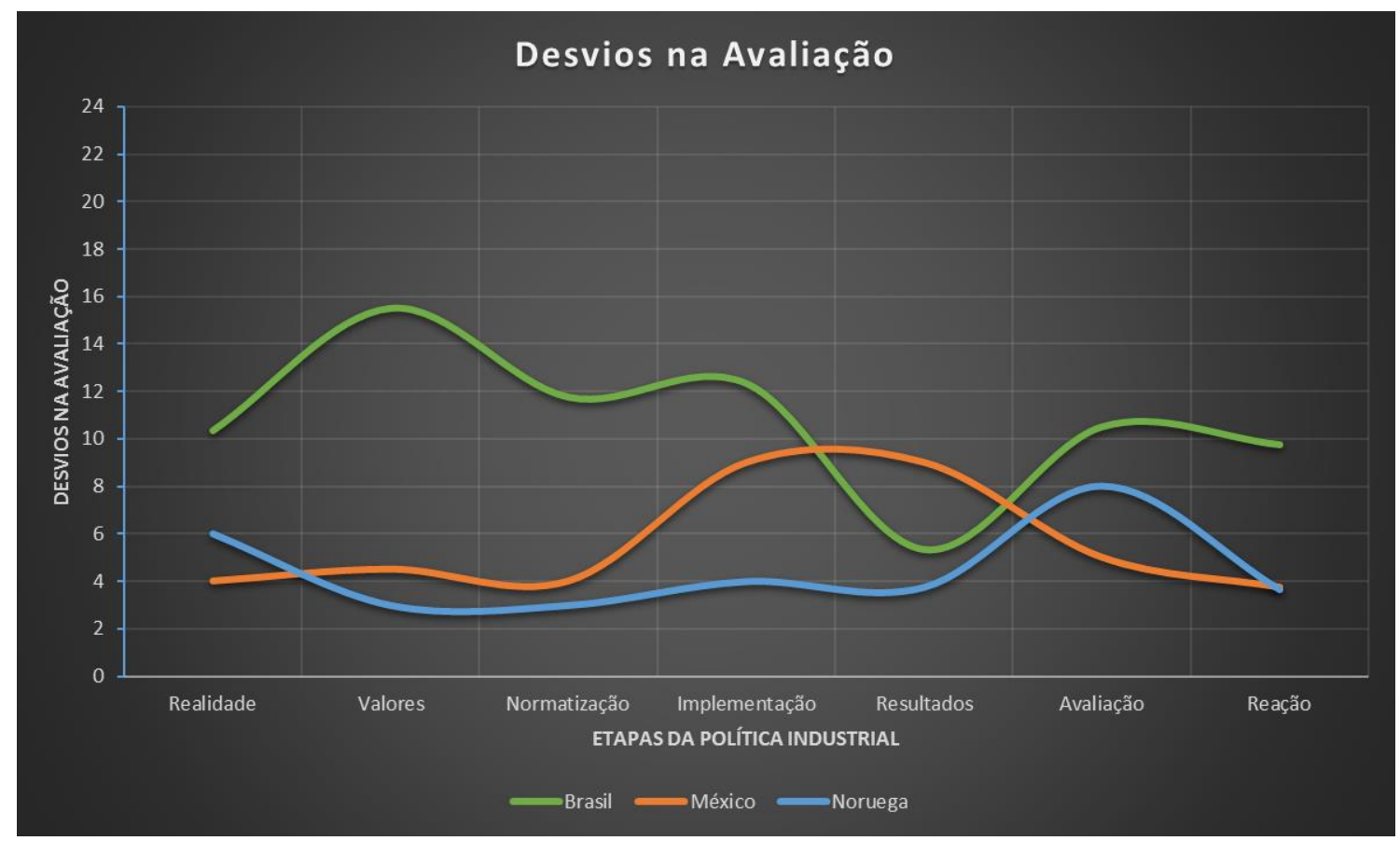

Gráfico 114 - Comparação dos desvios entre a avaliação de cada entrevistado e a média das avaliações dos dois grupos em cada país, para cada etapa da política industrial de petróleo e gás, nos três países.

Percebe-se neste gráfico que houve uma variação muito maior nas respostas dos entrevistados brasileiros, com relação às quatro primeiras etapas da política. Noruegueses e mexicanos apresentaram variações muito semelhantes e bem mais baixas que as variações brasileiras nestas etapas, com exceção das respostas sobre a implementação da política, onde os entrevistados mexicanos apresentaram uma variação intermediária. Com a forte diminuição na variação das respostas brasileiras sobre os resultados obtidos pela política, elas se aproximaram da variação das respostas norueguesas, deixando os entrevistados mexicanos com o maior desvio nas respostas sobre esta etapa. Já com relação aos mecanismos de monitoramento e avaliação, os desvios brasileiros voltam a ser os mais marcantes, e os mexicanos conseguem uma variação até mais baixa do que a dos noruegueses, que tiveram seu maior índice de divergências nas respostas sobre estes mecanismos. Na última etapa, sobre a reação aos dados de monitoramento e avaliação, os desvios entre as respostas do México e da Noruega voltam a ficar muito próximos e bastante baixos, enquanto as respostas do Brasil continuam com uma variação bem maior.

Este gráfico não responde diretamente à pergunta da pesquisa, mas oferece dados importantes para a análise. No capítulo anterior foram apresentados gráficos sobre a variação das respostas dentro de cada grupo, em cada país, que ajudaram na percepção 
sobre a homogeneidade das opiniões entre os representantes do governo e entre os representantes das associações empresariais. Na análise desta parte, como já explicado anteriormente, utiliza-se a média entre as todas as respostas dos dois grupos, o que permite uma percepção sobre a homogeneidade de opiniões entre todos os atores de cada país. Dessa vez, ao contrário da seção sobre a avaliação dos entrevistados, a relação será inversa, então, as etapas que apresentam uma variação maior estão relacionadas a uma maior divergência entre as opiniões dos entrevistados e entende-se que isso possa significar a existência de problemas com relação a estas etapas. Com base na literatura sobre a relação entre os atores envolvidos na definição de uma política, quanto menor for essa divergência, maior será o indicativo de uma relação saudável entre os atores, seja com relação à política que já está posta, como com relação àquela que ainda está por vir (LOWI, 1972; 1985; EASTON, 1953; 1957).

O gráfico 115, abaixo, apresenta a comparação entre o percentual de variação na avaliação de cada grupo sobre todas as fases da política industrial dos três países, nas respostas dos entrevistados dos dois grupos.

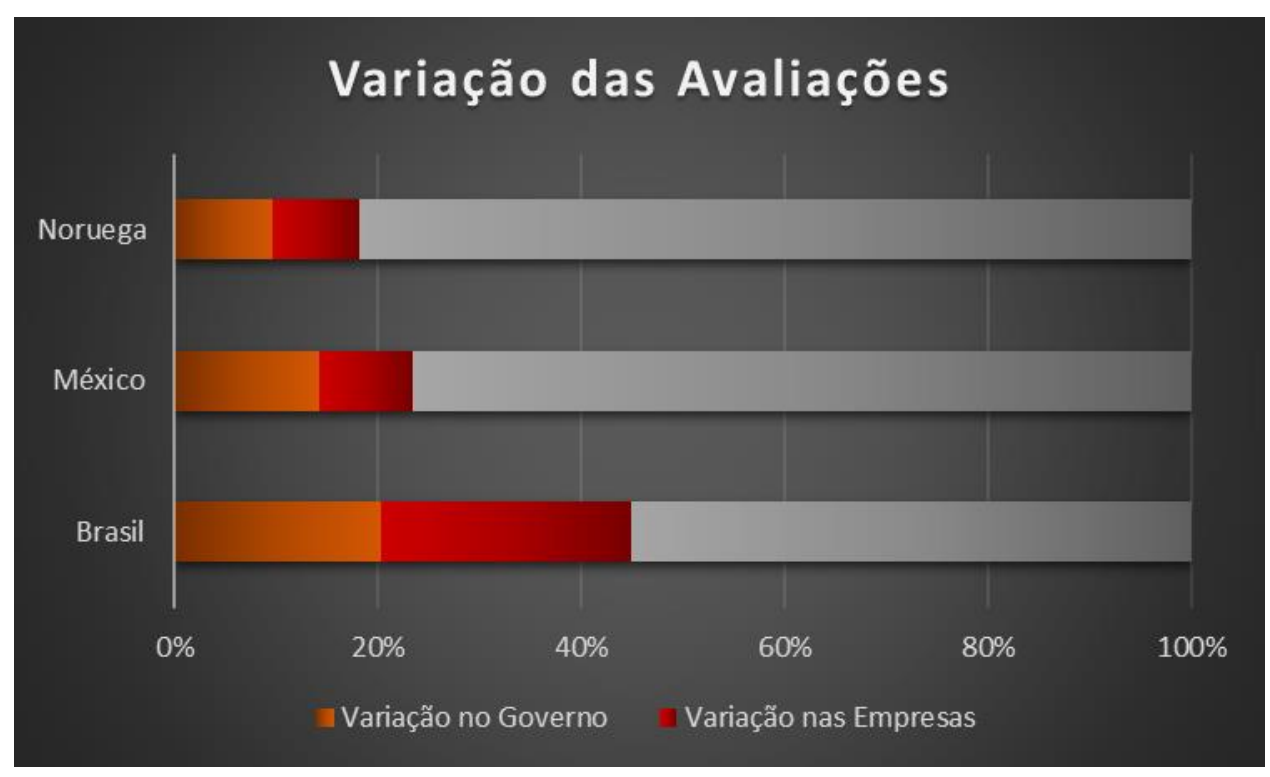

Gráfico 115 - Percentual de variação na avaliação de cada grupo, sobre todas as etapas da política industrial de petróleo e gás, em cada um dos três países.

Na comparação deste gráfico se percebe que o percentual de variação mais baixo foi o da Noruega, seguido de perto pelo México, apesar de ter havido uma variação consideravelmente maior entre os entrevistados do governo mexicano do que entre os entrevistados do governo norueguês. Já a variação total das repostas do Brasil foi muito 
superior às dos demais países, chegando a quase o dobro do percentual de variação apresentado pelos entrevistados mexicanos. Esta análise sobre o total das variações, funciona como um elemento a mais para a compreensão da qualidade do diálogo e interação entre os atores. Entende-se que num país onde haja um diálogo eficiente e o compartilhamento de informações e entendimentos sobre a política, a variação destas respostas deva ser baixa, enquanto países que apresentem problemas de comunicação e de percepção sobre a política devam apresentar variações mais altas.

\section{5 - Relação Entre Atores}

Para que se entenda melhor esta questão sobre o diálogo e a interação entre os atores, a última parte da análise comparativa trabalhará com as respostas abertas que os representantes do governo e das associações empresariais dos três países apresentaram sobre esta relação. Essa análise também será dividida entre as respostas sobre como um grupo de atores percebe os atores do outro grupo, as respostas sobre como cada grupo percebe a sua própria participação na política e as respostas sobre como cada grupo avalia a forma como a sua participação é recebida pelos atores do outro grupo. Para fundamentar esta comparação, utiliza-se tanto a literatura mencionada anteriormente sobre a relação entre os atores na definição da uma política (LOWI, 1972; 1985; EASTON, 1953; 1957), quanto a teoria que analisa mais especificamente o processo de retroalimentação da política, que de acordo com Luhmann (2012), deve ser definido com base em critérios relativos aos próprios sistema composto pela política industrial, e não por fatores externos a essa política. Ou seja, uma relação positiva entre os atores serve como construção da arena de disputa entre os atores envolvidos (LOWI, 1972; 1985), como indício sobre a qualidade da política à qual eles estão expostos (EASTON, 1953; 1957) e sobre a utilização de métricas e indicadores que correspondam à realidade enfrentada por estes atores, como forma de retroalimentação autopoiética que sirva de base para a definição da política industrial de cada país (LUHMANN, 2012). Ao final, será apresentada uma comparação entre o total dos dados sobre estas relações. 


\section{a) Percepção do Outro}

O gráfico 116, abaixo, apresenta a comparação entre o percentual de menções positivas e negativas nas respostas dos entrevistados dos três países, sobre a percepção que os atores de um grupo têm a respeito dos atores do outro grupo.

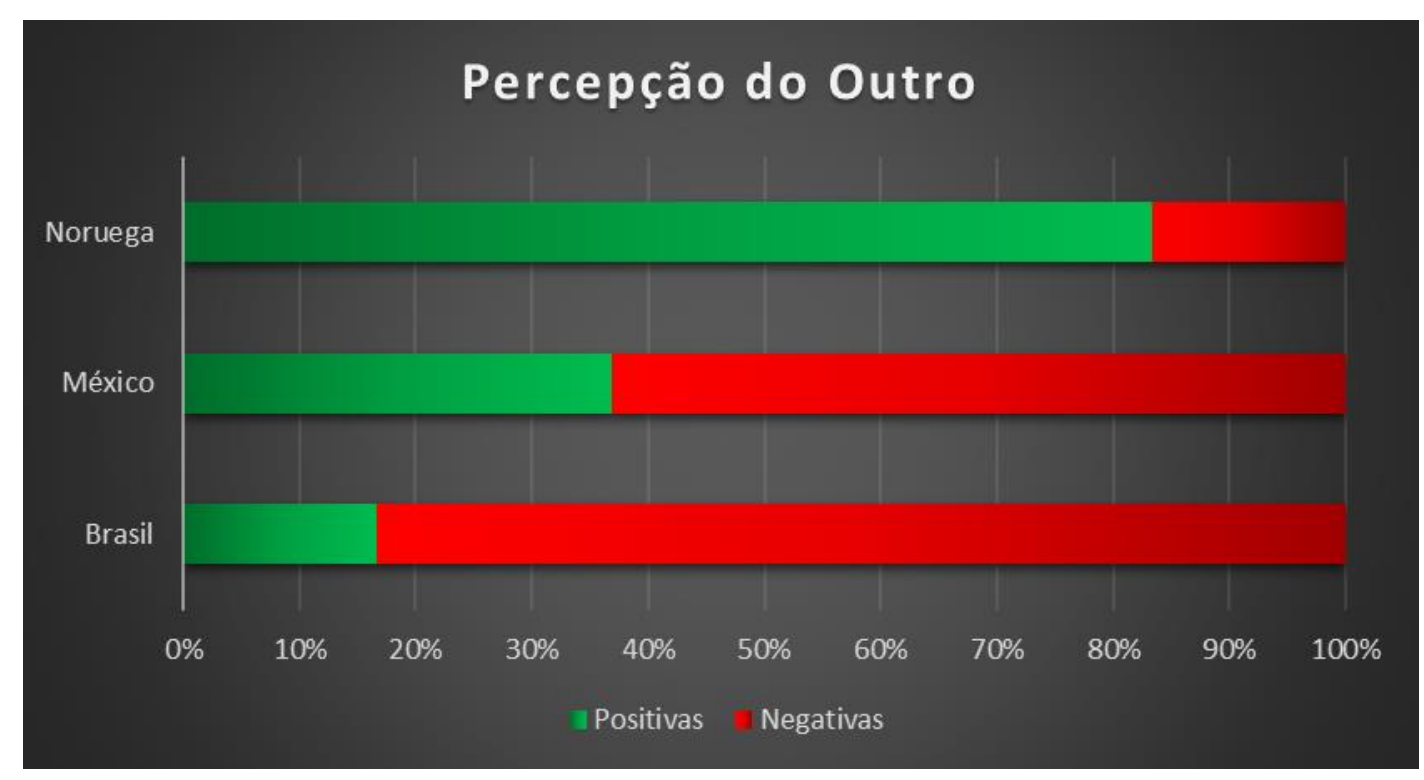

Gráfico 116 - Percentual de menções positivas e negativas nas respostas dos três países sobre a percepção que um grupo tem do outro.

Sobre a percepção que um grupo de atores tem do outro grupo, percebe-se que o percentual de menções positivas entre os entrevistados noruegueses é muito maior do que entre os entrevistados mexicanos e brasileiros, ficando acima dos $80 \%$. O percentual de menções positivas sobre o outro grupo de atores no México foi muito mais baixo, não chegando nem a 40\%. Enquanto o percentual brasileiro conseguiu ser ainda menor, não chegando nem a 20\%. Entende-se que a percepção do outro seja um fator importante na relação entre os atores. Percepções mais positivas devem indicar um melhor relacionamento entre eles, enquanto percepções mais negativas devem estar relacionadas com a existência de problemas entre os dois grupos, dificultando o trabalho em conjunto.

Entre os entrevistados brasileiros, os de governo dizem que as associações empresariais reclamam muito. As associações empresariais alegam que o governo tem dificuldades para implementar uma política, que é nacionalista e eleitoreiro e que adota políticas de governo, ao invés de políticas de Estado. Nas respostas dos entrevistados mexicanos foi dito que existem diferenças de interesses entre governo e empresas. $\mathrm{O}$ governo acha que as associações empresariais têm consciência de que a política industrial 
é um processo de longo prazo, mas percebe algumas reclamações por parte das empresas e entende que elas deveriam sair da lógica onde todo o setor funcionava em função da Pemex. As associações empresariais dizem que o governo tem uma boa capacidade de percepção da realidade, mas que lhe falta diálogo, transparência e prestação de contas. Também disseram que o governo estaria deixando de utilizar políticas de governo, para começar a utilizar políticas de Estado. Já entre os entrevistados noruegueses foi dito que existiria um acordo muito amplo entre governo e empresas, que teriam um bom diálogo e interação, pois compartilhariam dos mesmos interesses.

\section{b) Participação}

O gráfico 117, abaixo, apresenta a comparação entre o percentual de menções positivas e negativas nas respostas dos entrevistados dos três países, sobre a participação do seu próprio grupo na política industrial de petróleo e gás de seu país.

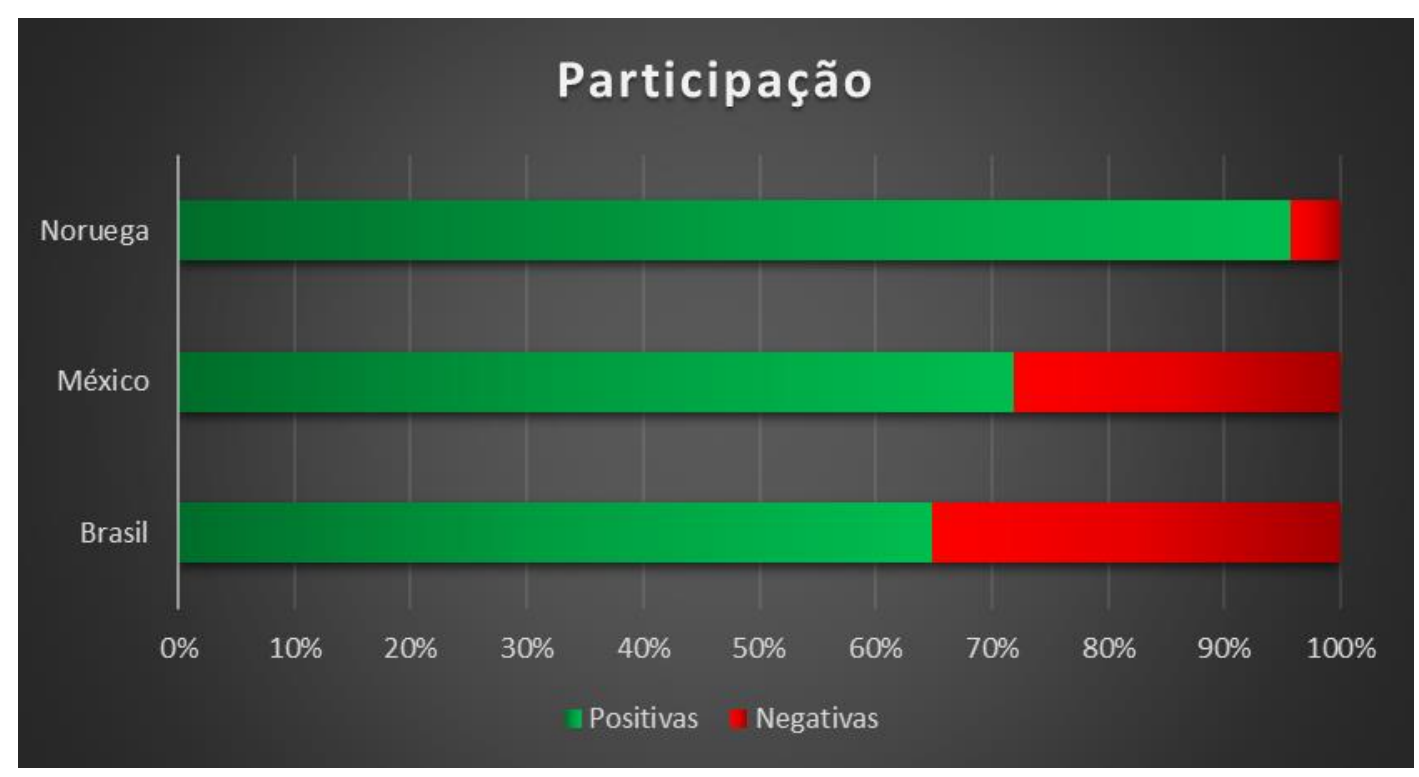

Gráfico 117 - Percentual de menções positivas e negativas nas respostas dos três países sobre a participação do seu próprio grupo na política industrial.

Sobre a participação na definição da política industrial de seu país, percebe-se que ocorre um percentual mais alto de menções positivas do que na análise anterior, especialmente no Brasil e no México. Os entrevistados brasileiros tiveram mais de $60 \%$ de menções positivas sobre suas próprias participações, enquanto os mexicanos tiveram 
mais de $70 \%$ e os noruegueses mais de $95 \%$. Mesmo que a avaliação sobre si próprio tenha uma tendência natural a ser melhor avaliada do que com relação a outros, pode-se perceber que mesmo assim existem problemas prejudicando essas avaliações, principalmente nos dois países latino americanos. Quanto melhor a percepção sobre a sua participação na política, se imagina que seja maior a chance dessa política ser definida com a participação dos atores envolvidos, e não de forma isolada pelo governo.

Os entrevistados brasileiros do próprio governo disseram sentir falta de uma maior influência, que existem problemas de diálogo interno e que teriam dificuldade de acesso a seus superiores. As associações dizem não participarem da definição da política, porque esta questão seria definida entre governo e Petrobras e que as discussões com o governo não são baseadas em nenhum tipo de métrica. Os entrevistados mexicanos divergiram entre si sobre a qualidade da comunicação dentro do governo. Também discordaram sobre o governo estar criando os mecanismos de participação necessários para a política, porque alguns entendem que o governo teria agido com pressa e sem planejamento. As próprias associações fizeram uma crítica a algumas associações empresariais mexicanas que seguem defendendo a manutenção de privilégios protecionistas no país. Já entre os noruegueses, foi dito que existe uma boa compreensão do papel de cada ator na política e um diálogo baseado na abertura e franqueza, que seria acima da média mesmo para os padrões europeus.

\section{c) Recebimento pelo Outro}

O gráfico 118, abaixo, apresenta a comparação entre o percentual de menções positivas e negativas nas respostas dos entrevistados dos três países, sobre o recebimento da sua participação pelo outro grupo, na definição da política industrial de petróleo e gás de cada país. 


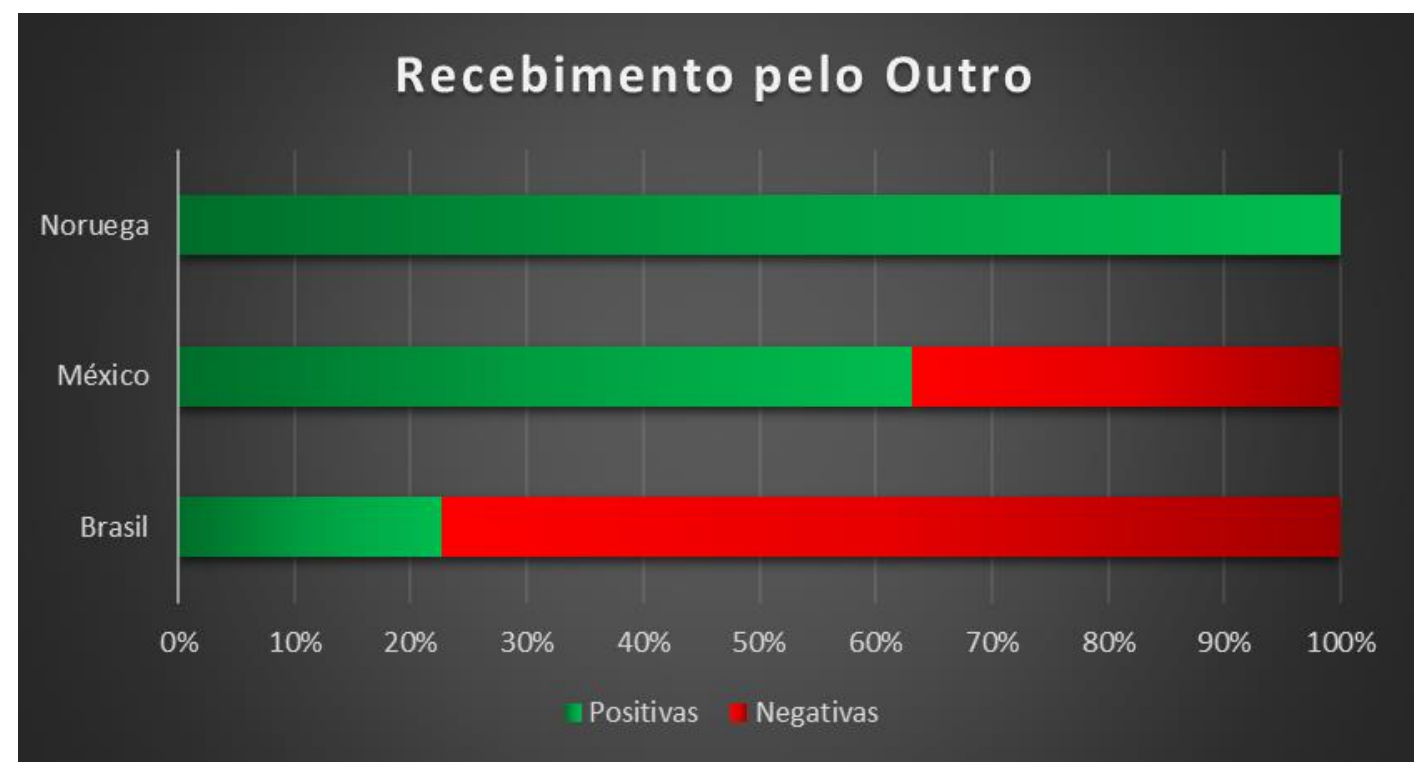

Gráfico 118 - Percentual de menções positivas e negativas nas respostas dos três países sobre o recebimento da sua participação pelo outro grupo.

Este provavelmente seja o gráfico que melhor responda à pergunta sobre o que serve de base para a política industrial norueguesa. A unanimidade na percepção positiva sobre a recepção do outro grupo à sua participação, é um forte indício de que este seja um elemento importante. Cruzando este dado com as informações obtidas nas análises anteriores, percebe-se objetivamente quão boa é a relação entre os atores noruegueses. Entende-se que esta questão envolva o atingimento prático de todo o objetivo da relação entre os atores e que, por isso, seja o elemento mais importante para a qualidade do processo de definição de uma política industrial.

Sobre este assunto, os entrevistados do governo brasileiro disseram não conhecer críticas por parte das empresas e que acreditam que elas poderiam ter investido e participado mais da política industrial de petróleo e gás brasileira. Também disseram que estas empresas ofereceriam resistência em todas as vezes que se tenta oferecer propostas de melhoras para a política. As associações empresariais brasileiras dizem que existe muito conflito de interesses dentro do governo e entre o governo e as empresas. Elas também manifestaram a impressão de as sugestões delas nunca são colocadas em prática pelo governo, que parece já ter suas decisões finais sempre pré-estabelecidas. Nas entrevistas do México, os entrevistados do governo manifestaram acreditar na existência de uma relação muito boa entre governo e empresas e que nunca teria havido tanto espaço para as empresas participarem de uma política industrial no país. Algumas associações 
têm a impressão de que suas opiniões são levadas em conta pelo governo, mas outras dizem que existem problemas, pois esse diálogo nunca seria colocado em prática. $\mathrm{O}$ governo seria às vezes mandatório, passando a ideia de que já tem sempre uma estratégia pré-definida e de ter sempre a última palavra. Já entre os entrevistados noruegueses, disseram que existem laços muito bons entre governo e empresas no país. Enquanto o governo demonstra apreço pela participação das empresas, as empresas valorizam a boa governança e a responsabilidade social. As empresas dizem sentir que têm voz forte nesse diálogo com o governo, pois a Noruega seria diferente de outros países, onde parece que o governo já tomou suas decisões antes mesmo de conversar com os demais atores.

\section{d) Interação de Atores}

O gráfico 119, abaixo, apresenta a comparação entre o percentual de menções positivas e negativas nas respostas dos entrevistados dos três países, sobre a interação entre os atores, na definição da política industrial de petróleo de cada país.

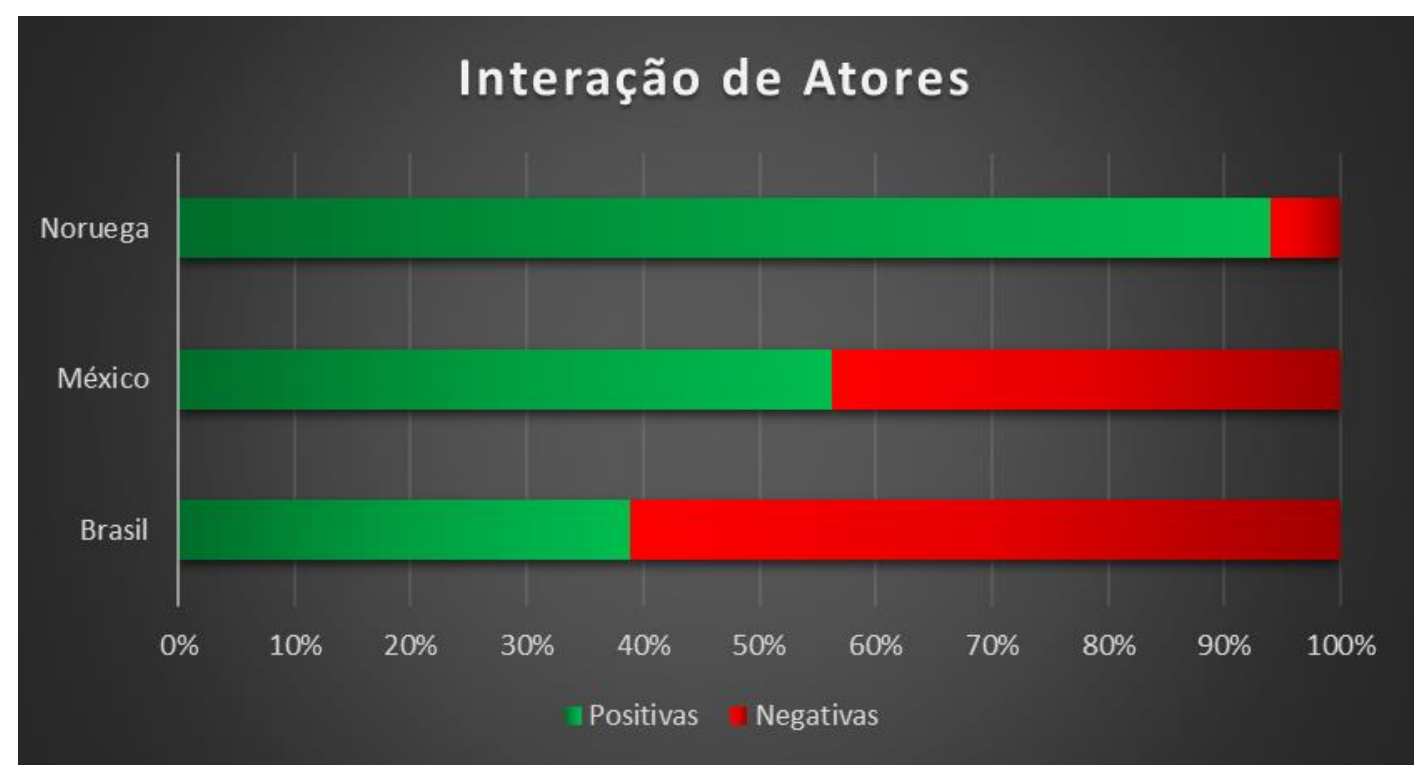

Gráfico 119 - Percentual de menções positivas e negativas nas respostas dos três países sobre a interação dos atores na definição da política industrial.

Aqui estão contabilizadas todas as menções positivas e negativas que todos os entrevistados fizeram sobre a relação deles com outros atores na definição da política industrial de seus países. Nas análises sobre o total e sobre os desvios nas avaliações de 
cada etapa da política, em diversos momentos a Noruega apresentou semelhanças com o Brasil, mas principalmente com o México. Para que estas semelhanças não tomem proporções maiores do que as que efetivamente têm, é importante que se tenha outros elementos, como a análise histórica e esta análise sobre a interação dos atores, servindo de contraponto e ajudando a esclarecer melhor onde estão as semelhanças e onde estão as diferenças entre estes três estudos de caso. 


\section{CONSIDERAÇÕES FINAIS}

Como resposta à pergunta de pesquisa deste trabalho, a literatura analisada e os dados coletados durante o trabalho de campo e através da revisão histórica sobre cada estudo de caso apontam para a negação da hipótese levantada no estudo de caso norueguês e para a sustentação da hipótese na análise dos casos brasileiro e mexicano. A definição da política industrial no Brasil e no México parece estar diretamente relacionada com a estratégia de desenvolvimento adotada por cada governo, enquanto a política industrial na Noruega parece ser definida com base em outros elementos, por não apresentar uma relação direta entre as variáveis analisadas.

As entrevistas em profundidade dos três países parecem reforçar esta conclusão, apresentando uma relação problemática entre os atores dos países latino americanos. Especialmente na análise sobre os elementos de interação entre os diferentes grupos, que quando analisados sob a perspectiva do referencial teórico utilizado, apontam para uma série de obstáculos e dificuldades que este tipo de relação acarreta. Seja na configuração das arenas onde ocorre a disputa entre os diferentes atores, seja na definição dos critérios técnicos que sirvam como indicadores de desempenho para a correta orientação da política ao longo do tempo. A literatura sugere e os casos analisados confirmam, que uma boa interação entre os atores está relacionada à existência de uma política que já apresente os resultados esperados e ao desenvolvimento de políticas que venham a alcançar os resultados desejados. Assim como, no sentido contrário, uma interação ruim entre os atores está relacionada a existência de uma política que ainda não apresenta os resultados esperados e ao desenvolvimento de políticas que não irão trazer os resultados desejados.

Os comentários feitos a respeito dos instrumentos de política industrial são contundentes sobre a existência de uma aceitação maior de políticas intervencionistas no Brasil do que nos demais países, apesar de existir uma considerável aceitação de políticas liberalizantes entre as associações empresariais brasileiras. No México, a aceitação maior parece estar relacionada com políticas liberalizantes. Já na Noruega prevalece a defesa de instrumentos que combinem elementos de intervenção e de liberação. Dessa forma, brasileiros e mexicanos indicam adotar um posicionamento polarizado e excludente com relação às diferentes alternativas de políticas industriais. No caso norueguês, mesmo existindo fases de política industrial bem definidas com relação à sua orientação 
intervencionista ou liberalizante, constata-se uma permanente combinação entre instrumentos intervencionistas e liberalizantes, que permitem um melhor aproveitamento das qualidades que ambos oferecem e que se minimize os efeitos negativos de cada um. Em comparação, as políticas brasileiras e mexicanas, ao negarem os instrumentos de política industrial com orientação oposta à estratégia adotada, abrem mão dos benefícios que podem ser alcançados com essa combinação. E ao se engajarem na defesa da orientação adotada em contraposição à orientação oposta, acabam negando também os efeitos negativos que a orientação adotada pode apresentar.

As respostas que comentaram sobre o que serve de base para definição da política industrial de petróleo e gás em cada país demonstram que existe uma forte influência de interesses políticos na definição das políticas brasileira e mexicana. Nestes dois países também há muitas reclamações sobre a falta de transparência e a impressão de que o governo tomaria decisões pré-definidas. O que reforça e ideia de que exista uma relação entre as estratégias de desenvolvimento adotadas por cada governo e a definição sobre a política industrial adotada, pois a diversidade de cada setor é tão grande que faz com que a utilização de estratégias pré-definidas não seja uma alternativa recomendável. Nas respostas dos entrevistados noruegueses, o grande destaque dado à excelente relação e diálogo entre os atores leva a entender que esta relação seja o principal elemento de definição da política de petróleo e gás da Noruega e com o seu considerável sucesso.

Os comentários feitos sobre a percepção que se tem sobre os outros atores e sobre o recebimento oferecido aos atores que participam da política parecem exemplificar a ideia de que predomina uma relação de competição entre os atores brasileiros e os atores mexicanos, e uma relação de cooperação entre os atores noruegueses. Os problemas enfrentados pelos dois países latino americanos nestes temas podem ser vistos como consequência da forma utilizada pelos governos desses países para definirem suas políticas industriais, sem levar em consideração a opinião dos outros atores. Por outro lado, esta relação problemática também pode ser entendida como um obstáculo para qualquer tentativa de aprimoramento nessas políticas. Dessa forma, a competição entre atores pode assumir o papel de efeito, quando analisada em relação à realidade que está dada, assim como pode assumir o papel de causa, quando analisada com relação à realidade que ainda está por vir. 
Nenhuma das análises desta pesquisa foi realizada de forma a procurar exaurir o debate sobre qualquer dos temas levantados. A transversalidade da análise fez com que fosse necessária uma abordagem mais ampla, que não se detivesse em especificidades que não fossem diretamente relacionadas com o objeto desta pesquisa. Devido a isso, esta pesquisa procura servir também de base para pesquisas futuras mais especializadas, que concentrem seu foco de forma isolada nos diversos elementos que compõem a análise realizada. Uma análise histórica mais completa - se aprofundando em questões sobre as estratégias de desenvolvimento adotadas pelos governos ao longo da história e sobre os instrumentos de política industrial adotados por eles - necessita de um estudo específico, que verifique registros históricos mais abrangentes do que os que foram utilizados aqui. A amostra utilizada também foi muito pequena, sendo importante que novos estudos utilizem mais respondentes entre os representantes dos governos e das empresas, para que os dados sejam mais representativos. A inclusão de outros grupos de respondentes, como representantes da classe trabalhadora e do meio acadêmico, certamente acrescentaria bastante, trazendo uma maior diversidade de percepções. $\mathrm{O}$ aprimoramento dos instrumentos de pesquisa também seria interessante, uma vez que a experiência com essas primeiras pesquisas revelou a existência de perguntas desnecessárias, mal definidas ou apresentadas, e que poderiam ser agrupadas de uma maneira mais eficiente para a pesquisa. Com o aumento da amostra e o aprimoramento dos instrumentos, seria possível a utilização de métodos estatísticos mais complexos e precisos para o cruzamento e apresentação dos dados. Sendo também fundamental destacar a importância da pesquisa continuada, que permita a formação de séries históricas, indispensáveis para comparações e análises de dados mais precisas sobre as políticas e os processos de desenvolvimento.

Assim como é importante esta definição clara e objetiva sobre as fronteiras deste trabalho, apresentando o que não faz parte dos objetivos desta pesquisa neste momento, também é de fundamental importância que estejam bem destacadas as conclusões obtidas ao longo desta tese de doutorado.

A primeira e mais fundamental de todas é a conclusão de que, mais importante do que identificar qual a melhor estratégia de desenvolvimento ou qual a melhor política industrial a ser adotada, é que a orientação da política seja feita com base nela mesma (ou seja, em elementos internos ao contexto da política industrial) e não em objetivos externos. Essa ideia parece estar alinhada com o conceito de sistemas autopoiéticos de Luhmann (2012). Dessa forma, pode-se evitar que a política seja definida com base na 
estratégia de desenvolvimento de cada governo, que pode sofrer grandes variações sempre que ocorre a troca de um mandato, expondo a política industrial a rupturas que inviabilizam o atingimento de objetivos de longo prazo, que são fundamentais para a eficiência de uma política industrial que vise o desenvolvimento de um país. A capacidade de auto-definição da política parece ser fundamental para o seu sucesso, uma vez que não existe uma estratégia única que sirva como modelo de sucesso para todos os casos. Nem mesmo uma simples posição de meio termo, ou de equilíbrio entre o papel do Estado e do mercado, parece servir como uma receita de sucesso. A análise sobre a história da política norueguesa indica que ela não se caracteriza por uma postura permanentemente equilibrada entre estas duas orientações estratégicas. Existem momentos onde predomina a intervenção estatal, outros onde predomina o papel dos mecanismos de mercado (inclusive seguindo a sequência indicada por List [1986], onde se começa com um período de liberalização, depois se passa a um período de intervenção estatal para o desenvolvimento da indústria nascente, e se volta a um período de liberalização, quando se atinge a maturidade dessa indústria), além de outros que apresentam combinações intermediárias das mais diversas. Com isso, se faz necessária a correção de rumos ao longo do processo de desenvolvimento da política industrial, exigindo um mecanismo eficiente de avaliação e de reação aos resultados obtidos nesta avaliação.

A segunda conclusão que se depreende do trabalho aqui realizado é a de que a separação da política industrial em subsistemas, relativos às diferentes etapas que compõem uma política, parece ser uma ferramenta importante para trabalhar com a complexidade que é característica de um objeto de pesquisa tão amplo. Durante as pesquisas de pré-campo, ficou marcante a dificuldade apresentada para que fosse possível identificar sobre o que tratavam as críticas e os elogios feitos à política industrial brasileira, que eram apresentados pelos entrevistados brasileiros de forma não sistematizada, dificultando uma análise mais objetiva. Essa sistematização em subsistemas permite a redução da complexidade do objeto de pesquisa para que seja possível a sua análise neste trabalho, mas também pode servir de base para uma melhor compreensão dos atores envolvidos sobre a realidade à qual eles estão expostos. Essa compreensão mais precisa e objetiva sobre onde estão os defeitos e qualidades da política, de acordo com o exemplo norueguês, parece ser um dos alicerces para um diálogo mais efetivo entre estes atores e uma consequente melhor interação entre eles. 
A terceira conclusão trazida pela pesquisa é a ideia de que uma boa relação entre os atores pode ser, também, mais importante do que a definição sobre quais sejam os instrumentos de política industrial mais indicados. Isso porque, mesmo que se adote instrumentos de forma equivocada, a boa relação entre os atores é uma excelente ferramenta para que este equivoco possa ser identificado através do diálogo e solucionado através da participação colaborativa destes atores. Assim como muitas das análises anteriores, esta conclusão utiliza como base teórica a abordagem sobre arenas políticas e a abordagem sistêmica. Além disso, essa boa relação pode estar relacionada com uma postura mais equilibrada do governo, como consequência de uma maior consciência sobre a importância de se ouvir e levar em consideração diferentes opiniões.

Como quarta conclusão deste trabalho, essa postura equilibrada do governo, assim como a boa relação entre os atores, parece ser a base para a adoção de instrumentos industriais capazes de equilibrar os aspectos positivos e negativos da intervenção estatal e da liberalização do mercado. Este equilíbrio parece ser possível apenas num ambiente onde a relação entre os atores aconteça de forma saudável e positiva. A adoção de instrumentos de política capazes de combinar e equilibrar a atuação do Estado e do mercado da melhor maneira possível, conforme cada caso, parece ser um dos fundamentos para uma política industrial de sucesso, por ser a maneira de se conseguir aproveitas as vantagens que cada estratégia oferece e procurar minimizar os efeitos negativos de cada uma.

O quinto elemento que resulta da análise realizada se refere aos comentários recorrentes sobre a inexistência de uma verdadeira política industrial no Brasil ou no México. Esta ausência de uma política para o setor industrial pode ser entendida como uma das consequências da adoção de políticas de governo, em detrimento de políticas de Estado e da prevalência de valores e interesses de curto prazo, ao invés de valores e interesses de longo prazo, como ocorre na Noruega. Mais uma vez, o problema de pesquisa demonstra a sua aplicação prática, uma vez que nestes casos a política industrial parece ser definida por elementos externos a ela, saindo novamente do modelo de sistema autorreferente (LUHMANN, 2012), que é utilizado como referência nessa pesquisa.

Uma sexta conclusão, que merece bastante destaque é o fato de a transparência e a prestação de contras sobre a política ter sido um dos temas mais levantados pelos entrevistados de todos os países. Chamou a atenção o fato de que, enquanto mexicanos e 
noruegueses destacam a importância de se combater a ocorrência de atos de corrupção, diversos entrevistados brasileiros mencionarem que a corrupção não seria um elemento importante para a definição da política. Um dos entrevistados noruegueses chegou, inclusive, a mencionar que a existência de corrupção inviabilizaria o sucesso de qualquer política. Esta diferença de opiniões sobre um tema tão importante é bastante interessante, principalmente ao se considerar o atual contexto da indústria de petróleo brasileira, onde estão sendo investigados grandes esquemas de corrupção.

A não utilização de critérios técnicos para o debate e definição sobre as políticas brasileira e mexicana também é um elemento que merece destaque e serve como sétima conclusão desta tese. A Noruega, mesmo que baseie seu debate em métricas mais bem definidas, assim como os outros dois países, não possui um sistema integrado de monitoramento e avaliação para a sua política industrial. Estes mecanismos seriam a forma ideal para que uma política industrial seja baseada em elementos relacionados a ela mesma, ou ao seu meio, e não em questões externas, como interesses políticos e eleitorais.

O estabelecimento destes mecanismos como ferramenta de retroalimentação da política, em conjunto com práticas de transparência e prestação de contas, pode ser fundamental, mesmo entre os noruegueses, para que se garanta uma oitava conclusão, que não foi diretamente analisada nesta pesquisa, mas que aparece como uma perspectiva muito rica e interessante para futuras análises. Utilizar estes elementos como base para a política industrial de cada país, pode ser um importante instrumento de legitimação desta política perante os atores envolvidos e toda a sociedade. Os governos do Brasil e de México já enfrentam contestações, seja da classe industrial, seja dos cidadãos, que têm organizado grandes manifestações de repúdio às políticas adotadas por seus governos.

Alguns trabalhos apontam para a dificuldade de implementação de sistemas de monitoramento e avaliação em países com restrições orçamentárias (KASAHARA; BOTELHO, 2016). Mesmo reconhecendo as dificuldades geradas por estas restrições, uma nona conclusão deste trabalho indica que, justamente nestes casos, é que a necessidade desses sistemas seria ainda mais importante. Quanto mais limitado um orçamento, mais importante que ele seja direcionado para as questões mais importantes, que tragam os maiores retornos. Mas para que se saiba quais são as questões mais importantes, são necessários indicadores precisos e sistemas integrados de monitoramento e avaliação. Mesmo a Noruega, que não enfrenta problemas desta 
magnitude, pode se beneficiar da adoção destes mecanismos como forma de se prevenir para cenários mais complexos do que os que foram enfrentados pelos noruegueses até aqui. A queda do preço do barril de petróleo e os conflitos políticos e migratórios que vêm se intensificando em muitos países do mundo, podem estar construindo um cenário desafiador até mesmo para a realidade norueguesa. Seja para o caso brasileiro, mexicano ou norueguês, entende-se que este trabalho possa contribuir com alguns elementos que ajudem na construção de mecanismos integrados de monitoramento e avaliação para uma política industrial de petróleo e gás que se baseie nela mesma, e não em interesses externos, o que parece ser a base para que qualquer política apresente os resultados desejados.

Como décima conclusão a ser apresentada, há que se lembrar sobre a desconstrução da lógica positivista, conforme se analisa o referencial teórico e os dados empíricos. Dessa forma, rompe-se com uma pretensa busca por verdades absolutas e universais, e se transfere o foco para a responsabilização do processo de tomada de decisão na definição de políticas. Seguindo esta mesma linha de questionamento à lógica positivista, encerra-se este trabalho, com o destaque à questão levantada durante as entrevistas, sobre a possibilidade ou não de replicação da experiência norueguesa em outros países. As dificuldades e os obstáculos enfrentados durante esta pesquisa reforçam a ideia de que qualquer tentativa de comparação significa um desafio metodológico. Olhar para a Noruega com o objetivo de encontrar respostas prontas, que possam ser copiadas em outras realidades, pode ser o primeiro passo para uma análise equivocada. Utilizar o exemplo norueguês para justificar a adoção de políticas que, na verdade, representam interesses que estão fora do âmbito destas políticas, é muito diferente de aprender com a experiência norueguesa. No mesmo sentido, acreditar que exista uma estratégia de desenvolvimento que seja sempre a mais adequada, independentemente das diferenças entre cada caso, se parece mais com um ato de fé, do que de razão. Como disse um dos entrevistados noruegueses tentando explicar a cultura de seu país: para que se possa encontrar a resposta de qualquer pergunta, é fundamental que não se tenha a ilusão de que já se sabe a resposta de antemão. 


\section{REFERÊNCIAS}

AGÊNCIA BRASILEIRA DE DESENVOLVIMENTO INDUSTRIAL. Referências para a Política Industrial do Setor de Petróleo e Gás: O Caso da Noruega. ABDI, Brasília, 2011.

ALMEIDA, M. Desafios da real política industrial brasileira do século XXI. Texto para discussão, n.1452. Brasília:IPEA, 2009.

ALMEIDA, M. F.; OLIVEIRA, R. L.; SCHNEIDER, B. R. Política industrial e empresas estatais no Brasil: BNDES e Petrobras. In: GOMIDE, A. A.; PIRES, R. (edit.). Capacidades estatais e democracia: a abordagem dos arranjos institucionais para análise de políticas públicas. Brasília: IPEA, p. 323-347, 2014.

ANDRÉS, L. A.; GAUSCH, J. L.; HAVEN, T.; FOSTER, V. The Impact of Private Sector Participation in Infrastructure: lights, shadows, and the road ahead. Latin American Development Forum Series. Washington: Inter-American Development Bank, 2008 .

ARIFFIN, N.; BELL M. Patterns of subsidiary-parent linkages and technological capability-building in electronics TNC subsidiaries in Malaysia. In: JOMO, K. S.; FELKER, G. (eds.). Industrial technology development in Malaysia. London : Routledge, 1996. p. 150-90.

BAER, W. The Brazilian Economy: growth and development. 6. ed. Boulder, CO: Lynne Rienner Publishers, 2008.

BAIN \& COMPANY e TOZZINIFREIRE ADVOGADOS. Estudos de alternativas regulatórias, institucionais e financeiras para a exploração e produção de petróleo e gás natural e para o desenvolvimento industrial da cadeia produtiva de petróleo e gás natural no Brasil: relatório consolidado. 1.ed. São Paulo, 2009. 236 p. ISBN $9788562690013 \quad$ Disponível em: <http://www.bndes.gov.br/SiteBNDES/export/sites/default/bndes_pt/Galerias/Arquivos/ empresa/pesquisa/chamada1/RelConsol-1de6.pdf> Acesso em 23 ago. 2016.

BELL, M. "Learning" and the accumulation of industrial technological capacity in developing countries. In: KING, K; FRANSMAN, M. (eds.). Technological capability in the Third World. London : Macmilan, 1984.

Technical change in infant industries: a review of the empirical evidence.

SPRU, University of Sussex, 1982. 
BELL, M.; PAVITT, K. Technological accumulation and industrial growth: contrasts between developed and developing countries. Industrial and corporate change, 2(2):157-211, 1993.

BELL, M. ROSS-LARSON, B.; WESTPHAL, L.E. Assessing the performance of infant industries. Washington DC, World Bank, 1984 (World Bank Staff Working Papers, n. 666.)

BERGER, S. Making in America: from innovation to market. Cambridge: MIT Press, 1989

BERMúdeZ, A. J. La Política Petrolera Mexicana. In: Cuadernos de Joaquín Mortiz, México, 1976.

BRESSER-PEREIRA, L.C. Globalização e Competição: porque alguns países emergentes têm sucesso e outros não? Campus: Rio de Janeiro, 2010.

CAPLAN, B. Why I am not an Austrian Economist. Unpublished manuscript, Department of Economics: George Manson University, 2003. Disponível em: <http://econfaculty.gmu.edu/bcaplan/whyaust.htm>

CÁRDENAS, L. Mensaje a la Nación, Decreto Expropiatorio, Gobierno de México, México, 1938.

CARDOSO, F. H.; GRAEFF, E. Political Leadership and Economic Reform: the Brazilian experience in the context of Latin America. In: SANTISO, J.; DAYTONJOHNSON, J. (Org). The Oxford Handbook of Latin American Political Economy. Oxford: Oxford University Press, 2012.

CHANG, H. J. The Political Economy of Industrial Policy. Great Britain: Macmillan, 1994.

Kicking away the ladder: development strategy in historical perspective. Londres: Anthem Press, 2002.

COUTINHO, L.; FERRAZ, J. C.; NASSIF, A.; OLIVA, R. Industrial Policy and Economic Transformation. In: SANTISO, J.; DAYTON-JOHNSON, J. (Org). The Oxford Handbook of Latin American Political Economy. Oxford: Oxford University Press, 2012.

DOSI, G. The microeconomic sources and effects of innovation. An assessment of some recent findings. SPRU, Univesity of Sussex, 1985. (DRC Discussion Paper n. 33.) 
The nature of the innovative process. In DOSI, G.; FREEMAN, C.; NELSON, R.; SILVERBERG, G; SOETE, L. (eds.). Technical change and economic theory. London : Pinter, 1988.

DRESSER, D. Mexico: Dysfunctional Democracy in DOMÍNGUEZ, J. I. e SHIFTER, M. Constructing Democratic Governance in Latin America, 3. ed. Baltimore: Johns Hopkins U. P., p. 242-263, 2008.

EASTON, D. The Political System: an inquiry into the state of political science. New York: Alfred A. Knopf, 1953.

An Approach to the Analysis of Political Systems. In: World Politics, 9(3), p. 383-400, 1957.

A Framework for Political Analysis. Englewood Cliffs, New Jersey: Prentice-Hall, 1965.

EKELUND, R. B., Jr.; HÉBERT, R. F. A history of economic theory and method. 4th ed. Waveland Press: Long Grove, 1997.

ENGEN, O. A. The development of the Norwegian petroleum innovation system: a historical overview. In: FAGERBERG, J. E.; MOWERY D. C.; VERSPAGEN, B. (Org.). Innovation, path dependency and policy: the Norwegian case. Oxford: Oxford University Press, 179-207, 2009.

EVANS, P. Embedded Autonomy: State and industrial transformation. Princeton: Princeton University, 1995.

Constructing the 21st century Developmental State: Potentialities and Pitfalls. (pp. 37-58) In EDIGHEJI, O. (ed). Constructing a Democratic Developmental State in South Africa: Potentials and Challenges. HSRC Press: Capetown, South Africa, 2010.

FEDERAÇÃO DAS INDÚSTRIAS DO ESTADO DA BAHIA. A Política Brasileira de Conteúdo Local para o Setor Petróleo e Gás: Análise e Sugestões de Aperfeiçoamento. [Bahia]: [s.n.], 2015. Disponível em: <http://sinaval.org.br/wpcontent/uploads/Relatorio_Final_COnteudo_local_FIEB-v05-02-2015.pdf >. Acesso em: 23 ago. 2016. 
FELIPE, E. S. Mudanças Institucionais e Estratégias Empresariais: a trajetória e o crescimento da Petrobras a partir da sua atuação no novo ambiente competitivo (19972010). 2010. 322 f. Tese de Doutorado (Doutorado em Ciências Econômicas) - Instituto de Economia. Universidade Federal do Rio de Janeiro, Rio de Janeiro, 2010.

FERRAZ, J. C.; KUPFER, D. e MARQUES, F. Industrial policy as an effective development tool: Lessons from Brazil. In: SALAZAR-XIRINACHS, J. M.; NÜBLER, I.; KOZUL-WRIGHT, R. (Org.). Transforming Economies: Making Industrial Policy Work for Growth. Jobs and Development. Genebra: International Labour Office, v. 1. p. 291-305, 2014..

FIGUEIREDO, P. C. N. Aprendizagem tecnológica e performance competitiva / Paulo N. Figueiredo; tradução Luiz Alberto Monjardim. - Rio de Janeiro : Editora FGV, 2003.

FLEURY, A.C.C. Análise a nível de empresa dos problemas tecnológicos do setor de máquinas- ferramentas. São Paulo : FCAV, 1977. mimeog.

The technological behavior of state-owned enterprises in Brazil. ILO, World Employment Programme Research, 1985. (Working Paper.)

FREEMAN, C. Continental, national and sub-national innovation systems: complementarity and economic growth. Research Policy, 31, 191-211, 2002.

FRIEDMAN, M. A Theoretical Framework for Monetary Analysis'. In: GORDON, R. (ed.) Milton Friedman's Monetary Framework: a debate with his critics. Chicago: University of Chicago Press, 1970.

GÁlVEZ, A. La industria petrolera en México. Una Crónica. III. Crisis del crecimiento y expansión de Petróleos Mexicanos (1970-1988). México: Petróleos Mexicanos, 1988.

GIRVAN, N.P.; MARCELLE, G. Overcoming technological dependency: the case of Eletric Arc (Jamaica) Ltd.: a small firm in a small developing country. World Development, 18(1):91-107, 1990.

GORTARI, C. S. La década perdida. México: Debolsillo, 1988 .

GRACIDA ROMO, E. M. El programa industrial de la Revolución. Premio Anual de Investigación Económica Maestro Jesús Silva Herzog. 1. ed. México: Instituto de Investigaciones Económicas, : Universidad Nacional Autónoma de México. 1994. 
GREENAWAY, D. \& MILNER, C. Trade and Industrial Policy in Developing Countries: a manual of policy analysis. London: Macmillan, 1993.

HAYEK, F. A. The Pure Theory of Capital. London: Routledge \& Kegan Paul, 1941.

HERBERT-COPLEY, B. Technical change in Latin American manufacturing firms: review and synthesis. World Development, 18(11):1.457-69, 1990.

Technical change in African industry: reflections on IDRC-supported research. Canadian Journal of Development Studies, 13(2):231-49, 1992.

HOBDAY, M. Innovation in East Asia: the challenges to Japan. Aldershot : Edward Elgar, 1995.

HUMPHREY, J. Fazendo o milagre. São Paulo : Vozes, 1982.

HWANG, H-R. Organisational capabilities and organisational rigidities of Korean Chaebol: case studies of semi-conductor (Dram) and personal computer (PC) products. SPRU, University of Sussex, 1998. (PhD Thesis.)

KASAHARA, Y.; BOTELHO, A. J. J. Catching up and Falling behind: An Appraisal of Brazilian Industrial Policy in the Twenty-First Century. ERLACS, (101), pp. 97-109, 2016. DOI: http://doi.org/10.18352/erlacs.10141

KATZ, J. Domestic technological innovations and dynamic comparative advantages: further reflections on a comparative case-study program. In: ROSENBERG, N; FRISCHTAK, C. (eds.). International technology transfer: concepts, measures and comparisons. New York : Praeger, 1985.

. Domestic technology generation in LCDs: a review of research findings. In: KATZ, J. (ed.). Technology generation in Latin America manufacturing industries. New York : St. Martin, 1987.

KEYNES, J. M. The General Theory of Employment, Interest and Money. London: Macmillan, 1936. 
KIM, D. Crisis construction and organisational learning: capability building in catchingup at Hyundai Motor. In: Hitotsubashi-Organisation Science Conference. Tokyo, Oct. 1995.

. The dynamics of Samsung's technological learning in semiconductors.

California Management Review, 39(3):86-100, 1997a.

Immitation to innovation: the dynamics of Korea's technological learning. Boston MA : Harvard Business School Press, 1997b.

KING, L. P.; SZNAJDER , A. The State-Led Transition to Liberal Capitalism: Neoliberal, Organizational, World-Systems, and Social Structural Explanations of Poland's Economic Success.” American Journal of Sociology, 112(3), 751-801, 2006.

KNIGHT, A. Salinas and Social Liberalism in Historical Context. In: Dismantling the Mexican State? AITKEN, R. et al. Londres: Macmillan, 1996.

KURTZ, M. J.; BROOKS, S. M. Embedding Neoliberal Reform in Latin America. World Politics, 60(02), pp. 231-280, 2008.

KUSEK, J. Z.; RIST, R. C. Ten steps to a results-based monitoring and evaluation system: a handbook for development practitioners. Washington: The World Bank, 2004.

KUZNETSOV, Y.; SABEL, C. New Open Economy Industrial Policy: Making Choices without Picking Winners. Prem Notes; No. 161.Washington, DC: World Bank, 2011.

LALL, S. Learning to industrialise: the acquisition of technological capability by India. London : Macmillan, 1987.

LEITE, A. D. A Energia do Brasil. 2. ed. rev. e atual. Rio de Janeiro: Elsevier, 2007.

LERPOLD, L. Reputation by Association. Exploring alliance formation and organizational identity adaptation. Tese de Doutorado (Doutorado em Filosofia - PhD). Stockholm: Stockholm School of Economics, 2003.

LEVY, D.; BRUHN, K.; ZEBADUA, E. México: The Struggle for Democratic Development. Los Angeles, University of California Press, 2001. 
LIN, J.; CHANG, H.-J. Should Industrial Policy in Developing Countries Conform to Comparative Advantage or Defy it? A Debate Between Justin Lin and Ha-Joon Chang. Development Policy Review, 27(5), 483-502, 2009.

LIST, F.G. Sistema nacional de economia política. São Paulo: Abril Cultural, 1986.

LITTLE, I.M.D. Economic Development: Theory, Policies and International Relations. New York: Basic Books, 1982.

LLÓRENTE, J. S. et al. Eı Petróleo en Veracruz, México, PEMEX, 1988.

LOHMANN, J. Energy, Environment and Development In: Mexico, EED Report 1990/16, 1990.

LOWI, T. J. Four Systems of Policy, Politics, and Choice. Public Administration Review, v.32, n.4, p. 298-310, jul/aug., 1972.

The State in Politics: the relation between policy and administration. In:

NOLL, R. G. (ed.) Regulatory Policy and the Social Sciences. University of California Press, p. 67-105, 1985.

LUHMANN, N. Society, Meaning, Religion: based on self-reference. Sociological Anal, vol. 46, n. 1, pp. 5-20, Oxford University Press, 1985.

The Paradoxy of Observing Systems. Cultural Critique, vol. 31, pp. 3755, University of Minnesota Press, 1995.

. What is Communication? In: RASCH, W. (Ed.), Theories of Distinction: Redescribing the Description of Modernity. Stanford: Stanford University Press, pp. 155$168,2002$.

2012.

Introduction to Systems Theory. 1th. ed. New York: John Wiley \&Sons,

La economía de la sociedad como sistema autopoiético. Revista Mad, vol. 29, pp. 1-25, Universidad de Chile, 2013.

LUNDVALL, B.A. Innovation system research where it came from and where it might go [Working Paper No. 2007-01]. The Global Network for Economics of Learning, Innovation, and Competence Building System, Saratov, 2007. 
MALERBA, F. Sectoral systems of innovation and production. Research Policy, 31, 247-264, 2002.

. Sectoral systems of innovation: concepts, issues and analyses of six majors sectors in Europe. Cambridge, England: Cambridge University Press, 2004.

MANDEVILLE, B. The Fable of the Bees and Other Writings. Hackett Publishing Company: Indianapolis, 1997.

MARCH, J.; SIMON, H. Organizations. New York : Wiley, 1958.

MEYER, L. México y Estados Unidos en el Conflicto Petrolero (1917- 1942). México: El Colegio de México, 1968.

MIDDLEBROOK, K. J. Mexico's Democratic Transitions: Dynamics and Prospects. In: MIDDLEBROOK, K. J. (Org.) Dilemmas of Political Change in Mexico. Londres: Institute of Latin American Studies, 2004.

MILL, J.S. Princípios de economia política. São Paulo: Nova Cultural, 1996.

MISES, L. Ação Humana: um tratado de Economia. Rio de Janeiro, Instituto Liberal, 1990.

MONTESQUIEU, C. S. B. Do Espírito das Leis. 7ª ed. São Paulo: Saraiva, 2000.

MORAES SILVA, D. R.; FURTADO, A. T. A natureza sistêmica dos surveys de inovação e da avaliação de políticas de inovação. 10/2015, XVI Congresso LatinoIberoamericano de Gestão da Tecnologia - ALTEC,Vol. 1, pp.1-17, Porto Alegre, RS, Brasil, 2015

MORAIS, J. M. Petróleo em águas profundas: uma história tecnológica da Petrobras na exploração e produção offshore. Brasília: Ipea: Petrobras, 2013.

MORENO-BRID, J. C.; ROS, J. Development and Growth in the Mexican Economy. A Historical Perspective. Oxford: Oxford University Press, 2009.

MUKDAPITAK, Y. The technology strategies of Thai firms. SPRU, University of Sussex, 1994. (PhD Thesis.) 
NELSON, R. The role of firms differences in an evolutionary theory of technical advance. Science and Public Policy, 18(6):347-52, 1991.

NELSON, R.; WINTER, S. An evolutionary theory of economic change. Cambridge MA : Harvard University Press, 1982.

OXFORD ANALYTICA Ltda. The Impact of Pre-Salt: a Long-Term Perspective. Oxford: Oxford Analytica, 2010.

PALMA, J.G. Structuralism. In: EATWELL, J.; MILGATE, M.; NEWMAN, P. (eds.) The New Palgrave: Economic Development. London: Macmillan, 1989.

PAPACONSTANTINOU, G; POLT, W. Policy Evaluation in Innovation and Technology: an overview". In: OECD (ed.) Policy Evaluation in Innovation and Technology: towards best practices, 1999.

PAVITT, K. Sectoral patterns of technical change: towards a taxonomy and a theory", in Research Policy, 13, p.343-373, 1984.

Strategic management in the innovating firm. SPRU, University of Sussex, 1988. (DRC Discussion Paper, n. 61.)

PEÑA NIETO, E. Mexico: the Great Hope. An Effective State for a Results Democracy. PARKER-STAINBACK , Michael [Trad]. México: Grijalbo, 224 p, 2012.

PENROSE, E.T. The theory of the growth of the firm. Oxford : Basil Blackwell, 1959.

PERES, W. Industrial policies in Latin America. Working Paper, World Insitute for Development Economics Research, (48), 2011.

PICCIOTTO, R. Democratic Evaluation for the 21st Century. Evaluation, v. 21. n.2, 2015.

PORTER, M. E. The Competitive Advantage of Nations. New York: Free Press, 1990.

PREBISH, R. El desarrollo económico de la América Latina y algunos de sus principales problemas. (1949) In: GURRIERI, A. La obra de Prebisch en la Cepal. México: Fondo de Cultura Económica, 1982. 
RAGIN, C. C. The comparative method: moving beyond qualitative and quantitative strategies. London: University of California Press, 1987.

RICARDO, D. Princípios da Economia Política e Tributação. São Paulo: Abril Cultural, 1982.

RIPPY, M. Oil and the Mexican Revolution. Leiden: E. J. Brill, 1972.

RUA, M. das G. Para Aprender Políticas Públicas - Volume 1: Conceitos e Teorias. Curso online Políticas Públicas. Instituto de Gestão Economia e Políticas PúblicasIGEPP, 2013. Disponível em http://igepp.com.br/uploads/ebook/ebookpara_aprender_politicas_publicas-2013.pdf

RUIZ NAUFAL, V. M. La industria petrolera en México. Una Crónica. II. gestación y consolidación de Petróleos Mexicanos (1938-1970). México: Petróleos Mexicanos, 1988.

RYGGVIK, H. Construindo uma indústria nacional de petróleo offfshore: a experiência da Noruega. Tradução de Edson Furmankiewicz. Rio de Janeiro: Elsevier, 2014.

. A Short History of the Norwegian Oil Industry: From Protected National Champions to Internationally Competitive Multinationals. Business History Review, 89, p. $3-41,2015$.

SANTOS, A.; TRUBEK, D. Introduction: the third moment in law and development theory and the emergence of a new critical practice. In: SANTOS, A. e TRUBEK, D. (org.).The new law and economic development; a critical appraisal. New York: Cambridge University Press, 2008.

SAY, J. B. A treatise on political economy: or the production, distribution, and consumption of wealth. Transl. by C. R. Prinsep. - M.A. Batoche Books, Kitchener, Ontario, Canada, 2001.

SCHRANK, A.; KURTZ, M. Credit where credit is due: open economy industrial policy and export diversification in Latin America and the Caribbean. Politics Society, 33 (4): 671-702, 2005.

SCHUMPETER, J.A. (1934), The Theory of Economic Development. Cambridge: Harvard University Press. 
(1939), Business Cycles: A Theoretical, Historical and Statistical Analysis

of the Capitalist Process, 2 vols., New York: McGraw-Hill.

SCOTT-KEMMIS, D. Learning and the accumulation of technological capacity in Brazilian pulp and paper firms. World Employment Programme Research, 1988. (Working Paper, n. 187.)

SERRANO, J. D. La Privatización del Petróleo Mexicano. Ciudad de México: Editorial Planeta Mexicana, 1992.

SIMON, H. Theories of decision making in economics and behavioral science. American Economic Review, 49(3):253-83, 1959.

Administrative behavior. A study of decision-making process in administrative organization. 2 ed. New York : Macmillan, 1961.

SMITH, A. A riqueza das nações: investigação sobre sua natureza e suas causas. São Paulo: Abril Cultural, 1983.

STEWART, F.; JAMES, J. Introduction. In: STEWART, F.; JAMES, J. (eds.). The economics of new technology in developing countries. London : Frances Pinter, 1982.

STIGLITZ, J. E.; LIN, J. Y. The Industrial Policy Revolution I: The Role of Government Beyond Ideology. Palgrave Macmillan, 2013.

TEECE, D. Technological change and the nature of the firm. In: DOSI, G; FREMMAN, C.; NELSON, R.; SILVERBERG, G.; SOETE, L. (eds.). Technical change and economic theory. London : Pinter, 1988.

TOLMASQUIM, M. T.; PINTO JR., H. Q. (Orgs.) Marcos Regulatórios da Indústria Mundial do Petróleo. Rio de Janeiro: Synergia, EPE, 2011.

TREBAT, T. J. Brazil's State-Owned Enterprises: a case study of the states as entrepreneur. Cambridge: Cambridge University Press, 1983.

TRINDADE, H. (org.). O Positivismo: teoria e prática. $3^{\text {a }}$ ed. Porto Alegre: UFRGS, 2007. 
VALDÉS, C. B. Political struggles and the forging of autonomous government agencies. Inglaterra: Palgrave Macmillan, 2011.

VANDEN, H. E.; PREVOST, G. Politics of Latin America: The Power Game. New York: Oxford University Press, 2002.

VEDUNG, E. Four Waves of Evaluation Diffusion. Evaluation, v.16, n.3, 2010.

VILLAFAÑE, V. L. México: globalización sin política industrial. In: CORDERA, R. (coord.) La globalización de México: opciones y contradicciones. Ciudad de México, Universidade Nacional Autónoma de México - Facultad de Economía, p. 187-201, 2006.

VISSER, J. From Keynesianism to the Third Way: labour relations and social policy in post war Western Europe. In: Economic and Industrial Democracy. pp. 421-456, 2000.

VIZCAÍNO, F. El nacionalismo mexicano en los tiempos de la globalización y el multiculturalismo. México: Universidad Nacional Autónoma de México - Instituto de Investigaciones Sociales, 2004.

WADE, R. H. What strategies are viable for developing countries today? The World Trade Organization and the shrinking of development space. Review of International Political Economy, 10(4), 621-644, 2003.

After the Crisis: Industrial Policy and the Developmental State in LowIncome Countries. Global Policy, 1(2), 150-161, 2010.

WEISS, J. Economic Policy Reform in Mexico. In: Dismantling the Mexican State? AITKEN, et al. (Org.) Londres: Macmillan, 1996.

WEISS, L. (ed.). States in the Global Economy: bringing domestic institutions back. Cambridge: University of Cambridge, 2003.

WINTER, S. Competence and the corporation. Journal of Law, Economics, and Organisation, 4(1):163-80, 1988.

WORLD DEVELOPMENT, 12(5/6), May/June 1984. (Special Issue.) 
ANEXO I

LISTA DE ENTREVISTADOS 


\section{Entrevistas Pré-Campo}

\section{Petrobras:}

Francisco Pais (Gerente Geral de Gestão Tecnológica do CENPES/GTEC)

Eduardo Fernando G. Santos (Gerente de Relacionamento com a Comunidade de C\&T)

Ronaldo M. L. Martins (Gerente de Desenvolvimento do Mercado)

Marcos Guedes Gomes Morais (Coordenador de Programa Tecnológico PROCAP)

Pedro Penido Duarte Guimarães (Coordenador do PROMINP)

Luiz Marastoni (Coordenador de Classificação de Materiaise Serviços)

\section{ANP - Agência Nacional do Petróleo, Gás Natural e Biocombustíveis:}

Michelle Maximiano Steenhagen (Coordenadoria de Conteúdo Local)

\section{ONIP - Organização Nacional da Indústria de Petróleo:}

Carlos Camerini (Consultor)

Luis Mendonça (Consultor)

IBP - Instituto Brasileiro de Petróleo, Gás e Biocombustíveis:

Pedro Alem Filho (Gerente Executivo de Política Industrial)

Vanessa Mello (Analista de Política Industrial E\&P)

\section{CNI - Confederação Nacional da Indústria:}

Carlos Eduardo Abijaodi (Diretoria de Desenvolvimento Industrial)

\section{NIBR - Norwegian Institute for Urban and Regional Research:}

Yuri Kasahara (Pesquisador Sênior)

\section{University of Oslo:}

Helge Ryggvik (Researcher - Centre for Technology, Innovation and Culture) 


\section{Entrevistas em Profundidade}

\section{BRASIL}

\section{GOVERNO}

Nome: Clayton de Souza Pontes

Instituição: Ministério de Minas e Energia - MME

Cargo: Coordenador Geral - Departamento de Exploração de Petróleo e Gás

Tempo de trabalho na Instituição: 10 anos

Nome: Igor Nogueira Calvet

Instituição: Ministério do Desenvolvimento, Indústria e Comércio Exterior MDIC

Cargo: Diretor - Departamento de Competitividade Comercial

Tempo de trabalho na Instituição: 12 anos

Nome: Marco Antônio Nunes Bastos

Instituição: Ministério do Desenvolvimento, Indústria e Comércio Exterior MDIC

Cargo: Analista de Comércio Exterior - Departamento de Competitividade Comercial

Tempo de trabalho na Instituição: 1 ano

Nome: Gustavo Cupertino Domingues

Instituição: Ministério do Desenvolvimento, Indústria e Comércio Exterior MDIC

Cargo: Coordenação-Geral de Petróleo e Gás

Tempo de trabalho na Instituição: desde 1999

Nome: Jorge Luis Ferreira Boeira

Instituição: Agência Brasileira de Desenvolvimento Industrial - ABDI

Cargo: Coordenador de Adensamento Produtivo

Tempo de trabalho na Instituição: desde $\mathbf{2 0 0 5}$

Nome: Michelle Maximiano Steenhagen

Instituição: Agência Nacional do Petróleo, Gás Natural e Biocombustíveis - ANP

Cargo: Especialista em Regulação - Coordenadoria de Conteúdo Local

Tempo de trabalho na Instituição: desde 2006

Nome: Catarina de Miranda Scherer

Instituição: Agência Nacional do Petróleo, Gás Natural e Biocombustíveis - ANP

Cargo: Especialista em Regulação - Coordenadoria de Conteúdo Local

Tempo de trabalho na Instituição: desde 2010 
Nome: Guilherme Vinícius Cadaval Pamplona

Instituição: Petróleo Brasileiro S.A. - Petrobras

Cargo: Gerente de Desenvolvimento do Mercado - Materiais/DEMF/DM

Tempo de trabalho na Instituição: 30 anos

\section{ASSOCIAÇÕES EMPRESARIAIS}

Nome: João Emilio Gonçalves

Instituição: Confederação Nacional da Indústria - CNI

Cargo: Gerente Executivo - Unidade de Política Industrial

Tempo de trabalho na Instituição:

Nome: Carlos Soligo Camerini

Instituição: Organização Nacional da Indústria de Petróleo - ONIP

Cargo: Consultor

Tempo de trabalho na Instituição: 5 anos

Nome: Pedro Alem Filho

Instituição: Instituto Brasileiro de Petróleo, Gás e Biocombustíveis - IBP

Cargo: Gerente Executivo de Política Industrial

Tempo de trabalho na Instituição: 1 ano e meio

Nome: Alberto Machado Neto

Instituição: Associação Brasileira da Indústria de Máquinas e Equipamentos ABIMAQ

Cargo: Diretor Executivo de Petróleo, Gás Natural, Bioenergia e Petroquímica

Tempo de trabalho na Instituição: Desde 2008 (7 anos) + 30 anos na Petrobras + superintendente da ONIP

Nome: João Augusto Azeredo

Instituição: Associação Brasileira das Empresas de Construção Naval e Offshore ABENAV

Cargo: Diretor Executivo

Tempo de trabalho na Instituição: 4 anos 


\section{MÉXICO}

\section{GOVERNO}

Nome: Rosanety Barrios Beltran

Instituição: Secretaria de Energía - SENER

Cargo: Coodinadora de Politicas de Transformación Industrial de Hidrocarburos

Tempo de trabalho na Instituição: 3 anos na SENER, 15 años na indústria e 13 anos na CRE

Nome: Dr. Héctor Márquez

Instituição: Secretaría de Economía - SE

Cargo: Unidad de Compras de Gobierno

Tempo de trabalho na Instituição: desde de 1990

Nome: Enrique Silva Perez

Instituição: Comisión Nacional de Hidrocarburos - CNH

Cargo: Director General de Regulación y Consulta

Tempo de trabalho na Instituição: 6 anos

Nome: Pablo Enriquez Rodriguez

Instituição: Comisión Nacional de Hidrocarburos - CNH

Cargo: Director de Asuntos Internacionales

Tempo de trabalho na Instituição: 4 anos

Nome: Mtra. Susana Ivana Cazorla Espínosa

Instituição: Comisión Reguladora de Energía - CRE

Cargo: Coordinadora General de Actividades Permisionadas de Gas LP

Tempo de trabalho na Instituição: 4 anos ( 7 anos no setor)

Nome: Carlos Elizondo

Instituição: Petróleos Mexicanos - PEMEX

Cargo: Miembro Independiente del Consejo de Administración

Tempo de trabalho na Instituição: 1 ano

Nome: Ana Rosa Guasque Garza

Instituição: Petróleos Mexicanos - PEMEX

Cargo: Gerencia de Vinculación y Proveeduría Local

Tempo de trabalho na Instituição: 16 anoss 


\section{ASSOCIAÇÕES EMPRESARIAIS}

\begin{tabular}{|l|}
\hline Nome: Andrés Rozental \\
\hline Instituição: Consejo Mexicano de Asuntos Internacionales - Comexi \\
\hline Cargo: Fundador, Ex-Presidente e Membro do Consejo Directivo \\
\hline Tempo de trabalho na Instituição: 15 anos \\
\hline
\end{tabular}

Nome: Antonio Juárez Alvarado

Instituição: Asociación Mexicana de empresas de Servicios Petroleros - AMESPAC

Cargo: Director - Gerente General

Tempo de trabalho na Instituição: 3 anos

Nome: Luis Cervera Mondragon

Instituição: Confederación de Cámaras Industriales de los Estados Unidos

Mexicanos - CONCAMIN

Cargo: Director de Apoyo Técnico

Tempo de trabalho na Instituição: 3 anos e meio

Nome: Jaime Williams Quintero

Instituição: Consejo Coordinador Empresarial - CCE

Cargo: Presidente de la Comisión de Energía

Tempo de trabalho na Instituição: desde o início da comissão em 2012-2011 


\title{
NORUEGA
}

\section{GOVERNO}

\begin{tabular}{|l|}
\hline Nome: Ole Anders Lindseth \\
\hline Instituição: Norwegian Ministry of Petroleum and Energy \\
\hline Cargo: Director General in the Department for Oil and Gas \\
\hline Tempo de trabalho na Instituição: 38 anos \\
\hline
\end{tabular}

Nome: Odd Raustein

Instituição: The Norwegian Petroleum Directorate - NPD (Norwegian Ministry of Petroleum and Energy)

Cargo: Senior Engineer

Tempo de trabalho na Instituição: de 1978 a 1997 na NPD, de 1997 a 2007 na

Norwegian Oil Industry Association, e de 2007 até hoje na NPD

\begin{tabular}{|l|}
\hline Nome: Petter Nore \\
\hline Instituição: Norwegian Ministry of Foreign Affairs \\
\hline Cargo: Chief Energy Analyst \\
\hline Tempo de trabalho na Instituição: - \\
\hline
\end{tabular}

\begin{tabular}{|l|}
\hline Nome: Paul Bang \\
\hline Instituição: Petroleum Safety Authority - PSA \\
\hline Cargo: Senior Adviser \\
\hline Tempo de trabalho na Instituição: desde 1987 \\
\hline
\end{tabular}

\begin{tabular}{|l|}
\hline Nome: Øystein Lind \\
\hline Instituição: Statoil \\
\hline Cargo: Lead Consultant Governmental and Public Affairs - Global Politics and \\
Public Affairs \\
\hline Tempo de trabalho na Instituição: 30 anos \\
\hline
\end{tabular}

\section{ASSOCIAÇÕES EMPRESARIAIS}

\begin{tabular}{|l|}
\hline Nome: Svein Heglund \\
\hline Instituição: Norwegian Agency for Development Cooperation: NORAD - Oil for \\
Development Programme \\
\hline Cargo: Senior Adviser \\
\hline Tempo de trabalho na Instituição: 8 anos (30 anos na indústria) \\
\hline
\end{tabular}

\author{
Nome: Georg Oftedal \\ Instituição: Norwegian Shipowners' Association \\ Cargo: Advisor \\ Tempo de trabalho na Instituição: 5 anos
}


Nome: Thomas Saxegaard

Instituição: Norwegian Shipowners' Association

Cargo: Advisor

Tempo de trabalho na Instituição: 2 meses

Nome: Frode Bøhm

Instituição: Norwegian Oil and Gas Association

Cargo: Manager - Fiscal Affairs

Tempo de trabalho na Instituição: 25 anos (antes na Mobil e Statoil)

Nome: Sjur E. Bratland

Instituição: Norwegian Oil and Gas Partners - INTSOK

Cargo: Managing Director

Tempo de trabalho na Instituição: 5 anos (25 anos na Hydro e Statoil) 
ANEXO II

ROTEIROS DAS ENTREVISTAS 


\section{ROTEIRO DAS ENTREVISTAS EM PROFUNDIDADE GOVERNO - BRASIL}

Todas as perguntas partem do pressuposto de que o principal foco da atual política industrial brasileira para o setor de petróleo e gás natural é o aumento do índice de conteúdo local em sua rede de fornecedores. Com base nisso:

\section{BLOCO 1 - A REALIDADE DA INDÚSTRIA}

Neste bloco serão feitas perguntas sobre o contexto que serviu de base para a formulação da atual política industrial de petróleo e gás natural no país. Nas respostas, procure levar em consideração os seguintes pontos:

a) tamanho das reservas em território nacional;

b) custo de extração nestas reservas;

c) capacidade tecnológica da indústria nacional;

d) preço do barril no mercado internacional;

e) outras questões sobre o potencial desta indústria no país.

01) Na sua opinião, qual o potencial brasileiro para o desenvolvimento de uma indústria nacional de petróleo e gás natural, em comparação com outros países?

R:

02) Na sua opinião, quais as desvantagens do Brasil, em comparação com outros países, para o desenvolvimento da indústria nacional de petróleo e gás natural?

R:

03) De um modo geral, como o(a) senhor(a) avalia o potencial brasileiro para o desenvolvimento da indústria de petróleo e gás natural no Brasil?

\begin{tabular}{|c|l|}
\hline A & Muito Bom \\
\hline B & Bom \\
\hline C & Pouco Bom \\
\hline D & Pouco Ruim \\
\hline
\end{tabular}




$$
\begin{array}{|l|l|}
\hline \text { E } & \text { Ruim } \\
\hline \text { F } & \text { Muito Ruim } \\
\hline
\end{array}
$$

04) Na sua opinião, o que as empresas fornecedoras nacionais pensam sobre este potencial de desenvolvimento da indústria?

R:

\section{BLOCO 2 - OS VALORES DA POLÍTICA}

Neste bloco serão feitas perguntas sobre os valores que orientam a atual política industrial. Nas respostas, procure levar em consideração os seguintes pontos:

a) subsolo como propriedade privada ou do Estado;

b) frutos da indústria voltados para necessidades imediatas ou para gerações futuras;

c) ritmo da exploração;

d) Petrobras deve ter foco no lucro ou ser ferramenta de desenvolvimento do país;

e) nacionalização ou internacionalização da rede de fornecedores;

f) outras questões sobre os valores que guiam a política.

05) Com base no potencial existente, pode-se adotar diferentes valores ou princípios para orientar a política industrial de um país. Na sua opinião, para a definição da atual política industrial brasileira, foram utilizados valores e princípios adequados?

R:

06) Na sua opinião, que valores deveriam ser priorizados na definição dessa política?

R:

07) De uma maneira geral, como o(a) senhor(a) avalia a escolha dos valores adotados pela atual política industrial brasileira?

\begin{tabular}{|l|l|}
\hline A & Muito Adequados \\
\hline B & Adequados \\
\hline C & Pouco Adequados \\
\hline D & Pouco Inadequados \\
\hline
\end{tabular}


\begin{tabular}{|l|l|}
\hline E & Inadequados \\
\hline $\mathrm{F}$ & Muito Inadequados \\
\hline
\end{tabular}

08) Na sua opinião, o que as empresas fornecedoras nacionais pensam sobre a adoção destes valores?

R:

09) O seu órgão já tomou alguma medida com relação à adoção destes valores? Caso positivo, que medidas foram tomadas? Qual foi a reação dos demais atores?

R:

\section{BLOCO 3 - A NORMATIZAÇÃO DA POLÍTICA}

Neste bloco serão feitas perguntas sobre a legislação que rege a atual política industrial. Nas respostas, procure levar em consideração os seguintes pontos:

a) participação dos atores envolvidos na definição das normas;

b) adequação das normas à realidade da indústria;

c) rigidez ou flexibilidade das normas;

d) aplicação das normas nos casos concretos;

e) outras questões sobre as normas que regem a política.

10) Qual a sua opinião sobre as regras (leis, normas e resoluções) que regem a atual política industrial brasileira para o setor de petróleo e gás natural?

R:

11) Na sua opinião, como deveriam ser as regras (leis, normas e resoluções) que regem a política industrial nacional?

R: 
12) De modo geral, como o(a) senhor(a) avalia as regras que regem a atual política industrial brasileira?

\begin{tabular}{|l|l|}
\hline A & Muito Adequadas \\
\hline B & Adequadas \\
\hline C & Pouco Adequadas \\
\hline D & Pouco Inadequadas \\
\hline E & Inadequadas \\
\hline F & Muito Inadequadas \\
\hline
\end{tabular}

13) Na sua opinião, o que as empresas fornecedoras nacionais pensam sobre a adequação destas regras?

R:

14) O seu órgão já tomou alguma medida com relação às regras consideradas inadequadas? Caso positivo, que medidas foram tomadas? Qual foi a reação dos demais atores?

R:

\section{BLOCO 4 - A IMPLEMENTAÇÃO DA POLÍTICA}

Neste bloco serão feitas perguntas sobre a forma como a atual política industrial de petróleo e gás natural é executada no Brasil. Nas respostas, procure levar em consideração os seguintes pontos:

a) metas e objetivos bem definidos;

b) transparência e prestação de contas;

c) atuação dos atores envolvidos;

d) diálogo entre os atores;

e) interação entre os atores;

f) parcerias com universidades e centros de pesquisa; 
g) integração com outras políticas;

h) existência de atos de corrupção;

i) outras questões sobre a implementação da política.

15) Qual a sua opinião sobre a forma como está sendo implementada a atual política industrial brasileira para o setor de petróleo e gás natural?

R:

16) Na sua opinião, de que forma deveria ser implementada a atual política industrial brasileira para o setor de petróleo e gás natural?

R:

17) De uma maneira geral, como o(a) senhor(a) avalia a implementação desta política industrial no Brasil?

\begin{tabular}{|c|l|}
\hline A & Muito Adequada \\
\hline B & Adequada \\
\hline C & Pouco Adequada \\
\hline D & Pouco Inadequada \\
\hline E & Inadequada \\
\hline F & Muito Inadequada \\
\hline
\end{tabular}

18) Na sua opinião, o que as empresas fornecedoras nacionais pensam sobre a forma de implementação desta política industrial?

R:

19) O seu órgão já tomou alguma medida com relação aos aspectos da implementação que são considerados inadequados? Caso positivo, que medidas foram tomadas? Qual foi a reação dos demais atores?

R: 


\section{BLOCO 5 - OS RESULTADOS DA POLÍTICA}

Neste bloco serão feitas perguntas sobre os resultados que estão sendo obtidos pela atual política industrial. Nas respostas, procure levar em consideração os seguintes pontos:

a) número de empregos e salários;

b) adoção de processos de aprendizagem tecnológica;

c) investimentos em P\&D;

d) registros de patentes;

e) capacidade produtiva (escala) e produtividade;

f) atração de investimentos;

g) índice de conteúdo local;

h) exportações;

i) outras questões sobre os resultados da política.

20) Qual a sua opinião sobre os resultados que estão sendo alcançados até aqui pela atual política industrial brasileira para o setor de petróleo e gás natural?

R:

21) Na sua opinião, que resultados deveriam, ou poderiam, estar sendo alcançados pela atual política industrial?

R:

22) De uma maneira geral, como o(a) senhor(a) avalia os resultados que estão sendo alcançados pela política?

\begin{tabular}{|c|l|}
\hline A & Muito Adequados \\
\hline B & Adequados \\
\hline C & Pouco Adequados \\
\hline D & Pouco Inadequados \\
\hline
\end{tabular}


\begin{tabular}{|l|l|}
\hline E & Inadequados \\
\hline F & Muito Inadequados \\
\hline
\end{tabular}

23) Na sua opinião, o que as empresas fornecedoras nacionais pensam sobre estes resultados?

R:

24) O seu órgão já tomou alguma medida com relação aos resultados considerados inadequados? Caso positivo, que medidas foram tomadas? Qual foi a reação dos demais atores?

R:

\section{BLOCO 6 - A AVALIAÇÃO DA POLÍTICA}

Neste bloco serão feitas perguntas sobre como são realizados o monitoramento e a avaliação da atual política industrial brasileira. Nas respostas, procure levar em consideração os seguintes pontos:

a) existência de mecanismos de monitoramento da política;

b) existência de mecanismos de avaliação da política;

c) integração entre estes mecanismo;

d) outras questões sobre o monitoramento e a avaliação da política.

25) Como são os mecanismos de monitoramento e de avaliação dos resultados da política industrial brasileira para o setor de petróleo e gás natural?

R:

26) Na sua opinião, como deveriam ser estes mecanismos? 
R:

27) Como o(a) senhor(a) avalia os atuais mecanismos de monitoramento e de avaliação da política industrial nacional?

\begin{tabular}{|c|l|}
\hline A & Muito Adequados \\
\hline B & Adequados \\
\hline C & Pouco Adequados \\
\hline D & Pouco Inadequados \\
\hline E & Inadequados \\
\hline F & Muito Inadequados \\
\hline
\end{tabular}

28) Na sua opinião, o que as empresas fornecedoras nacionais pensam sobre estes mecanismos de monitoramento e avaliação?

R:

29) O seu órgão já tomou alguma medida com relação à adequação destes mecanismos de monitoramento e avaliação? Caso positivo, que medidas foram tomadas? Qual foi a reação dos demais atores?

R:

\section{BLOCO 7 - A REAÇÃO AOS RESULTADOS DA POLÍTICA}

Neste bloco serão feitas perguntas sobre a utilização dos dados do monitoramento e da avaliação como base para a manutenção, a adaptação ou a mudança da política industrial brasileira. Nas respostas, procure levar em consideração os seguintes pontos: 
a) acesso aos dados sobre o monitoramento e a avaliação da política;

b) forma de debate sobre os dados do monitoramento e da avaliação;

c) interesses que definem a utilização ou não desses dados;

d) outras questões sobre a utilização dos dados do monitoramento e da avaliação.

30) As conclusões obtidas através do monitoramento e da avaliação dos resultados da política industrial são utilizadas como base para a manutenção, correção ou mudança desta política? Caso positivo, como é feito este processo? Caso negativo, na sua opinião, por que este processo não é realizado?

R:

31) Na sua opinião, como deveria ser o processo para a definição sobre a manutenção, correção ou mudança desta política industrial?

R:

32) Como o(a) senhor(a) avalia o atual processo de utilização das conclusões obtidas através do monitoramento e da avaliação dos resultados da política industrial como base para a manutenção, correção ou mudança desta política?

\begin{tabular}{|c|l|}
\hline A & Muito Adequado \\
\hline B & Adequado \\
\hline C & Pouco Adequado \\
\hline D & Pouco Inadequado \\
\hline E & Inadequado \\
\hline F & Muito Inadequado \\
\hline
\end{tabular}

33) Na sua opinião, o que as empresas fornecedoras nacionais pensam sobre este processo de definição sobre a manutenção, a correção ou a mudança da política industrial?

R: 
34) O seu órgão já tomou alguma medida com relação à adequação desse processo? Caso positivo, que medidas foram tomadas? Qual foi a reação dos demais atores?

R:

\section{BLOCO 8 - DADOS}

35) $\mathrm{O}(\mathrm{A})$ senhor(a) poderia apresentar alguns dados (com as respectivas fontes) que considere importantes para sustentar suas opiniões sobre os temas tratados nos blocos anteriores? (esses dados podem ser referentes a cada um dos 7 primeiros blocos da entrevista, ou apenas àqueles que o entrevistado julgar importante) (os dados podem ser apresentados por meio eletrônico ou impresso)

\begin{tabular}{|l|l|}
\hline A & Os dados foram apresentados antes da entrevista \\
\hline B & Os dados estão sendo apresentados no momento da entrevista \\
\hline C & Os dados serão apresentados depois da entrevista \\
\hline D & Os dados não podem ser apresentados \\
\hline E & Não considera haver dados importantes para destacar \\
\hline
\end{tabular}

DADOS PESSOAIS

\begin{tabular}{|l}
\hline Nome: \\
\hline Instituição: \\
\hline Setor: \\
\hline Cargo: \\
\hline Tempo de trabalho na Instituição: \\
\hline
\end{tabular}




\section{ROTEIRO DAS ENTREVISTAS EM PROFUNDIDADE EMPRESAS - BRASIL}

Todas as perguntas partem do pressuposto de que o principal foco da atual política industrial brasileira para o setor de petróleo e gás natural é o aumento do índice de conteúdo local em sua rede de fornecedores. Com base nisso:

\section{BLOCO 1 - A REALIDADE DA INDÚSTRIA}

Neste bloco serão feitas perguntas sobre o contexto que serviu de base para a formulação da atual política industrial de petróleo e gás natural no país. Nas respostas, procure levar em consideração os seguintes pontos:

a) tamanho das reservas em território nacional;

b) custo de extração nestas reservas;

c) capacidade tecnológica da indústria nacional;

d) preço do barril no mercado internacional;

e) outras questões sobre o potencial desta indústria no país.

01) Na sua opinião, qual o potencial brasileiro para o desenvolvimento de uma indústria nacional de petróleo e gás natural, em comparação com outros países?

R:

02) Na sua opinião, quais as desvantagens do Brasil, em comparação com outros países, para o desenvolvimento da indústria nacional de petróleo e gás natural?

R:

03) De um modo geral, como o(a) senhor(a) avalia o potencial brasileiro para o desenvolvimento da indústria de petróleo e gás natural no Brasil?

\begin{tabular}{|c|l|}
\hline A & Muito Bom \\
\hline B & Bom \\
\hline C & Pouco Bom \\
\hline D & Pouco Ruim \\
\hline
\end{tabular}




\begin{tabular}{|l|l|}
\hline E & Ruim \\
\hline F & Muito Ruim \\
\hline
\end{tabular}

04) Na sua opinião, o que o governo brasileiro pensa sobre este potencial de desenvolvimento da indústria?

R:

\section{BLOCO 2 - OS VALORES DA POLÍTICA}

Neste bloco serão feitas perguntas sobre os valores que orientam a atual política industrial. Nas respostas, procure levar em consideração os seguintes pontos:

a) subsolo como propriedade privada ou do Estado;

b) frutos da indústria voltados para necessidades imediatas ou para gerações futuras;

c) ritmo da exploração;

d) Petrobras deve ter foco no lucro ou ser ferramenta de desenvolvimento do país;

e) nacionalização ou internacionalização da rede de fornecedores;

f) outras questões sobre os valores que guiam a política.

05) Com base no potencial existente, pode-se adotar diferentes valores ou princípios para orientar a política industrial de um país. Na sua opinião, para a definição da atual política industrial brasileira, foram utilizados valores e princípios adequados?

R:

06) Na sua opinião, que valores deveriam ser priorizados na definição dessa política?

R:

07) De uma maneira geral, como o(a) senhor(a) avalia a escolha dos valores adotados pela atual política industrial brasileira?

\begin{tabular}{|l|l|}
\hline A & Muito Adequados \\
\hline B & Adequados \\
\hline C & Pouco Adequados \\
\hline D & Pouco Inadequados \\
\hline
\end{tabular}


\begin{tabular}{|l|l|}
\hline E & Inadequados \\
\hline $\mathrm{F}$ & Muito Inadequados \\
\hline
\end{tabular}

08) Na sua opinião, o que o governo brasileiro pensa sobre a adoção destes valores?

R:

09) A sua associação já tomou alguma medida com relação à adoção destes valores? Caso positivo, que medidas foram tomadas? Qual foi a reação dos demais atores?

R:

\section{BLOCO 3 - A NORMATIZAÇÃO DA POLÍTICA}

Neste bloco serão feitas perguntas sobre a legislação que rege a atual política industrial. Nas respostas, procure levar em consideração os seguintes pontos:

a) participação dos atores envolvidos na definição das normas;

b) adequação das normas à realidade da indústria;

c) rigidez ou flexibilidade das normas;

d) aplicação das normas nos casos concretos;

e) outras questões sobre as normas que regem a política.

10) Qual a sua opinião sobre as regras (leis, normas e resoluções) que regem a atual política industrial brasileira para o setor de petróleo e gás natural?

R:

11) Na sua opinião, como deveriam ser as regras (leis, normas e resoluções) que regem a política industrial nacional?

R: 
12) De modo geral, como o(a) senhor(a) avalia as regras que regem a atual política industrial brasileira?

\begin{tabular}{|c|l|}
\hline A & Muito Adequadas \\
\hline B & Adequadas \\
\hline C & Pouco Adequadas \\
\hline D & Pouco Inadequadas \\
\hline E & Inadequadas \\
\hline F & Muito Inadequadas \\
\hline
\end{tabular}

13) Na sua opinião, o que o governo brasileiro pensa sobre a adequação destas regras? R:

14) A sua associação já tomou alguma medida com relação às regras consideradas inadequadas? Caso positivo, que medidas foram tomadas? Qual foi a reação dos dema is atores?

R:

\section{BLOCO 4 - A IMPLEMENTAÇÃO DA POLÍTICA}

Neste bloco serão feitas perguntas sobre a forma como a atual política industrial de petróleo e gás natural é executada no Brasil. Nas respostas, procure levar em consideração os seguintes pontos:

a) metas e objetivos bem definidos;

b) transparência e prestação de contas;

c) atuação dos atores envolvidos;

d) diálogo entre os atores;

e) interação entre os atores;

f) parcerias com universidades e centros de pesquisa;

g) integração com outras políticas; 
h) existência de atos de corrupção;

i) outras questões sobre a implementação da política.

15) Qual a sua opinião sobre a forma como está sendo implementada a atual política industrial brasileira para o setor de petróleo e gás natural?

R:

16) Na sua opinião, de que forma deveria ser implementada a atual política industrial brasileira para o setor de petróleo e gás natural?

R:

17) De uma maneira geral, como o(a) senhor(a) avalia a implementação desta política industrial no Brasil?

\begin{tabular}{|c|l|}
\hline A & Muito Adequada \\
\hline B & Adequada \\
\hline C & Pouco Adequada \\
\hline D & Pouco Inadequada \\
\hline E & Inadequada \\
\hline F & Muito Inadequada \\
\hline
\end{tabular}

18) Na sua opinião, o que o governo brasileiro pensa sobre a forma de implementação desta política industrial?

R:

19) A sua associação já tomou alguma medida com relação aos aspectos da implementação que são considerados inadequados? Caso positivo, que medidas foram tomadas? Qual foi a reação dos demais atores?

R: 


\section{BLOCO 5 - OS RESULTADOS DA POLÍTICA}

Neste bloco serão feitas perguntas sobre os resultados que estão sendo obtidos pela atual política industrial. Nas respostas, procure levar em consideração os seguintes pontos:

a) número de empregos e salários;

b) adoção de processos de aprendizagem tecnológica;

c) investimentos em P\&D;

d) registros de patentes;

e) capacidade produtiva (escala) e produtividade;

f) atração de investimentos;

g) índice de conteúdo local;

h) exportações;

i) outras questões sobre os resultados da política.

20) Qual a sua opinião sobre os resultados que estão sendo alcançados até aqui pela atual política industrial brasileira para o setor de petróleo e gás natural?

R:

21) Na sua opinião, que resultados deveriam, ou poderiam, estar sendo alcançados pela atual política industrial?

R:

22) De uma maneira geral, como o(a) senhor(a) avalia os resultados que estão sendo alcançados pela política?

\begin{tabular}{|c|l|}
\hline A & Muito Adequados \\
\hline B & Adequados \\
\hline C & Pouco Adequados \\
\hline D & Pouco Inadequados \\
\hline
\end{tabular}


\begin{tabular}{|l|l|}
\hline E & Inadequados \\
\hline $\mathrm{F}$ & Muito Inadequados \\
\hline
\end{tabular}

23) Na sua opinião, o que o governo brasileiro pensa sobre estes resultados?

R:

24) A sua associação já tomou alguma medida com relação aos resultados considerados inadequados? Caso positivo, que medidas foram tomadas? Qual foi a reação dos demais atores?

R:

\section{BLOCO 6 - A AVALIAÇÃO DA POLÍTICA}

Neste bloco serão feitas perguntas sobre como são realizados o monitoramento e a avaliação da atual política industrial brasileira. Nas respostas, procure levar em consideração os seguintes pontos:

a) existência de mecanismos de monitoramento da política;

b) existência de mecanismos de avaliação da política;

c) integração entre estes mecanismo;

d) outras questões sobre o monitoramento e a avaliação da política.

25) Como são os mecanismos de monitoramento e de avaliação dos resultados da política industrial brasileira para o setor de petróleo e gás natural?

R:

26) Na sua opinião, como deveriam ser estes mecanismos? 
R:

27) Como o(a) senhor(a) avalia os atuais mecanismos de monitoramento e de avaliação da política industrial nacional?

\begin{tabular}{|c|l|}
\hline A & Muito Adequados \\
\hline B & Adequados \\
\hline C & Pouco Adequados \\
\hline D & Pouco Inadequados \\
\hline E & Inadequados \\
\hline F & Muito Inadequados \\
\hline
\end{tabular}

28) Na sua opinião, o que o governo brasileiro pensa sobre estes mecanismos de monitoramento e avaliação?

R:

29) A sua associação já tomou alguma medida com relação à adequação destes mecanismos de monitoramento e avaliação? Caso positivo, que medidas foram tomadas? Qual foi a reação dos demais atores?

R:

\section{BLOCO 7 - A REAÇÃO AOS RESULTADOS DA POLÍTICA}

Neste bloco serão feitas perguntas sobre a utilização dos dados do monitoramento e da avaliação como base para a manutenção, a adaptação ou a mudança da política industrial brasileira. Nas respostas, procure levar em consideração os seguintes pontos: 
a) acesso aos dados sobre o monitoramento e a avaliação da política;

b) forma de debate sobre os dados do monitoramento e da avaliação;

c) interesses que definem a utilização ou não desses dados;

d) outras questões sobre a utilização dos dados do monitoramento e da avaliação.

30) As conclusões obtidas através do monitoramento e da avaliação dos resultados da política industrial são utilizadas como base para a manutenção, correção ou mudança desta política? Caso positivo, como é feito este processo? Caso negativo, na sua opinião, por que este processo não é realizado?

R:

31) Na sua opinião, como deveria ser o processo para a definição sobre a manutenção, correção ou mudança desta política industrial?

R:

32) Como o(a) senhor(a) avalia o atual processo de utilização das conclusões obtidas através do monitoramento e da avaliação dos resultados da política industrial como base para a manutenção, correção ou mudança desta política?

\begin{tabular}{|c|l|}
\hline A & Muito Adequado \\
\hline B & Adequado \\
\hline C & Pouco Adequado \\
\hline D & Pouco Inadequado \\
\hline E & Inadequado \\
\hline F & Muito Inadequado \\
\hline
\end{tabular}

33) Na sua opinião, o que o governo brasileiro pensa sobre este processo de definição sobre a manutenção, a correção ou a mudança da política industrial?

R: 
34) A sua associação já tomou alguma medida com relação à adequação desse processo? Caso positivo, que medidas foram tomadas? Qual foi a reação dos demais atores?

R:

\section{BLOCO 8 - DADOS}

35) $O$ (A) senhor(a) poderia apresentar alguns dados (com as respectivas fontes) que considere importantes para sustentar suas opiniões sobre os temas tratados nos blocos anteriores? (esses dados podem ser referentes a cada um dos 7 primeiros blocos da entrevista, ou apenas àqueles que o entrevistado julgar importante) (os dados podem ser apresentados por meio eletrônico ou impresso)

\begin{tabular}{|l|l|}
\hline A & Os dados foram apresentados antes da entrevista \\
\hline B & Os dados estão sendo apresentados no momento da entrevista \\
\hline C & Os dados serão apresentados depois da entrevista \\
\hline D & Os dados não podem ser apresentados \\
\hline E & Não considera haver dados importantes para destacar \\
\hline
\end{tabular}

DADOS PESSOAIS

\begin{tabular}{|l}
\hline Nome: \\
\hline Instituição: \\
\hline Setor: \\
\hline Cargo: \\
\hline Tempo de trabalho na Instituição: \\
\hline
\end{tabular}




\section{GUIÓN DE ENTREVISTAS EN PROFUNDIDAD GOBIERNO - MÉXICO}

Todas las preguntas se basan en la suposición de que el principal objetivo de la actual política industrial mexicana para el sector del petróleo y gas es la atracción de la inversión privada y el incremento del contenido nacional en la cadena productiva. Basado en esto:

\section{BLOQUE 1 - REALIDAD DE LA INDUSTRIA}

Este bloque presenta preguntas acerca del contexto que sirvió de base para la formulación de la actual política industrial de petróleo y gas en el país. En las respuestas, busque considerar los siguientes puntos:

a) tamaño de las reservas en el país;

b) coste de la extracción de estas reservas;

c) la capacidad tecnológica de la industria nacional;

d) precio del barril en el mercado internacional;

e) otros factores que considere importante sobre el potencial de esta industria.

01) En su opinión, ¿cuál es el potencial de México para el desarrollo de una indústria nacional de petróleo y gas, en comparación con otros países?

R:

02) En su opinión, ¿cuáles son las desventajas de México en comparación con otros países, para el desarrollo de una industria de petróleo y gas?

R:

03) En general, ¿como usted evalúa el potencial de México para el desarrollo de la industria del petróleo y gas natural mexicana?

\begin{tabular}{|l|l|}
\hline A & Muy Bueno \\
\hline B & Bueno \\
\hline C & Poco Bueno \\
\hline D & Poco Malo \\
\hline
\end{tabular}


\begin{tabular}{|l|l|}
\hline E & Malo \\
\hline F & Muy Malo \\
\hline
\end{tabular}

04) En su opinión, ¿qué piensan los proveedores nacionales acerca del potencial de desarrollo de esta industria?

R:

\section{BLOQUE 2 - LOS VALORES DE LA POLÍTICA}

Este bloque presenta preguntas acerca de los valores que impulsan la actual política industrial. En las respuestas, busque considerar los siguientes puntos:

a) las riquezas del subsuelo como propiedad privada o del Estado;

b) ganancias de la industria para las necesidades inmediatas o para las generaciones futuras;

c) ritmo de la exploración;

d) Pemex debe centrarse en la eficiencia o ser herramienta de desarrollo del país;

e) nacionalización o internacionalización de la cadena de suministro;

f) otros factores que considere importante acerca de los valores que guían la política.

05) Con base en el potencial existente, podemos adoptar diferentes valores o principios para orientar la política industrial de un país. En su opinión, para la definición de la actual política industrial mexicana, se han utilizado los valores y principios adecuados?

R:

06) En su opinión, ¿qué valores se debería priorizar en la definición de esa política?

R:

07) En general, ¿como usted evalúa la elección de los valores adoptados por la actual política industrial mexicana?

\begin{tabular}{|c|l|}
\hline A & Muy Adecuados \\
\hline B & Adecuados \\
\hline C & Poco Adecuados \\
\hline D & Poco Inadecuados \\
\hline
\end{tabular}


\begin{tabular}{|l|l|}
\hline E & Inadecuados \\
\hline F & Muy Inadecuados \\
\hline
\end{tabular}

08) En su opinión, ¿qué piensan los proveedores nacionales acerca de la adopción de estos valores?

R:

09) Su institución ha tomado alguna medida con relación a la adopción de estos valores? Si la respuesta es sí, ¿qué acción fue tomada? ¿Cuál fue la reacción de los otros actores? R:

\section{BLOQUE 3 - LA NORMATIZACIÓN DE LA POLÍTICA}

Este bloque presenta preguntas acerca de la legislación que rige la actual política industrial. En las respuestas, busque considerar los siguientes puntos:

a) participación de las partes interesadas en la definición de las normas;

b) adecuación de las normas a la realidad de la industria;

c) rigidez o flexibilidad de las normas;

d) aplicación de las normas em los casos concretos;

e) otros factores que considere importante acerca de las normas que rigen la política.

10) ¿Cuál es su opinión sobre las normas (leyes, normas y resoluciones) que rigen la actual política industrial mexicana para el sector de petróleo y gas?

R:

11) En su opinión, ¿cómo deberían ser las normas (leyes, normas y resoluciones) que rigen la política industrial nacional?

R: 
12) En general, ¿como usted evalúa las normas que rigen la actual política industrial mexicana?

\begin{tabular}{|c|l|}
\hline A & Muy Adecuadas \\
\hline B & Adecuadas \\
\hline C & Poco Adecuadas \\
\hline D & Poco Inadecuadas \\
\hline E & Inadecuadas \\
\hline F & Muy Inadecuadas \\
\hline
\end{tabular}

13) En su opinión, ¿qué piensan los proveedores nacionales acerca de la adecuación de estas reglas?

R:

14) Su institución ha tomado alguna medida con relación a las normas consideradas inadecuadas? Si la respuesta es sí, ¿qué acción fue tomada? ¿Cuál fue la reacción de los otros actores?

R:

\section{BLOQUE 4 - LA IMPLEMENTACIÓN DE LA POLÍTICA}

Este bloque presenta preguntas acerca de cómo se lleva a cabo la actual política industrial de petróleo y gas en México. En las respuestas, busque considerar los siguientes puntos:

a) metas y objetivos bien definidos;

b) transparencia y rendición de cuentas;

c) el desempeño de los actores involucrados;

d) el diálogo entre los actores;

e) la interacción entre los actores;

f) alianzas con universidades y centros de investigación;

g) integración con otras políticas; 
h) existencia de actos de corrupción;

i) otros factores que considere importante acerca de la implementación de la política.

15) ¿Cuál es su opinión sobre la forma en que se está implementando la actual política industrial mexicana para el sector de petróleo y gas?

R:

16) En su opinión, ¿cómo debería implementarse la actual política industrial mexicana para el sector de petróleo y gas?

R:

17) En general, ¿como usted evalúa la aplicación de la actual política industrial en México?

\begin{tabular}{|c|l|}
\hline A & Muy Adecuada \\
\hline B & Adecuada \\
\hline C & Poco Adecuada \\
\hline D & Poco Inadecuada \\
\hline E & Inadecuada \\
\hline F & Muy Inadecuada \\
\hline
\end{tabular}

18) En su opinión, ¿qué piensan los proveedores nacionales acerca de cómo implementar esta política industrial?

R:

19) Su institución ha tomado alguna medida con relación a aspectos de la aplicación que se considera inadecuados? Si la respuesta es sí, ¿qué acción fue tomada? ¿Cuál fue la reacción de los otros actores?

R: 


\section{BLOQUE 5 - LOS RESULTADOS DE LA POLÍTICA}

Este bloque presenta preguntas acerca de los resultados que se consiguen mediante la actual política industrial. En las respuestas, busque considerar los siguientes puntos:

a) número de puestos de trabajo y salarios;

b) adopción de procesos de aprendizaje tecnológico;

c) inversiones en investigación y desarrollo;

d) registros de patentes;

e) la capacidad productiva (escala) y la productividad;

f) atracción de inversiones;

g) índice de contenido nacional;

h) las exportaciones;

i) otros factores que considere importante acerca de los resultados de la política.

20) ¿Qué piensa usted acerca de los resultados que se están consiguiendo hasta ahora por la actual política industrial mexicana para el sector de petróleo y gas?

R:

21) En su opinión, ¿qué resultados deberían, o podrían, ser alcanzados por la actual política industrial?

R:

22) En general, ¿como usted evalúa los resultados que se están obteniendo hasta ahora por la política?

\begin{tabular}{|c|l|}
\hline A & Muy Adecuados \\
\hline B & Adecuados \\
\hline C & Poco Adecuados \\
\hline D & Poco Inadecuados \\
\hline E & Inadecuados \\
\hline F & Muy Inadecuados \\
\hline
\end{tabular}


23) En su opinión, ¿̇qué piensan los proveedores nacionales de estos resultados?

R:

24) Su institución ha tomado alguna medida con relación a los resultados considerados inadecuados? Si la respuesta es sí, ¿qué acción fue tomada? ¿Cuál fue la reacción de los otros actores?

R:

\section{BLOQUE 6 - EVALUACIÓN DE LA POLÍTICA}

Este bloque presenta preguntas sobre la forma en que se llevan a cabo el monitoreo y la evaluación de la actual política industrial mexicana. En las respuestas, busque considerar los siguientes puntos:

a) existencia de mecanismos de monitoreo de la política;

b) existencia de mecanismos de evaluación de la política;

c) integración de estos mecanismos;

d) otros factores que considere importante acerca del monitoreo y de la evaluación de la política.

25) ¿Cuáles son los mecanismos de monitoreo y evaluación de los resultados de la política industrial de México para el sector de petróleo y gas?

R:

26) En su opinión, ¿cómo deberían ser estos mecanismos?

$\mathrm{R}:$ 
27) En general, ¿como usted evalúa los actuales mecanismos de monitoreo y evaluación de la política industrial nacional?

\begin{tabular}{|c|l|}
\hline A & Muy Adecuados \\
\hline B & Adecuados \\
\hline C & Poco Adecuados \\
\hline D & Poco Inadecuados \\
\hline E & Inadecuados \\
\hline F & Muy Inadecuados \\
\hline
\end{tabular}

28) En su opinión, ¿qué piensan los proveedores nacionales sobre estos mecanismos de monitoreo y evaluación?

R:

29) Su instituición ha tomado alguna medida con relación a la conveniencia de estos mecanismos de monitoreo y evaluación? Si la respuesta es sí, ¿qué acción fue tomada? ¿Cuál fue la reacción de los otros actores?

R:

\section{BLOQUE 7 - REACCIÓN A LOS RESULTADOS DE POLÍTICA}

Este bloque presenta preguntas acerca del uso de datos de monitoreo y evaluación como base para el mantenimiento, adaptación o cambio de la política industrial de petróleo y gas mexicana. En las respuestas, busque considerar los siguientes puntos:

a) acceso a los datos sobre el monitoreo y evaluación de la política;

b) forma de debate sobre los datos de monitoreo y evaluación; 
c) intereses que definen el uso o no de estos datos;

d) otros factores que considere importante acerca del uso de los datos de monitoreo y evaluación.

30) Las conclusiones alcanzadas por el monitoreo y la evaluación de los resultados de la política industrial son utilizadas como base para el mantenimiento, reparación o cambio de esta política? Si la respuesta es sí, ¿cómo se realiza este proceso? Si la respuesta es no, ¿por qué este proceso no se hace?

R:

31) En su opinión, ¿cuál debería ser el proceso para la definición de mantenimiento, reparación o cambio de esta política industrial?

R:

32) En general, ¿como usted evalúa el actual proceso de utilización de los resultados obtenidos a través del monitoreo y de la evaluación de los resultados de la política industrial como base para el mantenimiento, reparación o cambio de esta política?

\begin{tabular}{|c|l|}
\hline A & Muy Adecuado \\
\hline B & Adecuado \\
\hline C & Poco Adecuado \\
\hline D & Poco Inadecuado \\
\hline E & Inadecuado \\
\hline F & Muy Inadecuado \\
\hline
\end{tabular}

33) En su opinión, ¿qué piensan los proveedores nacionales acerca de este proceso de definición acerca del mantenimiento, la reparación o el cambio de la política industrial? R:

34) Su instituición ha tomado alguna medida con relación a la adecuación de este proceso? Si la respuesta es sí, ¿qué acción fue tomada? ¿Cuál fue la reacción de los otros actores? 
R:

\section{BLOQUE 8 - DATOS}

35) Usted podría presentar algunos datos (com las respectivas fuentes) que considere importantes para apoyar sus opiniones acerca de los temas tratados en los bloques anteriores? (Estos datos pueden estar relacionados con cada uno de los 7 bloques, o apenas a los que juzgue importante) (Los datos pueden ser presentados por medio electrónico o impresso)

\begin{tabular}{|l|l|}
\hline A & Los datos fueron presentados antes de la entrevista \\
\hline B & Los datos fueron presentados en la entrevista \\
\hline C & Los datos serán presentados después de la entrevista \\
\hline D & No se puede mostrar los datos \\
\hline E & No considera que hay datos importantes para destacar \\
\hline
\end{tabular}

INFORMACIÓN PERSONAL

Nombre:

Institución:

Sector:

Cargo:

Tiempo de trabajo en la institución: 


\section{GUIÓN DE ENTREVISTAS EN PROFUNDIDAD \\ EMPRESAS - MÉXICO}

Todas las preguntas se basan en la suposición de que el principal objetivo de la actual política industrial mexicana para el sector del petróleo y gas es la atracción de la inversión privada y el incremento del contenido nacional en la cadena productiva. Basado en esto:

\section{BLOQUE 1 - REALIDAD DE LA INDUSTRIA}

Este bloque presenta preguntas acerca del contexto que sirvió de base para la formulación de la actual política industrial de petróleo y gas en el país. En las respuestas, busque considerar los siguientes puntos:

a) tamaño de las reservas en el país;

b) coste de la extracción de estas reservas;

c) la capacidad tecnológica de la industria nacional;

d) precio del barril en el mercado internacional;

e) otros factores que considere importante sobre el potencial de esta industria.

01) En su opinión, ¿cuál es el potencial de México para el desarrollo de una indústria nacional de petróleo y gas, en comparación con otros países?

R:

02) En su opinión, ¿cuáles son las desventajas de México en comparación con otros países, para el desarrollo de una industria de petróleo y gas?

R:

03) En general, ¿como usted evalúa el potencial de México para el desarrollo de la industria del petróleo y gas natural mexicana?

\begin{tabular}{|l|l|}
\hline A & Muy Bueno \\
\hline B & Bueno \\
\hline C & Poco Bueno \\
\hline D & Poco Malo \\
\hline
\end{tabular}




\begin{tabular}{|l|l|}
\hline E & Malo \\
\hline F & Muy Malo \\
\hline
\end{tabular}

04) En su opinión, ¿qué piensa lo gobierno mexicano acerca del potencial de desarrollo de esta industria?

R:

\section{BLOQUE 2 - LOS VALORES DE LA POLÍTICA}

Este bloque presenta preguntas acerca de los valores que impulsan la actual política industrial. En las respuestas, busque considerar los siguientes puntos:

a) las riquezas del subsuelo como propiedad privada o del Estado;

b) ganancias de la industria para las necesidades inmediatas o para las generaciones futuras;

c) ritmo de la exploración;

d) Pemex debe centrarse en la eficiencia o ser herramienta de desarrollo del país;

e) nacionalización o internacionalización de la cadena de suministro;

f) otros factores que considere importante acerca de los valores que guían la política.

05) Con base en el potencial existente, podemos adoptar diferentes valores o principios para orientar la política industrial de un país. En su opinión, para la definición de la actual política industrial mexicana, se han utilizado los valores y principios adecuados?

R:

06) En su opinión, ¿qué valores se debería priorizar en la definición de esa política?

R:

07) En general, ¿como usted evalúa la elección de los valores adoptados por la actual política industrial mexicana?

\begin{tabular}{|l|l|}
\hline A & Muy Adecuados \\
\hline B & Adecuados \\
\hline C & Poco Adecuados \\
\hline D & Poco Inadecuados \\
\hline
\end{tabular}


\begin{tabular}{|l|l|}
\hline E & Inadecuados \\
\hline F & Muy Inadecuados \\
\hline
\end{tabular}

08) En su opinión, ¿qué piensa lo gobierno mexicano acerca de la adopción de estos valores?

R:

09) Su institución ha tomado alguna medida con relación a la adopción de estos valores? Si la respuesta es sí, ¿qué acción fue tomada? ¿Cuál fue la reacción de los otros actores? R:

\section{BLOQUE 3 - LA NORMATIZACIÓN DE LA POLÍTICA}

Este bloque presenta preguntas acerca de la legislación que rige la actual política industrial. En las respuestas, busque considerar los siguientes puntos:

a) participación de las partes interesadas en la definición de las normas;

b) adecuación de las normas a la realidad de la industria;

c) rigidez o flexibilidad de las normas;

d) aplicación de las normas em los casos concretos;

e) otros factores que considere importante acerca de las normas que rigen la política.

10) ¿Cuál es su opinión sobre las normas (leyes, normas y resoluciones) que rigen la actual política industrial mexicana para el sector de petróleo y gas?

R:

11) En su opinión, ¿cómo deberían ser las normas (leyes, normas y resoluciones) que rigen la política industrial nacional?

R: 
12) En general, ¿como usted evalúa las normas que rigen la actual política industrial mexicana?

\begin{tabular}{|c|l|}
\hline A & Muy Adecuadas \\
\hline B & Adecuadas \\
\hline C & Poco Adecuadas \\
\hline D & Poco Inadecuadas \\
\hline E & Inadecuadas \\
\hline F & Muy Inadecuadas \\
\hline
\end{tabular}

13) En su opinión, ¿qué piensa lo gobierno mexicano acerca de la adecuación de estas reglas?

R:

14) Su institución ha tomado alguna medida con relación a las normas consideradas inadecuadas? Si la respuesta es sí, ¿qué acción fue tomada? ¿Cuál fue la reacción de los otros actores?

R:

\section{BLOQUE 4 - LA IMPLEMENTACIÓN DE LA POLÍTICA}

Este bloque presenta preguntas acerca de cómo se lleva a cabo la actual política industrial de petróleo y gas en México. En las respuestas, busque considerar los siguientes puntos:

a) metas y objetivos bien definidos;

b) transparencia y rendición de cuentas;

c) el desempeño de los actores involucrados;

d) el diálogo entre los actores;

e) la interacción entre los actores;

f) alianzas con universidades y centros de investigación;

g) integración con otras políticas; 
h) existencia de actos de corrupción;

i) otros factores que considere importante acerca de la implementación de la política.

15) ¿Cuál es su opinión sobre la forma en que se está implementando la actual política industrial mexicana para el sector de petróleo y gas?

R:

16) En su opinión, ¿cómo debería implementarse la actual política industrial mexicana para el sector de petróleo y gas?

R:

17) En general, ¿como usted evalúa la aplicación de la actual política industrial en México?

\begin{tabular}{|c|l|}
\hline A & Muy Adecuada \\
\hline B & Adecuada \\
\hline C & Poco Adecuada \\
\hline D & Poco Inadecuada \\
\hline E & Inadecuada \\
\hline F & Muy Inadecuada \\
\hline
\end{tabular}

18) En su opinión, ¿qué piensa lo gobierno mexicano acerca de cómo implementar esta política industrial?

R:

19) Su institución ha tomado alguna medida con relación a aspectos de la aplicación que se considera inadecuados? Si la respuesta es sí, ¿qué acción fue tomada? ¿Cuál fue la reacción de los otros actores?

R: 


\section{BLOQUE 5 - LOS RESULTADOS DE LA POLÍTICA}

Este bloque presenta preguntas acerca de los resultados que se consiguen mediante la actual política industrial. En las respuestas, busque considerar los siguientes puntos:

a) número de puestos de trabajo y salarios;

b) adopción de procesos de aprendizaje tecnológico;

c) inversiones en investigación y desarrollo;

d) registros de patentes;

e) la capacidad productiva (escala) y la productividad;

f) atracción de inversiones;

g) índice de contenido nacional;

h) las exportaciones;

i) otros factores que considere importante acerca de los resultados de la política.

20) ¿Qué piensa usted acerca de los resultados que se están consiguiendo hasta ahora por la actual política industrial mexicana para el sector de petróleo y gas?

R:

21) En su opinión, ¿qué resultados deberían, o podrían, ser alcanzados por la actual política industrial?

R:

22) En general, ¿como usted evalúa los resultados que se están obteniendo hasta ahora por la política?

\begin{tabular}{|c|l|}
\hline A & Muy Adecuados \\
\hline B & Adecuados \\
\hline C & Poco Adecuados \\
\hline D & Poco Inadecuados \\
\hline E & Inadecuados \\
\hline F & Muy Inadecuados \\
\hline
\end{tabular}


23) En su opinión, ¿̇ué piensa lo gobierno mexicano de estos resultados?

R:

24) Su institución ha tomado alguna medida con relación a los resultados considerados inadecuados? Si la respuesta es sí, ¿qué acción fue tomada? ¿Cuál fue la reacción de los otros actores?

R:

\section{BLOQUE 6 - EVALUACIÓN DE LA POLÍTICA}

Este bloque presenta preguntas sobre la forma en que se llevan a cabo el monitoreo y la evaluación de la actual política industrial mexicana. En las respuestas, busque considerar los siguientes puntos:

a) existencia de mecanismos de monitoreo de la política;

b) existencia de mecanismos de evaluación de la política;

c) integración de estos mecanismos;

d) otros factores que considere importante acerca del monitoreo y de la evaluación de la política.

25) ¿Cuáles son los mecanismos de monitoreo y evaluación de los resultados de la política industrial de México para el sector de petróleo y gas?

R:

26) En su opinión, ¿cómo deberían ser estos mecanismos?

$\mathrm{R}:$ 
27) En general, ¿como usted evalúa los actuales mecanismos de monitoreo y evaluación de la política industrial nacional?

\begin{tabular}{|c|l|}
\hline A & Muy Adecuados \\
\hline B & Adecuados \\
\hline C & Poco Adecuados \\
\hline D & Poco Inadecuados \\
\hline E & Inadecuados \\
\hline F & Muy Inadecuados \\
\hline
\end{tabular}

28) En su opinión, ¿qué piensa lo gobierno mexicano sobre estos mecanismos de monitoreo y evaluación?

R:

29) Su instituición ha tomado alguna medida con relación a la conveniencia de estos mecanismos de monitoreo y evaluación? Si la respuesta es sí, ¿qué acción fue tomada? ¿Cuál fue la reacción de los otros actores?

R:

\section{BLOQUE 7 - REACCIÓN A LOS RESULTADOS DE POLÍTICA}

Este bloque presenta preguntas acerca del uso de datos de monitoreo y evaluación como base para el mantenimiento, adaptación o cambio de la política industrial de petróleo y gas mexicana. En las respuestas, busque considerar los siguientes puntos:

a) acceso a los datos sobre el monitoreo y evaluación de la política;

b) forma de debate sobre los datos de monitoreo y evaluación; 
c) intereses que definen el uso o no de estos datos;

d) otros factores que considere importante acerca del uso de los datos de monitoreo y evaluación.

30) Las conclusiones alcanzadas por el monitoreo y la evaluación de los resultados de la política industrial son utilizadas como base para el mantenimiento, reparación o cambio de esta política? Si la respuesta es sí, ¿cómo se realiza este proceso? Si la respuesta es no, ¿por qué este proceso no se hace?

R:

31) En su opinión, ¿cuál debería ser el proceso para la definición de mantenimiento, reparación o cambio de esta política industrial?

R:

32) En general, ¿como usted evalúa el actual proceso de utilización de los resultados obtenidos a través del monitoreo y de la evaluación de los resultados de la política industrial como base para el mantenimiento, reparación o cambio de esta política?

\begin{tabular}{|c|l|}
\hline A & Muy Adecuado \\
\hline B & Adecuado \\
\hline C & Poco Adecuado \\
\hline D & Poco Inadecuado \\
\hline E & Inadecuado \\
\hline F & Muy Inadecuado \\
\hline
\end{tabular}

33) En su opinión, ¿qué piensa lo gobierno mexicano acerca de este proceso de definición acerca del mantenimiento, la reparación o el cambio de la política industrial?

R:

34) Su instituición ha tomado alguna medida con relación a la adecuación de este proceso? Si la respuesta es sí, ¿qué acción fue tomada? ¿Cuál fue la reacción de los otros actores? 
R:

\section{BLOQUE 8 - DATOS}

35) Usted podría presentar algunos datos (com las respectivas fuentes) que considere importantes para apoyar sus opiniones acerca de los temas tratados en los bloques anteriores? (Estos datos pueden estar relacionados con cada uno de los 7 bloques, o apenas a los que juzgue importante) (Los datos pueden ser presentados por medio electrónico o impresso)

\begin{tabular}{|l|l|}
\hline A & Los datos fueron presentados antes de la entrevista \\
\hline B & Los datos fueron presentados en la entrevista \\
\hline C & Los datos serán presentados después de la entrevista \\
\hline D & No se puede mostrar los datos \\
\hline E & No considera que hay datos importantes para destacar \\
\hline
\end{tabular}

INFORMACIÓN PERSONAL

Nombre:

Institución:

Sector:

Cargo:

Tiempo de trabajo en la institución: 


\section{GUIDE TO IN-DEPTH INTERVIEWS \\ GOVERNMENT - NORWAY}

All the questions are based on the assumption that the main focus of the current Norwegian industrial policy for the oil and gas sector is the exportation of goods and services from its national suppliers. Based on this:

\section{SECTION 1 - INDUSTRY REALITY}

This section has questions about the context which based the formulation of the current oil and gas industrial policy in the country. In the answers, try to consider the following issues:

a) size of country's oil and gas reserves;

b) extracting cost of these reserves;

c) technological capability of domestic industry;

d) barrel price in the international market;

e) other issues that you consider important about the potential of this industry.

01) In your opinion, which is the Norwegian potential for the development of a national oil and natural gas industry, compared to other countries?

R:

02) In your opinion, which are the disadvantages of Norway, compared to other countries, for the development of a national oil and gas industry?

R:

03) In general terms, how would you evaluate the Norwegian potential for the development of a national oil and gas industry?

\begin{tabular}{|c|l|}
\hline A & Very Good \\
\hline B & Good \\
\hline C & Partially Good \\
\hline D & Partially Bad \\
\hline E & Bad \\
\hline
\end{tabular}




\section{F 1 Very Bad}

04) In your opinion, what do the national suppliers think about this potential for the industry development in Norway?

R:

\section{SECTION 2 - POLICY VALUES}

This section has questions about the values that drive the Norwegian oil and gas industrial policy. In the answers, try to consider the following issues:

a) mineral resources as private property or as state property;

b) industry profits for immediate needs or for future generations;

c) exploration pace;

d) Statoil should focus on profit or be a tool for the country's development;

e) nationalization or internationalization of the supply chain;

f) other issues that you consider important about the values that guide the policy.

05) Based on the existing potential, different values or principles can be adopted to guide a country's industrial policy. In your opinion, the values and principles used to define the Norwegian industrial policy were adequate for its reality?

R:

06) Which values should have been prioritized in the definition of the policy?

R:

07) In general terms, how would you evaluate the values adopted by the Norwegian industrial policy?

\begin{tabular}{|l|l|}
\hline A & Very Appropriate \\
\hline B & Appropriate \\
\hline C & Partially Appropriate \\
\hline D & Partially Inappropriate \\
\hline E & Inappropriate \\
\hline
\end{tabular}


\begin{tabular}{|l|l|l}
\hline F & Very Inappropriate \\
\hline
\end{tabular}

08) In your opinion, what do the national suppliers think about the adoption of these values?

R:

09) Has your institution taken any action regarding the adoption of these values? If so, what kind of action has been taken? How was the reaction from other stakeholders?

R:

\section{SECTION 3 - POLICY LEGISLATION}

This section has questions about the legislation that serves as legal basis for the Norwegian industrial policy. In the answers, try to consider the following issues:

a) participation of stakeholders in the legislation definition;

b) regultion adequacy to industry reality;

c) rigidity or flexibility of legislation;

d) rules application in specific cases;

e) other issues that you consider important about the regulation governing the industrial policy.

10) What is your opinion about the law (rules, regulations and resolutions) governing the Norwegian industrial policy for the oil and gas sector?

R:

11) In your opinion, how should the law (rules, regulations and resolutions) governing the national industrial policy be?

$\mathrm{R}:$ 
12) In general terms, how would you evaluate the rules governing Norway's oil and gas industrial policy?

\begin{tabular}{|l|l|}
\hline A & Very Appropriate \\
\hline B & Appropriate \\
\hline C & Partially Appropriate \\
\hline D & Partially Inappropriate \\
\hline E & Inappropriate \\
\hline F & Very Inappropriate \\
\hline
\end{tabular}

13) In your opinion, what do the national suppliers think about the adequacy of these rules?

R:

14) Has your institution taken any action regarding the rules considered inadequate? If so, what kind of action has been taken? How was the reaction from other stakeholders?

R:

\section{SECTION 4 - POLICY IMPLEMENTATION}

This section has questions about how the industrial policy for oil and gas is enforced (applied) in Norway. In the answers, try to consider the following issues:

a) well-defined goals and objectives;

b) transparency and accountability;

c) stakeholders performances;

d) dialogue between stakeholders;

e) interaction between stakeholders;

f) partnerships with universities and research centers;

g) integration with other policies;

h) existence of corruption;

i) other issues that you consider important about the policy implementation. 
15) What is your opinion about the way in which the Norwegian industrial policy for the oil and gas sector is being implemented?

R:

16) In your opinion, how should the Norwegian industrial policy for the oil and gas sector be implemented?

R:

17) In general terms, how would you evaluate the implementation of this industrial policy in Norway?

\begin{tabular}{|l|l|}
\hline A & Very Appropriate \\
\hline B & Appropriate \\
\hline C & Partially Appropriate \\
\hline D & Partially Inappropriate \\
\hline E & Inappropriate \\
\hline F & Very Inappropriate \\
\hline
\end{tabular}

18) In your opinion, what do the national suppliers think about the implementation of this industrial policy?

R:

19) Has your institution taken any action regarding the implementation of this industrial policy? If so, what kind of action has been taken? How was the reaction from other stakeholders?

R: 


\section{SECTION 5 - POLICY OUTCOMES}

This section has questions about the results being achieved by the Norwegian industrial policy. In the answers, try to consider the following issues:

a) number of jobs and wages;

b) adoption of technological learning processes;

c) R\&D investments;

d) patent registrations;

e) productive capacity (scale) and productivity;

f) investments attraction;

g) local content index;

h) exports;

i) other issues that you consider important about the policy outcomes.

20) What do you think about the outcomes that are being achieved so far by the Norwegian industrial policy for the oil and gas sector?

R:

21) In your opinion, what outcomes should, or could, be being achieved by this industrial policy?

R:

22) In general terms, how would you evaluate the outcomes achieved by this industrial policy in Norway?

\begin{tabular}{|l|l|}
\hline A & Very Appropriate \\
\hline B & Appropriate \\
\hline C & Partially Appropriate \\
\hline D & Partially Inappropriate \\
\hline E & Inappropriate \\
\hline
\end{tabular}


\begin{tabular}{|l|l|}
\hline F & Very Inappropriate \\
\hline
\end{tabular}

23) In your opinion, what do the national suppliers think about these outcomes?

R:

24) Has your institution taken any action regarding the outcomes considered inadequates? If so, what kind of action has been taken? How was the reaction from other stakeholders?

R:

\section{SECTION 6 - POLICY EVALUATION}

This section has questions about the monitoring and evaluation mechanisms of the Norwegian industrial policy for oil and gas. In the answers, try to consider the following issues:

a) existence of policy monitoring mechanisms;

b) existence of policy evaluation mechanisms;

c) integration of these mechanisms;

d) other issues that you consider important about the policy monitoring and evaluation mechanisms.

25) How are the mechanisms for monitoring and evaluation of outcomes achieved by the Norwegian industrial policy for the oil and gas sector?

R:

26) In your opinion, how should these mechanisms be? 
R:

27) In general terms, how would you evaluate the current monitoring and evaluation mechanisms of the Norwegian industrial policy foi oil and gas?

\begin{tabular}{|l|l|}
\hline A & Very Appropriate \\
\hline B & Appropriate \\
\hline C & Partially Appropriate \\
\hline D & Partially Inappropriate \\
\hline E & Inappropriate \\
\hline F & Very Inappropriate \\
\hline
\end{tabular}

28) In your opinion, what do the national suppliers think about these monitoring and evaluation mechanisms?

R:

29) Has your institution taken any action regarding the adequacy of these monitoring and evaluation mechanisms? If so, what kind of action has been taken? How was the reaction from other stakeholders?

R:

SECTION 7 - REACTION TO POLICY OUTCOMES

This section has questions about the use of monitoring and evaluation data as a basis for decision making about maintenance, adaptation or change of the Norwegian industrial policy. In the answers, try to consider the following issues: 
a) access to the policy monitoring and evaluation data;

b) debate about the policy monitoring and evaluation data;

c) interests that define the use (or the non-use) of such data;

d) other issues that you consider important about the use of monitoring and evaluation data.

30) Conclusions reached by monitoring and evaluation of outcomes reached by the Norwegian industrial policy are, in fact, used as a basis for decision making about maintenance, repair or change of this policy? If so, how is this process done? If not, in your opinion, why isn't this process done?

R:

31) In your opinion, how should the process for decision making about maintenance, repair or change of this industrial policy be?

R:

32) In general terms, how would you evaluate the current process of using the findings obtained through the monitoring and evaluation of the industrial policy outcomes as a basis for decision making about maintenance, repair or change of this policy?

\begin{tabular}{|l|l|}
\hline A & Very Appropriate \\
\hline B & Appropriate \\
\hline C & Partially Appropriate \\
\hline D & Partially Inappropriate \\
\hline E & Inappropriate \\
\hline F & Very Inappropriate \\
\hline
\end{tabular}

33) In your opinion, what do the national suppliers think about this decision making process about maintenance, repair or change of the industrial policy?

R: 
34) Has your institution taken any action regarding the adequacy of this process? If so, what kind of action has been taken? How was the reaction from other stakeholders?

R:

\section{SECTION 8 - DATA}

35) Could you present some data (with the respective sources) that you believe to be important to support your opinions about the topics covered in previous sections? (these data can be related to all the seven sections, or only to those you deemed most important) (the data can be presented electronically or printed)

\begin{tabular}{|l|l|}
\hline A & Data presented before the interview \\
\hline B & Data presented during the interview \\
\hline C & Data will be presented after the interview \\
\hline D & Data cannot be presented \\
\hline E & Believes to have no important data to highlight \\
\hline
\end{tabular}

PERSONAL DATA

Name:

Institution:

Department:

Role/Post:

Time working in the institution: 


\section{GUIDE TO IN-DEPTH INTERVIEWS}

\section{COMPANIES - NORWAY}

All the questions are based on the assumption that the main focus of the current Norwegian industrial policy for the oil and gas sector is the exportation of goods and services from its national suppliers. Based on this:

\section{SECTION 1 - INDUSTRY REALITY}

This section has questions about the context which based the formulation of the current oil and gas industrial policy in the country. In the answers, try to consider the following issues:

a) size of country's oil and gas reserves;

b) extracting cost of these reserves;

c) technological capability of domestic industry;

d) barrel price in the international market;

e) other issues that you consider important about the potential of this industry.

01) In your opinion, which is the Norwegian potential for the development of a national oil and natural gas industry, compared to other countries?

R:

02) In your opinion, which are the disadvantages of Norway, compared to other countries, for the development of a national oil and gas industry?

R:

03) In general terms, how would you evaluate the Norwegian potential for the development of a national oil and gas industry?

\begin{tabular}{|c|l|}
\hline A & Very Good \\
\hline B & Good \\
\hline C & Partially Good \\
\hline D & Partially Bad \\
\hline E & Bad \\
\hline
\end{tabular}




\section{\begin{tabular}{|l|l|}
\hline V & Very Bad \\
\hline
\end{tabular}}

04) In your opinion, what does the Norwegian government think about this potential for the industry development in Norway?

R:

\section{SECTION 2 - POLICY VALUES}

This section has questions about the values that drive the Norwegian oil and gas industrial policy. In the answers, try to consider the following issues:

a) mineral resources as private property or as state property;

b) industry profits for immediate needs or for future generations;

c) exploration pace;

d) Statoil should focus on profit or be a tool for the country's development;

e) nationalization or internationalization of the supply chain;

f) other issues that you consider important about the values that guide the policy.

05) Based on the existing potential, different values or principles can be adopted to guide a country's industrial policy. In your opinion, the values and principles used to define the Norwegian industrial policy were adequate for its reality?

R:

06) Which values should have been prioritized in the definition of the policy?

R:

07) In general terms, how would you evaluate the values adopted by the Norwegian industrial policy?

\begin{tabular}{|l|l|}
\hline A & Very Appropriate \\
\hline B & Appropriate \\
\hline C & Partially Appropriate \\
\hline D & Partially Inappropriate \\
\hline E & Inappropriate \\
\hline
\end{tabular}


\begin{tabular}{|l|l|l}
\hline F & Very Inappropriate \\
\hline
\end{tabular}

08) In your opinion, what does the Norwegian government think about the adoption of these values?

R:

09) Has your institution taken any action regarding the adoption of these values? If so, what kind of action has been taken? How was the reaction from other stakeholders?

R:

\section{SECTION 3 - POLICY LEGISLATION}

This section has questions about the legislation that serves as legal basis for the Norwegian industrial policy. In the answers, try to consider the following issues:

a) participation of stakeholders in the legislation definition;

b) regulation adequacy to industry reality;

c) rigidity or flexibility of legislation;

d) rules application in specific cases;

e) other issues that you consider important about the regulation governing the industrial policy.

10) What is your opinion about the law (rules, regulations and resolutions) governing the Norwegian industrial policy for the oil and gas sector?

R:

11) In your opinion, how should the law (rules, regulations and resolutions) governing the national industrial policy be?

$\mathrm{R}:$ 
12) In general terms, how would you evaluate the rules governing Norway's oil and gas industrial policy?

\begin{tabular}{|l|l|}
\hline A & Very Appropriate \\
\hline B & Appropriate \\
\hline C & Partially Appropriate \\
\hline D & Partially Inappropriate \\
\hline E & Inappropriate \\
\hline F & Very Inappropriate \\
\hline
\end{tabular}

13) In your opinion, what does the Norwegian government think about the adequacy of these rules?

R:

14) Has your institution taken any action regarding the rules considered inadequate? If so, what kind of action has been taken? How was the reaction from other stakeholders?

R:

\section{SECTION 4 - POLICY IMPLEMENTATION}

This section has questions about how the industrial policy for oil and gas is enforced (applied) in Norway. In the answers, try to consider the following issues:

a) well-defined goals and objectives;

b) transparency and accountability;

c) stakeholders performances;

d) dialogue between stakeholders;

e) interaction between stakeholders;

f) partnerships with universities and research centers;

g) integration with other policies; 
h) existence of corruption;

i) other issues that you consider important about the policy implementation.

15) What is your opinion about the way in which the Norwegian industrial policy for the oil and gas sector is being implemented?

R:

16) In your opinion, how should the Norwegian industrial policy for the oil and gas sector be implemented?

R:

17) In general terms, how would you evaluate the implementation of this industrial policy in Norway?

\begin{tabular}{|l|l|}
\hline A & Very Appropriate \\
\hline B & Appropriate \\
\hline C & Partially Appropriate \\
\hline D & Partially Inappropriate \\
\hline E & Inappropriate \\
\hline F & Very Inappropriate \\
\hline
\end{tabular}

18) In your opinion, what does the Norwegian government think about the implementation of this industrial policy?

R:

19) Has your institution taken any action regarding the implementation of this industrial policy? If so, what kind of action has been taken? How was the reaction from other stakeholders?

R: 


\section{SECTION 5 - POLICY OUTCOMES}

This section has questions about the results being achieved by the Norwegian industrial policy. In the answers, try to consider the following issues:

a) number of jobs and wages;

b) adoption of technological learning processes;

c) R\&D investments;

d) patent registrations;

e) productive capacity (scale) and productivity;

f) investments attraction;

g) local content index;

h) exports;

i) other issues that you consider important about the policy outcomes.

20) What do you think about the outcomes that are being achieved so far by the Norwegian industrial policy for the oil and gas sector?

R:

21) In your opinion, what outcomes should, or could, be being achieved by this industrial policy?

R:

22) In general terms, how would you evaluate the outcomes achieved by this industrial policy in Norway?

\begin{tabular}{|l|l|}
\hline A & Very Appropriate \\
\hline B & Appropriate \\
\hline C & Partially Appropriate \\
\hline D & Partially Inappropriate \\
\hline E & Inappropriate \\
\hline F & Very Inappropriate \\
\hline
\end{tabular}


23) In your opinion, what does the Norwegian government think about these outcomes? R:

24) Has your institution taken any action regarding the outcomes considered inadequates? If so, what kind of action has been taken? How was the reaction from other stakeholders?

R:

\section{SECTION 6 - POLICY EVALUATION}

This section has questions about the monitoring and evaluation mechanisms of the Norwegian industrial policy for oil and gas. In the answers, try to consider the following issues:

a) existence of policy monitoring mechanisms;

b) existence of policy evaluation mechanisms;

c) integration of these mechanisms;

d) other issues that you consider important about the policy monitoring and evaluation mechanisms.

25) How are the mechanisms for monitoring and evaluation of outcomes achieved by the Norwegian industrial policy for the oil and gas sector?

R:

26) In your opinion, how should these mechanisms be?

R: 
27) In general terms, how would you evaluate the current monitoring and evaluation mechanisms of the Norwegian industrial policy foi oil and gas?

\begin{tabular}{|l|l|}
\hline A & Very Appropriate \\
\hline B & Appropriate \\
\hline C & Partially Appropriate \\
\hline D & Partially Inappropriate \\
\hline E & Inappropriate \\
\hline F & Very Inappropriate \\
\hline
\end{tabular}

28) In your opinion, what does the Norwegian government think about these monitoring and evaluation mechanisms?

R:

29) Has your institution taken any action regarding the adequacy of these monitoring and evaluation mechanisms? If so, what kind of action has been taken? How was the reaction from other stakeholders?

R:

\section{SECTION 7 - REACTION TO POLICY OUTCOMES}

This section has questions about the use of monitoring and evaluation data as a basis for decision making about maintenance, adaptation or change of the Norwegian industrial policy. In the answers, try to consider the following issues:

a) access to the policy monitoring and evaluation data;

b) debate about the policy monitoring and evaluation data;

c) interests that define the use (or the non-use) of such data;

d) other issues that you consider important about the use of monitoring and evaluation data. 
30) Conclusions reached by monitoring and evaluation of outcomes reached by the Norwegian industrial policy are, in fact, used as a basis for decision making about maintenance, repair or change of this policy? If so, how is this process done? If not, in your opinion, why isn't this process done?

R:

31) In your opinion, how should the process for decision making about maintenance, repair or change of this industrial policy be?

R:

32) In general terms, how would you evaluate the current process of using the findings obtained through the monitoring and evaluation of the industrial policy outcomes as a basis for decision making about maintenance, repair or change of this policy?

\begin{tabular}{|l|l|}
\hline A & Very Appropriate \\
\hline B & Appropriate \\
\hline C & Partially Appropriate \\
\hline D & Partially Inappropriate \\
\hline E & Inappropriate \\
\hline F & Very Inappropriate \\
\hline
\end{tabular}

33) In your opinion, what does the Norwegian government think about this decision making process about maintenance, repair or change of the industrial policy?

R:

34) Has your institution taken any action regarding the adequacy of this process? If so, what kind of action has been taken? How was the reaction from other stakeholders?

R: 


\section{SECTION 8 - DATA}

35) Could you present some data (with the respective sources) that you believe to be important to support your opinions about the topics covered in previous sections? (these data can be related to all the seven sections, or only to those you deemed most important) (the data can be presented electronically or printed)

\begin{tabular}{|l|l|}
\hline A & Data presented before the interview \\
\hline B & Data presented during the interview \\
\hline C & Data will be presented after the interview \\
\hline D & Data cannot be presented \\
\hline E & Believes to have no important data to highlight \\
\hline
\end{tabular}

\section{PERSONAL DATA}

Name:

Institution:

Department:

Role/Post:

Time working in the institution: 